\title{
Beursfraude effectief aangepakt : een onderzoek naar het toezicht en de regulering van de Nederlandse en Amerikaanse effectenwetgeving
}

Citation for published version (APA):

Blagrove, M. I. (2003). Beursfraude effectief aangepakt : een onderzoek naar het toezicht en de regulering van de Nederlandse en Amerikaanse effectenwetgeving. [Doctoral Thesis, Maastricht University]. Wolf Legal Publishers. https://doi.org/10.26481/dis.20030409mb

Document status and date:

Published: 01/01/2003

DOI:

10.26481/dis.20030409mb

Document Version:

Publisher's PDF, also known as Version of record

Please check the document version of this publication:

- A submitted manuscript is the version of the article upon submission and before peer-review. There can be important differences between the submitted version and the official published version of record.

People interested in the research are advised to contact the author for the final version of the publication, or visit the DOI to the publisher's website.

- The final author version and the galley proof are versions of the publication after peer review.

- The final published version features the final layout of the paper including the volume, issue and page numbers.

Link to publication

\footnotetext{
General rights rights.

- You may freely distribute the URL identifying the publication in the public portal. please follow below link for the End User Agreement:

www.umlib.nl/taverne-license

Take down policy

If you believe that this document breaches copyright please contact us at:

repository@maastrichtuniversity.nl

providing details and we will investigate your claim.
}

Copyright and moral rights for the publications made accessible in the public portal are retained by the authors and/or other copyright owners and it is a condition of accessing publications that users recognise and abide by the legal requirements associated with these

- Users may download and print one copy of any publication from the public portal for the purpose of private study or research.

- You may not further distribute the material or use it for any profit-making activity or commercial gain

If the publication is distributed under the terms of Article 25fa of the Dutch Copyright Act, indicated by the "Taverne" license above, 


\section{Beursfraude effectief aangepakt}

Een onderzoek naar het toezicht en de regulering van de Nederlandse en Amerikaanse effectenwetgeving 



\section{Beursfraude effectief aangepakt}

Een onderzoek nad het toezicht en de regulering van de Nederlandse en Amerikaanse effectenwetgeving

\section{PROEFSCHRIFT}

ter verkrijging van de graad van doctor aan de Universiteit Maastricht, op gezag van de Rector Magnificus,

Prof.dr. A.C. Nieuwenhuijzen Kruseman

volgens het besluit van her College van Decanen,

in het openbaar te verdedigen

op woensdag 9 april 2003 om 14.00 uur

$$
\text { door }
$$

Marjorie Iris Jap-A-Joe Blagrove geboren op 7 oktober 1968 te Paramaribo, Suriname 


\author{
Promotores: \\ Prof.mr. C.A. Schwarz \\ Prof.dr. G.A.A.J. van den Heuvel \\ Prof.dr. Th.A. de Roos (Universiteir Leiden)
}

\author{
Beoordelingscommissie: \\ Prof.mr. E. Prakken (Voorzitter) \\ Prof.mr. B.T.M. Steins Bisschop (Universiteit van Nijenrode) \\ Prof.mr. F.A.M. Stroink
}


Beursfraude effectief aangepakt; Een onderzoek naar het toezicht en de regulering van de Nederlandse en Amerikaanse effectenwetgeving, Marjorie I. Jap-A-Joe Blagrove. Uitgegeven door Wolf Legal Publishers (WLP), 2003. ISBN: 90-5850-039-x

$\begin{array}{ll}\text { Uitgever: } & \text { Willem-Jan van der Wolf } \\ \text { Producticassistent: } & \text { René van der Wolf } \\ \text { Opmaak binnenwerk: } & \text { Evelin Karsten-Meessen } \\ \text { Omslagontwerp: } & \text { Sander Neijnens } \\ \text { Uitgeverij: } & \text { Wolf Legal Publishers, } \\ & \text { Postbus 31051, } \\ & \text { 6503 CB Nijmegen } \\ & \text { Tel: 024-3551904 } \\ & \text { Fax: 024-3554827 } \\ & \text { E-Mail: wlp@hetnet.nl } \\ & \text { Http://www.wlp.biz }\end{array}$

Alle rechten voorbehouden. Niets uit deze uitgave mag worden vermenigvuldigd, opgeslagen in een geautomatiseerd gegevensbestand of openbaar worden gemaakt, in enige vorm of op enige wijze, hetzij elektronisch, mechanisch, door fotokopieën, opnamen of op enige andere manier, zonder voorafgaande schriftelijke toestemming van de auteur en uitgever.

Voor zover het maken van kopieën uit deze uitgave is toegestaan op grond van artikel 16 b Auteurswet 1912 jo. het Besluit van 20 juni 1974, Stb. 351, zoals gewijzigd bij het Besluit van 23 augustus 1985 , Stb. 471 en artikel 17 Auteurswet 1912, dient men de daarvoor wetrelijk verschuldigde vergoedingen te voldoen aan de Stichting Reprorecht (Postbus 882, 1180 AW Amstelveen). Voor het opnemen van gedeelte(n) uit deze uitgave in bloemlezingen, readers en andere compilatie-werken (artikel 16 Auteurs-wet 1912) dient men zich tot de uitgever te wenden.

Hoewel aan deze uitgave de uiterste zorg is besteed, aanvaarden de auteur noch WLP aansprakelijkheid voor de anwezigheid van eventucle (druk)fouten en onvolkomenheden.

(C) 2003 ontwerp en productie WhP

(C) 2003 tekst M.I. Jap-A-Joe Blagrove 



\section{Voorwoord}

In 1996 interviewde ik in het kader van mijn scriptieonderzoek ${ }^{1} \mathrm{mr}$. J.H.M. Willems, vice-President van het Hof Amsterdam. Wat ik toen niet wist, was dat dit gesprek uiteindelijk zou leiden tot het schrijven van dit proefschrift. Op mijn vraag wat de beste voorbereiding was op het rechterschap, maakte Willems duidelijk dat het naar zijn mening beter was om na de afronding van de rechtenstudie niet meteen de RAIOopleiding te volgen, maar eerst "ervaring" op te doen. Zo kon onder meer gedacht worden aan het schrijven van een proefschrift, het doen van onderzoek. Immers, het rechterschap was niet eenvoudig; rechterlijke uitspraken kunnen een mensenleven veranderen.

In het najaar van 1996 solliciteerde ik op een promotieplek in Maastricht. Het onderzoek, toentertijd getiteld "Beursfraude", moest geen juridische analyse worden van beursdelicten, maar een criminologische beschrijving van dergelijke laakbare feiten. Na vijf jaar aan het manuscript gewerkt te hebben, kan ik niet anders concluderen dan dat het toch een puur juridische analyse is geworden. Mijn Maastrichtse capaciteitsgroepgenoot en tevens promotor, Grat van den Heuvel, zag dit al aankomen, maar heeft mij desondanks de ruimte gegeven om dit onderzoek te voltooien. Grat, mijn dank daarvoor. Mijn andere promotor, Theo de Roos, verliet Maastricht toen ik pas één jaar met het onderzoek bezig was. Gelukkig heb ik daar nooit nadeel van ondervonden. Theo, je maakte altijd wel tijd vrij voor een gesprek. De bezoekjes aan jouw werkplek in Leiden, onze lunchbesprekingen samen met Kid Schwarz en de avonden bij jou thuis in Utrecht waarin jij jouw kostbare vrije tijd aan mij afstond om te praten over het proefschrift, hebben mij het vertrouwen gegeven dat dit boek wel iets toevoegt aan de wetenschap. Zelfs net voor je vertrek naar Tsjechië, voor een korte vakantie in 2002, laat jij mij nog weten dat het "een mooi, leesbadr, interessant en niet te dik boek" wordt. Theo, bedankt voor jouw vertrouwen en grenzeloze inzet. Kid Schwarz, mijn andere Maastrichtse promotor, ik noemde je zojuist al. Als een echte rots in de branding heb jij mij gedurende de vijf jaar dat ik aan mijn onderzoek werkte daar gesteund waar ik het echt nodig had. Toen mijn onderzoek

Artikel 46 Werbock van Strafrecht en de (zware) georganiseerde criminalireit: cen doadgeboren kind? 
dreigde vast te lopen omdat de toenmalige Stichting Toezicht Effectenverkeer (nu Autoriteit Financiële Markten) achteraf nier mee wilde werken aan een praktijkonderzoek, schakelde jii je contacten in waardoor $i k$ aan het onderzoek een draai kon geven. Via jouw inspanningen in samenhang met de Onderzoeksschool Ius Commune en de Wetenschapscommissie van de Universiteit Maastricht kwam ik terecht in New York en in Washington D.C. Het onderzoek is er alleen maar beter van geworden. Ook zal ik onze periodieke besprekingen niet vergeten. Niet altijd, maar soms onder het genot van een biertje - al dan niet vergezeld van een harinkje - bespraken wij het verloop van mijn onderzoek. Kid, een aio - of zoals dat nu heet een "junior-onderzoeker" - is bij jou in goede handen; een promotor pur sang.

De leden van de beoordelingscommissie Ties Prakken, Frits Stroink en Bas Steins Bisschop, wil ik bedanken voor de nauwgezetheid waarmee ze mijn manuscript hebben gelezen. Vooral het eerste deel moet een taaie klus zijn geweest.

Daarnaast wil ik Gerard Mols bedanken. Op de momenten dat ik "vast" zat en een klankbord nodig had stormde ik jouw kamer binnen. Erg heb je het nooit gevonden. Mocht dat wel zo zijn, dan heb jij dat in ieder geval nooit laten blijken. Toen ik niet wist hoe ik dit onderzoek in de strafrechtelijke hoek moest trekken gezien het omvangrijke ondernemingsrechtelijk inventariserend onderdeel, gaf jij an dat het voor (strafrecht)advocaten erg nuttig kan zijn om alle informatie overzichtelijk bijeen te hebben. Bedankt voor je luisterend oor.

Verder wil ik mijn vroegere collega's van de capaciteitsgroep Strafrecht en Criminologie bedanken voor de stimulerende tijd die ik daar heb mogen doorbrengen, in het bijzonder Dorris de Vocht en Gerard de Jonge. Beiden hebben zich kritisch door mijn manuscript heen geworsteld vergezeld van commentaar. Mijn dank daarvoor. Wies Rayar, dankzij jouw tomeloze inzet kon mijn samenvatting op korte termijn op een fraaie wijze worden vertaald.

Buiten de faculteit zijn er velen die, de tijd dat ik aan dit proefschrift heb gewijd, hebben vergernakkelijkt. Een aantal daarvan zal ik noemen. Allereerst mijn ouders, ma en pa bedankt. Jullie steun en vertrouwen hebben bijgedragen aan de totstandkoming van dit boek. Het woord "trots" is vaak gevallen. Nu pas durf ik het aan te horen. Ook mijn schoonouders wil ik bedanken. Jullie kritische opmerkingen over mijn 
teksten en de regelmatig terugkerende vraag naar het stadium van mijn proefschrift, vormden voor mij een extra stimulans. Bovendien moeten jullie weten dat ik op de juiste momenten de nodige afleiding vond in jullie warme en liefdevolle nest. Vervolgens mijn trouwe vriendinnen Cheryl, Bianca, Ria, Neriman, Radha, Marilyn en Shirley. Jullie hebben altijd begrip getoond voor de keren dat ik verstek moest laten gaan en niet op onze periodieke reünies verscheen omdat mijn proefschrift voor ging. Ook al was het onderwerp voor jullie niet altijd even interessant, toch bleven jullie vragen hoe het ermee ging. Bedankt voor de vriendschap en jullie vertrouwen, vanaf nu ben ik er weer bij. Verder wil ik mijn collega's van de Open Universiteit bedanken. In het bijzonder Jan Reijntjes en Huub Spoormans, jullie gaven mij alle ruimte om "de laatste loodjes" af te leggen. Mark Liedekerken en Evelin Karsten, dankzij jullie mag de vormgeving van dit boek er zijn. Evelin, je hebt er hard aan gewerkt om het allemaal op tijd camera ready te maken. Bedankt voor jouw inzet. Ook wil ik mijn Maastrichtse lotgenote en tevens paranimf Yvonne Donders bedanken. Twee Utrechtse meiden in Maastricht, een mooie combinatie was dat. Gerard de Jonge, oud capaciteitsgroepgenoot en mijn andere paranimf. Jou heb ik goed leren kennen in de periode dat ik nog actief lid was van het Kunstkomitee van de Universiteit Maastricht. Recht door zee; je nam geen blad voor de mond. Ik heb dar altijd in jou gewaardeerd.

Last but not least mijn man Kenneth en dochter Jillean. Lieve Kenneth, zonder jou was dit proefschrift zeker niet geworden wat het nu is. Hoe vaak was ik niet op het ene moment én en al twijfel, op het andere moment weer erg stellig, soms lichrgeraakt dan weer erg afwezig? Het schrijven van dit proefschrift zorgde soms voor een Jekyll en Hyde situatie. Toch ben je er altijd voor mij geweest. Niets was jou teveel. Je dook zelfs in mijn juridische teksten en wist altijd de vinger op de zere plek te leggen. Ik heb mij daar (achteraf) menigmaal over verbaasd. In alle hectiek ben jij altijd mijn rustpunt geweest. Jouw liefde en vertrouwen heb ik altijd gevoeld. Mijn onmetelijke dank daarvoor. En Jillean, jouw glimlach heeft mamma vaak goede moed gegeven. Mamma heeft nu alle tijd voor jou. Het is afgelopen met de stress.

Dit manuscript is afgesloten in juli 2002. Met eventuele ontwikkelingen daarna is slechts incidenteel rekening gehouden. 



\section{Inhoudsopgave}

Voorwoord

Inhoudsopgave

Afkortingen

\section{Algemene inleiding}

$\begin{array}{ll} & \text { Inleiding I } \\ 1 & \text { Achtergronden I } \\ 2 & \text { Afbakening van het onderzoek } \quad V \\ 3 & \text { Probleemstelling VIII } \\ 4 & \text { De opbouw IX } \\ 5 & \text { Terminologie IX } \\ & \text { Het strafrecbtstheoretisch kader XIII } \\ 6 & \text { Het strafrecht en het effectentypisch toezicht XIII } \\ 7 & \text { Het bijkomend effect van het algemene strafrecht XIV } \\ 8 & \text { Strafrechtstheorieën en het bijkomend effect van het } \\ & \text { straf(proces)recht XXII } \\ 8.1 & \text { Het oogmerk van een strafrechtsleer XXII } \\ 8.2 & \text { De reikwijdte van een strafrechtelijk doel XXIV } \\ 8.3 \quad \text { Het strafrecht en de rechtsbescherming XXVI }\end{array}$

\section{Hoofdstuk 1 De ontwikkeling van de effectenhandel in Nederland}

1.1 Het ontstaan van de handel in effecten in Nederland 1

1.2 De georganiseerde handel in effecten 4

1.3 Overheidsinmenging 11

1.3.1 Ordenend overheidsoptreden 12

1.3.2 Dwingend overheidsoptreden 12

1.4 Een nieuwe koers 15

1.4.1 Van bedrijfsgroep tot landelijke organisatie 15

1.4.2 Modernisering effectenverwerking 17

1.4.3 De buitenbeurshandel 18

1.4.4 De positieverandering van beursactoren 20 
1.4.5 Het controlebureau 23

1.5 Internationalisering 27

1.6 Van vereniging naar naamloze vennootschap 31

Hoofdstuk 2 Toezicht en regulering van de Nederlandse effectenwetgeving

2.1 Inleiding 37

2.2 Van Stichting Toezicht Effectenverkeer naar Autoriteit Financiële Markten 39

2.3 De relevante Nederlandse effectenwetgeving 44

2.3.1 Externe regelgeving; de kaderwetgeving 45

2.3.2 Externe regelgeving; de uitvoeringsregels 74

2.3.3 Interne regelgeving; zelfregulering 84

2.3.3.1 De interne regelgeving van de Amsterdamse effectenbeurs 86

2.3.3.2 De interne regelgeving van Amsterdam Exchanges N.V. 102

2.3.3.3 Van nationale beurs naar pan-Europese beurs: Euronext N.V. 121

2.4 De rol van de externe toezichthouders: de Autoriteit-FM en DNB 124

2.4.1 Uitoefening van het toezicht: de STE en de Autoriteit-fM 125

2.4.2 Uitoefening van het toezicht: De Nederlandsche Bank N.V. 144

2.5 De verschillende handhavingsprocedures 153

2.5.1 De bestuursrechtelijke procedure 153

2.5.2 De civielrechtelijke procedure 171

2.5.3 De strafrechtelijke procedure 179

Hoofdstuk 3 Toezicht en regulering van de Amerikaanse effectenwetgeving

Inleiding 205

3.1 Een introductie in het Amerikaans recht 206

3.1.1 De verdeling van machten 206

3.1.2 De verschillende rechtsprekende instanties 210

3.2 De ontstaansgeschiedenis van de SEC 213

3.3 De relevante Amerikaanse effectenwetgeving 216 
3.3.1 Externe regelgeving; de kaderwetgeving 218

3.3.2 Externe regelgeving; de uitwoeringsregels 225

3.3.3 Interne regelgeving; zelfregulering 232

3.4 De rol van de externe toezichthouder: de SEC 247

3.4.1 Uitoefening van het toezicht 247

3.4.2 De interne structuur van de SEC 249

3.5 De afdeling Enforcement 251

3.5.1 De drie fases van een SEC onderzoek 252

3.6 De verschillende handhavingsprocedures 264

3.6.1 De administratieve procedure 264

3.6.2 De civielrechtelijke procedure 287

3.6.3 De strafrechtelijke procedure 300

Hoofdstuk 4 Het Nederlands toezicht; een knipoog naar Amerika?

$4.1 \quad$ Inleiding 321

4.2 De Nederlandse en Amerikaanse handhavingsinstrumenten 321

4.3 E.en knipoog naar Amerika? 330

Hoofdstuk 5 De relatie tussen de effectentypische wetgeving en het strafrecht

5.1 Inleiding 335

5.2 Het stigmatiserend effect als (bijkomend) neveneffect of als vergelding? 336

5.3 Strafrechtelijke handhaving van effectentypische wetgeving? 343

5.4 Conclusie 344

Samenvatting 347

Summary 353

Aangehaalde literatuur 359

Trefwoordenregister 370

Curriculum Vitae 379 



\section{Afkortingen}

AB-Holding

AEX

A-FM

AIDA

ALJ

$A M \vee B$

APA

Art.

ASSET

Autoriteit-FM

a.w.

Awb

$\mathrm{BAb}$

bmvk

Bte

$B W$

$\mathrm{CAD}$

$\mathrm{CB}$

CFR

CF-stuk

D.C.

d.d.

dl.

DNB

ECD

ECRM

EER

EHRM

EMU

EU

EUR

EVRM
Amsterdamse Beursholding Amsterdam Exchanges N.V. Autoriteit Financiële Markten Automatic Interprofessional Dealingsystem Amsterdam

Administrative Law Judge Algemene maatregell van bestuur Administrative Procedure Acr Artikel / article Amsterdam Securities Trading System Autoriteit Financiële Markten angehaald werk Algemene wet bestuursrecht Besluit financiële bijsluiter Beleggingsmaatschappij met veranderlijk kapitaal

Besluit toezicht effectenverkeer

Burgerlijk Wetboek

Capital Adequacy Directive

Controlebureau

Code of Federal Regulations

Centrum voor Fondsenadministratie-stuk. District of Columbia

de dato

deel

De Nederlandse Bank N.V.

Economische Controledienst.

Europese Commissie voor de Rechten van de Mens

Europese Economische Ruimte

Europees Hof voor de Rechten van de Mens

Europese Monetaire Unie

Europese Unie

Erasmus Universiteit Rotterdam

Europees Verdrag tot bescherming van de Rechten van de Mens en de fundamentele vrijheden 
FBI

FET

Fin.

FIOD

FOM

FRCP

FTA

FTC

HR

IAA

ICA

ICBE

IIE

Inst. Bel.

IOSCO

IRT

ISD

ITSA

i.t.t.

IVBPR

$j^{\circ}$

jrg.

K

$\mathrm{KB}$

KG

K-stuk

KUN

MSRB

$\mathrm{MvA}$

$\mathrm{MvF}^{F}$

MvT

NASD

NASDAQ

NECIGEF
Federal Bureau of Investigation

Dagblad de Financieel-Economische Tijd Financiële

Fiscale Inlichtingen- en Opsporingsdienst

Functioneel Openbaar Ministerie

Federal Rules of Civil Procedure

Financiële Termijnmarkt Amsterdam

Federal Trade Commission

Hoge Raad

Investment Advisers Act

Investment Company Act

Instelling voor Collectieve Beleggingen in Effecren

Interprofessioneel Instituut voor de

Effectenhandel

Institutionele beleggers

International Organization of Securities

Commission

Interregionaal Recherche Team

Investment Services Directive

Insider Trading Sanction Act

in tegenstelling tot

Internationaal Verdrag inzake Burgerrechten en

Politieke rechten

juncto

Jaargang

Wetboek van Koophandel

Koninklijk Besluit

Kort Geding

Klassiek-stuk

Katholieke Universiteit Nijmegen

Municipal Securities Rulemaking Board

Memorie van Antwoord

Ministerie van Financiën

Memorie van Toelichting

National Association of Securities Dealers

National Association of Securities Dealers

electronic Automated Quotation system

Nederlands Centraal Instituut voor Giraal

Effectenverkeer B.V. 
NJ

NJB

NOE

nr

nrte

N.V.

$\mathrm{OM}$

OTC

OvJ

p.

PUHCA

PVK

RB

red.

Roefex

$\mathrm{RvC}$

RFT

RUG

RUL

RUU

SA

SEA

SEC

SIPA

SIPC

Stb.

STE

Stcrt.

Sr

SRO

Sv

t.a.p.

TIA

Trb.

TVVS

UM

U.S.

USA
Nederlandse Jurisprudentie

Nederlands Juristenblad

Nederlandse Organisarie van het Effectenbedrijf nummer

Nadere regeling roezicht effectenverkeer

Naamloze Vennootschap

Openbaar Ministerie

Over-the-counter handel

Officier van Justitie

pagina

Public Utility Holding Company Act

Pensioen- \& Verzekeringskamer

Rechtbank

Redactie

Rotterdam Energy Futures Exchange

Raad van Commissarissen

Raad van Financiële Toezichthouders

Rijksuniversiteit Groningen

Rijksuniversiteit Limburg

Rijksuniversiteit Utrecht

Securities Act

Securities Exchange Act

Securities and Exchange Commission

Securities Investor Protection Acr

Securities Investor Protection Corporation

Staatsblad

Stichring Toezicht Effectenverkeer

Staatscourant

Strafrecht

Self regulatory organizations; zelfregulerende organisaties

Strafvordering

ter aangehaalder plaatse

Trust Indenture Act

Tractatenblad

Tijdschrift woor Vennootschappen, Verenigingen

en Stichringen

Universiteit Maastricht

United States

Verenigde Staten van Amerika 


$\begin{array}{ll}\text { USAM } & \text { United States Attorney Manual } \\ \text { USC } & \text { United States Code } \\ \text { Uitgev. Instell. } & \text { Uitgevende instellingen } \\ \text { v. } & \text { versus } \\ \text { Vgl. } & \text { Vergelijk } \\ \text { VEOE } & \text { Vereniging European Options Exchange } \\ \text { VvdE } & \text { Vere(e)niging voor de(n) Effectenhandel } \\ \text { VOC } & \text { Verenigde Oost-Indische Compagnie } \\ \text { VS } & \text { Verenigde Staten van Amerika } \\ \text { WBB } & \text { Wet invoering dwangsom en bestuurlijke boete } \\ & \text { in de financiële wetgeving } \\ \text { WBS } & \text { Wet bestuurlijke sancties financiële sector } \\ \text { WED } & \text { Wet op de economische delicten } \\ \text { Weh } & \text { Wet effectenhandel } \\ \text { Wffb } & \text { Wet financiële betrekkingen buitenland } \\ \text { WIC } & \text { West-Indische Compagnie } \\ \text { Wrmz } & \text { Wet Melding Zeggenschap in ter beurze } \\ & \text { genoteerde vennootschappen } \\ \text { WOI of WO II } & \text { Wereldoorlog I en Wereldoorlog II } \\ \text { WPNR } & \text { Weekblad voor Privaatrecht, Notariaat en } \\ & \text { Registratie } \\ \text { Wpr } & \text { Wet persoonsregistratie } \\ \text { Wsmv } & \text { Wet strafbaarstelling misbruik van } \\ & \text { woorwetenschap } \\ \text { Wtb } & \text { Wet Toezicht Beleggingsinstellingen } \\ \text { Wte } & \text { Wet Toezicht Effectenverkeer } \\ \text { Wrk } & \text { Wet Toezicht Kredietwezen } \\ \text { Wrn } & \text { Wet toezicht natura uitvaartverzekeringsbedrijf } \\ \text { Wtv } & \text { Wetboek van Strafrecht } \\ \text { WvSr } & \text { Wetboek van Strafvordering } \\ \text { WvSv } & \text { Zelfstandig bestuursorgaan } \\ \text { Zbo } & \text { Zelfregulerende organisatie } \\ \text { ZRO } & \end{array}$






\section{Algemene inleiding}

\section{Inleiding}

Deze studie beoogt een duidelijk beeld te scheppen van de verschillende toezichthouders binnen de sfeer van het Nederlands effectenverkeer; de effectentypische toezichthouders. De nadruk wordt gelegd op de bevoegdheden van deze toezichthouders in de toezichts- en handhavingsprocedures. In dit onderzoek wordt de positie van de Nederlandse effectentypische toezichthouder vergeleken met die van de Amerikaanse toezichthoudende SEC. Centraal staat de bestudering van de effectentypische handhaving vanuit een strafrechtelijke invalshoek. Hiermee wordt getracht om de rol van het straf(proces)recht binnen de effectentypische handhavingsprocedure te verduidelijken. Een onderzoek dat zich hoofdzakelijk richt op de bevoegdheden van de Nederlandse en de Amerikaanse toezichthouders en zich niet alleen bezighoudt met de wijze waarop zij deze uitoefenen, maar ook met een kritische blik de strafrechtelijke sanctionering van effectentypische wetsovertredingen bekijkt, is nog niet eerder in deze vorm en in een dergelijke opzet uitgevoerd.

Achtergronden

De inval op de Amsterdamse effectenbeurs op 25 oktober 1997 heeft destijds veel stof doen opwaaien. Plotseling kreeg heel Nederland via de media het beeld voorgeschoteld dat de Nederlandse effectenbeurzen een bolwerk zouden zijn van handelaren die er niet voor schroomden om dubieuze praktijken toe te passen. We kenden dat beeld reeds uit de Verenigde Staten van Amerika (VS), maar hadden tot dan toe nooit gedacht met zulke "Amerikaanse toestanden" te maken te krijgen. Zo bleken er hier in Nederland eveneens transacties te zijn uitgevoerd die niet in overeenstemming waren met de beursregels en de regels van de effectenwetgeving. Daarnaast werden de exorbitant hoge bedragen die als "winst" uit dergelijke transacties voortvloeiden, vermoedelijk niet bij de fiscus aangegeven. De hiernavolgende maanden bleef het beursschandaal, dat ondertussen de naam "operatie Clickfonds" had gekregen, 
velen tot de verbeelding spreken. Men had het al snel over "de beursfraudezaak: operatie Clickfonds". De media berichtten steeds weer wanneer het Openbaar Ministerie (OM) huiszoeking bij een nieuwe verdachte in de beursfraudezaak had verricht. Het OM wilde in heel Nederland en ver daarbuiten laten zien dat het zou afrekenen met personen die zich niet aan het (financieel) strafrecht en aan de effectenwetgeving hielden. Het OM begon aan een kruistocht tegen beurs"fraudeurs". Maar wat is eigenlijk beursfraude? Dit begrip dat nier in het Wetboek van Strafrecht of in een andere wet terug was te vinden, werd als algemene term toegepast voor de vele wettelijke en buitenwettelijke begrippen zoals: misbruik van voorwetenschap - artikel 46 Wet Toezicht Effectenverkeer 1995 (Wte'95) -, het misleiden van - potentiële - beleggers door opzettelijk belangrijke gegevens achter te houden - artikel 47 Wte"95 -, valsheid in geschrifte - artikel $225 \mathrm{Sr}-$, nalaten (juiste of volledige) belastingaangifte te doen - de artikelen 68 en 69 Algemene wet op de Rijksbelastingen (Awr) -, koersmanipulatiel koersorkestratie of koersbeïnvloeding en het overtreden van het verbod van cold callingl, churning ${ }^{2}$ en frontrunning ${ }^{3}$.

Ondanks het gegeven dat vele van de hierboven genoemde begrippen niet onder het bereik van het strafrecht vielen, doch onder het bereik van de beurseigen gedrags- of omgangsregels, dienden zij volgens de interne regels van de effectenbeurs toch te worden aangepakt. Hiertoe was in beginsel niet het OM als bevoegde instantie aangewezen, maar de toezichthouders van het Nederlandse effectenverkeer via het bestuurs(straf)recht. Deze toezichthouders, de Autoriteit Financiële Markten of de Autoriteit-FM (voorheen de Stichting Toezicht Effectenverkeer) en de Nederlandsche Bank (DNB), waren (en zijn nog) op grond van onze effectentypische regelgeving bevoegd tot het controleren van de naleving van deze wetten. In beginsel werd het systeem van sectoraal toezicht roegepast. Dat hield in dat de verschillende toezichthouders die werkzaam zijn op het terrein van de financiële markten, de Autoriteit-FM, DNB en

Zonder dat er sprake is van een zakelijke relatie porentiäle beleggers telefonisch benaderen.

2 Zonder dat de cliënt hiertoe opdracht heeft gegeven, effectentransacties uitvoeren om zodoende commissie op te kunnen strijken.

3 Het kopen dan wel verkopen van effecten op eigen rekening door intermediairs die vooruitlopen op een uit te voeren (grote) order. Dit om nadien mee te profiteren van koerswijzigingen. Dit lijkt sterk op het handelen met voorwetenschap. 
de Pensioen- \& Verzekeringskamer (PVK) ${ }^{4}$, zich zowel richtten op het prudentiee ${ }^{5}$ als op het gedragstoezicht ${ }^{6}$ van de instellingen die tot de desbetreffende toezichtsector behoorden. Zo werden verzekeraars ondergebracht bij de PVK, banken en beleggingsinstellingen bij DNB en de beurzen en effecteninstellingen bij de STE. Waar de toezichthouders zich tijdens de uitoefening van hun taken op 'sector' overschrijdende gebieden begaven, was er de Raad van Financiële Toezichthouders (RFT) als vangnet. In deze raad kwamen de verschillende toezichthouders samen om de aanpak van sectoroverschrijdende problemen te bespreken en te coördineren. Sinds maart 2002 is het sectoraal toezichtsysteem verlaten en wordt er in Nederland het systeem van functioneel toezicht toegepast. Dat houdt in dat de verschillende toezichthouders zich slechts op één toezichtdoelstel.ling richten. De PVK en DNB voeren het prudentiële toezicht uit over respectievelijk de verzekeraars en de banken, beleggingsinstellingen en effecteninstellingen.

De Autoriteit-FM is de rechtsopvolger van de in 1989 opgerichte Stichting Toezicht Effectenverkeer (STE). Deze laatste was in het leven geroepen om als zelfstandig bestuursorgaan toezicht te houden op her Nederlandse effectenverkeer. Daarnaast moest zij er zorg voor dragen dat de (potentiële) belegger er op kon rekenen dat zijn transacties naar behoren

Afhankelijk van het financiële product kan het zijn dat het product tevens onder her toezicht van de PVK valt. Als voorbeeld van een dergelijk product kan worden gedacht aan een werzekering waarvan de uirkering deels gekoppeld is aan een beleggingsproduct.

5 Het prudentieel toezicht is gericht op "de stabiliteit van financiëte instellingen, zaals reserve- en risicobeheer". Kamerstukken II, 2001/2002, 28 122, nr. 2, p. 2. In dit geval moet worden gedacht aan de financieel economische zekerheden. Zo moeten bedrijven onder meer over voldoende financiële middelen beschikken en dienen zij ervoor te zorgen dat hun administratieve organisatie aan de wettelijke eisen voldoet. Hiermee tracht de toezichthouder controle te houden over het risico van faillissementen. Vgl. Kamerstukken II, 2001/2002, 28 122, nr. 2, p. 10. Meer hierover in hoofdstuk twee.

Het gedragstoezicht richt zich op de wijze waarop de financiêle instellingen zich zowel ten opzichte van elkaar als ten opzichte van de consument dienen te "gedragen". Hierbij zijn de termen "transparantie en voorlichting" van groot belang. Vgl. Kamerstukken II, 2001/2002, 28 122, nr. 2, p. 2. De toezichthouder oefent het gedragstoezicht uir door er op toe te zien dat het marktproces ordelijk en zo transparant mogelijkt verloopt. Door de verhoudingen tussen de verschillende marktpartijen zo zuiver mogelijk te houden tracht de toezichthoudende Auroriteir-FM de consument van verschillende financiële producten te beschermen. Vgl. Kamerstukken II, 2001/2002, 28 122, nr. 2, p. 10. 
werden uitgevoerd. Verder diende de STE ervoor te zorgen dat er sprake was van een eerlijke en doorzichtige effectenmarkt, zodat het voor iedereen aantrekkelijk zou blijven om deel te nemen aan het effectenverkeer. Sinds 1989 is de positie van deze toezichthouder drastisch gewijzigd. Aanvankelijk was zij voor de uitvoering van haar taken grotendeels afhankelijk van de interne toezichthouder van de beurs, het Controlebureau. Daarom werd het toezicht destijds door STE slechts marginaal uitgevoerd. Na de fusie van de effectenbeurzen op 1 januari 1997, de invoering van de herziene Wet Toezicht Effectenverkeer (Wte) en de invoering van de wet bestuurlijke boetes en dwangsommen, werd de STE steeds meer gezien als een volwaardige toezichthouder op het gebied van het effectenverkeer. De wijziging van het toezichtsmodel - in deze studie ook wel de toezichtstructuur genoemd - en de toekenning van extra bevoegdheden heeft de positie van de toezichthouder, nu de Autoriteit-FM, nog meer solide gemaakt. Zij oefent nu het gedragstoezicht uit over alle financiële instellingen ${ }^{7}$. Doordat zij haar toezicht uitsluitend heeft gericht op het gedrag van álle financiële instellingen en voor de uitoefening van haar taken steeds meer wettelijke bevoegdheden krijgt toegewezen, wordt zij vandaag de dag niet alleen als een waakhond, maar als een "waakhond met tanden" beschouwd. De Autoriteit-FM maakt nu explicieter gebruik van haar bevoegdheden door daadwerkelijk bestuurlijke boetes ${ }^{8}$ op te leggen en gebruik te maken van het middel om opgelegde sancties openbaar te maken ${ }^{9}$. Verder laat de AutoriteitFM het publiek, al dan niet via de media, regelmatig weten over nog meer bevoegdheden te willen beschikken, zoals het zelf mogen ontnemen

7 Ondat het toezicht nu verder reikt dan alleen de effecteninstellingen, heeft de aamswijziging van de Stichting Toezicht Effectenverkeer (STE) in de AutoriteitFM platsgevonden.

De invoering van de Algemene wet bestuursrecht (Awb) geschiedr in tranches. De bestuurlijke boete, een worm van bestuurlijke handhaving, maakt onderdeel uit van de vierde tranche van de Awb. De Commissie wetgeving algemene regels van bestuursrecht, de commissie Schelrema, die is ingesteld bij besluit wan 23 augustus 1983 ( $\mathrm{Stb} .1983,417)$, treedt in deze op als adviescommissie van de Ministers van Justitie en van Binnenlandse Zaken en Koninkrijksrelaties.

Zie bijvoorbeeld de publieke berisping van de STE van bank- en verzekeraar Fortis door de haar opgelegde boete in bepaalde dagbladen te publiceren. Vgl. het NRC-Handelsblad "Hebzucht is een belangrijke mensellijk aandrift; her groeiende onbehagen van Arthur Docters van Leeuwen", NRC Handelsblad, 9 maart 2002. 
van wederrechtelijk verkregen voordeel ${ }^{10}$. Dit alles met als doel: "het bevorderen wan een ordelijk en transparant marktproces, zuivere verhoudingen tussen marktpartijen en bescherming van de consument op het gebied van transparantie en voorlichting" 11 .

Wat ook niet onbelangrijk is, is het gegeven dat vandaag de dag "een ieder" lijkt te beleggen. Was het beleggen halverwege de vorige eeuw zeker na de beurskrach aan het eind van de jaren twintig - een activiteit voor "gefortuneerde mensen", vandaag de dag kan ook Jan Modaal over aandelen en/of opties beschikken. Het (beleggend) publiek is niet alleen qua omvang toegenomen, het is ook bekend geraakt met de toezichthoudende Autoriteit-FM. De haar toegekende bevoegdheden en de wijze waarop zij deze uitoefent, hebben er toe bijgedragen dat de AutoriteitFM haar plaats binnen de financiële wereld definitief heeft verworven.

\section{Afbakening van het onderzoek}

De hiervoor geschetste bijzondere positie van de Autoriteit-FM creëert de grondslag voor een onderzoek naar de wijze waarop zij haar toezichtstaken en handhavingsbevoegdheden uitoefent. Hierbij staat vooral de handhaving van de effectentypische regelgeving centraal. Een andere niet onbelangrijke toezichthouder, De Nederlandsche Bank, zal slechts daar waar dat vanuit het oogpunt van deze studie wordt vereist expliciet aan bod komen. De reden hiervoor is diens gewijzigde positie. DNB is samen met de Pensioen- \& Verzekeringskamer (PVK), niet meer verantwoordelijk voor het gedrag van enkele financiële instellingen maar slechts voor het prudentieel toezicht op deze instellingen.

De schets van de bevoegdheden van de toezichthouders omvat tevens een aanduiding van de beperkingen of van de reikwijdte van dergelijke handhavingsbevoegdheden. Deze bevoegdheden van de Autoriteit-FM kunnen worden beperkt doordat zij in collisie komen met handhavingsbevoegdheden van andere rechtshandhavers. Zo zall blijken dat de

De bevoegdheid voor deze procedure ligt tot nu toe exclusief bij het OM. Vergellijk het interview in het NRC-Handelsblad met de voorzitter van de AutoriteitFM, Docters van Leeuwen, "Hebzucht is een belangrijke menselijk aandrift; het groeiende onbehagen van Arthur Docters van Leeuwen", NRC Handelsblad, 9 maart 2002 .

11 Vlg. Nieuwsbrief Autoriteit-FM te weten: InZicht, jrg. 1, nr. 2, 2002 , p. 4. 
bestuursrechtelijke bevoegdheden van de Autoriteit-FM hun grenzen daar bereiken waar het strafrecht aanvangt. Het strafrecht heeft van de wetgever een rol toebedeeld gekregen in de handhaving van de effectentypische regelgeving. Om uitholling van deze regelgeving te voorkomen is het cruciaal dat de naleving ervan wordt gecontroleerd en schending ervan wordt gesanctioneerd. Dit laatste vindt voornamelijk plaats via het bestuursrecht. Het sanctioneren van voornoemde schendingen kan daarnaast met behulp van het strafrecht geschieden door de Wet Toezicht effectenverkeer in samenhang met de Wet op de Economische Delicten toe te passen. Hierbij is er geen sprake van "eenrichtingsverkeer". De toepassing van het strafrecht kan niet alleen door de strafrechtelijke rechtshandhaver worden geëntameerd, maar ook de bestuursrechtelijke handhaver kan om de inzet van het strafrecht verzoeken ${ }^{12}$. De reden hiervoor is gelegen in het gegeven dat het de Autoriteit-FM aan een eigen vervolgingsbevoegdheid ontbreekt. Zij behoeft dan ook voor een strafrechtelijke vervolging de inzet van het Openbaar Ministerie. Het is daarom zinvol om de handelwijze van de Autoriteit-FM en haar samenwerking met het Openbaar Ministerie nader te bestuderen.

Het voorgaande geeft de importantie aan om in deze studie ook het terrein van het strafrecht te verkennen. Hierbij zal naar een strafrechtelijk theoretisch kader worden gezocht waarbinnen de handhaving van effectentypische regelgeving kan worden verantwoord. Het is immers bekend dat een strafproces ${ }^{13}$ een bepaalde impact op de betrokkenen kan hebben. Daarom zal, terugredenerend vanuit het teleologisch aspect van bepaalde straftechtstheorieën, worden getracht om aan te geven of de inzet van het strafrecht wel een geschikt middel is bij de handhaving van effectentypische regelgeving. Deze aanpak impliceert dat deze studie zich zal begeven op verschillende rechtsgebieden. Voor een overzicht van de bevoegdheden van de toezichthouder(s) zullen de bestuursrechtelijke en deels de civielrechtelijke bevoegdheden en procedures aan bod komen. Daarnaast zullen ook de straf(proces) rechtelijke bevoegdheden en procedures worden besproken.

Niet alleen de werking van verschillende rechtsgebieden, maar ook verschillende landen zullen in deze studie worden behandeld. Mede door de internationalisering en de snelle technologische ontwikkelingen zoals 
het internet vallen de verschillen en overeenkomsten in de bevoegdheidsuitoefening van toezichthouders in diverse landen eerder op. Zo zijn steeds meer overeenkomsten te vinden in de bevoegdheden van de Nederlandse toezichthouder(s), en die van hun collega's in Amerika, Engeland, Frankrijk en Duitsland. In deze studie is ervoor gekozen om de bevoegdheden van de Amerikaanse toezichthouder, de Securities and Exchange Commission (SEC), te vergelijken met die van haar Nederlandse evenknie. Naast een bespreking van de wijze waarop het toezicht en de handhaving van effectentypische regels in Nederland plaatsvinden, zal worden besproken op welke wijze de naleving van vergelijkbare regelgeving in de Verenigde Staten van Amerika (VS) wordt gecontroleerd. Gekozen is voor de VS omdat de Amerikaanse SEC al sedert 1933 - in de regel - zeer succesvol als effectentypische toezichthouder fungeert ${ }^{14}$ op deze veruit grootste aandelenmarkt en er destijds in Europa geen soortgelijke toezichthouder bestond met vergelijkbare bevoegdheden ${ }^{15}$. Het gevolg van deze keuze is dat bij de karakterisering van het Amerikaanse effectentypisch toezicht, rekening dient te worden gehouden met het Anglo-Amerikaans rechtssysteem; een common law stelsel, waarop het Amerikaans (effecten)recht is gebaseerd ${ }^{16}$. Het in Nederland gehanteerde continentaal systeem zal ertoe kunnen leiden dat bepaalde in het Anglo-Amerikaans systeem voorkomende (rechts)figuren, niet als zodanig worden herkend. Daarom zal ter introductie van het Amerikaans effectentypische toezicht, een korte inleiding in het

Zeer succesvol wil niet zeggen foutloos. Denk bijwoorbeeld aan de Enron-affaire, een Amerikaanse energiegigant, waar het toezicht door de SEC waarschijnlijk niet van een dusdanige aard was dat daardoor de (grensoverschrijdende) creatieve boekhoudkundige trucs van Enron aan het licht konden komen. Zie her redactioneel artikel, "Revisor kan zichzelf niet controleren", Dagbiad de Financieel-Economische Tij, 19 januari 2002. Zie ook Eisma, S.E., "De verbouwing wan het Nederlandse effectenrecht", NJB, 15 november 2002 , jrg. 77, p. 2050 .

15 "...modelling is patterned according to configurations of power. (...) Whatever the US do, if you follow the US you cannot be a loser". Braithwaite, J. en Drahos, P., Global Business Regulation, Cambridge University Press, 2000, p. 583.

Meer over studies naar Amerikaans recht in strafrechtelijk perspectief: Jörg, $\mathrm{N}$, "Strafbare rechtspersonen in Amerika", Arnhem, Gouda Quint B.V., 1990 en Roos, Th. de, "Economische mededinging en witteboordencriminaliteit; enkele opmerkingen over de criminalisering van anti-trust en kartelwetgeving" in de serie strafrecht en criminologie, deel 3, Ars Aequi Libri, Nijmegen, 1984, p. 129. 148. 
Amerikaans (effecten)recht worden gegeven. Voorts zullen voornoemde (rechts)figuren, waar dit verschijnsel zich kan voordoen en dit in het belang van deze studie is, nader worden besproken.

\section{$3 \quad$ Probleemsteiling}

Deze studie richt zich in het algemeen op de Nederlandse en Amerikaanse effectentypische regelgeving, in het bijzonder op de wijze waarop de effectentypische toezichthouders in Nederland en Amerika hun toezichtstaken en handhavingbevoegdheden uitoefenen dan wel uit behoren te oefenen. Daarnaast wordt aandacht besteed aan de positie van de strafrechtelijke rechtshandhavers, het Openbaar Ministerie en zijn Amerikaanse evenknie.

De centrale onderzoeksvraag luidt als volgt:

Wat is de pasitie wan de Nederlandse toezichthouder(s) in de bandhaving van de effecterwetgeving en boe verboudt deze zich tot die van de Amerikanse toezichthouder? Welke betekenis wordt er daarbij in beide landen an bet strafrecht toegekend?

De beantwoording van de onderzoekswraag geschiedr aan de hand van een bepaald stappenplan. Eerst zal bezien moeten worden hoe het toeziche wordt uitgeoefend op het Nederlandse en op het Amerikaanse effectenverkeer. Vervolgens wordt de positie van de toezichthouders bepaald, waarna de plaats van het strafrecht in de verschillende handhavingsprocedures kan worden verduidelijkt. $\mathrm{Na}$ een analyse van overeenkomsten en verschillen tussen het Nederlands en het Amerikaans effectentypische toezicht kan de vraag worden beantwoord of de toezichthouders, de Autoriteit-FM en de SEC, de handhaving van effectentypische regelgeving alleen aan kunnen of dat zij in bepaalde gevallen toch de hulp van het strafrecht nodig blijken te hebben. Aansluitend wordt bekeken of het strafrecht wel een geschikt middel is om effectentypische wetsovertreders aan te pakken. Hierbij wordt de nadruk gelegd op de gevolgen van een bijkomend effect van het strafrechtelijk traject ofwel een strafrechtelijke procedure, re weten de stigmatisering, voor de desbetreffende verdachte actor uit de effectenwereld. 


\section{De opbouw}

Dit onderzoek is deels inventariserend en deels beschrijvend van aard. Het begint met een introductie in de geschiedenis van de Nederlandse effectenwereld. Dan volgt - in hoofdstuk twee - een inventarisatie van de Nederlandse effectentypische regelgeving en in hoofdstuk drie een inventarisatie van de Amerikaanse effectentypische regelgeving. In beide hoofdstukken wordt de vraag gesteld welke positie de toezichthouder heeft in de rechtshandhaving. Deze vraag richt zich op de wijze van handhaving van de effectentypische regelgeving en de bevoegdheden van de effectentypische toezichthouders. De beantwoording van deze vraag bepaalt de reikwijdte van de (bestuurs) rechtelijke bevoegdheden van de effectentypische toezichthouders. Voorts wordt ook ingegaan op de rol van het strafrecht bij de effectentypische handhaving.

In het vierde hoofdstuk staat de vraag centraal of er overeenkomsten dan wel verschillen zijn tussen het Nederlandse en het Amerikaanse effectentypische toezicht. De vraag wordt beantwoord door de resultaten uit het tweede en derde hoofdstuk met elkaar te vergelijken. Bij deze vergelijking wordt rekening gehouden met de verschillende rechtssystemen en het verschil in invulling van rechtsbegrippen ${ }^{17}$. Via de vergelijking van de bevoegdheden van de toezichthouders kan de vraag worden beantwoord of de toezichthouders, de Autoriteit-FM en de SEC, de handhaving alleén aankunnen of dat zij in bepaalde gevallen toch het strafrecht moeten inschakelen. Deze vraag zal in het vijfde hoofdstuk aan bod komen en zal verduidelijken of ten aanzien van de AutoriteitFM dan wel de SEC de inzet van het strafrecht een noodzakelijkheid is of niet. Daarnaast zal duidelijk worden of het strafrecht wel een geschikt middel is om overtredingen van de effectentypische regelgeving aan te pakken. Deze studie wordt afgesloten met de conclusies die uit dit onderzoek kunnen worden getrokken.

\section{5 \\ Terminologie}

In deze studie worden verscheidene malen termen gebezigd die bij de lezer tot enige verwarring zouden kunnen leiden. Daarom is het van belang om aan te geven welke betekenis hier aan de desbetreffende term wordt toegekend. 


\section{Civiel recht, bestuursrecht en strafrecht - Nederland versus Amerika}

In dit onderzoek zijn de termen administratief recht en bestuursrecht als synoniem voor elkaar gebruikt. Dat dit in het verleden niet ongebruikelijk was bleek uit vroege werken van verschillende staats- dan wel bestuursrechtsgeleerden ${ }^{18}$. Vandaag de dag geven de bestuursrechtsgeleerden de voorkeur aan de hantering van de term "bestuursrechtelijk" boven het gebruik van de term "administratiefrechtelijk". Waar deze studie betrekking heeft op het Nederlands bestuursrecht, zullen dan ook de termen "bestuursrecht" en "bestuursrechtelijk" worden gehanteerd. Waar dit onderzoek zich richt op het Amerikaans recht wordt - indien toepasselijk - aan de term administratief recht vastgehouden, omdat deze term het beste past bij het Amerikaans (rechts)systeem. Verder wordt er - evenals bij de inventarisering van de Nederlandse handhavingsbevoegdheden - in dit onderzoek, bij de bestudering van het Amerikaans rechtssysteem, ook gebruik gemaakt van de begrippen: "civiel recht, administratief of bestuursrecht en strafrecht". De betekenissen die hier aan voornoemde begrippen zijn toegekend, staan niet gelijk aan de betekenissen die in het Anglo-Amerikaanse rechtssysteem aan deze begrippen worden toegekend ${ }^{19}$. In tegenstelling tot het continentale rechtssysteem wordt in het Anglo-Amerikaans rechtssysteem een minder scherpe scheiding tussen het administratief, civiel en strafrecht gehanteerd. Voorbeelden hiervan zijn in hoofdstuk 3 terug te vinden. Zo is het op zichzelf niet bijzonder dat de Amerikaanse toezichthouder, de $S E C$, in de hoedanigheid van zelfstandig bestuursorgaan ${ }^{20}$, als partij in een civiele procedure kan optreden. Wel bijzonder is haar "positie" als civiele partij. Zoals later uit deze studie zal blijken, is in een civiele procedure waar de SEC partij is geen sprake van gelijkwaardige partijen. Zo heeft de SEC niet alleen meer bevoegdheden dan haar tegenpartij, zij kan ook sneller dan haar tegenstander van de civiele rechter verwachten

Stroink, FA.M. en Steenbeek, J.G., "Inleiding in bet stants-en adminismatiefrecht", Samsom H.D. Tjeenk Willink, Alphen aan den Rijn, 1989, $3^{\text {de }}$ druk, p. 15.

Zie ook Roos, Th. de, "Economische mededinging en witteboondencriminaliteit; enkele opmerkingen over de criminalisering wan anti-trust en kartelwetgeving" in de serie strafrecht en criminologie, deel 3, Ars Aequi Libri, Nijmegen, 1984, p. 129 - 148, met mame p. 141 en Jörg, N. "Strafbate rechtspersonen in Amerika", Arnhem, Gouda Quint B.V., 1990.

De SEC is een "administrative agency" (een bestuursorgaan) "free from political acountability" (onathankelith ofwel zelfstandig); Gellhorn, E. en Levin, R.M., Administrative Law and Process in a nutshell, West Group, St. Paul: Minnesora, 1997 , p. 35 e.v. 
dat haar verzoeken worden ingewilligd. Dit vanwege het feit dat de SEC in een civiele procedure een "lichtere" bewijslast heeft. In Nederland kennen wij dit niet. Indien de Autoriteit-FM als partij in een civiele procedure optreedt, zal zij zich ten opzichte van de tegenpartij niet in een uitzonderingspositie bevinden. Beide partijen zullen een zelfde bewijslast hebben. Ook op een ander rechtsgebied blijkt de SEC zich in een andere positie te bevinden dan haar Nederlandse evenknie. Een opvallend verschil is de sanctie "ontneming van het wederrechtelijk verkregen voordeel". In Nederland kan deze maatregel alleen in een strafrechtelijke procedure door de Officier van Justitie worden gevorderd, en wel nadat een veroordeling voor een strafbaar feit heeft plaatsgevonden ${ }^{21}$. In de Verenigde Staten van Amerika is de SEC bevoegd om in een door haar gevoerde administratieve procedure gebruik te maken van de mogelijkheid om wederrechtelijk verkregen voordeel te ontnemen ${ }^{22}$. Meer hierover in hoofdstuk 3.

\section{Financieel (economisch) strafrecht}

Een andere term die verduidelijking behoeft is de definitie van het financieel strafrecht of van het financieel economisch strafrecht. In deze studie worden beide termen gebruikt en hebben hierbij beide dezelfde inhoudelijke betekenis toegekend gekregen. Niet alleen in deze studie maar in de talrijke teksten die de strafrechtelijke handhaving van effectentypische wetgeving beslaan, worden voornoemde termen aangehaald. Daarom is het voor de lezer niet overbodig om te weten welke inhoudelijke betekenis in deze studie aan bovengenoemde termen wordt toegekend. Op het gebied van het financieel (economisch) strafrecht al dan niet in relatie met het ondernemingsrecht hanteren De Roos en Doorenbos, definities die bruikbaar zouden kunnen zijn in deze studie. Wanneer we naar zijn definitie van het economisch strafrecht kijken,

Vgl. art. 36e WvSr.

In een Amerikaanse administratieve procedure dient een ontneming van wederrechtelijk verkregen voordeel of de "Accounting and Disgorgement" gericht te zijn op her herstellen in de rechtmatige toestand. Leedtoevoeging wordt niet beoogd en mag niet bij de toepassing hiervan worden beoogd. Vgl. paragraaf 3.6.1. en 15 U.S.C. $\$ 77 \mathrm{~h}$ (e) of section 8 (e) Securities Act '33; 15 U.S.C. $\$$ $78 \mathrm{u}-2(\mathrm{e})$ of section $21 \mathrm{~B}$ (e) van de Securities Exchange Act; 15 U.S.C. \$80a-9 (f)(5) of section $9(f)(5)$ van de Investmenr Company Act en 15 U.S.C. $\$ 80 b$ $3(\mathrm{k})(5)$ ook wel secrion $203(\mathrm{k})(5)$ van de Investment Advisers Act. 
zien we dat Doorenbos ${ }^{23}$ een onderscheid maakt tussen een formele en een materiële omschrijving. In de formele omschrijving staat de WED centraal en wordr dát tot een economisch delict gerekend wat in artikel 1 WED als delict wordt aangemerkt. De materiële definitie omschrijft Doorenbos alls volgt:

"... het complex van rechtsregels betreffende de strafrechtelijke handhaving van (...) (pseudo) wettelijke voorschriften wan (sociad-)economische aard"

De Roos ${ }^{24}$ houdt een ruimere definitie aan, waarin ook commune valsheids-en bedrogsdelicten tot het economisch strafrecht worden gerekend. In deze studie wordt de voorkeur gegeven aan de definitie zoals De Roos die hanteert. Dit, gezien de praktijk waarin bij overtredingen van de financiële regelgeving naast de in de WED strafbaar gestelde gedragingen, veelvuldig ook strafbare gedragingen zoals omschreven in het commune strafrecht, ten laste worden gelegd. Het financieel economisch strafrecht zou kunnen worden gezien als een samengaan van zowell het financiële strafrecht als het economische strafrecht. Hier wordt niet het ruimere financiële recht bedoeld. Dat laatste kan worden gezien als het genus waarvan het financiële strafrecht als species onderdeel uitmaakt. Zou men het financieel economisch strafrecht gelijkstellen aan het financieel strafrecht ${ }^{25}$, zonder daarbinnen onderscheid te maken, dan zou men het eerstgenoemde met Doorenbos als volgt kunnen definiëren ${ }^{26}$ :

"Onder een financieet-economisch's delict wordt (...) verstatn: de overtreding van een strafrechtelijk gesanctioneerd voorschrift dat bn tot het terrein van het financieel strafrecht moet worden gerekend, én binnen de werkingssfer van de Wet op de Econowisebe Delicten walt".

In deze laatste definitie kan ik mij wel vinden nadat zij iets zou zijn opgerekt. Hier doel ik op maatschappelijk onaanvaardbaar en laakbaar gedrag, dat weliswaar niet speciaal binnen het financieel-economisch

Vgl. Doorenbos, D.R., "Financied Strafrecht; een studie inzake strafrechtelijk gesanctioneende voorschriften wit de bank-en effectenwetgeving", dissertatie KUN, Kluwer B.V., Deventer, 1992, p. 9. poltiveke studie", dissertatie RUU, Gouda Quint B.V., 1987, p. 1 - 3. 
strafrecht als zodanig wordt beschouwd, maar waarvan er wel een maatschappelijke consensus bestaat over de afkeurenswaardigheid ervan. Wanneer dergelijk maarschappelijk afkeurenswaardig gedrag door de creativiteit van het Openbaar Ministerie als een ander strafbaar feit kan worden gekwalificeerd en ook ten laste kan worden gelegd, kan dat ook tot de financieel economische delicten worden gerekend. Een dergelijke overtreding van een strafrechtelijk gesanctioneerd voorschrift kan misschien wel tot het terrein van het financiële strafrecht worden gerekend, maar hoeft bijvoorbeeld niet onder de werkingssfeer van de WED te vallen omdat het bijvoorbeeld is gekwalificeerd als valsheid in geschrifte en tot het commune strafrecht gerekend zou moeten worden. In dat geval zou het buiten de omschrijving van Doorenbos vallen. Ik opteer dan ook voor de toevoeging van het woord "of" in voornoemde omschrijving van Doorenbos zodat het volgende komt te staan: "(..) voorschrift dat én tot bet terrein van het financieel strafrecht moet worden gerekend, én/of binnen de werkingssfeer van de Wet op de Economische Delicten valt."

\section{Het strafrechtstheoretisch kader}

\section{Het strafrecht en het effectentypisch toezicht}

In het inleidend gedeelte is aangegeven dat deze studie zich richt op de bevoegdheden van de bestuursrechtelijke toezichthouders. Desalniettemin wordt het strafrecht in algemene zin $^{27}$ hierbij betrokken. De inzet van het strafrecht geschiedt overwegend - daar waar andere rechtsgebieden onvoldoende werkzaam zijn - als "ultimum remedium", een uiterste redmiddel. Wanneer het strafrecht wordt ingezet, moet worden stilgestaan bij het feit dat het presumptio innocentiae-beginsel van zeer groot belang is. Dit beginsel omvat het uitgangspunt dat een ieder die wordt verdacht van het plegen van een strafbaar feit, voor onschuldig

Er van uitgaande dat het financieel economisch strafrecht, dar bestat uit financieel economische normarieve gedragingen aan de hand wan deze gecriminaliseerde gedragingen wordt beschreven.

Hier wordt bedoeld het strafrecht in het algemeen. Dit houdt zowel het materiele als het formele strafrecht in. Daar waar in deze studie gesproken wordt wan het straf(proces) recht of wan een straf(proces) rechelijke procedure staat het formele strafrecht centraal. 
moet worden gehouden totdat diens schuld wettelijk is bewezen ${ }^{28}$. Met andere woorden, men mag een verdachte niet als schuldig behandelen alvorens de rechter dat heeft beslist. Dat dient tot de implicaties van het inzetten van het strafrecht te behoren. De combinatie van handhavingsbevoegdheden van bestuursrechtelijke toezichthouders en het straf(proces)recht is op het eerste gezicht niet vanzelfsprekend, met name wanneer - zoals nog zal blijken - de effectentypische toezichthouders slechts de bevoegdheid hebben om aangifte van strafbare feiten te doen. Deze aangifte vormt tevens de grens met het strafrecht. In dit onderzoek zal worden aangetoond dat de handhaving van effectentypische regelgeving ook via het strafrecht kan plaatsvinden. Hierbij ligt de nadruk op de gevolgen van het "bijkomend effect" van een strafrechtelijke procedure - te weten de stigmatisering - voor bepaalde verdachten afkomstig uit de effectenwereld.

\section{Het bijkomend effect van het strafrecht}

Met het "bijkomend effect" van het algemene strafrecht, met name de bijbehorende strafrechtelijke procedure, wordt in deze studie gedoeld op bepaalde gevolgen van voomoemde procedure. Een rechterlijke procedure, in het bijzonder een strafrechtelijke procedure, kan verstrekkende gevolgen hebben voor de betrokkenen. Een strafrechtelijke procedure hoort geassocieerd te worden met verdachten en met het Openbaar Ministerie, met dwangmiddelen en rechtsbescherming en tenslotre met bewijs en een rechterlijk vonnis; een vrijspraak of een veroordeling. Men denkt in eerste instantie niet aan een procedure waarbij de (nog te bewijzen) schuld reeds bij aanvang van het onderzoek ter terechtzitting - of zelfs eerder - vaststaat. Een van de grondslagen van het strafrech ${ }^{29}$ is vergelding indien en nádat een rechter dat juist acht omdat hij zich over de zaak heeft gebogen. Het dient er toe om de schuldige te straffen voor het door hem toegebrachte leed. Dit kan pas geschieden nadat de waarheid is gevonden; waarheidsvinding staat dus centraal. Een andere grondslag van her strafrecht is de preventie; misdaad bestrijden door er vanuit te gaan dat het strafrechtelijk optreden van de overheid potentiële wetsovertreders ervan weerhoudt om de wet te 
schenden. Andere grondslagen van het strafrecht $t^{30}$ vertonen alle minstens één overeenkomst. Ze legitimeren de werking van het strafrecht in geval voor een rechter vast is komen te staan dat de verdachte daadwerkelijk het strafbaar feit heeft gepleegd. Alsdan staat de weg naar een eventuele sanctieoplegging open. Veroordeling zonder proces past niet binnen onze rechtscultuur. Desalniettemin komt dit in zekere zin regelmatig voor. Hieronder zal dit worden verduidelijkt.

Verwijzend naar het strafrecht kan worden gesteld dat binnen dat rechtsgebied, anders dan bij het civiel recht en het bestuursrecht het geval is, de stigmatisering grotere gevolgen kan hebben. Al kan een bestuursrechtelijke of een civielrechtelijke uitspraak, net als een strafrechtelijke uitspraak, eveneens leiden tot stigmatisering - denk aan een faillissement of een echtscheiding -, toch kan worden aangenomen dat op het terrein van het algemene strafrecht, specifieker het strafprocesrecht, de stigmatisering eerder kan optreden. Reeds vóór een rechterlijke uitspraak, kan sprake zijn van het opgelegd krijgen van een stigma. Zeker wanneer de media een actieve rol gaat spelen door niet alleen het onderzoek ter terechtzitting nauwlettend te volgen en te verslaan, maar ook de door het $\mathrm{OM}$ eerder verrichte onderzoeken. Juist binnen de financieeleconomische wereld zijn de gevolgen van dit laatste niet onbelangrijk. Binnen de voornoemde wereld is er door interventie van het strafrecht ${ }^{31}$, meer dan in het geval van rechtshandhaving door middel van het bestuursrecht of het civiel recht, sprake van een bijkomend effect, de

Denk naast de eerder genoemde vergelding en preventie aan het strafrecht als mogelijkheid tot sociale controle. Het strafrecht als middel om de maatschappij te "controleren". Dit door grenzen aan te geven waabinnen strafbare gedragingen kunnen plaats winden; her strafrecht als overheidsinstrument. Zie Enschedé, Ch.J., "Beginselen van het strafrecht"; bewerkt door Rüter C.F. en Stolwijk S.A.M., Kluwer, Deventer, $1995,8^{\text {ste }}$ druk, p. 12 . 
stigmatiserende werking ${ }^{32}$ van een strafrechtelijke procedure. Voornoemd effect kan vérstrekkende gevolgen hebben. Gedacht moet worden aan de gevolgen die een strafproces (in ruime zin) kan hebben voor de veroordeelden, maar belangrijker nog: voor de verdachten, in het bijzonder de verdachte actor werkzaam binnen de effectensfeer wiens zaak regelmatig de publiciteit haalt. Strafvervolgingen van effectentypische wetsovertredingen hoeven niet re leiden tot een door het Openbaar Ministerie gewenst resultaat ${ }^{33}$. Niet altijd leiden strafvervolgingen van effectentypische wetsovertreders tot een strafrechtelijke veroordeling. Dit kan het gevolg zijn van problemen omtrent de bewijsbaarheid van de gepleegde feiten. Waar het bij het bijkomend effect van de strafvervolging om gaat is het gegeven dat vooral verdachten uit de financieel-economische wereld via de verdachtmaking in de media, door het publiek kunnen worden "veroordeeld ${ }^{34 "}$ voordat de zaak ter

Volgens $\mathrm{H}$. Bianchi kan stigmatisering als wolgt worden gedefinieerd: "Het verschijnsel dat de samenleving afuigkende individuen op een bepaalde manier zichrbaar en herkenbaar maakt." In ruime zin kan volgens Bianchi onder stigmatilsering in ruime zin ook "enikettering" ofwel "labelling" worden begrepen. Hiermee wordt gedoeld op het "merken" her "aanbrengen van een kenteken" aan individuele personen met als doel deze te categoriseren. Volgens Bianchi is het stigma voor het leven bedoeld; "Eens een dief, altijd een dief". Vgl. Bianchi, H., "Stigmatisering", Kluwer, Deventer, 1971, p. 7 -9, m.n. p. 34 en p. 46. Meer over de criminologische gevolgen van stigmatisering zijn onder andere te vinden in: Lissenberg, E., Ruller, S. van Swaningen, $\mathrm{R}$. van, "Tegen de regels IV; eeva inleiding in de criminologie", Ars Aequi Libri, Nijmegen, 2001, p. $216-217 \mathrm{en}$ p. 231 - 234. Zie ook Levi, M., "Regulating Fraud, white-collat crime and the criminal process", Tavistock publications, London and New York, 1987, p. 327 - 329 waarin Levi het volgende stelt: "Even if people do not lose their formal positions, stigma of some kind may affect their lives, though they may seck to neutralize shame (to themselves and to others) by clatming that they are victims of some establishment conspiracy". Ook Erving Goffman stelt het wolgende: "(...) where are important stigmas, stach as the ones that prostitutes, thicues (...) hate, which require the individual to be carefully secret about bis failing to one class of persons, the police, while systematically exposing bimself to other classes of persons, namely (...) fellow members (...)". Zie Goffman, $\mathbb{E}$, "Stigma, notes on the managemen of spoiled identity", Penguin Books Led., Harmondsworth, Middlesex, England, 1981, p. 93.

Hetzelfde geldt natuurlijk voor de civielrechtelijke en de bestuursrechrelijke procedure.

Met "weroordeeld", wordt hier niet de veroordeling in strafrechtelijke zin bedoeld, maar wordt gedoeld op het gegeven dat het voor het publiek al duidelijk is - dat het al vaststaat - dat de verdachte her strafbare feit heeft gepleegd. Ook al heefr er nog geen onderzoek ter terechrzitting plaatsgevonden. 
terechtzitting is behandeld. Dit stigmatiserend (bijkomend) effect van een strafrechtelijke procedure, weegt extra zwaar in financieel-economische strafzaken ${ }^{35}$ en kan in de financiële wereld direct leiden tot: "(..) schade van een ongekende orde: miljoenenverlies door weglopen wan opdrachtgevers of afgedwongen overnames, ontslag, definitieve uitstoting wit de branche, gebroken relaties en reputaties ${ }^{1136}$. Aldus Baauw in zijn oratie. Baauw bespreekt de inhoud van een eerlijke berechting en meent dat een eerlijke berechting - vooral in financiële fraudezaken - niet samengaat met een openbare behandeling van de zaak omdat dit de verdachten veel schade kan berokkenen. Het strafproces stigmatiseert ook in financieel-economische zaken. De mate van stigmatisering wordt onacceptabel wanneer de verdachte, wiens schuld nog vastgesteld en bewezen moet worden, door een overvloed aan media-aandacht een brandmerk, een stempel, krijgt opgedrukt alvorens een rechter zich over de zaak heeft kunnen buigen. Hierdoor wordt de naam van de desbetreffende persoon voor (zeer) lange tijd gekoppeld aan de gedachte dat er "iets niet pluis is". Binnen de financieel-economische wereld, een wereld gebaseerd op naamsbekendheid en vertrouwen, kan deze stempel lang doorwerken. Bianchi meent dat het hebben van een stigma vaak een "veel erger en fruikender effect (...)" heeft "dan welke vrijheidstraf ook". Voorts kan volgens Bianchi "een aangebracht stigma levenslang duren" 37 . Dit kan, juist binnen de effectenwereld, schadelijk werken waar "de goede naam" van een (rechts)persoon zijn voornaamste bron van

Vanzelfsprekend speelt stigmatisering altijd. Zo heeft het stigmatiserend effect van een strafproces ook zijn uitwerking op een verdachte die zich niet binnen de financiële wereld bevindt. Ook de melkboer in de strat of de werkloze buurman, dan wel de thuiswerkende huiswrouw zal als verdachte in een strafproces an den lijve ondervinden war de gevolgen van dat proces en de gehele procedure zijn. Zodra het naar buiten komt dat iemand verdacht wordt van een strafbaar feit begint de lekenwijsheid naar voren te treden. Door het (niet door mij aangehangen) uitgangspunt "waar rook is, is vuur", wil men er in het algemeen al snel wanuit gaan dat het strafrechtelijk onderzoek door het OM wel terecht zal zijn. Hetgeen de verdachte reeds brandmerkt. Maar omdat dit onderzoek zich niet richt op de voornoemde personen, maar op de (rechts)personen werkzaam binnen de effectenwereld, bekijk ik de werking van een strafrechtelijke procedure op laatstgenoeinden. Hiermee wil ik niet ontkennen dar ook de gewone burger kan lijden onder de stigmatiserende gevolgen van een strafrechrelijke procedure.

Baauw, P.., "Eerlijke berecheing en bijzonder straf(proces) recht", oratie RUU, Gouda Quint, Deventer, 1999, p. 24. 
inkomsten is. Immers, (potentiële) beleggers - die zich richten op het kunnen vertrouwen van anderen - willen niet in zee gaan met een persoon of een onderneming die mogelijk onbetrouwbaar is. Het gegeven dat het Openbaar Ministerie onderzoek (heeft) verricht naar de desbetreffende organisatie kan voor sommige beleggers genoeg zijn om niet in een dergelijk fonds te beleggen. Dit kan zelfs leiden tot, en zoals hieronder zal blijken is dit niet onaannemelijk, een situatie waarin de desbetreffende verdachte personen ontslagen dan wel in geval van rechtspersonen, ontbonden kunnen worden. Of het strafrechtelijk onderzoek achteraf terecht was of niet, doet er uiteindelijk niet meer toe. Het leed is dan al geschied. Men is zijn "goede naam" kwijt en kan niet meer - al dan niet onder de eigen naam - werkzaam zijn binnen de effectenwereld ${ }^{38}$. Dit laatste is voor dit onderzoek van groot belang. Te wijzen valt op de HCS-zaak ${ }^{39}$ In deze zaak is de naam van de verdachte dusdanig bezoedeld geraakt, dat deze door zijn werkgever is ontslagen. Wanneer men vandaag de dag de naam van de toenmalige verdachte hoort, valt niet te ontkennen dat zijn naam gekoppeld wordt de HCS-zaak, ondanks de vrijspraak. Ook de Clickfondszaak kan ter illustratie dienen om de stigmatiserende werking van het straf(proces)recht - binnen de effectensfeer - aan te tonen ${ }^{40}$. In deze zaak, de eerste grote zaak waarin het Openbaar Ministerie zijn schijnwerpers op de effectenbeurzen en de handelaren op deze beurzen richtte, zien we dit verschijnsel - al dan niet in sterkere vorm - voorkomen. Via de media die al vanaf het eerste ogenblik verslag deden van de handelingen van het Openbaar Ministerie, kreeg het publiek het beeld voorgeschoteld dat het Openbaar Ministerie verschillende malafide actoren op het spoor was. Het Openbaar Ministerie suggereerde een structurele fraude op de beurs. Deze effectenhandelaren, vermogensbeheerders en tussenpersonen werden onder meer vervolgd

Zowel de eerder genoemde melkboer dan wel de letaar of de thuiswerkende huisvrouw kunnen verhuizen naar een andere wijk of werken op een andere school en zo weer een bestaan opbouwen, zonder dat men hoeft te weten dat hij of zij verdacht is geweest van een strafbaar feit. Waar de effectenhandelaar of ieder andere persoon werkzaam binnen de effecrensfeer ook wil werken, zijn naam draagt hij overal mee en dat maakr het hem dan ook moeilijk om een nieuwe betreklking te vinden of om een nieuw klantenbestand op te bouwen. HR 27 juni 1995 , NJ 1995, 662.

(9) Niet gepubliceerde uitspraak van de arrondissementsrechrbank Amsterdam d.d. 22 juni 2001 inzake Leemhuis \& Van Loon Vermogensbeheer B.V., parked/ zaaknummer: $13 / 129200-97$. 
wegens vermeende strafbare feiten zoals eerder genoemd aan het begin van deze inleiding. Daarnaast vervolgde het Openbaar Ministerie de desbetreffende (rechts) personen ook voor overtredingen van de belastingwetgeving. Uiteindelijk bleek vier jaren later dat het "slechts" ging om structurele belastingfraude; eveneens laakbaar gedrag, maar niet gebonden aan de effectenbeurs. Het Openbaar Ministerie had moeite om het bewijs sluitend te krijgen. Dit lag niet alleen aan de redactie van de wetsartikelen, maar ook aan de wijze waarop het Openbaar Ministerie aan her bewijs heeft willen komen ${ }^{41}$. Ondertussen waren de door het Openbaar Ministerie vervolgde (rechts) personen constant in het nieuws. Dit had tot gevolg dat niet alleen personen uit hun functies werden ontheven, zoals verschillen commissarissen van het verdachte effectenhuis Leemhuis \& Van Loon vermogensbeheer B.V., maar dat ook bedrijven er schade van ondervonden. Dit alles voordar de rechter uitspraak in de zaak had gedaan. In een voor het Openbaar Ministerie pijnlijk en vernietigend vonnis verklaarde de arrondissementsrechtbank te Amsterdam het Openbaar Ministerie in de zaak tegen het voormalige effectenhuis Leemhuis \& Van Loon Vermogensbeheer B.V. niet-ontvankelijk in zijn

Om inzage te krijgen in bepaalde Zwirserse dossiers heeft het Nederlandse Openbaar Miniserie, zeer waarschijnlijk, de naam wan de vermeende drugshandelar Johan V. alias 'De Hakkelaar' misbruikc en gekoppeld aan een verdachre in de Clickfondszaak om zodoende de hulp wan de Zwitserse Justitie af te dwingen. Zwitserland wil namelijk slechts onder bepaalde woorwarden arn een verzoek tot het verlenen van rechtshulp meewerken. Zo zal dat land niet meewerken aan onderzoek naar feiten die niet strafbaar gesteld zijn in Zwirserland. Een voorbeeld hierwan is "frontrunning". Verder zal Zw"itserland ook niet meewerken aan onderzoek naar ontduiking wan de Nederlandse belastingen. Door het hier nier over te hebben, maar door een beeld te creèren dat een verdachte in de Clickfondszaak, te weten Dirk de G., gelden afkomstig uit de drughandel (zie Johan V.) in Zwitserland had ondergebrachr, heef her O.M. inzage kounnen krijgen in financiële stukken van Dirk de G. Over deze handelwijze van het O.M. is zowell in de media als bij de verdediging heel veel ophef ontstaan. Zelfs de rechtbank heeft zich in een zeer wernietigend wonnis negatief uirgelaren over woornoemde handelwijze van het OM. Zie het niet gepubliceerde wonnis van de arrondissementsrechtbank Amsterdam d.d. 22 juni 2001 inzake Leemhuis \& Van Loon Vermogensbeheer B.V. parket/zaaknummer: 13/129200-97 en Oranje. I." "De Hakkelatr" als breekijzer", NRC-Handelsblad, d.d. 11 november 2001. 
vervolging tegen de verdachte betreffende het Clickfondsonderzoek ${ }^{42}$. Dit, omdat het onzorgvuldig optreden van het Openbaar Ministerie volgens de rechtbank niet alleen onnodig de belangen van Leemhuis \& Van Loon, maar ook van het personeel en wan de aandeelhouders "aanzienlijke schade" heeft aangericht. De Officier van Justitie had niet "uiterst behoedzaam" opgetreden terwijl "met name het voortbestaan van de onderneming van Leemhuis \& Van Loon B.V. op het spel" stond ${ }^{43}$. Het Openbaar Ministerie had volgens de rechtbank, op grond van het in het vonnis beschreven patroon van onzorgvuldigheden, zowel schade toegebracht aan verdachte als aan de strafrechtspleging in het algemeen. Hierdoor:

"moet worden gesproken van ernstige inbreuken op de beginselen van behoorlijk procesrecht, watudoor met grove veronachtzaming van de belangen van de verdachte aan diens recht op een cerlijke behandeling van zijn zaak is tekortgedaam. Dit brengt mee dat de offrier van justitie - in ieder geval ten aanzien van een deel van de op de daguadrding wermelde feiten - niet ontwankelijk is in zijn vervolging watn verdachte (...) ${ }^{4}$.

In een daarna volgend persbericht van het Openbaar Ministerie, gaf de voorzitter van het College van PG's J.L. de Wijkerslooth het volgende aan:

"... het publicitaire optreden van bet $O M$ in deze zaak is ongelukkig geweest. Tot die conclusie udren we zelf al gekomen en bet vonnis heefi dit nog eens bevestigd. Natuurlijk trekken wij ons die kritiek aan. Het OM moet in dit soort onderzoeken absoluut veel terughoudender met de pers communiceren".

Ten aanzien van de ten laste gelegde feiten betrekking hebbende op de ontduiking van loonbelasting en op het valselijk opmaken van alstes werd het Openbalar Münisterie wél ontvankelijk verklaard. Vergelijk rechtsoverweging 2.2 .6 in her vonnis de arrondissementsrechtbank Amsterdam d.d. 22 juni 2001 inzake Leemhuis \& Van Loon Vermogensbeheer B.V., parket/zaaknummer: 13/12920097.

Zie onder overweging B. 7 van het wonnis van de niet gepubliceerde uitspraak van de arrondissementsrechtbank. Amsterdam d.d. 22 juni 2001 inzake Leemhuis \& Van Loon Vermogensbeheer B.V., parket/zaaknummer: 13/129200-97.

Niet gepubliceerde uitspraak van de arrondissementsrechtbank Annsterdam d.d. 22 juni 2001 inzake Leemhuis \& Van Loon Vermogensbeheer B.V., parket/ zaaknummer: 13/129200-97. 
Vervolgens gaf De Wijkerslooth aan dat: "het werk van het OM altijd nieuws zal zijn. Het OM houdt zich eenmaal bezig met zaken die de aandacht trekken, die dicht bij de mensen liggen ${ }^{45}$." Waar terughoudendheid in strafzaken ooit de norm was ${ }^{46}$, is dat het nu veel minder. Niet alleen het $\mathrm{OM}$, dat via de instelling van een persofficier in steeds meer strafzaken commentaar verschaft, maar ook de media trekken zich minder an van dat wat ooit de norm was ${ }^{47}$. Dit alles versterkt de gedachte dat er stilgestaan dient te worden bij het stigmatiserend effect van het straf(proces) recht, met name de strafrechtelijke procedure, in een wereld waar de goede naam noodzakelijk is om effectief als actor op te kunnen treden binnen de sfeer van aandelen, obligaties en of derivaten ${ }^{48}$.

Voornoemd bijkomend effect van een straf(proces)rechtelijke procedure, het stigmatiserend effect, komt men niet snel tegen in een bestuursrechtelijke of een civielrechtelijke procedure. Een ingetrokken vergunning of een opgelegde bestuurlijke boete dan wel de oplegging van een stille curatele of de vereffening van een beleggingsfonds, haalt zelden de voorpagina van de landelijke dagbladen en is geen item van het NoS journaal. Ook al leidt cen strafproces niet altijd tot een veroordeling, vaak is het kwaad al geschied door de persconferentie waarop bijvoorbeeld de doorzoekingen van woningen of bedrijven bekend worden gemaakt. De verdachte is dan al negatief in de publiciteit gekomen. Deze reputatieschade komt in de wereld van de effectenhandel extra hard aan.

Resumerend: juist op her terrein van het effectentypische toezicht heeft het straf(proces) recht niet altijd een direct, maar bijna steeds een heftig bijkomend neveneffect. Dit laatste, zoals we uit onder andere de HCSzaak en de Clickfondszaak hebben kunnen opmaken, heeft op de betrokken actoren een enorme impact. Wat kan dit zogenoemd "bijkomend effect", dit "neveneffect" binnen de effecrenwereld voor de desbetreffende verdachte betekenen en sluit dit aan bij de bedoeling van het strafrecht? Aan de hand van een korte bespreking van verschillende

Persbericht Openbaar Ministerie, d.d. 6 juli 2001.

Denk aan het gegeven dat er in beginsel geen achternamen van verdachren, dan wel geen foto's werden afgebeeld.

47 Was het jaren geleden nog zo dat de foto wan de veroordeelde Ferdi $\mathrm{E}$. met cen zwarte balk voor zijn ogen in een weekblad werd gepubliceerd, vinndaag de dag wordt een foto van de verdachte Volkert van der $G$. zónder zwarte balk voor zijn ogen afgedrukt in een weekblad.

Derivaten zijn afgeleide financiële producten zoals opries. 
strafrechtstheorieën zullen deze vragen hieronder marginaal aan bod komen om vervolgens in her vijfde hoofdstuk integraal te kunnen worden behandeld.

\section{Strafrechtstheorieën en het bijkomend effect van het straf(proces) recht}

Wanneer de uirgangspunten van het strafrecht nader worden bestudeerd, kan niet van een éénduidige visie worden gesproken. Door de eeuwen heen hebben vele strafrechtsgeleerden zich over het (bestaans) recht van het strafrecht gebogen. De meningen van de geleerden verschilden; zoveel geleerden, zoveel meningen. Zo bestudeerden geleerden zoals Fichte, L. Polak, A.C. 't Hart en A.A.C. Peters het straffen door de overheid en trokken hieruit hun conclusies.

In dit onderzoek is het zaak om aansluiting te zoeken bij strafrechtstheorieën die binnen de lijnen van deze studie passen. Via drie vragen wordt gezocht naar de theoretische denkrichting binnen het strafrecht die her beste aansluit bij een strafrechtelijke handhaving van effectentypische wetgeving. Daarbij zullen voornoemde bijkomende effecten van dit rechtsgebied, te weten het strafrecht als schandpaal, tegen de achtergrond van de desbetreffende strafrechttheorie worden geplaatst. De vragen waar naar wordt verwezen zijn: dient het strafrecht behalve een grondslag ook een doel ${ }^{49}$ te hebben? Zo ja, reikt dit doel verder dan alleen het straffen; is het niet alleen punitief? En tor slot: welke rol vervult de rechtsbescherming?

\subsection{Het oogmerk van een strafrechisleer}

Tot de grondslagen van het strafrecht behoren onder meer de vergelding en de preventie. Deze grondslagen mogen niet ongelimiteerd tot uiting komen. Dat zou het geval zijn indien het her strafrecht aan een doel zou ontbreken. Immers, men kan als wetgever menen dat de overheid strafrechtelijk moet optreden tegen bepaalde gedragingen en daardoor het overheidsoptreden legitimeren, maar dan moet dat wel geschieden binnen de wettelijk gecreëerde grenzen. Zo niet, dan zouden wij vier eeuwen 
terug in de tijd belanden, namelijk in de periode waarin de axiomatische rechtsleren - de natuurlijke of de wilstheorieën - hoogtij vierden. Een kenmerk van deze theorieën is immers het ontbreken van een specifiek doel. De toepassing van het strafrecht, het opleggen van sancties, werd puur gelegitimeerd door de begane overtreding. Wat de straf tot gevolg had was niet van belang. De overtreder moest boeten omdat de straf alls voorwaarde gezien kon worden voor het begaan van het delict ${ }^{50}$. Vandaag de dag zou een dergelijke strafrechtstheorie niet meer worden geaccepteerd. De overheid mag niet lukraak sanctioneren puur omdat een bepaalde regel is overtreden. Dat de overheid mag straffen wordt over het algemeen wel geaccepteerd ${ }^{51}$, maar dat straffen moet dan wel een doel hebben; ergens toe leiden.

De door Fichte aangehangen verdragstheorie relativeert de hiervoor genoemde natuurlijke- of wilstheorie. Fichte's aangehangen theorie is ook gebaseerd op het "wrijwillig onderling gesloten maatschappelijke verdrag" dat burgers hebben aanvaard, maar gaat een stap verder. Schending van het verdrag heeft inderdaad bestraffing tot gevolg. De burger heeft 'recht' op bestraffing om niet als oursider buitengesloten te blijven, maar om weer binnen de maatschappij opgenonen te worden. Deze door Fichte aangehangen leer lijkt weliswatar niet aan een doel te ontbreken. Her doel van her strafrecht is in deze dan ook om tot de gemeenschap te kumnen blijwen behoren. Vgl. Remmelink, J., "Mr. D. Hazewinkel-Suringa"s Inleiding tot de studie van bet Nederlandse strafrecht" Deventer, Gouda Quint, $1996,15^{\text {de }}$ druk, p. 892. Zie ook Ensched., Ch. I., "Beginselen wan bet strafrech"; bewerkr door Rürer C.F. en Stolwijk S.A.M., t.a.p. noot 30, p. 11.

Met uirzondering van natuurlijk de abolitionisten die vinden dat de overheid geen enkele rechtwaardiging heeft om te straffen. Immers, (vrijheids)straffen "werken toch niet". Enkele rechtsgeleerden mer een abolitionistische visie zijn: Hulsman, L.H.C. mer medewerking wan Bernat de Celis, J. en Smits, H., "Afscheid van het strafrecht: een pleindooi voor zelfregulering", Het Wereldvenster", Houten, 1986, p. 79 - 81. Buanchi, H. en Swaaningen R. van, "Abolitionism: rowards a non-repressive approach to crime: proceedings of the second international conference on prison abolition Amsterdam 1985 uit de serie: Jurid"sche reeks Vrije Universiteit; nr. 3", Amsterdam, 1986, Free University Press, p. 13 e.w. en Meijer-Wichmann, C., "Tegen de heerschende opvattingen omrrent misdaad en straf, uit: uitgave van her Comite van Actie tegen de bestaande opvattingen omtrent Misdaad en Straf", Rotterdam, 1924, $3^{\text {de }}$ druk, P. 5 - 8. Meer over bovengenoemde auteurs in 0.a.: Remmelink, J." "M*. $D$. Hazewinkel-Suringa's Inleiding tot de studie van bet Nederlandse strafrecht". Deventer, Gouda Quint, 1996,15 druk, p. 914 - 916 en in Jörg, N. en Kelk C., "Strafrecht met mate", Samsom H.D. Tjeenk Willink, Alphen aan de Rijn, $2001,11^{\text {the }}$ druk, p. $370-372$. 


\subsection{De reikwijdte van een strafrechtelijk doel}

Nu duidelijk is dat het strafrecht een doel moet hebben met een maatschappelijk draagvlak, is het van belang te weten wat dit inhoudt. De volgende vraag die aldus moet worden beantwoord luidt als volgt: "Reikt dit doel verder dan alleen bet straffen; is het niet alleen punitief." Door deze vraag positief te beantwoorden kunnen bepaalde rechtstheoretische visies worden uitgesloten. Dat zijn de visies die behoren tot de absolute theorieën. Deze theorieën, welke binnen de literatuur tot de klassieke richting worden gerekend, zijn gericht op de vergelding en worden ook wel vergeldingstheorieën genoemd. Kenmerkend voor deze klassieke denkrichting binnen het strafrecht is dat men de oplegging van een straf inherent acht aan de overtreding van de rechtsregel; de daad wordt bestraft ${ }^{52}$. Binnen de vergeldingstheorie is het resultaat, het gevolg, van de op te leggen straf niet van belang. De staat hoort op te treden, te bestraffen omdat er een delict is gepleegd: "voor wat, hoort wat". Een bekende rechtsfilosoof die door enkele critici wel ${ }^{53}$ en door anderen niet ${ }^{54}$ tot aanhanger van de absolute theorie wordt gerekend, is Leo Polak. Deze Groningse hoogleraar kan niet gezien worden als een aanhanger van de pure absolute leer, maar eerder alls een "mediaan" russen de absolute theorie en de hierna te bespreken relatieve theorie ${ }^{55}$.

Vgl. o.a.: Remmelink, J., "Mr. D. Hazewinkel-Suringa's Inleiding tot de studie wan bet Nederlandse straffecht", Deventer, Gouda Quint, 1996,15 druk, p. 48, 891.

Vgl. Enschede, Ch.J., "Beginselezt van het strafrecht"; bewerkt door Rüter C.F. en Stolwijk S.A.M., ta.p. noot 30, p. 11.

Vgl. bijvoorbeeld Remmelink, J., "Mr. D. Hazewinkel-Suringrs'snleiding tot de studie van bet Nederlandse strafrecht", Deventer, Gouda Quint, 1996, 15 ${ }^{\text {ue }}$ druk, p. 898 , noot 1 .

Polak meende dat het wezenlijke wan de vergeldingstheorie niet te vinden was in her feit dat "vergelden moet omdat de dader's voordeel van het gepleegde misdrijf weggenomen moet worden". Hij geloofde dar de dader een "objectieve" plaats toegekend dient te worden. Dat houdt niet in een plats tegengesteld aan die van her slachtoffer (slachtoffer - dader), maar een plaats waarvan de maatschappij, de rechtsorde meent dat deze hem toekomt. Vgl. de oratie van Polak warin hij de leer van Hegel beschrijf. Dir; mede aan de hand van werken van anderen die de absolutistische visie aanhangen zoals Stahl, en Kant. Zie Polak, L., "Hegel's leer der straf": oratie Rijksuniversiteir Leiden, J. Emmering, Amsterdam, 1925, p. 5, 11 en met name p. 22. RUU, Kluwer, Deventer, 1972, p. 7, 17 en 18. 
De reeds aangehaalde relatieve theorieèn verschillen van de absollute doordat zij beogen dat het doel van de straf verder reikt dan het bestraffen op zichzelf. $\mathrm{Zij}$ worden ook well "doeltheorieèn" of "functionele theorieën" genoemd, omdat de oplegging van de straf gerelateerd is aan een doel, zoals de generale of de speciale preventie. Hier past naar mijn mening de visie van Polak beter. Immers, hij was onder meer gevoelig voor het gevolg van het straffen. Berouw, spijt van de dader zijn termen die volgens Polak invloed mochten hebben op de op te leggen straf ${ }^{56}$. De overheid, die volgens de relatieve leer een beschermende taak voor de burger heeft, hoopt - door te dreigen met een "nuttig", "geschikt" of een "effectief" middel - potentiële wetsovertreders af te schrikken en haar rechtsgoederen te beschermen. Dit kan geschieden via speciale of via generale preventie. Bij speciale preventie, een strafdoel dat niet wordt gerekend tot de klassieke maar tot de moderne richting binnen het strafrecht ${ }^{57}$, staat de invloed van de straf op de dader centraal. Getracht wordt om de dader te verbeteren. In de richting die een generalle preventie beoogt; wordt ervan uitgegaan dat de in het individuele geval op te leggen straf zijn uitwerking ook heeft op de hele maatschappij; een algemene afschrikkende werking. Over de vraag of deze "afschrikking" helpt, bestaat onder de aanhangers van deze straftheoretische richting geen consensus. Als het gaat on afschrikking door strafbedreiging zal deze - volgens critici - niet de uitwerking hebben die de overheild beoogt. Om "uirholling" van rechtsnormen te voorkomen is immers de handhaving, de oplegging van straf vereist ${ }^{58}$. Het strafrecht dient derhalve behalve een grondslag ook een doel te hebben en dat doel, dat verder moet reiken dan alleen het straffen op zich, moet effecrief zijn. De opvattingen van de absolute en de relatieve theorieën hebben zich verenigd in de zogenoemde "verenigingstheorie" of de "gemengde theorieën". Deze theorieën passen beter in de huidige tijd, omdat naast

Vgl. Polak, "Hegel's leer der straf: oratic Rijksuniversiteit Leiden", t.a.p. noot 55, p. $19-21$.

Vgl. o.a.: Remmelink, J., "Mr. D. Hazewinkel-Suringa's Inleiding tot de studie

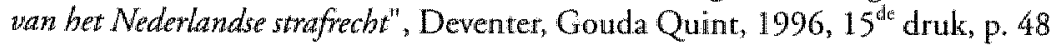
-52 en p. 891. 
de grondslag wan het strafrecht het doel van belang is 59 . De nadruk op vergelding dient in deze optielk niet te star te worden opgevat. Indien er mitigerende redenen en omstandigheden zijn dient de rechter in de gelegenheid te worden gesteld deze mee te laten wegen bij de oplegging van een straf. De op te leggen straf dient mede bepaald te worden door een evenredigheid aan leed toevoeging; namelijk zoveel als nodig is om de rechtsorde te handhaven.

In de hiervoor geplaatste opmerking dat de oplegging van een straf evenredig moet zijn aan het toegebrachte leed, huist de gedachte dat de burger miet als "speelbal" van de overheid gezien mag worden. Hoe kan men dat controleren? Dit brengt ons bij het laatste criterium: de rechtsbescherming.

\subsection{Het strafrecht en de rechtsbescherming}

Omdat rechtsbescherming inherent is aan het strafrecht, met name het strafprocesrecht, gezien de zwakke positie van de verdachte burger tegenover de machtige staat ${ }^{60}$, moeten in dit verband daarover enkele opmerkingen worden geplaatst. Het hiervoor besproken bijkomend effect, te weten het stigmatiserend effect van een strafrechtelijke procedure dat vooral de effectentypische verdachte juist daar treft waar hij het meest kwersbaar is en bescherming behoeft, versterkt de behoefte aan enige vorm van rechtsbescherming. Via de toepassing van de derde en laatste vraag zal worden bekeken of het eerder in paragraaf 7 besproken bijkomend effect van een strafrechtelijke procedure, de stigmatisering, wel past binnen de strafrechtelijke handhaving van effectentypische wetsovertreders gezien de bestaande strafrechtstheorieën.

\section{Welke rol vervult de rechtsbescherming?}

De verdachte moet in de gelegenheid worden gesteld om zich te verweren, want zijn schuld moet nog bewezen worden. De eerder geconstateerde

Deze gedachte word versterkt door de beleidsnota 'sancties in perspectief', een uitgave van het Ministerie van Justitie, waarin wordt uitgegaan van de verenigingstheorie. Zie de Ministerie van. Justitie, "Sancties in perspectief", Sidu, februari 2000, p. 25.

(60) Zie ook Reijncjes: "De essentie van het strafprocesrecht ligt juist in de bescherming wan de burger tegen (onjuist gebruik van) de stantsmacht bij de toepassing van bet strafrecht" Reijntjes, J.M., "Mr A. Minkenhof, de Nederlandse Strafvordering", Dewenter, Kluwer, 2002, $9^{\text {de }}$ druk, p. 1. 
ongewenste effecten van een strafrechtelijke procedure, die inhouden dat de verdachte - bijvoorbeeld door de berichtgeving in de media reeds veroordeeld lijkt te zijn voordat zijn zaak aan de beslissende rechter is voorgelegd, zijn volgens diverse auteurs in strijd met nationale wetgeving en internationale verdragen ${ }^{61}$. Strafrechtstheoretische denkrichtingen waar de rechtsbescherming van de verdachte centraal staat en waar het strafrecht niet puur als stuurmiddel wordt gezien leggen de nadruk niet zozeer op het materieel strafrecht, maar op het formele strafrecht. Immers, tijdens de strafrechtelijke procedure, het strafprocesrechtelijk traject, zal de verdachte de kans moeten krijgen om zijn rechten uit te oefenen. In dit verband moet vooral de benadering van A.A.G. Peters en zijn volgelingen, "de Neo-Utrechtse school62", worden genoemd. In de visie van Peters speelt de rechtsbescherming en de hierbij

Genoemde effecten zijn bovenal in strijd met her vermoeden van onschuld, thet presumptio innocentiae-beginsel, dat af te leiden is uir enkele artikelen van ons werbock van strafvordering, maar daarnast direct vermeld staat in het EVRM. Zo kan uit bijvoorbeeld artikel 271 lid 2 WvSy worden afgeleid dat de rechters ter terechtzitting het presumptio innocentiae-beginsel in acht moeten nemen. Dit artikel luidt als wolgt: "Noch de voorzitter, noch een der rechters geeft op de terechtzitting blijk van enige overtuging omtrent schuld of onschuld van de verdachte". Verder is het presumptio innocentiae-beginsel duidelijk weergegeven in artikel 6 lid 2 EVRM dar als volgt luidt: "Eenieder tegew wie een vervolging is ingesteld, wordt voor onschuldiggehouden totdat zijn schuld in rechte is komen vast te statu." Ook in artikel 14 lid 2 van het IVBPR is voornoemd beginsel neergelegd: "Een ieder die wegens een strafbata feit wordt vervolgd, wordt woor ownchuldig gebouden, totdat zijw schuld wolgens de wet is bewezen". Nast de verschillende wets- en verdragsartikelen blijkt het presumptio innocentiaebeginsel ook uit de jurisprudentie zoals uit de zaak Minelli ws. Zwitserlland, EHRM 25 maart 1983, NJ 1986,698 met noot van E.A. Alkemat en uit de zaak Barbeta, Messegue en Jabardo ws. Spanje, EHRM 6 december 1988, Series A, ne. 146 .

Volgens C. Kelk en N. Jörg, is het Peters geweest die via zijn oratie een nieuwe denkwijze invoerde en daarmee de Utrechtse school nieuw leven "in blies" tot de neo-Utrechtse school. In de Utrechtse school staat de mens achter de dader centraal. Vg1. Jörg, N. en Kelk C., "Strafrecht met mate", Samsom H.D. Tjeenk Willink, Alphen aan de Rijn, 2001, $11^{\text {de }}$ druk, p. 8 - 10. Idem Remmelink, J., "Mr. D. Hazewinkel-Swringa"s Inteiding tor de studie van het Nederlandse strafrecht", Deventer, Gouda Quint, 1996, 15 druk, p.912-913. De neo-Utrechtse school richt zich meer op de rechtsbescherming van de verdachte in her strafprocesrecht. De aanhangers van deze richting zoals G. Mols, T. Prakken en T. Spronken, concentreren zich meer op de werdediging en de limitering van de overheidsmacht (zie bijwoorbeeld de dissertatie wan T. Spronken: "Verdediging": Spronken, T., "Verdediging, een onderzoek natr de normering van bet optreden wan advocaten in het strafrecht", dissertatie UM, Gouda Quint B.V., 2001). 
behorende (straf)rechtsbeginselen een belangrijke rol ${ }^{63}$. Peters was erg kritisch over de macht van de overheid (het machtskritisch denken). Hij duidt in zijn oratie "Het rechtskarakter van het strafrecht", aan dat het specifieke van het (straf)recht niet moet worden gezocht in diens functies van misdaadbestrijding en/of ordenings-, controle- dan wel probleemoplossingsfuncties. Deze functies behoren volgens Peters tot de "profane sfeer". Hiermee wil hij zeggen dat voornoemde functies, "natuurlijk en relatief onproblematisch" zijn en in beginsel in iedere samenleving voor dienen te komen. Het tegendeel is onvoorstelbaar. Het specifieke van het (straf)recht moet volgens Peters eerder worden gezocht in de secundaire controle. Dat houdt volgens hem het volgende in: "het normeren van de maatschappelijke controle zoals die min of meer spontaan groeit of wordt gesteld door de staat en andere machthebbers" Kortom, het strafrecht heeft volgens Peters, meer nog dan het overige recht, de juridische taak om de staat en de andere machthebbers te controleren en niet in eerste instantie om de maatschappij te normeren of te controleren. Hij heeft het hier over "policing the police".

Wanneer we deze visie toepassen op de werking van het strafrecht op het terrein van het effectentypische toezicht, dan lijkt Peters'visie hier vooralsnog niet bij te passen. Immers, Peters richt zich meer op het controleren van de controleurs, van de toezichthouders en de andere uitwoerders en niet in eerste instantie op de wetsovertreder zelf tenzij het om diens rechtspositie gaat. In dat geval stelt Peters het belangrijk te vinden dat de wetsovertreder, in de ontwikkeling die de beleidsmatige doelstelling van de staat tracht te verwezenlijken - zoals het tegengaan van criminaliteit - in een contradictoir strafproces, de gelegenheid. wordt geboden om zich te verdedigen. Immers, een kritische evaluatie van de feiten; de bescherming van de vermeende rechtsovertreder tegen de stat en de mogelijkheid tot het scheppen van recht zijn volgens Peters de belangrijkste functies van een contradictoir strafproces. Bij deze opsomming ontbreekt datgene wat juist bij de handhaving van effectentypische regelgeving kan worden geconstateerd. Binnen de effectensfeer kan juist de dreiging van een strafproces of kunnen de gevolgen van een strafrechtelijke procedure al fataal zijn. Effectenhandelaren of andere actoren die zich binnen de sfeer van het effectenverkeer bevinden, kunnen door voornoemde dreiging worden getroffen in dat wat juist het 
belangrijkste is binnen de effectenwereld: hun "goede naam" en "betrouwbaarheid". Beschadiging van een goede naam of de afkalving van hun betrouwbaarheid vindt voornamelijk plaats in de fase voorafgaand aan het onderzoek ter terechtzitting, nog voordat hun eventuele strafrechtelijke schuld is bewezen.

Bij de handhaving van de effectentypische wetgeving is de directe werking van het strafrecht, - de veroordeling en of de mogelijkheid om reeds in een vroeg stadium dwangmiddelen in te zetten - niet de grootste dreiging voor de verdachte (van effectentypische wetsovertredingen). Uitgaande van de visie van Peters is de rechtsbescherming van de (rechts) persoon, zeker wat betreft de fase voorafgaand aan het onderzoek ter terechtzitting, van groot belang. Immers, ook de opsporingsfase kan ter terechtzitting onderwerp van discussie zijn. Een dergelijke discussie kan gevolgen hebben voor de resultaten van het onderzoek ter terechtzitting ${ }^{64}$. Rechtsbescherming begint niet met het uitroepen van een zaak. Hoe anders de "controleurs" te controleren wanneer de gehanteerde werkwijze niet kan worden bekritiseerd? Juist deze voorfase is niet altijd even doorzichtig. Daarom is het van belang dat de verdachte tijdens het gehele proces waarin hij onderwerp van onderzoek is, een beroep kan doen op de hem toekomende rechten.

\section{Het strafrecht als instrument}

Her instrumentalisme, de visie waarin het strafrecht puur als instrument wordt beschouwd om de door de overheid gestelde doelen te bereiken, vormt een tegenhanger van her machtskritisch denken. Wanneer het instrumentalisme vanuit het perspectief van de rechtsbescherming wordt bestudeerd, komt men al vrij snel tot de conclusie dat deze twee niet compatibel zijn. Het instrumentalisme ziet het strafrecht als een (machts)middel waarmee de staat het door hem gestelde doel, de bestrijding van de criminaliteit, effectief wil tegengaan. Hierbij is er

Denk bijwoorbeeld aan het Zwolsman arrest waarin de processuele gevolgen wan de hantering van onrechtmatige onderzoeksmethoden in de opsporingsfase ter discussie stonden. De Hoge Raad heeft onder meer bepaald dat wanneer op grond van de fieiten kan worden vastgesteld dat het OM gesanctioneerd dient te worden, dit tot bewijsuitsluiting of zelfs tot niet-ontvankelijkheid van het OM moet kunnen leiden. HR 19 december 1995, NJ 1996, 249. Zie ook Reijntjes: "De essentie wan bet strafprocesrecht ligu just in de bescherming wan de burger tegen (onjuist gebruik van) de statsmacht bij de toepassing wan het strafrecht" Reijntjes, J.M., "Mr A. Minkenhof, de Nederlandse Strafvordering", t.a.p. noot 60, p. 32. 
geen ${ }^{65}$ of weinig plaats voor rechtsbescherming. 't Hart heeft dit als volgt verwoord:

"(..) Zij is het instrument van een beleid: dat geen werkeligke alternatieven wil toelaten; dat de werkelijke keuzemonnenten verstopt in de diagnose vatn de maatschappij, die als "abjectief beeld wan 'de werkelijkheid" gepresenteerd wordt (de absolute clatim); dat de politieke discussie dan ook beperkt tot de mogelijkheden die het beleid zelf aandraagts zaals financiële prioriteiten, en dat tenslotte het recht inzet als lowter instrunnent orn dat beleid wit te voeren.

Dat de (extreem) instrumentalistische visie een richting is die niet ligt in de lijn van dit onderzoek zal duidelijik zijn. Dit, omdat deze richting afbreuk doet aan de visie dat rechtsbescherming inherent aan het strafrecht moet zijn. Vanzelfsprekend zijn er minder extreme visies binnen de instrumentalistische stroming anwezig die zich in de richting van het machtskritisch denken begeven. Daar moet enerzijds het standpunt in terug te vinden zijn dat het strafrecht als instrument dient, en anderzijds het standpunt dat het belang van de rechtsbescherming binnen het strafrecht hoog in het vaandel staat. Dit is dan ook de richting waar ik mij bij aansluit. Een dergelijke denkrichting is er een van deze tijd en stelt enerzijds dat het (straf) recht niet alleen maar instrumenteel mag zijn en anderzijds dat de rechtsbescherming niet al té ver doorgetrokken dient te worden ${ }^{67}$. Daarnaast is het "ethisch verantwoordelijk handelen" door enerzijds de burger omdat deze de door de maatschappij vastgestelde normen moet (willen) naleven, en anderzijds door de overheid omdat

Deze extreme variant van het instrumentalisme, ook wel het toralitair instrumentalisme genoend, scheidt niet alleen de techtsbeginselen van het door de overheid gestelde doel, mar plaatst de owerheidshandelingen zelfs vóór ethische waarden, voor rechts(beschermende)-beginselen. Een aanhanger van deze extreme richting was E. Goffmann. Vgl. Goffman, E., Totale Instituties, $3^{\mathrm{c}}$ druk, Universitaire Pers, Rotterdan, 1994.

Hart, A.C. "t, Totale instituties en het totalitaire; beschouwing bij de aanbieding van een bundel over "Rechtsbesherwing en totale instituties" aan Prof: Mr. C. Kelk bij zijn vifftigste verjatudag, uitgesproken te Urrecht op 22 oktober 1993 door A.C. I Hart, Gouda Quinc B. V., Arnhem, 1993, p. 12.

't Hart en Foqué stellen het volgende: "Wie pretendeert de rechtsorde te handhaven, zal dan ook steeds een vorm van evenwicht moeten verwezenlijkes in het spanningsteld tussen de instrumentele, doelvationele, en de machiskritische, beschermende, aspekten van het begrip rechtsorde. "Vgl. Hart, A.C. 't en Foqué, R., "Instrumentaliteit en rechtsbescherming; grondslagen van een strafrechtelijke waardendiscussie", Gouda Quint bv, Arlanem en Kluwer Rechtswetenschappen, Antwerpen, 1990, p. 15. 
deze wetten en regels aan de hand van een maatschappelijk draagvlak moet opstellen ${ }^{68}$, ook van belang. Ten slotte dient er - gezien de bezwaren tegen het stigmatiserend effect van het straf(proces)recht - getracht te worden deze zoveel mogelijk uit te sluiten ${ }^{69}$. Er dient aldus een "gulden" middenweg te worden gezocht en gevonden.

Alleen al de dreiging van een strafrechtelijk onderzoek kan genoeg zijn om schade aan potentiële effectentypische wetsovertreders toe te brengen. Dreigen met een eventuele strafrechrelijke procedure kan binnen de effectenwereld al "straffende" (bijkomende) effecten hebben. Bovendien lijken de rechtsbeschermingsidealen al snel zoek te zijn. Uitgaande van de visie dat her strafrecht niet alleen instrumenteel mag zijn, niet alleen op rechtsbescherming moet zijn gericht en nader ingevuld dient te worden door ethische aspecten, zal in deze studie onderzocht worden hoe de naleving van de effectentypische regelgeving het effectiefst en het meest wenselijk kan worden afgedwongen. Hierbij staan de gevolgen van de toepassing van het handhavingsmiddel, voor de desbetreffende effectentypische actor, centraal.

Vlg. Remmelink, J., "Mr. D. Hazewinkel-Suringa"s Mnleiding tot de studte wan bet Nedexlandse strafrecht", Deventer, Gouda Quint, 1996, $15^{\text {de }}$ druk, p. 48, 891 en 914.

69. Vgl. Braithwaite's reintegrative shaming theorie. G.A.A.l, van den Heuvel heeft in zijn vele publicaties Braithwaite's theorie meermalen aangehaald en uitgelegd. Vlg. bijvoorbeeld Van den Heuvel, G.A.A.J.,"Een criminologische agenda woor stmafrechthervorning in de bundel Legitieme strafuordering; rechten van de wews als inspinatie in de $2 I^{\text {sh }}$ eeww", Intersentia Rechtswatenschappen, AntwerpenGroningen, 2001, p. $173-188$, m.n. p. 175 noor 11 . 



\section{De ontwikkeling van de effectenhandel in Nederland}

De beurshandel in effecten, zoals wij die vandaag de dag kennen, vindt zijn oorsprong aan her eind van de achttiende eeuw. Ruim een eeuw later werd de Vereeniging voor den Effectenhandel ${ }^{l}$ (VvdE) opgericht en kon er daadwerkelijk gesproken worden van een georganiseerde effectenhandel. Voor deze periode werd er evenwel in effecten gehandeld, maar door individuele personen die niet georganiseerd waren. Dar wil zeggen dat deze personen weliswaar handelden in en met waardepapieren, maar zich niet als groep hadden samengevoegd of geprofileerd. De reden waarom de effectenhandelaren zich niet organiseerden was het maatschappelijk stigma dat de effectenhandel in de $16^{\mathrm{e}}$ en $17^{\text {de }}$ eeuw had. Het publiek vertrouwde effectenhandelaren niet omdat zij geen inzicht kon krijgen in de gejaagde wereld van de handelaren. Daarnaast waren de malafide handelaren niet altijd van de betrourwbare handelaren te onderscheiden.

\subsection{Het ontstaan van de handel in effecten in Nederland}

Rond het begin van de $17^{\text {de }}$ eeuw kwam de effectenhandel in de Republiek der Verenigde Nederlanden ${ }^{2}$ op en in 1606 gaf de Verenigde Oost-Indische Compagnie (VOC) het eerste gedrukte aandeel uit ${ }^{3}$. Ten tijde van de uitgifte van deze aandelen, gebruikte men de termen "aandeel" of "effecten" niet. Deze termen raakten pas rond de achttiende

1 De wereniging werd in 1876 opgericht.

2 Het exacte jaartal waarin de effecthandel duidelijk opkomt is niet mer alle zekerheid aan te geven. De vroegste datum die in de literatuur te vinden is, is het jaartal 1581. Volgens Davis is roen in Nederland eén van de eerste ondernemingen opgericht die aandelen uitgaf. Zie Davis, J.P., "Corporations." $A$ Study of the Origin and Development of Great Business Combinations and their Relations to the Authority of the State", Capricorn books, New York, 1961, p. 119.

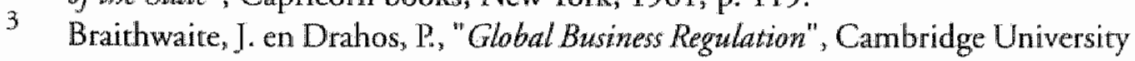
Press, 2000, p. 147 en Vries, J. de, "Een eeww wol effecten: Historische schets van de Vereniging woor de Effectenhandel en de Amsterdamse Effecterbeurs 1876 - 1976", B.V. Kunstdrukkerij Mercurius, Wormerveer, $1^{\mathrm{e}}$ druk, 1976 , p. 16. 
eeuw in gebruik. In de $16^{\text {de }}$ eeuw hanteerde men de termen "portie" of "partije", rond 1600 werd de term "actiën" ingevoerd en pas aan het eind van de achttiende eeuw, rond 1795, werd de term actiën door effecten vervangen ${ }^{4}$. De handel in effecten, zoals wij die nu kennen, stond in de $17^{\text {de }}$ eeuw bekend onder de naam "actiënhandel" en handelaren in effecten werden actionisten genoemd. De actiënhandel was een hectisch gebeuren. Dit blijkt onder andere uit het in 1688 verschenen boek van Spaanse schrijver De la Vega. Dit boek - genaamd Confusion de Confusiones - waarin hij het handelen op de beurs in Amersterdam beschrijft, wordt beschouwd als het eerste belangrijke boek over de Nederlandse effectenbeurs. In dit boek beschrijft De la Vega niet alleen de hectische handel in actiën, maar toont hij duidelijk aan welk maatschappelijk stigma er op deze handelsvorm rust ${ }^{5}$.

De termen portie, partije en actiën vinden hun oorsprong ten tijde van de stichting van de verschillende (Oost-Indische) Compagnieën. Ook de Verenigde Oost-Indische Compagnie (VOC) had voor zijn overzeese ondernemingen kapitaal nodig. Burgers konden intekenen op het kapitaal van de VOC $^{6}$. Hiervoor kregen zij geen aandeelbewijzen zoals men dat vandaag de dag kent. Deze burgers, participanten, konden aanspraak maken op dividend. Voorts hadden deze participanten na tien jaar recht op terugbetaling van het gestorte kapitaal ${ }^{7}$. Doordat de participanten hun aandelen, de actiën, mochten overdragen begon de beurshandel in actiën van de VOC. Aan de overdracht werden weinig formele eisen gesteld. Door in de boeken van de VOC de naam van de koper te vermelden, was de overdacht een feit. Bij het overschrijven van de actiën dienden wel twee bewindhebbers aanwezig te zijn ${ }^{8}$.

Vries, J. de, "Een eeww wal effecters: Historische schets wan de Vereniging toor de Effectenhandel en de Amsterdamse Effectenbeurs 1876-1976", t.a.p. noot 3, p. 19.

De la Vega, D.J., "Veruarring der verwatringen", (1688): vertaling van Confusion de Confusiones, door G.J. Geers, Martinus Nijhoff, 's Graventhage, 1939.

6 Heijden, van der E.I.J., "De ontwikkeling van de naamloze nennootschap in Nederland vór de codificatie" Vecht, Amsterdam, 1908, p. 45.

7 Heijden, van der E.J.J., "De ontwikkeling wan de natuloze vennootscbap in Nederland vóor de codificatie", t.a.p. noot 6, p. 48.

8 Vries, J. de, "Een eeww wal effectern: Historische schets tran de Vereniging woor de Effectemhandel en de Amsterdamse Effectenbeurs 1876-1976", t.a.p. noot 3, p. 15 en Heijden, van der E.J.J., "De ontwikkeling wan de naamloze wennoorschap in Nederland vóór de codificatie", t.a.p. noot 6, p. 47. 
De handel in actièn wan de VOC begon in de $17^{\text {de }}$ eeuw op te bloeien 9 Actionisten begonnen actiën te verkopen die zij zelf nog niet in het bezit hadden. De actiën die de actionisten nog niet in hun bezit hadden, maar wel verkocht hadden, probeerden zij alsnog tegen een lagere prijs te kopen. De ratio hiervan was dat zij de actiën tegen hogere prijzen probeerden te verkopen dan dat zij zelf ervoor zouden betalen. Dit soort handelen stond bekend onder de naam "blanco-verkoopen". Tegen de tijd dat de actionisten moesten leveren, maar de actiën nog niet in het bezit hadden, verspreidde men negatieve berichten. Hierdoor gingen de koersen dalen. In deze periode ontstond de speculatieve "windhandel ${ }^{10 "}$ in actiën. De windhandel is het tegengestelde van de reële handel. Bij reële handel worden de actiën daadwerkelijk gekocht en verkocht. Bij de windhandel werden actiën gekocht en verkocht die men (nog) niet in het bezit had. Het waren voornamelijk malafide handelaren die zich met deze vorm van handelen inlieten. De windhandel in actiën werd in 1610, op verzoek van de VOC, door de Staten van Holland en WestFriesland verboden maar ondanks het verbod ging deze windhandel door. Desalniettemin bleef de reële handel in actiën van de voC erg gewild. Niet alleen in actiën van de VOC werd frequent gehandeld maar ook voor de actiën van de eerste in 1621 opgerichte West-Indische Compagnie (WIC) en de tweede in 1672 opgerichte West-Indische Compagnie ontstond belangstelling. Naast de actiën gaven de VOC en de WIC's ook obligaties ${ }^{11}$ uit. Ook de overheid besloot tot uitgifte van obligaties over te gaan. Ondanks het feit dat er aan het eind van de zeventiende eeuw in actiën en obligaties werd gehandeld, kon er niet van een omvangrijke handel worden gesproken. Waarschijnlijk speelde het feit dat er niet veel keuze in werhandelbare stukken was en er niet (veel) in buitenlandse actiën gehandeld werd een rol.

Voor 1611 was er geen speciaal gebouw voor de beurshandel. De handel in zowel goederen als in actiën kon overal plaatsvinden, op straat, maar ook in ontmoetingsplaatsen zoals herbergen en/of kerkgebouwen ${ }^{12}$.

Meer over de geschiedenis van de VOC in: Heijden, van der E.J.J., "De ontwikkeling van de naamloze vennootschap in Nederland vö́r de codificatie" t.a.p. noor 6. Windcott, H., "The Stock Exchange" , Sampson low, London, 1946, p. 2.

11 Obligaties zijn schuldbewijzen van rentedragende leningen. Deze leningen kunnen door de Staat of een vennootschap zijn aangegaan. Obligaties zijn op de beurs verhandelbare schuldbewijzen. 
Ondanks het gemis van een apart gebouw, sprak men toch van een beurs. Immers, men kwam bijeen om te handelen, "om beurs te houden". In 1611, met de ingebruikname van her beursgebouw van Hendrick de Keyser, werd de actiënhandel in een speciaal gebouw ondergebracht en was de oudste effectenbeurs ter wereld een feit. De beurs van Hendrick de Keyser, een koopmansbeurs, was door de gemeente Amsterdam opgericht. Hier vond zowel de goederenhandel als de handel in actiën plaats. Er was geen speciale ruimte voor de verschillende soorten handel waar alleen erkende marktpartijen, de beëdigde makelaars, konden handelen. Streng was men niet. ledereen met geld kon meedoen. Het gevolg hiervan was clat ook niet kredietwaardige handelaren, de windhandelaren, daar actief konden zijn. Deze werden ook wel "beunhazen" genoemd. Ondanks het feit dat de goederen- en actiënhandel in een apart gebouw was ondergebracht, vond de beurshandel niet alleen plaats in het beursgebouw van Hendrick de Keyser. Daar deze beurs maar op bepaalde tijden geopend was, was er voor en na opening van de beurs ook beurshandel op de Dam en in de "Coffy-Huysen" 13 .

\subsection{De georganiseerde handel in effecten}

Zoals reeds opgemerkt was er in deze periode geen sprake van speciale regels. Reglementering van de actiënhandel was opgenomen in de regels die op de goederenhandel van toepassing waren. Zowel de actionisten als de goederenhandelaren moesten zich houden aan politievoorschriften en ordemaatregelen. Deze regels waren in het leven geroepen om de orde op de beurs van Hendrik de Keyser te kunnen behouden. Buiten het beursgebouw had de overheid geen greep op de handel ${ }^{14}$. Aan het eind van de $18^{\text {de }}$ eeuw nam de handel in actiën af en begon de handel in obligaties aantrekkelijk te worden ${ }^{15}$. Ter onderscheiding van de beunhazerij organiseerden de beurshandelaren zich voor het eerst in 1789 in het "Collegie tot Nut des Obligatiehandels". Dit Collegie had tot doel de belangen van de handelaren te behartigen ${ }^{16}$. De obligatiehandel

Vries, J. de, "Een eenu vol effecten: Historische schets wan de Vereniging voor de Effectenhandel en de Ansterdamse Effectenbetws 1876-1976", t.a.p. noot 3, p. 21.

14 Vries, J. de "Een eew vol effecten: Historische schets van de Vereniging voor de Effectenbandel en de Amaterdame Effectenbeur 1876-1976", t.a.p. noot 3, p. 45 . De obligatiehandel trok niet alleen de aandacht van de beurshandelaren, maar ook van vele "niet-beurshandelaren", de eerder genoemde beunhazen.

16 Günst, H.W. "115 jad Vereniging voor de Effectenhandel" uit: Trommelpapier, Beursdata B.V., 1991 , p. 15. 
die door diverse gebeurtenissen heftige koersschommelingen vertoonde, trok actionisten en windhandelaren. Zij begonnen de obligatiehandel steeds aantrekkelijker te vinden. Dit deed het Collegie rond 1795 besluiten over te gaan tot het uitgeven van een prijscourant van effecten. De publicatie van een prijscourant had tot gevolg dat de noteringen van nieuwe obligatie-handelaren gecontroleerd konden worden. De aanzienlijke koersschommelingen maakten niet alleen de behoefte aan controlenoteringen duidelijk, maar ook aan koersinformatie. De controle van het Collegie strekte zich uit tot het door een objectief college, genaamd "Beurszigt", laten opmaken van de prijscourant. Ondanks de publicatie in de prijscourant kon niet worden voorkomen dat effecten grote koersschommelingen vertoonden. De noteringen waren onnauwkeurig, hetgeen weer tot misbruik leidde ${ }^{17}$. Onderlinge meningsverschillen betreffende de publicatie en noteringswijze van de koersen, leidde in 1830 tot het ontstaan van een breuk in het Collegie. Drie jaren later, in 1833, waren er twee organisaties die de belangen van de beurshandelaren behartigden. "De Nieuwe Handel-Sociëteit" was te beschouwen als een afsplitsing van het Collegie. Pas in 1856 werden de twee organisaties het eens en ging men weer over tot het gezamenlijk behartigen van de belangen van de beurshandelaren. Het Collegie tot Nut des Obligatiehandels en De Nieuwe Handel-Sociëteit gingen op in het nieuwe "Algemeen-Beurscomité voor Publieke Fondsen"18. Dit comité richtte zich niet alleen op het scheppen van orde en regelmaat in de effectenhandel, maar wilde ook de belangen van de effectenhandel in de ruimste zin behartigen. Voor de effectenhandelaren was het van groot belang dat zij een aparte ruimte hadden om te kunnen handelen. Het feit dat de effectenbeurs nog geen eigen gebouw had maakte het voor niet-georganiseerde handelaren nog steeds mogelijk zich tussen de georganiseerde (effecten)handelaren te begeven. Indien mogelijk probeerden de nietgeorganiseerde handelaren ook een "gokje te wagen" hetgeen niet bevorderlijk was voor de orde en regelmaat op de beursvloer ${ }^{19}$. Het gevolg hiervan was dat de georganiseerde effectenhandelaren op een eigen ruimte bleven aandringen waar ze de mogelijkheid hadden om ongestoord te handelen. Effectenhandel en de Ansterdanse Effectenbeurs 1876-1976", t.a.p. noor 3, p. 46. 
De oprichting van het Algemeen Beurscomité had tot gevolg dat de twee reeds bestaande verenigingen werden ontbonden. Voorts had de oprichting tot gevolg dat er een vereniging was die namens de Amsterdamse effectenhandel kon optreden. Dit was van belang omdat de effectenhandel groeide en men steeds meer met buitenlandse beurzen handelde. In 1857 richtte het Algemeen Beurscomité een tweede vereniging op genaamd: "Effecten-Sociëteit, opgerigt door het Algemeen Beurscomité". De Effecten-Sociëteit hield zich bezig met het vaststellen van de dagelijkse koersen en de handel op de Amsterdamse beurs terwijl het Algemeen Beurscomité zich concentreerde op de effectenhandel in het buitenland. De vele organisaties mochten niet verhinderen dat ook bij deze comités onenigheid ontstond. Naast de meningsverschillen tussen de verschillende organisaties, waren er ook meningsverschillen met de gemeente Amsterdam. De georganiseerde effectenhandelaren hadden de gemeente, die het beursgebouw in beheer had, herhaaldelijk om ordemaatregelen verzocht. Zo hoopten de georganiseerde handelaren zonder inmenging van de niet-georganiseerden te kunnen handelen. $\mathrm{Om}$ aan de wensen van de georganiseerde handelaren gehoor te geven, stelde de gemeente het "reglement op de Groote Koopmansbeurs" op ${ }^{20}$. Met dit reglement trachtte zij orde en rust op de beurs te creëren. Het reglement mocht niet veel baten, hetgeen ertoe leidde dat de georganiseerde handelaren een eigen effectenbeurs wilden stichten waar orde en regelmaat hoog in het vaandel stond. Op 17 mei 1876 werd de "Vereeniging voor den Effectenhandel" (de VvdE) opgericht. De VvdE zorgde met de door haar ingevoerde dwingende voorschriften betreffende de handel, voor een afbakening van de ongeregelde handel in aandelen en obligaties $^{21}$. Ook streefde zij orde en regelmaat in de effectenhandel na. In navolging van het Algemeen Beurs-Comité voerde de VvdE nieuwe bepalingen en voorschriften in. Op 1 januari 1877 trad het Reglement voor de Noteering in werking. Drie maanden later, op 1 maart 1877 , volgde het Reglement voor de Effectenhandel. De structuur van de VvdE zag er als volgt uit: een Algemeen bestuur, Dagelijks bestuur, Huishoudelijke Commissie, Commissie voor de Notering, Commissie voor de fondsen en een Commissie voor de geschillen. De invoering van het Reglement voor de Noteering had tot gevolg dat er een nieuwe prijs- 
courant ontworpen moest worden. Men wilde een prijscourant waar geen verschillen in officiële en niet-officiële koersen in voorkwamen. De Commissie voor de Notering kreeg de zorg over de prijscourant. Tevens werd er een Commissie voor de Geschillen in het leven geroepen die zich bezig hield met de keuring van stukken.

De oprichting van de VvdE werd niet door iedereen toegejuicht. Dit uitte zich doordat niet een ieder die op de beurs handelde lid werd van de VvdE. Een aantal handelaren wilde om principiële redenen geen lid worden. Zij wilden niet eerst lid zijn om te mogen handelen. Hier kwam langzamerhand verandering in omdat men inzag dat de $\mathrm{VvdE}$ inderdaad bepaalde lacunes opvulde. Men kreeg gaandeweg meer ontzag voor de goed functionerende $\mathrm{VvdE}$. Het advies, aangaande het zegelrecht, dat de $V_{v d E}$ in 1883 aan de Minister voor Financiën gaf, versterkte het vertrouwen in de VvdE. De VvdE werd langzaamaan steeds meer gerespecteerd. Hierdoor werd zij in staat gesteld datgene te bereiken wat zij al sinds haar oprichting nastreefde, namelijk beschouwd te worden als synoniem voor de effectenhandel. Wanneer men over de effectenhandel sprak, moest de VvdE vanzelfsprekend ook genoemd worden. De $V v d E$ zei tegen de gemeente Amsterdam:

"Immers het is onbetwistbaar, dat de Vereeniging voar den Effectenhandel is De effectenhandel: (..).22.

Het bleef niet bij woorden. De VvdE nam maatregelen om haar doel te verwezenlijken. In een circulaire van 6 maart 1877 verbood zij haar leden transacties met niet-leden aan te gaan. Doordat de leden van de VvdE alleen met elkaar handelden, sloten zij de niet-georganiseerde handelaren uit van de handel in effecten. De groep niet-georganiseerde handelaren werd kleiner. Voor deze groep werd het moeilijker om te handelen in effecten. Immers, om te kunnen handelen in effecten moest men lid van de $\mathrm{VvdE}$ zijn geworden. Zo probeerde de Vereniging niet alleen de hele effectenhandel naar zich toe te trekken, maar tevens orde en regelmaat in de effectenhandel te scheppen. Inherent aan dit alles was de stijging in aanzien van de Vereniging. De opleving van de Nederlandse economie versterkte dit proces. De torstandkoming van de Vereeniging voor den Effectenhandel voltrok zich in de bloeitijd van 
het Nederlandse economische liberalisme ${ }^{23}$. Dat had tot gevolg dat de effectenbeurs volledig kon meegaan met de opwaartse conjunctuurbeweging die plaats vond in de Nederlandse economie. Het gevolg van deze expansie was dat de effectenhandel groeide en er op de beurs behoefte aan meer ruimte ontstond. De VvdE streefde een afgesloten ruimte voor de effectenhandel na en gaf de voorkeur aan een eigen handelsgebouw. In 1903 werd de Beurs van Berlage geopend en de Amsterdamse effectenhandel werd daarbij - in de Koopmansbeurs - ondergebracht. Deze situatie zou zich tot 1913 handhaven. Op 22 december van dat jaar opende de VvdE een eigen gebouw aan het Beursplein 5. Euronext Amsterdam N.V. heeft zich er nu deels gevestigd. Met het oog op de ordehandhaving en het zorgen voor regelmaat in de effectenhandel besloot de VvdE dat de effectenbeurs nu niet meer voor een ieder toegankelijk zou zijn.

De Amsterdamse effectenbeurs deed goede zaken. Dit in tegenstelling tot de effectenbeurs in de provincie ${ }^{24}$. Naast de VvdE, was er namelijk ook een effectenvereniging in Rotterdam. De Vereeniging van Effectenhandelaren te Rotterdam was in 1898 uit haar voorgangster, de Vereeniging voor den Handel in Publieke Fondsen, ontstaan. Zij was de enige beurs in de provincie en had slechts een locale waarde. In 1903 werd de Bond voor den Geld- en Effectenhandel in de provincie opgericht. Vele provinciale commissionairs en kassiers hadden zich in de Bond verenigd. De effectenhandelaren in de provincie waren zich bewust van hun afhankelijke positie van de Amsterdamse effectenbeurs. $\mathrm{Zij}$ konden geen lid van de $\mathrm{V}_{\mathrm{vd}} \mathrm{E}$ worden, omdat zij zich niet binnen de gemeentegrenzen van Amsterdam bevonden. Dit had tot gevolg dat de provinciale effectenhandelaren extra provisie aan hun Amsterdamse collega's moesten afdragen. Op den duur weigerden de provinciale beleggers de hoge provisiebedragen te betalen en wendden zij zich direct tot de Amsterdamse effectenhandelaren/ commissionairs die zelf lid van de $\mathrm{VvdE}$ waren. Hiervoor hoefden de beleggers niet per se naar Amsterdam af te reizen. Ze dienden zich slechts naar de filialen van de

23 Vries, J. de en Damen E., "Eevl eeuw vol effecten", Amsterdam, 2e druk, 1986, H. 3.

24 Met "provincie" werd alles aangeduid war zich toen buiten de grenzen van de gemeente Amsterdam bevond. 
Amsterdamse banken te begeven ${ }^{25}$. Hieruit kan worden geconcludeerd dat niet alleen de effectenbeurs, maar ook de banken goede zaken deden. Reeds in 1863 manifesteerde zich een explosieve groei in het aantal banken. Voor 1863 waren er naast De Nederlandsche Bank slechts twee kassiersmaatschappijen en enkele particuliere bankiers/kassiers ${ }^{26}$. In deze periode werden banken als de Rotterdamsche Bank, de Amsterdamsche Bank en Heldring \& Pierson opgericht. Zowel de kassiersmaatschappijen als de banken functioneerden als kredietverleners. Hierdoor konden zij langzaam maar zeker een opvallende plaats in het economisch stelsel innemen. De gelden afkomstig van de verleende kredieten zorgden ervoor dat het (handels)bankwezen van zowel het opbloeiende bedrijfsleven als van de particulieren kon profiteren.

De vele agentschappen van De Nederlandsche Bank en de hevige concurrentie van de vele bankiers hadden tot gevolg dat de effectencommissionairs hun onvrede uitten. Immers, zij werden meer en meer door de banken in hun werkterrein beperkt. Voor de opkomst van banken konden de beleggers in de provincie niet anders dan met behulp van de Amsterdamse commissionairs op de Amsterdamse effectenbeurs handelen. De opkomst van de banken en hun vele filialen die zelf ook lid van de VvdE waren, leidde ertoe dat de hulp van de Amsterdamse commissionairs overbodig werd. Niet alleen het commissionairsbedrijf, maar ook de hoekmannen vreesden voor de invloed van de (grote) banken ${ }^{27}$. De positie van de hoekmannen werd moeilijker omdat de bankiers een grote invloed op de vaststelling van de koersen uitoefenden. De onvrede van de effectencommissionairs en de hoekmannen ging zo ver dat zij voorstelden de Vereeniging voor den Effectenhandel te ont-

25 Viies, J. de, "Een eeww wal effecten. Historische schers wan de Vereniging woor de Effectenhandel en de Ansterdamse Effectenbeurs 1876-1976", t.a.p. noot 3, p. 97 $-98$.

26. De twee kassiersmaatschappijen waren: Associatie Cassa en de Ontvang- en Betaalkas. Uit: Vries, J. de, "Een eeww vol effectew: Historische schets van de Vereniging woor de Effectenhardel en de Amsterdamse Effectenbeum 1876 - 1976", ta.p. noot 3 . p. 87 .

27 De hoekman zorgde voor de totstandkoming wan een bepaalde prijs. In beginsel kwamen alle orders (in één hoek op de beursvloer) bij de hoekman terecht. Aan de hand van vraag en aanbod moest de hoekman erwoor zorgen dat hij een zodanige koers vaststelde dat er zoveel mogelijk orders uitgewoerd konden worden. Fen fonds mocht maar een hoekman hebben. De hoekman kon woor meerdere fondsen optreden. De commissionair treedt tegen betaling als tussenpersoon of op eigen naam óf op de naam wan een ander op bij de aan- of verkoop van effecten. 
binden en een nieuwe op te richten waarvan bankiers, zij het onder bepaalde beperkende voorwaarden, lid konden zijn. De $V w d E$ ging hier niet mee akkkoord. Zij streefde er naar zoveel mogelijk Amsterdamse effectenhandelaren als lid op te nemen. Zodoende kon de VvdE haar monopoliepositie handhaven terwijl er steeds meer niet-Amsterdamse effectenhandelaren en banken actief werden binnen de effectenwereld. Dit boezemde de VvdE angst in. De kans bestond dat er ook buiten Amsterdam, in de provincie, een effecten- en geldmarkt zou ontstaan. Indien de VvdE onder voorwaarden bankiers zou toelaten, zou de verdenking kunnen ontstaan dat zij een gesloten gilde beoogde ${ }^{28}$. De kans zou dan groot zijn dat de overheid zich met de organisatie van de $\mathrm{VvdE}$ en de effectenbeurs zou bemoeien. Een gesloten gilde paste volgens de overheid niet in een tijd waarin de effecten- en geldmarkt zich zo snel en omvangrijk ontwikkelde. Het gevaar zou dan bestaan dat de overheid de effectenbeurs tot een publieke effectenbeurs zou bestemmen. Dit zou betekenen dat de $\mathrm{VvdE}$ geen invloed meer op de effectenhandel zou kunnen uitoefenen, waardoor een ieder weer lid van de beurs zou kunnen worden. De VvdE nam het zekere voor het onzekere en besloot van het ballotagesyteem af te zien. Voortaan zou de $\mathrm{VvdE}$ haar leden op grond van formele vereisten toelaten of afwijzen ${ }^{29}$. Dit leidde er op 1 januari 1913 toe dat het Reglement tot toelating van bedienden op de beurs werd ingevoerd. Er kwam tevens een Commissie die toezicht op de toelating moest houden ${ }^{30}$. Deze Commissie was er een van vele binnen de VvdE. De VvdE richtte namelijk commissies op om specifieke vraagstukken op te lossen. De eerste ad hoc commissie, de Commissie voor het probleem van de rente bij prolongatie, werd in 1893 opgericht. Vanaf 1902 volgden meerdere ad hoc commissies: de Commissie voor de tijdaffaires (1902), de Commissie tot het uitbrengen van rapport inzake verplichte pensionering van bedienden (1904), de Commissie voor het Noteeringsvraagstuk (1907), de Commissie van Toezicht op den Bouw der Effectenbeurs (1910) en tenslotte de Commissie voor het Bedieningsvraagstuk $(1911)^{31}$.

Vries, J. de en Damen E, "Een eeuw wol effecten", t.a.p. noot 23, H. 3.

Vries, J. de. "Een eenw vol effecten: Historische schets van de Vereniging vaor de Effectenhandel en de Amsterdamse Effectenbeurs 1876 - 1976", t.a.p. noot 3, p. 96. Dat was de Commissie van Advies tot toelating van bedienden ter beurze.

31 Vries, J. de, "Een eeuw vol effecten: Historische schets van de Vereniging voor de Effectenhandel en de Amsterdamse Effectenbeurs 1876-1976", t.a.p. noot 3, p. 95. 
Aldus kan worden gesteld dat er vanaf de $16^{\text {de }}$ eeuw tot aan 1914 op het gebied van effectenhandel veel is veranderd. Na diverse pogingen is het de effectenhandelaren gelukt zich in de VvdE te organiseren. De VvdE ontwikkelde een monopoliepositie door te bepalen dat haar leden alleen met elkaar mochten handelen. Deze leden mochten niet met ongeorganiseerden uit Amsterdam of met handelaren dan wel commissionairs uit de provincie handelen. De opkomst van de Amsterdamse banken, welke vanaf 1863 is waar te nemen, benauwde de Amsterdamse hoekmannen en commissionairs. Zij zagen dat de banken steeds meer klanten van hen afnamen en probeerden de toelating van de banken tot de VvdE onmogelijk te maken. Uit angst voor de overheid stond de VvdE gildevorming niet toe. In plaats van handelaren en commissionairs, was er nu ook een derde belangrijke groep actief op de effectenbeurs: de banken en de kassiersmaatschappijen.

\subsection{Overheidsinmenging}

Tot aan 1914 kon er niet echt van overheidsinmenging in de effectenhandel worden gesproken. Met het uitbreken van de Eerste Wereldoorlog liet de overheid zich voor het eerst in met het beleid van de VvdE. De overheid liet zich, in deze economisch liberale periode, bewust nier uit over de interne autonomie en de privaatrechtelijke status van de $\mathrm{VvdE}$. Daarnaast ontbrak het de overheid aan deskundigheid om zich bezig te houden met de gecompliceerde materie van de effectenhandel. De cultuur op de beurs was erg gesloten; onbehoorlijkheden werden door de VvdE zelf afgedaan. $\mathrm{Zij}$ apprecieerde het niet wanneer de buitenwereld, of de overheid, werd ingelicht. Een treffend voorbeeld hiervan is een bericht uit 1913. In dat jar werd een effectenhandelaar de effectenbeurs uitgewerkt en op straat door een ex-beursbediende afgeranseld. De onfortuinlijke man werd toegetakeld omdat hij, tegen zijn belofte in, justitie had ingelicht over een diefstal op de beurs. De veroordeling van de dief hadden de effectenhandelaren de "verklikker" niet in dank afgenomen ${ }^{32}$. Door de hiervoor geschetste houding op en van de beurs, in samenhang met het gebrek aan kennis bij de overheid, heeft de effectenhandel overheidsinmenging lange tijd op afstand kunnen houden. 


\subsubsection{Ordenend overheidsoptreden}

Het tij keerde op woensdag 29 juli 1914. De dag na de oorlogsverklaring van Oostenrijk aan Servië, besloot het bestuur van de Effectenbeurs uit angst voor het instorten van de markt de deuren gesloten te houden. Daar de vooruitzichten niet rooskleurig waren, bepaalde de VvdE in overleg mer de leden de beurs voorlopig gesloten te laten. Op grond van een noodwet, de Beurswet 1914, werd op 9 februari 1915 besloten de beurs weer te openen. De beslissing omtrent de opening of sluiting van de beurs werd uit handen van het bestuur van de beurs genomen. De Minister van landbouw, nijverheid en handel had de taak gekregen om over de belangen van de Effectenbeurs te "waken". Later werd dit de taak van de Minister van Financiën ${ }^{33}$. Niet alleen de beslissing omtrent de opening of sluiting van de beurs werd aan de Minister overgedragen. De Minister was tevens bevoegd voorschriften te geven over de noteringen, de handelwijze op de beurs en de afwikkeling van leningen van voor 29 juli 1914 waarvoor fondsen tot onderpand dienden ${ }^{34}$. Ter uitvoering van deze noodwet werd de Minister bijgestaan door twee commissies. De "Commissie van Deskundigen" en de "Commissie van Bijstand voor de Uitvoering van de Beurswet 1914". Als toezichthoudend orgaan werd de Commissie van Bijstand voor de Uitvoering van de Beurswet 1914 aangewezen. Zij moest dagelijks op de beurs aanwezig zijn en toezicht houden. De praktische kant van de Beurswet 1914 werd door de op 15 januari 1915 vastgestelde Beursvoorschriften belicht.

\subsubsection{Dwingend overheidsoptreden}

Tot aan de Tweede Wereldoorlog was er op grond van de Beurswet 1914 alleen sprake van ordenend overheidsoptreden. De Beursvoorschriften 1940 gingen verder. In 1939 gaf de Minister van Financiën de Commissie van Deskundigen de opdracht advies uit te brengen of het wenselijk zou zijn wijzigingen in de Beurswet 1914 aan te brengen. Nog datzelfde jaar werd de Beurswet aangepast. $\mathrm{Nu}$ was het tijdelijke karakter van de noodwet, de Beurswet 1914, teniet gedaan. Voor de Beursvoorschriften 1915 gewijzigd konden worden, brak op 10 mei 1940 de Tweede

33 Arrikel 2 Beurswet 1914.

34 Vries, J. de en Damen E., "Een eeuw tol effecten", t.a.p. noot 23, H. 4 en J. De Vries, "Een eeww vol effecten: Historische schets van de Vereniging woor de Effectenhandel en de Amsterdatise Effecteribeurs 1876-1976', t.a.p. noot 3, p. 144. 
Wereldoorlog uit. Op die datum sloot de effectenbeurs weer. Dit keer bleef de beurs tot 15 juli 1940 gesloten. In tegenstelling tot de Beurswet 1914, vaardigde de overheid in de Beursvoorschriften 1940 ook dwingende voorschriften uit, bijvoorbeeld het verbod van de buitenbeurshandel in effecten; de ongereguleerde handel in effecten ${ }^{35}$. Voorts bevatte de Beursvoorschriften 1940 bepalingen aangaande de noteringswijze. Voor de toelating van fondsen tot de notering moest eerst toestemming van de overheid verkregen zijn. Tevens werd in de Beursvoorschriften 1940 beslist dat het bestuur en de ledenvergadering bepaalde besluiten mochten nemen na goedkeuring van de overheid gekregen te hebben. Daarnaast gaven de Beursvoorschriften 1940 aan dat er naast de effectenbeurs in Amsterdam, ook te Rotterdam en Den Haag effectenhandel bedreven mocht worden ${ }^{36}$. Dit alles vergde enige aanpassing van de $\mathrm{VvdE}$. Zij was nu niet meer de enige die over de gang van zaken in de effectenhandel kon beslissen. De overheid bepaalde nu wie er tot de effectenbeurzen gerekend mochten worden. De VvdE had haar monopoliepositie verloren.

Het overheidsingrijpen bleef hier niet toe beperkt. In oktober $1940 \mathrm{had}$ de secretaris-generaal van handel en nijverheid de commissie Woltersom ingesteld. Deze commissie moest de "reorganisatie van bet bedrijfleven" onder de loep nemen. De VwdE, als erkende vertegenwoordigster van de effectenhandel in Nederland, besloot zelf ook een commissie in te stellen. Deze commissie, de Commissie d'Ailly, zou moeten adviseren over de mogelijkheid van een bedrijfsorganisatie voor de effectenhandel. De VvdE beoogde samen met de twee andere beursbedrijven in Nederland, te weten: de Rotterdamse effectenbeurs en de Bond voor den Geld- en Effectenhandel in de Provincie, een organisatie te vormen. Pas dan zou er van eenheid binnen de effectenhandel gesproken kunnen worden. De Commissie d'Ailly stelde voor om de hele effectenhandel als hoofdgroep te beschouwen en de met de effectenhandel samenhangende bedrijven in vakgroepen onder te brengen. In beginsel kwam her plan van deze commissie overeen met het plan van de overheid, echter de Duitse overheersing bracht hier verandering in. De bezetter besloot de organisatie van het bankwezen ingrijpend te veranderen en voerde het leidersbeginsel in. Daartoe moest het gehele economisch bestel 
worden herordend, ook het bankwezen in 1941. Tijdens de bezetting was het bankwezen onderverdeeld in groepen. De banken werden als hoofdgroep aangewezen. Tot deze hoofdgroep behoorden vijf bedrijfsgroepen. De effectenhandel maakte deel uit van een van deze bedrijfsgroepen. De bedrijfsgroep effectenhandel bestond uit vakgroepen. De vier vakgroepen waren de administratiekantoren, de effectendepots, de trustkantoren en de effectenmakelaars. De Vereeniging voor den Effectenhandel werd als bedrijfsgroep aangewezen. Het gevolg was dat zij een publiekrechtelijke functie had met verordenende bevoegdheden. Feitelijk was de Vereeniging-bedrijfsgroep een verlengstuk van de ambtenaren en bleek haar verordende bevoegdheid slechts een lege huls te zijn. Immers, de beslissingen aangaande de effectenhandel werden door de Duitsers genomen. $Z_{\mathrm{ij}}$ bepaalden hoe de beurshandel daadwerkelijk moest verlopen. De Duitse bezetter had een destructieve werking op de beurshandel. De heropening van de beurs op 15 juli 1940 was het begin van een periode waarin belangrijke fondsen werden "afgestoten". De bezetter had verordend dat er nier meer in Duitse, Amerikaanse en Indische fondsen mocht worden gehandeld. Dit had de verstarring van het beursmechanisme tot gevolg 37 . Handelaren begonnen weer buiten de beurs om te handelen; er ontstond een zwarte beurs. Via zogenaamde commissionairsdwang probeerde de "overheid"38 de zwarte handel te bestrijden. Commissionairsdwang hield in dit geval in dat de handel in effecten alleen met tussenkomst van een lid van de Vereenigingbedrijfsgroep of van de Vakgroep effectenmakelaars kon geschieden. Overtreding hiervan werd zwaar bestraft.

Pas na de Tweede Wereldoorlog leefde de effectenbeurs weer op. Er was ten gevolge van de oorlogsjaren alleen onder bepaalde voorwaarden handel in effecten mogelijk. Deze situarie zou tot 1953 voortduren. Dat jaar wordt door de Effectenbeurs als "keerpunt" beschouwd. Dankzij de economische groei ${ }^{39}$ begon de effectenhandel weer op te bloeien. Met de oprichting van een Propaganda-adviescommissie ${ }^{40}$ zorgde de VvdE

37 Vries, J. de, "Een eeww wol effecten: Historische scbets wan de Vereniging woor de Effectenbandel en de Amsterdamse Effectenbeurs 1876-1976", t.a.p. noot 3, p. 176 $-186$.

38 Hier wordt bedoeld: de overheid in bezettingstijd. Bij besluit van 30 september 1942 van de secretarissen-generaal van de departementen financiën en justitie werd de commissionnairsdwang in her leven geroepen.

39. De economische groei begon rond 1950 en stabiliseerde zich rond 1970.

40 In 1955 veranderde de maam in: "Commissie voor Public Relations". 
ervoor dat de kennis van effecten en de bekendheid van de effectenbeurs zich uitbreidde. Mede dankzij de public relations - het werk van de Propaganda-adviescommissie - en dankzij de economische groei, nam het aantal leden van de $V_{v d E}$ weer toe.

\subsection{Een nieuwe koers}

Hallverwege de jaren vijftig van de vorige eeuw hoorde men alleen maar positieve geluiden over de ontwikkeling van de beurshandel. Ook het buitenland begon zich meer op Amsterdamse fondsen te richten. Er werd weer veelvuldig gehandeld. De tijd was aangebroken om Nederlandse fondsen in het buitenland te introduceren. Op 20 juli 1954 werd het fonds Koninklijke Petroleum op de New York Stock Exchange geintroduceerd $^{41}$. Het effectenverkeer internationaliseerde zich. Ondanks deze positieve gebeurtenissen kon niet worden verhinderd dat er ontevredenheid onder de beursleden ontstond. Het waren voornamelijk de jongere leden die klaagden over de bestaande beursstructuur. Zij vonden dat er diverse problemen opgelost dienden te worden. De problemen waar de jongeren op doelden hadden onder andere te maken met de effectenverwerking en de noteringswijze. Volgens de jongere garde moest de beurs haar totale structuur herzien om te overleven. Het zou anders snel afgelopen zijn met de Amsterdamse beurs. De kans was groot dat de beurs haar nationale en internationale positie niet zou kunnen behouden. Het liep anders. De beurs bezat toch het vermogen mee te gaan met de moderne tijd, al ging dit dan langzamer dan gewild.

\subsubsection{Van bedrijfsgroep tot landelijke organisatie}

In deze periode van veranderingen is de $\mathrm{V} v \mathrm{dE}$ niet lang een bedrijfsgroep gebleven. In 1954 hief de Minister voor publiekrechtelijke bedrijfsorganisaties de bedrijfsgroep effectenhandel op. Inmiddels had de VvdE een plek binnen de financieel-economische overlegstructuur van Nederland veroverd. Het bestuur van de $\mathrm{VvdE}$ wilde de samenwerking met de vereeniging van effectenhandelaten te Rotterdam en de Bond voor den Geld- en Effectenhandel in de Provincie te 's Gravenhage op vrijwillige basis voortzetten. Op 26 september 1955 verwezenlijkte deze samenwerking zich. De Nederlandse Organisatie van her Effectenbedrijf 
(NOE) werd opgericht ${ }^{42}$. Vanaf nu kon men spreken van een vrijwillige eenheid van organisatie in de effectenhandel. De NOE vergaderde regelmatig. Naar aanleiding van deze vergaderingen werden er diverse commissies in het leven geroepen. Belangrijke commissies van de VvdE werden vervangen door soortgelijke commissies van de NOE zoals: De Commissie voor de Geschillen, de Commissie voor de keuring der stukken, de Provisiecommissie en de Commissie voor de belastingen. De invloed van de NOE strekte zich verder uit. De NOE richtte haar aandacht niet alleen op de effectenhandelaren, maar ook op de banken en de overheid. Binnen de NOE had de VvdE de meeste invloed. Dit uitte zich onder andere op het gebied van het stemrecht. De stemverhouding tussen de Vereeniging voor den Effectenhandel te Amsterdam, de Vereeniging van Effectenhandelaren te Rotterdam en de Bond voor den Geld- en Effectenhandel in de Provincie te 's Gravenhage was 2:1:1.

In de jaren zeventig van de twintigste eeuw ging het stroef met de economie en dus ook met de effectenhandel. Het gevolg hiervan was een herbezinning. De door de VvdE in 1970 opgerichte Commissie Herziening Beursstructuur constateerde in 1972 dat de positie van de Vereeniging voor den Effectenhandel te Amsterdam in de NOE verloren dreigde te raken. Deze Commissie adviseerde de VvdE dat zij zich meer moest profileren. De nadruk moest op het landelijke karakter van de effectenmarkt worden gelegd. De effectenbeurs te 's Gravenhage was feitelijk alleen nog maar een beurs in naam. De beurs te Rotterdam was minder actief dan de VvdE. Om een zachite dood te voorkomen en om sterker te staan fuseerden de drie beurzen. De sterkste van de drie, de VvdE, werd de landelijke organisatie van het Effectenbedrijf. Met ingang wan 31 december 1973 werd de NOE ontbonden. Sedert de oprichting wan de VvdE in 1876, was er in 97 jaar veel veranderd. De VvdE was nu geen plaatselijke, maar een landelijke organisatie. Het gevolg hiervan was dat het voor de banken en commissionairs - gevestigd buiten Amsterdam - mogelijk werd om rechtstreeks het lidmaatschap van de VvdE te verkrijgen. De Commissie Herziening Beursstructuur werd later de Commissie Reglementering. De taak van deze commissie was de organisatie van de beurshandel zodanig te wijzigen dat de continuiteir van de beurshandel kon worden gewaarborgd. Naast positieverbetering en Effectenrecht dl. 15, Kluwer B.V., Deventer, 1988, p. 3. 
gaf de Commissie Herziening Beursstructuur in haar beleidsplan "De Amsterdamse Effectenbeurs op een nieuwe koers", het advies meer veranderingen door te voeren. Bij deze wijzigingen lag de nadruk op de interne structuur van de organisatie ${ }^{43}$. Voorts werd in 1972, vanuit het oogpunt van modernisering, de naam van de VvdE aangepast. Voortaan sprak men niet meer over de "Vereeniging voor den Effectenhandel", maar over de "Vereniging voor de Effectenhandel". Ook visueel veranderde het een en ander op de beursvloer. In 1973 werden er koerspublicatieborden en lichtkranten in de beurszaal in gebruik genomen. Twee jaren later zou de beurs overgaan tot automatisering van de koerspublicatie.

\subsubsection{Modernisering effectenverwerking}

Niet alleen de economische bloei en de internationalisering van het effectenverkeer, maar ook het gebruik van kleine coupures veroorzaakten een enorme toename van het antal administratieve handelingen. $\mathrm{Om}$ haar concurrentiepositie te kunnen behouden, werd de Amsterdamse effectenbeurs gedwongen haar transacties sneller, efficiënter en goedkoper te verwerken.

Kort na de invoering van een nieuw fondsenreglement ${ }^{44}$ begon de $V_{v d E}$ tot actie over te gaan. $\mathrm{Zij}$ moderniseerde de administratieve zijde van de handel in aandelen door in 1961 de Effectenclearing N.V. op te richten. De oprichting van de Effectenclearing N.V. bracht de Amsterdamse effectenbeurs in een voorsprongpositie, andere beurscentra achter zich latend ${ }^{45}$. Met een in 1967 doorgevoerde reglementswijziging, waarin werd bepaald dat de transacties van de leden uitsluitend door tussenkomst van de Effectenclearing mochten geschieden, was de positie van de Effectenclearing verzekerd. Alle beurstransacties werden vanaf dat mo-

43. Korthals-Altes, J.Ph., De Amsterdamse effectenbeurs op cen nieuwe koers; voorstellen van de Commissie Herziening Beursstrucuur, mede houdende een voorstel tot wijziging van de Statuten van de Vereeniging voor den Effectenhandel, Beleidsnota, 1972, p. 7 en 8.

In 1958 werd een nieuw fondsenreglement ingevoerd. Dit fondsenreglement bevatte, in tegenstelling tor het vorige reglement, alle gepubliceercle en nietgepubliceerde voorschriften. Door de codificatie van deze voorschriften werd de zeer gecompliceerde fondsenmaterie overzichtelijker. Vereniging voor de Effectenbandel 1876-1996", Joh. Enschede, Amsterdam, 1998, p. 22 . 
ment via de effectenclearing afgewikkeld ${ }^{46}$. Naast de Effectenclearing N.V. werd in 1964 het Centrum voor Fondsenadministratie N.V. opgericht ${ }^{47}$. Door de toename van interesse in de aandelenhandel stegen de kosten voor het verwerken en knippen van de dividendbladen en/of de coupons. De oprichting van dit centrum moest een eind aan dat kostenprobleem maken. Besloten werd de effecten in een nieuwe vorm uit te geven. In plaats van de grote klassieke stukken werden kleinere $\mathrm{CF}$-stukken gebruikt ${ }^{48}$. Het Centrum voor Fondsenadministratie werd de administratieve schakel tussen de bewaarders van aandelen en de uitgevende instellingen. De CF-stukken werden niet aan de aandeelhouder meegegeven. De banken bewaarden deze stukken. De aandeelhouders hoefden nu voor uitbetaling niet meer coupon- of dividendbladen in te leveren. Het Centrum voor Fondsenadministratie incasseerde het dividend voor de bewaarders. Dit ging als volgt: de uitgevende instelling maakte op de dag van uitbetaling het verschuldigde bedrag aan het centrum over. Het Centrum voor Fondsenadministratie verdeelde het geïncasseerd dividend naar rato van de dividendgerechtigheid. Tedere bewaarder had een aantal dividendbladen op zijn naam staan. Aan de hand van het aantal dividendbladen kreeg een bewaarder dividend uitgekeerd. Vervolgens zorgden de bewaarders er zelf voor dat hun cliënten het bedrag waar zij recht op hadden kregen uitgekeerd. De oprichting van dit centrum heeft tot een snellere leverings- en verwerkingswijze van effecten geleid. Met de invoering van de Wet Giraal Effectenverkeer, in 1977, zou de levering en verwerking van effecten nog efficiënter worden ${ }^{49}$.

\subsubsection{De buitenbeurshandepo}

In de jaren zeventig, een periode van economische stagnatie en interne veranderingen, richtte de beurs zich ook op de buitenbeurshandel. Ook hier diende het een en ander te veranderen.

46 Vries, J. de, "Een eeww vol effecten: Historische schets wan de Vereniging woor de Effectenhandel en de Ansterdanuse Effectenbeurs 1876-1976", t.a.p. noor 3, p. 249 en 250 .

47 Vries, J, de en Damen E., "Een eeww vol effecten", t.a.p. noor 23, H.6.

$48 \mathrm{CF}$-stuk is een afkorting van Centrum woor Fondsenadministratie-stuk.

49 Meer hierover in paragraaf 1.5. Internationalisering.

50 Onderstaande tekst is geschreven op basis van een door mij verricht deskonderzoek in de archieven van Amsterdam Exchanges. De beurshistoricus van Amsterdam Exchanges, de heer G.M. Kroeze, heeft mij schriftelijke toestemming verleend om de informatie in deze tekst te verwerken. 
Er bestaat en bestond geen algemeen anvaarde definitie van de "buitenbeurshandel". Enerzijds werd hieronder verstaan: "de handel die buiten de beurs om gaat; handel in niet-genoteerde fondsen". Men zou kunnen denken aan malafide tussenpersonen/ handelaren in effecten. Bij deze redenering past het beeld dat de belegger ${ }^{51}$ makkelijk misleid kon worden omdat hij niet zou kunnen weten of de fondsen waarin de malafide handelaar handelde wel gangbaar dan wel genoteerd was. $\mathrm{Om}$ de belegger in dat geval te beschermen was regelgeving noodzakelijk. Niet alleen de belegger, maar ook de hele effectenhandel was daarmee gemoeid. Het reguleren van de buitenbeurshandel zou gelijk staan aan het in bescherming nemen van de belegger. Dit schiep het beeld van een betrouwbare handel in effecten. Anderzijds verstond men onder het begrip "buitenbeurshandel": "de bandel, door de grote partijen (banken), buiten de hoekmannen van de beurs om". In dit geval wilden de grote partijen niet via de beurs handelen omdat het ze geld kostte en ze minder winst konden maken. Deze partijen besloten onderling (grote) hoeveelheden te verhandelen. De beurs wilde de buitenbeurshandel aanpakken. Deze vorm van handelen werd met name door de te hoge provisietarieven van de hoekmannen aangewakkerd. De buitenbeurshandelaren probeerden de hoge tarieven te ontduiken Dit had tot gevolg dat de VvdE minder inkomsten ontving en veel geld misliep. De VvdE zag dat het gevaar bestond dat er veel handel was die én buiten de handel van de VvdE omging én in de ogen van buitenstaanders als officiële handel gezien werd, zonder dat de VvdE er grip op had. De VvdE wilde hier controle over en verklaarde de belangen van de belegger te willen waarborgen. In deze mindere tijden kon de beurs het zich niet veroorloven geld door haar vingers te laten glippen. Vastbesloten besloot de beurs dat er een eind aan de buitenbeurshandel moest komen. Onder het mom van een eerlijke, doorzichtige handel in effecten met bescherming van de belangen van beleggers begon de beurs een campagne tegen de buitenbeurshandel. Dit terwijl de buitenbeurshandel altijd bestaan heeft en de beurs dat waarschijnlijk ook wist. Weliswaar dient hier te worden opgemerkt dat men zich in perioden van economische vooruitgang niet snel stoorde aan de buitenbeurshandel. Het ging een ieder immers goed. De economische stagnatie aan het begin van de jaren zeventig gaf de beurs aanleiding om de buitenbeurshandel aan te pakken. $\mathrm{Zij}$ begon het beeld te schetsen dat de enige betrouwbare handel zich bij haar afspeelde. 
Immers, op de beurs waren er regels die de belangen van de beleggers voor ogen hield. Dit beeld werd langzamerhand door de maatschappij geaccepteerd. Aan het eind van de jaren zeventig, in 1978, zou de beurs een gewijzigde reglement voor de effectenhandel invoeren. Het was de bedoeling om zo meer vat op de gehele handel in effecten te krijgen. Het gevolg van een nieuw reglement was dat de officiële prijscourant en het reglement voor de Notering dienden te worden aangepast. De buitenbeurshandel kreeg uiteindelijk een negatieve naam. Dit leidde, met de invoering van de Wet Effectenhandel in 1985, tor het aan banden leggen van deze vorm van effectenhande ${ }^{52}$. De zelfregulering van de VudE heeft de basis gelegd voor de wettelijke aanpak van de buitenbeurshandel.

\subsubsection{De positieverandering van beursactoren}

Dat er op de beurs in de jaren zeventig het een en ander was veranderd, is hiervoor al gebleken. In dit kader dient de positieverandering van de beursactoren ook te worden vermeld. Dit heeft uiteindelijk tot een duidelijke functiescheiding op de beursvloer geleid. Wat de aanleiding hiertoe was en hoe het uiteindelijk tot een functie afbakening heeft kunnen komen zal hieronder worden beschreven.

Zo lang als men zich kan herinneren concentreerden diverse beursactoren zich liever dan dat zij zich afsplitsten. Een voorbeeld is het fuseren van commissionairs met banken en/of banken met banken. Fusies tussen banken hadden tot gevolg dat het aantal bankleden afnam. Hetzelfde geldt voor de commissionairs. De gefuseerde banken openden, vaak ten koste van de zelfstandige provinciale bankiers, filialen in de provincie. Doordat de zelfstandige provinciale bankier wegviel, had de commissionair rechtstreeks contact met zij.n cliënten. De banken voorzagen dit en opende speciale afdelingen waar effecten aan bankrelaties konden worden verhandeld. De fusies hadden tot gevolg dat het totale aantal beursactoren inkromp. Niet alleen de fusies, maar ook de opkomst van het collectief sparen en de concentratie van de institutionele beleggers, de levensverzekeraars en de spaarbanken, verkleinden het aantal beursactoren. Hierdoor concentreerde de orders zich bij een kleine groep. De concentratie van het bedrijfsleven heeft geleid tot vermindering van het aantal genoteerde fondsen. 
Aan het begin van de jaren zeventig begon duidelijk te worden dat de hoekman het slachtoffer van de machtige gefuseerde partijen was geworden. Omdar de gefuseerde partijen het aantal beursactoren drastisch hadden verminderd, konden de hoekmannen zich moeilijk staande houden; zij kregen minder orders binnen. Om te voorkomen dat de banken en andere grote partijen hun eigen hoekman in een hoek plaatsten, besloot de beurs naar aanleiding van het rapport van de Commissie Herziening Beursstructuur dat er een beperking in het aantal hoekmannen per hoek moest komen ${ }^{53}$. Voorts besloot de $\mathrm{VvdE}$ dat een hoekman geen commissionairsactiviteiten meer mocht verrichten. Daarnaast mochten banken en commissionairs niet de functie van hoekman vervullen ${ }^{54}$. Zo'n duidelijke functiescheiding had niet eerder op de beurs plaatsgevonden. Met deze functiescheiding konden de beursactoren geen dubbele posities meer innemen ${ }^{55}$. Her rapport van de Commissie Herziening Beursstructuur bracht ook op het gebied van de bevoegdheden van de beursactoren veranderingen teweeg. De VvdE besloot deze bevoegdheden vast te leggen. Ze maakte een onderscheid tussen haar leden in bedrijfsleden en in individuele beursleden. Tot de bedrijfsleden behoorden de ondernemingen. In geval van ondernemingen dient men te denken aan ondernemingen in alle mogelijke juridische vormen. De natuurlijke personen die met de bedrijfsleden verbonden waren, werden de beursleden genoemd ${ }^{56}$. Tot de beursleden behoorden ook de beherende vennoten, bestuurders van de bedrijfsleden en hun vervangers. Vervolgens bakende de VvdE de functies van de leden af. De VvdE maakte een onderscheid tussen bedrijfsleden die wel en bedrijfsleden die niet onder de Wet Toezicht Kredietwezen (W/tk) vielen. Een bedrijfslid dat in een van de registers van de Nederlandse Bank N.V. (DNB) stond ingeschreven viel onder de Wtk. De bedrijfsleden die niet

53 Vries, J. de, Damen E., Kamp, K. en Berger, I., "120 jadr beurshandel in vrogelulucht: Vereniging voor de Effectenhandel $1876-1996^{\prime \prime}$, t.a.p. noot 45, p. 23.

54 Hier verwijs ik naar her eerder genoemd deskonderzoek in de archieven van Amsterdam Exchanges. Zie verder Korthals-Altes, J.Ph, "De Amsterdarnse effectenbeurs op een nieuwe koers; voorstellen van de Commissie Herziening Beursstructuur, mede houdende een voorstel tot wijziging van de Statuten van de Vereeniging voor den Effecten-handel", Beleidsnota, 1972, p. 11, 15 en 16.

55 Vries, J. de, "Een eeww wol effecten: Historische schets wan de Vereniging woor de Effecterhandel en de Amsterdamse Effectenbeurs 1876-1976", t.a.p. noot 3, p. 260 -262 .

56 Cross, D.H. en Diephuis, J.H., "De.Amsterdamse effectenbeurs", uir de serie Banken Effectenrecht dll. 15 , t.a.p. noot 42 , p. $6-7$ en p. 19. 
onder deze wet vielen, omdat ze niet in een van de registers stonden ingeschreven, kwamen onder het in 1973 opgerichte Interprofessioneel Instituut voor de Effectenhandel (IIE) te staan. Dit bedrijfslid kon alls commissionair, dat wil zeggen voor derden, de effectenhandel uitoefenen. Tevens kon dit bedrijfslid voor eigen rekening als effectenhandelaar optreden. Een bedrijfslid dat wel in een van de registers van DNB was ingeschreven, kon als bank(ier) of als commissionair de commissiehandel in effecten uitoefenen. Voorts kon dit bedrijfslid als effectenhandelaar voor eigen rekening optreden. Het laatste onderscheid dat door de VvdE gemaakt werd was het hoekmansbedrijf. Een hoekman mocht de commissiehandel in effecten uitsluitend voor rekening van medeleden uitoefenen en mocht wel voor eigen rekening handelen in effecten. In dat geval kocht of verkocht hij van zijn eigen geld zonder te weten of hij al een koper had voor zijn gekochte effecten. Voor de niet-ingeschreven leden was het IIE van belang. Dankzij het IIE konden de niet-ingeschreven leden hun cliënten dezelfde diensten aanbieden als de wel-ingeschreven leden. In dit geval dient men te denken aan de administratie van gelden effectenrekeningen. Daarnaast verzorgde het IIE ook de bewaring van effecten en de kredietverlening. De IIE gaf de Kas-Associatie N.V., destijds de bank van de effectenbeurs, de opdracht deze diensten aan de niet-ingeschreven leden te verlenen.

De vele hierwoor genoemde wijzigingen leidden tot een verzwaring van de bestuurstaken van de VydE. De Commissie Herziening Beursstructuur stelde in haar rapport voor om een beroepsvoorzitter aan te stellen. De voorzitter, die geen lid van de VvdE mocht zijn, zou de hoogste functionaris binnen de $\mathrm{VvdE}$ zijn. Op 22 februari 1973 werd de heer J.Ph. Korthals Altes tot beroepsvoorzitter benoemd. Naast de aanstelling van een beroepsvoorzitter, stelde de commissie tevens voor de controle op naleving van de regelgeving door een zelfstandig controlebureau uit te laten voeren. Dit controlebureau, met een registeraccountant aan het hoofd, zou rechtstreeks onder de voorzitter moeten komen ${ }^{57}$. 


\subsubsection{Het controlebureau 58}

In het kader van beleggersbescherming zag de VvdE in dat zij in de gelegenheid moest worden gesteld haar leden aan een onderzoek te onderwerpen. Naar aanleiding van fusiegeruchten en de mogelijke gevolgen hiervan voor de aandelen op de beurs, werd het de voorzitter van de $V_{v d E}$ duidelijk dat er geen onderzoek door de beurs kon plaatsvinden. Noch de statuten, noch de reglementen lieten dat toe. De noodzaak tot een reglementswijziging dat de $\mathrm{VvdE}$ de bevoegdheid zou bieden op te treden werd duidelijk. Het besef onbevoegd te zijn om zaken van leden te onderzoeken en het advies van de Commissie Herziening Beursstructuur, hadden in 1973 geleid tot het besluit een controlebureau in te stellen. De VvdE besloot, via zelfregulering, dat er een controlebureau en een controlereglement moest komen. Dit reglement moest een juridische grondslag vormen voor het verrichten van onderzoeken bij de leden.

In het eerste concept-controlereglement de dato 26 september 1973 werd gesteld dat het controlebureau onder de VvdE ressorteerde. In het controlereglement is een takomschrijving van het controlebureau te vinden. Volgens artikel 4 van dit reglement moest het controlebureau in staat zijn inlichtingen in te winnen zodat de zaken van bedrijfsleden konden worden beoordeeld. Tevens vermeldde het eerste conceptcontrolereglement dat het controlebureau de naleving door bedrijfsleden van de in de statuten, reglementen en andere voorschriften vervatte bepalingen moest controleren. Niet alleen de bepalingen, maar ook de in de effectenhandel algemeen geldende gedragsregels moesten door het controlebureau kunnen worden gecontroleerd. Het toezicht door het controlebureau was ook gebaseerd op "algemene regels van behoorlijk gedrag". Nadrukkelijk werd er in de takkomschrijving gewezen op de gedragsregels welke tijdens de aan- en verkoop van effecten in het maatschappelijk verkeer door de vele Amsterdamse banken moesten worden gehanteerd. Men diende onder andere te denken aan regels welke gericht waren op het voorkomen van her misbruik van voorwetenschap. Voorts moest het controlebureau kunnen onderzoeken of de leden (nog steeds) voldeden aan de aan hen gestelde eisen. Ook de juistheid van de door de een persoonlijk deskonderzoek in de archieven van Amsterdam Exchanges tot stand gekomen. Zie noot 50 . 
leden afgelegde verklaringen moest door het controlebureau kunnen worden onderzocht. Tenslotre werd in het concept-controlereglement vermeld dat het controlebureau een enquêtebevoegdheid had. Het concept-controlereglement vermeldde tevens dat het controlebureau zowel schriftelijk als mondeling inlichtingen mocht inwinnen. Het moeten indienen van periodieke gegevens werd gelijk gesteld aan het inwinnen van inlichtingen. Voorts was het controlebureau gerechtigd boeken en bescheiden van de leden in te zien. Een ingesteld onderzoek kon plaatsvinden op initiatief van het hoofd van het controlebureau, maar ook in opdracht van de voorzitter van de VvdE of in opdracht van het bestuur van de VwdE. Alvorens een onderzoek te starten, diende het desbetreffend bedrijf(slid), dat subject van onderzoek was, via een introductiebrief op de hoogte te worden gesteld van het onderzoek. In deze brief werd de aard van het in te stellen onderzoek aangegeven. De opgedane bevindingen van het controlebureau werden uitsluitend aan de voorzitter gerapporteerd. Indien het hoofd van het controlebureau meende dat het bedrijf(slid) ook geïnformeerd diende te worden, mocht hij daartoe overgaan. In de rapportage werden in beginsel geen andere gegevens dan noodzakelijk vermeld. Mocht de voorzitter van mening zijn toch hierover te moeten beschikken, kon hij dit verlangen ${ }^{59}$. Mocht de voorzitter daarnaast, naar aanleiding van de rapportage, van mening zijn dat het bestuur hiervan in kennis gesteld diende te worden, dan liet hij dat aan het desbetreffende lid weten. Indien er bezwaar bij het lid mocht bestaan, kon deze in beroep bij de adviescommissie in controleaangelegenheden. Deze commissie werd door het bestuur benoemd. Pas na machtiging van deze commissie kon de voorzitter het bestuur inlichten.

Op 2 oktober 1.973 werd er een tweede concept-controlereglement gemaakt. Hier werden voornamelijk wat schoonheidsfoutjes weggewerkt. Bepaalde artikelen werden in tweeën gesplitst waardoor ze makkelijker te begrijpen waren. In artikel 4 (later 5) werd niet alleen in een alinea gesproken over algemeen geldende gedragsregels en misbruik van voorwetenschap. Dit was gesplitst en duidelijker omschreven. Ook dit controle-reglement kreeg geen algemene goedkeuring hetgeen tot gevolg had dat er op 23 oktober 1973 een derde concept-controlereglement werd gemaakt. Dit concept had de vereniging op 1 november 1973 
besproken. Tijdens de artikelsgewijze behandeling van het derde conceptcontrolereglement werd verzocht het reglement door juristen te laten nakijken om juridische oneffenheden te voorkomen. In januari 1974 werd het derde concept-controlereglement door juristen van de Algemene Bank Nederland N.V. nader bekeken. In de vorm van een nota hadden de juristen het bestuur van advies voorzien. Nadrukkelijk wezen de juristen erop dat de nota bedoeld was om op de eventuele gevaren te wijzen en niet om aan te geven hoe de controle geregeld diende te worden. De juristen wezen er destijds op dat het van belang was om alle grote leden (de banken Bank Mees \& Hope, AMRO, ABN en Pierson, Heldring $\&$ Pierson) erbij te betrekken. De kans bestond dat deze grote partijen bang zouden zijn om de touwtjes uit handen te geven. Als meest invloedrijke partijen stonden voor hen grote belangen op het spel. Het was voor deze partijen dan ook zaak dat zij bij het ontwerpen van het controlereglement aanwezig waren en hieraan konden deelnemen.

In de nota inzake het controlereglement van de VvdE werd uitgegaan van het laatste concept. Opvallend was dat de juristen de taak van het controlebureau, te weten het toezicht (controle en handhaving van de leden), in beginsel niet zagen zitten. Zij wonden het moeilijk te accepteren dat een niet-overheidsorgaan een soort politionele taak toebedeeld zou krijgen. Volgens de juristen paste het niet bij de VvdE om cliënten door de leden te laten controleren. Het is van belang te melden dat de hier genoemde banken indertijd, net als heden het geval is, een belangrijke positie binnen de structuur van de Amsterdamse Effectenbeurs bekleedden. $\mathrm{Zij}$ hadden een zeer grote invloed. De reden voor hun terughoudendheid was angst. Angst dat er gegevens van cliënten van leden bij het controlebureau terecht zouden komen die via de voorzitter uiteindelijk bij het bestuur bekend zouden worden. Hierdoor zouden de bedrijfsleden uiteindelijk door de leden aansprakelijk kunnen worden gesteld. Banken waren (en zijn) commerciële instellingen. Indien cliënten zouden vermoeden dat derden over hun gegevens konden beschikken, zouden zij minder snel geneigd zijn bij zo'n bank te bankieren. Banken zagen een potentieel gevaar om vooral de zeer vermogende cliënten te verliezen. Voorts is het niet onbelangrijk te vermelden dat de concurrentie tussen de banken van invloed was op het standpunt van de banken. Zij zouden het zeer onaangenaam vinden wanneer een concurrent wist welke diënten tot hun cliëntèle konden worden gerekend en wat voor zaken zij met deze cliënten deden. De concurrent zou deze banken immers te slim af kunnen zijn. De kans dat een concurrent aan belangrijke 
informatie zou kunnen komen was groot. Immers, binnen het bestuur van de VydE waren meerdere (zo niet alle) grote banken vertegenwoordigd en het controlebureau zou zijn informatie aan het bestuur moeten doen toekomen. De juristen gaven ook aanvullende kritiek op onder andere de formulering van bepaalde artikelen. Dit gold bijvoorbeeld voor de zinsnede "in het maatschappelijk verkeer aanvaarde gedragsregels". Zij vroegen zich af wie bepaalde wat maatschappelijk (on)aanvaardbaar was. De juristen prefereerden een minder vage omschrijving van meerdere bepalingen. Wat betreft het misbruik maken van voorkennis waren zij het er mee eens dat dit bestreden diende te worden. Het probleem was echter de definiëring van misbruik maken van voorkennis. De juristen wezen erop dat in het Rapport inzake misbruik van voorwetenschap van 23 juli 1973 van de commissie Vennootschapsrecht nog geen definitie van misbruik van woorwetenschap bestond. De rechtskundigen bleven terughoudend ten opzichte van de bevoegdheden die het controlebureau zou krijgen. Ze benadrukten in de nota dat het beter zou zijn dit aan de overheid over te laten. Volgens hen kon de overheid op grond van de wet strengere controles uitvoeren ${ }^{60}$. De juristen, afkomstig van de belangrijkste bedrijfsleden, verklaarden dat het gevaar zou bestaan dat de bedrijfsleden door hun cliënten aansprakelijk gesteld zouden worden. Op het gebied van misbruik van voorwetenschap erkenden zij het belang van een goede bestrijding hiervan. De vraag was wie dat zou moeten uitvoeren: de vereniging of de wetgever? De juristen gaven duidelijk aan dat in geval de vereniging niets zou ondernemen, de wetgever zou optreden en zij stelden dat de wergever een strengere controle zou kunnen uitoefenen dan de vereniging ${ }^{61}$.

Op 15 februari 1974 hadden juristen van een aantal bedrijfsleden de hierboven genoemde nota besproken. Er werden wat wijzigingen in het concept-controlereglement doorgevoerd. Te weten: "de naleving door cliënten van bedrijfleden wan door het bestuur nodig geachte en/of in bet maatschappelijk verkeer aanvaarde gedragsregels", kwam nu niet voor in de tekst van het controlereglement. Tijdens een vergadering, op 7 maart 1974, werd de gewijzigde tekst besproken. Er werd besloten om de verplichting tot naleving door de cliënten te laten vervallen. Na nog wat

60 Een interne beleidsnota genaamd: "Nota inzake controlereglement van de Vereniging voor de Effecten", januari 1974.

61 Nota inzake controlereglement wan de Vereniging voor de Effecten, januari 1974. 
kleine wijzigingen te hebben doorgevoerd, werd het controlereglement op 16 mei 1974 tijdens een ledenvergadering aangenomen. Op 1 juni 1974 trad dit reglement in werking. Een jaar later, op 3 april 1975 , sprak de vereniging over de bemanning en de uitbreiding van de staf van het secrerariaat van het controlebureau. Vanuit het bestuur werd voor de functie van hoofd van het controlebureau de voorkeur gegeven aan een registeraccountant. Deze zou in dienst van de VvdE treden. Niet alleen het toezicht op de naleving van de regels, maar ook het toezicht op de financiële aspecten voortkomend uit de relatie tussen de Vereniging, IIE en de Kas-Associatie ${ }^{62}$ zouden tot de taak van het hoofd van het controlebureau behoren. Op donderdag 7 augustus 1975 meldde de $V_{v d E}$ dat de heer drs. R.A. Bothof, een register-accountant ${ }^{63}$, aangenomen was als hoofd van het controlebureau. Het controlebureau was hiermee een feit. Toezicht op de regelgeving van de beurs, de zelfregulering, was vanaf nu in handen wan het controlebureau.

\subsection{Internationalisering}

Begin jaren tachtig van de twintigste eeuw waren de beursomzetten hoger dan ooit. Dit waren goede tijden voor de Amsterdamse Effectenbeurs. De beurs breidde haar handel uit hetgeen leidde tot verdere internationalisering. In 1975 besloot de VvdE een commissie in te stellen die de mogelijkheid en wenselijkheid van de vestiging van een optiemarkt in Amsterdam moest bestuderen. Het advies van deze commissie was positief. Naar aanleiding van dit advies stelde het bestuur van de VvdE een technische commissie in. Deze commissie kreeg tot taak zowel de optiebeurzen als de clearingorganisaties in Chicago, New York en Toronto grondig te bestuderen. Na een bezoek aan de Verenigde Staten te hebben gebracht bracht deze commissie haar rapport uit aan het bestuur. $\mathrm{Na}$ een verklaring van geen bezwaar van de Minister van Financiën kon op 30 november 1977 de Vereniging European Options Exchange (VEOE) worden opgericht ${ }^{64}$. De VEOE was een pure Amsterdamse aangelegen-

De Kas-Associatie kan gezien worden alls de "bank" van de beurs. Het is in 1806 ontstaan en heette toen "Associatie-Cassa". In 1865 werd naast de AssociatieCassa de "Kas-Vereeniging" opgericht. Uiteindelijk fuseerden beide in $1952 \mathrm{en}$ gingen op in de Kas-Associatie.

Cross, D.H. en Diephuis, J.H., "De Amsterdamse effectenbeurs" wit de serie Banken Effectenrecht dl. 15, t.a.p. noot 42, p. $21 \mathrm{en} 22$. 
heid. Met de oprichting van een optiebeurs wilde de VvdE een samenwerkingsverband met de beurs van Londen aangaan. De opties zouden over beide beurzen verdeeld worden. Zowel vanaf de Amsterdamse als van de Londense vloer zou gehandeld kunnen worden. De afwikkeling zou door een gezamenlijke clearingorganisatie geschieden. Chauvinisme wordt als belangrijkste reden voor het afblazen van de AmsterdamLondense samenwerking gezien ${ }^{65}$. Daarnaast werkten de afwijkende wettelijke voorschriften waaraan deze beurzen waren onderworpen, meer tegen dan mee 66 .

De optiebeurs trok de aandacht van het buitenland hetgeen tot verdere internationalisering leidde. Opvallend was dat er aan het eind van de jaren zeventig niet meer of heel weinig met fysieke aandelen werd gehandeld. De tijd van de oorspronkelijke aandelen met coupons/ dividendbladen, de klassieke stukken of $\mathrm{K}$-stukken, was voorbij ${ }^{67} . \mathrm{Om}$ een goede concurrentiepositie te kunnen behouden moest het effectenverkeer zo professioneel mogelijk verlopen. In 1977 maakte de wet Giraal Effectenverkeer het mogelijk effecten efficiënt te leveren en die levering te verwerken. Voortaan werden effecten giraal geleverd. De girale levering verliep als volgt: deelnemers aan het effectenverkeer stortten een bepaald bedrag bij een centrale instantie genaamd NECIGEF ${ }^{68}$. Wanneer men bepaalde aandelen verkocht en moest leveren, gaf het lid van de $\mathrm{VvdE}$ NECIGEF de opdracht de waarde van de aandelen van zijn rekening af te schrijven en op de rekening van de koper bij te schrijven. De koper, een lid van de VvdE, had natuurlijk ook een rekening bij NECIGEF. Her gevolg van dit systeem was dat de stukken in de kluis bleven liggen en er uitsluitend administratief werd gelleverd. De belegger had zijn stukken in open bewaring gedeponeerd en was nu niet meer eigenaar van een bepaald te individualiseren stuk, maar mede-eigenaar van alle stukken van hetzelfde fonds die bij de bewaarder berustten. In geval hij zijn aandelen weer wilde doorverkopen, werd de waarde van zijn aandelen van zijn rekening afgeschreven.

65 Er kan van chauvinisme worden gesproken wanneer het niet mogelijk, dan wel erg moeilijk is om te handelen in opties van niet-Nederlandse aandelen. Vries, J. de en Damen E., "Een eeuw vol effecten", t.a.p. noot 23, H.7.

67 Een obligatie bestaat uit cen mantel en een couponblad. Een aandeel uir een mantel en een dividendblad.

68

NECIGEF, een dochter van de VvdE, is een afkorting van Nederlands Centraal Instituut voor Giraal Effectenwerkeer B.V. en stond destijds onder toezicht van de Minister van Financiën. 
De internationalisering had tot gevolg dat de handel steeds omvangrijker en onoverzichtelijker werd. Het verdwijnen van de oude generatie en de komst van jongere leden zorgden ervoor dat niet iedereen elkaar kende. Hierdoor vielen overtredingen van beursregels niet snel op. De beursstructuur was duidelijk - wat het toezicht op de beursvloer betrof - aan enige wijziging toe. Tot 1980 oefende de Commissie van Dienst het toezicht uit over de effectenhandel op de beursvloer. Deze commissie bestond uit negen leden van de VvdE. De leden waren afkomstig van banken, hoeklieden en commissionairs. Beurtelings waren deze leden Commissaris van Dienst. In deze functie beschikten zij over bepaalde informatie waarover zij zelf beroepsmatig niet mochten beschikken. In de funcrie van Commissaris van Dienst mochten de leden in de boeken van hun concurrenten kijken. Dit veroorzaakte enige wrevel op de beursvloer. Het werd tijd voor een "niet aan een ander lid verbonden persoon" die onafhankelijk was en in dat opzicht geen persoonlijk belang had bij de beschikbare fondseninformatie. In 1980 werd de eerste beroepscommissaris voor de Notering door de VvdE ingesteld. De taak van de Commissaris voor de Notering was het houden van toezicht op de beurs(vloer). Dit deed hij door er rond te lopen en de koersen te volgen. Indien er koersontwikkelingen waren die buiten een bepaalde bandbreedte vielen, werden deze gesignaleerd en in de gaten gehouden. Zodra de commissaris iets afwijkends constateerde werd de handel stilgelegd en teruggedraaid. Het terugdraaien van de handel geschiedde in overleg met de voorzitter van de VvdE. Onverwijld werd het controlebureau ingelicht. Een jaar na het aantreden van de nieuwe voorzitter van de VvdE, B.F. Baron van Ittersum, werd een onafhankelijke klachtencommissie opgericht. Dat gebeurde in $1982^{69}$. De invoering van een klachtencommissie was revolutionair. Daar waar een juridische procedure jarenlang kon duren, zorgde de klachtencommissie ervoor dat klachten sneller afgedaan konden worden. De instelling van een klachtencommissie had een commerciële reden. Nu straalde de Amsterdamse Effectenbeurs en haar leden nog meer betrouwbaarheid uit. Immers, in geval er iets mis zou gaan, kon de gedupeerde altijd naar de onafhankelijke klachtencommissie stappen. 
De internationalisering had ook meer mechanisering en meer automatisering tot gevolg. De jaren tachtig van de vorige eeuw kenmerkten zich door een economische groei. De groei van de financiële sector, in combinatie met de opkomst van de informatietechnologie, zorgden voor een steeds snellere handel in effecten. In 1985 ging de beurs over tot doorlopende notering van alle fondsen. Voorts werd een "Stockwatch" ingesteld. Dat had tot gevolg dat de koersbewegingen nauwkeurig werden gevolgd en geanalyseerd. Aan her begin van de jaren tachtig begon men meer en meer over de aanpak van misbruik van voorwetenschap te discussiëren. Om een eerlijke markt te kunnen garanderen voerde de VvdE in 1987 de Modelcode voorkoming voorwetenschap in. De overheid reageerde hierop door in 1989 misbruik van voorwetenschap strafbaar te stellen ${ }^{70}$. In 1995 werd de eerdergenoemde Modelcode door de $V_{v d E}$ geactualiseerd ${ }^{71}$.

Op 19 oktober 1987, de zogenaamde zwarte maandag, vond er een beurskrach plaats. De krach was afkomstig van de New York Stock Exchange, de effectenbeurs te New York. Binnen enkele uren hadden verschillende beursen over de hele wereld onder de gevolgen te lijden. Deze crash had tor gevolg dat het beleggend publiek voorzichtiger met effecten omging. Naar aanleiding van de gevolgen van de beurskrach deelle de VvdE haar leden in het jaarverslag van 1987 mede dat er maatregelen genomen moesten worden. Deze maatregelen moesten ertoe leiden dat de Amsterdamse Effectenbeurs haar structuur zou wijzigen. Hierdoor zou zij de steeds sneller veranderende markt kunnen bijhouden ${ }^{72}$. De effectenbeurs zou zo in staat zijn een slagvaardiger beleid te voeren om haar plaats op de internationale financiële markt te behouden ${ }^{73}$. In 1989 richten de VvdE en de VEOE de Stichting Toezicht Effectenverkeer $^{74}$ (STE) op. Hiermee werd het toezicht op Amsterdamse beurzen $^{75}$ een taak van de STE en ontwikkelde zich een nieuwe vorm van toezicht. De STE oefende in het begin haar toezichtstaken uit door het controlebureau op te dragen bepaalde onderzoeken in te stellen.

70 In 1989 werd misbruik van voorkennis via de invoering van artike. 336 a Werboek van Strafrecht strafbaar gesteld.

71 Jaarverslag 1995 van de Amsterdamse Effectenbeurs, p. 26.

72 Jaarverslag 1987 van de Amsterdamse Effectenbeurs, p. 2-3 (Engelse versie),

73 Jaatverslag 1995 van de Amsterdamse Effecrenbeurs, p. 49.

74 Meer over de STE en later de Autoriteit-FM, in hoofdstuk 2.

75 Te weten de VvdE, de VEOE en de Financiële Termijnmarkt (FTA). 
Het toezicht van de STE was niet alleen gericht op de interne regelgeving, maar ook op de regelgeving afkomstig van de overheid, de externe regelgeving. Bij een beschikking ${ }^{76}$ van de Minister van Financiën kreeg de STE de bevoegdheid toezicht op de beurzen uit te oefenen ${ }^{77}$.

Vanaf het begin van de jaren negentig drong het bij de VvdE door dat zij haar structuur ingrijpend moest wijzigen omdat zij anders haar internationale positie niet zou kunnen handhaven ${ }^{78}$. Het gewijzigd beleid van de $V_{v d E}$ kwam onder andere tot uiting in de afschaffing van de beursbelasting en de vrijlating van provisietarieven. Wat opviel was dat niet alleen het beleid zich had gewijzigd, maar dat er ook in de structuur van de VvdE veranderingen waren doorgevoerd. In 1990 werd er, in tegenstelling tot de voorgaande jaren, een organisatorisch onderscheid gemaakt tussen de interne regelgever en toezichthouder - te weten de VvdE - en het beursbedrijf. Juridisch was de structuur niet gewijzigd; de verenigingsstructuur bleef bestaan. Helaas mocht dit niet baten. Concurrentie dwong de VvdE in 1995 weer tot nadenken over herstructurering van de Amsterdamse effectenbeurs. Besloten werd over te gaan tot een "organisatie met meer slagkracht" ${ }^{179}$. De juridische structuur zou ditmaal worden gewijzigd. In plaats van een vereniging met leden, zou de vereniging opgaan in een vennootschapsvorm met aandeelhouders. De Vereniging voor de Effectenhandel zou de eenentwintigste eeuw niet halen.

\subsection{Van vereniging naar naamloze vennootschap}

Zoals reeds uit paragraaf 1.5 is gebleken bracht de internationalisering van de beurshandel vele vernieuwingen met zich mee. Niet alleen de snel veranderende financiële wereld, maar tevens de technologische veranderingen - zoals de wereldwijde handel via computerschermen, ook wel de genoemd "de schermenhandel" - legden veel druk op de Amsterdamse effectenbeurs. Concurrentie dwong de Amsterdamse effectenbeurs tot veranderingen. Het was niet meer vanzelfsprekend dat handelaren en beleggers zich lieten leiden door traditie. De jaren negentig maakten

\footnotetext{
76 Beschikking van Minister van Financiën d.d. 24 januari 1989, Stcrt. 1 februari 1989. 
duidelijk dat de keuze van handelaren en beleggers bepaald werd door lage kosten, liquiditeit en een veilige en toegankelijke markt. De eenwording van Europa en de komst van een monetaire unie, de EMU, leidden tot het ontstaan van een Europese kapitaalmarkt. De Amsterdamse effectenbeurs had in tegenstelling tot de beurzen in Londen, Frankfurt en Parijs geen grote economische thuismarkt. Dit kon nadelig zijin woor de Amsterdamse effectenbeurs. De grotere beurzen probeerden en proberen vandaag de dag nog steeds om de buitenlandse fondsen binnen te halen. De Amsterdamse effectenbeurs besefte dit al vroeg en wilde haar invloed niet verliezen. Via een fusie tussen de nationale beurzen trachtte zij zich tegen de opkomende concurrentie te wapenen. Het bestuur van de $\mathrm{VvdE}$ besloot een commissie in het leven te roepen die zou moeten adviseren omtrent een mogelijke fusie tussen de Amsterdamse beurzen. Tevens zou de commissie hierover aanbevelingen opstellen. In oktober 1995 accepteerde het bestuur van de VvdE de aanbevelingen van deze commissie, genaamd de commissie Hoogendijk. De commissie stelde voor de beurzen onder te brengen in een aparte vennootschap. Tevens werd voorgesteld de effectenclearingen van de Amsterdamse effectenbeurs en de VEOE in de vorm van een gezamenlijk afwikkelingsinstituut in een tussenholding onder te brengen. Tenslotte makate de commissie het voor de leden mogelijk om bij de beurs te worden betrokken door in het kapitaal mee te delen. Dat kapitaal van de beurzen zou als volgt verdeeld moeten worden: de leden zouden $50 \%$ van het kapitaal ontvangen en de institutionele beleggers en de uitgevende instellingen zouden ieder $25 \%$ van het kapitaal krijgen.

Ten gevolge van de Europese éénwording kwam er op het gebied van het effectenverkeer steeds meer regelgeving. Deze vele Europese richtlijnen hadden evenzoveel wetswijzigingen tot resultaat. In het kader van de Wet Toezicht Effectenverkeer 1995 (Wte'95) zouden alleen leden toegang tot de beurs kunnen krijgen. Nu zou het wettelijk geregeld zijn dat men eerst lid van de beurs moest zijn aleer men op de beurs mocht handelen. Hierover zouden destijds wel afspraken met de STE gemaakt moeten worden. In december 1995 werden de aanbevelingen door de leden van de $\mathrm{VvdE}$ aangenomen. Naar aanleiding hiervan werd een stuurgroep ingesteld. Nog voor de fusie plaatsvond zijn er wijzigingen in de aanbevelingen van de commissie Hoogendijk aangebracht. Een van de wijzigingen was het afzien van een ledenorganisatie. In plaats van een ledenstructuur besloot men over te gaan tot een vennootschapsvorm. De fusie tussen de $\mathrm{VvdE}$ en de VEOE zou ertoe leiden dat de 
aandelen $\mathrm{A}$ (winstbewijzen) onder de leden zouden worden verdeeld. De aandelen $B$ zouden met behulp van een "bookbuildingssyteem ${ }^{80 "}$ herplaatst worden. Dit hield in dat alle aandelen B bij institutionele beleggers geplaatst zouden worden. Op 1 januari 1997 was de fusie een feit. Uit de VvdE, de VEOE en de FTA is Amsterdam Exchanges N.V. (Amsterdam Exchanges/AEX) ontstaan; een structuurvennootschap. Zie figuur 1.2. De drie beurshouders gingen op in een beurshouder. De drie beurzen waren bij AEX N.V. in de vorm van werkmaatschappijen ondergebracht. De werkmaatschappijen waren: AEX-Effectenbeurs voor de effecten; AEX-Optiebeurs voor opties en futures; AEX-Agrarische termijnmarkt; AEX-Clearing and Depository voor afwikkeling en bewaarneming; AEX-Information Technology voor automatisering en systeembeheer. De koersinformatie was ondergebracht bij AEX-Data Services. De werkmaatschappijen hadden geen eigen regelgevende bevoegdheid. Regelgeving was afkomstig van AEX N.V. ${ }^{81}$. Ze kregen eigen inkomsten en budgetverantwoordelijkheid. Aan het hoofd van iedere werkmaatschappij stond een directeur. De directeur werd ondersteund door verschillende stafafdelingen. De stafafdelingen waren: financiële zaken, interne accountants-diensten, marketing en productontwikkeling, mediavoorlichting en public affairs, personeelszaken en regelgeving en juridische zaken. De directie van Amsterdam Exchanges moest verantwoording afleggen aan de Raad van Commissarissen.

80 De voorinschrijving onder institutionele beleggers met als doel de vraag nat de te plaatsen aandelen in kaart te brengen staat bekend onder de naam bookbuilding. Werkmaatschappijen zijn bedrijfseenheden die zelfstandig binnen Amsterdam Exchanges opereren. Persinformatie wan Amsterdam Exchanges, 1997, p. 6. 


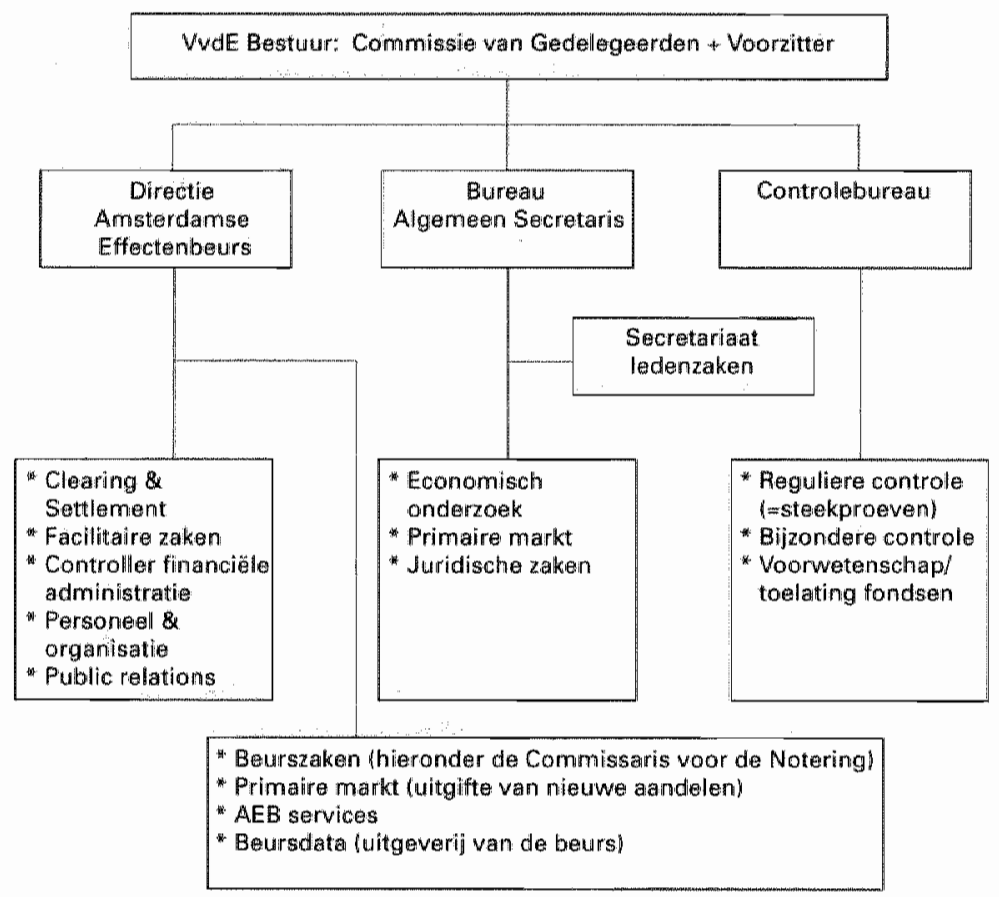

FIGUUR 1.2 Organisatiestructutur Amsterdam Exchanges per I januari 1997

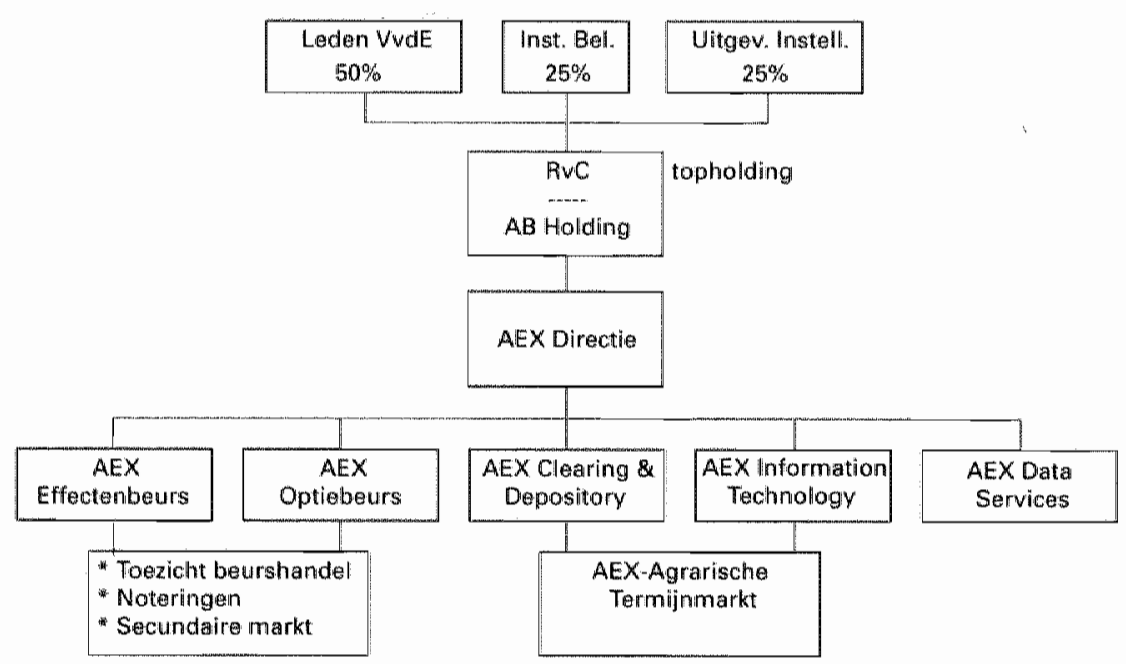


Zoals uit de figuren 1.1 en 1.2 kan worden afgeleid, heeft de herstructurering van de beurzen veel veranderd. De interne regelgeving kwam niet meer door het bestuur en de ledenvergadering tot stand. De directie van de gefuseerde beurzen besliste nu over nieuwe "leden". Aangezien er van een verenigingsvorm was afgestapt, paste het gebruik van de term leden niet meer. In plaats van leden sprak men nu over toegelaten instellingen. De toegelaten instellingen waren gebonden aan de door het bestuur genomen beslissingen. Tot de toegelaten instellingen behoorden in eerste instantie de bestaande leden van de VvdE en de VEOE. Op grond van hun lidmaatschap waren zij leden van de VvdE, de VEOE en de FTA. Deze leden waren nu niet aan een nieuwe toelatingsprocedure onderworpen. $\mathrm{Zij}$ werden van rechtswege tot $\mathrm{AEX}$ toegelaten onder de voorwaarde dat zij binnen een maand na de fusie een toelatingsovereenkomst getekend zouden hebben. De beursleden, zetelvertegenwoordigers en beursgemachtigden moesten zich opnieuw laten registreren. Voorts moesten de leden instemmen met de overdacht van oude dossiers van de VvdE, VEOE en FTA naar AEX. De reikwijdte van de vergunningen werd aangepast. Daar waar de VvdE vermeld stond, werd AEX ingevuld. Op het moment van de fusie waren er nog geen nieuwe reglementen. De gefuseerde beurzen gaven aan dat er voorlopig nog onder de oude regels gewerkt zou worden. Een ieder die na 1 januari 1997 actief op AEX wilde zijn, moest zich onderwerpen aan de reglementen van Amsterdam Exchanges N.V. De binding tussen de toegelaten instellingen en AEX berustte op een contract. Het gevolg hiervan was dat er geen beursleden meer bestonden. Tevens konden er geen bewindvoerders benoemd worden. Daarnaast hadden toegelaten instellingen geen inspraak meer bij een nieuwe toelating. Een bijkomend gevolg van de fusie was de vermindering van zelfregulering. In het kader van de fusie had de beurs afspraken met de toezichthoudende STE gemaakt. Amsterdam Exchanges N.V. bleef verantwoordelijk voor de handel op de beurs. Zij moest wel periodiek rapporteren aan de STE. In geval van misbruik van voorwetenschap was alleen de STE bevoegd om op te treden. Naast deze veranderingen waren er op het gebied van regelgeving meerdere veranderingen doorgevoerd. Internationalisering, globalisering en concurrerende (Europese) beurzen hebben er uiteindelijk toe geleid dat uit een fusie van de beurzen te Amsterdam, Parijs en Brussel, Euronext Amsterdam N.V. is ontstaan ${ }^{82}$. 



\section{Toezicht en regulering van de Nederlandse effectenwetgeving}

\section{$2.1 \quad$ Inleiding}

"We spelen allemaal gradg een beetje kat en muis onder elkaar; als commissionatis en boeklieden in een boek. Ook onder elkatr en over en weer dan ook nog. Dat boort nit eenmaal bij bet beursplel en dat zal waarschijnlijh wel alijd zo blijwen. Het moet misschien ook maar zo blijuen want witeindelijk moet de slimste in staat zijn de orders beter wit te woeren dan iemand die iets minder slim is. Dat is de spont die erin moet $z i j n n^{\prime \prime}$

Dit citaat van de heer Van Marken, oud-voorzitter van de VvdE, toont duidelijk aan hoe er in de 60-er jaren van de vorige eeuw werd en waarschijnlijk ook vandaag de dag nog tegen de effectenbeurs en de handel in effecten wordt aangekeken. Uit het citaat blijkt dat ingewijden de beurshandell als een spel beschouwen. Ieder spel heeft zo zijn regels. Voor het beursspel gelden regels die in deze studie worden onderverdeeld in twee categorieën: enerzijds de regels opgelegd door of vanwege "de externe regelgeving" en anderzijds door zelfregulering ${ }^{2}$, de interne regels ofwel "de interne regelgeving". Dat laatste kan worden omschreven als "de handelsregels" van de beurs. De verschillende beursactoren zijn verplicht zich op de beurs te houden aan de interne effectenregelgeving. De effectenbeurs creëert deze regelgeving zelf en is eindverantwoordelijke voor de naleving van voornoemde regels. Zowel de beurzen als de beursactoren moeten binnen het effectenverkeer rekening houden met de externe regels uitgevaardigd door de Nederlandse toezichthouder. Vanaf 1 maart 2002 is dat de Autoriteit Financiële Markten (AutoriteitFM). Voorheen was dat de Stichting Toezicht Effectenverkeer (STE) ${ }^{3}$. In

De heer J.C. van Marken is voorzitter van de VwdE geweest. Deze uitspraak heeft hij in de ledenwergadering van 1 juni 1965 gedaan..

2 Zelfregulering heeft tot gevolg dat het overheidstoezicht op de beurzen terughoudend van aard is. Volgens de Kamerstukken $\mathrm{II}_{1}, 1993 / 94,3$, p. 8 (MvT) is de "toetsing van zowel de regels als de handhaving" van het hiervoor genoemd toeziche slechts marginaal.

3 Hieronder meer over de Autoriteit-FM en de STE. 
het verleden, ten tijde van de STE, kwam het regelmatig voor dat de toezichthouder bij de uitvoering van haar toezicht rekening diende te houden met een andere toezichthouder binnen het effectenverkeer, namelijk de Nederlandsche Bank (DNB). Om deze reden zal waar dat van toepassing is, DNB aan bod komen. Met de overgang van de STE naar de Autoriteit-FM, is de toezichtsstructuur veranderd. Hiermee heeft ook een beperking van de rol van DNB als toezichthouder voor effectentypische actoren plaatsgevonden. Hierover later meer. Vast staat dat de Autoriteit-FM in Nederland, sinds de oprichting van de STE, meer en meer de vorm van een volwaardige toezichthouder begint aan te nemen. Aan het eind van de jaren negentig heeft zij meer bevoegdheden gekregen om het toezicht op het Nederlandse effectenverkeer effectiever uit te oefenen. Zeer belangrijk hierbij is de toekenning van de bevoegdheden om boetes en dwangsommen uit te vaardigen op grond van de Wet bestuurlijke sancties financiële sector (WBS). Meer hierover in paragraaf 2.5.1. Mede door de gewijzigde rol van de Autoriteit-FM, heeft zij vandaag de dag een prominente positie als toezichthouder van onder andere effectentypische actoren. Daarom is het voor deze studie van belang om haar positie nader te bestuderen.

In dit hoofdstuk zal het toezicht uitgeoefend door de Autoriteit-FM en de daartoe strekkende bevoegdheden centralal staan. In paragraaf 2.2 wordt begonnen met de ontstaansgeschiedenis van de Autoriteit-FM. Vervolgens zal in paragraaf 2.3 de relevante Nederlandse effectenregelgeving worden besproken. Hierdoor kan de reikwijdte van de bevoegdheden van de Autoriteit-FM in beeld worden gebracht. Daarna zal worden weergegeven hoe de toezichtuitoefening daadwerkelijk geschiedt en welke afdeling van de Autoriteit-FM daar een belangrijke rol in vervult. Nadat duidelijk is geworden hoe de toezichthouder mogelijke wetsovertreders traceert, volgt een bespreking van de verschillende handhavingsprocedures waarmee een effectentypische wetsovertreder kan worden geconfronteerd. Dit hoofdstuk zal vooral de positie van de AutoriteitFM in de handhaving van de effectentypische wetgeving verduidelijken zodat deze in het vierde hoofdstuk met haar Amerikaanse collega, de Securities Exchange Commission, kan worden vergeleken. 


\subsection{Van Stichting Toezicht Effectenverkeer naar Autoriteit Financiële Markten}

Het toezicht op het Nederlands effectenverkeer is in verschillende wetten geregeld. Deze wetten wijzen verschillende toezichthouders aan. De meest bekende toezichthouder op het terrein van het Nederlands effectenverkeer is de Autoriteit Financiële Markten, bekend als de Autoriteit-FM of in de volksmond de A-FM. Dit is niet altijd zo geweest. Tot en met 31 januari 1989 viel het toezicht op het effectenverkeer, waaronder het toezicht op de Amsterdamse Effectenbeurs, onder de Minister van Financiën. Op grond van de Beurswet 1914 werd dit toezicht deels door de Commissie van Bijstand voor de Uitvoering van de Beurswet 191.44 uitgeoefend. De in hoofdstuk een genoemde commissies van toezicht ${ }^{5}$ hielden toezicht op de andere beurzen, namelijk de Optiebeurs en de Financiële Termijnmarkt Amsterdam ${ }^{6}$.

Aan het eind van de zeventiger jaren, begin van de tachtiger jaren van de vorige eeuw viel er op het gebied van het effectentoezicht langzamerhand een wijziging te constateren. Niet alleen de Nederlandse overheid, maar ook op Europees niveau werd nagedacht over het functioneren van de effectenhandel. Het gevolg hiervan was een toename aan regels die later - in de vorm van harmonisatierichtlijnen - in onder andere Nederland de basis zouden vormen voor nieuwe regelgeving. Begonnen werd met de invoering van de Wet effectenhandel (Weh) en met een algemene herziening van de bestaande effectenwetgeving. In de lijn van het door het tweede kabinet Lubbers gevoerd beleid ${ }^{7}$, besloot het effectenwezen ${ }^{8}$ in samenspraak met de Minister van Financiën om, evenals in het

Zie ook paragraaf 1.3 .1 .

Te weten de Commissie van Toezicht op de Optiebeurs en de Commissie van Toezichtr op de Financiële Termijnmarkt Amsterdam.

6 Mok, M.R, Toezichs effectenverkeer (I), TVVS, 1989 , nr. 3, p. 77.

Het beleid dat het tweede kabinet onder leiding van Minister-president R. Lubbers, in de periode 1986 - 1989 heeft gevoerd, was gericht op het werzelfstandigen van bepaalde owerheidstaken. Kamerstukken II, 21038, 3, p. 12. (MvT)

8 Te weten de Effectenbeurs, Optiebeurs. De Financiële Termijnmarkt Amsterdam (F"TA) kreeg pas onder de Wte' 92 de status van effectenbeurs, maar rapporteerde desondanks aan de STE. STE, Jaarverslag 1989, Amsterdam, mei 1990, p. 12 en STE, Jatroerslag 1990, Amstelveen, mei 1991, p. 5. 
Verenigd Koninkrijk het geval was ${ }^{9}$, het toezicht op het effectenverkeer niet meer door de Minister maar door een zelfstandige instelling te laten verrichten. Deze instelling moest formeel los van de overheid $\operatorname{staan}^{10}$. Aangezien de in 1986 ingevoerde Weh niet de mogelijkheid bood om de krachtens deze wet uit te oefenen controle te delegeren, bleef het toezicht op de buitenbeurshandel een taak van de Minister van Financiën. Deze Minister besloot, naar aanleiding van voornoemd overleg, zijn bevoegdheden betreffende de beurshandel bij Ministeriële Beschikking aan een zelfstandig toezichthoudende instelling - de Stichting Toezicht Effectenverkeer - te delegeren. Met de instelling van de STE werden de Commissie van Bijstand voor de Uitvoering van de Beurswet 1914 en de Commissies van Toezicht opgeheven en kreeg de STE de verantwoordelijkheid over her beurstoezicht. Op 21 juli 1988 was het zover; de oprichring van de STE was een feit. Ruim zes maanden later, op 1 februari 1989, droeg de Minister bij Ministeriële Beschikking ${ }^{11}$ het dagelijks toezicht op alle beurzen ${ }^{12}$ over aan de nieuwbakken stichting ${ }^{13}$. Reeds bij haar oprichting was er in de statuten bepaald dat het bestuur van de STE zou moeten bestaan uit 4 tot 6 leden welke door de Minister zouden worden benoemd, geschorst dan wel ontslagen. Voorts was er in de

9 De Amsterdamse beurzen en de Minster van Financiën hielden de beurzen van her Verenigd Koninkrijk nauwlettend in de gaten ondat zij als Amsterdam's grootste concurrent werden beschouwd. Kort erwoor, in 1986, heeft het Verenigd Koninkrijk haar effectenwetgeving veranderd. De invoering van de Financial Services Act 1986 vormde het wetrelijk kader voor deze wetgeving. In de Financial Services Act 1986 was het toezicht op het effectenverkeer geregeld. De toezichthouder op de Londense beurzen, het in 1985 opgerichte Securities and Investment Board (SIB), was een privaatrechtelijke rechtspersoon. Deze stond formeel los van de overheid, maar diende wel verantwoording aan de Minister voor Handel en Industrie af te leggen. Kamerstukken II, 1988/89, 21038, 3, p. 13-15. (MvT) Kamerstukken II, 1988/89, 21038, 3, p. 12 en 13. (MvT)

Ministeriële Beschilkking van 24 januari 1989 , nr. $88 / 784$, Stcrt. 23,1 februari 1989.

12. Naast de Effectenbeurs en de Optiebeurs, valt ook de door de Minister van Financiën in 1989 erkende Rotterdam Energy Futures Exchange (Roefex), onder het toezicht van de STE. STE, fatrvershg 1989, Amsterdam, mei 1990, p. 12 13. Op verzoek van de Roefex en na de STE gehoord te hebben, heeft de Minister van Financiën de beursvergunning van de Roefex per 27 september 1990 laten verwallen. STE, Jaaverslag 1990, Amstelveen, mei 1991, p. 14. De FTA zou pas medio 1992 onder het wettelijk toezicht van de STE komen te staan. STE, Jatrverslag 1990. Amstelveen, mei 1991, p. 5 en STE, Jaarvershag 1991, Amstelveen, mei 1992, p. 5.

13 Uit: Kamerstukken II, 1988/89, 21038, 3, p. 12 (MvT) 
statuten bepaald dat de door de bedrijfstak ${ }^{14}$ voorgedragen bestuursraden ${ }^{15}$ door de Minister moesten worden benoend. Alle oprichters, de VvdE, de VEOE en de Minister, beoogden met een "stichting" een zo onafhankelijk mogelijk lichaam in het leven te roepen. De oprichters deelden de mening dat de rechtsfiguur van een stichting het best in staat zou zijn om de "rechtshandelingen in onafhankelijkheid" te verrichten, omdat daarbinnen geen goedkeuring van een leden - of aandeelhoudersvergadering was vereist ${ }^{16}$. Het toezicht op de effectenbeurzen werd gebaseerd op gemandateerde bevoegdheden die de Minister, op grond van de Beurswet 1914, had opgedragen aan de $S T^{17}$.

De STE, die vanaf haar oprichting als "waakhond" van het Nederlands effectenverkeer in het algemeen en van de beurzen in het bijzonder wordt beschouwd ${ }^{18}$, oefende zowel het prudentieel als het gedragstoezicht uit over het merendeel van de effectentypische (financiële) instellingen. In dit toezichtsmodel, ook well het sectoraal toezichtsmodel genoemd, bestond de kans op tegenstrijdige toezichtsdoelstellingen, hetgeen weer spanningsvelden kon creëren. Daar waar de toezichthoudende STE geconfronteerd werd met sectoroverschrijdende onderwerpen, kon zij de hulp van de Raad van Financiële Toezichthouders (RFT) inroepen ${ }^{19}$. Naast het feit dat de STE het toezicht uit kon oefenen door regels vast te stellen, was zij bevoegd om aan de hand van de bepaalde criteria er op toe te zien dat zowel de regels als de naleving van deze regels in overeenstemming met deze maatstaven waren. De criteria die de STE hierbij hanteerden zijn:

\section{- voldoende bescherming voor de belegger en}

- een behoorlijke functionering van de effectenhandel.

14. De beurzen dragen een bestuursraad voor. Na de imwerkingtreding van de Wet Toezicht Effectenverkeer in 1992, de Wte' 92 , zou een organisatie in de buitenbeurshandel ook een bestuursraad mogen voordragen. Kamerstukken $\mathbb{I I}_{4}$ 1988/89, 21038,3 , p. 13 en 14 (MvT). De We 92 zal in $\$ 2.3$. nader worden besproken.

15 Een bestuursrad behoort niet ror het bestuur en heeft geen stemrecht. Zij worden door de bedrijfstak voorgedragen en hebben een adviserende functie. Kamerstukken IT, 1988/89, 21038, 3, p. 13 (MvT).

6a Kamerstukken II, 1988/89, 21038,3, p. 13 (MvT) en Mok, M.R., Toezicht effectenverkeer (II), TVWS, 1989, nr. 89/4, p. 103.

17 Zie Ministeriële Beschikking van 24 januari 1989, nr. 88/784, Stcrt. 23, 1 februari 1989 en STE, jaarverslag 1989, Ansterdam, mei 1990, p. 5.

18 Rank, W.A.K, Stichting Toezicht Effectenverkeer (STE), Nieuwsbrief bedrijfsjuridische berichten, 7 maart 1989 , n.r. 5 , p. 50 .

19 Kamerstukken II, 2001/2002, 28122, nr. 2, p. 6 . 
Ondanks de inspanningen van de financiële toezichthouder, te weten de STE, DNB en PVK bleek de toezichtsuitoefening efficiënter te kunnen. Tegenstrijdige toezichtsdoelstellingen, zoals een botsing tussen het prudentieel - en het gedragstoezicht, bemoeilijkten nodeloos de taakuitoefening van de verschillende toezichthouders. Daarnaast was het voor de consument van financiële producten niet altijd even duidelijk bij welke toezichthouder zij terecht kon. Naar aanleiding van een door de Minister van Financiën ingediend wetsvoorstel, brak er voor de toezichthouders van de financiële sector, waaronder de effectentypische toezichthouders, op 6 februari 2002 een nieuwe periode aan. De door de Minister ingediende nota "Hervorming toezicht financiële marktsector ${ }^{20 "}$ heeft geleid tot een reorganisatie van de toezichtsstructuur op de financiële marktsector. Voornoemde nota heeft de basis gecreëerd voor het verlaten van het sectorale toezichtsmodel en het toepassen van het functionele toezichtsmodel. Dit heeft, op 1 maart 2002, geleid tot de overgang van STE in de Autoriteit Financiële Markten. Met deze naamswijziging heeft zowel een verruiming van financiële doelstellingen als van de bevoegdheden plaarsgevonden. Voor de bovengenoemde hervorming van het toezicht op de financiële marktsector, waar het effectenverkeer een onderdeel van uitmaakt, heeft de wetgever aan de hand van de drie algemene financiële doelstellingen, het nieuwe toezichtsmodel nader ingevuld. De algemene doelstellingen die binnen de wereld van de financiële toezichthouders gelden zijn:

a. bet systeemtoezicht; gericht op de stabiliteit van het systeem

b. het prudentielle toezicht; gericht op de soliditeit van financiële instellingen; en

c. het gedragstoezicht; gericht op goed gedrag, op transparantie op de markt

Bovengenoemde doelstellingen zijn gericht op het belang van de consument. Desondanks bestaat er tussen de eerste twee doelstellingen, het systeemtoezicht en het prudentieel toezicht, meer samenhang dan met de derde doelstelling: het gedragstoezicht. Het systeemtoezicht en het prudentieel toezicht blijken nauw met elkaar te zijn verbonden omdat zij beide, weliswaar vanuit een andere benaderingswijze, gericht zijn op de financiële stabiliteit van bedrijven. De derde algemene doelstelling, het gedragstoezicht, is in beginsel losgekoppeld van de financiële soliditeit 
van instellingen en richt zich uitsluitend op de verhoudingen van marktpartijen, de relaties tussen de verschillende financiële actoren. Dit onderscheid, deze rweedeling tussen de algemene financiële doelstellingen heeft er onder meer aan bijgedragen dat de wijziging, van het toezichtsmodel van sectoraal naar functioneel, heeft kunnen plaatsvinden. Daarnaast speelde ook de efficiëntie een belangrijke rol. In het sectorale toezichtsmodel kwam het geregeld voor dat zowel de STE als DNB inefficiënt werkten. Dit kwam doordat zij zichzelf onnodig administratief belastte. Daar deze toezichthouders op bepaalde punten aan dezelfde administratieve eisen moesten voldoen, leverde dit niet alleen doublures op, maar kon dat ook leiden tot verwarring en onnodige irritatie bij de (financiële) instelling. Op grond van het voorafgaande was de Minister van Financiën van mening dat de invoering van een functionele toezichtsstructuur op zijn plaats was. In het functionele toezichtsmodel is het systeemtoezicht een taak voor de DNB ${ }^{21}$. DNB heeft ook het prudentieel toezicht over banken, beleggingsinstellingen en over effecteninstellingen. De PVK oefent het prudentieel toezicht uit over de verzekeraars. Daar waar DNB en de PVK geconfronteetd worden met sectoroverschrijdende onderwerpen, kunnen zij gebruik maken van een nauw samenwerkingsverband. De Autoriteit-FM oefent nu het gedragstoezicht uit over zowel effectentypische als over niet-effectentypische (financiële) instellingen zoals de banken, de beleggingsinstellingen, de effecteninstellingen en de verzekeraars ${ }^{22}$. Deze verruiming van doelstellingen heeft ertoe geleid dat de naam van haar rechtsvoorganger te beperkt was geworden. Aangezien de wetgever meent dat de toezichthouder moet uitgroeien tot een echte autoriteit van de financiële markten heeft hij hem wat gereedschap aangereikt en meer bevoegdheden toegekend. Zo heeft de Minister de Autoriteit-FM de bevoegdheid

\footnotetext{
2" Dat was het ook ten rijde van het sectoraal model met de RFT als sectoroverschrijdend orgaan. Vgl. Kamerstukken II, 2001/2002, 28122, nr. 2, pagina's 4, 10 11,17 en 22 .

22 Kamerstukken II, $2001 / 2002,28122$, nr. 2, p 22 .
} 
verleend om niet alleen het toezicht uit oefenen, maar ook om regels te stellen aangaande:

\section{- de financiele bijsluiter ${ }^{23}$ \\ - bet consumentenkrediet ${ }^{24}$ \\ - beleggingsinstellingen ${ }^{25}$ \\ - consumenteninformatie en consumentenadvisering}

Meer over de bevoegdheden van de Autoriteit-FM en of DNB in de hierna volgende paragrafen.

$\mathrm{Na}$ deze historische bespreking van de STE en haar rechtsopvolger de Autoriteit-FM, zal in paragraaf 2.4 uitwoerig worden ingegaan op her toezicht dat deze toezichthouder op het effectenverkeer uitoefent. Maar alvorens daarmee wordt gestart, volgt in de volgende paragraaf eerst een bespreking van de relevante Nederlandse effectenwetten.

\subsection{De relevante Nederlandse effectenwetgeving}

Zoals aan het begin van dit hoofdstuk is opgemerkt zijn de Nederlandse effectenwetten, de externe regels, afkomstig van de overheid. De overheid probeert met deze regels bepaalde (rechts)gebieden te ordenen en schakelt hierbij de hulp in van daartoe aangestelde toezichthouders, de AutoriteitFM en De Nederlandsche Bank ${ }^{26}$. In Nederland hanteert de overheid, onder andere op het gebied van het effectenverkeer, een normatief toezichtsysteem ${ }^{27}$. Dit houdt in dat de kwaliteit van het toezicht door wetgeving wordt gegarandeerd en dat de toezichthouder onafhankelijk

2. Alle aanbieders van (complexe) financiële producten worden verplicht om op een zodanige wijze informatie over deze producten te verstrekken, zodat de belangrijkste kenmerken voor de consumenten duidelijk zijn. Vgl. Kamerstukken II, $2001 /$ 2002,28122 , nr. 2, p 29.

24. Op grond van de Wet op het consumentenkredier (W $\mathrm{ck}$ ) dient een kredietwerstrekker 'zich als goed kredietgever te gedragen (..)'. Daarnaast dient een kredietverstrekker zich te houden aan 'regels ten aanzien van informatieverstrekking'. Kamerstukken II, 2001/2002, 28122, nr. $2, \mathrm{p} 32$.

25 Het toezicht over de beleggingsinstellingen werd op grond van de Wet toezicht beleggingsinstellingen (Wtb) in het sectoralle model uitgeoefend door DNB. In het functionele toezichtsmodel is dit tot taak van de Autoriteit-FM verworden. Meer hierover in paragraaf 2.3 .1 de externe regelgeving; de kaderwetgeving.

26. De PVK geen rol bij het toezicht op de effectentypische instellingen.

27. Handelingen Eerste en Tweede Kamer der Staten-Generaal, tekst wan vergadering $51,1996-1997,18$ februari 1997, p. 1. 
van de overheid dient te functioneren. Daarnaast worden degenen die onder toezicht staan, in de gelegenheid gesteld om binnen het geldend wettelijk kader en in de praktijk gebezigde toezichtnormen te handelen.

In de hierna volgende subparagrafen zullen we de belangrijkste externe regelgeving bespreken. Hierbij zal er een onderscheid worden gemaakt tussen de regels die door de regering zijn uitgevaardigd, de kaderwetten, en andere regels die deze wetten nader invullen. Hiertoe behoort onder andere de regelgeving die is uitgevaardigd door of vanwege lagere (semi-)overheden; de uitvoeringsregels. In subparagraaf 2.3.1 wordt aangevangen met de meest relevante kaderwetten. Als eerste zal naar de Beurswet 1914 worden gekeken. Deze wet luidde het begin in van een nieuw tijdperk; een tijdperk van overheidsinterventie op het gebied van de effectenhandel. De Beurswer werd in het begin van de jaren tachtig opgevolgd door de Wet Effectenhandel. Laatstgenoemde wet zal vervolgens worden behandeld. Na de inwerkingtreding van de Wet Effectenhandel is gebleken dat de bestaande effectenwetgeving geheel diende te worden herzien. In versnelde mate is er vervolgens nieuwe effectenwetgeving tot stand gekomen. Aan het eind van deze subparagraaf zal deze herziening van de effectenwetgeving uitvoerig worden besproken. De uitvoeringsregels zullen in subparagraaf 2.3.2 aan bod komen waarna in de daaropvolgende paragraaf de regels zullen worden besproken die weliswaar niet door of vanwege de (lagere) overheid zijn uitgevaardigd, maar die desondanks een grote uitwerking kunnen hebben op het effectenverkeer. Hierbij dient men te denken aan regels die in het leven zijn geroepen door en voor een bepaalde groep actoren, bijvoorbeeld de commissionairs, en die ook alleen voor deze groep gelden. Deze vorm van reguleren, zelfregulering, wordt in deze studie tot de interne regelgeving gerekend.

\subsubsection{Externe regelgeving; de kaderwetgeving}

Op het gebied van het effectenverkeer is de externe regelgeving vrij laat tot stand gekomen. Zoals uit het eerste hoofdstuk is gebleken, nam de Nederlandse effectenhandel reeds in de $16^{\mathbb{E}}$ eeuw een vaste vorm aan. $\mathrm{Na}$ drie eeuwen, in 1876, werd de Vereeniging voor den effectenhandel opgericht. De overheid heeft zich tot 1914 niet met de effectenregulering bemoeid. Pas onder de dreiging van WOI, herzag zij haar standpunt. De Beurswet 1914 bleek, voor de regulering van de effectenhandel, het begin te zijn van overheidsinterventie. 


\section{De Beurswet 1914}

Het geldend wettelijk kader voor het toezicht op het effectenverkeer, de externe regelgeving, vindt zijn oorsprong in de invoering van de Beurswet in 1914 en de daarbij behorende uitvoeringsbeschikkingen. Zowel de omvang als de invloed van deze wet waren erg beperkt. De wet, welke de beurzen formeel onder toezicht van de Minister plaatste, bestond uit tien bepalingen. In artikel 2 lid 2 Beurswet 1914 werd bepaald dat de Minister in verband met het toezicht voorschriften kon (doen) geven. Tevens werd in de Beurswet 1914 gesteld dat de Minister de bevoegdheid had om te (laten) bepalen welke fondsen tot de notering dienden te worden toegelaten ${ }^{28}$.

\section{Artikel 2:}

1 De beurzer staan onder toezicht wan Onzen Minister wan Landbow, Nijperheid en Handel.

2 In werband met bet toeztht, in bet eerste lid bedold, is Onze genoemde Minister bevoegd, voorschriften te geven of te doen geven omtrevt:

$1^{\circ}$ de opening en de sluiting der bewrzen;

$2^{\circ}$ de noteeringen en de wijze, waarop ter beurze zaken worden gedaan;

$3^{\circ}$ de afuikkeling wan prolongaties, woorschotten in rekening-coumant of andere leeningen, welke van voor 29 Juli 1914 loopen en watruar fondsen tot onderpand werden gegeven, onverschillig of die leeningen al dan niet ter betwze werden gesloten; een en ander woor zooved noodig onder af wijking van de voor eenige beurs bestaande reglementen van bet platatselijk bestuw of wan eenige verecniging.

De Beurswet 1914 was in het leven geroepen om de beurzen ten tijde van oor $\log ^{29}$ open te kunnen houden en had derhalve een tijdelijk karakter. De overheid besloot ordenend op te treden en zich alleen te richten op de handel die zich binnen de officiële effectenbeurs afspeelde; de "beurshandel". Deze ordenende overheid liet de beurzen vrij om eigen aanvullende regels op te stellen en de naleving van deze regels te controleren. Zelfs de buitenbeurshande ${ }^{30}$ werd in de Beurswet 1914 ongemoeid gelaten. Met de invoering van de Beursvoorschriften 1940 en 1947 werd duidelijk dat de overheid afstand begon te nemen van haar ordenende

28. De term "fonds" is een verzamelnaam voor alle effecten die tot een bepaalde groep horen. Hierbij dient gedacht te worden aan effecten die door een onderneming zijn uitgegeven en die alle houders van dergelijke effecten, naar de mate van belang dat zij in het fonds hebben, gelijke rechten verleent. Vgl. Artikel 1 lid 5 fondsenreglement versie juni 1997.

30 Meer over de buitenbeurshandel in paragraaf 1.4.3. 
houding ${ }^{31}$. De in 1986 ingevoerde Wet effectenhandel gaf blijk van de nieuwe houding van de overheid.

\section{De Wet effecienhandel}

Doordat Nederland ten opzichte van de haar omringende landen een grote achterstand had op het gebied van effectenwetgeving, trok dit vele malafide effectenhandelaren aan. Dit had tot gevolg dat het aantal gevallen van effectenfraude een zorgwekkende vorm aannam ${ }^{32}$. Deze buitensporigheden in de handel die buiten de beurs om werd gevoerd ${ }^{33}$ vormden aan het eind van de twintigste eeuw - de jaren zeventig en tachtig - de directe aanleiding tot het versneld invoeren van effectenwetgeving. Vooruitlopend op een algehele herziening van de effectenwetgeving, werd in 1985 de tijdelijke Wet effectenhandel (Weh) ingevoerd ${ }^{34}$. Deze wet trad op 1 mei 1986 in werking en reguleerde de (buiten)beurshandel. Vanaf dat moment werd niet alleen de handel ter beurze, maar ook de effectenhandel die zich buiten de beurzen om afspeelde, aan regelgeving onderworpen. De Weh was erop gericht de particuliere beleggers, de niet-professionals, beter tegen misleidende beleggingsaanbiedingen te beschermen. Hierdoor wilde de wetgever het vertrouwen in het Nederlands effectenverkeer vergroten. Immers, de markt zou dan veilig(er) zijn hetgeen het vertrouwen van (particuliere) beleggers in de Nederlandse kapitaalmarkt moest opwekken c.q. versterken $^{35}$. Met de invoering van de Weh werd bepaald dat het toezicht op de buitenbeurshandel zowel formeel als materieel bij de Minister van Financiën zou berusten ${ }^{36}$. De Weh bestond uit 18 artikelen en bevatte

Zie paragraaf 1.3 .2 .

Hillen, J.L.S.M., "Effectenwetgeving", d. 143-Il Schuurman \& Jordens Nederlandse wetgeving, Tjeenk Willink, Deventer, 1997, $2^{\circ}$ druk, p. 4. Kamerstukken II, 1984/85, 18750, 4, p.1-2 en Kamerstukken II, 1984/85, 1.8750,3, p. $8-9$.

33 Deze handel, de buitenbeurshandel, viel buiten het bereik van de Amsterdamse effectenbeurs. Laatstgenoemde kon geen toezichts- en/of controlebevoegdheden over deze handelwijze uitoefenen. Srb. 1985,570 .

35 Kamerstukken II, 1984/85, 18750,3, p. 10 (MvT)

36 Rank, W.A.K., "Wet Toezicht effectenverkeer: een nieuwe Lente, een niexw gelwid?", Nieuwsbrief bedriffjuridische berichten, 13 juni 1989 , nr. 12, p. 132 . 
drie kernbepalingen: de artikelen 4, 6 en $9 \mathrm{Weh}^{37}$. Deze artikelen luidden als volgt:

\section{Artikel 4}

1. Het is verboden in of vanuit Nederland buiten een besloten kring bij witgifte effecten aan te bieden wan nakurlijke personen en rechtspersonen die niet beroeps- of bedrijfsmatig bandelen of beleggen in effecten.

2. Het in het eerste lid vervatte verbod is niet van toepassing, indien

a) de aan te bieden effecten zijn toegelaten tot een beurs of aannemelijk is dat zij daartoe spoedig zullen worden toegelaten, of

b) ter zake van het alnbod een prospectus algemeen verkrighaar is dat voldoet aan bij algemene maatregel van bestuur te stellen regels mits daamaar in elke scbriftelijle bekendmaking wan het aanbod wardt verwezen.

3. Voor de toepassing van dit hoofdstuk en de daarop berustende bepalingen urordt onder bet bij uitgifte anbieder wan effecten mede verstaan het aanbieden wan effecten van een soort, dat sedert de uitgifte nog niet buiten een besloten kring verkriggbaar is geweest.

In lid 1 van bovengenoemd artikel heeft de toenmalige wetgever bepaald dat het verboden was om in of vanuit Nederland (buiten een besloten kring) bij uitgifte effecten aan te bieden aan natuurlijke of rechtspersonen die niet beroepsmatig, dan wel bedrijfsmatig handelden of belegden in effecten. In lid 2 onder a heeft de wetgever een uitzondering op het eerste lid aangenomen. Hij heeft namelijk vastgesteld dat het in lid 1 vervatte verbod niet van toepassing was op effecten die reeds waren of nog zouden worden toegelaten tot de officiële notering aan een beurs. Voorts bevatte dit lid de bepaling dat bij het aanbod van effecten verwezen diende te worden naar een algemeen verkrijgbare prospectus ${ }^{38}$. Dit prospectus ${ }^{39}$ diende te voldoen aan bij Algemene Maatregel van Bestuur (AMvB) gestelde regels ${ }^{40}$. Tenslotte heeft de wetgever in het derde lid bepaald dat onder "het bij uitgifte aanbieden van effecten" mede werd verstaan het aanbieden van effecten van een soort dat sedert de uitgifte nog niet buiten een besloten kring verkrijgbaar was geweest. Dit aanbiedingsverbod was alleen van toepassing indien een tussenpersoon

Kamerstukken II, 1984/85, 18750,3 , p. 10 (MvT)

Een prospectus is een schriftelijke aankondiging en beschrijwing van de door aankomende of bestaande effectenuitgevende instellingen te leveren diensten. Mok. M.R., Regulering effectentandel, TVVS, 1985, nr. 85/1, p. 21.

Deze gegevens zijn redelijkerwijs van belang voor de beoordeling van onder andere de financiële positie en de perspectieven van de uitgevende instelling. Zie de hoofdstukken I en II van het Besimit Toezicht Effectenverkeer 1995 (Bre'95), bijlage bij artikel 2 Wte' 95 . Meer over de Bte'95 in paragraaf 2.3.2. 
zijn bemiddelingsdiensten bij effectentransacties bewust aan het publiek aanbood $^{41}$.

Een volgend kernartikel van de Weh was artikel 6:

\section{Artikel 6:}

1. Het is verboden zonder vergunning in of vanuit Nederland buiten een besloten kring bemiddeling bij effectentransacties aan te bieden aatn natuturlijke personen en rechtspersonen die niet effecten plegen uit te geven of daarin beroeps- of bedrijfsmatig bandelen of beleggen.

2. Onze Minister verleent, op verzoek, een vergunning als bedoeld in het eerste lid, indien de aanvrager aantoont dat wordt voldaan aan bij algemene matatregel van bestuur te stellen eisen ten aanzien wan:

a. deskundigheid en betrouwbarheid:

b. financiële watarborgen;

c. bedriffsoering:

d. aan het publiek te verstrekken informatie.

3. Aan een vergunning kunnen beperkingen worden gesteld en voorschriften worden verbonden met bet aog op het tegengaan wan ongewenste ontwikkelingen bij de handel in effecten. De beperkingen kunnen uitshitend worden gesteld ten annzien van de effectentransacties waarop de verguning betrekking heeft.

In lid 1 en 2 van artikel 6, de tweede kernbepaling, bepaalde de wetgever dat bij effectentransacties een vergunningensysteem voor de bemiddeling van toepassing was. De effectenbemiddelaar die in of vanuit Nederland - buiten een besloten kring $^{42}$ - zijn diensten aanbood aan natuurlijke en/of aan rechtspersonen (die zelf geen effecten uitgaven dan wel beroepsof bedrijfsmatig mee handelden of belegden), diende in het bezit te zijn van een vergunning. De Minister van Financiën verleende voornoemde vergunning indien voldaan was aan de in lid 2 onder a tot en met $d$ genoemde eisen. Deze eisen kwamen neer op het volgende: de effectenbemiddelaar moest naast deskundig, ook betrouwbaar zijn. Daarnaast moest hij voldoende financiële waarborgen hebben en voldoen aan eisen aangaande zijn bedrijfsvoering. Tot slot bepaalde de wetgever in dit artikel dat de effectenhandelaar zich moest houden aan de toen geldende eisen

41 Kraaiveld, C.J. en Nieuwenhuyzen, W.J.M. van den, Wet Effectenhandel, WTNR, 24 mei 1986, nr. 5786 , p. 371.

42 Over het begrip "besloten kring" zijn de meningen binnen de effectenwereld verdeeld. Gemakshalve kan de besloren kring van personen worden opgewat als een beperkte groep wan personen. Deze groep is niet alleen beperkt van omvang, maar ook nawwkeurig te omschrijven. Dit begrip zal verder in deze paragraaf uitwoerig worden besproken. 
betreffende de aan het publiek te verstrekken informatie ${ }^{43}$. Lid 3 van dit artikel bepaalde dat er beperkingen aan een vergunning konden worden gesteld. De ratio van deze bepaling lag in het tegengaan van ongewenste ontwikkelingen bij de handel in effecten. Naast beperkingen mochten er ook voorschriften aan de vergunning worden verbonden. Dit vergunningensysteem was niet van toepassing op beursleden ${ }^{44}$ die handelden in beursgenoteerde fondsen ${ }^{45}$. Immers, zij stonden reeds onder "controle" van de beurs. Tot slot de laarste kernbepaling van de Weh; artikel 9.

\section{Artikel 9:}

1. Het is verboden om zonder vergunning in of vanuit Nederland buiten een besloten kring de deelneming in een fonds woor gemene rekening open te stellen voor natuurlijke personen of rechtpersonen die niet beroeps- of bedrijfsmatig bandelen of beleggen in effecten.

2. Onze Minister verleent, op verzoek, een vergunning als bedoeld in bet eerste lid, indien ter zake van de deelneming een prospectus algemeen verkrighbaar is dat woldoet aan bij algemene maatregel van bestuur te stellen regels, degene die bet fonds voor gemene rekening beheert een rechtspersoon is en de aanurager tevens aantoont dat wordt voldan an bij algemene matregel van bestuur te stellen eisen ten acazien van:
a. deskundigheid en betroumbarkeid
b. financiele warbargen
c. bedrijfswoering
d. an bet publiek te verstrekken informatie.

3. Aan een vergunning kunnen beperkingen uorden gesteld en voorschriften worden werbonden wet bet og op bet tegengaan wan angewenste ontwikkelingen bij de bawdel in effecten.

In deze laatste kernbepaling had de wetgever de vergunningsverplichting voor de openstelling van deelneming in een fonds voor gemene rekening opgenomen met dezelfde beperkingen als genoemd in artikel 6. Naast deze bepalingen was ook artikel 16 van de Weh van belang. In dit artikel werd bepaald dat de overtredingen van de in de Weh genoemde verbodsbepalingen economische delicten waren. Het overtreden van de Weh stond door deze koppeling met de Wet Economische Delicten (WED),

43. Kamerstukken II, $1984 / 85,18750$, nr. 3, p. 12 (MvT)

44. Met het begrip "beursleden" wordt verwezen naar de leden van de Vereniging voor de Effectenhandel wan de Amsterdamse effectenbeurs. De leden werden onderscheiden in beursleden, bedrijfsleden en buitengewone bedrijfsleden. Deze begrippen worden uitvoering behandeld in paragraaf 2.3 .3 en 2.3.3.1. 
gelijk aan het plegen van een strafbaar feit. Dit had tot gevolg dat de Economische Controle Dienst (ECD) verantwoordelijk werd voor de naleving van de Weh.

Uit het bovenstaande kan worden opgemaakt dat behoudens vrijstelling of ontheffing van de vergunningsplicht, het op grond van de Weh verboden was om buiten een besloten kring te bemiddelen bij effectentransacties $^{46}$. De gevolgen van de Weh waren verstrekkender dan de Beurswet 1914. Verschillende ongereguleerde handelingen, zoals aanbieden van effecten en de effectenbemiddeling werden door de Weh aan een vergunningensysteem gebonden. Op 22 januari 1987 werd bij Ministeriële beschikking bepaald dat kredietinstellingen en overige kapitaalmarkcinstellingen, die destijds onder toezicht van De Nederlandsche Bank N.V. stonden, vrijstelling van de vergunningsplicht konden krijgen ${ }^{47}$. Naast de beursleden die reeds vrijstelling van het vergunningsvereiste hadden gekregen, kregen ook bepaalde kredietinstellingen vrijstelling omdat de Minister van mening was dat zij reeds onder een goede toezichtsstructuur stonden van de Vereniging voor Effectenhandel en/ of De Nederlandsche Bank N.V. Met de invoering van de Weh richtte de wetgever zich voornamelijk op het spoedig beëindigen van malafide praktijken. De invoering van het vergunningsvereiste heeft niet alle overige, weliswaar minder spoedeisende, problemen op het gebied van het effectenverkeer kunnen verhelpen. De effectenwetgeving had behoefte aan nog meer regelgeving om zo de vele hiaten te dichten. Er diende namelijk regels gecreëerd te worden die, in tegenstelling tot de Beurswet 1914 en de Beursvoorschriften 1940, in konden spelen op de toenmalige ontwikkelingen op de effectenmarkt. Laatstgenoemde wetten waren reeds achterhaald, immers de Beurswet 1914 bood slechts een wettelijk grondslag voor het toezicht op de beurzen. Doordat in de Beurswet 1914 de omschrijving van de toezichtbevoegdheden vrij algemeen was, bestond er rechtsonzekerheid over de reikwijdte van deze bevoegdheden ${ }^{48}$. Nieuwe wetgeving zou deze onzekerheid moeten

46 Er wordt gesproken van "bemiddelen bij effectentransacties", wanneer men als tussenpersoon bij de totstandkoming van effectentransacties werkzaam is. Zie Schlingmann, F.M., Tien jaar effectenrecht II, De Naamloze Vennootschap, april 1996 , nr. $73 / 4$, p. 94 .

48 Hillen, "Effectenwetgeving", dl. 143-II Schuurman \& Jordens Nederlandse weegeving, t.a.p. noot 32 , p. 8 . 
verhelpen. Daarnaast kwamen uit de ontwikkelingen in de effectenwereld nieuwe problemen voort waarvoor specifieke wetgeving was vereist zoals het voorkomen van misbruik van voorwetenschap en van publieksmisleiding. In 1992 werd met de invoering van de Wet toezicht effectenverkeer (Wte'92) een begin gemaakt aan een algehele herziening van de effectenwetgeving.

\section{De algehele berziening van de effectenwetgeving}

Aan het begin van de jaren negentig werd er een daadwerkelijke start gemaakt met de algehele herziening van de effectenwetgeving. Deze herziening bestond uit drie wetten:

\section{$A$ de Wet toezicht effectenverkeer 1992 en de Wet toezicht effectenverkeer 1995; \\ $B$ de Wet Melding Zeggenschap 1992 en 1996, en \\ $C$ de Wet toezicht beleggingsinstellingen.}

De hierboven genoemde wetten zullen hierna worden besproken.

\section{A De Wet toezicht effectenverkeer 1992}

Op 15 juni 1992 zijn de Wet toezicht effectenverkeer 1992 (Wte'92) ${ }^{49}$, het Besluit Toezicht Effecteninstellingen (Bte) ${ }^{50}$, het Delegatiebesluit Toezicht Effectenverkeer ${ }^{51}$, de Ministeriële Vrijstellingsregeling Wet toezicht effectenverkeer ${ }^{52}$ en de Nadere Regeling Toezicht Effectenverkeer ${ }^{53}$ in werking getreden. Met de invoering van de W/te' $92^{54}$ en diens uitvoeringsregelingen werd het toezicht op het gehele Nederlandse effectenverkeer in een wet geregeld, inclusief de beurshandel en de buitenbeurshandel. Hierdoor kwamen zowel de Beurswet 1914 als de Weh van 1985 te vervallen. Door de invoering van de Wre'92 versterkte de wetgever niet alleen het toezicht op de beurzen, maar werden tegelijkertijd ook bepaalde taken en bevoegdheden aangaande het toezicht

\footnotetext{
4) Stb. 1991 , nr. 141 .

50 Stb. 1991, n.r. 750 .

s1 Srb. 1991, nr. 751 .

92 Besluit van 25 maart 1.991, Stcrt. 1992, nr. 93.

53 Besluit van de Stichting Toezicht Effectenverkeer van 28 april 1992, Stcrt. 1992 , nr. 93.

54. De Wre'92 fungeert als kaderwet. Bij AMvB wordt er een nadere invulling gegeven aan de in de Wte gestelde eisen. STE, jaarverslag 1990. Amstelveen, mei 1991, p. 15.
} 
op het effectenverkeer aan een onafhankelijke toezichthouder, de Stichting Toezicht Effectenverkeer (STE) gedelegeerd. De Wte'92 streefde 'een adequate functionering van de effectenmarkt na. Daarnaast trachtte deze wet de (potentiële) beleggers en spaarders tegen malafide aanbiedingen, onvoldoende informatie en ondeskundig optreden te bescher$m^{2} n^{55}$. Niet alleen het bevorderen van het vertrouwen van beleggers en spaarders in het financiële bestel, maar ook de goede naam van de Nederlandse financiële markten stond in deze wer centraal ${ }^{56}$. Met de Wre' 92 , een product van de algemene herziening van de effectenwetgeving, heeft de wetgever getracht om de diverse hiaten op het gebied van het effectenrecht op te vullen. Er was namelijk gebleken dat er verscheidene gebieden waren die niet door de Beurswet 1914, Beursvoorschriften en/of de Weh werden bestreken. Een voorbeeld hiervan was de informatievoorziening door niet-genoteerde instellingen. Voor de buitenbeurshandel was er alleen de Weh. Deze wet regelde niets over de informatievoorziening door niet-genoteerde instellingen ${ }^{57}$. Dankzij de Wte' 92 was het beleggend publiek in staat om zich, door middel van prospectussen bij de uitgifte van effecten, of door middel van de periodieke financiële verslagen van de uitgevende instellingen, een (goed) beeld te vormen van de risico's van de aangeboden aandelen. Mede door de in de Wte'92 gecreëerde regelgeving aangaande de informatievoorziening was het duidelijk geworden dat de overheid voornemens was om de transparantie van de financiële markten te bevorderen ${ }^{58}$.

Door de steeds belangrijker wordende internationalisering ontstond er bij de Nederlandse beurzen de drang om te groeien en zo de bestaande internationale positie te handhaven dan wel te vergroten. Dit leidde ertoe dat er bij de beurzen een weliswaar ambivalente, maar steeds groeiende behoefte aan regulering opkwam. Enerzijds betekende dit dat de beurzen zich aan de regels van de overheid zouden moeten gaan houden, wat een afbrokkeling van de bestaande zelfregulering inhield. Anderzijds betekende overheidsregulering een imago-verbetering wat weer van belang was in de concurrentiestrijd tussen de Europese beurzen.

\footnotetext{
55. Kamerstukken II, 1988/89, 21038, nr. 3, p. 2 (MvT)

56. Doorenbos, D.R., "Misbruik wan voorwetenschap als economisch delict", TVVS, 1989 , nr. 89/12, p. 303.

57 Rank, W. A.K., "Wet Toezicht effectenverkeer: een niewwe lente, en nienw gelwid?", t.a.p. noot 36,132 .

58 Kamerstukken II, 1988/89, 21038, 3, p. 4 (MvT)
} 
Immers, wanneer de overheid ook belangen zou hebben in een goede en gezonde effectenmarkt, zou zij deze met zorg bewaken en excessen zo mogelijk (doen) tegengaan. Zowel de Nederlandse als de buitenlandse beleggers zouden hierdoor naar de Amsterdamse Effectenbeurs worden getrokken en de voorkeur aan deze effectenbeurs geven, omdat deze regelmaat en betrouwbaarheid zou uitstralen. Kortom, een door de overheid gereguleerde beurs betekende een onafhankelijke toezichthouder die de belangen van de belegger in het oog hield. Een ander segment van de internationalisering was de internationale samenwerking. De Beurswet 1914 en de Weh boden niet de vereiste basis voor internationale samenwerking, terwijl dit wel voor een toenemende internationalisering van belang was. Op grond van de Wre' 92 kregen de toezichthoudende instellingen, onder andere, inlichtingen en onderzoeksbevoegdheden. Ook werd het de toezichthouders mogelijk gemaakt om informatie met hun collega's in het buitenland uit te wisselen ${ }^{59}$. Voordat de W'te'92 kon worden toegepast diende de wetgever ervoor te zorgen dat deze duidelijk en helder was. De betekenis van centrale begrippen, zoals het begrip "effecten", moest voor een ieder duidelijk zijn. Daarom heeft de toenmalige wetgever in artikel 1 een aantal begrippen gedefinieerd.

\section{Artikel 1 onder a}

effecten:

ol aandeelbewijzen, schuldbrieven, winst- en oprichtersbewijzen, optiebewijzen, warrants, en soortgelijke waardepapieren;

"2 rechten van deelgenootschap, opties, rechten op overdracht op termijn van zaken, inschrijuingen in atandelen-en schuldregisters, en soortgelijke, al dan niet voorwuatudelijke, rechten;

03 cerrificaten van waarden als biervoor bedoeld:

of recepissen van watarden als hiervoor bedoeld;

Deze opsomming omvatte tevens her begrip effecten zoals dat in de Weh werd gebruikt met als verschil dat het begrip effecten in de Wte'92 ruimer is ${ }^{60}$. Niet alleen het begrip "effecten", maar ook de regels voor degene die met effecten werken, dienden duidelijk te zijn. Daarom waren er in de W'te' 92 ook regels te vinden over de uitoefening van het beroep

59 Wind, E. de, "De Wet effectenbandel in de pratktijk", De Naamloze Vennootschap, april 1991, nr. 69/4, p. 92.

60 Het omvat namelijk tevens waardepapieren aan toonder waarvan de rente gedurende de looptijd niet opeisbaar wordt. Uit: Grundmann, C.M., Wet toezicht ffectenverkeer 15 juni $1992 \mathrm{in}$ werking, Nieuwsbrief bedrijfsjuridische berichten, 29 mei 1992 , nr. 11, p. 113. 
of bedrijf van effectenbemiddelaar en over de uitoefening van het beroep of bedrijf van vermogensbeheerder. In deze wet werd een nieuwe definitie van het begrip effectenbemiddelaar" naar voren geschoven:

\section{Artikel 1 onder b:}

effectenbemiddelaar:

of Degene die als tussenpersoon, anders dan op grond van een overeenkomst als bedoeld onder $c^{\text {ot }}$, beroeps- of bedrijfmatig werkatam is bij de totsandkoming wam transacties in effecten;

-2 Degene die beroeps- of bedrijfmatig de mogelijkbeid aanbiedt, door het openen wan een rekening worderingen te verkriggen luidende in effecten, wharbij door widdel wan deze rekening ransacties in effecten kunnen worden bewerkstelligd;

-3 Degene die als effectenhandelat voor rekening effectentransacties verricht teneinde een markt in effecten te onderhouden of een woordeel te behalen wit een verschil twssen vraag- en aunbodprijzen van effecten.

Daarnaast wijzigde de wetgever in de Wte' 92 het uit de Weh afkomstige aanbiedingsverbod ${ }^{62}$ en bemiddelingsverbod en liet hij het "professionelen"-criterium ${ }^{63}$ vervallen ${ }^{64}$. Verder maakte de Wte' 92 , in tegenstelling tot de Weh, voor "tussenpersonen" een onderscheid tussen effectenbemiddelaars en vermogensbeheerders. In lid 1 onder c van de W'te' 92 was een aparte definitie van het begrip "vermogensbeheerder" te vinden.

\section{Artikel I onder $c$}

uermogensbeheerder:

Degene die beroeps- of bedrijfsmatig op grond van een overenkomst het beher woert over effecten die toebehoren an een naturalijke persoon of rechtspersoon dan wel over aan deze persoon toebehorende middelen ter belegring in effecten, datander begrepen bet verrichten of doen verrichten van effectentransacties woor rekening van de persaon met wie de overeenkomst is gesloten.

61 Onder c staat dat het gaat om een overeenkomst wan vermogensbeheer. Artikel 1 onder c geefi een definitie wan het begrip vermogensbeheerder.

62 Hiermee wordt het zonder vergunning aanbieden van effecten bedoeld. Dit werd in de Weh verboden.

63 De professionele partijen zijn hierdoor vrijgesteld van de werking van de Wte'92. Het is voor hen, in tegenstelling tor particulieren, immers makkelijker om malafide en/of ondeskundige effectenberniddelaars en/of vermogensbeheerders op te sporen. De professionelen kunnen nu, in tegenstelling tot de Weh, flexibeler optreden. Vgl. Kamerstukken II, 1988/89, 21038, 3, p. 7 (MvT)

64 Schlingmann, EM., Tien jadr effectenrecht, De Naamloze Vennootschap, april 1996 , nr. $73 / 4$, p. 95 . 
Zowel de effectenbemiddelaars als de vermogensbeheerders werden op grond van de Wte'92 vergunningsplichtig. De wetgever had dit in de artikelen 6 tot en met 13 van hoofdstuk III van de Wte' 92 ondergebracht.

\section{Artikel 6}

1 Het is verboden om zonder vergunning als effectenbemiddeladar in of vanuit Nederland diensten atn te bieden of te verrichten voor natuurlijke personen of rechtspersonen niet behorende tot een besloten kring.

\section{Artikel 10}

I Het is verboden zonder vergunning als vermogensbeheerder in of vanuit Nederland diensten aan te bieden of te verrichten woor natuurlijke personen of rechtspersonen niet behorende tot een besloten kring.

In de voornoemde artikelen kwam steeds het begrip "besloten kring" terug. De definitie van dit begrip bleek in de praktijk niet altijd even duidelijk. Volgens de Memorie van Toelichting mocht er van een besloten kring worden gesproken indien:

- De groep van personen tot wie men zich wendt, beperkt van omang is alsmede natuwkeurig amschreven dan wel bepadd:

- Deze personen in een zekere relatie staan tot degene die bet anbod doet. respectievelijk de deelneming openstelt, dir impliceert dat er naast de financiële relatie tussen de betrokken partijen nog andere relaties a anwezig moeten zijn;

- Bij de presentatie duidelijk kenbatar is gemaakt dat bet ingaan op het adnbod op bet deelnemen witsluitend an de groep personen is voorbehouden waarop de eerste en tweede overweging van toepassing is.

Ondanks een dergelijk uitleg, bracht het begrip "besloten kring" veel jurisprudentie tot stand.

In artikel 8 en 12 van de Wte' 92 had de wetgever een voorschrift opgenomen dat leden van effectenbeurzen vrijstelling van de vergunningsplicht konden krijgen. In artikel 8W' 92 stond de effectenbemiddelaar centraal; artikel 12 richtre zich op de vermogensbeheerder. Hieronder zal alleen de tekst van artikel 8 worden weergegeven, daar deze bijna gelijk is aan de tekst van artikel 12 . 


\section{Artikel 8}

1 Van het in artikel 6 , eerste lid vervatte verbod zijn wrijgesteld effectenbemiddelaars die zijin aangesloten bij een organisatie, waatraan de houder een erkenning beeft als bedoeld in antikel $16^{66}$, voor zover hux bemiddeling effecten betreft die zijn toegelaten tot de notering adn die effectenbeurs of waluan aannemelijk is dat zij daurtoe spoedig zullen worden toegelaten.

In lid 2 van dit artikel was een voorschrift aan voornoemde vrijstelling toegevoegd.

2 Aan de vrijstelling als bedoeld in het eerste lid is het voorschrift verbonden dat de effectenbemiddelats voor wie de vrijstelling geldt zich bouden ann de regels die zijn gesteld door de organisatie watrbij die effectenbemiddelaurs zijn anangesloten en aan de regels die zijn gesteld door de houder van de desbetreffende effectenbeurs.

In verband met de vrijstelling bevatte artikel 8 lid 3 een aanwijzingsbevoegdheid van de Minister.

3 Indien Onze Minister ervan kennis neemt dat een effectenbemiddelaar als bedoeld in bet eerst lid zich niet houdt of heeff gehouden atan het voorschrift als bedoeld in her tweede lid, kan bij aan de organisatie watubij die effectenbemiddelaar is aangesloten dan wel aan de bouder van de desbetreffende effectenbeurs een aanwijzing geven met betrekking tot een door deze jegens de effectenbemiddeladr te volgen gedragsizin.

Opvallend was de in de Wte' 92 opgenomen bepaling waaruit bleek dat voor het houden van een effectenbeurs, erkenning van de Minister van Financiën werd vereist. Op grond van de W'te'92 werd een algemene vrijstelling gecreëerd voor leden van effectenbeurzen in andere lidstaten van de Europese Gemeenschappen ${ }^{67}$. De houders van de effectenbeurzen die reeds op grond van de Beurswet 1914 functioneerden, werden bij de inwerkingtreding de W/te'92 automatisch erkend.

In artikel 16 staat dat de effectenbeurzen eerst een vergunning van de Minister moeten hebben, alvorens zij beurs kunnen houden. 


\section{Artikel 16:}

1 Het houden wan een effectenbeurs is niet toggestat dan wa verkregen erkenning van onze Minister.

2 De erkenning wordt verleend indien bet boudew van de effectenbewts, de voor de effectenbeurs te hanteren regels en bun toepasting en de controle op de naleving wan die regels zullen voldoen aam hergeen nodig is met bet oog op een adequate functionering wan de effectenmarkten en de positie pan de beleggers op dic markten.

3 Aan de erkenwing kunnen beperkingen worden gesteld en voorschrificn wordem verbonden met bet oog op een adequate functionering wan de effectentwarkten en de positie un de beleggers op die markten.

\section{Artikel 37:}

Op bet tijdstip watap artikel 16 van deze wet in werking treedt, bebben de bouders wan de effectenbeurzen die zijn geopend op grond wan artikel 2 , tweede lid, onder $1^{\circ}$, wan de Bewrswet 1914 (Stb. 1914,445) een erkenning als bedoeld in artikel 16 van deze wet.

Uit het voorafgaand blijkt een duidelijk verschil tussen de Weh en de Wre'92. Laarstgenoemde heeft verstrekkende gevolgen gehad voor de effectenregulering. Zo kan gesteld worden dat de Weh zich hoofdzakelijk heeft gericht op het reguleren van de buitenbeurshandel om zo de particuliere belegger te beschermen. Dit, in tegenstelling tot haar opvolgster die zich op het grote geheel zou richten. De Wte"92 streefde een adequate functionering van de effectenmarkt na en trachtte daarbij de positie van de beleggers op deze markt te verbeteren. Deze structuur is door haar opvolgster, de W'te' 95 , behouden. De toenemende internationalisering en het streven van de Europese Unie naar harmonisatie van effectenwetgeving hebben samen met de Europese regelgeving uiteindelijk de grondslag gevormd voor de Wte' 95 . Zo heeft Nederland in het kader van haar lidmaatschap van de Europese Unie gehoor gegeven aan de invoering van twee Europese richtlijnen: de richtlijn beleggingsdiensten - de Investment Services Directive (ISD) - en de richtlijn kapitaaltoereikendheid van beleggings-en kredietinstellingen - de Capital Adequacy Directive (CAD) ${ }^{68}$ - Hierdoor zou de Wte' 92 geen lang leven beschoren blijven. Bij wet van 16 november $1995^{69}$ is de Wte' 92 gewij-

Richtlijn nr. 93/22/EEG van de Raad van de Europese Gemeenschappen van 10 mei 1993 en richtlijn nr. 93/6/EEG van de Raad van de Europese Gemeenschappen van 15 maart 1993. 
zigd en met ingang van 31 december 1995 is 70 de Wet toezicht effectenverkeer 1995 (W'te'95) in werking getreden. De Wte'95 en de daarbij horende uitvoeringsbesluiten ${ }^{71}$ zijn naar aanleiding van de uitvoering van de harmonisatierichtlijnen van de Europese Gemeenschappen tot stand gekomen. In de W'e'95 zijn deze EG-richtlijnen geïmplementeerd en is het toezicht op het effectenverkeer verder versterkt ${ }^{72}$. De rïchtlijn beleggingsdiensten heeft volgens de Memorie van Toelichting onder andere tot doel:

".de minimal noodzakelijke harmonisatie van vergunning-en toezichtstelsels tot stand te brengen voor instellingen die beroeps- of bedriffrimatig een of meer van de in deel A wan de bijlage bij de richtijin genoemde effectendiensten verrichten ${ }^{, 73}$.

De invoering van deze richtlijn heeft ertoe geleid dat een effecteninstelling zoals Amsterdam Exchanges N.V., op grond van haar vergunning die is verleend door de bevoegde autoriteit (de Minister van Justitie/STE) van de lidstaat van herkomst (Nederland), bepaalde activiteiten binnen de Europese Unie mag verrichten. Dit kan zowel door het vrij verrichten van diensten als door het openen van een bijkantoor in een lidstaat. Het toezicht op deze effecteninstelling, in dit geval Amsterdam Exchanges N.V., wordt door de daartoe bevoegde autoriteit in de lidstaat van herkomst (de Minister van Financiën/STE) uitgeoefend. Soms is de bevoegde autoriteit in de lidstaat van ontvangst ${ }^{74}$ degene die het toezicht moet uitoefenen. In de richtlijn zijn hiertoe bepalingen opgenomen welke de onderlinge samenwerking tussen de beide toezichthouders moet bevor--

70 Voorstel wan Wet, Kamerstukken II, 1993/94, 23 874, nr. 2, p. 1 en Organisatic toezicht effectenverkeer, brief en rapport, Ministerie van Financiën, 30 augustus 1996, p. 3.

71. Tegelijkertijd met de Wre"95 zijn de uitvoeringsbesluiten te weten her Besluit toezicht effectenverkeer 1995 (Bre'95) en het Delegatiebesluit Wer toezicht effectenverkeer 1995( het Overdrachtsbeshuit Wte 95) in werking getreden. Vgll. het besluit d.d. 14 december 1995, Stb. 1995, 646. Meer hierover in paragraaf 2.3.2. Externe regelgeving; de uitvoeringsregels.

72. De regelgeving afkomstig uit het Europese (harmonisatie) richtlinnenstelsel is met name woor het effectentypische toezicht van groot belang gebleken. Voorstel van Wet, Kamerstukken II, 1993/94, 23 874, nr. 2, p. 1 en Organisatie toezicht effectenverkeer, brief en rapport, Ministerie van Financiën, 30 augustus 1996 , p. 3.

Kamerstukken II, 1993/94, 23874, 3, p. 4 (Mv'T)

De lidstaar op wiens grondgebied de betrokkene effectendiensten verricht. Kamerstukken II, 1993/94, 23874,3, p. 4, (MvT) 
deren. Om het doel te verwezenlijken is aan de richtlijn een scala van vergunningsvereisten en toezichtregels voor vergunninghouder roegevoegd. Verder heeft de richtlijn "beleggingsdiensten" tot doel de toegang tot het lidmaatschap van effectenbeurzen en andere erkende gereglementeerde markten te liberaliseren ${ }^{75}$. Dit heeft tot gevolg dat alle erkende effectenbeurzen en kredietinstellingen waaraan een lidstaat reeds een vergunning had afgegeven, in alle andere lidstaten van de Europese Unie en in de landen binnen de Europese Economische Ruimte ${ }^{76}$, gelijk moeten worden behandeld. Dat wil zeggen dat zij onder gelijke voorwaarden als de instellingen die in de andere lidstaten zijn gevestigd toegang moeten krijgen tot zowel de gereglementeerde markt als de clearing- en afwikkelingsstelsels van dat land ${ }^{77}$. De richtlijn ISD, die tot doel heeft een goede controle van het effectenverkeer mogelijk te maken, beoogt daarbij de doorzichtigheid van prijsvorming bij effectentransacties te waarborgen ${ }^{78}$. Uit het voorgaande kan de conclusie worden getrokken dat de richtlijn beleggingsdiensten de effecteninstellingen een Europees paspoort verschaft. Dit paspoort is alleen van toepassing op effecteninstellingen uit de lidstaten dan wel uit de staten van de Europese Economische Ruimte die deze richtlijn hebben geïmplementeerd ${ }^{79}$. De andere richtlijn "kapitaaltoereikendheid van beleggings- en kredietinstellingen" heeft tot doel de voorschriften welke zijn gericht op de financiële soliditeit van effecteninstellingen, in het kader van wederzijdse erkenning van vergunning en toezichtstelsels, te harmoniseren. De voorschriften van deze richtlijn, die onder andere betrekking hebben op het eigen vermogen en het aanvangskapitaal van effecten- en kredietinstellingen, zijn in de artikelen 16 en 17 Wre' $^{\prime} 95$ verwerk $^{80}$. Hiermee

Kamerstukken II, 1993/94, 23874, 3, p. 4, (Mv'T)

76 De landen die Van Dijk noemt zijn onder meer: IJsland, Noorwegen en Liechtenstein. Vgl. Dijk, J.M. van, "Wet toezicht effectexwerkeer 1995"; artikelsgewijs commentaar in de serie Tekst \& Commentaar, deel Ondernemingsrecht, Kluwer, Deventer, 2000 , p. 789.

7 Hiermee worden de systemen bedoeld waarmee de afwikkelling van alle op de beurs uitgevoerde transacties worden verwerkt. De afdeling clearing van de beurzen draagt zorg voor de uit deze afwikkeling voortvloeiende verplichtingen jegens de marktpartijen. Van de internetpagina van AEX N.V. d.d. 04-11-1998: http:// www.aex.nl/aexorg.html\#eff Kamerstukken II, 1993/94, 23874, 3, p. 4, (MvT)

79 Luyn, M van, "Wet toesicht effectenverkeer 1995", Vennootschap en Organisatie, februari 1996, afl. 2, p. 21.

80 Hillen, J.L.S.M., "Effectenwetgerving", dl. 143-II Schuurman \& Jordens Nederlandse wetgeving, ta..p. noot 32, p. 19. 
vormen deze voorschriften een gemeenschappelijk kader dat de risico's die effecten-en kredietinstellingen lopen, bewaakt ${ }^{81}$. Deze vrij technische richtlijn beoogt de in de richtlijn beleggingsdiensten genoemde doelen te realiseren.

Evenals bij de Wte' 92 , is het voor de toepassing wan de W belang te weten wat er onder het begrip "effecten" moet worden verstaan. In de Wte'95 is de definitie van dit begrip opnieuw gewijzigd. In artikel 1 onder a sub 2 is de volgende definitie te vinden:

-2 rechten vadn deelgenootschap, opties, rechten op overdracht op termijn wan goederen. inschrijuingen in aandelen-en schuldregisters, en soortgelijke, al din niet vaorwatardelije, rechten;

Uit bovenvermelde definitie kan de conclusie worden getrokken dat de definitie zoals die in de Wte" 92 was gegeven, in de Wte'95 is verruimd. Onder effecten worden nu ook "rechten op overdracht op termijn van goederen" verstaan. In plaats van de term "zaken", is nu de term "goederen" gebruikt. Voorts is in artikel 1 onder b en onder c van de W/te'95 ook de definitie van de begrippen "effectenbemiddelaar" en "vermogensbeheerder" uitgebreid.

\section{Artikel 1 onder $b$}

effectenbemiddelar:

-3 Degene die beroeps-of bedrijfmatig anders dan bij uitgifte van effecten, voor eigen rekening effectentransacties verricht teneinde een markt in effecten te onderbouden of een voordeel te behalen uit een verschil tussen vraag-en aanbodprijzen van effecten;

In vergelijking met de Wte'92, is het begrip "effectenhandelaar" nu vervangen door datgene wat hierboven onderstreept is. Daarnaast is in de Wte'95 het begrip "effectenhandelaar" verruimd met:

-4 Degene die beroeps- of bedrijfsmatig effecten, bij uirgifte ervan, owemeemt of phatst;

-5 Degene die, al dan niet als wussenpersoon en anders dan op grond van een overeenkomst als bedoeld onder $c$, beroeps of bedrifsmatig werkzaam is bij do totstandkoning van rente-, valuta- of aandelenswaps of soortgelijke overeevamsten; 
Het begrip "vermogensbeheerder" is in artikel 1 onder $\mathrm{c}$ uitgebreid met:

.2 Degene die beroeps- of bedrijfinatig op grond van een overeenkomst bet beheer woen over rente-, valuta- of adandelenswatps of soortgelifke overeerkomsten;

Anders dan in de Wte'92, worden in de Wte' 95 in de verbodsbepalingen de begrippen "effectenbemiddelaars" en "vermogensbeheerders" niet op verschillende wijzen gedefinieerd. De effectenbemiddelaar en de vermogensbeheerder worden in hetzelfde artikel, artikel 7, aan een vergunningsplicht onderworpen. Daarnaast zijn de leden van erkende effectenbeurzen niet meer, zoals dat in de Wte' 92 het geval was, vrijgesteld van de vergunningsplich $\mathrm{t}^{82}$ omdat in artikel 9 Wte' 95 is bepaald dat deze leden vergunningsplichtig zijn geworden. Immers op grond van de richtlijn beleggingsdiensten kunnen de leden van een gereglementeerde effectenbeurs hun effectendiensten slechts vrij in andere Europese lidstaten verrichten, indien zij over vergunning beschikken die zij in hun land van vestiging hebben verkregen. Ter verduidelijking worden de desbetreffende passages uit de hierboven genoemde wetartikelen weergeven.

\section{Artikel 7:}

1. Het is verboden zonder vergunning als effectenbemiddelatu of vermogensbeheerder in of vawit Nederland diensten aan te bieden of te verrichten.

2. Het eerste lid is niet van toepassing op:

a. $-b(\ldots)$

i. effecteninstellingen diezijn genestigd in cen andere lid-stad, wiet zijnde instellingen als bedoeld onder $b^{33}$. die door middel wan een bijkantoor in Nederland als effectenbemiddelatr of vermogetubbeerder diensten anbieden of verrichten, indien:

$I^{\circ}$ zij van de toezichtboudende antoriteit wan die andere lid-stat een voor de uitoefening wan bet beroep of bedrij van offectenbemiddelata of vernogenseheerder benodigde vergunning bebben verkregen:

$2^{\circ}$ Onze Minister wan de toezichthoudende aturiteit van die andere lid-stat eex kenwisgeving heeft onwangen, die betrat:

- een pragramma wan werkaaawheden waarin de voorgenomen werkaambeden en de organisatiestrucum wan bet bijkantoor zijn vermeld;

Vgl. de artikelen 8 en 12 Wre' 92.

3,3 De hierbij bedoelde instellingen zijn: de kredietinstellingen of financiële instellingen die effectendiensten of vermogensbeheer in Nederland willen aanbieden en daartoe een vergunning hebben gebaseerd op de Wet Toezicht Kredietwezen 1992 (Wtk'92). Deze instellingen zijn uitgezonderd van de vergunningsplicht van de richtlijn beleggingsdiensten. Kamerstukken II, 23874, nr. 3, p. 42. (MvI) 
- bet adres van die bijkintoor;

- de identiteit wan de personen die bet dagelijks beleid wan bet bijkantoor bepalen; th

- gegevens omtremt do toepasselijkheid wan een ganantieregeling op de werplichtingen van bet bijkantow; en

$3^{\circ}$ Onze Minister de ontvangst van de kennisgewing, bedold onder $2^{\circ}$, en de inhoud daarvan aan de effecteninstelling heeft bekendgemakt dan wel er twee maanden zijn verstreken vanaf het tijdstip watrop Onze Minister die kennisgeving beeft ontuangen;

j. effecteninstellingen die zijn gevestigd in een andere lid-stat, niet ajinde instellingen als bedoeld onder $h$, die, anders dan door middel van cen bijkantoor in Nederland, als effectenbemiddelaar of wermogenbeheerder diensten anbieden of verrichten. indien:

$I^{\circ}$ zij (...) verkregen; en

$2^{\circ}$ zij awn de toezichthoudende autoriteit wan die andere lid-staat een kennisgeving hebben gezonden, die een opgate van de voorgenomen werkzambeden bevat.

\section{Artikel 8}

1. Indien een andere lid-staat de richtijn beleggingsiensten of de richulijn kapitaaltoereikendheid niet of onvolledig beeft witgevoerd, kan Onze Minister bepalen dat artikel 7 , tweede lid, aanbef en onder i en $j$, niet van toepassing is op effecteninstellingen die in die andere lid-statat zijn gevestigd.

2. Met ingang van bet tijdstip waarop de matatregel, bedoeld in bet eerste lid, ten aanzien van een lid-stat wordt ingetrokken, wordt ten anzien wan een in die lid-statat gevestigde effectesninstelling die op dat moment bet beropp of bedrif wan effecteninstelling door middel van een bijkantoor of door middel van het verrichten van diensten in Nederland uitoefent en die daarvoor een vergunning als bedaeld

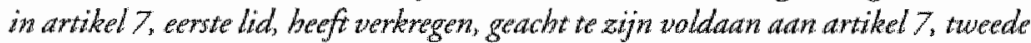
lid, onderdeel $i$, onder $2^{\circ}$ en $3^{\circ}$, onderschetdenlijk onderdeel $j$, oveler $2^{\circ}$. De aan de efferteninstelling verleende vergunning verwalt op dat tijdstip wan rech tswege.

\section{Artikel 9}

Onze Minister verleent, op verzoek, een vergunning als bedoeld in artikel 7 , erste lid, aan een effecteninstelling die is angesloten bijeen organisatie watuan de leden toegang bebben tot een effectenbeurs warvan de bouder een erkenning heeft als bedoeld in artikel 22, woor zover bet betreft bet als effectenbemiddelat of vermogensbeheerder atabieden of verrichten van diensten die onderworpen zijn aun door die arganisatic en door de houder van die effecteribeurs gestelde regels, indien Onze Minister van die organisatie een kennisgeving beeft ontvangen, die bevat:

a. een programma wan werkzambeden warin de woorgenomen werkzambeden on de organisatiestructuur van de effecteninstelling zijn vernold:

b. het adres van de effecteninstelling; en

c. de identiteit wan de personen die het dagelijks beleid van de effecteninstelling bepalen, tenzij Onze Minister vaststelt dat sprake is vam een omstandigheld die ingevolge artikel 19 , eerste lid, een intrekkingrand zou opleveren. 
Uit de redactie van artikel 7 Wte'95, de opvolger van artikel 6 Wte'92, blijkt dat het in de Weh enWte' 92 gebruikte begrip "besloten kring" is komen te vervallen. De achterliggende reden is het gegeven dat in de richtlijn beleggingsdiensten geen onderscheid wordt gemaakt tussen de werkzaamheden binnen en buiten besloten kring. Een volgende vernieuwing in de WTe' 95 is het vereiste om een verklaring van geen bezwaar te bezitten alvorens het een effecteninstelling is toegestaan om een gekwalificeerde deelneming van meer dan $5 \%$ in een effecteninstelling te houden. Deze vereisten zijn opgesomd in arrikel 16 Wte' $95^{84}$.

\section{Artikel 16}

1. Het is verboden, anders dan na verkregen verklaring wan geen bezwad, een gekwalificeerde deelneming te houden. te verwerven of te vergroten in een effecteninstelling waandan een vergunning is verleend op grond wan artikel 7 , vierde of zesde lid, of artikel 9, dan wel enige zeggenschap verbonden aan een (...) gekwalificeerde deelneming uit te oefenen in een instelling als hiervoor bedoeld.

In de Wre'95 zijn niet alleen de hiervoor genoemde richtlijnen verwerkt, maar zijn er ook strafbepalingen opgenomen. Deze bepalingen hebben betrekking op het gebruik van voorwetenschap en op publieksmisleiding bij de plaatsing van effecten ${ }^{85}$. Deze wet heeft geen verandering in het toezichtstructuur van de Wte' 92 aangebracht. Nog steeds is de Minister van Financiën verantwoordelijk voor de erkenning van de beurzen en was de onathankelijke Stichting Toezicht Effectenverkeer, nu de Autoriteit-FM, de controlerende instantie voor het gedragstoezicht op de naleving van de Wte' $95^{86}$. Niet alleen voor de Wte' 95 , maar ook voor andere wetten heeft de wetgever de Autoriteit-FM de status van gedragstoezichthouder verleend. Naast de Wte'95, is de Autoriteit-FM ook verantwoordelijk voor het gedragstoezicht op de naleving van de Wet Melding Zeggenschap door ter beurze genoteerde vennootschappen ${ }^{87}$.

Hillen, "Effectenwetgewing", dl. 143-II Schuurman \& Jordens Nederlandse wetgeving, t.a.p. noot 32 , p. 18.

89

86

Hillen J.L.S.M, "Effectenwetgeving", dl. 143-II Schuurman \& Jordens Nederlandse wetgeving, t.a.p. noot $32, \mathrm{p}$. V.

Dit is gebaseerd op het Koninklijk Besluit (KB) van 18 december 1991, Starsblad (Stb.) 751 en KB 8 december 1995, Stb. 624. Regeling aanwijzing bevoegde autoriteiten Wet toezicht effectenverkeer 1995 d.d. 21 december 1995, Staatscourant (Stcrt.) 1996, 251.

Het delegatiebesluit, ook wel genoemd het Overdrachtsbesluit Wet melding zeggenschap 1996, d.d. 14 mei 1997, Stb. 209. 
Deze wet, die dient te worden geplaatst in het kader van de algehele herziening van de effectenwetgeving, komt hieronder aan de orde.

B De Wet Melding Zeggenschap in ter beurze genoteerde vennootschappen

De algehele herziening van de effectenwetgeving heeft naast de invoering van de Wte tevens geleid tot de Wet Melding Zeggenschap in ter beurze genoteerde vennootschappen $(\mathrm{W} / \mathrm{mz})$. Dit gebeurde op 1 februari 1992 en was gebaseerd op de Europese richtlijn ${ }^{88}$ betreffende de melding van zeggenschap. Met de invoering van de W/mz' $92^{89}$ ontstond een meldingsplicht in geval van verkrijging of vervreemding van aandelen dan wel van zeggenschap in Nederlandse beursgenoteerde vennootschappen. Hierdoor heeft de wetgever getracht om de doorzichtigheid van de effectenmarkt te vergroten door de marktbewegingen openbaar te maken. Om dit te realiseren voerde hij in de W/mz' 92 een meldingsen openbaarmakingsplicht in. De meldingsplicht richtte zich tot de belegger. Op grond van de W'mz'92 was de belegger-aandeelhouder van een Nederlandse beursgenoteerde vennootschap verplicht om de stemrechten of het belang in het kapitaal van deze vennootschap te melden in geval zijn rechten en/of belangen voor het eerst werden toegellaten tot de officiële beursnotering en die rechten en/of belangen een van de wettelijke percentages van $5,10,25,50$ of $66^{2} / 3$ of meer bereikten dan wel passeerden ${ }^{90}$. Deze belegger diende dit zowel aan de desbetreffende vennootschap, als aan de Minister van Financiën te melden, maar op grond van het delegatiebesluit van de Wet Melding Zeggenschap geschiedde de daadwerkelijke melding aan de rechtsvoorgangster van de Autoriteit-FM, de STE. De openbaarmakingsplicht van de $W_{m z}{ }^{\prime} 92$ richtte zich tot de vennootschap. Deze diende ervoor te zorgen dat de melding van de belegger aan de desbetreffende toezichthouder, openbaar werd gemaakt. Het overtreden van zowel de meldingsplicht als de openbaarmakingsplicht werd door de wetgever in

88. Richdijn 88/627/EEG van de Raad van de Europese Gemeenschappen d.d. 12 december 1988 .

89. Ook wel genoemd de Wmz'91 zie Hillen, J.L.S.M., "Effectenwetgeving", d1. 143II Schuuman \& Jordens Nederlandse wetgeving, t.a.p. noot 32, p. 351 .

90" Hillen, J.L.S.M., "Effectenwetgeving", dl 143-Il Schuurman \& Jordens Nederlandse wergeving, t.a.p. noot 32 , p. 351 . 
de W/mz bestempeld als een economisch delict ${ }^{91}$. Doordat de W/mz'92 niet bepaalde dat de bestaande stemrechten en/of belangen gemeld moesten worden, kreeg men geen duidelijk beeld van de bestaande verhoudingen. Deze ervaringen met de $\mathrm{Wmz}^{\prime} 92$ hebben er toe geleid dat op 1 juni 1997 een verbeterde Wmz in werking trad; de Wmz' $96^{92}$. In de Wmz'96 heeft de wetgever de meldingsplicht, na een inhoudelijke wijziging, gehandhaafd. Een vernieuwing ten opzichte van de $\mathrm{W} / \mathrm{mz}^{\prime} 92$, is de ingevoerde initiële meldingsplicht. Dit houdt in dat een ieder die, tijdens de officiële beursnotering, stemrechten dan wel een belang van vijf procent of meer in de beursgenoteerde vennootschap heeft, dit dient te melden ${ }^{93}$. Ook de belegger die stemrechten dan wel belangen heeft in een vennootschap welke in de periode tussen de inwerkingtreding van de Wmz'92 en de inwerkingtreding van de Wmz'96 tot de officiële notering was toegelaten, dient dit op grond van de initiële meldingsplicht te melden ${ }^{94}$. Naast voornoemde initiële meldingsplicht, is in de Wmz'96 de meldingsplicht van emissie- -95 en herplaatsingrestanten ${ }^{96}$ verduidelijkt.

9: In deze studie wordt de definitie van cconomische delicten aangehouden zoals De Roos deze in het kader van zijn proefschrift beschrijft. Hij omschrijft een economisch delict als volgt: "delicten begaan door ondememingen ew personen in de economische sfeer; dat wil zeggen: door ondernemingen, in bet kader wan bun deelnewing an bet ecomomische verkeer alsmede door personen in bet kader wan de "conomische activiteit wan ondernemingen." Vgl. Roos, Th.A. de, "Strafbaarstelling nan economishe delicten; een crimineel-politieke studie", dissertatie RUU, Gouda Quint B.V., 1987, p. 1 .

Wet van 29 november 1996, Stb. 629.

Hillen, J.L.S.M., "Effectenwetgeving", dl. 143-II Schuurman \& Jordens Nederlandse wetgeving, t.a.p. noor 32 , p. 352 .

Kamerstukken $\mathbb{I}, 1995 / 96,24626,3$, p. 2 (MvT)

95 Een aandelenemissie is her uitgeven van nieuwe aandelen. Er kan van een aandelenemissie worden gesproken wanneer een vennootschap nieuwe aandelen uitgeeft om zo in hat financieringsbehoefte ve voorzien. Voordat de vennootschap harr aandelen kan uirgeven, dient zij eerst te worden genoteerd. De beursnotering is a an regels gebonden. De vennootschap kan zich niet rechtstreeks tot het publiek richten. Hiervoor dient zij contact op te nemen met een hierin gespecialiseerde bank en/of effectenkantoor. Deze bank en/of effecrenkantoor, ook wel introducenten genoemd, nemen de noteringsregels in acht en informenen het publiek via een introductiebericht. Hierna kan her publiek besluiten om aandelen tegen een bepaalde prijs an te schaffen. Na de uitgifte van de aandelen heeft het bedrijf meer kapitaal en kunnen de aandeethouders bepaalde rechten aan hun aandeel ontlenen. Amsterdamse Effectenbeurs, "Beturs en effecten: de beurshandel en de wormen van beleggen", uitgeverij Contact, Amsterdam/Antwerpen, 1993, p. 112118. 
Dit vond de wetgever ten tijde van de totstandkoming van deze wet van belang voor de professionele handelaren die in het bezit waren van een handelsportefeuille ${ }^{97}$ en een beleggingsportefeuille ${ }^{98}$. Op grond van de Wmz'92 moesten deze handelaren alleen de aandelen en/of stemmen die zich in de beleggingsportefeuille bevonden, bij de toezichthoudende STE aanmelden. De inhoud van de handelsportefeuille was destijds vrijgesteld van de meldingsplicht ${ }^{9 \%}$. Ondanks deze regeling bleek het in de praktijk anders uit te pakken. Het onderscheid tussen een handelsen een beleggingsportefeuille was niet altijd even duidelijk. Hierdoor werden bepaalde stemmen of aandelen ten onrechte niet aan de STE gemeld $^{100}$. Om onduidelijkheden te voorkomen heeft de wetgever in artikel 5 van de Wmz' 96 bepaald dat de professionele beleggers gedurende drie maanden na verkrijging van de stemmen of aandelen van beursgenoteerde vennootschappen, deze niet tot hun handelsportefeuille mogen rekenen ${ }^{101}$. Na het verstrijken van voornoemde periode worden de stemmen of aandelen automatisch tot de beleggingsportefeuille gerekend. Zodra de aandelen uit de handelsportefeuille over gaan naar de beleggingsportefeuille, komt de vrijstelling te vervallen en dient er

Herplaatsingsrestanten zijn restanten van de herplaatsing van bijwoorbeeld aandelen. Wanneer een aandee thouder een groot gedeelte wan het axdelenkapitaal van een vennootschap ïn handen heeft en daar in eén keer afstand van zou willen doen, heeft dat rot gevolg dat de koersprijs zal dalen. Om dit te voorkomen kan de aandeellhouder over gaan tot het herplaatsen wan aandelen. Evenals bij emissie her geval is, kunnen (potentiële) kopers zich inschrijven op de aandelen. Op deze manier kan de andeelhouder zijn aandelen wan de hand doen en woorkomen dat de koersprijs drastisch daalt.

${ }^{97}$ De naam "handelsportefeuille" impliceert dat de aandelen in deze portefeuille zijn bestemd voor de verkoop; voor de handel. De professionele handelaar kan deze aandelen niet aanwenden om er zeggenschap mee tuir te oefenen. Artikel 5 W'mz'96.

98 De beleggingsportefeuille is niet voor de handel bestemd, maar voor "eigen" gebruik. De handelaar kan zeggenschap met deze aandelen uitoefenen. Artikel 7 Wmz'96.

100 Hillen, J.L.S.M., "Effectenwetgeving", dl. 143-II Schuurman \& Jordens Nederlandse wetgeving, t.a.p. noot 32 , p. 355 .

Kamerstukken II, 1995/96, 24626,3, p. 3. (MwT) Hierdoor wordt voorkomen dat de professionele beleggers de uit emissie- of herplaatsing overgebleven aandelen in een beleggingsportefeuille kunnen plaatsen zonder dat dit aan de STE te melden. Dit zou betekenen dat de uit emissie- of herplaatsing overgebleven aandelen van de meldingsplicht uitgesloten zijn, wat in strijd is met de doelstelling van de Wimz. 
onmiddellijk aan de toezichthouder te worden gemeld ${ }^{102}$. Ook op het terrein van de openbaarmakingsplicht heeft de wetgever de W'mz'96 gewijzigd. Nu is niet meer de vennootschap, maar de toezichthouder verplicht om een ontvangen melding openbaar te maken ${ }^{103}$. Een andere wijziging is het systeem van de "bandbreedtes"104. In de Wmz'92 werd het systeem van verschillende bandbreedtes gebruikt. Deze bandbreedtes waren zodanig gekozen dat ieder zeggenschapspercentage onder een bepaald "blok" kon worden gebracht ${ }^{105}$. In geval een wijziging in percentage tot gevolg had dat men onder een andere bandbreedte viel, moest dit worden gemeld ${ }^{106}$. Het in de Wmz'92 gebezigde systeem bleek niet praktisch te zijn. Het was voor de meldingsplichtigen niet altijd duidelijk wanneer zij een wijziging moesten melden. In geval zij naar een hogere bandbreedte gingen, meldde men dat wel. Andersom verzuimde men dit vaak te melden ${ }^{107}$. Dat laatste gaf de wetgever aanleiding om in de W/mz'96 een ander systeem te bezigen en de inhoud van de bandbreedtes duidelijker aan te geven ${ }^{108}$. Zekerheidshalve heeft de wetgever in de parlementaire stukken van de Wmz'96 aangegeven dat men niet alleen een meldingsplicht heeft ingeval men onder een

102 Hillen, J.L.S.M., "Effectenwetgewing", dl. 143-II Schuurman \& Jordens Nederlandse wetgeving, t.a.p. noot 32, p. 354 .

10* Kamerstukken II, 1995/96, 24626, 3, p. 3. (MvT) Meer over de openbaarmakingsplicht in paragraaf 2.1.2.

ind Dit zijin zes blokken aan de hand warvan wordt vastgesteld of er sprake is wan het percentage zeggenschap in een effecteninstelling dat kan leiden tot het werplicht mellen van deze percentage aan de STE. Kamerstukken I.I, 1995/96, 24626, 3, p. 3. (Mv'T)

105 Kamerstukken II, 1995/96, 24626, 3, p. 3. (MvT)

Hack cen wijziging dit niet tot gevolg, maar bleef men binnen dezelfde bandbreedte, dan kon een melding achterwege blijwen. Hillen, J.L.S.M., "Effectenwetgeving", dI. 143-II Schuurman \& Jordens Nederlandse wetgeving, t.a.p. noot 32, p. 355.

107 Kamerstukken II, 1995/96,24626,3, p. 4. (MvT)

ias Artikel 1 lid 1 sub cWmz' 96 geeft de volgende bandbreedtes aan: 0 tot 5,5 tot 10 , 10 tot 25,25 tot 50,50 tot $66^{2} / 3$ en $66 \%$ procent of meer. De Ministers van Financiën en Justitie hebben in 2002 cen wetsvoorstel ingediend dat de herziening van de W'mz'96 tot gevolg zal hebben. Deze herziening is een onderdeel van "voorstellen die de doorzichtigheid wan de Nederlandse effectenmarkt voor zowel beleggers als bewrsvenwootschappen moeten beworderen". Met deze herziening van de W'mz'96 zullen ondermeer de hiervoor angegeven bandbreedres worden vernauwd. Dat houdt in dat er bandbreedtes van $15 \%$ en van $20 \%$ zullen worden ingevoerd. Voorts zal deze herziening tot gevolg hebben dat de beursvennootschappen een meldingsplicht bij kapitaalwijzigingen zullen krijgen. Actualiteiten, "Doorzichtigheid effectenmarkt", NJB, 22 november 2002 , jrg. 77, p. 2123. 
hogere bandbreedte valt, maar ook indien men onder een lagere bandbreedre valt ${ }^{109}$. Dit werd onder de vorige wetgeving niet altijd begrepen. Tot slot is in de W'mz'96 de verplichting tot melding van het zeggenschap in beleggingsmaatschappijen met veranderlijk kapitaal gewijzigd. OP dit gebied is de meldingsplicht beperkt. Vóór de Wmz'96 waren beleggers verplicht om telkens weer de percentages in deze beleggingsmaatschappijen aan te geven. Het melden van het steeds veranderend kapitaal dat inherent is aan dit soort maatschappijen, bewerkstelligt de ondoorzichtigheid van de effectenmarkt. Daarom heeft de wetgever in de W'mz'96 de meldingsplicht van deze beleggingsmaatschappijen beperkt. Voor deze maatschappijen gelden maar vier bandbreedtes ${ }^{110}$. Ze hebben nu een grotere speelruimte waardoor ze minder vaak hoeven te melden. Hierdoor kan het aantal meldingen afnemen wat weer zal zorgen voor een overzichtelijker en doorzichtiger geheel.

\section{$\mathrm{C}$ De Wet toezicht beleggingsinstellingen}

De in 1990 ingevoerde Wet toezicht beleggingsinstellingen (Wtb) vormt het sluitstuk van de algehele herziening van de effectenwetgeving. Deze wet bevat regels aangaande een bepaalde groep beleggers; de beleggingsinstellingen. Met de invoering van de W/tb wordt uitvoering gegeven aan de Europese richtlijn ${ }^{111}$ betreffende de coördinatie van bepalingen over een bepaald soort beleggingsinstellingen. In artikel 1 sub c Wrb wordt een beleggingsinstelling omschreven als:

"... een beleggingsmaatschappij of beleggingsfonds".

In artikel 1 sub a Wtb is de volgende definitie van het begrip "beleggingsmaatschappij' te vinden:

"de rechtspersoon die gelden of andere goederen ter collectieve belegging tratagt of heeft verkregen teneinde de deelnemers in de opbrengst un de beleggingen te doen delen".

\footnotetext{
Kamerstukken II, $1995 / 96,24626,3$, p. 4. (MvI)

110 Hillen, J.L.S.M., "Effectenwetgeving", dl. 143-II Schuurman \& Jordens Nederlandse wetgeving, t.a.p. noot 32 , p. 355.

11 Richtlijn 85/611 PB L 375 van de Raad van de Europese Gemeenschappen d.d. 20 december 1985.
} 
In sub b van dit artikel uit de Wtb heeft de wetgever de volgende omschrijving aan het begrip "beleggingsfonds" gegeven:

"een witer in een rechtspersion ondergebracht vermogen waarin ter collectieve belegging gevragde of uerkyegen gelden of andere gaederen zijn of worden opgenomen teneinde de deethemers in de opbrengst van de beleggingen te doen delen;".

Beide instellingen hebben als doel de deelnemers in de opbrengst te laten delen; het zijn instellingen die onder meer collectief beleggen in effecten. De Wtb heeft zich bij de uitvoering van de ICBE-richtlijn ${ }^{112}$ op de hier voor genoemde instellingen gericht. Met de invoering van deze wet heeft de wetgever beoogd om deze instellingen, ook wel ICBEinstellingen genoemd, een gelijke behandeling in de lidstaten te garanderen. ICBE-instellingen, instellingen voor collectief beleggen in effecten, zijn instellingen waarbij deelnemers op eigen verzoek kunnen inkopen en op eigen verzoek worden terugbetaald ${ }^{113}$. Evenals de Wte' 95 heeft de Wtb tot algemeen doel: "het bevorderen van een adequate werking van de financiële markten en de bescherming van de beleggers op die markten ${ }^{114 "}$. De wetgever heeft met de Wtb beoogd om in het bijzonder het vertrouwen van beleggers in de kapitaalmarkt als in de actoren op deze markt, te verbeteren. Dit zou tor gevolg moeten hebben dat de bellegger meer vertrouwen in de financiële sector moet krijgen, wat de beleggingsinstellingen weer ten goede zou komen. Door in eerste instantie onder meer eisen te stellen aan de betrouwbaarheid, de deskundigheid en secundair aan de solvabiliteit van de beleggingsinstellingen, heeft de wet getracht om een toezichtskader te scheppen. De regels van de Wtb richten zich niet alleen op de financiële waarborgen, zoals de solvabiliteiteis, maar ook op de transparantie van de beleggingsmarkt. De reden hiervoor is dat de wetgever het niet tot de taak van de overheid beschouwt om via het toezicht de mate te bepalen waarin de belegger risico's mag nemen. De belegger is vrij om risico's te nemen.

112 Een ICBE, d.w.z. "Instelling ter Collecrieve Belegging in Effecten"; vgl ICBErichdijn $85 / 611 / \mathrm{EEG}$.

113 Dit worden ook wel 'open-end'-instellingen genoemd. Hillen, J.L.S.M., "Effectenusetgewing", dl. 143-II Schuurman \& Jordens Nederlandse wergeving, t.a.p. noot 32, p. 201. Open-end instellingen zijn beleggingsmaarschappijen die hatr deelnemingsrechten op verzock wan haar deelnemers terugkopen.

14 Hillen, J.L.S.M., "Effectenwergeving", dl. 143-IT Schumrman \& Jordens Nederlandse wetgeving, t.a.p. noot 32, p. 202. 
Met de invoering van de Wtb heeft de wetgever beoogd om te waarborgen dat het publiek een duidelijk en helder beeld moet kunnen vormen van de beleggingsmarkt. Kortom de markt moet zo transparant zijn dat de belegger zelf de risico's kan bepalen ${ }^{115}$.

$\mathrm{De} \mathrm{W} t \mathrm{~b}$ heeft haar eigen vergunningsregeling voor beleggingsinstellingen. Het in de Wte gesteld verbod om in of vanuit Nederland buiten een besloten kring effecten bij uitgifte an te bieden is niet van toepassing op het aanbieden van deelnemingsrechten in bepaalde beleggingsinstellingen ${ }^{116}$. Artikel $4 \mathrm{Wtb}$, dat de kern vormt van deze wet, richt zich speciaal op deze specifieke instellingen.

\section{Artikel 4 lid 1}

Het is verboden in of vanuit Nederland butten een besloten kring gelden of andere goederen ter deelneming in een beleggingsinstelling wadran geen vergunning is verleend, te vragen of te verkrijgen dan wel rechten wan deelnerning in een dergelijke beleggingsinstelling aan te bieden.

Na een vergunning op grond van de Wtb te hebben ontvangen, worden voornoemde instellingen ingeschreven in het register van de $\mathrm{W}_{\mathrm{tb}}{ }^{117}$ en mogen zij buiten een besloten kring gelden voor collectieve beleggingen werven. Alvorens een vergunning wordt verleend, wordt bij de aanvraag nagegaan of de beleggingsinstelling voldoet aan de wettelijke eisen. In de Wtb worden twee vergunningenstelsels toegepast. Deze stelsels kunnen worden onderscheiden in een algemeen en een bijzonder stelsel. Het algemeen stelsel is gebaseerd op artikel $5 \mathrm{Wtb}$ en geldt voor alle

115 Samenharg en verschillen tussen de financiële toezichrwetten, notitie, Ministerie van Financiën, Den Haag, 30 augustus 1996, p. 6.

${ }_{116}$ Dit verbod wordt genoemd in artikel 3 lid 1 Wte'95. Grundmanm-Van de Krol, C.M., Recente wetgeving effectentransacties, Gouda Quint B.V., Arnhem, 1995 , p. 52.

117 Arrikel 3 lid 2 onder d Wre'95 jo arrikel 18 lid 1 Web. 
beleggingsinstellingen. Her bijzondere stelsel is gebaseerd op artikel 6 van deze wet. Lid 1 van artikel $5 \mathrm{Wtb}$ heeft de volgende redactie:

\section{Artikel 5}

1. Onze Minister verleent een beleggingsinstelling, op verzoek en met inachtneming van artikel $G$, een vergunning indien de aanurager adntoont dat de beleggingsinstelling en de benuarder, indien adn de beleggingsinstelling verbonden, voldoen aan de bij of krachtens algemene maatregel vam bestuur te stellen eisen met betrekking tot:

a. deskundigheid en betrowwbaarheid;

b. financiele warborgen:

c. bedriffswoering; en

d. bet verstrekken van informatie aan de deelnemers in de beleggingsinstelling en aan bet publiek.

In het eerste lid van bovenstaand artikel heeft de wetgever bepaald dat alle belleggingsinstellingen een vergunning kunnen krijgen indien zij voldoen aan de algemene eisen van deskundigheid, betrouwbaarheid, financiële waarborgen, bedrijfsvoering en indien zij zowel informatie verstrekken aan de deelnemers in de beleggingsinstelling, als aan het publiek. In de overige leden van artikel 5 Wtb, lid 2 en 3 , worden meer eisen gestell. In lid 2 wordt de eis gesteld dat de beheerder van het beleggingsfonds rechtspersoonlijkheid dient te hebben. Voorts wordt er in dit lid van artikel 5 Wtb bepaald dat de vermogens van de dagelijkse leiding van het fonds en van het fonds gescheiden moeten zijn. Tot slot heeft de wetgever in het derde lid opgenomen dat de Minister, indien hij daartoe aanleiding ziet, alsnog een vergunning aan een beleggingsinstelling kan verlenen die niet aan alle vereisten voldoet.

Het bijzonder stelsel is gebaseerd op artikel $6 \mathrm{Wtb}$.

\section{Antikel 6:}

1 De anw wager wan ean werghnning voor en beleggingsinstelling:

a. watrvan bet statutaine of reglementaire doel witslutend is bet beleggen in effecten met toepassing wan bet beginsel van risicospreiding:

b. wanvan de nechten van deelneming op werzok van de deelnemer ten laste van de activa rechstreeks of middellijk worden ingekoch of terugbetaald; en

c. waturwn de zetel of wanner bet een beleggingsfonds betreft, die wan de bebeender. in Nederland is getegen:

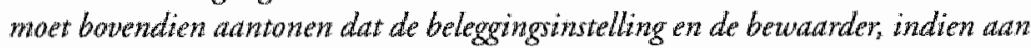
de beleggingsinstelling verbonden, voldoen aan bet tweede tot en met het zesde lid.

2. Het hoofdkantoor van de beleggingsmatschappij dan wel wan de beherder van bet beleggingsfonds is in Nederland gelegen. 
3. De werkzaamheden wan de bebeerder van bet beleggingsfonds zijn beperki tot bet bebeer van de belegringsinstellingen.

4. De beleggingsinstelling verwult geen andere werkzanmbeden dan die bedoeld in het eerste lid.

5. De activa van de beleggingsmaatschappij worden in bewaring gegeven bij een van haar onafhankelijke bewaarder. Bij of krachtens algemene maatregel wan besun kan voor beleggingmaatschappijen wan dit wereiste worden afgeweken overeenkomstig de bij of krachtens die matregel te stellen regels.

6. De bewaarder van de beleggingsinstelling heeft zijn zetel in een Lid-Staat en heeft een vestiging in Nederland.

7. Artikel 5, derde lid, is van overeenkomstige toepassing.

In dit artikel is bepaald dat bepaalde beleggingsinstellingen pas na het voldoen aan aanvullende vergunningseisen, een vergunning kunnen krijgen. De aanvullende eisen worden in de leden 2 tot en met 6 van artikel $6 \mathrm{~W}$ tb vermeld. Onder het bijzonder stelsel vallen in beginsel de Nederlandse ICBE's ${ }^{118}$. Ook hier is weer een uitzondering op mogelijk. In artikel $7 \mathrm{Wtb}$ wordt bepaald dat niet alle Nederlandse ICBE's onder het regime van artikel 6 Wtb vallen ${ }^{119}$. De ICBE die volgens artikel 7 Wtb onder het algemene vergunningenstelsel van artikel 5 Wtb valt, is een beleggingsinstelling die:

- geen gelden en/of andere goederen van het publiek in de Lid-Staten ter belegging vratgigt of werkrijgt:

- kradhtens baar statuten of reglementen, hadr rechten van deelneming slechts bij het publiek in lavden buiten de Lid-Sitaten mag plataten ${ }^{120}$;

In artikel $12 \mathrm{Wtb}$ is bepaald dat de beleggingsinstellingen die in het bezit zijn van een vergunning, zich aan de wettelijke regels en doelstellingen van de Wtb moeten houden. Evenals in de Wte is in de Wtb bepaald dat het toezicht berust bij de Minister van Financiën, maar in artikel 29 van de Wtb is de mogelijkheid gecreëerd om bij algemene maatregel van bestuur taken en bevoegdheden aan een rechtspersoon over te dragen. In tegenstelling tot de Wte had de wetgever in eerste instantie niet de STE, maar De Nederlandsche Bank N.V. (DNB) als toe-

118 Artikel 6 lid $1 \mathrm{~W}$ tb.

119. Artikel 7 Wtb. Men kan als voorbeeld de beleggingsinstellinginstellingen nemen die hoofdzakelijk in niet-genoteerde effecten beleggen of men kan aan "leveraging" denken. Leveraging is het vergroten van her belegde vermogen door het opnemen van geldleningen. Zie Hillen, J.L.S.M., "Effectenwetgeving", dl. 143-II Schuurman \& Jordens Nederlandse wetgeving, t.a.p. noot 32, p. 235. 
zichthouder ${ }^{121}$ aangewezen. Dit had de wetgever in lid 4 van voornoemd artikel aangegeven. Na de wijziging in toezichtsmodel, heeft de wetgever artikel 29 Wtb dusdanig gewijzigd zodat het gedragstoezicht vandaag de dag onder de supervisie van de Autoriteit-FM valt en het prudentieel toezicht onder de supervisie van DNB.

\section{Artikel 29 (oud)}

4. Indien bij algemene matregel van bestuur taken en bevoegdheden als bedoeld in het eerste lid zijn overgedragen aan De Nederlandsche Bank N.V., is de Bank bevoegd deze taken uit te voeren en deze bevoegdheden uit te oefenen.

Tot slot heeft de wetgever in artikel 39 van de W/tb vermeld dat het overtreden van bepaalde artikelen uit deze wet als een economisch delict wordt beschouwd. Meer hierover in paragraaf 2.5.3.

De in deze paragraaf genoemde wetten kunnen als kaderwetten worden beschouwd die een praktische uitwerking vereisen. Dit is geschied via nadere regelingen en besluiten. In de volgende paragraaf zullen we deze vorm van regelgeving, de externe regelgeving, bespreken. In paragraaf 2.3.3 komt de interne regelgeving aan bod.

\subsubsection{Externe regelgeving; de uitwoeringsregels}

Zoals reeds uit voorafgaande paragrafen naar voren is gekomen, zijn de hiervoor genoemde kaderwetten niet altijd even duidelijk omschreven. Hiertoe hebben de wetgever en de toezichthoudende STE, later ook de Autoriteit-FM, nadere regelgeving gecreëerd waarmee de werkbaarheid van de eerder aangehaalde kaderwetgeving wordt beoogd. De wetgever heeft naast de Wte'95, ook het Besluit toezicht effectenverkeer 1995 (Bte'95) en het Delegariebesluit Wet toezicht effectenverkeer 1995 (Delegatiebesluit ${ }^{122}$ ) tor stand gebracht ${ }^{123}$. Laatstgenoemde besluiten hebben weer geleid tot de totstandkoming van de Nadere regeling toezicht effectenverkeer 1999 (Nrte '99) door de rechtsvoorganger van

121 Koninklijk Beshir van 14 augustus 1990, Stb. 458.

122. Ook wel het overdrachrsbesluit Wet toezicht effectenverkeer 1995 genoemd. Meer hierover in paragraaf 2.5.1.

123 In het Besluit d.d. 14 december 1995, Stb. 1995, 646, is neergelegd dat voornoemde wetten en besluiten op 31 december 1995 in werking zouden moeten treden. 
de Autoriteit-FM. Alvorens wij de Nrte' 99 behandelen, bekijken wij het Bte' 95 . Het Delegatiebesluit komt bij de bespreking van het Bte'95 aan bod.

\section{Het Besluit toezicht effectenverkeer 1995}

In paragraaf 2.3.1, bij de behandeling van de kaderwetgeving, is het Bte' 95 reeds genoemd. Dit daar het tegelijkertijd met de Wte' 95 en alle andere uirvoeringsregels is ingevoerd. De naam "uitvoeringsregels", maakt al snel duidelijk wat het doel van de Bte'95 is, namelijk de kaderwet - de Wte'95 - uitvoerbaar maken. Wanneer de artikelen van de Wte'95 nader worden bestudeerd, wordt duidelijk dat de aanbieding van effecten buiten een besloten kring vergezeld hoort te gaan van het aanbod van een prospectus. Verder vermeldt lid 2 onder $b$ van voormeld artikel dat een dergelijk prospectus aan bepaalde eisen hoort te voldoen. Deze eisen zijn bij of krachtens AMvB vastgesteld. In casu is de AMvB het Besluit toezicht effectenverkeer 1995. Zo bevat de Wte' 95 meerdere verwijzingen naar dit besluit. Met het Bte'95 heeft de wetgever beoogd om de uitvoering te vergemakkelijken door de volgende artikelen te verduidelijken: de artikelen 3 lid 2 onder b en c, 5 lid, tweede volzin, 7 lid 4 , 11 lid 1,17 lid 1 en 48d lid 5 Wte'95. In artikel 3 lid 2 onder b en c Wte' 95 wordt, zoals reeds even is aangestipt, aangegeven dat een prospectus gegevens moet bevatten die

"redelijkerwijs van belang zijn woor de beoordeling van het vermogen, de financielle positie, het resultaat en de vooruitzichten van de uitgevende instelling en van de rechten en verplichtingen die atan de effecten verbonden zijn "24"

Verder worden er zowel in de overige leden van artikel 2 Bte 95 als in de artikelen 3 tot en met 6 Bte' 95 meerdere punten genoemd waaraan een prospectus moet voldoen. Niet alleen de Bte'95 bevat aanwijzingen omtrent de uirvoering van artikel 3 lid 2 onder b en c Wte' 95 , maar ook de door de STE uirgevaardigde Nadere regeling toezicht effectenverkeer 1999. Hierover later meer. Voorts zijn er in de artikelen 7 tot en met 9 Bte' 95 bepalingen te vinden die de uitvoering van artikel 5 lid 1 tweede volzin Wte'95 moeten verduidelijken en vergemakkelijken. Laatstgenoemd artikel heeft betrekking op de doorlopende informatieverplichting. In dit geval dient men te denken aan periodieke verslaggeving op het gebied van de financiële positie van de uitgevende instelling. 
Daarnaast dient de uitgevende instelling volgens lid 1 van artikel 5 W'te'95 ook informatie te verschaffen die betrekking heeft op de koers van de effecten van de uitgevende instelling. Volgens de van toepassing zijnde artikelen uit de Bte"95 dient de uitgevende instelling uitwoering te geven aan voornoemde informatieverplichting door ieder boekjaar een jaarrekening en een jaarverslag vast te stellen die aan de in het besluit genoemde eisen voldoen ${ }^{125}$. Verder zijn er in de artikelen 10 tot en met 20 Bte'95 criteria te vinden die van belang zijn voor de uitvoering van artikel 7 lid 4 Wte'95. In dit artikel is het verbod neergelegd om zonder vergunning als effectenbemiddelaar of vermogensbeheerder in of vanuit Nederland diensten aan te bieden of te verrichten. Eerder is vermeld dat de toezichthouder op grond van het delegatiebesluit vervat in artikel 40 Wre'95 ${ }^{126}$, de vergunningsplichtige een vergunning kan verlenen. In het sectorale toezichtsmodel diende de toenmalige toezichthouder, de STE, de vergunning te verlenen in geval de vergunningsaanvrager voldeed aan de in de Bte" 95 gestelde eisen, waaronder de eis van deskundigheid en betrouwbaarheid ${ }^{127}$; voldoende eigen vermogen en andere eisen zoals werden genoemd in de hiervoor vermeldde artikelen. De overgang naar een functioneel toezichtsmodel geeft de huidige Autoriteit-FM de bevoegdheid om de onder haar toezicht staande instellingen op hun gedrag te controleren. Daar waar de controle de solvabiliteit en andere

125 Volgens artikel 7 dient de jaarrekening onder meer informatie te bevatren omtrent de solvabiliteit en de liquiditeit van de uitgevende instelling. Het jaarverslag dient onder meer een getrouw beeld te geven omtrent de roestand op de balansdatum en de gang van zaken gedurende het boekjaar.

Artikel 40 Wte'95 luidt als volgt:

"Taken en bevogdheden die onze Minister ap grond vaw deze wet beef, kwnen, met witzondering uan de taken en bevoegdbeden, bedoeld in de artikelen $8,10,18,22$, 25, 26, 27, 41,42,45,46b, derde lid, onder $c$, en wijfle lid, 46d, 48a, 48b, derde lid, en $48 \mathrm{~m}$, wweede lid, en met witzondering wan bet werlenen vat vrijatelling als bedoeld in de artikelen a en 5, bij algemene matregel wan beswur worden overgedragen aan een of meer rechtspersonen. Alsdan gelden de verplichtingen op grond wan deze wet jegens Onze Minister als werplichtingen jegens de desbetreffende nchspersoon of rechtspersonen.(..)". In artikel 2 van het Delegatiebesluit, ook wel het Overdrachtsbesluit Wte' 95 , zijn voornoemde taken en bevoegdheden als volgt overgedragen aan de STE: "Met inachtneming van artikel 40, eerste lid, wan de wet worden de taken en bevoegdheden die Onze Minister op grond wan de wet beeft, overgedragen aan de Stichting (de STE), met uitzondering van: (...)". Vgl. artikel 2 van het besluit van 8 december 1995, houdende uitvoering van artikel 40 , eerste lid, van de Wer toezicht effectenverkeer 1995 ; $\mathrm{KB}$ van 14 december 1995 , Stb. 1995, 646. in werking treding 31 december 1995.

Vgl. arrikel 10 lid 1 en 2 Bte' 95. 
financiële bestaanskwesties van een instelling raakt, is het toezicht onder de prudentiële toezichthouder, DNB komen te staan.

De rechtsvoorganger van de Autoriteit-FM, de STE heeft zelf ook regels gesteld die haar eigen beleid inzake artikel 7 lid 4 Wite'95 moesten verduidelijken. Deze regels zijn terug te vinden in de Nadere regeling toezicht effectenverkeer 1999 (Nrte'95). Later zal er worden teruggekomen op de Nrte'95. Wanneer het Bte' 95 nader wordt bestudeerd, wordt duidelijk dat de artikelen 21 tot en met 44 de uitvoering van artikel 11 lid 1 Wte"95 ${ }^{128}$ moesten verduidelijken. In laatstgenoemd artikel worden de regels aangegeven waaraan vergunninghouders, zoals bedoeld in artikel 7 lid 1 Wte' $95,{ }^{129}$ zich moeten houden. In de Bte'95 zijn voornoemde vergunninghouders onderverdeeld in drie categorieën die in verschillende paragrafen worden onderverdeeld. Zo is in paragraaf 1 , de artikelen 21 tot en met 32 Bte' 95 , een nadere uitleg te vinden over de regels aangaande effecteninstellingen met een vergunning zoals genoemd in artikel 7 lid 1 Wte'95. De artikelen 33 tot en met 42, paragraaf 2, bevatten nadere regels betreffende de in Nederland gevestigde kredietinstellingen en financiële instellingen die op grond van de artikelen 6 of 38 Wet toezicht kredietwezen "92 (W'k'92) een vergunning hebben dan wel die een verklaring van ondertoezichtstelling hebben zoals vermeld in artikel 45 Wrk' 92 . Verder bevat paragraaf 3 , de artikelen 43 en 44 Bte'95, regels voor kredietinstellingen, financiële instellingen en andere effecteninstellingen die in een andere lid-staat zijn gevestigd maar die hun werkzaamheden in Nederland uitoefenen. Voorts wordt er in artikel 45 Bte"95 "uitvoering" gegeven aan artikel 17 lid 1 Wte'95. In latstgenoemd wetsartikel wordt aangegeven dat houders van een verklaring

128 Artikel 11 lid 1 Wre'95 luidt als volgt: "Een effecteninstelling wataraan een vergunning als bedoeld in artikel 7 , eerste lid, is verleend, houdt zich aan bij of krachtens algemene maatregel van bestutur te stellen regels ten aanzien van: a. deskundigheid en betrouwbaarheid; $b$. financiële waarborgen, al dan dient tevens op geconsolideerde basis; $c$. bedriffsvoeringen vestiging van het hoofdkantoor; $d$. aan Onze Minister en aan bet publiek te verstrekken informatie; en e. waarborgen voor een adequat toezicht op de naleving van de bij of krachtens deze wet gestelde regels.

129 Artikel 7 lid 1 Wre' 95 luidt als volgt: "Het is verboden om zonder vergunning als effectenbemiddelaar of vermogensbeheerder in of wanuit Nederland diensten aan te bieden of te verrichten." 
van geen bezwaar zich aan bepaalde regels dienen te houden ${ }^{130}$. Bij nadere bestudering van artikel 45 Bte' 95 blijkt dat er in deze AMvB slechts wordt aangegeven dat de toezichthoudende autoriteit regels kan stellen om te voorkomen dat een handeling als bedoeld in artikel 16 lid 1 Wte' $95^{131}$ ertoe zou kunnen leiden dat men een dusdanige invloed op een effecteninstelling zou krïgen die in strijd is met een gezonde en prudente bedrijfsvoering van de desbetreffende effecteninstelling. Tot slot bevat de Bte' 95 nog twee artikelen, te weten 46 en 47 , die aangeven wanneer het besluit in werking dient te treden en hoe het aangehaald dient te worden. Kortom, de AMvB waarnaar in de Wte' 95 meermalen wordt verwezen en het Bte' 95 dat de bedoeling heeft om deze kaderwet uitvoerbaar te maken, hebben in bepaalde gevallen nog ondersteuning nodig van andere regelgeving. Deze ondersteuning wordt aangetroffen in de eerder aangehaalde Nrte'95 die hieronder zal worden besproken.

De Nadere regeling toezicht effectenverkeer 1999

Aangetoond is dat er in het Bte'95 meermalen wordt verwezen naar de bevoegdheden van de toezichthouder, de huidige Autoriteit-FM. In het kader van de uitvoering van haar taak, is de Autoriteit-FM als rechtsopvolger van de STE zelf bevoegd om ter aanvulling op de Wte'95 en de bijbehorende Bte'95 regels te stellen. Zoals eerder is genoemd, zijn deze regels te vinden in de nadere regeling toezicht effectenverkeer 1999 (Nrte'99). Volledigheidshalve mag een bespreking van de Nrte"99 hier niet ontbreken. In de Nrte'99, die op 1 februari 1999 in werking is getreden $^{132}$, worden de eisen genoemd die enkele bepalingen van het bte' 95 moeten verduidelijken. Via de Nrte'99 heeft de STE destijds

130 Artikel 17 lid 1 Wte'95: "De houder van en verklaring wan geen bezwaur die is werleend op grond van artikel 16 , vierde lid, watron temminste en docbtemaatschappij een effecteninstelling is waaratn een vergwnning is verieend als bedoeld in awtikel 7 , erste lid boudt zich an bij of krachtens algemene matregel van bestuwr te stellen regels om te vookomen dat de bandelingen wawnoor de verklaring wan geen bezwatr is werleend,zou leiden of zon kunnen leiden tat een invloed op de betrokken effecteninstelling die in strijd is met een gezonde of prudente bedrijfsoering van die instelling.

131 Arrikel 16 lid 1. Wte'95: "Het is verboden, awders dan nat verkregen verklaring van geen bezwat, een gekwalificerde deelnewing te houden, te verwerven of to vergroten in een effecteninstelling watran en vergwning is werleend op grond wan artikel 7 . vierde of zesde lid" dan wel enge zeggenschap verbonden aan een gekwalificerde deelneming wit te oefenen in een instelling als biervoor bedoeld."

152 Vlg. de Nadere regeling toezicht effectenverkeer 1999, d.d. 7 januari 1999 , Stcrt. $1999,12$. 
uitvoering gegeven aan het bte' 95 . De zeer omvangrijke Nrte' 99 bestaat uit 47 artikelen die allen vergunning-en toezichtregels bevatten. Opvallend is dat er hier gesproken wordt over de Nrte'99 en niet zoals in geval van de Wte'95 en het Bte'95 over de Nrte'95. De laatste heeft tot 1 februari 2000 gegolden, maar is vervangen door de huidige Nrte' 99 , hiertoe genoodzaakt door de fusie van de erkende effecten- en optiebeurzen in Nederland. Deze fusie luidde op 1 januari 1997 een nieuw toezichtsbeleid in en stond gelijk aan het aflopen van een periode waarin de zelfregulering door voornoemde beurzen een doorslaggevende rol speelde in de toezichtsuitoefening. In het nieuwe toezichtsbeleid heeft de STE een zwaarwegende rol gekregen welke weer is geformaliseerd in de Nrte' 99 . Verder bevat de Nrte'99 ook toezichtsregels voor effecteninstellingen die zijn toegelaten tot de AEX NV. Hiervan zijn de beurstypische regels uitgezonderd. Wanneer de opbouw van de Nrte'99 nader wordt bestudeerd, kunnen gelijkenissen met de Bte' 95 worden aangetroffen. Artikel 1 Nrte'99, de inleidende bepaling, bevat de definities van begrippen gebruikt in de Nrte'99. Artikel 2 bevat regels die de uitvoering van artikel 2 Bte'95 moet vergemakkelijken. Zoals hierboven al is aangegeven, zijn in artikel 2 Bte' 95 criteria te vinden waaraan een prospectus moet voldoen. Hier vult de Nrte'99 de Bte' 95 duidelijk aan doordat er nadere regels worden gegeven met betrekking tot de indeling van het prospectus zoals, naast dat wat in het Bte'95 wordt vereist, ook nog een samenvatting van de kerngegevens waarin tenminste de naam van de uitgevende instelling moet zijn vermeld en waarin onder meer ook de datum moet zijn vermeld waarop het prospectus is vastgesteld. Ook heeft de rechtsvoorganger van de Autoriteit-FM nadere regels met betrekking tot de uirvoering van artikel 7 Bte' 95 vastgesteld. Deze zijn te vinden in artikel 3 Nrte'99. De extra eisen aangaande het eigen vermogen en het toetsingsvermogen van een uitgevende instelling waarnaar de artikelen 12 en 13 Bte'95 verwijzen, worden onder meer angevuld in artikel 4 Nrte" 99. Zo vermeldt laatstgenoemd artikel het volgende:

\section{Artikel 4}

Een effecteninstelling beschikt doorlopend over een eigen vermogen als omschreven in bijlage 1, van tenminste:

a. 35000 euro, als de effecteninstelling de effectendienst bedoeld in artikel 1 , onder $h$, sub 1 , verricht, mits de effecterinstelling deze dienst niet, overeenkomstig artikel 13 of 14 van de wet (ite weten de Wte'95), verricht of woornemens is te verrichten in een andere stat die partij is bij de Overeenkomst betreffende de Europese Economische Ruinte; 
b. 50.000 euro, als de effecteninstelling een of meer van de volgende effectendiensten verricht:

- de effectendienst bedoeld in artikel 1 , onder $h$, sub 1 , indien de effecteninstelling deze dienst, overcenkomstig artikel 13 of 14 van de wet verricht of voomemens is te werrichten in een andere stati die partij is bij de Overeenkomst betreffende de Europese Economische Ruimte;

- de effectendienst bedoeld in artikel 1, onder b, sub 2, sub 4, sub 7 of sub 8;

c. 730000 euro, als de effecteninstelling al dan niet naast de onder a en b genoemde effectendiensten, een of meer van de effectendiensten bedoeld in artikel 1 , onder $h$, sub 3, sub 5 of sub 6 verricht.

Aan de hand van bovenvermeld artikel wordt duidelijk hoe de STE door middel van de Nrte' 99 heeft getracht om de uitwoering van de Bte'95 en dus van de Wte'95 te verduidelijken.

In de Nrte' 99 heeft de STE naast de eerder genoemde artikelen 2 en 7 Bte'95, ook de artikelen $12,13,15,16,17,23,24,25,28,29,30,34$, $35,36,38,39,40,41,43$, en 44 van het besluit toegelicht. Niet altijd is de STE in haar poging geslaagd om het Bte'95 en de Wte'95 te verhelderen, uit de praktijk is gebleken dat de wet en de bijbehorende uitvoeringsregels niet altijd even bevattelijk zijn. Dit was en is mede te wijten aan de ruime en vaak vage wetsteksten. Om te voorkomen dat de verschillende beursactoren tegen hun wil in strijd met het beleid van de toezichthouder handelen, kunnen zij haar visie in deze vragen. Op deze manier heeft de toezichthouder ten aanzien van veel voorkomende vragen, een beleid ontwikkeld welke bijna hetzelfde gewicht heeft als de wetsuitleg door de rechter ${ }^{133}$. Of dit een ontwikkeling is die men moet toejuichen valt te betwijfelen. Ook al behoedt Autoriteit-FM door haar uitleg potentiële wetsovertreders voor een misstap, het is niet de taak van de toezichthouder om op de stoel van de rechter te gaan zitten. De wetgever moet in dat geval maar voor duidelijke wetgeving zorgen. Op deze manier wordt er ten onrechte teveel "feitelijke" macht aan de toezichthoudende Autoriteit-FM, een zelfstandig bestuursorgaan ${ }^{134}$, toegekend.

\section{Het Beshuit toezicht beleggingsinstellingen}

Niet alleen voor de Wte"95, maar ook voor Wtb zijn er uitvoeringsregels gecreèerd. Deze zijn vastgelegd in het Besluit toezicht beleggings- 
instellingen (Btb) ${ }^{135}$. Evenals het Bte'95, bevat het Btb regels die de uitvoering van - in dit geval - de Wet toezicht beleggingsinstellingen moeten vergemakkelijken. De artikelen 2 tot en met 7 Btb hebben betrekking op de uitvoering van artikel 5 lid 1 Wtb. Zoals reeds is aangegeven in paragraaf 2.3.1 onder punt $C$ van de algehele herziening van de effectenwetgeving, is in dit artikel de algemene regel met betrekking tot het vergunningsstelsel voor beleggingsinstellingen neergelegd. Zo wordt er in artikel $5 \mathrm{Wtb}$ aangegeven dat alle beleggingsinstellingen een vergunning behoeven en dat er bij AMvB eisen zullen worden gesteld waaraan de vergunningsaanvrager zich zal moeten houden wil hij een vergunning verleend krijgen.

\section{Artikel 5:}

8. Onze Minister verleent een beleggingsinstelling; op verzoek en met inachnoming van artikel 6 , een vergunning indien de aanvager aantoont dat de beleggingsinstelling en de bewadrder, indien aan de beleggingsunstelling verbonden, voldoen aan de bij of krachtens algemene mataregel wan bestuwr te stellen eisen met betreking tot:

a. deskundigheid en betrowwbaarheid;

b. financièle wataborgen;

c. bedrijfsoering; en

d. bet verstrekken wan informatie ala de deelnemers in de beleggingsinstelling en aan het publiek.

De AMvB waarnaar in de Wtb wordt verwezen, is de Btb. In artikel 2 $\mathrm{Btb}$ zijn de regels aan te treffen die vermelden aan welke eisen de vergunningsaanvrager moet voldoen. Deze eisen beslaan het terrein van de deskundigheid en betrouwbaarheid, de financiële waarborgen, de bedrijfswoering en de informatieverschaffing. Een voorbeeld van voornoemde regels is ook te vinden in artikel $3 \mathrm{Btb}$ :

\section{Artikel 3}

1. De beleggingsinstelling dient te beschikken aver eew eigen wermogen wan ten minste f500.000,

2. De bewadader dient te beschikken over een eigen vermogen wan ten minste $f 250.000,-137$

3. De bewaarder dient voldoende zekerbeid te stellen met het oog op de aansprakelijkbeid voor schade die voor de bewaarder kaw voortwloeien uit brand, verwoer van geld en watardepapieren, fraude en beroving.

Besluit d.d. 25 september 1990, Stb. 504.

Dat is ongeveer $€ 226.890,11$.

137 Omgerekend zou dar een bedrag van $€ 113.445,05$ inhouden. 
Bovenstaande criteria die de solvabiliteit en de liquiditeit van een instelling betreffen, dienen volgens het huidige functionele toezichtsmodel onder het prudentieel toezicht van DNB te vallen. Naast bepalingen die de criteria voor het verlenen van een vergunning bevatten, geven de artikelen 8 tot en met $10 \mathrm{Btb}$ regels die de uitvoerbaarheid van artikel 6 lid 5 Wtb beogen. Lid 5 van artikel 6 Wtb heeft betrekking op het bijzondere vergunningstelsel dat van toepassing is op bepaalde beleggingsinstellingen die eerst aan aanvullende vergunningseisen moeten voldoen voordat zij over de vereiste vergunning kunnen beschikken. Verder dienen de artikelen 11 tot en met 23, artikel 12 lid 2 Wtb te verduidelijken. Ook hier betreffen de eisen de beleggingsinstellingen die onder het bijzondere vergunningssysteem vallen en die aan extra eisen moeten voldoen alvorens zij een vergunning verleend kunnen krijgen. De vermelding in artikel $12 \mathrm{Wtb}$ dat deze instellingen zich moeten houden aan de wettelijke regels en doelstellingen van de Wtb, wordt nog eens nader ingevuld door de bepalingen van de artikelen 11 tot en met $23 \mathrm{Btb}$. Hierin vinden wij niet alleen nadere regels over de deskundigheid en betrouwbaarheid van onder meer personen die als bestuurder of bewaarder verbonden zijn aan beleggingsinstellingen, maar ook regels hoe de bedrijfsvoering van een dergelijke instelling eruit moet zien. Ook de artikelen 24 tot en met $45 \mathrm{Btb}$ hebben betrekking op artikel $12 \mathrm{Wtb}$. Zo zijn er in artikel 28 lid $1 \mathrm{Btb}$ regels te vinden die aangeven op welke wijze de hiervoor genoemde beleggingsinstellingen moeten beleggen.

\section{Artikel 28}

1. De gelden van de beleggingsinstelling dienen slechts in de wolgende soorten effecten te worden belegd:

a. andeelbewijzen, schuldbrieven, winst- en oprichtersbewijzen, warrants, en soortgelijke wardepapieren:

b. rechten wan delgenootschap, inschrijungen in aandelen-en schuldrgezester, en soortgelijke, al dan niet voorwadelijke, rechten: of

c. certificaten en recepissen van watrden als biervoor bedold.

Ook bepalingen met betrekking tot de oplegging van een bestuurlijke boete vinden wij terug in de Btb. Artikel 45a van het besluit geeft dat als volgt aan: 


\section{Artikel $45 a$}

1. Het bedrag wan de boete, bedoeld in artikel 33 , eerste lid wan de wet wordt bepaald op de wijze, voorzien in bijlage $C$.

2. De toezichthoudende autoriteit ${ }^{138}$ kan het bedrag wan de boete lager stellen dan in de bijlage is bepaald, indien bet bedrag van de boete in een bepald geval op grond wan bijondere omstandigheden onevenredig hoog is.

Het Btb eindigt met de slotbepalingen 46 en 47 die aangeven wanneer het besluit in werking treedt en hoe het aangehaald dient te worden.

Zoals is aangegeven moeten de actoren die zich in Nederland bewegen op het enorme terrein van het effectenverkeer zich niet alleen houden aan de regels van de Wte"95; de Wmz ${ }^{139}$ en de Witb, maar ook aan de uitwoeringsregels van voornoemde kaderwetten. Daarnaast moeten bepaalde spelers, afhankelijk van het feit of ze al dan niet beursgenoteerd zijn, zich ook houden aan de regels van de erkende effectenbeurzen. Welke regels dat zijn, zal hieronder worden besproken teneinde een zo volledig mogelijk beeld te kunnen vormen van de spelregels die her speelveld van deze actoren bepalen.

${ }^{138}$ In casu is dat DNB. Meer hierover in paragraaf 2.3.1 onder punt C.

139 In het kader van de uitvoering van de Wmz, is er het overdrachtsbesluit Wnz'96, besluit d.d. 14 mei 1997, Stb. 209, dat uitwoering geeft an artikel 11 van de Winz'96. In dat artikel wordt gesteld dat taken en bevoegdheden van de Minister van Financiën, kunnen worden overgedragen bij AMvB aan een rechtspersoon. Op grond van de artikelen $1 j^{\circ} 2$ van voornoemd besluit is bepaald dat deze rechtspersoon de STE is. Vandaag de dag zal de Autoriteit-FM het gedragstoezicht uitoefenen. Daar war het prudentiele zaken betreft, is DNB de bevoegde toezichthoudende instantie. In het besluit is woorts in arrikel 3 bepaald dat de toezichthouder regels mag stellen maar dat zij "de regels ten awzien wan de wijze waarop de samenstelling wan bet percentage, bedoeld in artitel 6 , erste lid, onder $c_{\text {n }}$ van de wet (Wmz: MJB), moet worden kexbaat gemaakt, woord alan Onze Minister" voorlegt. Voornoemd artikel $6 \mathrm{~W} / \mathrm{mz}$ geeft criteria aan hoe een melding dient te geschieden. In artikel 3 van het besluit wordt angegeven dat de toexichthouder een bepaald in artikel $6 \mathrm{Wmz}$ genoemd criterium, te weten de percentage aandelen in bet kapitaal en percenage stemmen dat op het geplatste kapital kan worden witgebnacht, watrover de meldingsplicht beschikt (vgl. artikel 6 lid 1 onder $\mathrm{C}$ Wmz), nader kan invullen. Verder geeft het beshuit aan dat de toezichthouder schriftelijke afspraken met buitenlandse autoriteiten kan en mag maken om wo uitwoering te gewen aan dat wat er in artikel $10 \mathrm{~W} / \mathrm{mz}$ is bepaald, te weten het samenwerken met andere staten om zo goed toezicht op de internationale financiële markten te beworderen. In het kader hiervan bevar lid 1 van laatstgenoemd artikel een geheimhoudingsverbod, waardoor de desbetreffende toezichthouder de verkregen informatie niet woor andere doeleinden kan gebruiken dan voor de toepassing van de W/mz. Let wel, in 


\subsubsection{Interne regelgeving; zelfregulering}

Naast de hiervoor behandelde externe regelgeving, is er binnen de effectenregelgeving nog een andere vorm van regelgeving die rechtstreeks van belang is voor bepaalde actoren binnen her effectenverkeer namelijk de interne regelgeving, ook wel de zelfregulering genoemd. Bij een bespreking van zelfregulering, kan niet aan de vraag worden ontkomen "waarom de zelfregulering nog nodig is?". Het antwoord op deze vraag luidt volgens Van Driel:

"De belangrijkste drijfveer van het bedrijfleven voor de vaststelling uan zelfregutering is eigenbelang. Andere motieven die een rol kunnen spelen zadls bet willen voorkomen wan overheidsregulering, het tegemoet komen aan de wensen van maatschappelijke groepen en het tonen van een sociaall gezicht zullen daarmee hoe dan ook in verband staan ${ }^{140}$

Uit het voorgaande is af te leiden dat er binnen de sfeer van het Nederlands effectenverkeer, steeds minder plaats voor zelfregulering is overgebleven en dat overheidsregulering steeds meer op de voorgrond is getreden. Dit roept de vraag op of het de beursactoren aan eigenbelang schort doordat zij geen zelfregulering, maar overheidsregulering voorstonden of zijn de beursactoren, in het bijzonder de effectenbeurshouders, ingehaald door de tijd en vereist de huidige technologie en vervaging van grenzen een nauwkeurige vorm van toezicht en een ruimere mate van verantwoordelijkheid dan wel van aansprakelijkheid? Opgemaakt zal kunnen worden dat het de beursactoren niet aan eigenbelang heeft

geval het gedragstoezicht betreft en de rechtsopvolger van de STE, de AutoriteitFM, met een buitenlands autoriteit schriftelijke afspraken wil maken, dient deze gedragstoezichthouder dit voornemen wel eerst voor te leggen aan de Minister wan Financièn. Pas na goedkeuring kan de Autoriteit-FM deze nakomen. Volgens artikel 3 onder $\mathrm{b}$ zal de goedkeuring "slechts worden onthouden indien naar het oordeel van Onze Minister de belangen die worden gediend door verdragen tot informatie-uitwisseling die het Koninkrijk met andere staten beeft gesloten, dan wel het algemeen belang zich tegen die affpraken verzetten;". In geval de toezichthouder de voornoemde afspraken voorlegt aan de Minister en deze nier binnen 30 dagen na ontvangst reageert, kan er volgens artikel 3 onder $d$ van bovengenoemd besluit van uit worden gegaan de goedkeuring is verleend. Naast het overdrachtsbesluit Wmz" 96 is er onder meer een regeling van de STE, d.d. 22 mei 1997, Stcrt. 98, dat uitvoering moet geven aan artikel $6 \rrbracket i d ~ l o n d e r d W / m z$ en artikel 3 onder a van het overdrachtsbesluit $W_{m z z}{ }^{\prime} 96$; de eerder genoemde percentages. Op grond van deze regeling heeft de STE een meldingsformulier ontwikkeld, die men in geval wan een melding verplicht is te gebruiken.

140 Driel, M. van, "Zelfregulering, hoog opspelen of thuisblijven", dissercatie RUU, Kluwer, Deventer, 1989, p. 9. 
geschort. Overheidsregulering was eerder een noodzaak, uit puur eigenbelang. Niet alleen de huidige technologie, zoals de computer, het internet en de razendsnelle schermenhandel, maar ook de deels hieraan inherente vervaging van de nationale landsgrenzen dwongen de beurzen er eigenlijk toe om de regulering grotendeels aan de overheid over te laten. Immers, zoals al vaak is opgemerkt, een goed gereguleerde beurs is en blijft aantrekkelijk voor (potentiële) beleggers. Alle "ballast" over boord gegooid hebbende, reguleerden de beurzen slechts de beursgerelateerde regels en hielden zij daar ook toezicht op, met het wakend oog van de STE op de achtergrond. Zoals hierboven is vermeld, stonden de beurzen ook onder het toezicht van de toenmalige toezichthoudende STE. Op grond van de Wte'92 en later de Wte'95 mochten de beurzen niet zonder erkenning het beursbedrijf uitoefenen. Voor het verkrijgen van een dergelijke erkenning dienden de beurzen zich te houden aan de wettelijke regels. Zo heeft de wetgever in de Wte'95 de bepaling opgenomen dat de effectenbeurzen regels moesten hebben opgesteld, waaraan zowel de beurs als de actoren op de beurs zich moesten houden. Hierdoor beoogde de wetgever te bewerkstelligen dat er

"een adequate functionering van effectenmarkten of de positie van de beleggers op die markten "kan plaatsuinden 941 .

14] Vgl. art. 22 lid 2 Wte'95. Dit sluit aan bij de checklist voor zelfregulering die door Van Driel is opgesteld. Volgens haar dienen opstellers van zelfregulering zich aan 6 punten te houden in geval van autonome zelfregulering of zoals hier het geval us: zelfregulering ter aanvulling van overheidsregulering. De zes punten op de checklist van Van Driel zijn: 1. De noodzakelijkheid zan zelfregulering en proportionaliteit. Dat wil zeggen dat alvorens er tot zelfregulering wordt overgegaan, dit grondig is overdacht en alle relevante punten zijn bekeken. 2. De natio van de regeling. Dat houdt in dat er voor elke vorm van zelfregulering een duidelijke doelstelling atnwezig moet zijn. 3. De coördinatie. Voorkomen moet worden dat in her geval er meerdere zelfreguleringsregels zijn, er verwarring en tegenstrijdigheid. kan ontstaan. 4. De inhoud. Hiermee geeft Van Driel aan dat de normen inhoudelijk duidelijk en goed te begrijpen moeten zijn. 5. De bandhaving en bestuwrlijke belasting. Het slagen van zelfregulering kan niet zonder een adequate sanctionering. Hicrtoe is het volgens $V_{\text {an }}$ Driel van belang dat de te reguleren normen vanzelfsprekend zijn en "leven" woor de geadresseerden. Verder dient het orgaan dar toezicht op de naleving van de regels zal houden, zijn taak zo goed mogelijk uit: kunnen voeren, met een zo min mogelijke belasting. Tot slot 6. De effecten en neveneffecten. Vanzelfsprekend zullen de regels getoetst moeten worden op hun doelmatigheid en op proportionaliteit, (Van Driel stelt letterlijk: "'een reäle verhowding tussen beoogde effecten en ongewenste neveneffecten". Verder dienen naast de individuele effecten ook de sociaal-economische effecten wan de regels meegenomen te worden. Driel, M. van, "Zelfregulering, boog opspelen of thuisblijven", dissertatie RUU, t.a.p. noot 140, p. 120 - 127. 
Het gevolg van een dergelijke regel is dat de grens voor zelfregulering door de wetgever was vastgesteld. De beurs kon worden afgerekend op ontoereikende interne regelgeving. Om dit te voorkomen zag en ziet zij vandaag de dag zelf streng toe op de naleving van haar beurseigen regels. Hierbij had en heefi zij de hulp van een speciaal daartoe ingesteld controleorgaan: het controlebureau.

De interne regelgeving, of de zelfregulering, zijn aldus de (spel)regels die een privaatrechtelijke instelling, - in dit geval de beurzen te Amsterdam - zichzelf hebben opgelegd en die alleen gelden voor de tot de beurzen toegelaten instellingen ${ }^{142}$. Dat de beurzen te Amsterdam door zelfregulering het interne toezicht uitoefenen is hiervoor besproken, maar hoever reikt deze vorm van toezicht? De reikwijdte van het toezicht op de naleving van de interne regelgeving is in de loop der jaren steeds beperkter geworden. Tijdens het bestaan van de Amsterdamse effectenbeurs (AEB) was er nog veel plaats voor zelfregulering. Ten tijde van Amsterdam Exchanges N.V. en Euronext Amsterdam, is er steeds minder plaats voor zelfregulering en steeds meer plaats voor overheidsregulering gereserveerd. De systematiek van dit onderzoek noopt tot het aanvangen met de bespreking van de interne regelgeving zoals dat na de herziening van de beursstructuur, sinds het begin van de jaren zeventig, is gehanteerd tot aan het ontstaan van Euronext Amsterdam. Tot slot zal de regelgeving van Amsterdam Exchanges N.V. en Euronext Amsterdam N.V. worden behandeld. Ter verduidelijking van de structuur van AEB, AEX N.V. en Euronext Amsterdam N.V., zal bij de behandeling daarvan een schematisch overzicht van de desbetreffende beurs worden gegeven.

\subsubsection{De interne regelgeving van de Amsterdamse effectenbeurs}

Gedurende het bestaan van de Amsterdamse effectenbeurs (AEB), was de benaming voor de toegelaten instellingen: "bedrijfsleden of beursleden ${ }^{143 "}$. Deze effectenbeurs werd door de privaatrechtelijke Vereniging

142. Cross, D.H., in: De opkomst wan een rechtsgebied, Lustrumbundel 1997 Vereniging voor Effectenrecht, Vennootschaps-en Rechtspersonenrecht, deel 58 uit de Serie monografieën vanwege her Van der Heijden-instituut te Nijmegen, Deventer, Kluwer, 1997, 33.

143 De ondernemingen die handelden op de beurs werden "bedrijfsleden" genoemd. Natuurlijke personen die verbonden waren aan de bedrijfsleden werden "individuele beursleden" genoemd. In paragraaf 1.4.4 wordt verder ingegann op het verschil tussen de beursleden en bedrijfsleden. 
voor de Effectenhandel ( $\mathrm{vdE}$ ) georganiseerd ${ }^{144}$. In figuur 2.1 is ter verduidelijking van de structuur van $A E B$ een organogram van deze beurs weèrgegeven. Zoals uit figuur $2.1 \mathrm{kan}$ worden opgemaakt bestond het bestuur van de VvdE uir de commissic van Gedelegeerden en de voorzitter. Het bestuur vertegenwoordigde alle categorieën van leden te weten: de hoeklieden, banken en commissionairs ${ }^{145}$ en werd bijgestaan door een soort "dagelijks bestuur" namelijk: de commissie van Gedelegeerden. In deze commissie zat niet alleen de voorzitter, maar zaten minimaal drie door het bestuur gekozen bestuursleden. In tegenstelling tot het bestuur, vergaderde de commissie van gedelegeerden vaker. $\mathrm{Zij}$ bereidde dan onder meer de zaken voor die door het volledige bestuur moesten worden behandeld ${ }^{146}$. Bij het ten uitwoer leggen van zijn taak kon de voorzitter worden bijgestaan door de algemeen secretaris en het hoofd operationele zaken en commissies van advies. In deze adviescommissies, welke door de bestuursleden waren gekozen, konden zowel beursleden als niet-beursleden zitting nemen. De algemeen secretaris werd op voordracht van de voorzitter door her bestuur ingesteld ${ }^{147}$ en had de leiding over het beleidsvoorbereidend en regelgevend bureau van de $V v d E$. Ook de direcrie van de $\mathrm{AEB}^{148}$ werd, op voordracht van het bestuur, door de voorzitter benoemd.

De directie die de dagelijkse leiding had over de $A E B$, bestond uit de directoraten beurszaken, operationele zaken en commerciële zaken. Besluiten werden met meerderheid van stemmen genomen. Indien de stemmen staakten, besliste de algemeen directeur. De algemeen directeur diende namens de directie verantwoording af te leggen aan het bestuur. Om de VvdE juridisch re binden ${ }^{149}$, waren in beginsel zowel de handtekeningen nodig van de voorzitter, de algemeen secretaris als van een directielid van de AEB of een handtekening van een van deze functionarissen tezamen met een bijzonder gevolmachtigde ${ }^{150}$. Tot slot had het bestuur tot taak te bepalen welke fondsen er in de officiële

Meer over de Vereniging voor de Effectenhandel in paragraaf 1.2 en verder.

Cross D.H. en Diephuis, J.H., "Amsterdanse effectenbeurs uit: de serie Bank-en Effectemrecht dl. 15", Kluwer B.V., Deventer, 1988, p. 20.

Artikel 21 lid 3 statuten VvdE en Cross, D.H. en Diephuis, J.H., "Amsterdamse effectenbeurs uit: de serie Bank-en Effectenrecht dl. 15", t.a.p. noot 145, p. 20.

Artikel 22 leden 1 en 2 statuten VvdE.

Arrikel 22 lid 3 statuten $V v d E$.

Artikel 23 statuten VvdE.

Artikel 23 lid 3 statuten VvdE. 
prijscourant ${ }^{151}$ mochten worden opgenomen. Zij bepaalde ook hoe de in het prijscourant te publiceren koersen moesten worden vastgesteld ${ }^{152}$.

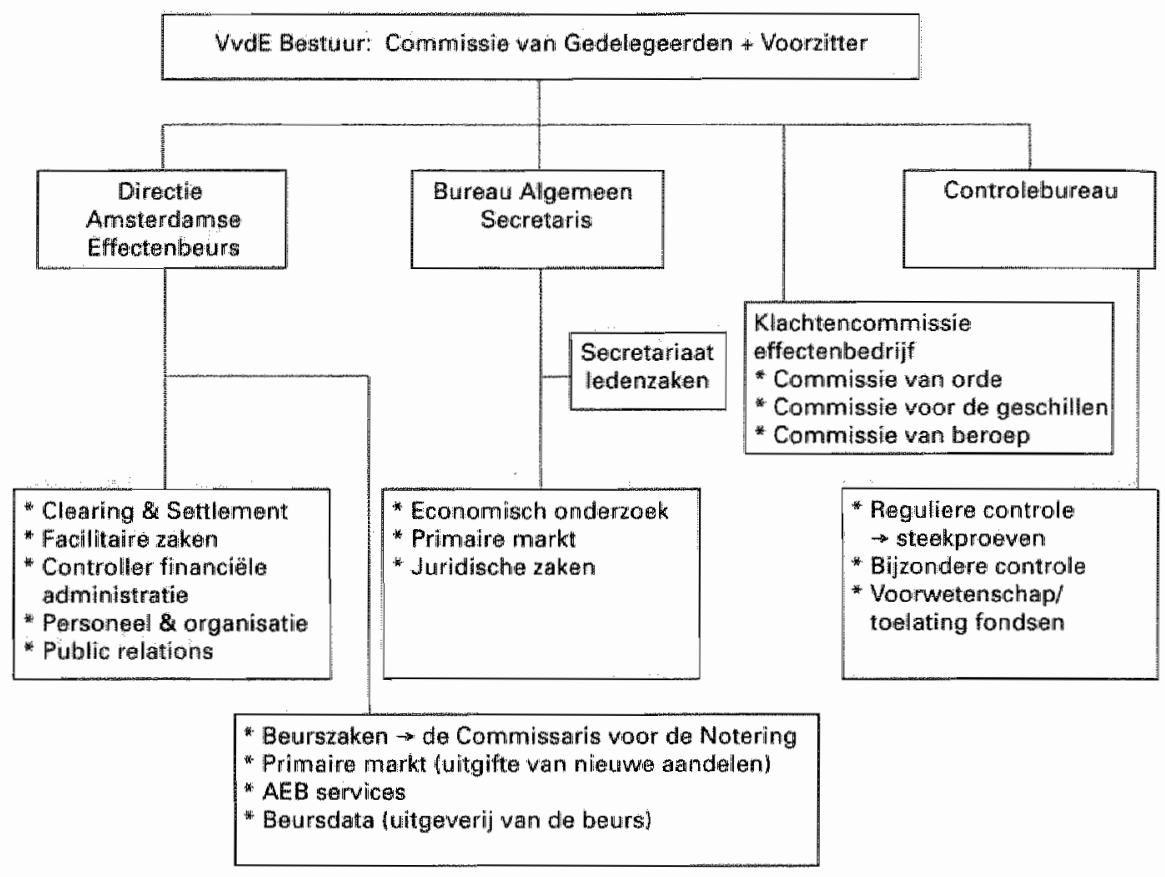

FIGUUR 2.1 Onganisaticstructuru Amsterdamse effectenbeurs (AEB)

De VvdE had volgens haar statuten tot doel:

".. het bevorderen van de belangen van de effectewhandel in de ruimste zin, daaronder begrepen de geldhandel, woor zover met de effectenhandel in verband stadnde." 153

151 De officiête prijscourant is een officiele publicatie van de VvdE (en vanaf 1 januari 1997 van AEX N.V.). In deze prijscourant zijn de officiële lijsten van de optiebeurs, de effectenbeurs en de financiële termijnmarkr Amsterdam verwerkt. Daarnaast zijn in de prijscourant ook de dagomzetten van aandelen en obligaties vermeld. Voorts bewat de officiële prijscourant ook berichten over de opneming, opschorting of de vervallenverklaring van fondsen. Verder worden in de prijscourant ook omrekeningskoersen, wisselkoersen, de rentestand van DNB en andere relevante gegevens vermeld. Pas nadar de commissaris voor de notering de prijscourant heeft ondertekend, mag dir de naam: "officiële prijscourant" dragen. De officiële prijscourant wordt op elke beursdag gepubliceerd. Amsterdamse effectenbeurs, Bewrs en effecten; de beurshandel en de vormen wan beleggen, uitgeverij Contact, Amsterdam/Antwerpen, 1993, p. 169-170.

153 Vereniging voor de Effectenhandel, swotwten, artikel 3. 
Ter verwezenlijking van haar doelstelling vermeldde artikel 4 wan de statuten van de $\mathrm{VvdE}$ dat zij ten gunste van de Nederlandse economie, voorwaarden mocht scheppen die er onder meer voor moesten zorgen dat de effectenmarkt in Nederland zich zou ontwikkelen ${ }^{154}$. In hetzelfde artikel had de $\mathrm{VvdE}$ tevens enkele verantwoordelijkheden aangegeven zoals het vaststellen en publiceren van koersen, het uitgeven van een prijscourant en het verschaffen van algemene en bijzondere voorlichting omtrent de effectenhandel in Nederland. Daarnaast was zij ook verantwoordelijk voor het vaststellen van de (handels-) voorschriften en reglementen; bepalingen betreffende het opnemen van fondsen en moest zij tevens toezien op de naleving hiervan. In haar statuten onderscheidde de VvdE haar leden in bedrijfsleden, buitengewone bedrijfsleden en beursleden. Daarnaast kenden de VvdE ook beursgemachtigden en beursemployes. Om als bedrijfs- of beurslid tor de VvdE toegelaten te kunnen worden, moest eerst aan de door de VvdE gestelde eisen worden voldaan. Deze toelatingseisen waren terug te vinden in de artikelen 6 en 7 van de statuten van de $V_{v d E}{ }^{155}$. In artikel 6 lid 4 van haar statuten had de VvdE de eisen aan het lidmaatschap van deze beursleden aange-

154 Arrikel 4 onder a: "het scheppen van de voorwaarden ter instandhouding en verdere ontwikkeling van een centrale effectenmarkt in Nederland ten bate vatn de nationale economie in het algemeen".

In artikel 6 lid 2 vermeldde de volgende toelatingseisen voor bedrijfsleden: a. vennootschappen en rechtspersonen, die onder eigen naam of onder firma als hoofdbedrijf resp. als belangrijke tak van bedrijf de commissiehandel in effecten uitoefenen of als handelaar de handel in effecten bedrijven woor eigen rekening. b. In een groep optredende rechtspersonen die - behoudens dispensatie van de commissie van Gedelegeerden - zowel gezamenlijk als ieder afzonderlijk als belangrijke tak van bedrijf de commissiehandel in effecten uitoefenen, in welk geval de topholding wan een zodanige groep wordt aangemerkx als "leidende" rechrspersoon en aldus als bedrijfslid. De commissie van gedelegeerden kan in dit verband onder "groep" mede verstaan een organisatorisch verbonden economische eenheid van rechtspersonen die onderdeel uitmaken van een grotere eenheid in welk geval de topholding van dat onderdeel wordt aangemerkt als "leidende" rechtspersoon. Onverlet het gegeven dat de "leidende" rechtspersoon wordt aangemerkt als bedrijfslid, dienen de in de groep optredende rechtspersonenafzonderiijk te voldoen aan de eisen gesteld in de staturen en reglementen van de Vereniging, als waren zij bedrijfsleden. (De commissie van Gedelegeerden bestond uit minimaal drie bestuursleden en een voorzitter. De voorzitter werd door het bestuwr uit zijn midden gekozen. Zie arrikel $21 \mathrm{VvdE}$ versie december 1995) 
geven $^{156}$. Behalve de voornoemde toelatingseisen had zij in haar statuten ook regels met betrekking tot de beëindiging van een lidmaatschap neergelegd. Deze regels waren te vinden in de artikelen 12 en verder van de statuten ${ }^{157}$. Het ledenreglement werkte de regels aangaande het lidmaatschap nader uit. Om lid van de $\mathrm{VvdE}$ te kunnen worden en het lidmaarschap te kunnen behouden, moesten de bedrijfs- en beursleden

Artikel 6 lid 4 van de Statuten VwdE met betrekking tot beursleden:

a. Natuurlijke personen, die optreden als beherende vennoten of bestuurders van bedrijfsleden en buitengewone bedrijfsleden.

b. Natuurlijke personen die door bedrijfsleden, als bedoeld in artikel 7, eerste lid, letter a en $b$ alsmede buitengewone bedrijfsleden als bedoeld in het derde lid van dit artikel met betrekking tot het beurslidmaatschap als plaatsvervangers conform artikel 8 , derde lid, onder 2 , voor hun beherende wennoren resp. bescuurders zijn aangewezen.

c. Natuurlijke personen die als bestuurders optreden van de "leidende" rechtspersoon, als bedoeld in het tweede lid wan dit artikel alsmede natuurlijke personen die door de "leidende" rechtspersoon als plaatsvervangers van hun bestuurders zijn aangewezen. Plaatswervangers dienen werkzaam te zijn bij de "leidende" rechtspersoon.

Zowel het (buitengewoon) bedrijfslidmaatschap als het beurslidmaatschap eindigden door dit schriftelijk aan her bestuur te melden. Het bestuur lichtte de overige ledem hiervan in. In de officiële prijscourant werd vervolgens, onder vermelding van de desbetreffende teden, een bericht van opzegging geplaatst. Enkele redenen voor opzegging konden volgens de artikelen $12 j^{\circ} 16$ van de statuten zijn:

Her niet krijgen van de benodigde vergunning, zoals is vermeld in de W/te '95; het intrekken wan de hierboven genoemde vergunning en of het verstrekken van onjuiste of onvolledige gegevens en/of bescheiden waardoor er anders op de lidmaatschapsaanvwaag of op het vergunningsverzoek was beslist dan wanneer er correcte gegevens waren verstrekt. Bij vennootschappen en rechtspersonen kon het bedrijfshidmaatschap volgens artikel 14 van de statuten worden beëindigd: indien er sprake was van ontbinding; indien de in Nederland gevestigde beherende wennoren of bescuurders geen beutslid meer waren en ook niet voor vervanging hadden zorg gedragen dan wel indien een in Nederland gevestigde vennoot niet het beurslidmaatschap bezat en daartoe ook geen aanvraag had ingediend dan wel deze vennoot geen plaatsvervanger had die wel het beurslidmaatschap bezat. Het lidmaatschap van een buitengewoon bedrijfslid eindigde volgens hetzelfde artikel indien: her lid volgens de wetgeving van het land wan westiging niet meer bestond; er minder dan twee beherende vennoten of bestuurders waren; her lid niet langer meer kantoor hield in het land van vestiging. Buj beursleden gaf artikel 15 van de statuten te kennen dat her lidmaatschap eindigde indien: - zij de leefrijdsgrens hadden beraikt zoals was bepaald in het ledenreglement; zij overleden; zij niet meer handelingsbevoegd waren; zij geen binding meer hadden met het desberreffende (buitengewone) bedrijfslid of indien het bedrijfslidmaatschap was beẹindigd. 
aan de statutaire eisen (blijven) voldoen. Deze in de statuten genoemde eisen, die zich richtten op de deskundigheid, de betrouwbaarheid, de financiële waarborgen en de onafhankelijkheid van de leden, werden in het ledenreglement nader uitgewerkt ${ }^{158}$. Naast de statutaire eisen, werden er in het ledenreglement ook nog aanvullende eisen gesteld. Artikel 6 lid 6 van de statuten bevatte een verwijzing naar deze eisen. Tot slot duidde lid 7 van dit artikel aan dat buitengewone bedrijfsleden, gezien hun bijzondere status, aan speciale regelingen konden worden gebonden. Tot de bedriigssleden konden behoren ${ }^{159}$ :

1. de (spaar)banken (mits de bank zich voornamelijk bezig bield met de bandel in effecter.):

2. de commissionatr effectenkredietinstelling ${ }^{160}$;

3. de commissionairs effectenhandelaren ${ }^{16 I}$;

4. de hoekmannen ${ }^{162}$;

5. de interdealer-brokers 163 en tot slot

6. de daghandeladiffoorbraker 164 .

Artikel 6 lid 5 staturen VvdE, december"95.

De nummers 1 en 2 moesten ingeschreven staan in een van de registers gehouden door de DNB.

Hiermee worden de commissionairs/effectenkredietinstelling bedoeld die waren ingeschreven in een door de DNB gehouden register. Tot deze groep behoorden: de commissionair die de commissichandel in effecten als hoofdbedrif uitoefende en de ingeschreven effectenhandelaren die voor eigen rekening handelden.

Onder deze groep vielen de niet-ingeschreven commissionairs die wel als hoofdbedrijf de commissiehandel in effecten uitoefenden. Hetzelfde gold voor de effectenhandelaar omdat hij handelde voor eigen rekening.

Hokmannen kunnen of uitsluitend voor rekening van bedrijfsleden de commissiehandel in effecten uitoefenen of woor eigen rekening handelen in effecten.

Een Interdealer-broker is een instelling die uitsluitend voot rekening van (buitengewone) bedriffsleden de handel in effecten bedrijf. Alle transacties voor de (buirengewone) bedryjfleden die zouden kunnen leiden tot een eigen positie van de Interdealer-broker, zijn uitgesloten wan de effecrenhandel. Vgl. artikel 8 richtijn met betreklking tot de administratieve organisaties en interne controle als bedoeld in artikel $5 . \mathrm{C}$, onder 2 van het ledenreglement.

Floorbrokers zijn óf onafhankelijk óf in dienst van een bank/commissionair. Een. daghandelaar of floorbroker is een instelling die uitsluitend als handelatar in effecten handelt. Dit hoeft niet alleen voor eigen rekening van de handelaar te geschieden. Het is ook mogelijk dat de daghandelaar/floorbroker de commissiehandel in effecten uirshuitend met en woor rekening van bedrijfleden un̈toefent. Vgl. artikel 8 richtlijn mer betrekking tot de administratieve organisaries en interne controle als bedoeld in artikel 5.C., onder 2 van het ledenreglement. 
Naast de opzegging of een vervallen verklaring van het lidmaatschap, kon een lid ook worden geschorst ${ }^{165}$. Tussen de voornoemde bedrijfsleden had de VvdE een nader onderscheid gemaakt. Deze leden werden onderverdeeld in
a) bedrijfleden die bandelden op de beursen toegang hadden tot de geveglementeerde handelssystemen;
b) bedrijfileden die niet op de beurs bandelden en geen toegang badden tot de gereglementeerde bandalsystemen en
c) de hoekmansbedrijuen.

De bedrijfsleden mochten en konden slechts behoren tot de hierboven genoemde categorieën. In de statuten waren meerdere regels omtrent de leden van de VvdE te vinden zoals bijvoorbeeld de eis van een meerhoofdige leiding; de bedrijfsleden dienden namelijk ten minste twee beherende vennoten of bestuurders te hebben ${ }^{166}$. Van deze twee beherende vennoten of bestuurders diende er minstens een in Nederland te zijn gevestigd ${ }^{167}$. Ook de statutaire zetel en het hoofdkantoor dienden zich in Nederland te bevinden.

Eerder kwam het ledenreglement al aan de orde. Zo is hierboven vermeld dat de in de statuten genoemde regels aangaande het lidmaatschap in dit reglement werden uitgewerkt. Daarnaast bevatte het ledenreglement ook regels aangaande de financiële waarborgen van de bedrijfsleden ${ }^{168}$, en het onaflankelijkheidsvereiste van de (buitengewone) bedrijfsleden ${ }^{169}$. Voorts bevatte het ledenreglement ook een regeling ter voorkoming van misbruik van voorwetenschap. Op grond van deze regeling diende:

\footnotetext{
ths Artikel 14-A staruten VudE.

1.66 Cross, D.H. en Diephuis, J.H.,"Amsterdamse effectenbeurs wit: de serie Bank-en Effectenrecht d. 15", t.a.p. noot 145, p. 6-7. In het ledenreglement werd over de eis van tweehoofdige leiding gesproken. Zie arrikel 2 lid 3 ledenreglement VvdE september 1994.

Het bestuur kon dispensatie verlenen. Zie statuten VvdE artikel 8 lid 2.1 sub b.ii. Artikel 3 ledenreglement $1994 \mathrm{VvdE}$.

69. Het onafhankelijkheidsvereiste hield, naar aanleiding wan de zogenaamde "Onafhankelijkheidsrichtlijn", in dat van (buitengewone) bedrijfsleden een onafhankelijke posicie werd gewenst.
} 
... bet bedrifflid (.) ten aanzien van bet omgatan met wertrowwelijke koergevwelige informatie een adequate interme regeling te banteren woor de vertrowwelijke bebandeling van die informatie en op de naleving van die regeling toe te wien. Onder vertrowuelijke koersgevoelige informatie werd verstaan een niet openbatr gegeven, indien wan bet openbaar worden van dat gegeven een aanmerkelijke inwloed op de koers wan de desbetreffende soorten effecten redelijkerwijs was te verwachon ${ }^{170}$.

Om (de schijn van) misbruik van voorwetenschap te voorkomen lag de verantwoordelijkheid om passende maatregelen te treffen bij het bedrijfslid. Vertrouwelijke koersgevoelige informatie tussen het krediet-, de emissie- en het effectenbemiddelingbedrijf moest gescheiden worden behandeld ${ }^{171}$. Daarnaast mocht een lid niet, direct of indirect, voor eigen rekening handelen in effecten waarvan hij wist dat hij over vertrouwelijke en koersgevoelige informatie beschikte. Noch zou hij aansporen om in de hiervoor genoemde effecten wel of niet te handelen. Deze verboden golden ook voor de commissarissen van de bedrijfsleden ${ }^{172}$. Verder was er in het ledenreglement een diversiteit aan richtlijnen te vinden. Te beginnen met de richtlijn over de vermogensbeheerovereenkomst $^{173}$. Deze richtlijn bepaalde wat er in een vermogensbeheerovereenkomst moest zijn opgenomen. Hier diende men te denken aan de personalia van de cliënt en het bedrijfslid. Tevens moest er nauwkeurig aangegeven worden welke diensten het bedrijfslid voor de cliënt zou verrichten. Het bureau van de Vereniging beschikte over een model vermogensbeheerovereenkomst dat aan de genoemde criteria voldeed ${ }^{174}$. Een volgende richtlijn was de "richtlijn met betrekking tot de administratieve organisatie en interne controle ${ }^{175 "}$. De grote risico's die met de effectenhandel gepaard kunnen gaan", aldus artikel 1 van voornoemde richtlijn vormden voor het bestuur de aanleiding om hoge eisen aan de administratieve organisatie en interne controle van de bedrijfsleden te stellen ${ }^{176}$. Het doel van deze richtlijn was om voorwaarden op te stellen, waaraan de inrichring van de organisaties van de verschillende leden

Artikel 10 sub a ledenreglement.

Artikel 10 sub b ledenreglement.

Arrikelen 11 en 12 ledenreglement.

Als bedoeld in artikel 5.B. onder 2.4 van het ledenreglement en vastgesteld in de bestuursvergadering d.d. 7 april 1994.

Artikel 2 van de richtlijn ter zake van de vermogensbeheerovereenkomst.

Als is bedoeld in artikel 5 .C. onder 2 van het ledenreglement en vastgesteld in de besturursvergadering d.d. 4 mei 1995.

Artikel I richtlijn met betrekking tot de administratieve organisatie en interne controle als bedoeld in artikel 5.C, onder 2 van het ledenreglement. 
moest voldoen, zodat de aan de effectenhandel inherente risico's werden geminimaliseerd. Met de in de richtlijn aangehaalde term "administratieve organisatie", ook wel bestuurlijke informatieverzorging genoemd, werden alle maatregelen bedoeld gericht op het systematisch verzamelen, vastleggen en verwerken van gegevens. Deze maatregelen waren niet alleen gericht op de informatieverstrekking voor het kunnen besturen, functioneren en beheersen van de huishouding van het bedrijfs.lid, maar ook voor de verantwoordingen die hierover moesten worden afgelegd. Met de term "interne controle" werd bedoeld: de controle op het handelen van anderen, uitgeoefend door of namens de directie van het bedrijfslid. Tijdens deze onderzoeken stonden de oordeelsworming en activiteiten van de gecontroleerde personen centraal ${ }^{177}$. Bij de interne controle was het van belang dar de aard van het bedrijf een dergelijke vorm van controle vereiste. Aan de leden van de VvdE werden voorwaarden gesteld aangaande de administratieve organisatie en de interne controle. Deze voorwaarden verschilden per ledencategorie, te weten de categorieën banken en effectenkredietinstellingen (EKI ${ }^{178}$ ); de categorie niet-effecten kredietinstellingen (NEKI ${ }^{179}$ ); de categorie hoekmansbedrijven ${ }^{180}$,

177 Artikel 4 richtlijn mer betrekking tot de administratieve organisaties en interne controle als bedoeld in arrikel 5.C., onder 2 van het ledenreglement.

178 Een. EKI was ten rijde van de VvdE een commissionair die als hoofdbedrijf de commissiehandel in effecten uitoefende en/of als handelaar voor eigen rekening handelde in effecten. Daarnaast was vereist dat het bedrijf moest staan ingeschreven in het door De Nederlandsche Bank N.V. gehouden register zoals aangegeven in de Wet Toezicht Kredietwezen 1992. Indien het cen buitenlands bedriff betrof mocht het ook zijn ingeschreven in de registers van een vergelijkbare buitenlandse autoriteit. Artikel 6 richtijn mer betrekking tot de administratieve organisaties en interne controle als bedoeld in artikel 5.C., onder 2 van het ledenreglement.

79 Een NEKI was ren rijde van de VvdE cen commissionair die als hoofdbedrijf de commissichandel in effecten vitoefende en/of als handelaar voor eigen rekening handelde in effecren. Omdat de NEKI geen krediet(verlenende) instelling was, werd in regenstelling tot de EKI niet vereist dat het bedrajf moest zijn ingeschreven in het register van De Nederlandsche Bank N.V.Artikel 7 richtlijn met betrekking tot de administratieve organisaties en interne controle als is bedoeld in artikel 5.C., onder 2 van het ledenreglement.

180 Een hoekmansbedrijf was ten tijde van de VvdE een instelling die de commissichandel in effecten uirsluitend voor rekening van bedrijfsleden uitoefende. Her was ook mogelijk her ook voor leden van andere erkende beurzen handelde, maar dan alleen na aanwijzing van het bestuur. Daarnaast mochten hoekmansbedrijven ook voor eigen rekening handelen in effecten. Vgl. artikel 8 richrlijn mer betrekking tot de administratieve organisaties en interne controle als bedoeld in artikel 5.C., onder 2 van het ledenreglement. 
interdealer-broker ${ }^{181}$ en daghandelaar/ floorbroker ${ }^{182}$. Deze categorieën dienden aan de voorwaarden, zoals was vermeld in deze richtlijn, te voldoen. Ter verduidelijking van het begrip "eigen vermogen" had het bestuur de richtlijn eigen vermogen vastgesteld ${ }^{183}$. In het ledenreglement was ook "de onafhankelijkheidsrichtlijn ${ }^{184 " ~ o p g e n o m e n . ~ V o l g e n s ~ a r t i k e l ~}$ 4 van dit reglement was het gewenst dat (buitengewone) bedrijfsleden in de uitoefening van hun funcrie onafhankelijk waren. De mate van onafhankelijkheid werd door het bestuur of de commissie van gedelegeerden ${ }^{185}$ bepaald. Hiertoe waren zij bevoegd om een (buitengewoon) bedrijfslid te toetsen aan de hand van ingewonnen informatie ${ }^{186}$. Tot slot bevatte het ledenreglement ook een richtlijn waarin de solvabiliteitsvereisten waren uitgewerkt. De solvabiliteitsrichtlijn $\mathrm{CAD}^{187}$, welke naar haar Europese voorbeeld de "Capital Adequacy Directive ${ }^{188 "}$ was genoemd, diende ter verduidelijking van artikel 3 lid 5 van het ledenreglement. Dit artikel luidde als volgt:

\section{Artikel 3}

5. Met betrekking tot de financielle waarborgen, als bedoeld in artikel 6 , vijfle lid wan de statuten, stelt bet bestuw woorts regels vast omtrent de solvabiliteitsnormen. welke bedrijsleden in acht dienen te nemen (zie bijlage 3. wijfde lid, bij dit Reglement).

Een Interdealer-broker was destijds een instelling die uitsluitend woor rekening van (buitengewone) bedriffleden de handel in effecten bedreef. Alle transacties voor de (buitengewone) bedriffleden die zouden kunnen leiden tot een eigen positie wan de Interdealer-broker, waren witgesloten van de effectenhandel. Vgl. artikel 8 richtijn met betrekking tot de administratieve organisatives en interne controle als bedoeld in artikel 5.C., onder 2 van het ledenreglement.

Een daghandelaar of floorbroker was toentertijd een instelling die uitsluitend als handelaar in effecten handelde. Dit hoefde niet alleen voor eigen rekening van de handelaar te geschieden. Het was ook mogelijk dat de daghandelaar/floorbroker de commissiehandel in effecten uirstuitend met en voor rekening van bedrijsleden uitoefende. Vgl. artikel 8 richtlijn met betrekking tot de administratieve organisaties en incerne controle als bedoeld in artikel 5.C., onder 2 van het ledenreglement.

13. Vastgesteld in de bestuursvergadering d.d. 7 december 1995.

184 Vastgesteld in de bestuursvergadering d.d. 7 juli 1994 en gewijzigd in do bestuursvergadering d.d. 7 september 1995.

185 Deze commissie kan beschouwd worden als "her dagelijks bestuur" van de VwdE.

186. Vgl artikel 2.1.1 richdijn wan het bestuur ter zake van het vereiste van onafhankelijkheid (de onathankelijkheids-richtlijn)

187 Vastgesteld in de bestuursvergadering d.d. 7 december 1995.

188 Richtlijn 93/6//EEG van de Europese Raad d.d. 15 maart 1993. Meer hierover in hoofdstuk 2.1 de externe regelgeving. 
Op grond van de externe regelgeving, de Wte"95 en richtlijn $\mathrm{CAD}$, moesten de bedrijfsleden doorlopend over voldoende vermogen beschikken om zodoende hun risico's te kunnen dekken. Het vermogen moest minstens gelijk zijn aan de som van de uitstaande risico's. Bepaalde bedrijfsleden waren verplicht om conform de richtlijn $\mathrm{CAD}$ maandelijks aan het controlebureau ${ }^{189}$ te rapporteren ${ }^{190}$. Naast een diversiteit aan richtlijnen, was er in het ledenreglement ook een bepaling aan de commissaris voor de notering gewijd. In dit reglement werd bepaald dat de commissaris voor de notering, die onder andere de orde op de beursvloer moest handhaven, kon vaststellen dat een beurslid of beursgemachtigde zich op de beursvloer misdroeg. Dit kon tot gevolg hebben dat het desbetreffend lid een waarschuwing kreeg. Mocht deze waarschuwing niet tot het gewenste resultaat hebben geleid, dan kon de commissaris voor de notering een boete opleggen. Het lid diende deze boete meteen te voldoen. Zolang het desbetreffende lid de boete nog niet had betaald, mocht de commissaris hem de toegang tot de beurswloer weigeren ${ }^{191}$. In het reglement voor de notering waren de taken en bevoegdheden van de commissaris voor de notering nader uitgewerkt. Een andere uitwerking van de Wte' 95 is de instelling van een klachtenbureau. Zoals we eerder zagen diende de effectenbeurs zich bij een beurserkenning te houden aan de externe regels. Hiermee beoogde de wetgever te bewerkstelligen dat er "een adequate functionering van effectenmarkten of de positie van de beleggers op die markten" kon plaatsvinden. Tegen deze achtergrond werd een klachteninstantie onontbeerlijk. Immers, aan gedupeerde beleggers werd zo de mogelijkheid geboden om hun klachten bij de beurs bekend te maken en eventueel genoegdoening te krijgen. Om de belegger daadwerkelijk te beschermen tegen onheuse behandeling van een lid besloot de VvdE een instelling op te richten die woor beide partijen bindend kon beslissen ${ }^{192}$. In 1983 werd de klachtencommissie effectenbedrijf $\mathrm{f}^{193}$ in het leven geroepen ${ }^{194}$. Vanaf dat moment werd het

189. Het controlebureau hield toezicht op de naleving van de regels die golden voor de leden van de beurs.

19. Artikel 2 van de richtlijn CAD.

191 Artikel 16 ledenreglement.

192 Arrikel 35 statuten VwdE en artikel 5 lid 2 reglement klachtencommissie effectenbedrijf.

193 Artikel 35 statuten j 4 lid 1 reglement klachtencommissie effectenbedrijf 1993.

19. Cross, D.H. en Diephuis, J.H., "Amsterdansie effectenbeurs wit: de serie Bank-en Effectenrecht dl. 15", t.a.p. noot 145, p. 63. 
voor direct belanghebbenden ${ }^{195}$ mogelijk om een klacht tegen een lid van de VvdE in te dienen. In het reglement klachtencommissie waren de bepalingen over de samenstelling, benoeming en werkwijze van de klachtencommissie te vinden ${ }^{196}$. Om een klacht te kunnen indienen moest de klager volgens artikel 4 lid 1 van het reglement klachtencommissie effectenbedrijf "door een handelen of nalaten van een bedrijfslid, een beurslid of een remisier als zodanig direct in zijn belang ${ }^{197}$ zijn getroffen ${ }^{198^{* 1}}$. Een andere commissie waar naast belanghebbenden, ook leden mochten klagen was de commissie van orde. Deze commissie fungeerde als intern tuchtrechtelijk college van de $\mathrm{VvdE}^{199}$. Alleen de commissie van gedelegeerden kon een klacht tegen een lid bij de commissie van orde indienen ${ }^{200}$. Her was ook mogelijk dat de commissie van orde voorwaarden stelde alvorens zij overging tot de indiening van

195 Vak waren dit cliënten van de bedrijfsleden en beursleden. Zie Cross, D.H. en Diephuis, J.H., "Amsterdamse effectenbeurs wit: de serie Bank- en Effectenrecht dl. $15^{\prime \prime}$, t.a.p. noot 145, p. 25.

De blachtencommissie bestond uit minstens wijf personen, te weren de voorzitter, de plaatswervangend voorzitter en drie leden. Vgl. artikel 2 lid 1 reglement klachtencommissie effectenbedrijf. Op woordracht van het bestuur werden de leden van de klachtencommissie, door de president van de arrondissementsrechtbank te Amsterdam, voor een periode van drie jaren benoemd. Zile artikel 2 leden 5 en 6 reglement klachtencommissie effectenbedrijf. Indien men zeventig jaar of ouder was, kon men niet worden (her)benoemd. Vgl. Artikel 2 lid 7 reglement klachtencommissie effectenbedrijf.

Artikel 4 lid 1 reglement klachtencommissic effectenbedrijl.

Vgl, artikel 7 reglement klachtencommissie effectenbedrijf. Voorts diende het indienen van een klacht schriftelijk te gebeuren. Een ingediende klacht had niet altijd een bindend advies tot gevolg. De klachtencommissie kon beslluiten om een klachr niet in behandeling te nemen. In dat geval stelde zij de partijen op de hoogte van de gronden voor her niet ontwankelijkheid zijn wan de klacht. Deze gronden waren: dat de belangen die met de klacht waren gemoeid te weinig betekenis hadden; dar de periode, tussen het kennisnemen wan de feiten en het woorleggen van de klacht aan de beklaagde, meer dan een jaar was; dat de feiten waar de klacht op was gebaseerd te ver in het verleden lagen en dat de klager niet aanvaardde dat de uitspraak van de klachtencommissie als bindend advies moest worden beschouwd. Vgl. artikel 7 lid 5 reglement klachtencommissie effectenbedrijf. Arrikel 7 lid 5 reglement klachtencommissie effectenbedrijf.

De commissie van orde werd voorgezeten door bestuursleden die niet tegelijkertijd in de commissie van gedelegeerden mochten zirten. Vgl, artikel 2 reglement van orde $\mathbb{1} 993$.

De uitspraken van de commissie wan orde zouden dan niet onder de schijn van partijdigheid uit kunnen komen. Dit zou het naleven van de uitspraken bemoeilijken. 
de klacht. Op deze wijze kon de beklaagde alsnog aan de voorwaarden voldoen ${ }^{201}$. Dit had tot gevolg dat de klacht niet meer bij de commissie van orde mocht worden ingediend ${ }^{202}$. Mocht de commissie na een hoorzitring tot het oordeel komen dat er een straf diende te worden opgelegd, kon zij tegen het beklaagde lid een waarschuwing uit laten gaan, het lid berispen, een boete van maximaal $f 500.000$,- opleggen (vandaag de dag zou dat neerkomen op een bedrag van $€ 226.890,11)^{203}$ dan wel het lid schorsen voor de periode van maximaal vijf maanden of ontzetting uir het lidmaatschap. Een commissie waar geen externe belanghebbenden, maar alleen leden toegang tot hadden was de commissie voor de geschillen. Als niet anders was overeengekomen hadden de leden de verplichting om in geval van onderlinge geschillen betreffende de effectenhandel die niet in onderling overleg konden worden opgelost ${ }^{204}$, de commissie voor de geschillen te raadplegen. Het was niet toegestaan om her geschil aan de rechter voor te leggen ${ }^{205}$. De taken en samenstelling van de commissie voor de geschillen werden in het geschillenreglement vermeld. Een bij de commissie van orde ingediende klacht werd vervolgens door vijf commissieleden behandeld ${ }^{206}$. Het was mogelijk om tegen een beslissing van de commissie voor de geschillen in beroep te gaan. Dit gebeurde bij de commissie van beroep. Indien men niet binnen tien beursdagen na kennisgeving van de beslissing in beroep ging, kreeg de beslissing tussen partijen de kracht van bindend advies ${ }^{207}$.

De vootwaarden die de commilssie van gedelegeerden konden stellen en die in artikel 4.1 lid 2 van het reglement van orde werden genoemd zijn:

a. Betaling aan de Vereniging voor de Effectenhandel van een geldsom van geval tot geval door de commissie van gedelegeerden te bepalen met inachtneming van een doot het bestuur woor dir doel algemeen vast te stellen en te wijzigen maximum; b. Gehele of gedeeltelijke vergoeding wan de door het geincrimineerde doen of nalaten veroorzaakte schade;

c. Berusten in cen waarschuwing.

Artikel 4.a. lid 1 reglement van orde.

De schorsing kon vergezeld gaan van een boete tot maximaal $f$ 500.000,- of $€ 226.890,11$. Artikel 9 lid 1 reglement van orde.

Volgens Cross kwam de commissie woor de geschillen niet vaak bijeen omdat het merendeel van de geschillen wel in onderlinge overleg kon worden opgelost. Cross, D.H. en Diephuis, J.H., "Amsiterdamse effectenbeurs uit: de serie Bank-en Effectenrecbed. $15^{\prime \prime}$, ta.p. noot 145 , p. 24.

Artikel 35 lid 1 statuten VvdE.

Artikel 2 lid 2 geschillenreglement.

Artikel 11 geschillenreglement. Volgens Cross duurde de beroepstermijn 10 beursdagen. Zie Cross, D.H. en Diephuis, J.H., "Amsterdamse effectenbeurs wit: de serie Bank-en Effectenrecht dl. 15", t.a.p. noot 145, p. 24. 
Voornoemde commissie van beroep was de hoogste interne beroepsinstantie van de Amsterdamse Effectenbeurs. De commissie van beroep behandelde in laatste instantie niet alleen het beroep in lidmaatschapsaangelegenheden ${ }^{208}$ en het beroep in geschillen ${ }^{209}$, maar ook het beroep in ordezaken ${ }^{210}$ en het beroep inzake stille curatele ${ }^{211}$. In het reglement van beroep werden de taken en bevoegdheden van de commissie geregeld $^{212}$.

Controle en naleoing van de interne regels

Het controlebureau ${ }^{213}$, beter bekend als de "waakhond" van de VvdE, werd in 1973 opgericht. Dit bureau zag erop toe dat alle leden zich aan de regels van de $\mathrm{V} v \mathrm{dE}$ hielden. In het controlereglement werden de samenstelling, taak en bevoegdheden van het controlebureau geregeld. Volgens dit reglement diende het hoofd van het controlebureau een registeraccountant $\mathrm{t}^{214} \mathrm{zijn}$. Deze stond direct onder de voorzitter van de $\mathrm{VvdE}^{215}$. Zowel het hoofd van het controlebureau als de overige medewerkers van het controlebureau hadden een geheimhoudingsplicht. In artikel 3 lid 4 van het controlereglement was dit als volgt verwoord:

\section{Artikel 3}

Het hoofd van het controlebureaw en al zijn medewerkers zijn verplicht tot geheimhouding van datgene, wat in hun functie angiande bedriffleden enlof beursleden en cliëntern van bedrijfleden te hunner kennis komt. Hiervan is uitgezonderd bet doen van mededelingen, watrtoe zij krachtens dit reglement, de statuten en het Reglement van Beroep verplicht zijn. Gelijke geheimhoudingsplicht geldt woor de deskundigen, als bedoeld in artikel 4 .

Zie de artikelen 4 tot en met 8 wan het reglement van beroep.

Zie de artikelen 9 tot en met 16 wan het reglement van beroep.

Zie de artikelen 17 tot en met 24 van het reglement van beroep.

Zie de arrikelen 25 tot en met 30 van het reglement van beroep.

Artikel 35 statuten VwdE.

Artikel 24 statuten $\mathrm{VwdE}$.

Cross, D.H. en Diephuis, J.H., "Amsterdamse effectenbeurs wit; de serie Bank-ext Effectenrecht dl. $15^{\prime \prime}$, t.a.p. noor 145, p. 20.

Artikel 3 lid 1 controlereglement 1991. 
Door het instellen van onderzoeken en het inwinnen van inlichtingen ${ }^{216}$ kon het controlebureau niet alleen de zaken van een bepaald bedrijfslid en bepaalde acriviteiten van alle bedrijfsleden beoordelen, maar kon het ook nagaan of de bedrijfsleden (nog) voldeden aan de vastgestelde voorschriften voor onder andere het eigen vermogen, de liquiditeit en de solvabiliteit ${ }^{217}$. Indien de leden de gevraagde inlichtingen te laat verstrekten of zelfs weigerden te verstrekken, was de voorzitter van de VvdE bevoegd om een boete ${ }^{218}$ op te leggen. Hij kon zelfs besluiten om de namen van de weigeraars te publiceren ${ }^{219}$. Een aspirant-lid kwam reeds bij de indiening van de (buitengewone) bedrijfslidmaatschapsaanvraag, in contact met het controlebureau. In artikel 6 sub f van het ledenreglement was bepaald dat het toekomstig lid tegelijkertijd met het indienen van de lidmaatschapsaanvraag onder meer een verklaring moest indienen waarin stond dat de aanvrager over voldoende financiële waarborgen, of eigen vermogen ${ }^{220}$, beschikte en hij in de uitoefening van zijn bemiddelende functie onafhankelijk kon zijn ${ }^{221}$. Deze verklaringen konden alleen door het controlebureau worden afgegeven ${ }^{222}$. Naast het afgeven van de hiervoor genoemde verklaringen, werden de bedrijfsleden door het controlebureau ook gecontroleerd op het afgeven van juiste verklaringen. Indien nodig, kon het controlebureau ook bepaalde vennootschapscontracten inzien ${ }^{223}$. Het controlebureau mocht een onderzoek instellen dat op verzoek van de STE of van de voorzitter plaats vond en, zowel gericht kon zijn op de algemene gang zaken in relatie tot een lid, als op bepaalde activiteiten van de leden. Het controlebureau

216 Thlichtingen konden mondeling en/of schriftelijk worden ingewonnen. Onder het inwinnen van inlichtingen werd ook begrepen: het door leden moeten inleveren van periodieke gegevens bij het controlebureau. Vgl. artikel 6 leden 1 en 2 van het controlereglement.

217 Artikel 5 controlereglement.

218 Het bestuur van de VvdE bepaalde het maximum van de op te leggen boete. Vgl. artikel 7 lid 2 controlereglement.

26. Artikel 7 controlereglement.

220 Artikel 3 ledenreglement 1996.

224 Artikel 4 leden reglement.

222. Artikel 5 lid 2 controlereglement.

223. Het soort vennootschapscontract dat hier wordt bedoeld is: "een verklaring watarbij de anumger van bet bedrifflidmaatschap respectievelijk buitengewoon bedrijfintmaatshap zich verplicht zijw vestigingen in Nederland of de met bem administratief gelievde instellingen, waarover bij bet roezicht uitoefent, de reglewenten en ardere woorschriften wan de Vereniging te doen wakomen," Vgl. de artikelen 5 lid 2 controlereglement i 6 sub c ledenreglement. 
mocht ook een onderzoek instellen indien het van mening was dat een bepaald lid de regels van de VvdE overtrad ${ }^{224}$. Tot slor stelde het controlebureau ook een onderzoek in wanneer de voorzitter gebruik maakte van zijn recht van enquête. Mocht deze menen dat hij nader ingelicht zou moeten worden omtrent de werkzaamheden van buitengewone bedriifsleden op het terrein van de efficiency, de rentabiliteit en de ontwikkelingen in het effectenbedrijf, dan kon dit aan bedrijfsleden en/of buitengewone bedrijfsleden worden gevraagd. Evenals een onderzoek naar een mogelijke overtreding van de beursregels, werd ook dit onderzoek door het controlebureau verricht. Daarnaast kon dit onderzoek ook door deskundigen of organisatieadviseurs ${ }^{225}$ worden uitgevoerd 226 . Bij het verrichten van een onderzoek mocht het controlebureau zich laten bijstaan door deskundigen ${ }^{227}$. Degenen die in opdracht van het controlebureau bij een bedrijfslid inlichtingen gingen inwinnen en/of een onderzoek wilden instellen dienden, volgens artikel 9 van het controlereglement, voor de aanvang van de werkzaamheden een introductiebrief te overhandigen die was getekend door de voorzitter en het hoofd van het controlebureau en waarin de aard van de opdracht was aangegeven ${ }^{228}$. De leden hadden de verplichting om tijdens een dergelijk onderzoek medewerking aan het controlebureau te verlenen. Immers, op hen rustte de statutaire verplichting om op verzoek van de $\mathrm{VvdE}$ alle gegevens en inlichtingen te verstrekken die noodzakelijk waren voor het vervullen van de taken van de vereniging of van een van haar organen, bijvoorbeeld het controlebureau ${ }^{229}$. Dit bureau moest in de gelegenheid worden gesteld om de boeken en bescheiden van de leden te kunnen inzien. Vanzelfsprekend hadden het controlebureau en deskundigen wat betreft het onderzoek een geheimhoudingsplicht. Zij lichtten alleen de voorzitter, dan wel de toezichthoudende instantie ${ }^{230}$ in over het onder-

224 Artikel 8 controlereglement.

Waarschijnlijk werd met organisatieadviseurs bedoeld: aan de VvdE gelieerde adviseurs.

226 Artikel 26 statuten VvdE

227 Dat kon bijvoorbeeld een register-acountant zijn. Deze werd ingeschakeld indien de vermogenspositie van een bedrijfslid diende te worden onderzocht. Vgl. Cross, D.H. en Diephuis, J.H., "Amsterdamse effectenbeurs uit: de serie Bank- en Effectenrecht dl. $15^{\prime \prime}$, t.a.p. noot 145 , p. 22 en artikel 4 van het controlereglement. Artikel 9 controlereglement.

229 Artikel 25-A statuten VvdE.

230 Naast een door de STE opgedragen onderzoek, bleef het controlebureau aan de STE de bevindingen van de periodieke rapportages doorgeven. Vgl. artikel $10 \mathrm{lid}$ 2 controlereglement. 
$z^{2} \mathrm{k}^{231}$. Alleen indien dit woor de beoordeling van het resultaat van het onderzoek noodzakelijk was, kon het controlebureau inlichtingen, bijwoorbeeld namen van cliënten of specifieke gegevens over zaken van de onderneming en/of leden, aan de voorzitter of de STE verschaffen ${ }^{232}$. In het kader van de uitoefening van haar taken was de VvdE, op grond van artikel 25-A lid 2 van de statuten, bevoegd om informatie uitwisselen met andere effectenbeurzen.

\subsubsection{De interne regelgeving van Amsterdam Exchanges N.V.}

Op 1 januari 1997 fuseerden de VVdE, de VEOE en de FTA ${ }^{233}$. Bij deze fusie kwam de structuurvennootschap Amsterdam Exchanges N.V. (AEX N.V.) tot stand. De hiervoor genoemde beurzen zijn door de fusie geherstructureerd; zij werden werkmaatschappijen van AEX N.V. die zelfstandig opereerden ${ }^{234}$. AEX N.V. werd beurshouder ${ }^{235}$ en was hierdoor verplicht om haar interne regels, te weten het algemeen reglement en de overige specifieke reglementen, volgens de geldende effectenwetgeving toe te passen $^{236}$. Zoals uit de vorige paragraaf kan worden opgemaakt, kwam de interne regelgeving ten tijde van de AEB tot stand door het bestuur en door de ledenvergadering. De fusie bracht op dit gebied veranderingen teweeg. De interne strucruur van de beurzen werd gewijzigd en de beslissingen werden genomen door de directie van AEX N.V. In figuur 2.2 is de structuur van AEX N.V. weergegeven.

231 Artikel 10 lid 1 controlereglement.

232 Artikelen 25 lid 2 statuten jo 11 leden 1 en 2 controlereglement.

233 VEOE is de Vereniging European Oprions Exchange, ook wel de optiebeurs genoemd en de FTA is de Financiële Termijnmarkt Amsterdam.

334 Zie hoofdsuk 1.6 voor meer informatie over de fusie en de werknatschappijen van AEX N.V.

2.35 Beurshouder in de zin van artikel 22 Wte" 95 . Zie paragraf 2.1.

23.4 Arrikel 1 lid 2 algemeen reglement AEX juni 1997. 


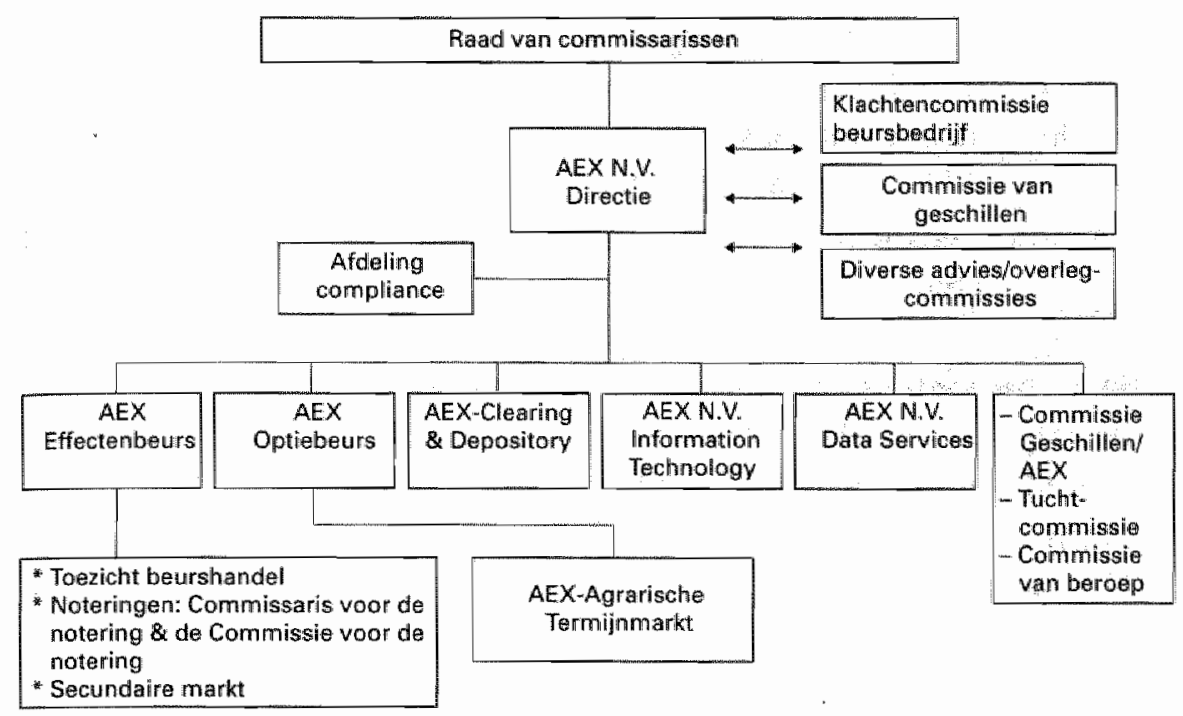

In tegenstelling tot de $\mathrm{AEB}$, kende $\mathrm{AEX} N . \mathrm{V}$. geen leden maar "toegelaten instellingen". Deze kwamen zowel bij de AEX-effectenbeurs, de AEXoptiebeurs als bij de FTA voor. De toegelaten instellingen waren gebonden aan de door AEX N.V. gestelde eisen. Na de fusie kregen de oud-leden van de $\mathrm{VvdE}$ de kans om tot de toegelaten instellingen te behoren. Zij zouden alleen van rechtswege worden toegelaten indien zij aan bepaalde voorwaarden voldeden. De leden van de $\mathrm{VvdE}$ konden hun werkzaamheden, na de fusie, niet zonder meer voortzetten. Zij moesten zich opnieuw laten registreren. Voorts moesten deze oud-leden, binnen een maand na de fusie, een toelatingsovereenkomst tekenen en werd van hen verlangd om in te stemmen met de overdracht van oude dossiers van de VvdE/VEOE naar AEX N.V. Ondertekening van deze overeenkomst heeft niet alleen tot gevolg gehad dat de aanvrager zich aan alle op dat moment geldende regels moest houden, maar ook aan alle toekomstige regels van AEX N.V. ${ }^{237}$. Zowel oud-leden die van rechtswege zijn toegelaten, als een ieder die na 1 januari 1997 actief op een van beurzen van AEX N.V. zou worden, verplichtten zich door ondertekening van de toelatingsovereenkomst om de AEX N.V.-reglementen in acht te nemen. De toelatingsvereisten van AEX N.V. waren onderverdeeld in algemene en prudentiële vereisten ${ }^{238}$. In de algemene vereisten waren de voor- 
waarden voor toelating tot een functie van AEX N.V. aangegeven ${ }^{239}$. De prudentiële vereisten gaven de voorwaarden aan waaraan een toegelaten instelling moest voldoen voordat zij haar gewenste functie kon en mocht uitoefenen ${ }^{240}$. Daarnaast moest volgens artikel 3 lid 2 sub b van het algemeen reglement de aanvrager houder zijn, van ten minste een aandeel $A$, in het kapitaal van AEXN.V. ${ }^{241}$. Tot slot moest de toe te laten instelling voldoen aan alle andere voorwaarden van AEX N.V.242. Om de belangen van de toegelaten instelling te kunnen waarborgen had AEXN.V. bepaalde maatregelen getroffen zoals het invoeren van een overgangstermijn voor de oud-leden van de VvdE; het instellen van een onafhankelijke commissie van geschillen en het opzetten van een advies- of overlegstructuur aan de hand warrvan bestuursbeslissingen tot stand dienden te komen. Wanneer de structuur van AEX N.V. wordt vergeleken met die van de AEB, dan vallen de nieuwe adviescommissies op. Deze commissies dienden er voor te zorgen dat er regelmatig contact met en tussen de diverse actoren op de beurs was. Naast het overleg met de economische faculteiten van de Nederlandse universiteiten, was er voor elke beursactor een overlegstructuur gecreëerd. Zo bestonden er voor de toegelaten instellingen zes commissies: de commissie primaire markt, de commissie aandelenhandel, de commissie obligatiehandel, de commissie agratische producten, de commissie clearing en depository en tot slot de commissie oprions $\&$ futures. Voor de beleggers waren er

Om toegelaten te kunnen worden, moest ex sprake zijn van een meerderjarige natuurlijke persoon, een rechtspersoon, een vennootschap onder firma of een commanditaire vennootschappen dan well daarmee te vergelijken personenvennoorschappen naar buitenlands recht, die in het kader van zijn beroep bij de toegelaten instelling betrokken zou zijn. Vgl. artikel 3 en verder wan bet algemeen reglement AEX, juni 1997. Een Commanditaire vennootschap, ook wel genoemd: de vennootschap bij wijze van geldschieting. Deze wordt in beginsel aangegaan tussen een persoon of meerdere hoofdelijk verbonden vennoten en een of meer personen als geldschieters; vgl. arrikel 19 Wetboek van Koophandel. Een Vennootschap onder Firma is een samenwerkingsverband/maatschap, dar is aangegaan om onder gemeenschappelijke naam een bedrijf uit te oefenen; vgl. artikel 16 Wetboek wan Koophandel.

240 Deze vereisten golden behoudens dispensatic of nadere voorwaarden. Vgl. artikel 5 algemeen reglement AEX, juni 1997.

24 Aandelen A waren winstbewijzen., m.a.w. een bewijsstuk voor het recht op een andeel in de winst wan i.c. AEXN.V.

24.2 Deze voorwaanden hadden onder andere berrekking op de activiteiten van aanvrager, de vermogenspositie, de onathankelijkheid van de aanvrager, het administracief systeem, de betrouwbaarheid en deskundigheid. Deze opsomming was niet limitatief. Zie artikel 3 lid 2 sub a algemeen reglement AEX, juni 1997. 
twee soorten overlegorganen in het leven geroepen namelijk: het ronde tafel overleg particuliere beleggers en het ronde tafel overleg institutionele beleggers. Tot slot vond er in de adviesraad uitgevende instellingen, voor de uitgevende instellingen overleg plaats tussen deze instellingen en AEX N.V. ${ }^{243}$.

Op het gebied van de interne regelgeving, had AEX N.V. naast een paar algemeen geldende reglementen ${ }^{244}$, specifieke reglementen voor iedere werkmaatschappij gecreëerd. De algemeen geldende reglementen functioneerden naast de specifiek voor de verschillende beurzen ontworpen regels. Zo hadden de AEX-effectenbeurs ${ }^{245}$, de AEX-optiebeurs en de FTA ieder hun eigen regels. Omdat het te uitvoerig zou zijn om alle beurzen te bespreken, richt dit onderzoek zich uitsluitend op de effectenbeurs. Daarom zal hieronder alleen op de voorschriften aangaande deze beurs worden ingegaan. Te beginnen met de algemeen geldende AEX-reglementen.

\section{De algemeen geldende reglementen}

Zowel AEX N.V. als de diverse actoren op de beurzen van AEX N.V. moesten zich aan het algemeen reglement houden. Dit reglement was te vergelijken met de oude statuten van de VvdE. Deze vergelijking gaat niet helemaal op omdat de gewijzigde structuur van de beurzen, ook een gewijzigde structuur van de regels ten gevolge had gehad. Volgens het algemeen reglement was AEX N.V. op grond van haar statuten verantwoordelijk voor:

... het organiseren, besturen, controleren, in stand houden en ontwikkten var de effectenen derivatenhandel op dor AEX gehouden beurzen of systemen, van faciliteiten voor de ontwikkeling van transacties in effecten en derivaten, alsmede wat facilititen wor de bewaring van effecten en deriuaten. AEX zal op de door AEX gehouden bewrzen een of meer beursuloeren of andere handelsfaciliteiten invichten en onderbouden ${ }^{2 * 6}$.

AEX N.V., jaarverslag 1997, Amsterdam, maart 1998, p. 22.

244 De reglementen die woor eenieder gelden zijn: het algemeen reglement; het nader reglement toegelaten instellingen $\mathrm{AEX}$; het geschillenreglement $\mathrm{AEX}$; het reglement geschillen/AEX, het reglement $k$ lachtencommissie beursbedrijf; het tuchtreglement AEX en her reglement van beroep.

265 Voor de AEX-effectenbeurs gelden de volgende specifielke reglementen: her reglement toegelaten instellingen AEX-effectenbeurs; het reglement voor de effectenhandel; het courtagereglement; het reglement procedure beursnotering: het reglement voor de notering; her reglement tarieven toelating en notering en het fondsenreglement.

246 Artikel 1 lid 1 algemeen reglement $\mathrm{AEX}$, juni 1997. 
Voorts bepaalde het algemeen reglement dat AEX N.V. toezicht hield op de effectenhandel en dat zij er tegelijk op zou toezien dat de door haar vastgestelde regels werden nageleefd ${ }^{247}$. Daarnaast werd in het algemeen reglement bepaald dat AEX N.V. verantwoordelijk was voor het vaststellen en publiceren van, onder andere, de effectenkoersen ${ }^{248}$. Op de AEXeffectenbeurs (de effectenbeurs), konden volgens het algemeen reglement de volgende functies door toegelaten instellingen worden uitgeoefend:
1. commissionair ${ }^{249}$;
2. broker-ATM ${ }^{250}$
3. EOCC clearing instelling $25 t$
4. boekmansbedrijf ${ }^{252}$.
5. interdealer-broker ${ }^{253}$;

Artikel 1 lid 5 algemeen reglement AEX, juni 1997.

Arrikel 1 lid 6 algemeen reglement AEX, juni 1997.

249 De Commissionair mocht voor het uitoefenen van de effectenhandel gebruik maken van de handelssystemen van de AEX-effectenbeurs. Artikel 2 algemeen reglement $\mathrm{AEX}$, juni 1997.

De broker-ATM oefende de commissiehandel in effecten uit of kon woor eigen rekening in effecten handelen. Hierbij mocht hij alleen gebruik maken van het ATM-segment van de handelssystemen van de effectenbeurs. Arrikel 2 algemeen reglement AEX, juni 1997.

Een EOCC Clearing instelling mocht alleen woor rekening en risico van toegelaten instellingen die werkzaam waren op de AEX-optiebeurs of FTA- ter afdekking van de door hen ingenomen posiries in derivaten-, gebruik maken van de handielssystemen van de effectenbeurs. Zodoende kon een EOCC Clearing instelling de commissichandel in effecten uitoefenen. Arrike 2 algemeen reglement $\mathrm{AEX}$, juni 1997.

252 Een dergelijk bedrijf mocht alleen gebruik te maken van de handelssystemen van de effectenbeurs om, uitsluitend woor rekening van commissionairs en woor rekening wan andere door de AEX aangewezen instellingen, de commissiehandel in effecten uit te oefenen. Daarnaast mocht een hoekmansbedriff ook voor eigen rekening in effecten handelen. Artike 2 algemeen reglement AEX, juni 1997.

De interdealer-broker mocht alleen gebruik maken van de handelssystemen van de effectenbeurs, indien hij uitsluitend voor rekening van roegelaten instellingen in effecten handelde. Effectentransacties die zouden kunnen leiden tot het innemen van een eigen positie van de interdealer-broker, werden uirgesloten. Artikel 2 algemeen reglement. 
6. daghandelanrfloorbroker ${ }^{254}$ en
7. niet-handelende commissionatir

Voordat voormelde functies konden worden uitgeoefend, diende men een schriftelijke aanvraag bij AEX N.V. in te dienen ${ }^{256}$. Hierna onderzocht AEX N.V. of de aanvrager aan alle eisen voldeed ${ }^{257}$. Nadat AEX N.V. positief over de toelating had beslist en deze definitief was geworden, stelde zij de toezichthouder hiervan schriftelijk op de hoogte ${ }^{258}$. Indien dat was vereist nam deze een beslissing over het verlenen van een vergunning. Pas nadat de toezichthoudende STE een vergunning aan de instelling had verleend, mocht deze een van de hierboven genoemde functies bij AEX N.V. uitoefenen ${ }^{259}$. De toegelaten instellingen dienden zich naast de wettelijke voorschriften ${ }^{260}$, ook te houden aan gedragsrregels ${ }^{261}$ en aan een meldingsplicht ${ }^{262}$. Hiermee probeerde AEX N.V. de toegelaten instelling bij de uitoefening van hun functie te houden aan een specifieke eis, te weten: het vertonen van eerlijk marktgedrag. Op deze wijze trachtte AEX N.V. het vertrouwen van niet alleen de beleggers, maar van een ieder

254 Een daghandelaar of floorbroker mocht alleen gebruik maken van de handelssystemen van de effectenbeurs, indien hij als effectenhandelaar voor eigen rekening handelde of indien hij uitsluitend met de rekening van een toegelaten instelling, voor rekening van deze instelling de commissiehandel in effecten uitoefende. Artikel 2 algemeen reglement.

De nier-handelend commissionair was bevoegd om, bij de speciaal hiervoor aangewezen commissionairs, cliènten en effectenorders voor rekening van cliënten aan te brengen. Arrikel 2 algemeen reglement AEX, juni 1997. Arrikel 4 lid 1 algemeen reglement AEX, juni 1997.

Arrikel 4 lid 5 algemeen reglement AEX, juni 1997.

Arrikel 4 lid 10 algemeen reglement AEX, juni 1997.

Artikel 4 lid 10 algemeen reglement j 7 Wre'95.

Bijvoorbeeld de Wte"95. Vgl. artikel 5 lid 6 sub a algemeen reglement AEX, juni 1997.

Deze zijn door AEX N.V. wastgesteld en moeten op de door de toegelaten instelling uitgeoefende functie van toepassing zijn. Artikel 5 lid 6 sub b algemeen reglement AEX, juni 1997.

Het kan voorkomen dat de toegelaten instelling een vorm van dienstwerlening uitoefent, warbij het in het belang van diens clienten noodzakelijk is om schriftelijke overeenkomst te sluiten warop de dienstverlening is gebaseerd. Vgl. Artikel 5 lid 6 sub c algemeen reglement AEX, juni 1997. 
in de beurzen te houden. Het algemeen reglement vermeldde deze gedragsregels als volgt:

\section{Artikel 7}

2. De toegelaten instellingen dienen daor een eerlijk marktgedrag bij te dragen tot het vertroutwen in bet functioneren van de effecten-en derivatenmark, de doeltreffende werking datrvan en een goede bescherming van de belangen wan bet beleggend publiek, zelfs indien dit voor hen in bepalde gevallen her afzien van bepaalde recbtstrekse financielle voordelen wou kunnen inbouden.

6. De toegelaten instellingen hebben de plicht het wertrouwen van de beleggers in de eerlijkbeid van de effecten-en derivatenmarkt in stand te bouden door rechtschapen handel te drijuen en zich steeds te bouden aan de beroepsethiek. Zij zullen met name moeten weigeren om medewerking te verlenen atan hen, die pogen af te wijken wan de beginselen van exlijk marktgedrag en dienen zich niet te lenen voor gedragingen waardoor de nomale werking van de effecten-en derivatenmarkt kan worden gefrustreerd of geschaad.

c. Toegelaten instellingen mogen niet de effecten-en derivatenmarkt manipuleren; noch door middel wan een of meer transacties, noch door middel wan bet verspreiden of het bevorderen van geruchten of informatie, noch anderszins met het oogmerk oxn:

(i) een wallse en misleidende voorstelling te creëren van de handelsactiviteiten op een effecten-en deriwatermarkt of wan een specifieke effect te verhandeld op een effecteren derinatenmarkt, of

(ii) on tranaties van anderen op een effecten-en derivatenmarkt te beinvloeden. AEX kan de reikwijdte van deze gedragsregels, met name in bijzondere situaties, nader wituserken.

Met de inhoud van sub c probeerde AEX N.V. elke vorm van manipulatie van de markt te voorkomen. Zij had onder de punten d. en h. van bovenvermeld artikel ook gedragsregels opgenomen die zich richtten op de behandeling van koersgevoelige informatie.

d. Een togulaten instelling zal niet, in welke boedanighed dan ook, betzij direct of indivect, woor eigen rekening effecten en derivaten kopen en werkopen wanneer bij met betrekking tot die effecten en derivaten kennis dragt wan vertrouwelijke koersgevaelige informatie.(.)

b. Tedere toegraten instelling zal zich onthowden wan gedragingen die de naan. reputatie of belangen wan $A E X$ schaden of wel dretgen to schaden.

Voornoemde gedragsregels waren niet alleen in artikel 7 van het algemeen reglement te vinden. In andere bepalingen waren ook gedragsregels terug te vinden. Zo was de toegelaten instelling gehouden om zijn nietprofessionele cliënt op de hoogte te stellen van de mogelijke risico's die aan de effectentransacties waren verbonden. Verder moest de instelling 
ervan overtuigd zijn dat de cliënt deze risico's kende ${ }^{263}$. AEX N.Y. hield zelf toezicht op de naleving van het bovenstaande gedragregels. De STE controleerde de naleving van de regels die door de W/te werden gesteld ${ }^{264}$. Ter uitvoering van haar controlebevoegdheden, mocht AEX N.V. inlichtingen aan de toegelaten instelling vragen en zelfs een onderzoek instellen. Deze instellingen of accountants ${ }^{265}$ van deze instellingen hadden een informatieplicht en zij waren verplicht om mee te werken en de gevraagde informatie binnen een door AEX N.V. gesteld termijn te verstrekken ${ }^{266}$. Indien AEX N.V. had vastgesteld dat een toegelaten instelling, diens (plaatsvervangende) beursgemachtigde of een zetelvertegenwoordiger de door AEX N.V. gestelde regels of voorwaarden niet naleefde, kon zij besluiten om de instelling voor de duur van maximaal zes maanden (voorwaardelijk) te schorsen ${ }^{267}$. Zowel AEX N.V. ${ }^{268}$ als de toegelaten instelling, diens beursgemachtigde of de zetelvertegenwoordiger was bevoegd de toelatingsovereenkomst op te zeggen ${ }^{269}$. Een dergelijke opzegging kon gelegen zijn in het feit dat de toegelaten instelling, de beursgemachtigde of zetelvertegenwoordiger niet meer voldeed aan de toelatingsvoorwaarden en/of regels van AEX N.V. ${ }^{270}$. Daarnaast kon het ook zijn dat de vereiste vergunning was ingetrokken ${ }^{271}$. Verder kon het voorkomen dat achteraf bleek dat de toelating was gebaseerd op grond van gegevens dan wel stukken die onjuist of onvolledig waren en dat de desbetreffende instelling bij de juiste en/of volledige informatie niet zou zijn toegelaten ${ }^{272}$. Naast deze redenen werden de rechten van een toegelaten instelling ook beëindigd wanneer de toegelaten instelling de vrije beschikking over zijn vermogen verloor: Tenslotte had de ontbinding van de toegelaten instelling of, in geval de toegelaten instelling cen natuurlijke persoon is, de dood van deze persoon, de dood van de

\footnotetext{
263 Artikel 5 lid 6 sub d algemeen reglement $\mathrm{AEX}$, juni 1997.

264 Artikel 8 lid 1 algemeen reglement AEX, juni 1997.

26.5 Of een andere deskundige die de boekhouding en jaarrekening controleert. Vgl. artikel 8 lid 2 algemeen reglement AEX, juni 1997.

266 Artikel 8 algemeen reglement AEX, juni 1997.

267 Artikel 9 lid $1 j^{\circ} 11$ lid 3 sub a algemeen reglement $A E X$ juni 1997.

26\% Arrikel 10 lid 1 sub c algemeen regllement AEX, juni 1997.

269 Arrikel 10 lid 1 sub b j $j^{\circ} 11$ lid 4 sub a onder 2 algemeen reglement AEX, juni 1997.

270 Artikel 10 lid 1 sub $c j^{\circ} 11$ lid 4 sub a onder 4 a allgemeen reglement AEX, juni 1997.

271 Arrikel 10 lid 1 sub c allgemeen reglement.

272 Artikel 10 lid 1 algemeen reglement AEX, juni 1997.
} 
beursgemachtigden of van de zetelvertegenwoordiger, de beëindiging van de toelatingsovereenkomst tot gevolg ${ }^{273}$.

Het kon voorkomen dat er een geschil was tussen enkele tot AEX N.V. toegelaten instellingen of tussen een toegelaten instelling en AEX N.V. Wanneer de instellingen niet zelf uit een meningsverschil kwamen, bestond de mogelijkheid om zich tot de commissie van geschillen of de commissie geschillen/AEX te wenden. Beide commissies waren in het leven geroepen om onderlinge conflicten op te lossen. Eerstgenoemde commissie beslechtte de geschillen tussen de toegelaten instellingen ${ }^{274}$. Laatstgenoemde commissie loste alleen de conflicten op tussen een toegelaten instelling en AEX N.V. ${ }^{275}$. Aangezien de regels van deze commissie sterke overeenkomst vertoonden met de regels van de commissie van geschillen, werden beide commissies tezamen behandeld. De hiervoor genoemde geschillencommissies vervingen de vroegere commissie voor de geschillen. Zij vertoonden naast veel overeenkomsten, ook veel verschillen met hun voorgangster ${ }^{276}$. Gelijk de oude commissie voor de geschillen $^{277}$, stelden de commissie van geschillen en de commissie geschillen/AEX nagenoeg dezelfde inhoudelijke eisen aan het in behandeling nemen van een $\mathrm{klacht}^{278}$.

Artikel 10 lid 1 sub a jo 11 lid 4 sub a onder 1 algemeen reglement AEX, juni 1997.

274 Artikel 12 lid 1 geschillenreglement AEX $1997 j^{\circ}$ de artikelen 1 tor en met 13 geschillenreglement AEX.

275 Artikel 12 lid 2 geschillenreglement $A E X j^{\circ}$ de arrikelen t, tot en met 14 reglement geschillen/AEX.

276 Zo verschilde de samenstelling van de commissies. De commissie van geschilhen en de commissic geschillen/AEX bestond uit minimaal tien personen, terwijl hun voorgangster uitt wijf personen heeft bestaan. Daarnaast verlangden de reglementen van de nieuwe commissies dat de voorzitter en diens plaatsvervanger benoembaar tor rechter in een arrondissementsrechrbank moesten zijn. Zij moesten op zijn minst juristen zijn. Het reglement van de commissie voor de geschillen stelde deze eisen niet. Vgl. de arrikelen 3 lid $\mathbb{1}$ en 2 geschillenreglement AEX 1997, artikel 3 lid 1 en 2 reglement geschillen/AEX en arcikel 2 lid 2 geschillenreglement AEB.

27. Hiermee wercien de commissies van geschillen ren tijde van de Amsterdannse Effectenbeurs en ten tijde van de VvdE bedoeld.

Een bij laatstgenoemde commissies ingediende klacht diende, evenals bij hun voorgangster her geval was, schriftelijte te worden ingediend. Vgl. de artikelen 7 geschillenreglement $\mathrm{AEX}$ en 5 geschillenreglement $\mathrm{AEB}$ en vgi. de artikelen 7 geschillenreglement $A E X$, artikel 7 reglement geschillen/AEX en arrikel 5 geschillenreglement AEB. In tegenstelling tot de oude commissie voor de geschillen, stelden haar opvolgsters de eis dat de klacht per aangerekende brief 
Niet alleen de toegelaten instellingen en AEX N.V. hadden de mogelijkheid gekregen om hun ongenoegen over elkaar te uiten; maar ook direct belanghebbende die geen toegelaten instelling waren konden klagen. Deze groep diende naar de klachtencommissie beursbedrijf toe te stappen. Voornoemde commissie bestond reeds tijdens de $\mathrm{VvdE}$, maar haar werking was na de fusie tussen de beurzen veranderd. Na deze fusie was de oude klachtencommissie effectenbedrijf overgegaan in een nieuwe klachtencommissie beursbedrijf 279 .

moest arriveren. Zie artikel 7 lid 1 geschillenreglement AEX en artikel 7 lid1 reglement geschillen/AEX. De hiervoor genoemde commissies en hun voorgangsters willen op grond van artikel 7 lid 2 geschillenreglement $A E X$; artikel 7 lid 2 reglement geschillen/AEX en artikel 5 geschillenreglement $A E B$, dat de klacht niet alleen de personalia van beide partijen moest bevatten, maar ook een omschrijving van het geschil en de vordering van de verzoeker moesten inhouden. Een door een toegelaten instelling ingediende klacht werd op grond van artikel 5 lid 1 geschillenreglement AEX en artikel 5 lid 1 reglement geschillen/AEX, behandeld door maximaal vijf commissieleden, te weten de voorzitter en vier door hem aangewezen commissieleden. Evenals bij overige AEX N.V.-commissies het geval is, mochten de leden uit deze commissie op grond van de artikelen 5 lid 2 geschillenreglement $A E X$ en 5 lid 2 reglement geschillen/AEX generlei wijze aan de verweerder zijn verbonden. Overeenkomstig de commissie voor de geschillen, konden de toegelaten instellingen de leden van de commissie van geschillen en van de commissie geschillen/AEX volgens artikel 6 geschillenreglement $A E X$, artikel 6 reglement geschillen/AEX en artikel 6 geschillenreglement AEB wraken. De toegelaten instelling en de AEX N.V. mochten zich rijdens de behandeling wan de zaak laten bijstaan door een deskundige of een juridische raadsheer. Vgl. artikel 8 lid 2 geschillenreglement $A E X$, arrikel 8 lid 2 reglement geschillen/AEX en artike! 7 lid 4 geschillenreglement AEB. Evenals bij de commissie voor de geschillen het geval was, konden haar opvolgsters, in het kader wan het onderzoek, parrijen het een en ander opleggen. Zo mochten de commissie van geschillen en de commissie geschillen/AEX van partijen verlangen dat zij alle informatie verstrekten die nodig was. Daarnazst konden zij, gelijk hun woorgangster, van partijen verlangen dat deze alle relevante boeken en bescheiden lieten inzien. De beide geschillencommissies van AFX N.V. konden bovendien getuigen horen. Vgl. artikel 9 geschillenreglement $\mathrm{AEX}$, artikel 9 reglement geschillen/ AEX en artikel 8 lid 1 geschillenreglement AEB. Overeenkomstig de procedure bij de geschillencommissie van de VrdE, gold in de procedure van de geschillencommissies van AEX N.V. dat zij witerlijk binnen drie maanden na de zitting een beslissing moest nemen. Zie artikel 10 lid 1 geschillenreglement $\mathrm{AEX}$, artikel 10 lid 1 reglement geschillen/AEX en artikel 9 lid 1 geschillenreglement $\mathrm{AEB}$. Het was mogelijk om tegen een beslissing van de commissie geschillen/ AEX in beroep te gaan. Dir gebeurde bij de commissie van beroep. Tegen een beslissing van de commissie van geschillen van AEXN.V. was geen beroep mogeliflk. $\mathrm{Vgl}$. artikel 16 algemeen reglement $\mathrm{AEX}$.

279 Artikel 13 algemeen reglement $j^{\circ}$ de artikelen 1 tot en met 15 reglement klachtencommissie beursbedrijf 1997. 
Zoals aan het begin van deze subparagraaf is vermeld, golden er voor de AEX-effectenbeurs naast de hiervoor behandelde commissies en reglementen, ook andere reglementen. De reglementen voor de AEX-effectenbeurs varieerden van specifieke regels woor toegelaten instellingen tot bepalingen betreffende de fondsen.

\section{De AEX-effectenbetursreglementen}

Een van de werkmaatschappijen van AEX N.V., de AEX-effectenbeurs, was belast met de organisatie van de openbare kapitaalmarkt van AEX N.V. Op deze beurs konden niet alleen warrants, maar ook aandelen en obligaties worden verhandeld. De openbare kapitaalmarkt werd verdeeld in een primaire en een secundaire markt. Op de primaire markt werden en worden nieuwe effecten uitgegeven door kapitaalbenodigde ondernemingen. Door op de AEX-effectenbeurs genoteerd te staan konden de fondsen op de secundaire markt worden verhandeld ${ }^{280}$. De actoren op de effectenbeurs, waaronder de hoekmannen, commissionairs en (institutionele) belegger, moesten zich houden aan de regels die golden voor deze beurs. Deze regels waren neergelegd in diverse reglementen. Tot de AEX-effectenbeursreglementen behoorden:

1. bet reglement toegelaten instellingen AEX-effectenbeurs;

2. bet reglewent voor de effectenhandel;

3. bet courtagereglement;

4. bet reglement procedure beursnorering;

5. het reglement woor de notering;

6. bet reglement whiten toelating en notering en bet fondsenteglement.

Hieronder zal in grote lijnen worden aangegeven wat de strekking van deze regels waren. Van sommige reglementen, waarvan een uitvoerige behandeling niet strookt met de lijn van dit onderzoek, zal dit slechts marginaal gebeuren.

De AEX-effectenbeursreglementen begonnen met het reglement toegelaten instellingen AEX-effectenbeurs. Deze bepalingen hadden een aanvullende werking op het voornoemde algemeen reglement. In het reglement toegelaten instellingen AEX-effectenbeurs werden diverse onderwerpen behandeld. Naast een aantal gedragsregels waren er ook regels te vinden over de verschillende functies op de effectenbeurs. Een van de gedragsregels was te vinden in artikel 2 lid 1 van dit reglement. 
In dit artikel was bepaald dat voordat een toegelaten instelling een medewerker voor de effectenhandel kon aannemen, zij eerst inlichtingen bij de vorige werkgever van deze medewerker moest inwinnen. Op deze manier hadden de toegelaten instellingen de mogelijkheid om zo volledig mogelijk te worden ingelicht over de deskundigheid en betrouwbaarheid van de toekonstige medewerker. Met dit voorschrift trachtte de AEX(-effectenbeurs) de dubieuze medewerkers voor de effectenhandel buiten de deur te houden. De AEX(-effectenbeurs) probeerde vervolgens ook om de toegelaten instellingen meer bij hun diënten te betrekken ${ }^{281}$. Verder bevatte het reglement toegelaten instellingen AEX-effectenbeurs ook voorschriften waarin de functie eisen van de verschillende beroepen werden aangegeven ${ }^{282}$. Naast deze bepalingen trachtte de AEX (-effectenbeurs) door een aantal voorschriften om niet alleen het vertrouwen van de beleggers, maar om ook de integriteit van de effectenmarkt vast te houden. In deze voorschriften was onder meer bepaald dat toegelaten instellingen in de uitoefening van hun bemiddelende functie onafhankelijk dienden te zijn ${ }^{283}$. Het volgende AEX-effectenbeursreglement, het reglement voor de effectenhandel, was samen met het hierna te noemen fondsenreglement erg omvangrijk. Eerstgenoemde, dat voor alle partijen op de effectenbeurs bindend was, was van toepassing op de handel van toegelaten AEX N.V. instellingen in beursgenoteerde fondsen ${ }^{284}$. AEX N.V.

Zo was in artikel 2.2 wan het reglement toegelaten instellingen AFX-effectenbeurs bepaald dat een toegelaten instelling bij effectenbemiddeling eerst de persoonlijke achtergronden van haar cliënt diende te kennen, voordat zij haar bemiddelingsactiviteiten kon uitoefenen. Deze toegelaten instelling moest onder meer weten wat haar cliënt aan relevante effectenkennis had. Zodoende kon zij haar bemiddelingsactiviteiten bewuster uitoefenen.

In artikel 5 lid lvan het reglement, een regel die inging op de verschillende funcries op de AEX-effectenbeurs, was bepaald dat zetelvertegenwoordigers minstens twee jaren in de effectenbranche werkzaam moesten zijn geweest, en daar relevante werkervaring moesten hebben opgedaan. Een zetelvertegenwoordiger was iemand die als vertegenwoordiger woor een toegelaten instelling oprrad. Deze persoon vertegenwoordigde de toegelaten instelling in alles betreffende de uitoefening van haar functie. De zetelvertegenwoordigster mocht de toegelaten instelling niet in de feitelijke handel wertegenwoordigen.

Zie hiervoor artikel 7 sub $a, b$ en $c$ reglement toegelaten instellingen AEXeffectenbeurs juni "97. De AEX N.V. had een richtlijn vastgesteld waarin de vereisten voor onafhankelijkheid waren verwerkt. Deze richtlijn genaamd "onafhankelijkheidsrichtlijn" is als bijlage toegevoegd aan thet reglement toegelaten instellingen AEX-effectenbeurs.

284 Arrikell lid 1 sub $1 j^{\circ}$ artikel 1 lid 1 sub 4 reglement voor de effectenhandel juni 97. 
trachtte met dit reglement om naast het vastleggen van de geldende voorschriften, ook de verschillende handelssystemen ${ }^{285}$ van de beurs te verduidelijken $^{286}$. Daarnaast had AEX N.V. geprobeerd om de taken en verplichtingen van de belangrijke tussenpersonen te verduidelijken waaronder de van toepassing zijnde gedragsregels ${ }^{287}$. Naast deze marktsystemen, het centrale marktsysteem ${ }^{288}$ en andere professionele handels-

285 In het reglement voor de effectenhandel was er een onderscheid gemaakt tussen de centrale marktsystematiek en de overige handelssystemen op de beurs. Tot de overige handelssystemen behoorden: het Interdealer-broker systeem; het Automatic Interprofessional Dealingsystem Amsterdam (AIDA) en het Amsterdam Securities Trading-system (ASSET)

Vgll artikel 1 lid 1 sub 2 reglement voor de effectenhandel. Zo was in het reglement voor de effectenhandel duidelijk onderscheid gemaalkt tussen wholesale- en retailorders van cliënten. In geval van een wholesalegrens stelde de AEXN.V. per fonds het atantal effecten of de (nominale of effectieve) waarde van de effecten vast. Op advies van de commissaris voor de notering stelde AEX N.V. de whollesalegrens vast. Indien het te werhandelen aantal effecten onder de wholesalegrens viel, sprak men van een tetailorder. Vgl. bijlage II van het reglement voor de effectenhandel. Een voorbeeld hiervan was artikel 1 lid 2 van dit reglement. In dit artikel was bepaald dar de toegelaten instellingen, in geval wan een order boven de wholesalegrens, een extra inspanningsverplichting hadden om de best mogelijke voorwaarden woor hun cliënten te bereiken of om het beste advies aan deze cliënten te geven. In het reglement voor de effectenhandel werden naast de verplichtingen ven de hoekmannen, ook de verplichtingen van commissiehuizen aangegeven. Vgl. artikel 3 lid 2 sub 1 onder 1 tot en met 5 en artikel 3 lid 2 sub 2 reglement voor de effectenhandel. In bijlage XVI van het reglement woor de effectenhandel, genaamd "gedragsregells voor de vloer van de AEX-effectenbeurs", had AEX N.V. de voor de effectenbeurs van toepassing zijnde gedragsregels aangegeven. Hierin stelde zij onder meer dat de beursgemachtigden en werknemers van toegelaten instellingen die toegang hadden tot de beursvloer, deze slechts mochten betreden indien $x$ ij cortect gekleed zouden zijn. Daarnaast was in die bijlage bepaald dat bezoekers alleen de beursvloer mochten betreclen, nadat zij toestemming van de commissaris voor de notering hebben gekregen. Voorts was in de bijlage vermeld dat AEX N.V. het gebruik van alcoholhoudende dranken op de beursvloer had afgekeurd. Bovendien was het gebruik van draadloze telefoons niet toegestaan op de beurswloer. Tot slot was in de bijlage in algemene bewoordingen aangegeven dat onbetamelijk gedrag op de beurswloer niet werd getolereerd. AEX N.V. had met het reglement voor de effectenhandel en de aanvullende bijlage, uitwoering gegeven aan de Europese richdijn "beleggingsdiensten" en ther in de Wte' 95 genoemde artikel 11 lid 3 .

Zoals het centrale marktsysteem, waar officièle en controleerbare notering tot stand komen en waar ieder beursgenoteerde fonds maar op een manier kan worden verhandeld. Dit systeem was verplicht gesteld voor her aantal te verhandelen fondsen dat onder de wholesale grens viel. In artikel 1 lid 3 sub a tor en met $f$ waren er zes witzonderingen op de verplichting tor het gebruiken van het centrale marktsysteem opgesond. Commissionairs mchten deze orders niet "op eigen boek 
systemen $^{289}$, bevatte het reglement voor de effectenhandel ook functieamschrijvingen van de hoekmannen en commissichuizen die gebruik maakten van voornoemde systemen. Tot slot de verplichte melding van transacties door toegelaren instellingen. Zoals hierboven reeds is vermeld, gaf het reglement voor de effectenhandel uitvoering aan de Europese richtlijn "beleggingsdiensten" en het in de Wte'95 genoemde artikel 11 lid 3. Dit artikel, dat de effecteninstellingen verplichtte de regels van AEX N.V. op te volgen, luidde als volgt:

Een effecteninstelling watratn een vergunning als bedoeld in artikel 7. eerste lid, is verteend en die is a angesloten bij een organisatie als bedoeld in atrikel 9 , bouds zich, in afuijking van bet eerste lid, voor zover bet betweft de werkaamheden, bedoeld in artikel 9, an de regels die door die organisatie en door de bowder wan die effecterbeurs met bet oog op een adequate functionering van de effectenmarkten of de posivie van de beleggers op die markton zijn gesteld.

nemen", zodat ze niet anders dan via het centrale marktsysteem moesten gaan. Het "op eigen boek nemen" betekende dat de commissionairs niet zelf als tegenpartij mochten optreden. Dir werd ook wel "principal trading" genoend. In tegenstelling tot de overige handelssystemen, kon op het centrale marktsysteem slechts binnen de door AEX N.V. vastgestelde officiële beursuren worden gehandeld. Vgl. artikel 1 lid 3 sub 5 reglement voor de effectenhandel.

Nadat de wholesalegrens van een bepaalde fonds was overschreden, waren de toegelaten instellingen vrij om de orders van hun cliënt nier via het centrale marktsysteem af te wikkelen. Zij konden dan kiezen voor de drie systemen té weten: het Interdealer-brokersysteem; het Automatic Interprofessional Dealingsystem Amsterdam (AIDA) en het Amsterdam Securities Trading-system (ASSFT). Partijen konden pas in het Interdealer-broker systeem handelen wanneer hun orders voor een bepaald fonds minimaal gelijk waren aan de wholesalegrens van dat fonds. De toegelaten instellingen gaven hun koop-of verkooporders aan de Inrerdealer-broker door. Fen Interdealer-broker handelde uitsluirend voor rekening met de toegelaten instellingen. De Interdealer-broker mocht geen effectentransacties verrichten die tot een eigen posirie zouden leiden. Wilden partijen in het AIDA kunnen handelen, dan was vereist dat hun order nier alleen minimaal gelijk aan de wholesalegrens van cen bepaald fonds was, maar ook dat zij hun orders (proposities) volledig anoniem inlegden. Aangezien her AIDA-systeem in tegenstelling tor her hiervoor genoemde Interdealer-broker systeem geen menselijke intermediair had, betaalden partijen geen courtage. Het laatste op de effectenbeurs toegestane handelssysteem was her ASSET-systeem. Op dit systeem konden ook de instellingen die nier door AEX N.V. werden toegelaten, zien wat de roegelaten instellingen aanboden. Het waren alleen de toegelaten instellingen die hun biedof laatprijzen op het ASSET-scherm konden tonen. In tegenstelling tot het centrale marktsysteem kon de handelsperiode van het ASSET-systeem, afwijken van de officiële beurstijd. VgL artikel $\mathbb{1}$ lid 3 sub 5 onder g reglement voor de effectenhandel. 
Op grond van de hierwoor genoemde richtlijn en artikel 11 lid 3 W'te'95 hadden alle toegelaten instellingen van AEX N.V. de (wertelijke) plich.t om zich aan haar regels te houden; waaronder de plicht om bepaalde van de door hun uitgevoerde transacties te melden. De transacties die moesten worden gemeld waren volgens artikel 6 lid 1 onder 2 reglement voor de effectenhandel:

(...) alle transacties in andelen of andere instrumenten die toegang tot het kapital verlenen en obligaties en andere met abligaties gelijk te stellen instrumenten voorzover de transacties uitgevoerd zijn in bet kader wan aan of werkoop van effecten (... $)^{290}$.

Naast de hierboven opgesomde onderwerpen, sneed het reglement voor de effectenhandel, in artikel 5 lid 4, zijdelings het onderwerp koersmanipulatie aan. Het artikel luidde als volgt:

Het is toegelaten instellingen niet toegestaan de koersen van een bepaald fonds te manipuleren dan wel daaraan medewerking te verlenen. AEX verstrekt richtlijnen omtrent hetgeen daarander dient te worden verstadn, (...). Koersstabilisatie (...) kan op zichzelf niet als zodanig worden aangemerkt.

In de bijlage op dit artikel, bijlage $V$ reglement voor de effectenhandel, ging AEX N.V. uitwoeriger in op het onderwerp koersmanipulatie. AEX N.V. had in deze bijlage vermeld dat koersmanipulatie in de Nederlandse strafwetgeving onder het strafbaar feit "het verspreiden van leugenachrige berichten", artikel 334 Wetboek van Strafrecht (WvSr) was geplaatst. Artikel 334 WvSr:

Hij die, met bet oggmerk on zich of een ander wederrechtelijk te bewoordelen, door bet werspreiden van een leugenachtig bericht de prijs van koopwaren, fondsen of geldswaandig papier doet stijgen of dalen, word gestraft met gewangenisstraf van ten hoogste twee jaren of geldboete tan de vijfle categorie ${ }^{25 !}$. 
Volgens de tekst van haar richtlijn over koersmanipulatie ${ }^{292}$, had artikel $334 \mathrm{WvSr}$ niet het gewenste effect. Hierdoor richtte AEX N.V. zich op de relevante buitenlandse wetgeving en op de normen van onder andere de EU en IOSCO. Het resultaat was een door AEX N.V. algemeen gebezigde norm, die als volgt luidde:

Het is de toegelaten instellingen niet toegestaan de koersen van een bepaald fonds te manipuleren dan wel daaraan medewerking te verlenen. Bij koersmanipulatie kan in de eerste plaats worden gedacht alan de verspreiding van een onwaar bericht teneinde de koers van een bepaald fonds te beïnoloeden. Ook bandelingen of gedragingen ${ }^{293}$, waardoor een onware of misleidende indrak van de markt in een bepaald fonds ontstat kan, de omstandigheden van bet geval in alamerking nemend, als koersmanipulatie worden aangemerkt. Hierbij wordt aangetekend dat het enkele kopen of verkopen in het reguliere beursverkeer niet als koersmanipulatie kan worden aangemerkt; om bepaald handelen als koersmanipulatie te kunnen aanmerken is nodig dat er zich in een concrete situatie bepaalde -niet specifiek te omschrijuen-bijkomende omstandigheden voordoen.

In het volgende reglement, het courtagereglement, werd vastgesteld wanneer een hoekman makelaarsloon aan commissiehuizen mocht berekenen en wat het maximale courtagebedrag mocht zijn. De tarieven waren niet altijd gelijk. Ze werden afhankelijk van het effectentype, bijvoorbeeld een obligatie of aandeel en afhankelijk van het handelssysteem vastgesteld. Laatstgenoemd reglement was aanvullend op het fondsenreglement, de toelatingscriteria voor een fonds tot de officiële markt van de AEX-effectenbeurs. Tot de AEX-effectenbeursreglementen behoorde ook het reglement voor de notering. In dit reglement werden de taken aangegeven van de commissaris voor de notering en van de commissie voor de notering. Deze instituten bestonden reeds ten tijde van de Amsterdamse Effectenbeurs (AEB) en de Vereniging voor de Effecten, zie hiervoor paragraaf 2.3.3.1. Het ontstaan van AEX N.V. leidde niet tot een inhoudelijke wijziging van de taken en bevoegdheden van deze instituten. De commissaris voor de notering werd nog steeds belast

292 De richtlijn over koersmanipulatie bevatte enkele woorbeelden van koersmanipulatie, waaronder het verrichten van schijntransacties die de markt werkeerd inlichten. Hierdoor konden (potentiële) kopers of verkopers handelen op onjuiste informatic over het fonds of het specifieke bedrijf. Het handelen op grond van onjuiste of ongelijke marktinformatie, wat ook het geval is bij misbruik van woorwetenschap, staat haaks op een wan de doelstellingen van effectenregulering, namelijk het streven naar een transparante markt.

293 Ook her "nalaten" kan als gedraging worden gezien. De richtlijn merkte koersstabilisatie bij emissie niet aan als een handeling of gedraging in de zin van de richdijn. Vgl. Bijlage $\mathrm{V}$ bij het reglement voor de effectenhandel, p. V-1. 
met de handhaving van de orde op de beursvloer en het vaststellen van de officiële prijscourant ${ }^{294}$. Voorts fungeerde de commissie voor de notering nog steeds als adviesorgaan van de commissaris en droeg zij samen met hem de verantwoordelijkheid voor het regelmatig verlopen van veilingen van nieuwe fondse ${ }^{295}$. In het reglement voor de notering werden ook technische gegevens vermeld ${ }^{296}$. Tot slot stond in het reglement voor de notering vermeld dat de commissaris bevoegd was om onderzoeken in te stellen naar vermoedelijke overtredingen van dit reglement door toegelaten instellingen of zetelvertegenwoordigers. In het fondsenreglement waren de regels en vereisten aangegeven waaraan de genoteerde fondsen of de nog te noteren fondsen zich moesten houden ${ }^{297}$. De regels behandelden de aanvraag tot toelating van een fonds, tot aan de hiervoor genoemde behandelings-, toelatings- en jaarlijkse noteringskosten. Wanneer AEX N.V. ontdekte dat een reeds genoteerde instelling zich niet hield aan de in het fondsenreglement genoemde verplichtingen, schond deze instelling het door haar ondertekende noteringsovereenkomst en kon AEX N.V. verschillende

Artikel 2 lid 2 reglement woor de notering juni 1997.

Artikel 3 lid $4 \mathrm{en}$ artikel 4 reglement voor de notering. Om tot de notering te worden toegelaten diende eerst een aanvraag tot toelating van een fonds, tor bijvoorbeeld de officiële markt, te worden ingediend. In het reglement tarieven toelating en notering waren de vereisten vermeld voor het indienen van de annvraag tor toelating. Een dergelijk aanvraag gebeurde in de vorm van een prospectus. Dit is een publicatie die verkriigbaar werd gesteld door de uitgevende instellingen zodat geinteresseerden in verband met de komende emissie zich kunnen informeren over de desbetreffende onderneming. Voordar de aanwraag in behandeling kon worden genomen, diende de aanvrager een vergoeding te betalen. Deze vergoeding, ook wel genoemd "behandelingskosten" verschilde naar de mate van uitvoerigheid van de prospectus. Zo is in artikel 1 lid 1 van het reglement tarieven toelating \& notering vermeld dat de kosten voor bijvoorbeeld het beoordelen van een cenvoudig prospectus in $1997 f 1.500$,- bedroegen, omgerekend zou dar neerkomen op ongeveer $€ 680,67$. Voor het beoordelen van andere dan eenvoudige prospectussen moesten hogere bedragen worden betaald. In het reglement tarieven toelating \& notering werd een onderscheid gemaakt tussen eenvoudige-, standaard- en uitgebreide prospectussen. Het verschil tussen de prospectussen is in het fondsenreglement aangegeven. Zie artikel 1 reglement toelating \& notering juni $1997 j^{\circ}$ het fondsenreglement juni 1997. Amsterdamse Effectenbeurs, Beurs en effecten; de beurshandel en de vormen van beleggen, uitgeverij Conract, Amsterdam/ Antwerpen, 1993, p. $176-179$.

296. Er werd bijvoorbeeld vermeld dat de notering van obligaties diende te gebeuren in percenten en notering voor overige fondsen in guldens of in buitenlandse valuta. Zie hiervoor artikel 6 lid 1 reglement voor de notering. 
maatregelen treffen zoals het schorsen van een fonds dan wel het schrappen van een fonds uit de officiële notering ${ }^{298}$. De uitgevende instellingen konden op grond van artikel 65a lid 1 van het fondsenreglement en artikel 25 Wte'95 in beroep gaan bij de toezichthouder van AEX N.V.

\section{Controle en naleving: de afdeling compliance en de STE}

De fusie tussen de nationale beurzen had voor het interne toezicht tot gevolg dat de AEX N.V. niet zelf het gehele toezicht uitoefende. De beurshandel werd destijds in samenwerking met de STE gecontroleerd. Naar de wens van de Tweede Kamer verloren de beurzen niet alle zelfregulering. AEX N.V. mocht de verantwoordelijk behouden voor de primaire markt en de uitgevende instellingen op deze markt ${ }^{299}$. Zij werd dan ook bevoegd om regels te stellen en toezicht te houden op het gebied van de handel en/of de notering ${ }^{300}$. Het gevolg van de vermindering van de zelfregulering van de beurzen, was dat AEX N.V. haar toezichttaken slechts binnen her door de toezichthouder gegeven toezichtskader mocht uitoefenen $^{301}$. Het oude toezichts- en controleorgaan van de beurs, het controlebureau, hield op te bestaan en haar taken werden grotendeels door de STE overgenomen. De resterende taken van het oude controlebureau voerde de afdeling compliance van AEX N.V. uit, welke de bevoegdheid kreeg om het interne toezicht van AEX N.V. uit te oefenen. Dat hield in dat deze afdeling controleerde of de toegelaten instellingen de specifieke "beurseigen regels" naleefden. Deze beursregels hadden een aanvullende werking op de Wer roezicht effectenverkeer en de bijbehorende uitvoeringsvoorschriften ${ }^{302}$. Tot de beurseigen regels werden gerekend:
1. de voorschriften over de beurshandel,
2. de toelating van effecten tot de notering,
3. de overige noteringsregels, en tot slot,
4. de afwikkeling en bewaring van de verschillende AEX-beurzen.

\footnotetext{
Arrikel 65 lid 2 fondsenreglement juni 1997.

Salet, R., persbericht Ministerie van Financiën nr. 96/208, d.d. 20 december 1996, onder punt 3.2 .

300 Mer andere woorden: "de handelsregels wan de beurs". STE, Jaarverslag 1997, Anstelveen, april 1998 , p. 10.

301 STE, jaarverslag 1997, Amstelveen, april 1998, p. 10.

302 Salet, R, persbericht Ministerie van Financiën nr. 96/208, d.d. 20 december 1996, onder punt 3.2 .
} 
Tot de toezichtstaken van de afdeling compliance behoorde het uitvoeren van reguliere controles op de toegelaten instellingen van AEX N.V. De afdeling compliance rapporteerde het resultaat van deze controles aan de eindverantwoordelijke instantie; de STE. Deze kon, evenals ten tijde van het controlebureau, gebruik maken van de diensten van de afdeling compliance $^{303}$. Op dit punt was er niets veranderd. De overige regels, waaronder het toezicht op de toegelaten instellingen, werden door de toezichthoudende STE gecontroleerd. Naast controlerende taken, had de afdeling compliance ook adviserende taken. $\mathrm{Zij}$ kon zowel bij de notering van nieuwe fondsen als bij de toelating van toegelaten instellingen, adviseren ${ }^{304}$. De fusie tussen de nationale beurzen gaf het takenpakket van de STE de volgende vorm: zij diende naast het verlenen van vergunningen en het afgeven van verklaring van geen bezwaar, na te gaan of de instellingen voldoende kapitaalkrachtig waren ${ }^{305}$. Wat betreft het verlenen van vergunningen, vormde het wettelijk verbod om zonder vergunning effectendiensten aan te bieden, de grondslag hiervan. Een effecteninstelling mocht immers niet zonder deze vergunning tot de beurs worden toegelaten ${ }^{306}$. De vergunningsaanvragen werden door de STE niet meer marginaal getoetst, maar integraal ${ }^{307}$. Door het afgeven van de hiervoor genoemde vergunning aan de toegelaten instellingen, werd de STE verantwoordelijk voor het toezicht op deze instellingen. De vereiste verklaring van geen bezwaar was noodzakelijk in geval een toegelaten instelling voor minimaal $5 \%$ wilde deelnemen in her kapitaal van een effecteninstelling. Wanneer de STE van mening was dat de effecteninstelling betrouwbaar was en het afgeven van een dergelijke verklaring niet strijdig met de bedrijfsvoering van de instelling zou zijn, kon zij overgaan tot de afgifte van voornoemde verklaring. Naast het verlenen van vergunningen en het afgeven van verklaringen van geen bezwaar, controleerde de STE of de toegelaten instellingen zich aan de AEX N.V.-reglementen hielden. Dit gebeurde door de reguliere controles. Voor de reguliere controles hoefde de STE geen aanleiding te hebben.

30. Salet, R., persbericht Ministerie van Financiën nr. 96/208, d.d. 20 december 1996, onder punt 3.2 .

304 Internetpagina AEX N.V. d.d.18 november 1998:

http://wwwaex.nl/aexstarus.htm]

STE, Jaarverslag 1997, Amstelveen, april 1998, p. 13.

Vgl. de artikelen $7 j^{\circ} 9$ Wite' 95.

307 Ten tijde van het controlebureau werden de annragen slechts marginaal getoetst door de STE. 
Deze maakten onderdeel uit van de vereisten voor het hebben of het verkrijgen van een vergunning. Indien de STE dit nodig achtte kon zij overgaan tot het uitvoeren van bijzondere controles ${ }^{308}$. Deze controles werden alleen uitgevoerd indien de STE het vermoeden had dat een toegelaten instelling AEX N.V.-regels had overtreden. De in het najaar van 1997 door de STE verrichtte onderzoeken naar de handelingen van verschillende toegelaten instellingen die door justitie werden verdacht van het plegen van diverse strafbare feiten, operatie Clickfonds, zijn een voorbeeld van een bijzonder onderzoek.

De door de toegelaten instellingen of door de afdeling compliance van de AEX N.V. verstuurde periodieke rapportages konden de toezichthouder aanleiding geven om nader onderzoek te verrichten. In dat geval zou de STE financiële controles uitvoeren. Naast de hiervoor genoemde taken en bevoegdheden, konden zowel de afdeling compliance als de STE informatie uit wisselen met andere toezichthoudende instanties. Afhankelijk van de informatie, was of de afdeling compliance of de STE bevoegd. Om te voorkomen dat onderzoeken dubbel werden uitgevoerd, keken zowel de afdeling compliance als de STE naar de overtreden regel. Indien dit een beurseigen regel was, was het een zaak voor de afdeling compliance. Andere overtredingen werden door de STE afgedaan. De beide instanties informeerden elkaar over de opgedane bevindingen ${ }^{309}$.

\subsubsection{Van nationale beurs naar pan-Europese beurs: Euronext N.V.}

Drie jaar na de nationale beurzen fusie, besloot de Amsterdamse effectenbeurs, AEX N.V., in september 2000 te fuseren met de effectenbeurzen van Brussel en Parijs. Deze pan-Europese alliantie, die de naam Euronext N.V. (Euronext) draagt, - een Nederlandse vennootschap heeft ook de Londense derivatenbeurs Liffe ingelijfd ${ }^{310}$ en is hierdoor een volwaardige speler in de Europese effectenwereld geworden. Met de overname van Liffe is niet alleen duidelijk geworden dat de Amsterdamse optiehandel, de derivatenhandel van Euronext in Amsterdam, te zijner tijd zal worden verplaatst naar Londen. De overname had tevens tor gevolg dat het Engelse handelssysteem Connect als standaard zal worden

STE, Jaurverdag 1997, Amstelveen, april 1998, p. 12.

Salet, R., persbericht Ministerie van Financiën nr. 96/208, d.d. 20 december 1996 , onder punt 3.2 .

Eind oktober 2001 was de overname van de Londense derivatenbeurs Liffe een feit. Vlg. Witt, P. de, in het NRC Handelsblad d.d. 30 oktober 2001. 
overgenomen woor de derivatenhandel van Euronext ${ }^{311}$. Deze fusie ging gepaard gegaan met de nodige reglementwijzigingen ${ }^{312}$ en met nieuwe (Franse) handelsregels; een harmonisatie en unificatie van het (handels)systeem. Daarnaast heeft deze fusie een wijziging in actoren teweeg gebracht. Zo is de figuur van de traditionele hoekman verdwenen ${ }^{313}$ en zijn er andere figuren bijgekomen waarvan de animateur ${ }^{314}$, ook wel liquidity provider genoemd ${ }^{315}$, er een van is. Verder wordt er weer gebruik gemaakt van begrippen die nog uit de tijd van de VvdE stammen. Euronext kent namelijk in tegenstelling tot de vroegere AEX N.V. "members" en spreekt over membership in plaats van aandeelhouders. De fusie en de daaropvolgende verschillende inlijvingen dan wel aansluitingen van andere Europese beurzen bij Euronext zoals de Portugese effectenbeurs te Lissabon, hebben de structuur van de beurs gewijzigd. Op dit moment heeft de Nederlandse holdingmaatschappij,

3il Vgl. Wirt, P. de, in het NRC Handelsblad d.d. 30 oktober 2001.

3i2 Zoals het nieuwe "Rule Book" wan Euronext Amsterdam dat, sinds 29 oktober 2001, de oude regels - zoals die ten tijde van de AEX N.V. - heeft verwangen. Deze Rule book bestaat uit Book I de regels die voor alle Euronext beurzen gelden en Book II de regels die voor de lokale beurzen gelden, dus alleen Euronext Amsterdam, Euronext Brussels of Euronext Paris. In Book II van Euronext Amsterdam zijn een aantal reglementen van AEX N.V. terug te vinden die al dan niet zijn aangepast. Een voorbeeld hiervan is het Fondsenreglement. Daarnaast zijn er ook reglementen vervallen. Vgl. Eisma, S.E. en Schlingmann, F.M., Kroniek wan bet effectenrecht, NJB, 8 maart 2002 , j.g. 77, p. 545.

313 Mer her in gebruik stellen van het Franse handelssysteem op 29 oktober 2001 , is de figuur van de hoekman vervangen door de animateur. Vgl. het NRC Handelsblad, 29 oktober 2001.

34 De invoering van het handelssysteem zoals dat door de beurzen in Frankrijk werd en wordt gebruikt, - het NSC systeem - heeft de animateur doen introduceren in de Nederlandse beurswereld. De animateur kan gezien worden als een financiële partij die zich bezig houdt met de verhandelbaarheid van een bepaald aandeel; van kleine fondsen clie weinig worden werhandeld. Dit doet hij door zich viat het innemen van posities garant te stellen voor de continuïteit van het desbetreffende aandeel of van de desberreffende aandelen. Witt, P. de, in het NRC Handelsblad, 23 oktober 2001 en het NRC Handelsblad, 29 oktober 2001 . Volgens De Witt en J. Wester van het NRC Handelsblad, d.d. 20 oktober 2001 over de animateur het volgende: "De animatew onderhoudt waww contact, op bijna dagelijkse basis, met bet beursfonds waavoor bijoptreed. Dat kan bem een kenniswoorsprong opleveren met betrekking tot koengevoelige informatie. In dat geval overweed de animateur per definitie de Nederlandse wet. Geonge Möller (destijds hoogste man bij Euronext Amsterdam: MJB) benadrukt dat een animateur straks niez over meer informatie beschikt dan de markt".

$315 \mathrm{Vgl}$. Eisma, S.E. en Schlingmann, F.M., Kroniek uan bet effectenrecht, NIB, 8 maart 2002, jirg. 77, p. 545. 
Euronext N.V. drie werkmaatschappijen ${ }^{316}$, te weten Euronext Amsterdam N.V. (Euronext Amsterdam), Euronext Brussels N.V. (Euronext Brussel) en Euronext Paris N.V. (Euronext Paris) en staat zij zelf sinds juli 2001 genoteerd. Aandelen worden nu verhandeld via een 'gateway', een toegangspoort; een handelsplatform van Euronext. Al met al is de Nederlandse effectenbeurs geëvolueerd van een kleinschalige $V$ vdE, naar een groots opgezette internationale pan-Europese effectenbeurs Euronext N.V.

Deze schaalvergroting heeft ook op het terrein van de toezich tsbevoegdheden tot wijzigingen geleid. Zo is er al sinds de herijking van de Wte in 1999 de tendens te bespeuren dat toezichtsbevoegdheden worden overgeheveld van de nationale effectenbeurzen, naar de nationale toezichthouders. Zoals hiervoor al is aangegeven, kreeg destijds de STE het toezicht over de beursleden, vandaag de dag is de Autoriteit-FM de bevoegde instantie terzake informatieverplichtingen van onder meer beursgenoteerde ondernemingen en oefent zij ook het toezicht uit over de toelating van effecten tot de notering ${ }^{317}$. Daarnaast hebben er ook verschillende wijzingen in regelgeving plaatsgevonden. Uit alle wijzigingen ${ }^{318}$ was de overgang naar een functioneel toezichtsmodel duidelijk te bespeuren; het gedragstoezicht is ondergebracht bij de Autoriteit-FM en de nadruk is sterker komen te liggen op toezicht en handhaving van de financiële integriteit, transparantie en bescherming van de (niet-) professionele belegger.

Uit het voorafgaande is gebleken dat in de effectentypische regelgeving verschillende toezichthouders worden genoemd: de Autoriteit-FM - diens rechtswoorganger de STE - en DNB. Nu duidelijk is geworden op welke wetten hun toezichthoudende bevoegdheden zijn gebaseerd en er een tendens in de wijze van bevoegdheidsuitoefening zichtbaar is geworden, zullen deze bevoegdheden in de volgende paragraaf inhoudelijk worden bekeken. Hierbij staat de vraag centraal op welke wijze het toezicht door deze toezichthouders wordt uitgeoefend.

STE, jaarverslag 2000, Amstelveen, aprill 2001, p. 20.

Vgl. Eisma, S.E. en Schlingmann, F.M., Kroniek wan bet effectenrecht, NJB, 8 maart 2002, jrg. 77 , p. 546.

318

Zoals de wijziging van de Nadere regeling toezicht effectenverkeer 1999. Hiermee heeft de STE, nu Autoriteit-FM gehoor gegeven aan de uitwoering van het Besluit financiële bijsluiter (Bfb), zie Stcrt. 28 december 2001, nr. 250, p. 129. Vgl. het Bfb, Stb. $2001,670$. 


\subsection{De rol van de externe toezichthouders: de Autoriteit-FM en DNB}

Naar aanleiding van de in 1996 gewijzigde structuur van de Nederlandse effectenmarkten gaf ook de STE haar interne structuur een andere vorm. Aangezien zij vanaf 1 januari 1997 verantwoordelijk was geworden voor het toezicht op de toegelaten instellingen, wijzigde de STE vanaf 1997 niet alleen de besturing van haar organisatie, maar ook de werkverdeling. De STE was opgebouwd uit vijf afdelingen: Afdeling Toezicht Toegelaten Instellingen (TI); Toezicht Buitenbeurshandel (TB); Toezicht Markten (TM), Afdeling Juridische Zaken (JZ) en een beleidsafdeling Afdeling Beleid $^{319}$. In haar jaarverslag van 1997 gaf zij aan dat ze het erg belangrijk vond om het toezicht efficiënt uit te voeren. Deze interne structuurwijziging moest het streven van de STE naar een doelmatige uitvoering van haar toezichttaken in de toekomst verwezenlijken.

Naast de interne maatregelen om het toezicht beter uit te oefenen, trof deze toezichthouder ook externe maatregelen om zo haar toezichtstaak effectiever uit te oefenen. Zo meldde zij in haar jaarverslag van 1997 dat het gewijzigd. Besluit Politieregisters het voor haar mogelijk maakte om inzage in het politieregister te krijgen. Voordat zij het politieregister daadwerkelijk kon gebruiken, diende er eerst een convenant tussen de STE, de Minister van Financiën, de justitiële autoriteiten en de Verzekeringskamer te worden afgesloten. Naast de STE hield de DNB zich bezig met het toezicht op het effectenverkeer. Dat laatste was gebaseerd op de Wet toezicht Beleggingsinstellingen. Met de overgang naar een functionele toezichtsstructuur is her gedragstoezicht van DNB, dat was gebaseerd op voornoemde wet, overgeheveld naar de Autoriteit-FM en is al het prudentieel gerelateerd toezicht dat reeds door DNB werd uitgeoefend, een taak van DNB gebleven. Het gegeven dat de rechtsopvolger van de STE op het gebied van het gedragstoezicht een uitermate belangrijke rol toegekend heeft gekregen (welke zij in beginsel niet hoeft te delen met andere toezichthouders), heeft ertoe geleid dat in de hierna volgende paragrafen de nadruk wordt gelegd op haar toezichtsuitoefening. 


\subsubsection{Uitoefening van het toezicht: de STE en de Autoriteit-FM}

In de beginperiode van de STE was de heersende politieke opvatting dat haar toezicht marginaal moest zijn ${ }^{320}$. Immers, in het oude toezichtstelsel ${ }^{321}$ was er veel ruimte voor zelfregulering. De beurzen controleerden zelf de naleving van de door hen in het leven geroepen regels. De overheid was van mening dat de beurzen dan ook genoeg ruimte moesten overhouden voor zelfregulering. Deze mening werd niet lang door de overheid aangehangen, zij nam een andere houding aan. Vanuit het oogpunt van een welvarend Nederland, vond de overheid het noodzakelijk om een nieuw wettelijk kader te creëren. Dit deed zij via een algehele herziening van de effectenwetgeving. Deze herziening moest een goed functionerende effectenmarkt bewerkstelligen zodat de overheid en het bedrijfsleven hun financiering uit deze markten konden (blijven) betrekken. De overheid hoopte dat Nederland op deze manier een goede bekendheid als financieel centrum zou kunnen genieten ${ }^{322}$. Sinds de invoering van de Weh was duidelijk geworden dat de overheid zich distantieerde van haar ordenende houding en dat zij zich een regulerende houding aanmat. De Wte'92 demonstreerde de gewijzigde visie van de overheid op het toezicht.

Aan de uitoefening van het toezicht door de Autoriteit-FM, zoals dat vandaag de dag plaatsvindt, is een hele geschiedenis voorafgegaan. Niet alleen op het gebied van de interne regelgeving, maar zeker ook de externe regelgeving hebben bijgedragen aan de huidige wijze van toezichtuitoefening. Hieronder zal via deze regelgeving een beeld van de uitoefening van het toezicht door de STE en later de Autoriteit-FM worden geschetst. Verder zullen ook de toezichtsbevoegdheden van DNB worden weergegeven voor zover zij gedragsgerelateerd zijn. Dit om een zo volledig mogelijk beeld van het gedragstoezicht op het effectenverkeer weer te geven. Vanzelfsprekend beperkt de weergave van de gedragsgerelateerde toezichtsbevoegdheden van DNB zich tot de eerder genoemde wijziging van de toezichtsstructuur.

In haar jaarverslag van 1989 meldt de STE tevreden te zijn over het verloop van het toezicht op de zelfregulering van de beurzen. STE, Jaarverslag 1989, Amsterdam, mei 1990 , p. 6 .

Kamerstukken II, 1988/89, 21038,3, p. 2 - 4. (MvT) 


\section{De STE}

Op het gebied van de externe regelgeving, te beginnen mer de Wte"92 kon men vier toezichtgebieden onderscheiden, te weten: effectenuitgevende instellingen, effecteninstellingen, effectenbeurzen en misbruik van voorwetenschap en publieksmisleiding ${ }^{323}$. Voor een goede uitwoering van de Wet toezicht effectenverkeer was een solide samenwerking vereist tussen de toezichthoudende instanties op het gebied van het bestuursrechtelijk en het strafrechtelijk toezicht ${ }^{324}$. Het door de STE uitgeoefende toezicht richtte zich destijds zowel op de beurs - als op de buitenbeurshandel. Voor de invoering van de Wte' 92 mocht zij, op grond van mandatering, alleen toezicht op de effectenbeurzen uitoefenen. Met de inwerkingtreding van deze wet droeg de Minister van Financiën de meeste bevoegdheden ter uitvoering van de Wte' 92 over aan de STE. De bevoegdheden die niet aan haar werden overgedragen waren: de bevoegdheid tot beurserkenning, de bevoegdheid om vrijstellingen te verlenen en de bevoegdheid om de regels ten aanzien van beschermingsconstructies te beoordelen ${ }^{325}$. Op grond van de W'te'92 was er geen sprake meer van mandatering ${ }^{326}$, maar van delegatie ${ }^{327}$ van bevoegdheden.

323 Effectenuitgewende instellingen mogen alleen buiten een besloten kringen effecten bij uitgifte a anbieden in geval er een prospectus verkrijgbaar is dat voldoet an de wettelijke eisen. Effecteninstellingen zijn instellingen die effectenbemiddeling en individueel vermogensbeheer, kortom effectendiensten, aanbieden en witvoeren. Voor de effectenbeurzen geldt dat het houden ervan niet anders kan dan na erkenning van de Minister van Financiën. Her laarste roezichtgebied, misbruik van woorwetenschap en publieksmisleiding is pas in 1992 onder de Wte geplaatst. Handhaving integriteit effectenwezen, notitie en bijlagen, Ministerie van Financiën, 16 februari 1996, p. 2.

Handhaving integriteit effectenwezen, notitie en bijlagen, Ministerie van Financiën, 16 februari 1996, p. 3.

STE, Jaarverslag 1992, Amstelveen, april 1993, p. 9.

Bij mandatering krijgt een orgaan dan wel een ambtenaar de opdracht om een bepaalde bevoegdheid, beshuit te nemen en/of uit te voeren in nam en verantwoordelijkheid van het opdrachtgevend orgaan. Vgl. artikel 10:1 en 10:2 Awb: "Onder mandata word werstatan. de bevoegdheid om in naam van een besuursorgan beshiten te nemen." En "Een door de gemathateerde binnen de grenzen van zinn bewogedheid genomen beshit geldt als een beshit wan de mandaatgever.".

In geval van delegatie worden de oorspronkelijke (grondwettelijke) bevoegdheden tot het nemen van besluiten, welke reeds door middel van attributie aan een orgaan waren toegekend, overgedragen aan een ander orgaan. Dit laatste orgaan kan vervolgens zelfstandig over de gedelegeerde bevoegdheden beschikken en zo de bevoegdheid als "eigen" bevoegdheid uitoefenen. Delegatie van geattribueerde bevoegdheden is slechts mogelijk indien de grondwet daartoe de mogelijkheid 
In de door de STE vastgestelde nadere regeling toezicht effectenverkeer $1992^{328}$ (Nrte'92) gaf zij uitvoering aan haar bevoegdheid om de "open en algemene" normen van de Wte'92 en het Delegatiebesluit Toezicht Effectenverkeer nader in te vullen. Deze regeling gaf invulling aan:

- de wijze waarop het prospectus diende te worden ingedeeld en de periodieke informatie,

- de eisen betrefferde bet ëgen vernogen en de eigen widdelen wan effecteninstellingen,

- de eisen watraan de structur van een effecteninstelling noest voldoen ter voorkoming wan tegenstrijdigheid van belangen tussen de instellingen en diens cliënten of tussen de clïnten onderling de regeling dat de rekeningen van cliènten en de rekeningen wan de effecteninstelling gescheiden dienden te zijn,

- de inrichting stan de administratie van de effecteninstelling; de gedragsregels die binnen de effecteminstelling dienden te worden nagelegal en de aujze waarop de effectennota diende te worden gebanterd ${ }^{29}$.

Op grond van de W/te'92 werd de STE bevoegd om de op grond van deze wet verstrekken vergunningen te verlenen. Veel instellingen die onder de Weh waren vrijgesteld van de vergunningsplicht, kregen onder de Wte'92 ook vrijstelling ${ }^{330}$. De Wte'92 wijzigde de voorschriften die aan de vrijstellingen waren verbonden. De instellingen die niet aan de in de Wte" 92 gestelde eisen voldeden, kregen een jaar ${ }^{331}$ de tijd om zich aan te passen ${ }^{332}$. De STE was, op grond van de Wte' 92 , bevoegd om bij de onder deze wet vallende instellingen onderzoek te doen naar de naleving van die nieuwe wettelijke regels ${ }^{333}$. De invoering van de W'te' 92

biedt. Zo kunnen alleen (grondwettelijke) bevoegdheden worden gedelegeerd indien de grondwettelijke bepalingen de woorden: "bij of krachtens de wet"; "de wet regelt" dan wel "de wer stelt regels" bevat. Een voorbeeld hiervan is artikel 88 van de grondwet: "De wet regelt de bekendmaking en de inwerkingtreding van de wetten. Zij treden niet in werking voondat zij zijn bekendgemaakt." Vgl. de artikelen 10:13 Awb en verder: "Onder delegatie wordt verstatan: bet overdragen door eev bestutursorgaan wan zijn bevoegdheid tot bet nemen wan beshiten aln cen ander die deze onder eigen verantwoordelijkheid witoefent." Verder in 10:18 Awb: "Het bestuurrorgat kan de gedelegeerde bevoegdheid niet meer zelf witoefenen.". Vastgesteld d.d. 28 april 1992.

STE, jatarverslag 1991, Amstelveen, mei 1992, p. 14.

Bij vrijgestelde beursleden ziet de STE er voornamelijk op toe dat de voor deze leden geldende regels owereenkomt met de in de Nrte gestelde regels. STE, jaarverslag 1992, Amstelween, april 1993, p. 10.

Het aanpassen aan de vrijstellingsvoorschriften diende binnen een jaar na inwerkingtreding van de Wte" 92 te geschieden.

STE, jaarverslag 1991, Amstelveen, mei 1992, p. 14.

STE, jaarverslag 1992, Amstelveen, april 1993, p. 9-10. 
gaf haar ook de bevoegdheid om gegevens en inlichtingen aan effectentoezichthouders in het buitenland, en andere toezichthouders in Nederland te verstrekken ${ }^{334}$. Mede dankzij verdragen, waar de "Overeenkomst tussen het Koninkrijk der Nederlanden en de Verenigde Staten van Amerika inzake wederzijdse administratieve bijstand bij de uitwisseling wan informatie op het effectengebied" er een van is ${ }^{335}$, mocht de STE ook in de verdragslanden om inlichtingen vragen. In voornoemd verdrag, dat werd afgesloten met de Verenigde Staten, was bepaald dat er meerdere bevoegde toezichthouders waren.

\section{Artikel 1 .}

1. Voor de toepassing van deze Overeenkomst wordt werstaan onder:

a. Bevoegde Aucoriteit:

- voor bet Koninkrijk der Nederlanden, de Minister van Financiën of degene die daartoe door deze is angewezen.

- voor de Verenigde Staten van Amerika, de United States Securities and Exchange Commission (Commissie) of degene die daartoe door de Commissie is atangeuezen en andere door de Regering van de Verenigde Staten aangewezen autoriteiter.

Naast de STE zijn in het verdrag ook de Minister van Financiën en DNB bevoegd verklaard. Iedere toezichthouder mocht dezelfde bevoegdheden behouden die hij of zij reeds op nationaal niveau had. Zo bleef de uiteindelijke bevoegdheid om beurserkenningen en vrijstellingen te verlenen bij de Minister van Financiën. DNB behield, op grond van dit verdrag, het toezicht op beleggingsinstellingen en de STE behield de bevoegdheid om de overige belangen op het terrein van het effectenverkeer te behartigen ${ }^{336}$. Voorts is in het verdrag bepaald dat de Securities and Exchange Commission (SEC) de bevoegde toezichthouder in de Verenigde Staten van Amerika is. De Amerikaanse president heeft de

33 Te denken valt aan de toezichthouder op grond van de Wer Toezicht Kredietwezen: De Nederlandsche Bank en de toezichthouder op grond van de Wet Toezicht Verzekeringsbedrijf: de Verzekeringskamer. Mok, M.R., Toezicht effectenverker, TVVS, 1992, ni: 92/7, p. 176.

Verdrag wan 11 december 1989, Trb. 1990, 11 en Trb. 1992, 91. Daarnaast zijn er nog andere verdragen gesloten, bijwoorbeeld her met de Europese Lid-Staten afgesloten Verdrag inzake handel met woorkennis van 20 april 1989, Trb. 1994 , 158, inwerkingtreding 1 november 1994. Op 1 oktober 1991 trad het Protocol bij het Verdrag inzake handel met voorkennis van 11 december 1989, Trb. 1993, 112 in werking.

336 STE, jaaverslag 1992, Amstelveen, april 1993, p. 29. 
toezichthoudende bevoegdheden gedelegeerd aan de SEC, waardoor zij de toezichthouder op het gebied van het effectenverkeer is geworden ${ }^{337}$.

Op het gebied van de beurshandel hield de uitvoering van haar taken en bevoegdheden in, dat de STE moest nagaan of de beursregels - waaronder de modelcode ter voorkoming van misbruik van voorwetenschap ${ }^{338}$ werden nageleefd. Indien dit niet het geval was, trad zij in overleg met de beursleiding teneinde de overtreder ertoe te bewegen om de beursregels na te leven. Mocht blijken dat een overleg niet tot een voor de STE bevredigend resultaat leidde, kon zij - op grond van de Beurswet 1914 de beurs voorschriften geven ${ }^{339}$. Omdat de STE, vanwege de beperkte geldmiddelen, geen eigen opsporingsbevoegdheid en/of opsporingsmiddelen had, moest zij lange tijd voor de uitoefening van haar toezichtstaken gebruik maken van het controleapparaat van de beurzen; het controlebureau $(\mathrm{CB})^{340}$. Verder kreeg de STE de bevoegdheid om de

337 De SEC is de Amerikaanse federale toezichthouder van de beurs. Aan het hoofd van de SEC staat een commissie die uit vijf leden bestaat. Deze leden worden door de president van de Verenigde Staten, in overleg mer de Senaat, voor een periode van vijf jaar benoemd. Zie de internet page van de SEC d.d. 23-11-1998: http://www.sec.gov/asec/asecart.htm Meer over de SEC in hoofdstuk 3.

${ }_{338}$ De modelcode tot voorkoming misbruik van voorwetenschap bevat regels die het misbruiken wan voorwetenschap verbieden en waaraan beursgenoteerde instellingen zich moeten houden. Deze code is op 1 januari 1987 door de Vereniging voor de Effectenhandel $(\mathrm{V} v \mathrm{dE})$ ingevoerd en is van toepassing op alle instell lingen die zijn toegelaten tor de notering. Alworens deze instellingen tot de notering worden toegelaten, moeten zij de $V_{v d E}$ schriftelijk te kennen geven dat zij de inhoud van de modelcode respecteren en soortgelijke regelingen binnen het bedrijf zullen hanteren. Door de schriftelijke verklaring gaan de beursgenoteerde instellingen de verplichting aan om de regels van de code, behorende tor de beursregels, te allen tijde na te leven. Dat houdt in dat ook alle werknemers van deze instellingen aan de modelcode zijn gebonden en gecontroleerd kunnen worden op de naleving van deze regels. Bijlage IX bij het fondsenreglement VvdE, versic september 1992 en Cross, D.H. en Diephuis, J.H., De Amsterdamse effectenbeurs wit: de serie Bank-en Effectenrecht dl. 15, Kluwer B.V., Deventer, 1988, p. 57.

STE, Jaarverslag 1989, Amsterdam, mei 1990, p. 5.

340 Dit leidde destijds tot aanpassing van de statuten van de Vereniging voor de Effectenhandel ( $V$ wdE) waarin reeds was opgenomen dat de interne controle door het $\mathrm{CB}$ geschiedde. Het $\mathrm{CB}$ was, ter bewerkstelliging van een goede uitoefening van haar werkzaamheden, bevoegd om een onderzoek in te stellen gericht op zaken van een bepaald beurslid. Daarbij was het bevoegd om inlichtingen in te winnen over de bepaalde activiteiten van de beursleden. Tijdens een door het $C B$ ingesteld onderzoek werd nagegaan of de leden de statuten, reglementen en/of andere beursvoorschriften hadden overtreden. Dit onderzoek kon op verzoek van 
opneming van effecten, opties en termijncontracten in de beursnotering uit te voeren ${ }^{341}$. $\mathrm{Zij} \mathrm{kreeg}$ ook de bevoegdheid om het $\mathrm{CB}$ om alle informatie betreffende de gang van zaken op de beursvloer te verzoeken en om onderzoeken door het CB in te laten stellen ${ }^{342}$. De door de STE verrichtre controles waren altijd secundair en in die zin marginaal; alleen de inhoud van de beursregels en de naleving van deze regels stonden centraal. In deze periode trok de STE haar conclusies op grond van het door het $\mathrm{CB}$ verrichtte onderzoek ${ }^{343}$. Via controlerapporten die bij haar werden ingediend, kwam de STE er in 1989 achter dat de Wer persoonsregistratie (W $\mathrm{pr}$ ) de controlewerkzaamheden van het $\mathrm{CB}$ bemoeilijkte. De effecteninstellingen weigerden vrijwillig aan een $\mathrm{CB}$ onderzoek mee te werken. Volgens deze instellingen was de kans groot dat zij schadeclaims van hun cliënten konden verwachten wanneer zij de privé-gegevens van deze cliënten aan het $C B$ gaven. Door de $W_{p r}$ in te zetten probeerden de effecteninstellingen zelf te bepalen welke informatie zij aan het $C B$ gaven ${ }^{344}$. Dit alles frustreerde het toezicht en de controle op

de voorzitter van de $\mathrm{VvdE}$ worden ingesteld. Indien dit her geval was, werd er direct aan de voorzitter gerapporteerd. De voorzitter van de beurs kan alleen maar om informatie verzoeken indien her beursleden betreft. In de aangepaste sratuten van de VvdE werd vermeld dat de STE ook gebruik mocht maken van de diensten van her $C B$. In het geval het $C B$ voor de STE werkte, werd er niet aan de voorzitter van de VvdE, maar aan de STE verslag uitgebracht. Daarnaast rapporteerde het CB maandelijks aan de STE. In deze controlerapporten deelde het CB de STE mede welke besluiten het beursbestuur had genomen en welke beursreglementen waren aangepast. Daarnaast omvatte de controlerapporten de wijzigingen van het ledenaantal en onderzoeken betreffende mogelijke overtredingen van de beursregels. Cross, D.H., De regulering van de effecternhandel; recente antwikkelingen, TVVS, 1992, nr. 92/3, p. 63 en STE, Jaarverslag 1989, Amsterdam, mei 1990, p. 10.

34 In 1989 heeft de STE 169 fondsen toestemming gegeven om opgenomen te worden in de beursnotering. STE, Jaarverslag 1989, Amsterdam, mei 1990, p. 11. Indien de STE om een onderzoek yerzocht, hoefde het niet alleen beursteden te betreffen; her kon ook om de buitenbeurshandel gaan. STE, Jaarverslag 1989, Amsterdam, mei 1990, p. 5.

Van Nus noemt dit in haar dissertatie "voordeurcontroles". Hiermee maakt zij duidelijk dat de effecteninstellingen tijd rekten, door het $\mathrm{CB}$ niet verder dan de tot de "voordeur" van de instelling te laten komen. Het CB mocht namelijk niet zelf de stukken inzien, maar kreeg de stukken van de gecontroleerde instelling. Pas wanneer her $C B$ vermoedde dat het dossier niet volledig was, kon zij-met een door de STE formeel gegeven onderzoeksopdracht- de ontbrekende stukken inzien. Nus, J.G.L. van, Overheidstoezicht op afstand; verzelfstandiging van toezichthoudende taken naar zelfstandige bestuursorganen verkend; dissertatie RUL, MAKLU: lus Commune reeks, 1995, p. 617. 
de naleving door de beursleden van onder andere de modelcode tot voorkoming van misbruik van voorwetenschap. Mede omdat deze controles van belang waren voor de op 15 februari 1989 in werking getreden Wet strafbaarstelling misbruik van voorwetenschap (Wsmv), heeft de Minister van Financiën in de tweede $\operatorname{Nota}^{345}$ van wijziging van het voorstel van de Wte' $92^{346}$ maatregelen getroffen om deze frustratie te beëindigen ${ }^{347}$.

Zoals hiervoor is vermeld heeft de STE de bevoegdheid gekregen om op grond van de Wte'92 ook het toezicht op de buitenbeurshandel uit te oefenen. Dit toezicht richtte zich zowrel op "effectenuitgevende instellingen die buiten de beurs effecten bij uitgifte aanbieden" als op "effecteninstellingen die geen beurslid zijn en in of vanuit Nederland hun effectendiensten aanbieden of verrichten" ${ }^{1348}$. Het was deze instellingen niet toegestaan om zonder een vergunning actief te zijn in het effectenverkeer. Om voor een vergunning in aanmerking te kunnen komen moesten de instellingen aan diverse eisen voldoen waaronder de eis van betrouwbaarheid. Het gevolg was dat alle bestuurders en beleidsbepalende personen en/of personen die bevoegd waren de bestuurders te benoemen of te ontslaan, een betrouwbaarheidstoets moesten ondergaan. Voor deze toetsing gebruikte de STE niet alleen de door haar verzamelde informatie, maar ook wisselde zij informatie met andere toezichthouders uit. Zij kon bijwoorbeeld de ECD om een antecedentenonderzoek verzoeken en indien de STE tot de conclusie kwam dat de persoon niet betrouwbaar was, dan verleende zij hem geen vergunning of verklaring van geen bezwaar. In geval er reeds een vergunning was verleend, trok de STE de reeds verleende vergunning of verklaring weer in. Het ontbreken van beursregels in de buitenbeurshandel, zorgde ervoor dat de STE daar rechtstreeks toezicht hield. Bij het toezicht op de buitenbeurshandel

De Minister van Financiën heeft deze nota op 3 mei 1990 naar de Tweede Kamer gestuurd. In de nota wordt voorgesteld om de toezichthouder de bevoegdheid te geven om bij de ondertoezicht gestelden zowel inlichtingen te vragen als een onderzoek in te stellen. Hierdoor zou de toezichthouder effectiever kumnen controleren of er wel of geen aangifte van misbrük van voorwetenschap moet worden gedaan. STE Jaarverslag 1989, Amsterdam, mei 1990, p. 15.

De tweede nota is in artikel 21 Wte'92 opgenomen. STE, Jaarverslag 1990 , Amstelween, mei 1991 , p. $\mathbb{1} 1$.

STE, Jaarverslag 1989, Amsterdam, mei 1990, p. 10.

Handhaving integriteit effectenwezen, notitie en bijlagen, Ministerie van Financiën, 16 februari 1996, p. 3. 
zette zij de hiervoor genoemde CB"s van de beurzen in. Deze CB's handelden dan onder haar verantwoordelijkheid ${ }^{349}$. In haar jaarverslag van 1992 meldde de STE klachten te hebben ontvangen over buitenlandse effecteninstellingen die hun diensten zonder vergunning aan het Nederlandse publiek aanboden. Omdat deze buitenlandse effecteninstellingen de (effecten)wetgeving uit de (lid)staat van herkomst niet schonden ${ }^{350}$, kon de STE niet slagvaardig optreden. Daarnaast kon het desbetreffende land de handelingen van deze instellingen niet bestraffen. Om de beleggers enigszins te kunnen beschermen, restte de STE niets anders dan het publiek te waarschuwen tegen deze instellingen die vaak agressief te werk gingen $^{351}$. Op deze wijze trachtte de STE, in nauwe samenwerking met zowel de Economische Controledienst als het Openbaar Ministerie, het beleggend publiek alsnog te beschermen ${ }^{352}$. De bevoegdheden van de STE bleven niet beperkt tot het hiervoor genoemde. De Europese richtlijnen die zorgden voor een aanpassing van de Nederlandse effectenwetgeving droegen bij aan een vervanging van de Wte'92. Deze werd na drie jaar opgevolgd door de $\mathrm{W} / \mathrm{te}$ '95. Op grond van deze op 31 december 1995 in werking getreden wet en de hierbij behorende nadere regeling toezicht effectenverkeer 1995 (Nrte'95) heeft de Minister van Financiën de STE aangewezen om als bevoegde autoriteit uitvoering te geven aan de taken zoals omschreven in de richtijnen ${ }^{353}$.

Hoewel de introductie van de Wre'95 een verdere versterking van het toezicht op het effectenverkeer tot gevolg heeft gehad, behield de Minister bepaalde bevoegdheden ${ }^{354}$. De ten opzichte van de Wte'92 gevoerde

3.9 STE, jaarvershag 1991, Amstelveen, mei 1992, p. 15.

350 Immers, dergelijke handelingen waren in het land van herkomst niet strafbaar gesteld.

35. De agressieve werkwijze hield in dat de buitenlandse instellingen mensen opbelden en erg aantrekkelijke beleggingsvoorstellen deed. Vervolgens belden de instellingen de cliëncen op en zette hen vervolgens onder druk om maar zo snel mogelijk op de voorstellen te reageren. Zodra de instellingen her geld van hun cliënten hadden ontvangen, bleef er vaak weinig van de "aantrekkelijke" beleggingsvoorstellen over en dupeerden zij hun cliënten door spoorloos met het geld te verdwijnen. STE, jaarverslag 1992, Amstelveen, april 1993, p. 19.

35: STE, jatrverilag 1995. Amstelveen, april 1996, p. 19.

354 Bijwoorbeeld de bevoegdheid tot het erkennen van beurzen, het verlenen van vrijstellingen en de bevoegdheid tot het beoordelen en toepassen van regels voor beschermingsconstructies. STE, jatrterslag 1996, Amstelveen, april 1997, p. 8. 
wijzigingen lagen op het vlak van de bemiddeling in effecten en van vermogensbeheer $^{355}$. De Wte'95 gaf de STE de bevoegdheid om, als eindverantwoordelijke, vergunningen voor effectenbemiddeling en vermogensbeheer te verlenen en in te trekken. Bepaalde, onder de Wre"92 geldende uitzonderingen, vervielen onder de Wte' $95^{356}$. Het gevolg hiervan was dat deze effecteninstellingen onder de Wte'95 vergunningsplichtig waren geworden. Daarnaast werden ook de leden van erkende effectenbeurzen verplicht om een vergunning aan te vragen. Onder de Wte' 92 was dit immers niet vereist en hadden deze leden geen vergunning nodig. Met de inwerkingtreding van de Wre'95 mocht de STE, op basis van een kennisgeving van de desbetreffende beurs, de effecteninstelling een vergunning verlenen ${ }^{357}$. Een ander gevolg van de invoering van de Wte'95 was de aanwijzingsbevoegdheid van de toezichthouder. De STE kreeg niet alleen woor de beurshouder, maar voor alle effecteninstellingen en leden die onder de Wte '95 vielen, deze aanwijzingsbevoegdheid ${ }^{358}$. Daarnaast bevond zich in de Wte' 95 het verbod om zonder verklaring van geen bezwaar een gekwalificeerde deelneming ${ }^{359}$ in een effecteninstelling te houden, te verwerven of te vergroten. De verklaring van geen bezwaar werd door de STE onder bepaalde voorwaarden afgegeven $^{360}$. Indien de STE van mening was dat het afgeven van voornoemde verklaring

"zou leiden of zou kunnen leiden tot een invloed op de betrokken effecteninstelling die in strijd is met een prudente bedrijfswering van die instelling",

weigerde zij de afgifte ${ }^{361}$. Wanneer een bij een erkende beurs aangesloten effecteninstelling om een verklaring van geen bezwaar verzocht, dan

355 STE, jaarverslag 1994, Amstelveen, maart 1995, p. 17.

3\%.6. De regeling dat effecteninstellingen die uitsluitend met professionele wederpartijen handelden uitgezonderd waren varu de vergunmingsplicht, bleek in strijd te zijn mer de richtlijn beleggingsdiensten te zijn en is hierdoor komen te vervallen.

357 Deze kennisgeving wordt door de STE getoetst. STE, jaarverslag 1995, Amstelveen, april 1996 , p. 19.

358 Effecteninstellingen zijn instellingen die effectendiensten - effectenbemiddeling en individueel vermogensbeheer - aanbieden en verrichten. Handhaving integriteit effectenwezen, notitie en bijlagen, Ministerie wan Financiën, 16 februari 1996, p. 2.

359. Het gaat in dit geval om deellnemingen in her kapital of de zeggenschap van effecteninstellingen vanaf 5\%. STE, jaarverslag 1994. Amstelveen, maart 1995, p. 17 .

360 Te denken aan de eis van betrouwbaarheid.

361 STE, jaarverslag 1995, Amstelveen, april 1996, p. 19. 
besliste de STE pas na van de desbetreffende beurs een kennisgeving te hebben ontvangen over afgifte van deze verklaring ${ }^{362}$. Verder bepaalde de Wte'95 dat indien effecteninstellingen uit Nederland een "Europees paspoort" 363 zouden willen hebben; zij dit bij de STE moesten aanvragen. De STE lichtte vervolgens eerst de in het buitenland bevoegde toezichthouder in voordat de desbetreffende effecteninstelling haar diensten in het buitenland mag aanbieden ${ }^{364}$. De invoering van de Wte'95 heeft ook tot gevolg dat de STE niet meer afhankelijk was van de controlebureaus $^{365}$ van de beurzen. Zij stelde een eigen controleafdeling in ${ }^{366}$. Per 1 april 1996 vervulde de controleafdeling van de STE de taken en werkzaamheden die voor deze datum door het $\mathrm{CB}$ van de beurzen werden verricht ${ }^{367}$. Door de instelling van een eigen controleafdeling was de STE beter in staat om de werkzaamheden van de CB's van de beurzen te toetsen. Dit benadrukte de onafhankelijke positie van de STE als toezich thouder. De controleafdeling van de STE zorgde ervoor dat zij een andere werkwijze aannam. Ingeval zij onderzoek zou willen verrichten naar de activiteiten van een effecteninstelling welke niet tot de toegelaten instellingen ${ }^{368}$ van een beurs behoorde, kon de STE haar eigen controleafdeling inschakelen. Deze afdeling van de STE kon ook worden ingezet indien het onderzoek naar misbruik van voorwetenschap betrof. De reden hiervoor was gelegen in de exclusieve bevoegdheid van de STE orm misbruik van voorwetenschap te controleren. De inschakeling van een eigen

36: STE, fatroerlag 1995, Anstelveen, april 1996, p. 20.

363 Met het Europees paspoort hebben effectenbeurzen en beleggingsinstellingen die reeds een vergunning hebben onrvangen van een Europese (lid)stat (bijvoorbeeld Nederland), onder gelijke woorwaanden als de instellingen die in een andere lidstat van de Europese Economische Ruimte (bijwoorbeeld Duitsland) actief zijn, toegang tot de gereglementeerde markt en tot de clearings-en afwikkelingsstelsels van dat land.

364 STE, jatwershog 1995, Amstelveen, april 1996, p. 20.

365 Het controlebureau is de interne toezichtorgaan van de beurzen. De beperkte geldmiddelen dwong de STE er in het verleden toe, om voor de uitoefening van hatar toezichtstaken gebruik van het controleapparaar van de beurzen, het controlebureau in re schakelen.

\$6r Het principe van functiescheiding tussen toezichthouder en ondertoezich gestelden \eidde in 1996 tot een eigen controleafdeling. Handhaving integriteit effectenwezen, notitie en bijlagen, Ministerie van Financiën, 16 februari 1996, p. 5.

367 STE, jaamershg 1995, Amstelveen, april 1996, p. 18.

369 Sinds de fusie van de beurzen op 1 januari 1997, spreekt men niet meer ower "beursleden", mar over "toegelaten instellingen". Zie hoofdstuk 1, paragraaf 6. 
controleafdeling heeft tot gevolg gehad dat het $\mathrm{CB}$ van de beurs alleen nog maar toezicht mocht houden op het juiste verloop van de handel in effecten; de naleving van de beurseigen regels ${ }^{369}$.

Verder heeft de Wte'95 er toe geleid dat de bevoegdheden van de STE om naleving van de wettelijke bepalingen te controleren, werden uitgebreid. Uit artikel 29 lid 2 Wte"95 jo artikel 5:15 Awb kon worden afgeleid dat de STE als toezichthouder zelfs een (opsporings) bevoegdheid had gekregen.

\section{Artikel 5:15 Awb}

1. Een toezichthonder is betoegd, met medeneming wan de benodigate apparatur, elke plaats te betreden met witzondering van een woning zonder toestemming van de bewoner:

2. Zo nodig verschaft bij zich toegang met behulp wan de sterke arm.

3. (...)

Tot slot nog enkele opmerkingen over de stille curator, de publicatie van aanwijzingen en de uitsluiting van een accountant. Per 1 februari 1999 werd de STE op grond van artikel 28 lid 4 onder a Wte' 95 bevoegd om, indien zij dit nodig acht omdat de Wte'95 is overtreden, een stille curator aan te stellen. Dit hield in dat indien de STE dat nodig achtte, zij ertoe kon overgaan om vanaf een bepaald tijdstip alle of bepaalde organen van de betreffende instelling de mogelijkheid te geven om alleen dan hun bevoegdheden uit te kunnen oefenen na goedkeuring te hebben ontvangen van een of meer door de STE aangewezen personen en met inachtneming van de opdrachten van deze personen ${ }^{370}$. Daar deze curatele niet wordt gepubliceerd, spreekt men over een "stille curatele". Redenen om een dergelijk figuur in te zetten zouden kunnen zijn: het niet reageren op een aanwijzing waardoor het gezien de adequate functionering van de effectenmarkten dan wel gezien de positie van de beleggers op voornoemde markten noodzakelijk is geworden om een stille curator aan te stellen. Let wel, niet altijd hoefde een aanwijzing aan een ondercuratelestelling vooraf te gaan ${ }^{371}$. Volgens haar jaarverslag 2000 had de STE reeds gebruik gemaakt van deze bevoegdheid ${ }^{372}$. Verder

369 Handhaving integriteit effectenwezen, notirie en bijlagen, $a_{n} u n$, p. 10.

${ }^{370} \mathrm{Vgl}$. artikel 28 lid 4 onder a jo 40 Wre $^{\prime} 95 \mathrm{j}^{\circ} 2$ Overdrachtsbesluit Wte' 95.

${ }^{371}$ Volgens artikel 28 lid 6 Wte 95 kan een ondercuratelestelling onverwijld geschieden.

${ }^{372} \mathrm{STE}$, jaarverslag 2000 , Amstelween, april 2001 , p. 16. 
kon de STE op grond van hetzelfde lid artikel 28 Wte'95, maar dan onder $b$ een aanwijzing publiceren. Naast bovengenoemde bevoegdheden, mocht de STE op grond van de Wre een accountant bannen of uitsluiten. Deze bevoegdheid was gebaseerd op grond van artikel $28 \mathrm{~b}$ Wre'95. Dit artikel gaf de STE de bevoegdheid om een accountant of om meerdere individuele accountants te beletten om in de desbetreffende zaak een accountantsverklaring af te geven door de desbetreffende daartoe onbevoegd te verklaren. Dit, omdar zij bijwoorbeeld niet meer aan de benodigde vereisten voldeden die in het kader van een door hen verricht onderzoek waren vereist.

De STE was niet alleen op grond van de Wre'95 toezichthouder, maar ook op grond van de Wmz. Als zelfstandig bestuursorgaan was zij al in een vroeg stadium, reeds in de fase van een voorontwerp, actief met deze wet omdat dit haar bevoegdheden raakte. In deze fase bracht de STE, op verzoek van de Minister, advies uit over het wetsvoorste ${ }^{373}$. Ter uitvoering van de W'mz'92 had de STE een geautomatiseerd systeem opgezet dat de verwerking en de toegankelijkheid van gegevens moest verbeteren. Daarnaast richtte de STE zich voor de uitvoering van deze wet, op de noemergegevens ${ }^{374}$ van die vennootschappen die onder de W/mz vielen. De W/mz'92 gaf de STE niet de bevoegdheid om noemergegevens bij de meldingsplichtigen op te vragen. $\mathrm{Zij}$ kon wel via het fondsenreglement en de noteringsovereenkomst met de VvdE aan deze gegevens komen $^{375}$. De afdeling noteringen van de VvdE hield deze noemergegevens namelijk met behulp van een databank bij. Veranderingen van voornoemde gegevens moest deze afdeling aan de STE doorgeven $^{376}$. De STE maakte met de ECD de afspraak om de overtredingen waar zij kennis van droeg aan de $\mathbb{E C D}$ door te geven. Deze afspraak leidde tot diverse processen-verbaal ${ }^{377}$. Op grond van de Wmz'92 bleef het voor de STE moeilijk om inzicht te verkrijgen in zowel de verdeling van het kapitaalbelang als in de verdeling van het stemrecht van de genoteerde vennootschappen. De invoering van de $\mathrm{W} / \mathrm{mz} z^{2} 96$ zorgde

STE, jaarverslag 1989, Amsterdam, mei 1990, p. 15.

Noemergegevens zijn gegevens over her geplaatste kapitaal van de meldingsplichtigen.

STE, jatrwershg 1991, Amstelveen, mei 1992, p. 16.

Onder de meldingsplichtigen bescond onzekerheid over het wel of niet melden aan de STE wanneer men bijvoorbeeld terug wiel in een andere bandbreedre. STE jatrwerslag 1992, Amstelveen, april 1993, p. 20.

STE, jaarwerslag 1992, Amstelveen, april 1993, p. 22. 
uiteindelijk voor meer duidelijkheid. Op grond van het Delegatiebesluit Wet Melding Zeggenschap werd de uitvoering van de Wmz aan de STE opgedragen $^{378}$. Zoals reeds in paragraaf 2.3.1 is opgemerkt, wijzigde de W/mz'96 de openbaarmakingsplicht. De STE werd hiermee belast. Het voordeel hiervan was dat de kenbaarheid van de meldingen werd verhoogd. De vennootschap mocht nu niet meer kiezen tussen het publiceren van de inzageplaats van de vennootschapsgegevens en het openbaar maken van deze gegevens als zodanig ${ }^{379}$. De STE bezigde een vaste openbaarmakingprocedure ${ }^{380}$. Door deze procedure mocht zij het nalaten om bij verschillende dagbladen naar een eventuele melding te informeren. $\mathrm{Zij}$ had immer kennis van de inhoud van de melding daar zij zelf voor de publicatie van de melding moest zorgdragen. Dit leidde ertoe dat de STE het gedelegeerde toezicht efficiënter kon uitoefenen en dat de advertentiekosten konden verminderen ${ }^{381}$ " De openbaarmakingprocedure had ook tot gevolgd dat de kans op een foutieve openbaarmaking werd verkleind doordat de STE de openbaarmaking verzorgde. Daarnaast maakte zij alle ontvangen meldingen meteen aan de desbetreffende vennootschap bekend. Hierbij meldde zij haar voornemen tot openbaarmaking van de melding. Op deze manier kon de vennootschap nagaan of melding die zij had ontvangen gelijk was aan de melding die ze van de meldingsplichtige aandeelhouder had gekregen ${ }^{382}$.

378 Kamerstukken II, 1995/96, 24626, nr. 3, p. 1 (MvT)

379 Kamerstukken II, 1995/96, 24626, nr. 3, p. 7 (MvT)

380 Artikel 7 lid 2 W'mz'96 bepaalt dat de STE pas na vijf dagen en binnen negen dagen na verzending van de mededeling aan de desbetreffende vennootschap, tot openbaarmaking mocht overgaan. De STE kon de melding openbaar maken door "in een in de betrokken lid-staat landelijk werspreid" dagblad te publiceren. Mocht de vennootschap binnen deze periode schriftelijk verzoeken om de openbaarmaking achterwege te laten, kon de STE oordelen of openbaarmaking in strijd met het algemeen belang zou zijn. Dit kon tot gevolg hebben dat de STE niet tot publicatie over zou gaan. Ook ingeval publicatie ertoe zou leiden dat "' de vennootschap daardoor erwstig naded zou kunnen onderwinden en bet achterwege blijuen van de openbaamaking niet kan (kon) Leiden tot misleiding van hat publiek met betrekking tot feiten en omstandigheden die voor de beoordeling van de door de vennootschap witgegeven anndelen wan wezenlijk belang (zouden) zijn", mocht de STE dit achterwege laten. Artikel 7 lid 3 Wmz'96.

3\$1 Dat kwam doordat de over de vennootschappen omgeslagen advertentiekosten lager uitkwamen doordat de STE zelf voor de publicatie moest zorgen. Zive Kamerstukken II, 1995/96, 24626, nr. 3, p. 3. (MvT)

Kamerstukken II, 1995/96, 24626, ni. 3, p. 3. (Mv T) 
De overgang naat een ander financieel toezichtsmodel heeft niet alleen de bekende naamswijziging van de STE naar de Autoriteit-FM tot stand gebracht, maar ook een wijziging in bevoegdheden veroorzaakt. Deze zullen - voor zover zij passen binnen het kader wan deze studie - nader worden besproken.

\section{De Autoriteit-FM}

Vanaf haar oprichting tot de statutaire wijziging op 1 maart $2002^{383}$, heeft de STE een enorme groei doorgemaakt. Deze groei is niet alleen terug te vinden in een wijziging van de organisatiestructuur of in het aantal medewerkers, maar zeker in de omvang van de haar toegekende taken en bevoegdheden waar hiervoor al meermalen naar is verwezen. Zo begon zij in 1989 met drie medewerkers en had zij er in 2001 reeds 189 in dienst $^{384}$. Het is niet onwaarschijnlijk dat dit aantal zal toenemen daar de toekenning van meer taken en bevoegdheden en de hieraan voorafgaande wijziging in toezichtsstructuur, de inzet van meer mankracht van de toezichthouder vereist. Wat de organisatiestructuur betreft is er sinds de oprichting van de STE veel veranderd. Deze veranderingen waren en zijn inherent aan de toename van toezichtstaken en bevoegdheden en natuurlijk aan een wijziging in het "denken over de uitoefening van het toezicht". Ten tijde van de instelling van de Stichting AutoriteitFM beschikte deze toezichthouder over negen sectoren bestaande uit toezichtssectoren met daaraan gekoppelde ondersteunende sectoren. De toezichtssectoren te weten: de Primaire markt ${ }^{385}$, Secundaire markt ${ }^{386}$,

383 Vgl. artikel 1 van de gewijzigde statuten Autoriteit-FM.

38 Auroriteit-FM, jaarverslag 2001, Amstelveen; maart 2002, p. 39.

385. Deze sector oefent het toezichr uit op de verhouding tussen kapitaalvragers en de beleggers. Daarnaast oefent zij ook her toezichr uit op de primaire buitenbeurshandel en her dagelijks toezicht op de openbare biedingen op effecten.

Vlg. hutp://www.Autoriteit-FM.nl (mei 2002)

s* Deze sector dient ervoor te zorgen dat de financiële markten adequaar (blijwen) functioneren. Zo dient zij niet alleen toezicht te houden op de beurzen, maar ook op het marktpersoneel en moet zij acht slaan op alle handelingen die een potentiäle bedreiging kunnen zijn woor het goed functioneren wan woornoemde markten. Vgll hrtp://www.Autoriteit-FM.nl (mei 2002) 
Instellingen ${ }^{387}$ en de sector Handhaving \& Integriteit ${ }^{388}$ werden volgens het organogram van de Autoriteit-FM onder meer ondersteund door de sectoren Strategie ${ }^{389}$, Juridische Zaken ${ }^{390}$, Informatisering ${ }^{391}$, de sector $\mathrm{BCC}$ of de sector Bestuursondersteuning, Communicatie en Control ${ }^{392}$ en tot slot de sector Human Resources en Facilitair Bedrij $\mathrm{P}^{393}$. Bepaalde

387 Deze sector houdt de relaties tussen het (beleggend) publiek en de intermediairs in het oog. Dit doet zij door bijvoorbeeld vergunningen voor intermediairs af te wijzen, te verstrekken of juist in te trekken. Vgl. hrtp://www.Autoriteit-FM.nl (mei 2002)

38a De sector Handhaving en Integriteir heeft de raak gekregen toezicht te houden op ongeoortoofde aanbiedingen van effectendiensten; her uirvoeren van onderzoelken naar de betrouwbarheid wan bestuurders en beleidsbepalers van effecteninstellingen; het uitvoeren van wervolgonderzoeken waar een strafrechtelijke afdoening wordr beoogd en die reeds door andere sectoren van de Autoriteit-FM in kaart zijn gebracht; het eventweel doen van aangifte indien een strafrechtelijke afdoening wordt beoogd; her maken van duidelijke afspraken met her OM, de FIOD en de ECD voor wat betreft de keuze tussen een bestuurstechtelijke en een strafrechtelijke afdoening; verder heeft deze sector het bewaken wan de strafrechtelijke afhandeling en de voortgang van voornoemde onderzoeken tot taak. Zie http://www.Autoriteit-FM.nl. (mei 2002). Zie ook STE, jaarverslag 2000, Amstelveen, april 2001, p. 32 .

349 De sector heeft de verantwoordelijkheid over onder andere de interpretatie van wergeving. Dit geschiedt door de afdeling Beleid. Deze afdeling is ook belast met de opstelling van nieuwe regels van de Autoriteit-Fm en heefr een adviserende rol bij nieuwe wet- en regelgeving. Daarnaast bestaat deze sector ook uit de afdeling Research en de afdeling Internationaal Secretariaat. Deze houden zich respecricvelik bezig met onderzoek naar de doeltreffendheid en doelmatigheid wan het toezicht en de bijbehorende regelgeving. Vgl http:/www.Autoriteit-FM.nl (mei 2002)

390 Deze sector, die zoals de naam al suggereert, verantwoordelijk is woor de juridische en bestuurlijke kanten van de Autoriteit-FM, handelt de bezwaarschrifren en eventuele beroepschriften af en bereidt de uitwoering van de boetes en de last onder dwangsom voor. Daarnaast zorgt de sector Juridische zaken er ook voor dat zowel national als international informatie wordt uitgewisseld. Zie http:// www.Autoriteit-FM.nl ( mei 2002)

391 Deze sector houdt zich voornamelijk bezig met de geautomatiseerde informatievoorziening binnen de Autoriteit-FM. Vgl. hotp://www.Autoriteit-FM.nl (mei 2002)

392 Deze sector bestaat uit vier afdelingen die samen zorgdragen voor een specifieke ondersteuning wan het bestuur en de organisatie. Voornoemde ondersteuning heeft betrekking op het communicatiebeleid van de Autoriteit-FM, zowel intern als extern, de planning en concrol, en de financiele administratie. Vgl. http:// www.Autoriteit-FM.nl (mei 2002)

$3 \% 3$ Deze sector richt zich op (de aanstelling van) het personeel van de Auroriteit-FM. Vgl. http://www.Autoriteit-FM.nl (mei 2002) 
sectoren waren onderverdeeld in afdelingen of accounts. Een voorbeeld hiervan was de sector Primaire markt die beschikte over een afdeling Emissies en Periodieke informatieverschaffing, een afdeling openbare biedingen op effecten en een afdeling Financiële verslaggeving ${ }^{394}$. Het organogram bevat ook de zogenaamde compliance officer welke los staat van de overige sectoren en die direct rapporteert aan het bestuur. Hieronder het organogram van de Autoriteit-FM zoals het 2001 werd ingevoerd $^{395}$. Zeer waarschijnlijk zal de structuur van de Autoriteit-FM, door de toename en wijziging van taken en bevoegdheden, binnenkort moeten worden gewijzigd ${ }^{396}$.

De overgang van de Stichting Toezicht Effectenverkeer naar de Stichting Autoriteit Financiële Markten, heeft aan de reeds bestaande toezichtstaken die gerelateerd konden worden aan het gedrag van de onder toezicht staande instellingen, weinig veranderd. Deze toezichtstaken zijn nagenoeg geruisloos overgegaan naar de Autoriteit-FM. Zoals de Autoriteit-FM het zelf stelt:

"Als toezichthouder bliff ons vizier gericht op het tegengatan van marktimperfecties en onrechtvaardigheid. Wij moeten die doelen op een zodanige manier nastreven dat de discipline van de markt haar werk kan blijven doen. Drie begrippen staan daarbij centrat: discipline, level playing field en transparantie.

Naast de bestaande gedragstoezichtstaken heeft een uitbreiding van bevoegdheden plaatsgevonden. De Autoriteit-FM heeft bepaalde toezichtstaken van een andere financiële toezichthouder overgenomen. Zo

394 Vlg. de website wan de Autoriteit-FM: http:/www.Autoriteit-FM.nl (mei 2002)

305 Vlg. STE, jaarverslag 2000, Amstelveen april 2001, p. 33 en de website van de Autoriteir-FM: http://www.Autoriteit-FM.nl (mei 2002)

$396 \mathrm{Vgl}$. Eisma in her NJB, nr $41 \mathrm{jrg}$. 77. Eisma geeft in dit artikel aan dat her gehele Nederlandse effectentecht vanwege de uniformering van her recht en van de prakrijk binnen Europa "gerenoveerd" zal moeten worden. Eisma, S.E., "De verbouwing van het Nederlandse effectenrechr", NJB, 15 november 2002, jig. 77. Zie verder een redactieartikel in her NRC Handelslad van 15 nowember 2002, "Regels voor herstel marktwertrouwen", waarin wordt gerneld dat de AutoriteitFM, meer toexichtstaken toebedeeld zal krijgen.

397 Autoriteit-FM, jaarverslag 2001, Amstelveen, maart 2002, p. 7. Her begrip level playing field omvar een door de overheid te creëren speelveld - all dan nier door her scheppen wan een wettelijk kader; van randwoorwaarden - waar bedrijven met elkaar kunnen concurreren. Hierbij moet rekening worden gehouden met de verschillende concurrentieposities van bedrijven. 
zal de Autoriteit-FM ook het gedragstoezicht uitoefenen over de verstrekking van consumentenkredieten. Zij is namelijk de verantwoordelijke toezichthouder geworden voor de uitvoering van de Wet op het consumentkrediet (Wck); een bevoegdheid die voorheen door DNB werd uitgeoefend. Daarnaast oefent zij ook het gedragstoezicht uit over beleggingsinstellingen en ziet er op toe dat de gedragsregels bij de banken conform de wettelijke regels zijn. Hetzelfde geldt voor het gedragstoezicht op bepaalde pensioenfondsen en verzekeraars ${ }^{398}$. Let wel, de AutoriteitFM heeft slechts de bevoegdheden van DNB en de PVK overgenomen die passen binnen het kader van de uitoefening van haar taken als gedragstoezichthouder. Zo hebben de DNB en de PVK bevoegdheden behouden die gerelateerd kunnen worden aan het prudentiële toezicht, waaronder de administratieve organisatie van onder toezicht staande instellingen; de solvabiliteit en de liquiditeit van deze (rechts) personen. Verder heeft de Autoriteit-FM de uitvoering van het toezicht op de financiële bijsluiter toegekend gekregen. $\mathrm{Zij}$ dient er op toe te zien dat er een zodanige informatieverstrekking van de aangeboden financiële producten plaatsvindt, dat de potentiële consumenten over de belangrijkste kenmerken van het financieel product kunnen beschikken ${ }^{399}$. Naast al deze bevoegdheden heeft de Autoriteit-FM - voor wat het gedragstoezicht betreft ook het alleenrecht verkregen op de uitvoering van de wet melding ongebruikelijke transacties (Wet mot) en de Wet identificatie bij dienstverlening 400 .

Dat de Autoriteit-FM bij de witoefening van haar taken de bescherming van de (financiële) consument hoog in haar vaandel heeft geschreven, blijkt onder meer uit de uitoefening van het toezicht over de eerder genoemde financiële bijsluiter waaraan alle aanbieders van (complexe) financiële producten moeten voldoen.

Zoals eerder naar voren is gekomen, is het niet onwaarschijnlijk dat de wetgever de Autoriteit-FM in de toekomst meer bevoegdheden zal toekennen. Immers, haar toezichtstaken zijn niet alleen beperkt tot her Nederlands effectenverkeer, maar reiken over het geheel van de 
Nederlandse financiële markten. Het bestuur van de Autoriteit-FM heeft dit in het jaarverslag van 2001 als volgt verwoord:

"In de talakontwikkeling wan de Autoriteit-FM past ook het toezicht op de financiële werslaggeving, de heraiening en de witbreiding van de Wet melding zeggenschap in ter beurze genoteerde vemnootschappen 1996, de berijking van bet toezicht op de primaire markt, de tweede fase van het toezicht openbare biedingen op effecten, en corporate governance.

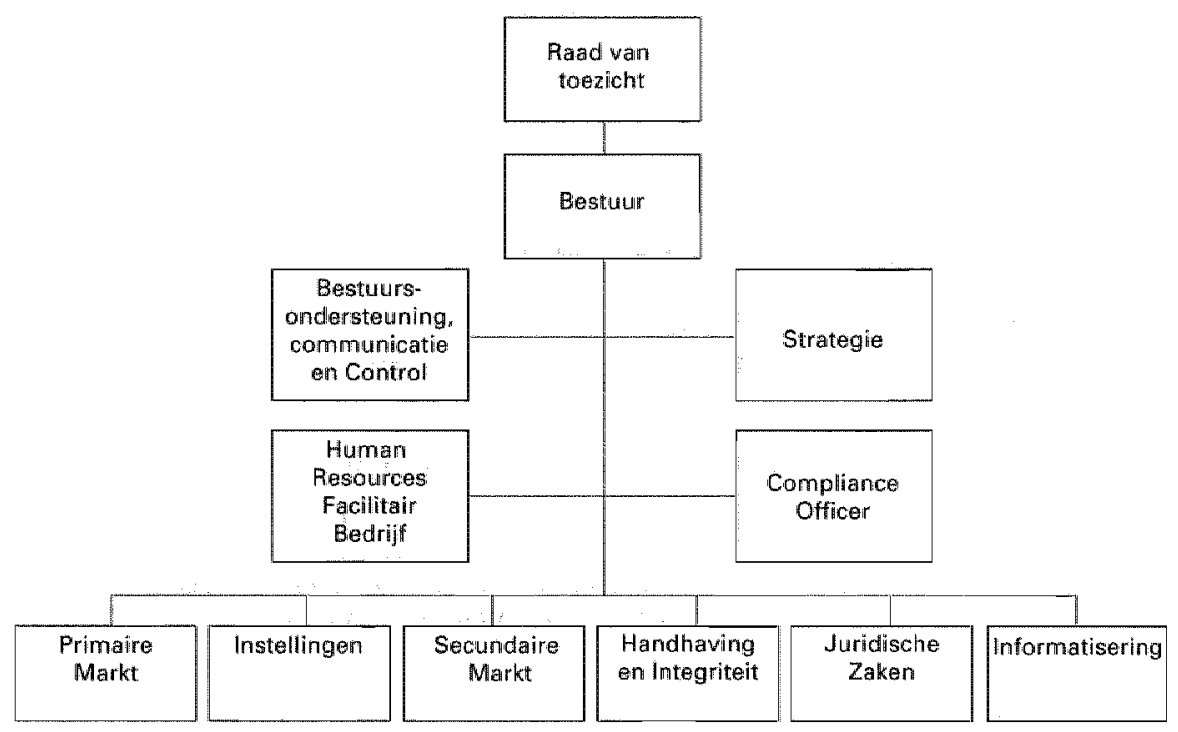

\section{FIGUUR 2.3 Organggram Antorteit-FM}

bron: jatatserslag STE 2000 end de website wan de Antoniteit-FM mei 2002.

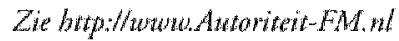

Daarnaast heeft deze toezichthouder al via de media te kennen gegeven ook over de bevoegdheid te willen beschikken om wederrechtelijk verkregen voordeel te ontnemen ${ }^{402}$. Deze bevoegdheid behoort in ons land niet toe aan een administratief bestuursorgaan, maar aan het Openbaar Ministerie. Het Openbaar Ministerie kan deze strafrechtelijke maatregel slechts via de strafrechter aan een (rechts)persoon opleggen

401 Autoriteit-FM, jaarverslag 2001, Amsrelwaen, maart 2002, p. 8 .

402 Vgl. het interwiew in het NRC-Handelsblad met de voorzitter wan de AutoriteitFM, Docters van Leeuwen, "Hebzucht is een belangrijke menselijk aandrift; het groeiende onbehagen van Arthur Docrers van Leeuwen", NRC Handelsblad, 9 maart 2002. 


\begin{tabular}{|c|c|c|}
\hline Mtrity & 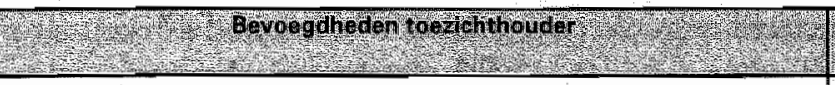 & 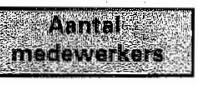 \\
\hline 1989 & $\begin{array}{l}\text { N.a.w. de Beurswet } 1914 \text { : met behulp van de CB's van de beurzenn, } \\
\text { toezicht op de beurzen uitoefenen; daamaast beslissan ower een } \\
\text { eventuele toelating van effecten tot de natering. }\end{array}$ & 3 \\
\hline 1990 & Idem & 5 \\
\hline 1991 & Idem & 6 \\
\hline 1992 & $\begin{array}{l}\text { N.a.v. Wte' } 92 \text {; marginaal toezicht beurshandel, integraal toezicht op } \\
\text { buitembeurshandel; Overhevelen van artikelen inzake misbruik wan } \\
\text { woorkennis naar de Wte. N.a.v. Wmz" } 92 \text {; toezicht uitoefenen. }\end{array}$ & 9 \\
\hline 1993 & Idem & 12 \\
\hline 1994 & Idem & 13 \\
\hline 1995 & Idem & 13 \\
\hline 1996 & $\begin{array}{l}\text { N.a.v. de Wte'95: ook aan beursleden wergunningen verlenen; invoeren } \\
\text { van een verklaring van geen bezwaarprocedure; STE heeft nu meor } \\
\text { bevoegdheden bij de bestrijding van misbruik van voorwetenschap. } \\
\text { N.a.y. Wmz'96. toezicht uitoefenen en de openbaarmakingsplicht van } \\
\text { meldingen. }\end{array}$ & 17 \\
\hline 1997 & $\begin{array}{l}\text { idem aan } 1996 \text { maar nu spreakt men niet van beursleden maar van } \\
\text { toegelaten instellingen } A E X \text {. }\end{array}$ & 43 \\
\hline 1998 & Idem & \pm 55 \\
\hline 1999 & $\begin{array}{l}\text { O.g.w. de herijking Wte'95 staan alle effecteninstellingen, zowel de } \\
\text { toegelaten als de niet toegelaten instellingen, onder toezicht vam de STE. } \\
\text { Hiermee is de zelfregulering van de AEX op de toegelaten instellingen } \\
\text { in het algemeen beeindigd. Verder op grond van de Wte" } 95 \text { bevoegheid } \\
\text { tot het instellen van een stille curator; uitsluiten van een accountant; } \\
\text { uitvoering Nrte'99; bevoegdheid om doorhaling van registratio } \\
\text { cliëntenremisier indien twifel aan betrouwbaarheid; } \\
\text { vergunningvertening voor een alternatief handelssystem. }\end{array}$ & 90 \\
\hline 2000 & 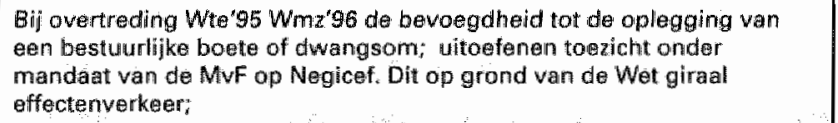 & 139 \\
\hline 2001 & $\begin{array}{l}\text { STE H. p de Sociaal Economische Raad de bevoegde toezichthouder op } \\
\text { openbare biedingen in Nederland. }\end{array}$ & 189 \\
\hline 2002 & 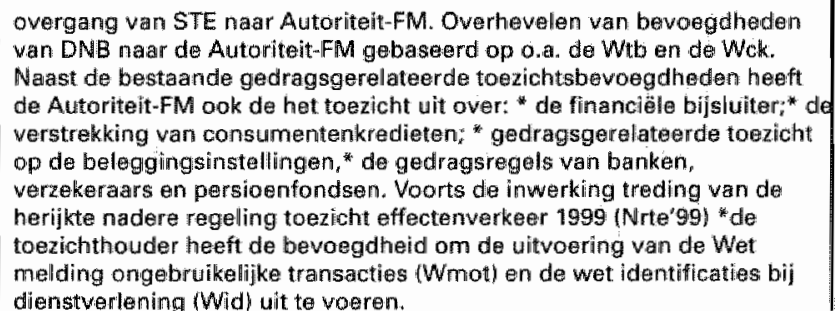 & $* 403$ \\
\hline
\end{tabular}

\section{FIGUUR 2.4 Eexn overzicht van bevoegdheden van de STE dan wel de Antoriteit-FM} Gebaseerd op een schema van mr. K. Werkhorst, werkzaam bij het Ministerie van Financièn in 1998

403 Ten tijde van de afsluiting van dit onderzoek waren deze cijfers nog niet bekend. Deze zullen in het jaarverslag van 2002 worden gepubliceerd. 
die is veroordeeld wegens een strafbaar feit, indien dit in een afzonderlijke rechterlijke beslissing geschiedt ${ }^{404}$. Zoals we in het volgend hoofdstuk zullen zien, kan de Amerikaanse evenkie van de Autoriteit-FM wel over voornoemde bevoegdheid beschikken. Let wel, de bevoegdheden van de Amerikaanse toezichthouder kunnen niet één op één met de bevoegdheden van de Autoriteit-FM worden vergeleken. Meer hierover in de algemene inleiding, hoofdstuk drie en in het vierde hoofdstuk. Voor een overzicht van de bevoegdheden van de STE en de Autoriteit-FM, zie figuur 2.4.

\subsubsection{Uitoefening van het toezicht: De Nederlandsche Bank N.V.}

Eerder is vermeld dat de Wet toezicht beleggingsinstellingen (Wtb) tot doelstelling heeft een betrouwbare en zo transparant mogelijke bankwereld te creëren. In tegenstelling tot de Wte en de Wmz was in beginsel in de W/tb niet de STE, maar DNB tot de bevoegde toezichthouder aangewezen. Daarnaast was DNB ook toezichthouder krachtens andere wetten, te weten: de Wet Toezicht Kredietwezen 1992 (Wtk'92) en de Wet inzake de Wisselkantoren (Wwk).

De herziening van het toezichtsmodel, een nieuwe toezichtsstructuur, heeft tot gevolg gehad de DNB vandaag de dag het prudentieel toezicht uitoefent over de financiële instellingen. Zoals reeds naar voren is gekomen, omvat het prudentieel toezicht onder meer het controleren van de financiën van een (rechts)persoon met als doel de financiële consument, in casu de belegger, te beschermen tegen partijen die niet aan hun verplichtingen zullen kunnen voldoen wanneer zij niet langer over de vereiste solvabiliteit beschikken. In deze studie wordt de nadruk niet gelegd op de solvabiliteit, en dus het prudentieel toezicht, maar op de wijze waarop de gedragstoezichthouder haar taken uitoefent. Dit maakt een nauwkeurige beschrijving van de organisatie van DNB overbodig. Desondanks zal hieronder ter wille van de volledigheid in grove lijnen een beeld van DNB worden geschetst voor zover zij betrekking heeft op het gedragstoezicht van effectengerelateerde (rechts) personen.

De organisatie van DNB is in 2000, een periode waarin zij nog als gedragstoezichthouder fungeert, als volgt. Het is onderverdeeld in een directie en in verschillende directoraten. In de directie hebben de 
president van de Nederlandsche Bank en de directeuren van de voornoemde directoraten zitting. Onder de directie zijn er drie directoraten, te weten: het directoraat toezicht, het directoraat monetaire zaken en het directoraat betalingsverkeer en intern bedrijf. De directoraten zijn weer onderverdeeld in verschillende afdelingen. Deze worden ook wel (sub)sectoren genoemd. Voor dit onderzoek zou het directoraat toezicht een belangrijke rol kunnen spelen ware het niet dat de wijziging van het toezichtsmodel in 2002 deze gedachte heeft doorkruist. In de periode voor de wijziging van het toezichtsmodel waren er voor de uitvoering van het toezicht door DNB verschillende secties. Deze hielden zich onder meer bezig met het toezicht op de grote internationale instellingen; het toezicht op de strategie, het beleid en de voorzieningen van zowel binnenlandse als buitenlandse banken en tot slot een sectie die zich bezig hield met de uitvoering van de Wtb en de W/wk. Laatstgenoemde sectie richtte zich op het toezicht op de beleggingsinstellingen en wisselkantoren: de sectie toezicht banken, beleggingsinstellingen en wisselkantoren. De andere secties richtten zich onder meer op het toezicht op systemen voor de afwikkeling van het betalings- en effectenverkeer en informatietechnologie ${ }^{405}$. Binnen het directoraat toezicht waren er tevens twee afzonderlijke eenheden opgericht; de unit handhaving Wtk en de integriteitunit. Laatstgenoemde had onder meer tot taak om in het bijzonder voor de sectie beleggingsinstellingen en wisselkantoren, specialistische ondersteuning te bieden. Deze unit zorgde voor een effectieve ondersteuning door contacten met de verschillende instanties te onderhouden. Tor deze instanties behoorden: de Ministeries van Financiën en Justitie, het $\mathrm{OM}$, de ECD, de CRI, politie, collega toezichthouders en functionarissen van de ondertoezicht staande instellingen ${ }^{406}$. Om haar toezicht goed uit te kunnen voeren had het directoraat, door de vorming van multidisciplinaire accountantsgroepen, de operationele toezichtstaken per (groep van) instelling(en) geordend. Dit heeft ertoe geleid dat de onder toezicht staande instellingen vaste aanspreekpunten binnen het directoraat toezicht kregen. DNB nam zich voor om, vanwege de snelle veranderingen in de financiële wereld, extra te investeren "in de ontwikkeling van kennis en functiemobiliteit van medewerkers" 407 .

\footnotetext{
405 Kamerstukken II, 1997/98, 25830, nr. 2, p. 7. Ook wel de nota Integriteit. financiële sector genoemd. 
Het directoraat toezicht trachtte bovendien een actief beleid te voeren voor de informatisering en automatisering. Om dit te verwezenlijken riep DNB de sectie facilitaire voorzieningen toezicht in het leven. In figuur 2.5 wordt de organisatie van DNB zoals die er in 1997 uitzag deels weergegeven.

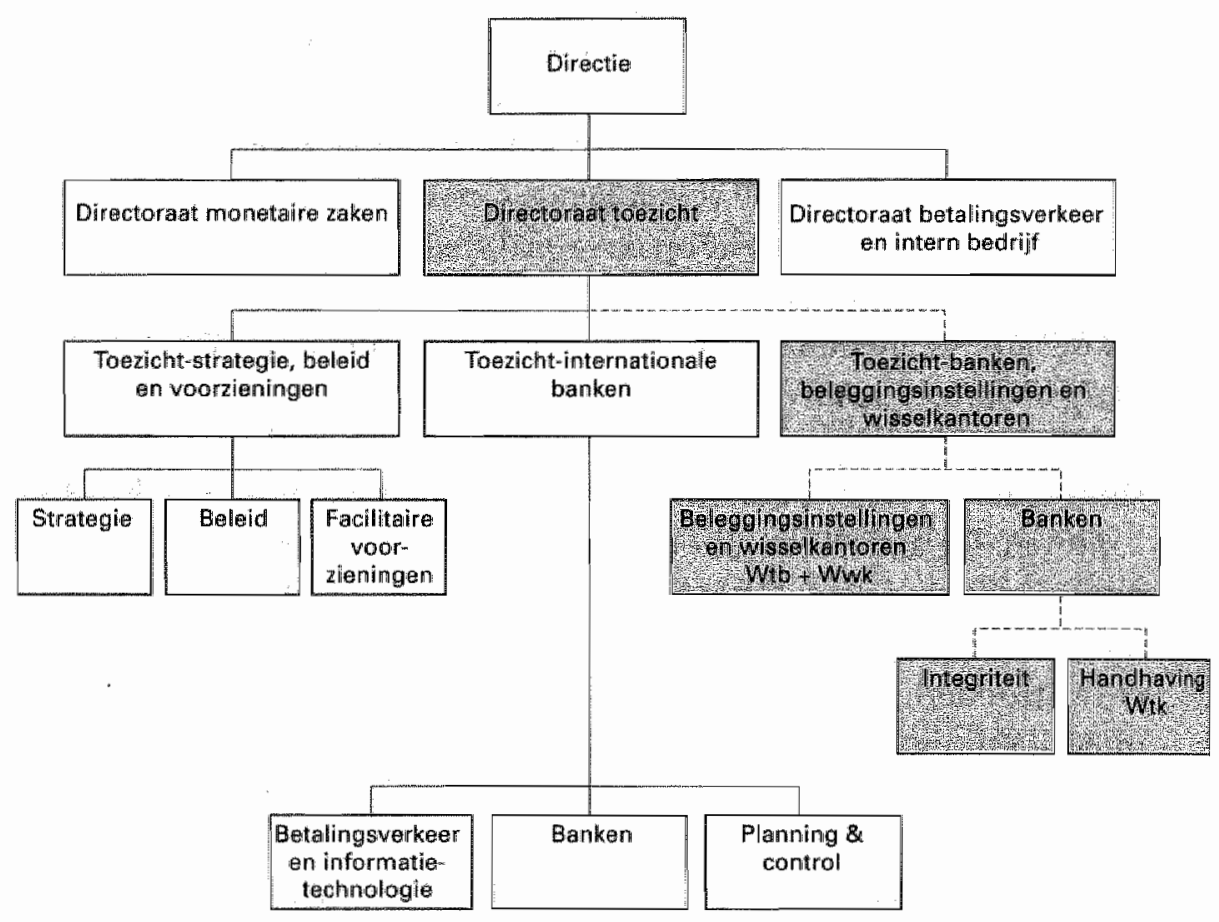

FIGUUR 2.5 Het directorat toezicht wan DNB rond jull 1997

Bron: Brochtwe "Het roezicht op bet bankuezen door de Nederlandsche Bank", witgegeven door De Nederlandschte Bank NV. 1997

Op grond van de Wtb had DNB de volgend taken toegekend gekregen: het toezicht op de naleving van de regels van de Wrb; het voorbereiden van het te volgen beleid en de zorg voor de uitvoering van de Wtb. Voor het uitoefenen van het toezicht voor de structuurwijziging van het toezichtsmodel heeft DNB gebruik gemaakt van de interne controleafdelingen van de onder toezicht staande instellingen ${ }^{408}$. Eerder is vermeld dat de instellingen die over een vergunning beschikten, zich aan de wettelijke regels en doelstellingen van de Wtb dienden te houden. 
Deze instellingen moesten aan de in de artikelen 5 en $6 \mathrm{~W}$ tb genoemde eisen voldoen. Indien dit niet het geval is en was, kon DNB op grond van artikel 19 en $20 \mathrm{Wtb}$ :

"inlichtingen vagen of een onderzoek instellen of doen instellen ten winde nat te gutn of kon worden voldaan dan wel werd voldan aan de bij of krachtens deze wet gestelde eisen, regels, beperkingen of gegeven toorschrifien".

Dergelijke inlichtingen of dergelijk onderzoeken mochten ook worden ingesteld ten behoeve van buitenlandse toezichthouders ${ }^{409}$. Naast inlichtingen vragen was $\mathrm{DNB}$ ook bevoegd om de vergunninghouders aanwijzingen te geven indien deze niet aan de eisen, regels, beperkingen of voorschriften van de Wtb voldeden ${ }^{410}$. Aan voornoemde aanwijzingen diende binnen een door DNB gesteld termijn te worden voldaan. Mer het geven van deze aanwijzingen beoogde DNB te bewerkstelligen dat door de desbetreffende instelling of bewaarder ${ }^{411}$ alsnog aan de regels van de Wtb werd voldaan. Daarnaast kon DNB beschikken over een zeer ingrijpend middel; de instelling van een "stille curator". Dit wil in dit geval zeggen dat:

"vanaf een bepaald tijjstip alle of bepaalde organen" ${ }^{412}$ wan de beleggingsinstelling of van de bewaarder bun bevoegdheden slechts nogen uitaefenen na gredkeuring door een of meer door Onze Minister (DNB) aangewezen personen en met inachtneming wan de opdrachten van deze personen. ${ }^{1 / 1}$.

Vgl. artikel $27 b$ Wtb.

Vgl. artikel 21 . W b jo29 Wtb jo 3 Overdrachtsbesluit W/b. Zie het overdrachtsbesluit Wer toezicht beleggingsinstellingen Besluit van 14 augustus 1990, houdende overdracht van taken en bevoegdheden ingevolge artikel 29 van de Wet toezicht beleggingsinstellingen aan. De Nederlandsche Bank N.V., Stb. 1997, 703.

De bewaarder is volgens artikel I sub $f W t b$ : "degenen die belast is met do bewaring van de activa van de beleggingsinstelling". De bewaarder bewaart de vaste activa van een beleggingsfonds. Hij ziet er op toe dat de beheerder van het fonds volgens de statuten en de reglementen van het fonds handelt. De beheerder van een fonds kan niet zonder toestemming van de bewaarder over het vermogen wan het fonds beschilken. Niet alle beleggingsfondsen zijn verplicht om een bewarder in te stellen. De voornoemde ICBE's zijn op grond van artikel 6 lid 5 Wub verplicht om en onafhankelijke bewatarder in te stellen Hillen, J.L.S.M., "Effectenwetgew"ng", dl. 143-II Schuurman \& Jordens Nederlandse wetgeving, t.a.p. noot 32, p. 227 229.

Bijwoorbeeld het bestuur of de raad van commissarissen.

Artikel $22 \mathrm{~W}$ tb. Er wordt gesproken over een stillte curator omdat de ondercuratelestelling niet wordt gepubliceerd. 
Met de stille curator heeft de Wtb beoogd om via het versterken van de organen, de beleggingsinstelling beter te laten functioneren ${ }^{414}$. Vanaf het moment van ondercuratelestelling mogen alle of bepaalde organen van de betreffende beleggingsinstelling of van de bewaarder hun bevoegdheden alleen uitoefenen na goedkeuring door een of meer door onze Minister aangewezen personen en met inachtneming van de opdrachten wan deze personen ${ }^{415}$. Indien een orgaan van de beleggingsinstelling of van de bewaarder in strijd met een aanzegging van DNB bepaalde handelingen verrichtte waardoor er schade was ontstaan, waren de leden van dit orgaan persoonlijk aansprakelijk jegens de beleggingsinstelling of de bewaarder. In geval de wederpartij wist dat er geen goedkeuring was gegeven voor het verrichten van de handeling, kon de beleggingsinstelling of de bewaarder de ongeldigheid van de desbetreffende handeling inroepen ${ }^{416}$. Verder was er in artikel $15 \mathrm{~W}$ tb voor DNB de bevoegdheid neergelegd om de verleende vergunning weer in te trekken. Op grond van artikel 16 lid 2 Wtb kon DNB de rechtbank verzoeken om de beleggingsmaatschappij waarvan de vergunning is ingetrokken, te ontbinden. Indien tot ontbinding van een dergelijke beleggingsinstelling zou worden overgegaan, diende het vermogen op grond van artikel 16 lid $3 \mathrm{Wtb}$ binnen een door DNB te bepalen termijn te worden vereffend. In de artikelen 39 en $40 \mathrm{Wtb} \mathrm{j}^{\circ}$ artikel 1 sub $2 \mathrm{~W} / \mathrm{tb}$ werd bepaald dat, indien de beleggingsinstelling niet mee werkte aan het geven van inlichtingen, het doen van een onderzoek, het opvolgen van een aanwijzing of niet meewerkte tijdens de stille ondercuratelestelling, dit alls een economisch delict moest worden beschouwd. Tot slot de uitsluiting van een accountant. Evenals de rechtsvoorganger van de Autoriteit-1FM, de STE, was DNB bevoegd om te bepalen dat de accountant, die onderzoek had verricht naar een beleggingsinstelling teneinde een accountantsverklaring af te geven, belet kon worden om een dergelijke verklaring af te geven. Deze bevoegdheid van DNB was terug te vinden in artikel $21 \mathrm{a} \mathrm{W} \mathrm{tb}^{417}$. De overgang naar een nieuwe

4 Volgens artikel 22 Wt is ondercuratelestelling wenselijk wanneer bijzondere gebeurtenissen een adequate functionering van de beleggingsinstelling of de bewaarder in gevaar brengen én naar het oordeel van onze Minister versterking van de organen van de beleggingsinstelling of de bewaarder wenselijk maken. Hillen, J.L.S.M., "Effectenuetgeving", dl. 143-II Schuurman \& Jordens Nederlandse wergeving, r.a.p. noot 32, p. 251.

415 Artikel 22 lid $1 \mathrm{~W}$ rb.

$4: 16$ Artikel 22 lid 2 onder $\mathrm{d}$ Wrb.

a17 Vgl. artikel $21 \mathrm{aj} 29 \mathrm{Wtb} j^{\circ} 3$ Overdrachtsbesluit Wet toezicht beleggingsinstelling. 
toezichtsstructuur of een ander toezichtsmodel heeft ertoe geleid dat bepaalde taken en bevoegdheden vanaf 2002 naar de Autoriteit-FM worden overgeheveld. Gedacht moet worden aan taken en bevoegdheden die passen binnen het gedragtoezichtskader van de Autoriteit-FM zoals: het doen van onderzoek, om inlichtingen verzoeken en her geven van aanwijzingen ${ }^{418}$. Bepaalde bevoegdheden die een specifiek prudentieel toezichtskarakter dragen heeft DNB behouden. In dit geval moet worden gedacht aan de instelling van de hiervoor genoemde stille curator.

Uit de voorafgaande paragrafen is duidelijk geworden dat effecteninstellingen voor de wijziging van het structuurmodel eerst in bezit van een vergunning moesten zijn voordat zij actief hun werkzaamheden mochten uitvoeren. Deze vergunning kan worden afgegeven door de nationale toezichthouder of door een toezichthouder in een lidstaat van de Europese Gemeenschappen alwaar de instelling is gezeteld. Om de vergunning toegewezen te krijgen, diende en dient er aan verschillende wettelijke vergunningseisen te zijn voldaan. Deze eisen hadden en hebben betrekking op deskundigheid, betrouwbaarheid van ondermeer bestuurders, bedrijfswoering, administratieve organisatie, financiële waarborgen en overige sector-specifieke vergunningseisen en uitoefenvoorwaarden ${ }^{419}$. Indien de desbetreffende toezichthouder aan een instelling een vergunning zou verlenen, blijft deze instelling constant onder her toezicht van de toezichthouder staan. Mede door de periodieke rapporten van de onder toezicht staande instellingen, kunnen toezichthouders nagaan of de voorschriften wel worden nageleefd. Indien de desbetreffende toezichthouder daartoe aanleiding ziet, kan deze het besluit nemen om zelf onderzoek bij de instelling te doen en zo nodig over gaan tot het afdwingen van de naleving van de wetrelijke eisen. Het is dus zaak dat de instelling zich houdt aan de roezichtvoorwaarden c.q. vergunningsvereisten.

Naast de hiervoor besproken STE, de Autoriteit-FM en DNB is er nog een instantie die hier vermeld dient te worden: de International Organisation of Securities Commissions (IOSCO). IOSCO is een internationale samenwerkingsverband, een multilateraal overlegorgaan, van effectentoezichthouders. De afspraken gemaakt binnen deze organisarie, die een betere regulering van de effectenmarkten en een effectiever toezicht op

419. Samenhang en verschillen tussen de financiële toezichtwetten, notitie, Ministeric van Financiën, 30 augustus 1996, p.5. 
deze markten tot doelstelling heeft, werken door in het Nederlands toezicht. Ondanks het feit dat $105 \mathrm{CO}$-resoluties geen juridisch bindende kracht hebben, worden ze wel door hun leden, in ons geval de AutoriteitFM, nageleefd ${ }^{420}$. Deze heeft namelijk sinds 1989 , via de STE, het IOSCOlidmaatschap van het Ministerie van Financiën overgenomen ${ }^{421}$. Door met haar collega toezichthouders afspraken omtrent het effectentoezicht te maken, is er een officieus beleid op het internationale effectentoezichtsgebied ontstaan. Wellicht dat dat in de toekomst tot officieel beleid wordt verheven. De structuur van IOSCO, welke uit verschillende comités bestaat, wordt in figuur 2.6 weergegeven. In grote lijnen ziet de structuur van de $1 O S C O$ er als volgt uit. $Z \mathrm{ij}$ wordt voorgezeten door een presidents committtee. In dit comite hebben de voorzitters van de toezichthouders die lid zijn van IOSCO zitting. De presidents committtee komt een keer per jaar samen. Om de belangen van IOSCO tussentijds te behartigen is het executive committee in het leven geroepen. Dit comite komt een paar keer per jaar samen en bestaat uit leden die deels door de presidents committee zijn gekozen, en deels door de vier regionale comites ${ }^{422}$. De executive committee is bevoegd om alle beslissingen te nemen welke van belang, dan well noodzakelijk zijn om de doelstellingen van IOSCO te verwezenlijken. In dit comite hebben ook de voorzitters van de emerging markets zitting genomen ${ }^{423}$. Daarnaast behoort ook de voorzitter van de technical committee tot de executive committee ${ }^{424}$. De steeds verdergaande ontwikkelingen op het gebied van het

40 Aldus Mulder, PA.W., Het intemationale roezicht: $10 S C O$, in de bundel Financièle integriteit, normafwijkend gedrag en (zelf)regulering binnen het financiële stelsel, Gouda Quint bv, Arnhem, 1995, p. 119.

424 Informatie over de IOSCO is gebaseerd op de IOSCO-site. Zie htep:/ wwwilosco.org. (bijwerkt in mei 2002)

422 De regio's zijn als volgt onderverdeed: de Interamerican regional committee; de Earopean regional Committee; de Asia-Pacific regional committee en de AfricaMiddle East regional committee.

423 Emerging markets zijn de opkomende markcen.

42i Met her technical committee wordr de technische commissie bedoeld. In dit comite zijn de roezichthouders van de grote effectenmarkten vertegenwoordigd. Zij beogen de belangrijke punten, die te maken hebben met de internationale aandelenhandel op het gebied van de regulering, te volgen. De technical committee is onderverdeeld in vijf grote deelgebieden te weren: Mulcinational disclosure and accounting; Regulation of secondary markets; Regulation of market incermediaries; Enforcement and the exchange of information en Irvestment management. 
effectenverkeer, denk bijvoorbeeld al aan de ontwikkeling van het handelen via het internet en andere technologische of maatschappelijke ontwikkelingen zoals de terroristische aanslag in de Verenigde Staten op 11 september 2001, zullen er zeer waarschijnlijk voor zorgen dat er binnen de IOSCO de nodige aanpassingen zullen plaatsvinden.

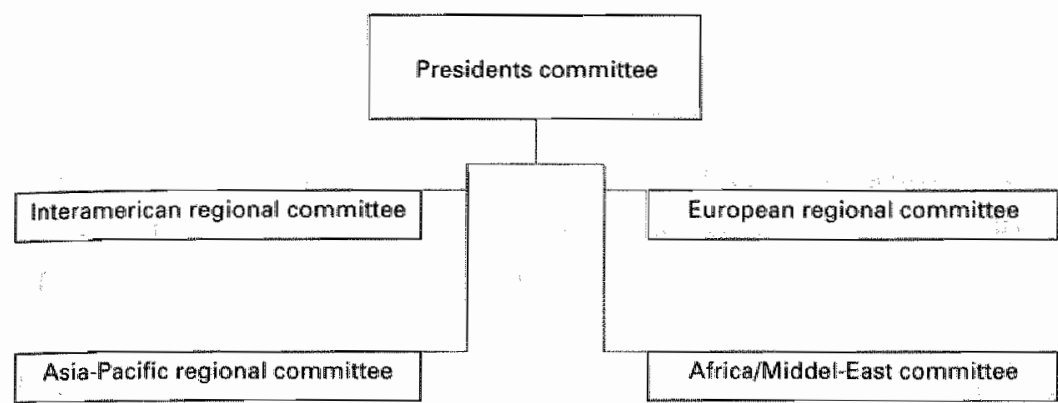

Technical committee Executive committee Emerging markets committee

General secretariat

Sro ${ }^{425}$ consultative committee

FIGUUR 2.6 Destructurur van $10 \mathrm{OSCO}$

bron: internetpagina van IOSCO. brtp://www iosco.org/gen-infa.htonl

Naast de hiervoor genoemde comités zijn er vier regionale comités. Binnen deze comités proberen de daarin vertegenwoordigde landen samen regionale problemen over het effectenverkeer op te lossen. Om te zorgen dat de problemen die in de deelgebieden ${ }^{426}$ voorkomende daadwerkelijk kunnen worden opgelost, heeft de IOSCO werkgroepen

626. Neem bijwoorbeeld de problemen die zich kunnen voordoen bij grensoverschrijdende transacries. 
ingesteld $^{427}$. De Autoriteit-FM, als lid van het technical committee, maakt deel uit van de off-market tradingwerkgroep en de capital requirements for investment firms-werkgroep. Als lid van een werkgroep is zij - net als de STE - verplicht om een paar keer per jaar met de gehele werkgroep samen te komen om zo eventuele gesignaleerde problemen op te lossen. De eerder genoemde emerging markets committee, is in het leven geroepen om de efficiëntie van "nieuwe opkomende" markten te bevorderen. Deze commissie probeert haar doelstellingen te verwezenlijken door niet alleen minimumvoorwaarden voor deze markten te creëren, maar ook kennis-, informatie- en technologie overdracht te verzorgen ${ }^{428}$. Daarnaast worden er door laatstgenoemde commissie ook trainingsprogramma's voor het personeel van de leden verzorgd. Tot slot de SRO consultative committee ${ }^{429}$. Dit comité bestaat uit IOSCO-leden die tegelijkertijd zelfregulerende organisaties zijn. Door deze leden samen te laten werken beoogt IOSCO de dialoog tussen de zelfregullerende organisaties te houden ${ }^{430}$, wat weer tot positieve gevolgen voor IOSCO zal moeten

427 Werkgroep nr. 1 : multinational disclosure and accounting doet onderzoek naar recente technieken voor multinationale emisssies van aandelen. Voorts doet deze werkgroep onderzoek naar de mogelijke problemen die zich kunnen voordoen in geval van notering in meerdere landen. Tevens doet werkgroep nr. 1 onderzoek naar het identificeren van de verschillende soorten emittenten. Daarnaast stelt de werkgroep de door de regelgeving veroorzaakte problemen vast. Tot slot stinuleert de werkgroep regelgeving die het " $\mathbb{1}^{\mathrm{c}} \mathrm{klas}$ " emittenten mogelijk maakt om op een doelmatige wijze op de internationale kapitaalmarkten kapitaal aan te trekken. In werkgroep ne. 2, regulation of secundary markets, zijn de schermenhandel en de doorzichtigheid van handelssystemen het middelpunt. Binnen deze werkgroep worden op dit gebied niet alleen studies, maar ook aanbevelingen voorbereid. In werkgroep nr. 3: regulation of marker professionals staan de kapitaaleisen voor effecteninstellingen centraal. Tor slot werkgroep nr. 4: enforcement and the exchange of information. Deze werkgroep houdt zich bezig met de uirwisseling van informatie tussen de toezich thouders. Vanaf 1992 houdr deze werkgroep zich bezig mer fraude op elektronische markten en het witwassen van geld op de effectenmarkt. STE Jaarwershag 1991, Amstelveen, mei 1992, p. 19-21.

Evenals het technical committee, is ook de emerging markets committee in vijf grote deelgebieden onderverdeeld. Deze deelgebieden welke (bijna) gelijk zijn aan de deelgebieden van de technical committee zijn: Disclosure and accounting; Regulation of secondary markets; Regularion of market intermediaries; Enforcement and the exchange of information en Investment management.

629 SRO's is een afkorting van Self-Regulatory Organizations of zelfregulerende organisaties.

430 Voorbeelden van IOSCO leden die to de zelfregulerende organisaties behoren, zijn de National Association of Securities Deaters (NASD) en de New York Stock Exchange (NYSE). 
leiden. Binnen dit comité zijn er personen aangewezen die contact met de werkgroepen van de technical committee moeten onderhouden.

Naar aanleiding van het bovenstaande kan worden geconcludeerd dat de afspraken die gemaakt zijn binnen IOSCO-verband wel degelijk hun doorwerking kunnen hebben op de wijze waarop de Autoriteit-FM in Nederland toezicht op het effectenverkeer uitoefent.

\subsection{De verschillende handhavingsprocedures}

Wanneer de Autoriteit-FM tijdens een door haar verricht onderzoek onregelmatigheden op het spoor is gekomen, kan dit verschillende gevolgen hebben. Zo kan zij zelf maatregelen treffen via de oplegging van bestuurlijke boetes, het opleggen van een last onder dwangsom of het intrekken van een vergunning. Het kan ook zijn dat de AutoriteitFM aangifte doet bij de FIOD-ECD ${ }^{431}$. Dit kan ertoe leiden dat het Openbaar Ministerie (OM) tot vervolging overgaat; het begin van een strafrechtelijke procedure omdat op grond van de Wet op de Economische Delicten (WED), overtredingen van bepaalde voorschriften uit de Wmz, de Wtb en de Wte' 95 economische delicten zijn ${ }^{432}$. Tot slot kan her zijn dat gedupeerde beleggers in een civiele procedure, via een onrechtmatige daadactie, schadevergoeding gaan vorderen. Deze drie procedures: de bestuursrechtelijke, de civielrechtelijke en de strafrechtelijke zullen vervolgens aan de orde komen.

\subsubsection{De bestuursrechtelijke procedure}

Zoals reeds uit paragraaf 2.2 naar voren is gekomen, hebben de oprichters van de STE de vorm van een stichting geprefereerd boven andere privaatrechtelijke vormen. Gevreesd werd dat een naamloze vennoot-

(33) Ondar de wetgever heeft geconstateend dat financieel-economische fraude vaak samengaat met fiscale fraude heeft zij besloren om de ECD dac onder het Ministerie van Economische Zaken was gebracht, over te hevelen naar de belastingdienst. Hiermee werd de ECD onder regie van de fiscale opsporingsdienst; de FIOD, gebracht. De wetgever heeft met deze overheveling een samenwerking tussen het FIOD en de ECD beoogd om zo tot een betere opsporing van strafbare feiten te komen. Door deze samenvoeging van bovengenoemde bijzondere opsporingsdiensten wordt er dit punt in het onderzoek niet meer gesproken over of het FIOD of de ECD maar over de FIOD-ECD. Vgl. Kamerstukken II, 2001/02, 17050 , nr. 225 , p. 2-7. 
schap of zelfs een wereniging de toentertijd voor ogen staande "onafhankelijke besluitvorming" van deze toezichthouder in de weg zou kunnen $\operatorname{stan}^{433}$. Critici hebben hun verbazing uitgesproken over de stichtingsvorm van zelfstandig bestuursorgaan ${ }^{434}$ (zbo). Zeker daar zelfstandige bestuursorganen overheidsinstanties zijn die:

"bij of krachtens de unet in bet leven (zijn: MJB) geroepen bestumrsorganen (en: MJB) die wiet bij een decentrale overheid beboren maar die ook nier deel uitmaken van en Minusterie, zodat ze niet biëratchisch ondergeschikt zijn aan een Minister of statatssecretaris 435 .".

433 Kamerstukken II, 1988/89, 21038, 3, p. 13 (MvT) en Mok, M.R., Toezicht effectenverkeer (ID), TVVS, 1989, nr. 89/4, p. 103.

In haar dissertatie omschrijft J.L.G. van Nus de STE als een zelfstandig bestuursorgaan. Vgl. Nus, J.G.L. van, a.w, p. $607-608$.

435 Aan het eind van de jaren tachrig schreven Van Wijk en Konijnenbelt dat "iselfstandig bestuwrsorganen (zbo"s) overheidsinstanties zijn die wel-krachtons attributie of delegatic-bestwursbevoegdbeden bezitten matr die geen bestursorgatn van en openbaar lichaam zijn en evenmin ambenaar, aan zo 'n orgaan ondergeschikt". Deze definitie is inmiddels achrerhaald omdat ook bestuursorganen wan een openbaar lichaam zelfstandige bestuursorganen kunnen zijn. Zbo's zijn in beginsel zelfstandig en dus niet ondergeschilkt aan de Minister tenzij dat bij Wet wordt vastgesteld. Vgl. Wijk, H.D. van en Konijnenbelt, W., Hoofdsukken van administratief recht, 1991, $7^{\text {de }}$ druk, $2^{\text {te }}$ oplage, Lemma B.V., Utrecht, p. 153 en Wijk, H.D. van, Konijnenbelt en Van Male, "Hoofdstukken van bestuursrecht, $11^{\text {de }}$ druk, Den Haag, 1999. hier is geciteerd. Een zbo is wolgens Van Wijk en Konijnenbelt niet hiërarchisch ondergeschikt aan een Minister. Ook met betrekking tot de Autoriteit-FM is dit het geval. Immers, in artikel 40 van de W/te' 95 is aangegeven dat de Minister (van Financiën) de hem geartributeerde taken en bevoegdheden ter uitwoering van de Wte' 95 , bij A.M.v.B. kan overdragen aan een of meer rechtspersonen. In dat geval gelden de verplichtingen op grond van voornoemde wet als verplichtingen jegens de rechtspersoon. De A.M.v.B. waar naar wordt verwezen is het Overdrachtsbeshit Wet toezicht effectenverkeer 1995 (overdrachtsbesluit Wte'95/ Delegatiebesluit Wte"95). In dir besluit d.d. 8 december 1995 (Stb. 1995, 646), dat bestat uit 5 artikelen, worden de meeste taken en bevoegdheden die op grond van de W/te" 95 aan de Minister van Financiët toekomen, aan de STE nu de Autoriteir-FM overgedragen. Het overdrach tsbesluit Wte'95 is meermalen gewijzigd. Vlg. Stb. 1997, 703 waarin wijzigingen in het kader wan de Awb hebben plaatsgevonden; Stb. 1999, 360 waarin er wijzigingen van bepaalde bevoegdheden van de STE plaats hebben gevonden. De STE moest - en nu de Autoriteit-FM - desgevraagd aan de Minister van Financien alle inlichtingen te werschaffen die noodzakelijk blijken te zijn om over te gaan tot een wijziging, intrekking en eventuele invoering van een nieuwe regeling (Nrte) en $5 \mathrm{tb}$. 2001, 286 warmee het verbod is ingevoerd om zonder verklaring van geen bezwaar deelneming te vergroten, houden dan wel verwerven in de houder van een effectenbeurs wanneer deze deelneming de grens van $10 \%$ te boven gaat. De Autoriteit-FM dient te adviseren omtrent het al dan niet verlenen/intrekken 
Immers, was het wel "wewselijk (...) dat de overheid de witvoening van een publiekrechtelijke taak delegeert aan privaatrechtelijke rechtspersonen", aldus

van een verklaring van geen bezwaar. Zij kan aan voomoemde verklaring, indien nodig, nadere bepertingen dan wel nadere voorschriften werbinden. Om deze takk naar behoren uit te kunnen woeren, heeft de Autoriteit-FM de bevoegdheid om inlichtingen in te winnen. Op grond van dit overdrachtsbeshut moet de rechtsopvolger van de STE deze informatie aan de Minister van Financiën verstrekken. Wanneer we terug gaan naar het overdrachtsbesluit 1995, zien we dat er bepaalde taken aan de Minister voobehouden blijven. Deze taken hebben volgens artikel 2 wan woomoemd besluir betrekking op her gebruik van beschermingsconstructies door beursgenoteerde vennootschappen. In het vijfde lid van artikel 40 We'95 heef de wetgever aangegeven dat de desbetreffende rechtspersoon eenmaal per jaar verslag aan de Minister (van Financièn) moet uirbrengen over de uitoefening wan de overgedragen (lees gedelegeerde) taken en bevoegdheden. Uit de wet (artikel 40 Wte'95) en het hieraan verbonden Delegatiebesluir Wte'95 of het overdrachtsbesluit Wte'95 (artikel 3 lid 6), blijkt dar de STE en nu de Autoriteit-FM toestemming of goedkeuring van de Minister nodig heeft wanneer zij gebruik wil maken van haar bevoegdheid om bepaalde nadere regels te stellen, zoals de vereisten waaraan een prospectus moet voldoen. Dit suggereert dat de Autoriteit-FM als zbo wel afhankelijk is van de toestemming van de Minister, maar ondergeschike. Zoals reeds gesteld is de Autoriteit-FM een zelfstandig bestuursorgaan en heeft de Minister van Financièn slechts die bevoegdheden die hem expliciet bij wet zijn toegekend. Tot deze bevoegdheden kan het volgende worden gerekend: op grond van artikel 40 lid 2 onder $c$ Wte'95 is de Minister bevoegd on de bestuursleden van de Autoriteit-FM te benoemen, schorsen/of te ontslaan. De Minister van Financiën kan in bepaalde gevallen tevens goedkeuring aan de Autoriteit-FM on thouden, doordat bijvoorbeeld de door de Autoriteit-FM opgestelde regels van algemene strekking niet conform het beleid van de Minister zijn. Deze bevoegdheden van de Minister zorgen nier voor enige hierarchische ondergeschiktheid aan de Minister. In tegenstelling tor departementsambtenaren, zijn bestuurders van zbo's geen hierarchisch ondergeschikte ambtenaren. Hierdoor kan de Minister op grond van hiërarchische verhoudingen geen algemene of bijzondere aanwijzingen geven. Dat kan wel in geval van deconcentratie waar departementsambtenaren met eigen bevoegdheden, zoals de inspecteur der belastingen, verplicht zijn de aanwijzingen van de Minister op te volgen. Zie Stroink, F.A.M., "het leerstuk der deconcentratie"; uit de serie bestuurlijke verkennungen nr. 27, dissertatie RUU, Vuga boekeri, "s-Gravenhage, $1978 \mathrm{cn}$ vgl, artikel 3 lid overdrachtbesluit Wre' 95 . VIg, artikel 3 Delegatiebesluit Wte'95; KB d.d. 8 december 1995, inwerkingtreding 31 december 1995. Zie en Mok, M.R., Toezicht effectenverkee (II), TVVS, 1989, nr. $89 / 4$, p. 103. Zie voor kritische opmerkingen betreffende zbo's in privaatrechtelijke zin: Schreuder, C.A., "Publiekrechtelijke raken, private personen", dissertatie RUG, Deventer 1994. Zie verder Zijlstra, S.E., "Zelfstandige bestuursorganén in een denocratische rechtsstaat", dissertatie EUR, Den Haag, 1997 en tot slot, J.L., J. de Ridder en Scheltema, M., "Zelfstandige bestuursorganen in soorten; verslag van een onderzoek naar de praktijk wan zelfstandige bestuursorganen, in opdracht van her Ministerie van Binnenlandse Zaken", Kluwer, Deventer, 1989. 
Sllagter ${ }^{436}$. Mok stelt:

"Gebruik van de stichting door bogere en lagere overbeden voor de vervulling van overheidstaken achten wij ${ }^{437}$ weinig gelukkig. (...). De overheidstichting behartigt belangen waarvan de overheid de behartiging aan zich beeft getrokken, doch dit op verbulde wizze door deze onder te brengen in een privaatrechtelijke organisatievorm".

Volgens Mok hadden de oprichters van de STE voor de uitvoering van deze publiekrechrelijke toezichthoudende taak, beter voor een publiekrechtelijke rechtspersoon kunnen kiezen, omdat dan de lijnen betreffende de Ministeriële verantwoordelijkheid en de rechtsbescherming duidelijker zouden zijn ${ }^{438}$.

Ondanks de vele kritische geluiden heeft de STE, als zbo ${ }^{439}$, destijds de bevoegdheid gekregen om regels te stellen waaraan de onder toezicht staande instellingen zich dienen te houden. Daarnaast moeten deze instellingen zich vanzelfsprekend ook houden aan de kaderwetgeving zoals de Wte'95. Mocht nu uit rapportages, een door de Autoriteit-FM ingesteld bijzonder of periodiek onderzoek, meldingen van onder meer belanghebbenden of via een andere weg blijken dat voornoemde instellingen zich nier aan de desbetreffende regelgeving houden en het aan medewerking schort, biedt de wet deze toezichthouder de mogelijkheid om gebruik te maken van bepaalde handhavingsinstrumenten. Indien nodig mag zij zelfs, binnen het bestuursrechtelijk toezichtinstrumentarium ${ }^{440}$, de hulp van de sterke arm inroepen ${ }^{441}$. Dat blijkt

436 Vgl. Slagter, W.J., "Het fonds CSM wit de beurnotering?" "TVVS, 1994, nr. 94/12, p. $326-327$.

437 In casu Asser en Van der Grinten.

438 Mok citeert hier Van der Grinten. Vgl. Mok, M.R Toezicht effectenverkeer (D), TVVS, 1989, nr.89/4, p. 103 en Grinten, Van der W.C.L. en Asser, Vertegenwoordiging en rechtspersoon, de rechtspersoon, Zwolle, 1991, p. 172, Nus, J.G.L. van, a.w. p. 607 en ook F.A.M. Stroink en Nus, J.G.L. van, Bestuursrechteligke consequenties wan privatisering", in: Privatisering; themanummer Stichting \& Vereniging, jrg. 1994, mei/juni, nr. 3, p. $66-69$.

439 Was er in het begin nog sprake van een zbo in privatrechtelijke vorm, vergelijk de hiervoor aangehaalde citaten van Mok en Van der Grinten, in haar eerste nieuwsbrief InZicht geeft zij aan een "publiekrechtelijke" zbo te zijn. Vgl. nieuwsbrief STE, nr. 1, jrg. 1, 2001, p. 3. In beginsel is een bestuursorgaan publiekrechtelijk, een zbo dus ook.

*40 Grundmann-Van de Krol, C.M. en Van den Ingh, F.J.P., Parlementaire geschiedenis wan de Wet toezicht effecterwerkeer 1995, Kluwer B.V., Deventer, 1996, p. 93.

441 Dat mag slechts indien dit redelijkerwijs noodzakelijk blijkt te zijn. 
bijvoorbeeld uit het hieronder weergegeven artikel 5:15 jo 5:11 Awb. Deze bevoegdheid is voor de Autoriteit-FM niet nieuw. Reeds op grond van het oude 29 lid 3 Wte' 95 was haar rechtsvoorganger, de STE, hiermee bekend.

\section{Artikel 5:15 Awb}

1. Een toezichthouder is bevoegd met medeneming van de benodigde apparatuw, elke plats te betreden met uitzondering wan een woning zonder toestemming wan de bewoner.

2. Zo nodig werschaft bij zich toegang met belnulp van de sterke arm.

3. Hij is bevoegd zich te doen vergezellen door personen die dartoe door bem zijn aangewezen.

\section{Artikel 29 lid 3 Wte oud}

3. De door Onze Minister met bet toezicht belaste personen zijn bevoegd elke platats te betreden voor zover dat voor de vervulling wan bun taak redelijkerwijs nodig is. Zonodig verschaffen zij zich toegang met behulp wan de sterke arn. Zij zijn bevoegd zich te doen vergezellen door personen die dadrtoe door hen zijn aangewezen, woor zover dit woor bet dael wan bet betreden redelijkerwijs nodig is.

Tijdens een onderzoek mocht de rechtsvoorganger van de AutoriteitFM volgens lid 4 van artikel 29 Wte oud, om inzage van gegevens en bescheiden vragen, voor zover dat redelijkerwijs nodig is. Van deze gegevens en bescheiden mocht zij kopieën maken of de stukken zelfs voor korte rijd meenemen ${ }^{442}$.

4. De door Onze. Minuster met het toezicht belaste personen xijn bevaegd inzage te verlangen van zaketijke gegevens en bescheiden, woor zover dat woor de verwuling wan bun taak redelijkenwijs nodig is. Zij zijn bevoegd wan de gregevens en bescheiden kopieèn te maken. Indien het maken van kopieën niet ter plaatse kan geschieden, zijn zij bevoegd de gegevens en bescheiden woor dat doel karte tijd mee te nemen tegen een door ben of te geven schriftelijk bewijs.

Artikel 29 lid 5 Wre'95 oud, bepaalde dat een ieder verplicht is om medewerking aan een dergelijk onderzoek te verlenen. Momenteel is dat geregeld in artikel 29 lid 2 jo 5:20 Awb.

5. Een icder is verplicht aan de door Onze Minister met bet toezicht belaste personen alle medewerking te verlenen die deze redelijkerwijs kunnen verlangen ter witoefening wan but berogdheden. 
Vandaag de dag is bovengenoemd artikel 29 Wte'95 gewijzigd en heeft de wetgever voor de hantering van dezelfde bevoegdheden als in artikel 29 lid 3 en verder Wte oud, verwezen naar de artikelen 5:12 tot en met 5:17 en 5:20 Awb. Zo bepaalt artikel 5:16 Awb dat de toezichthouder, de Autoriteit-FM bevoegd is om inlichtingen te vorderen. Het hieropvolgend artikel geeft aan dat deze toezichthouder inzage mag vorderen van zakelijke gegevens en bescheiden, daarvan kopieën mag maken dan wel voornoemde informatie mee mag nemen teneinde deze te kopiëren.

Wanneer zij het vermoeden heeft dat een instelling in strijd met de Wte'95 handelt, kan de toezichthouder de beleggers op de markt waarschuwen door het geven van een openbare kennisgeving ${ }^{443}$. Net als de STE kan de Autoriteit-FM de effectenuitgevende instelling ook een aanwijzing geven $^{444}$ en een verleende vergunning of verklaring van geen bezwaar aan nadere beperkingen of voorschriften onderwerpen en zelfs weer intrekken ${ }^{445}$. Tot het intrekken van een vergunning zal zij niet snel overgaan omdat de Autoriteit-FM dat als zwaarste sanctie en laatste redmiddel, een ultimum remedium, beschouwt.

Lange tijd heeft de rechtsvoorganger van de Autoriteit-FM alleen de mogelijkheid gehad om de bovengenoemde handhavingsinstrumenten toe te passen. $\mathrm{Zij}$ heeft gezocht naar een middenweg tussen het intrekken van een vergunning en het geven van een waarschuwing, immers eerstgenoemde was gedurende enige tijd haar enige geduchte sanctiemogelijkkeid. Voor bepaalde overtredingen was de sanctie van intrekking van een vergunning volgens haar te vergaand. Daarnaast trof een ingetrokken vergunning ook derden en niet alleen de wetsovertreder ${ }^{446}$. Daarom restte het de STE destijds alleen de mogelijkheid om aangifte te doen bij de Economische Controle Dienst (ECD), maar zij was zich ervan bewust dat het strafrecht, gezien de tijdrovende en kostbare

Artikel 32 Wte'95.

Artikel 6 Wte'95 voor beursgenoteerde instellingen en artikel 28 Wre'95 voor niet-genoteerde instellingen. Met de aanwijzingsbewoegdheid is voor de STE en nu de Autoriteit-FM de mogelijkheid gecreëerd om de beurs(houder) te wijzen op zijn verplichting om bij overtreding van de beursregels passende maacregelen regen de betrokkene te treffen. De aanwijzingen dienen, binnen een door de toezichthouder te bepalen termijn, te worden opgevolgd. 
procedures, niet altijd de oplossing zou bieden ${ }^{447}$. Verder meende de STE dat door de toepassing van het strafrecht het justitiële apparaat ten onrechte met de lichte overtredingen zou worden belast ${ }^{448}$. De STE bleef zoeken naar sanctiemogelijkheden waarmee ze haar toezichtstaken directer en effectiever kon uirvoeren. $\mathrm{Zij}$ besloot mee te werken aan de totstandkoming van een wetsvoorstel dat het mogelijk zou maken om in de financiële sector bestuurlijke boeten en dwangsommen op te leggen. Op 1 januari 2000 is de Wet bestuurlijke sancties financiële sector (WBS) inwerking getreden en heeft de STE de mogelijkheid gekregen om naar gelang de ernst van de wetsovertreding een last onder dwangsom of een bestuurlijke boete op te leggen ${ }^{449}$. Daarnaast heeft zij haar bevoegdheid gehouden om, indien gewenst, een vergunning in te trekken dan wel bestaande handhavingsinstrumenten toe te passen. Deze bevoegdheden zijn mee overgegaan op haar rechtsopvolger, de Autoriteit-FM.

De inwerking getreden WBS bestaat uit diverse wetswijzigingen. De wijzigingen hebben plaatsgevonden in 8 wetten te weten: de W'te'95, de Wmz, de Wet toezicht kredietwezen 1992 (Wtk'92), de Wet toezicht natura uitvaartverzekeringsbedrijf (Wtn), de Wet toezicht verzekeringsbedrijf 1993 (Wtv'93), de Wwk, de Wtb en de Wet financiële betrekkingen buitenland 1994 (Wfbb'94). Voor al deze wetten is de Minister van Financiën verantwoordelijk. De toezichthoudende taken worden uitgevoerd door zowel de Autoriteit-FM, de Pensioen \& Verzekeringskamer (PVK) en DNB ${ }^{450}$. Niet alleen de rechtsvoorganger van de Autoriteit-FM maar ook DNB hebben op grond van de WBS de bevoegdheid gekregen om de sanctie van een last onder dwangsom dan wel van een bestuurlijke boete toe te passen ${ }^{451}$. In artikel 5:32 van de

447 Kamerstukken II, 1997/98, 25 821, 3, p. 3-4. (MvT)

448 STE, jaarwershag 1995, Amstelveen, april 1997, p. 20.

4 Wet van 28 oktober 1999, Stb. nr. 509, inwerkingtreding 1 januari 2000 . Let wel, het is een zbo in privatrechtelijk vorm in welk geval de Ministeriële verantwoordelijkheid ontbreekt. Zoals Hartmann reeds heeft opgemerkt, wordt " $d t$ bandhaving door middel wan bestuwlijke boetes (...) werricht door publiekrechtelijke bestumrorgatnen": Hartmann geeft aan dar het opleggen van een bestuurlijke boete een besluit is in de zin van de Awb. Vgl. Hartmann, A.R., "De wettelijke regeling wan de besturulijke boete naar vorm en inboud" in: Doelder, H. de, Meijer. M.E. de en Otto, D., De bestaurlijke boete in perspectief; in: SI-EUR-reeks, dl. 20, Gouda Quint, 1999, p. $39-62$; in het bijzonder p. 41 .

450 Kamerstukken II, 1997/98, 25 821, 3, p. 2.(MvT)

451 Zie Kamerstukken I, 1999/00, 25 821, 9, p. 1. (MvA) 
Algemene wet bestuursrecht (Awb), staat het volgende omtrent de dwangsom vermeld:

\section{Artikel $5: 32$}

1. Een bestutrsorgatan dat bewoegd is bestuwrdwang toe te passen, kan in phats daanan an de avertreder een last onder dwangsom apleggen.

2. Een last onder dwangsom strekt ertoe de overtreding ongedatan te maken of verdere overtreding dan wel een herbaling van de overtreding te woorkomen.

3. Voor het opleggen van een last onder dwangsom wordt niet gekozen, indien bet belang dat bet betrokken woorschriff beoogt te beschermen, zich daantegen verzet.

4. Het bestuwrsorgatn stelt de dwangson vast betzij op een bedrag ineens, hetzij op een bedrag per wijdseenheid watrin de last niet is witgevoerd, dan wel per overtreding van de last. Het beswursorgan stelt tevens een bedrag vast waarboven geen dwangson meer wordt verbeurd. Het vastgestelde bedrag statit in redelijke verbouding tot de zwatarte wan bet geschonden belang en de beoogde werking wan de duangsomoplegging.

5. In de beschikking tot oplegging van een last onder dwangsom die strekt tot bet ongedaan maken wan een overtreding of bet voottomen wan verdere overtreding, uordit een termijn gesteld gedurende welke de overtreder de last kan uitwoeren zonder dat een duangsom wordt werbeurd.

Op grond van bovenvermeld artikel kan de toezichthouder de overtreders van de effectenwetgeving een last onder dwangsom opleggen. Het doel van een last onder dwangsom is, volgens lid 2 , het ongedaan maken van een wetsovertreding en/of het voorkomen van verdere overtredingen. Een voorbeeld hiervan is het weigeren van de ondertoezicht gestelde om mee te werken aan een onderzoek van de toezichthouder. De toezichthouder kan medewerking eisen op straffe wan een dwangsom. $\mathrm{Bij}$ een bestuurlij.ke boete ${ }^{452}$ ligt het accent op genoegdoening. Hierdoor, vanwege haar repressieve aard, kan worden gesteld dat de bestuurlijke

452 Van Russen Groen plaatst in zijn proefschrift, de bestuurlijke boete onder her bestuursstrafrecht. Volgens hem behoren deze geldboetes, die door het bestuur worden opgelegd, nier geheel tor her strafrecht, maar ook niet helemaal tot het bestuursrecht. Immers, de op te leggen sanctie - het betalen van een geldboete kan gezien zijn bestraffende karakter, als criminal charge in de zin van artikel 6 EVRM worden beschouwd. Temeer daar de sanctie geen reparatoir karakter heeft, maar juist penaliserend; her heeft een leedtoevoegend karakter. Van Russen beschrijft het bestuursstrafrecht als volgt: "Het van het bestuursrecht en het strafrecht te onderscheiden deel van het recht watarin publiekrechtelijke bestuursorganen, zonder tussenkomst van de betrokkene of een onafbankelijke rechter, saricties met een bestraffend karakter kunnen opleggen". Vgl. Van Russen Groen, P.M., "Rechtsbescherming in bet bestumasstrafrecht", dissertatie EUR, Gouda Quint, 1998. p. 6, 7, 8 en 311 . 
boete een strafrechtelijk karakter heeft ${ }^{453}$. Het ne bis in idem beginsel staat in het algemeen een cumulatie van een bestuurlijke boete en een strafrechtelijke vervolging in de weg ${ }^{454}$. Immers, in Nederland mag men

453 Kamerstukken II, 1997/98, 25821,3, p. 5 (MvT). In de zaak Oztïrk, EHRM 21 februari 1984, NJ 1988, 937, dat ging om het recht van gratis tolkenbijstand, zoals vervat in artikel 6 lid 3 onder wan het EVRM, werd door de Duitse aanklager gesteld dar de heer Öztük daar alleen rechr op had in geval zijn verkeersovertreding (aanrijding) kon worden aangemerkt als een "criminal offence". Volgens het Duits recht was een verkeersovertreding een administratief delicr (Ordnungswidrigkeitengesetz) en geen strafrechtelijk feit. De ECRM vond dat het EVRM was gesclionden en legde de zaak voor aan het hof. Dit Europees Hof voor de Rechten wan de Mens gaf aan dat het er niet toe deed welk "etiket" een lid-staar plakt op een bepaalde gedlraging. Het Hof gaf in dit arrest aan dat zij zelf (autonoom) bevoegd is om te bepalen of er wel of geen sprake is van een dergelijk "offence". Hierbij is niet alleen de plaats die de normschending inneemt binnen het rechtssysteem van de lid-staat (is het privaat-, straf- of administratief recht?); maar ook de aard van deze overtreding (allereerst: tor wie richt zich de overtreden norm; tot alle burgers of tot een bepaalde groep? Vervolgens wat is her doel van de sanctie? Is het afschrikwekkend en punitief? Draagt de overtreden norm een algemeen karakter en heeft de sanctie een afschrikwekkend en punitief doel, dan kan er gesproken worden van een strafsancrie.) Tevens is de zwaarte van de opgelegde sancrie bepalend (Is er de maximale straf opgelegd of gaat her om de daadwerkelijke - oorspronkelijke - straf?) De laatste twee criteria zijn doorslaggevend. Wanneer deze dusdanigg (onevenredig) zwaar zijn en een punitief karalkter dragen, is er volgens het EHRM sprake van een "criminal charge" of een strafrechtelijke vervolging. In dit laatste geval heeft de betrokkene dan ook recht op de rechtswaarborgen zoals vervat in artikel 6 EVRM. Vgl. de arresten van het EHRM: Ötürk, EHRM 21 februari 1984, NJ 1988, 937; Engel and others, EHRM 8 juni 1976, NJ 1978, 705 warin vijf Nederlandse dienstplichtige millitairen procedeerden tegen de oplegging wan tuchtrechtelijke straffen die niet voldeden aan de eisen zoals gesteld in artikel arcikel 6 EVRM. Het Hof is tot de conclusie gekomen artikel 6 EVRM wel van toepassing was omdar de gedraging reeds binnen het nationale recht als strafbaar werd aangemerkt maar vooral omdat de zwaarte van de opgelegde straffen hiertoe noopte. Verder Lutz, EHRM 25 augustus 1987, NJ 1988, 938 waarin geilijk Oztürlk sprake was van een werkeersovertreding en de Ordnungswidrigkeit een rol speelde. Het EHRM plaatste in dit arrest de aard van de overtreding tegenover de aard en zwaarte van de sancti en concludeerde dat reeds op grond van de "aard van de overtreding", artikel 6 EVRM toepasselijk bleek te zijn. Viering, M.L.W.M., "Het toepassingsgebied van artikel 6 EVRM", dissertatie KUN, W.E.J. Tjeenk Willink i.s.m. NISER, Zwolle, 1994, hfd. 5.

454 Daar is woor gekozen. In het algemeen is cumulatie van een bestuurlijke boere en strafrechelijke verwolging wel mogelijk indien de beide sancties niet gelijkrijdig worden opgelegd. Voorwaarde is dan dat er geen specifiek wettelijk verbod is gegeven. Doelder, H. de, Meijer, M.E. de en Otto, D., De bestaurlike boete in perspectief, in: SI-EUR-reeks, a.w., p. 7. 
niet tweemaal worden berecht terzake hetzelfde van feit. Deze regel is geformaliseerd in artikel $68 \mathrm{WvSr}$ en terug te vinden in artikel. 14 lid 7 van het Internationaal Verdrag inzake Burgerrechten en Politieke rechten (IVBPR $)^{455}$. In de WBS is het ne bis in idem beginsel te vinden in het verbod om een boete op te leggen indien voor dezelfde overtreding reeds een strafvervolging is ingesteld en het onderzoek ter terechtzitting reeds is aangevangen. Daarnaast mag de toezichthouder op grond van de WBSS ook geen boete opleggen indien het recht tot strafvervolging is vervallen doordat de overtreder aan een transactievoorstel van het Openbaar Ministerie heeft voldaan zoals vermeld in artikel $74 \mathrm{WvSr}$. Voorts is in de WBS aangegeven dat het recht tot strafvervolging vervalt wanneer er terzake van dezelfde overtreding reeds een bestuurlijke boete is opgelegd. Het is derhalve aan de toezichthouder om te beslissen welke weg zij in wil slaan: de bestuursrechtelijke of de strafrechtelijke weg ${ }^{456}$. Om te voorkomen dat er teveel onduidelijkheid is omtrent de te kiezen weg, zijn er tussen de toezichthouders en het Openbaar Ministerie afspraken gemaakt. Deze afspraken zijn vastgelegd in het convenant bestuurlijke boete en strafrechtelijke sancties ook well het "Convenant betreffende de afstemming over de keuze tussen de oplegging van bestuurlijke boeten

455 Verdrag van 19 december 1966, Trb. 1969, 99. Dit verdrag dat burger-en politieke rechten beschermt kent, evenals het later te behandelen $\mathbb{E V R M}$, een individueel klachtrecht. Voornoemd klachtrecht dar door Nederland is erkend, wgl. Corstens, G.J.M., Het Nederlandse Strafprocesrecht, 2002, vierde druk, Kluwer, Dexenter, p. 31 en 762 e.v..., geeft slechts individuen de mogelijkheid om te klagen indien, volgens artikel 1 van het facultatief protocol van 19 december 1966, Tr. 1969, 99 (Nederlandse vertaling Trb. 1978, 177), deze personen onder de rechtsmacht vallen van een staar die partij is bij her IVBPR en die tevens voornoemd protocol heeft erkend, en die "beweren bet skachtoffer te zijn wan schending door die Stat, die partif is, wan exig in dat Verdrag genoend recht". Vgl, ook artikel 2 lid 1 IVBP. "Iedere Statu die partij is bij dit Verdrag verbindt wich de in dit Verdrag erkende rechten te exbiedigen en deze an eenieder die binnen zijn grondgebied verblijf en atw zijn rechtsmacht is ondeworpen te verzekeren, zonder onderscheid wan welke aand ook, zoals ras, buidsklewr, geskacht, tal, godsdienst, politieke of andere overtuiging, nationale of matschappelijke afkomst, welstand, geboorte of enige andere omstandigheid." Let wel: Nederland heeft nier her hele verdrag geratificeerd. In casu is er met betrekking tot bovenstaande verdragsartikel en met betrekking tor artikel 14 IVBPR, waaronder lid 7 , geen voorbehoud gemaalkt. Vgl ook Viering, M.L.W.M., "Het toepassingygebied wan artikel 6 EVRM", dissertatie KUN, W.E.J. Tjeenk Willink i.s.m. NISER, Zwolle, 1994. hfd. 3.2.3.

456 Volgens de memorie van toelichting wordt binnen de WBS her "una via systeem" toegepast; de keuze voor een cenmaal gekozen weg is bindend. Vgl. Kamerstukken II, $1997 / 1998,25821,3$, p. 6 (MvT) 
of strafrechtelijke afdoening bij bepaalde overtredingen van de financiële wetgeving" (convenant). Het convenant bestaat uit 9 artikelen ${ }^{457}$. In artikel 2 van het convenant is aangegeven dat het Openbaar Ministerie de STE en nu haar rechtsopvolger de Autoriteit-FM aan moet geven wanneer het wel of niet tot vervolging zal overgaan ${ }^{458}$.

\section{Artikel 2}

Indien en zodra het Openbadr Ministerie bekend is met de feiten, omstandigheden of gedragingen die duiden op een overtreding, informeert het de betreffende toezichthouder dadrover met het oog op de afstemining over de wijze van afdoening.

Volgens artikel 3 bestaat er ook aan de kant van de toezichthouder een verplichting om in voorkomende gevallen contact met het Openbaar Ministerie op te nemen. Dit zal her geval zijn indien de toezichthouder besluit om een bestuurlijke boete op te leggen van de hoogste categorie ${ }^{459}$. In alle lagere categoriën, 1 tot en met 4, dient de toezichthouder contact met het Openbaar Ministerie op te nemen, wanneer er sprake is van samenloop met minimaal een afzonderlijke gedraging die uitsluitend via het strafrechtelijk traject afgehandeld kan worden. In een dergelijk

${ }^{457}$ Convenant bestuurlijke boeten en strafrechtelijke sancries, Stcrt, nr. 4, jrg. 2000. De parrijen die dit convenant op 23 december 1999 hebben ondertekend zijn: het OM, de STE, DNB, De Pensioen \& Verzekeringskamer (PVK), MvF, en de belastingdienst/ECD.

${ }^{458}$ De "sfeerovergang", mer andere woorden de sfeercummulatie (in casu een bestuurlijke en strafrechtelijke procedure naast elkaar) AFM en OM moet zich nog uitkristalliseren. AFM is bezig een beleid te ontwikkelen maar dat moet nog uitgewerkt worden. De geschiedenis is hard gegaan; in de jaren $80 \mathrm{kwam}$ het controlebureau tor stand dat in eerste instantie aan VvdE gelieerd was en nu geheel onder is gebrache bij de AFM. Van een effectieve samenwerking met het OM is nog geen sprake, denk bijwoorbeeld aan Cor Boonstra. De AFM heeft aangifte van handelen met voorkennis gedaan, maar het $O M$ ging niet over tot vervolging. De samenwerking tussen het $O M$ en de AFM moet worden verfijnd. Zij moeten zich nog op elkaar afstemmen.

${ }^{459}$ In de wer zijn de op te leggen bestuurlijke boetes afhankelijk van de verschillende tariefnummers (1-5) waarmee de wetsovertredingen corresponderen, her daaraan gekoppeld geldbedrag en de categorieèn (I-V) die bepalen of een boete moet worden vermenigvuldigd met factor $1,2,3,4,5,6$ of 10 . Wat tot de hoogste categorie behoort kan per wet verschillen. De WBS heeft aan haar hoogste tariefnummer een bedrag van $f 10.000,-$ gekoppeld $( \pm 4.537,80)$. De Wmz' 96 kent haar zwaarste overtredingen het tariefnummer 4 toe. De Wtb, W/te' 95 , W'k'92, Wtz, Wtn en de Wwk hebben aan hun zwaarste overtredingen her tariefnummer 5 of boetebedragnummer 5 toegekend. De verschillende wetsovertredingen hebben ieder een eigen nummer toegewexen gekregen. De relatief minst 
geval zou de toezichthouder door het opleggen van een bestuurlijke boete, het Openbaar Ministerie in de wielen kunnen rijden. Hetzelfde geldt in geval er sprake is van recidive van wetsovertredingen die het boetebedrag nummer 3 of 4 hebben toegewezen gekregen. Tot slot dient de toezichthouder contact met het Openbaar Ministerie op te nemen indien bijzondere omstandigheden daartoe aanleiding geven, zoals de ernst van het feit of de omvang van de schade.

\section{Artikel 3}

1. Indien en zodra de toezichthouder voornemens is terzake een overtreding een beswurlijke boete op te leggen, warbij boetebedranummer 5 wan toepassing is, informeert bij het Openbaar Ministerie in casu bet arrondissementsparket Amsterdam, daarover met bet oag op de afstemming over de wijze van afdoening.

2. Indien en zodra de toezichthouder voornemens is terzake een overtreding eet bestuurlijke boete op te leggen, watarbij een boetebedragnummer wan I tot en met 4 van toepassing is, informeert bij het Openbaar Ministerie, in casu bet arrondissementsparket Amsterdam, daarover met bet oog op afstemming over de wijze wan afdoening:

a wanneer sprake is van samenloop van een overtreding met een of meer afzonderlijke. gedraginger watrwoor witsluitend strafrechtelijke afdoening open stat:

b. wanneer sprake is wan een herbaling wan een overtreding (recidive) warbij ex boetebedragnummer van 3 of 4 wan toepassing is; of

erge overtredingen zijn ondergebracht onder het boetebedragnummer $\mathbb{1}$ en de ergste onder boetebedragnummer 5 . Deze nummers verschillen per wet en zijn gekoppeld aan een geldbedrag of een vast tarief dat kan oplopen tot $f 192.000,-n$ $( \pm 87.125,80)$. Dit is bijvoorbeeld het geval in de Wte' 95 . In deze wet is nummer 1 gekoppeld aan $f 1.000,-( \pm € 453,78)$; nummer 2 an $f 2.000,-( \pm € 907,56)$; nummer 3 aan een bedrag van $f 12.000,-(* € 5.445,36)$; nummer 4 aan $f 48.000,-$ $( \pm 21.781,45)$ en nummer 5 aan $f 192.000,-( \pm € 87.125,80)$. De Wfbb kent daarentegen weer een andere indeling. In deze wet is de relatief minst erge overtreding, genummerd 1 , gekoppeld aan een tarief wan $f 5.000,-( \pm € 2.268,90)$ en zijn de zwardere overtredingen gekoppeld aan nummer 2 met een bedrag van $f 10.000,-( \pm 4.537,80)$. Aan de hand van de tariefnummer, de hieraangekoppelde boetebedragen en de bij her eigen vermogen wan de (rechts)persoon bijbehorende categorie, wordt de uiteindelijke te betalen boete vastgesteld. Op grond van de W'e'95 zullen de boetebedragen voor (rechrs) personen en vennootschappen met een eigen vermogen $(\mathrm{EV})$ dan wel een privé-vermogen van minimaal $f$ 10.000.000.w ( $€ € 4.537 .802,16)$ vermenigvuldigd worden met factor 5 . (Rechrs)personen met cen EV of privé-vermogen van minder dan $f 300.000$,$( \pm 136.134,06)$ zullen op grond van voornoemde wer onder worden gebrach bij categorie I, met het gevolg dat het boetebedrag zal worden vermenigvuldigd met factor 1.Vgl. WBS, Stb. nr. 509, 1999. p. $41-58$. 
c. wanneer nat bet aondeel wan de toezichthowder sprake is wan evertreding watrbij de specifleke omstandigheden van bet geval-beoordeeld in het licht uan de ernst wan de oventreding de mate nan opzet en verwijualabeid, de ominang van de scbade en in relatie tot de bescherming van het publiek - aanleiding geven rot bet informeren van het Openbaar Ministerie, in casu het arrondissementsparket Amsterdan.

De hiervoor genoemde aard van de bestuurlijke boete vereist in het licht van de mensenrechtenverdragen een zorgvuldige werkwijze. Immers, de artikelen 6,7 van het Europees Verdrag tor bescherming van de Rechten van de Mens en de fundamentele vrijheden ${ }^{460}$ (EVRM) en 14 IVBPR verplichten de Nederlandse wetgever om in de wetgeving de rechtswaarborgen op te nemen die voortvloeien uit voornoemde verdragen. Voor zover de bepalingen uit voornoemde en eventuele andere verdragen

Verdrag van 4 november 1950, Trb. 1951, 154. In dit verdrag is de Universele verklaring van de rechten van mens vervat. Het EVRM is van belang voor zowel het burgerlijke (proces)recht als het strafrechtelijke (proces)recht. Ter handhaving van de (grond)rechten en plichten voortvloeiende uit dit verdrag is er een Europese Commissie voor de Rechten van de Mens (ECRM) en een rechterlijk college, het Europees Hof voor de Rechten van de Mens (EHRM), in het leven geroepen. Dit Hof en het ECRM zetelen in Straatsburg. Zowel de landen die aangesloten zijn bij dit verdrag (Statenklachtrecht) als de burgers uit deze staten (individueel klachtrecht) zijn op grond van de artikelen 33 en 34 EVRM bevoegd om een klacht in te dienen bij de ECRM en vervolgens het EHRM over beweerde schendingen van het verdrag en of de bijbehorende protocollen. Het EHRM kan zelf besluiten dar de wetgeving van een "Hoge verdragsluitende Partij" (lidstaat) in strijd is met het verdrag en derhalve niet rechtsgeldig. Dit is geregeld in de artikelen 19 e.v. van het EVRM. Let wel, het EVRM beperkr de rechten die men nationaal rechatelijk geniet niet. Dat is bepaald in artikel 53 EVRM. Alvorens een burger toegang tot het ECRM of het EHRM kan krijgen, dienen wel alle nationale rechtsmiddelen te zijn uitgeput. Verder mag de klacht niet later dan zes maanden na de datum van de definitieve nationale beslissing bij het ECRM zijn ingediend. Overige voorwaarden voor het kunnen indienen van een klacht, zoals het verbod van anonieme verzoekschriften, zijn te vinden in artikel 35 EVRM. De hiervoor genoemde "aard" van de bestuurliike boete, zorgt ervoor dat een dergelijke boere met de waarborgen omgeven moet zijn die gelden binnen het straf(proces)recht. Om in het kader van her straf(proces)recht een beroep te kunnen doen op het EVRM - in het bijzonder op de eerder genoemde waarborgen vervat in artikel 6 EVRM-, moet er sprake zijn van een "criminal charge" of een strafrechtelijke vervolging. Hierover later meer. Zie ook Viering, M.L.W.M., "Het toepassingsgebied van artikel 6 EVRM", dissertatie KUN, W.E.J. Tjeenk Willink i.s.m. NISER, Zwolle, 1994. 
een ieder verbinden ${ }^{461}$, kunnen en mogen de Nederlandse burgers er rechtstreeks een beroep op doen. Het kan zelfs zo zijn dat de burger via de rechter rechten aan dergelijke verdragsbepalingen kan ontlenen en deze van de overheid kan afdwingen en zo krijgt het verdrag voorrang boven de nationale wet ${ }^{462}$. Voomoemde verdragen, het EVRM en het IVBPR, verplichten de toezichthouders om onder meer de regels van een eerlijk proces in acht te nemen. Een uitvloeisel hiervan is expliciet terug te vinden in artikel 14 lid 3 onder $g$ van het $\operatorname{IVBPR}^{463}$ en in de jurisprudentie van artikel 6 EVRM $^{464}$.

\section{Artikel 14 IVBPR}

3. Bij bet bepalen van de gegrondheid van een tegen hem ingestelde strafvervolging beefi een ieder, in volle gelijkheid, recht op de volgende minumumgaranties...

(g) niet te worden gedwongen tegen zichzelf te getügen of een bekentenis af te leggent.

"46" Artikel 93 van de Grondwer luidt als volgt: "Bepalingen van verdragen en van besluitew van volkenrechtelijke organisaties, die naar haar inhoud enieder kunnen verbinden , bebben verbindende kracht nadat zij zijn bekendgemaakt.".

Vgl. artikel 94 van de Grondwet: "Binnen bet Koninkrijk greldende wettelije voorschriften vinden geen toepassing, indien deze toepassing niet verenigbaar is met cenieder werbindende bepalingen wan werdragen en van bestuiten wan volkenrechtelijke arganisaties.".

${ }_{463}$ Het verbod om niet tegen zichzelf te hoeven getuigen wordt ook wel her zelfincriminatieverbod genoemd.

464 Vgl. bijwoorbeeld het Funke arrest van het EHRM d.d. 25 februari 1993, NJ 1993, 485 en het Saundersarrest, EHRM 17 december 1996, NJ 1997.699. Meer over laatstgenoend arrest in paragraaf 2.5.3 "de strafrechtelijke procedure". In het Funkearrest gaat het om een verdache van belastingfraude. De in Frankrijk wonende Duitser Funke, weigerde in te gaan op de vordering van de Franse douane om bepaalde documenten af te gewen omdat die als bewijs tegen hem zouden kunnen worden gebruikt. Funke's weigering resulteerde in een veroordeling tor een geldboete en een dwangsom voor elke dag dat hij te laat was met het verlenen van inzage in de desberreffende stukken. Het Funke arrest is van belang voor het Nemo Tenetur beginsell, het niet verplicht zijn om mee te werken aan de eigen veroordeling. Dit beginsel is impliciet terug te vinden in artikel 6 lid 1 van het EVRM; namelijk in het recht op een "fair hearing", een eerlijk proces. Alvorens er een beroep op artikel 6 EVRM kan worden gedaan, dient er te worden wastgesteld of er sprake is van een "criminal charge". Hiervoor is het van belang dat er sprake is van een strafrechtelijke vervolging; de criminal charge. Het arrest Funke is vooral van belang woor de vaststelling van het moment waarop de strafrechtelijke vervolging aanbreekt. Immers, de desberreffende persoon kan geen beroep doen op her EVRM indien er geen sprake is wan een vervolging. In dat geval kan de "verdachte" verplicht worden om bewijs tegen zichzelf te leveren. In dit geval zouden de documenten van Funke wel afgegeven mogen worden. Let wel, dat bewijs moer op andere wijze tot stand zijn gekomen dan door zijn eigen verklaring. 


\section{Artikel 6 EVRM}

Bij bet vasststellen van zijn burgerlijke rechten en verplichtingen of bij bet bepalen van de gegrondheid van een tegen hem ingesselde vervolging beeft een ieder recht op een eerlijke en openbare behandeling van zijn zaak, birnern een redelijke termijn, door een onafhankelijk en onpartijdig gerecht dat bij de wet is ingesteld.(...)

En tot slot artikel 7 EVRM. Uit dit artikel, in samenhang met artikel 6 EVRM, vloeien straf(proces) rechtelijke waarborgen voort die toepasselijk zijn bij boeteopleggingen welke beschouwd kunnen worden als punitieve sancties zoals bedoeld in artikel $6 \mathrm{EVRM}^{465}$.

\section{Artikel 7 EVRM}

1. Niemand mag worden veroordeeld wegens een bandelen of nalaten, dat geen strafbaar feit naar national of internationaal recht witmakike ten tijde dat bet bandelen of nalaten geschiedde. Evenmin mageen zwatardere straf worden opgelegd daw die, die ter tijde wan bet began van bet strafbare feit van toepasing was.

2. (...)

Op grond van deze artikelen zijn de toezichthouders verplicht om in het kader van toezichtshandelingen die kunnen leiden tot het opleggen van een bestuurlijke boete, de cautie te geven vanaf het moment van een "criminal charge"; het moment waarop voor de overtreder duidelijk is

Met andere woorden, materiaal warvan het bestaan niet-afhankelijllk is van de wil van de werdachre. Voor Funke was her dus zaak dat er sprake was van een criminal charge. Het EHRM heef dat laatste dan ook vastgesteld. Volgens het Hof werd er in de zaak Funke "inbreuk (...) gemaakt op de onschuldpresumptie indien oper cemands schuld in een tegen bem gewezen vomis cen oordeel wordt gegeven "withowt his baving the opportunity of exercising bis rights of defense". Volgens her Hof had Funke weinig keuze. Die Franse douane had via de rechtbank een drukmiddell toegepast om bewijsmateriaal tegen Funke in handen te krijgen. Dit werd door het Hof ontoelaatbaar geacht. "The Court notes that the customs secured Mr Funke's conviction in order to obtain certain documents which they believed must exist, although they were not certain of teh fact. Being unable or unwilling to procure them by some other means, they attempted to compel the applicant binuself to provide the evidence of offences be bad allegedly committed. The special features of customs law (...) cannot justify such an infringernent of the right of anyone 'charged with a criminal affence' within the autonomow meaning of this expression in Art. 6 , to remain silent and not to contribute to incriminate bimself. This bas axtordingly been a breach of Art. 6 5 1.". In het Saundersarrest verschafte her EHRM meer duidelijkheid over de ratio en de reikwijdre van het Nemo Tenetur beginsel. Zie paragraaf 2.5.3.

Meer hierover in de dissertatie van Karianne Albers hoofdstuk 3 , in het bijzonder p. 84. Albers, C.L.G.FH., "Rechtsbescherming bij bestuurlijke boeten; balanceren op een magische lijn?", dissertatie UM, Sdu Uitgevers B.V., Den Haag, 2002, p. 84. 
dat hem een boete zal worden opgelegd. Immers, in geval van strafvervolging of een sanctie die gezien de aard en zwaarte gelijk kan worden gesteld aan een strafsanctie, heeft men recht op berechting door een rechter in een "fair trial". Dat wil niet zeggen dat de bestuurstechtelijke instantie geen boete met een strafrechtelijke aard mag opleggen. Het kan, als de regels van voornoemde verdragsartikelen in acht worden genomen. Het EVRM stelt als eis dat men ergens in het gehele proces toegang moet krijgen tot een rechter en een rechterlijke procedure ${ }^{466}$. Deze procedure moet voldoen aan de eisen zoals gesteld in het EVRM. Daarnaast bepaalt het IVBPR het volgende:

\section{Artikel 14 IVBPR}

5. Een ieder die wegens een strafbaar feit is veroordeeld beeft het recht de schuldigverklaring en veroordeling opnieuw te doen beoordelen door een hoger rechtscollege overeenkomstig de wet.

De wetgever was zich ervan bewust dat de oplegging van een boete door een bestuursrechtelijke instantie zonder de mogelijkheid van een rechterlijke beoordeling een schending van voornoemd verdrag zou inhouden. Daarom heeft hij met de invoering van de WBS de bestaande rechtsgang in financiële zaken herzien. Met ingang van 1 januari 2000 is in eerste aanleg, na eerst een bezwaarschriftprocedure te hebben doorlopen, de rechtbank Rotterdam aangewezen als centrale administratieve rechter voor financiële wetten en in hoger beroep het College van Beroep voor het bedrijfsleven (CBB) ${ }^{467}$. Omdat de cautieplicht en het zwijgrecht alleen van toepassing zijn bij de bestuurlijke boete, hoeft dit niet bij de oplegging van een last onder dwangsom te geschieden. Uit de herstellende

406 Corstens geeft in zijn afscheidsrede aan dat het bestuursrecht in beginsel niet is ingesteld op bestraffing. Hij meent dat de bestuursrechter in geval van een op te leggen bestuursboete de artikelen 6 EVRM en 14 IVBPR moet respecteren. Verder stelt Corstens dat "Een stelsel van bestumsboeten (...) dusdanig moeten zijn ingericht dat het gemakkelijk banterbat is, voldoende wataborgen voor onparrijdigheid biedt en de burger wiet echt van de rechter afboudt". Corstens warschuwt onder meer woor het teveel overhevelen van gedragingen uit het strafrecht; het decriminaliseren, waardoor de positie van het strafrecht - het klassieke strafrecht als zodanig - van karakter verandert en het gevaar van verharding op de loer ligt. Hij pleit voor een "punitief sanctierecht" let wel dat is geen bestuursstrafrecht. Binnen het punitief sanctierecht zouden de punitieve sancties die binnen de verschillende rechtsgebieden worden toegepast, onder kunnen worden gebracht Vgl. Corstens, G.J.M., Een stille revolutie in bet strafrecht; aficheidsrede Karbolicke Universiteit Nijmegen", Gouda Quint B.V., Arnhem, 1995, p. 26-29 en $31-38$. 
aard $^{468}$ van de dwangsom ${ }^{469}$ vloeit voort dat het EVRM en het IVBPR niet van toepassing zijn op de procedure die daaraan vooraf gaat ${ }^{470}$. Bij de oplegging van een last onder dwangsom kunnen de toezichthouders hun gedragingen slechts baseren op de controlerende bevoegdheden die voortvloeien uit de verschillende effectenwetten. In dat geval kunnen de toezichthouders de onder toezicht gestelde (rechts)personen om informatie verzoeken en dienen laatstgenoemden deze te verstrekken. Een voorbeeld hiervan is het op grond van haar controlebevoegdheden gebaseerd verzoek van de Autoriteit-FM om inzage in boeken. Indien de ondertoezichtgestelde weigert om aan dit verzoek te voldoen en derhalve een overtreding begaat, kan de Autoriteit-FM een last onder dwangsom opleggen. Immers, hiermee tracht zij de overtreding ongedaan te maken; de Autoriteit-FM verlangt inzage in bepaalde boeken om zo te kunnen

468 In de zin wan de Commissie Scheltema. Vgl de algemene inleiding.

469 In haar promotieonderzoek heeft Karianne Albers de "herstellende" aard van de dwangsom kritisch bestudeerd en meent zij dat deze niet altijd een "herstellend" karakter hoeft te hebben. Volgens haar is het verdedigbaar dat her verbeuren van een last onder dwangsom punitief kan zijn. Vgl. Albers, C.L.G.F.H., "Rechtsbescherming bij bestuurlijke boeten; balanceren op een magische lijn?" " dissertatie $\mathrm{UM}_{n}$ Sdu Uitgevers B. V, Den Haag, 2002.

470 Ook al geldt hier de bescherming van het EVRM of het IVBPR niet, de toezichthouder blijft - zeker daar waar het beschikkingen betreft - gebonden aan rechtsnormen zoals neergelegd in de Awb en de nog niet gecodificeerde algemene beginselen van behoorlijk bestuur. Enkele algemene beginselen van behoorlijk bestuur zijn:

1. het materiële zorgvuldigheidsbeginsel (de overtheid moet de voor de burger minst onaangename oplossing kiezen;

2. het verbod van detournement de pouvoir (de overtheid mag de toegekende bevoegdheid slechts aanwenden voor het door de wetgever beoogd doel);

3. het gelijkheidsbeginsel (de overheid dient gelijke gevallen gelijk te behandelen);

4. het eventedigheidsbeginsel. (de door de overheid opgelegde sanctie dient niet onevenredig te zijn aan de overtreden regel);

5. het vertrouwensbeginsel (de overheid houdt zich niet aan de door haar beleid gewekte werwachringen);

Zoals Van Wijk en Konijnenbelt het stellen:" De algemene beginselen van beboorlijk bestum bevatten nomen wattaan bet besturwshandelen altijd moet voldoen. ook als de wettelijke regels beleidsrumte later; dat is de aanvullende werking wan de beginselen" W Wijk, H.D. van en Konijnenbelt, W., Hoofdstukken van administratief recht, $1991,7^{\text {de }}$ druk, $2^{\text {de }}$ oplage, Lemma B.V., Utrechr, p. 69 e.v. en p. 131, Wijk, H.D. van, Konijnenbelt en Van Male, Hoofdstukken van bestuursrechr, $11^{\text {de }} \mathrm{druk}$, Den Haag, 1999. Zie ook Stroink. F.A.M en Steenbeek, J.G." "Inleiding in het statas-en administratief recbt", $1989,3^{\text {th }}$ druk, Samsom H.D. Tjeenk Willink, Alphen aan den Rijn, p. 66 - 69 en p. 115. 
voldoen aan haar controlerende taken ${ }^{471}$. Bij de bestuurlijke boete zou het voorafgaande niet van toepassing zijn. De oplegging van dit specifieke bestuursrechtelijk handhavingsinstrument heeft een vergeldend karakter, hetgeen zorgt voor de koppeling met de hiervoor genoemde wetten en verdragen. Dat betekent onder meer dat de Autoriteit-FM de desbetreffende persoon dient te wijzen op zijn zwijgrecht alvorens zij om informatie kan verzoeken. In dit geval is het van belang dat de toezichthouders, die nu tevens bevoegd zijn om naast de uirvoering van het toezicht ook sancties op te leggen, binnen hun organisatie een functiescheiding creëren. Met name de Eerste Kamer der Staten Generaal heeft dit benadrukt en is van mening dat:

"de toezichthouders ervoor moeten zorgen dat niet dezelfde personen bij de uitoefening van toezichttaken een overtreding constateren en vervolgens zijn belast met het opleggen van dwangsommen en bestuurlijke boeten "if72

De STE en DNB zouden op grond van het voorafgaande een dergelijke functiescheiding in het leven moeten roepen omdat zij mogelijk door een rechter, die zich over oplegging van een bestuurlijke boete kan buigen, hierop gewezen zouden kunnen worden. Dit zou dan in het uiterste geval kunnen leiden tot een vernietiging van de opgelegde bestuurlijke boete. De STE en nu de Autoriteit-FM dient naast de speciale afdelingen die belast zijn met het toezicht, aparte secties in het leven te roepen die moeten beoordelen of er al dan niet gesanctioneerd dient te worden. De wetgever heeft een dergelijke scheiding in ieder geval voorzien en in verschillende voorschriften aansporingen hiertoe gegeven. Een voorbeeld is te vinden in de wettekst van artikel 481 Wte' $95^{473}$.

\section{Artikel $48 l$ wte'95}

De uverkadambeden in verband met het opleggen van een dwangsom of van een boete worden verricht door personen die niet betrokken zijn geweest bij het vaststellen van de overtreding en het dataraan voorafgatande onderzoek.

47 Een ander voorbeeld van een herstellende ofwel een reparatoire sanctie is her verwijderen van cen illegaal bouwwerk. In dat geval is het handellen van de desbetreffende toezichthoudende bestuursorgaan gericht op het herstellen van de overtireden norm. Ofwel zoals $\mathbb{K}$. Alberts stelt: "De onrechtmatige situatie moet op Last wan het bestuur worden bersteld in een rechtmatige situatie". Vgl. Albers, $\mathrm{K}$, "' Erikettenschwindel" in her administratieve sanctierecht?", NJB, jrg. 76, 2001. nr. 25.

473 Zie ook de artikelen $331 \mathrm{Wtb}$; $901 \mathrm{Wtk} 92 ; 23 \mathrm{k}$ Wwk en $13 \mathrm{k}$ Wmz. 
Dat de STE en nu ook de Autoriteit-FM gepoogd heeft zich aan bovengenoemde functiescheiding te houden blijkt uit het feit dat zij de sector Juridische Zaken, die verantwoordelijk is voor het afhandelen van beroeps- en bezwaarschriften, de taak heeft gegeven om zorg te dragen voor de uitvoering van op te leggen boetes en dwangsommen. Dir geschiedt via een speciaal hiervoor gecreëerde functie: de boetefunctionaris ${ }^{474}$. Of hiermee ook daadwerkelijk (een schijn van) partijdigheid kan worden voorkomen, zal in hoofdstuk 4 worden besproken.

Kortom, in de bestuurstechtelijke procedure kan de Autoriteit-FM een openbare kennisgeving uitvaardigen, aanwijzingen aan de onder toezicht gestelde (rechts) personen geven, vergunningen dan wel verklaringen van geen bezwaar beperken of aan voorschriften onderwerpen, een last onder dwangsom opleggen, de overtreder verplichten tot het betalen van een bestuurlijke boete, de verleende vergunning intrekken of op grond van artikel 28 lid 6 Wte' 95 een stille curator instellen. DNB heeft, in beginsel, de beschikking over gelijksoortige handhavingsinstrumenten ${ }^{475}$. Dat wil zeggen dat de door de Autoriteit-FM afgegeven verklaring van geen bezwaar niet bij DNB voorkomt. DNB geeft wel verklaringen af aan ICBE's dat zij voldoen aan de ICBE richtlijnen. Met deze verklaringen kunnen de desbetreffende beleggingsinstellingen ook actief zijn in andere EG lidstaten ${ }^{476}$.

Naast de bestuursrechtelijke procedure kan een overtreder van de effectenwetgeving ook met een civielrechtelijke procedure worden geconfronteerd. Hoe dat kan en wat dit inhoudt zal in de volgende paragraaf worden besproken.

\subsubsection{De civielrechtelijke procedure}

In de Nederlandse effectenregelgeving heeft onze wetgever zich voornamelijk gericht op sancties die voortvloeien uit de bestuursrechtelijke en/of strafrechtelijke procedure. Over eventuele middelen

STE, jaarverslag 2000, Amstelween, maart 2001, p. 13.

Vgl. voor her geven van aanwijzingen en aanzeggingen, de arcikelen 21 en 22 lid $1 \mathrm{Wtb}$; voor het intrekken dan wel werbinden wan voorschriften aan vergunningen, de artikelen 15 en 30 Wrb. De wijziging in toezichtstructuur en de hieraan inherente overdracht van bevoegdheden aan de Autoriteit-FM zullen hoogstwaarschijnlijk ook op dit vlak gevolgen voor de bevoegdheden van DNB hebben.

Vgl. artikel 13 Wtb. 
die voortvloeien uit een civielrechtelijke procedure, de civielrechtelijke "sancties", heeft de overheid zich bewust dan wel onbewust zuinig uitgelaten. Naar alle waarschijnlijkheid is dat een weloverwogen keuze geweest, beïnvloed door de aard van een civiele procedure. De ordenende houding van onze wetgever komt vooral tot uiting in procedures waar de burger zich, al dan niet in de hoedanigheid van belegger, ten opzichte van de "sterkere, beter geïnformeerde" (overheids) partij in een zwakkere positie bevindt en daardoor (wettelijke) bescherming behoeft. Zowel de bestuursrechtelijke als de straf(proces) rechtelijke wetsbepalingen zijn beide een goed voorbeeld van ordenend overheidsoptreden. Om de (grond)rechten van de burger te waarborgen, worden de overheid en eventuele andere partijen aan regels gebonden. Een voorbeeld hiervan is de in paragraaf 2.5.1 genoemde cautieplicht. Het civiele recht kent in beginsel gelijke (burger)partijen waardoor het niet in aanmerking komt voor beschermend overheidsoptreden.

Binnen de effectenwet- en overige regelgeving is de wetgever terughoudend geweest met het opnemen van civielrechtelijke middelen. In tegenstelling tot het bestuursrecht en het strafrecht, hebben de toezichthouders weinig civielrechtelijke middelen tot hun beschikking. Wanneer wij de toezichthouders gaan vergelijken met de gedupeerde beleggers' aandeelhouders, kunnen de eerstgenoemde instellingen hun toevlucht niet nemen tot het instellen van een onrechtmatige daadactie. Dit zou waarschijnlijk wel mogelijk zijn indien de toezichthouders zouden kunnen aantonen dat $z i j$ schade hebben geleden door het onrechtmatig handelen van de beleggingsinstelling of van de effectenhandelaar en dat er een causaal verband zou bestaan tussen de schade en de gewraakte gedraging. Let wel, daarnaast dient er ook nog rekening te worden gehouden met het relativiteitsbeginsel. Dit beginsel kan roet in het eten gooien. Het is niet ondenkbaar dat de overtreden norm niet strekt tot bescherming van de belangen van de toezichthouders ${ }^{477}$. Zoals we hieronder zullen zien, strekken de bepalingen uit de effectenwetgeving voornamelijk ter bescherming van de belangen van de beleggers en trachten zij door middel van regulering een betrouwbare en zo transparant mogelijke effectenhandel te creëren. Weliswaar lijkt het mij niet mogelijk om een directe link te leggen tussen de taken van de toezichthouders en de doelstellingen van de effectenwetgeving. Wel zou het een uitkomst 
voor de toezichthouders zijn wanneer het relativiteitsbeginsel dusdanig zou kunnen worden "opgerekt" dat de belangen van de beleggers (in)direct onder de belangen van de toezichthouders kunnen worden gebracht. Of dit reëel is en de toezichthouders daardoor, bij het overtreden van de effectenregelgeving, een beroep op 6:162 BW kunnen doen lijkt mij erg ver gezocht. Daarom zullen we hieronder alleen de civielrechtelijke mogelijkheden voor gedupeerde beleggers bekijken. De Autoriteit-FM en DNB worden hierdoor tijdelijk op de achtergrond geplaatst.

Aldus is reeds aangegeven dat de wetgever terughoudend was in het vaststellen van civielrechtelijke middelen bij overtredingen van de effectenregelgeving. Slechts in de Wmz' 96 en in de Wtb heeft hij expliciet verwezen naar dergelijke "sancties". De Wte'95 kent als enige civielrechtelijk middel, de onrechtmatige daadactie. Voornoemde middelen die toegepast kunnen worden bij overtredingen van de effectenwetten, zijn onder te verdelen in maatregelen die door de rechtbank kunnen worden opgelegd en in de onrechtmatige daadactie zoals genoemd in artikel 6:162 BW. Allereerst zullen de maatregelen genomen via de rechtbank aan bod komen, daarna de onrechtmatige daad.

\section{Maatregelen bij de rechtbank}

In zowel de Wmz'96 als in de Wtb heeft de wetgever bepalingen opgenomen die het de (gedupeerde) belegger, vennootschap en/of andere belanghebbenden ${ }^{478}$ mogelijk maken om, buiten het strafrecht of het bestuursrecht om, juridische stappen te ondernemen tegen de beleggingsinstelling, de beleggingsmaatschappij, het beleggingsfonds en/of de bewaarder. Op grond van artikel 9 Wmz'96 en artikel 2:15 BW kunnen bepaalde aandeelhouders, de vennootschap ${ }^{479}$ en belanghebbenden, bij de rechtbank ${ }^{480}$ maatregelen tegen de desbetreffende vennootschap

Wellicht kunnen ook de toezichthouders, voorheen de STE, nu de AutoriteitFM en indien van toepassing DNB, als belanghebbende instellingen maatregelen bij de rechtbank vorderen.

479 Arrikel 9 lid 2: Tot het instellen van een vordering zijn bevoegd:

a een of meer houders van aandelen in het kapitaal van de vennootschap die alleen of gezamenlijk ten minste een twintigste gedeelte van her geplaatste kapitaal vertegenwoordigen;

b. de vennootschap.

De arrondissementsrechtbank in de vestigingsplaats van de desbetreffende vennootschap. Vgl. art. 9 lid $1 \mathrm{Wmz}^{\prime} 96$. 
vorderen ${ }^{481}$. Deze maatregelen kunnen op grond van artikel 2:15 lid 3 onder $\mathrm{b} B \mathrm{BW}$ daarnaast ook tegen een ander, een door de president van de rechtbank aangewezen persoon, worden ingesteld. Alvorens de maatregelen kunnen worden opgelegd, dient vastgesteld te worden dat de betrokken vennootschap zich niet aan de reeds bekende meldplicht van de Wmz'96 heeft gehouden ${ }^{482}$. Wanneer dit het geval is en de vennootschap het passeren van een drempel niet heeft gemeld, kan dit volgens lid 4 van voornoemd artikel leiden tot:

- een veroordeling tot het melden overeenkomstig de meldingsplicht;

- de schorsing van de witoefening van bet stemrecht won (alle ${ }^{483}$ ) aandelen voor de dutu ton max. 3 jaar;

- de schorsing wan een beshit van de algemene vergadering van aandeelbouders (ava) totdat over de vernietiging van een besluit van de ava door de rechter onberroepelijk is beslist:

- de vernietiging van een beshit van de ava voor zover kan worden angetoond dat bet beshit niet zou zijn genomen wanneer de stemmen van de meldingsplichtige niet zouden zijn uitgreofend:

- het gevebtelijke bevel an de meldingsplichtige om woor de duur vat maximaal 5 jaren geen beschikking over aandelen in bet kapitad wan de wennootschap te mogen verkriggen of bet verbod om beschikking over stemmen te mogen verkerigen die op bet geplatatste kapitad van die vennootschap kunnen worden witgebracht.

De civielrechtelijke middelen die voortvloeien uit de Wtb kunnen door de rechter worden opgelegd wanneer blijkt dat de beleggingsinstelling of het beleggingsfonds niet heeft voldaan aan de wettelijke verplichting om onder meer informatie te verstrekken. De informatie dient op grond van artikel $5 \mathrm{lid} 1$ onder $\mathrm{W}$ W/b te worden verstrekt. Onderstaand artikel

481 Vgl. artikel 9 Wz"96 jo 2:15 lid 3 sub a BW. Artikel 2:15 lid 3 luidt als volgt:

Vernietiging geschiedt door een uirspraak van de rechtbank wan de woonplaats. van de rechtspersoon:

a. op cen vordering tegen de rechtspersoon van iemand die een redelijk belang heeft bij de naleving van de verplichting die niet is nagekomen, of

b. op vordering van de rechtspersoon zelf; ingesteld krachtens bestuursbesluit tegen degene die door de president der rechtbank is aangewezen op een daartoe gedaan verzoek van de rechtspersoon; in dat geval worden de kosten van het geding door de rechrspersoon gedragen.

4 V.2. paragraaf 2.3.1.

48. Vgl. Van der Grinten, W.C.L., Kortman S.C.J.J, en Perrick, S., "Civielrechtelijke gevolgen wan handelen in strijd met effectenregelgeving: preadvies voor de Vereniging woor Effectenvecht 1994", Kluwer B.V., Deventer, 1996, p. 39. 
$5 \mathrm{Wtb}$ verplicht iedere vergunninghouder om aan $\mathrm{DNB}^{484}$, de deelnemers in de beleggingsinstelling en aan het publiek informatie te verstrekken.
Artikel 5 Wtb
Onze Minister verleent een beleggingsinstelling op verzaek en met inachtneming wan artikel 6 , een vergunning indien de aanvager adntount dat de beleggingsinstelling en de bewaarder, indien aan de beleggingsinstelling verbonden, voldoet atan de bij of kraclitens algemene matregel wan bestur te stellen eisen met betrekking tot:
a. deskundigheid en betrounbaarheid;
b. financielle watarborgen;
c. bedrifswoering; en
d. aan de deelnemers in de beleggingsinstelling en aan het publiek te verstrekken informatie.

Naast artikel 5 voorziet de Wtb ook via artikel 11 in civielrechtelijke mogelijkheden. Laatstgenoemd artikel bepaalt dat Nederlandse ICBE's niet bevoegd zijn om hun statuten of reglementen zodanig te wijzigen dat zij geen ICBE's meer zijn. Lid 2 van dit artikel jo 2:14 Bw bepaalt dat een verboden wijziging van statuten of reglementen nietig is en dat het OM de rechter mag verzoeken om een bewindvoerder te benoemen die de gevolgen van de nietige handeling ongedaan kan maken ${ }^{485}$. Voorts kent de Wtb ook de ontbinding van de rechtspersoon als civielrechtelijke "sanctie". Wanneer een beleggingsinstelling zich niet aan de vergunningseisen heeft gehouden, kan DNB op grond van artikel $15 j^{\circ} 29$ lid $4 \mathrm{~W} / \mathrm{tb}$ besluiten om de verleende vergunning in te trekken. Indien de intrekking van de vergunning is geschied bij een beleggingsmaatschappij, kan DNB op grond van artikel 16 lid $2 \mathrm{j}^{\circ} 33 \mathrm{~W}$ tb de rechtbank verzoeken om over te gaan tot ontbinding van de desbetreffende rechtspersoon ${ }^{486}$. In geval het een beleggingsfonds betreft, is ontbinding niet mogelijk omdat we

484 Artikel 29 lid 4 Wtb delegeerr de taken en bevoegdheden van de Minister aan DNB: "Indien bij algemene maatregel van bestuur taken en bevoegdheden als bedoeld in het eerste lid zijn overgedragen aan De Nederlandsche Bank N.V., is de Bank bevoegd deze taken uit te voeren en deze bevoegdheden uit te oefenen." Vgl. Van der Grinten, W.C.L., Kortman S.C.J.J en Perrick, S., "Civielrechrelyjke gevolgen van handelen in sirijd met effectenregelgeving: preadvies voor de Vereniging woor Effectenrecht 1994", t.a.p. noot 483, 25-28.

4\$6 Vgl, de arrikelen 2:19 ${ }^{3}$ onder Fen $2: 19^{5}$ BW. Zie Van der Grinten, W.C.L. Kortman S.C.J.J. en Perrick, S., "Civielrechtelijke gevolgen wan bandelen in strijd met effectenregelgeving: preadvies voor de Verentging voor Effectenrecht 1994", t.a.p. noor 483, p. 25. 
niet met een rechtspersoon te maken hebben. De rechter kan in dat geval besluiten dat het vermogen van het desbetreffende fonds, binnen een door hem te bepalen termijn, moet worden vereffend ${ }^{487}$.

De Wte'95 kent, in tegenstelling tot de Wtb en de Wmz, geen bepalingen met civielrechtelijke middelen welke door de rechter kunnen worden opgelegd. Op grond van de Wte'95 kunnen (gedupeerde) aandeelhouders wel een onrechtmatige daadactie instellen.

\section{Onrechimatige daad}

Wanneer beleggingsinstellingen of de hieraan verbonden tussenpersonen buiten een besloten kring effecten aanbieden, en dat aanbod achteraf in strijd met de wet blijkt te zijn geschied, kunnen beleggers op grond van de artikelen 3 lid 1 Wte $95 j^{\circ}$ 3:40 lid $2 j^{\circ} 6: 162 \mathrm{BW}$, een onrechtmatige daadactie entameren. De reden hiervoor is gelegen in de strijdigheid van het aanbod met de wet ${ }^{488}$. Omdat artikel 3 lid 1 Wte'95 strekt tot de bescherming van slechts 1. partij bij een meerzijdige rechtshandeling, te weten de beleggers en spaarders, is vernietigbaarheid volgens het rweede lid van artikel 3:40 BW de juiste sanctie ${ }^{489}$ Naast voornoemd artikel uit de Wte'95, kan ook het niet naleven van artikel 7 lid 1 Wte'95, het zonder vergunning als effectenbemiddelaar of vermogensbeheerder in of vanuit Nederland aanbieden of verrichten van diensten, tot een civiele "sanctie" leiden. Een overtreding van artikel 3 lid 1 en/of artikel 7 lid 1 is niet alleen een economisch delict ${ }^{490}$, maar kan ook civielrechtelijke gevolgen hebben. Te denken valt aan het nietig verklaren van de bemiddelingsovereenkomst met de effectenbemiddelaar of het vernietigen van voornoemde overeenkomst op grond van artikel 3:40 BW 491 ,

Zie artikel 16 tid 3 jo 33 Web.

Van der Grinten, W.C.L., Kortman S.C.I.I. en Perrick, S., "Civielnechtelijke gevolgen wan bandelon in strijd met effectenregelgeving: preadvies voor de Vereniging voou Effectenrecht 1994", t.a.p. noot 483, p. 11.

Vgl. Van der Grinten, W.C.L., Kortman S.C.J.J. en Perrick, S., "Civielrecbtelijke gevolgen wan bandelen in sirijd met effectenregelgeving: preadvies voor de Vereniging voor Effectentecht $1994^{\prime}$, t.a.p. noot 483 , p. 9.

Op grond van artikel 49 Wte 95 jo 1 sub I WED zijn owertredingen van beide artikelen economische delicten.

1. "Een rechtshandeling die door inhoud of strekting in strijd is met de goede zeden of de openbare onde, is nietig.

2. Strijd met een dwingende wetsbepaling leidt tot nietigheid wan de rechtshandeling, doch, indien de bepaling witslutend strekt ter bescherming wan een der partijen bij en meevijdige rechtshandeling, slechts tot vernietigbaarbeid een en ander woor zover nie uit de strekking wan de bepaling anders voortwloeit" 
maar hierover verschillen de meningen. Volgens critici zou in beginsel de nietigheid van de bemiddelingsovereenkomst ingeroepen kunnen worden, maar omdat artikel 7 Wte' 95 strekt tot bescherming van slechts 1 partij bij een meerzijdige rechtshandeling, te weten de belegger, menen zij dat vernietigbaarheid het juiste middel is ${ }^{492}$. Anderen menen dat de bemiddelingsovereenkomst niet (ver) nietig(baar) is, maar geldig ${ }^{493}$ : In geval de nietigheid of vernietigbaarheid van de bemiddelingsovereenkomst heeft geleid tot aamwijsbare schade bij de belegger, wat niet ondenkbaar is, kan deze een onrechtmatige daadactie instellen en schadevergoeding vorderen.

Naast de Wte'95, kan ook de W'mz'96 een basis bieden voor een vordering tot schadevergoeding naar aanleiding van een onrechtmatige daad jegens gedupeerde. In geval de meldingsplichtige heeft verzuimd om de

492 Vgl. Franken, A. Civielrechtelijke gevolgen wan bandelen in strijd met effectenregelgeving-recente ontwikkelingen in: Vennootschap of Onderneming, 1999, afl. 5 , mei, p. 57.

Van der Grinten spreekt ower twee soorten overeenkomsten:

a. de bemiddelingsovereenkomst tussen de bemiddelaar in effecten $(X)$ en de cliènt $(Y)$ en

b. de overeenkomst tussen cliënt $X$ en de (ver) koper wan effecten $(Z)$, tot stand gekomen door de eerdere bemiddelingsovercenkomst $(X-Y)$.

Volgens Van der Grinten zijn de overeenkomsten onder de punt a en b geldig en hiermee spreekt hij de president van de Rechtbank Amsterdam tegen (President Rechrbank Amsterdam, 2 maart 1995, KG 1995, nr. 204). Laatsrgenoemde heeft bepaald dat de overeenkomst onder a vernietigbaar is. In casu vroeg eiser om restitutie van zijn inleggeld, dat hij had gestort om onder meer gedaagde American Futures $\&$ Options $\mathrm{GmbH}$ overeenkomstig een bemiddelings-contract, termijntransacties op naam en voor rekening van eiser te laten verrichten. Hierwoor zou American per afgesloten contract commissie ontvangen. Nadat eiser zich aan zijn deel wan de bemiddelingsovereenkomst had gehouden, te weten het voldoen van inleggeld, is gebleken dat de bemiddelaar in effecten niet over de wettelijk vereiste wergunning van 6 We'92 (nu 7 Wre'95) beschikte. En dar de STE openlijk werklaarde niet met het bedrijf "in zee te gaan". De president van de rechtbank heeft het volgende bepaald: ".. de overeenkomst op grond wan bet bepalde in art. 3.40 lid 2 BW wemigtigbaar is artikel 6 Wte strekt immers ter bescheming wan een der partijen bijeen meerzijdige rechtshandeling, tertwijl wit de strekking van de bepaling niet anders woortoloeit. Het beroep op wernietigbaarbeid wordt dus an wadad.. " "Zie Van der Grinten, W.C.L., Kortman S.C.I.J. en Perrick, S., "Civielrechtelijke gewolgen wan handelen in strijd mer effectenregrelgeving: preadvies voor de Vereniging voor Effectenrecht 1994", ta.p. noot 483, p. $15-18$ en Franken, A., Civielredbelijke gevolgen van bandelen in strijd met effectenregelgewing - recente ontwikkelingen in: Vennootschap \& Onderneming, 1999, af. 5, mei, p. 57. 
overschrijding van een bandbreedte te melden zou dat, op grond van artikel $2 \mathrm{Wmz}^{\prime} 96 \mathrm{j}^{\circ}$ 6:162 BW, via een onrechtmatige daadactie tot een schadevergoeding voor de gedupeerde (belegger) kunnen leiden. Een voorbeeld van Perrick is de schade van een belegger die door een aan- of verkoop van aandelen is ontstaan omdat de meldingsplichtige niet heeft angegeven een bepaalde hoeveelheid aandelen te hebben ge- of verkocht. Dit zal zeker het geval zijn indien de belegger aan kan tonen dat hij de desbetreffende aandelen niet zou hebben ver- of gekocht indien de meldingsplichtige zijn meldplicht onmiddellijk zou zijn nagekomen en de belegger over deze extra informatie had kunnen beschikken. Hetzelfde geldt voor een gedupeerde venootschap. Ook in dat geval kan volgens Perrick schade ontstaan door het niet nakomen van de meldingsplicht. Het kan namelijk zijn dat de vennootschap kosten heeft gemaakt om, na het ontstaan van de meldingsplicht, fusieonderhandelingen voort te zetten terwijl dat misschien niet nodig zou zijn geweest omdat er meer aandelen dan wel stemrechten zouden zijn verkregen ${ }^{494}$.

Naast de Wte'95 kent ook de Wtb een informatieplicht. Dit suggereert dat ook de Wtb een grond voor schadevergoeding uit onrechtmatige daad kan zijn. Vanzelfsprekend betreft het beleggingsinstellingen. In een dergelijk geval zal de vordering gebaseerd moeten worden op artikel 5 Wtb Jo $6: 162 \mathrm{BW}$. Artikel $5 \mathrm{Wtb}$ verplicht iedere vergunninghouder aan DNB, de deelnemers in de beleggingsinstelling, en het publiek informatie verstrekken. Wanneer het verzuimen van voormelde plicht tot schade heeft geleid bij de deelnemers en/of andere belanghebbenden, kan de beleggingsinstelling verplicht worden de geleden schade te vergoeden ${ }^{495}$.

In tegenstelling tot de enkele hiervoor genoemde civiele "sancties" dan wel middelen of handhavingsmogelijkheden, kunnen er bij overtredingen van de effecten wet en regelgeving verschillende strafrechtelijke sancties worden opgelegd. Welke dat zijn zullen we in de volgende paragraf bespreken.

494 Zie Vin der Grinten, W.C.L., Kortman S.C.J.J. en Perrick, S., "Civielrechtelijke gevolgen wan handelen in strijd met effectenregelgeving preadvies voor de Vereniging woor Effectenrecht 1994", t.a.p. noot 483, 1996 , p. 53.

495

Van der Grinten en Kortmann in: Van der Grinten, W.C.L., Kortman S.C.J.J. en. Perrick, $S_{\text {, }}$ "Civielrechtelijke gevolgen van handelen in strijd met effectenregelgeving: preadvies voor de Vereniging voor Effectenrecht 1994", t.a.p. noor 483, p. $28-29$. 


\subsubsection{De strafrechtelijke procedure}

De tot nu toe besproken toezichtprocedures zouden in beginsel beide door de Autoriteit-FM kunnen worden geëntameerd. Bij het instellen van een strafrechtelijke procedure heeft de Autoriteit-FM minder invloed omdat zij nier de bevoegdheid heeft om tot vervolging over te gaan. De Autoriteit-FM is hiervoor aangewezen op het Openbaar Ministerie. Eerstgenoemde kan alleen angifte doen bij het Openbaar Ministerie waarna deze kan besluiten om de desbetreffende zaak nader de onderzoeken en eventueel te vervolgen. Naast aangifte van de AutoriteitFM, kan het Openbaar Ministerie ook zelfstandig overgaan tot het instellen van een strafrechtelijke onderzoek bijvoorbeeld naar aanleiding van klachten of berichten in de media. Het kan namelijk voorkomen dat krantenkoppen de aandacht van het Openbaar Ministerie trekken, maar het Openbaar Ministerie maakt in beginsel geen actief gebruik van de openbare bronnen. Een andere mogelijkheid om een strafrechtelijk onderzoek te entameren is via de aangifte van gedupeerden. Mocht bijwoorbeeld een belegger menen dat hij of zij is benadeeld door onder meer frauduleus handelen, kan er aangifte bij het Openbaar Ministerie worden gedaan. Wat er na een aangifte kan gebeuren zal in deze derde en laatste procedure worden besproken.

\section{Het Functioneel Openbaar Ministerie}

Het Openbaar Ministerie, dat de regie heeft over de strafrechtelijke procedure, heeft de exclusieve bevoegdheid te beslissen on tot vervolging over te gaan. In beginsel kan de Autoriteit-FM daar geen direct invloed op uitoefenen. Wel bestaat er de mogelijkkheid om via artikel $12 \mathrm{WvSv}$ schriftelijk beklag bij het gerechtshof te doen omtrent het nietvervolgen ${ }^{496}$. Voornoemde bevoegdheid van het Openbaar Ministerie

Vgl. artikel 12 WvSv:

1. Wordt cen strafbaar feit niet vervolgd of de vervolging niet woortgezet, dan kan de rechtstreeks belanghebbende daarower schriftelijk beklag doen bij her gerechtshof, binnen het rechtsgebied waarvan de beslissing tot niet vervolging of niet verdere vervolging is genomen. Indien de beslissing tot niet verwolging is genomen door de officier van justitie bij her landelijk parket, is bevoegd het gerechtshof te 's-Gravenhage.

2. Onder rechtstreeks belanghebbende wordt mede verstaan een rechtspersoon die krachtens zijn doelstelling en blijkens zijn feitelijke werkzaamheden een belang behartigt dat door de beslissing tor niet vervolging of niet verdere vervolging rechtstreeks wordt getroffen. 
wordt het opportuniteitsbeginsel genoemd 497 . Over het algemeen is, hiërarchisch gezien, het parket waartoe de locus delicti behoort bevoegd om strafbare feiten te verwolgen. Dat wil zeggen dat waar het feit wordt gepleegd, er vervolgd kan worden. Er zijn uitzondering op deze regel. Een voorbeeld hiervan is het geval van misbruik van voorwetenschap; het overtreden van artikel 46 Wte' $95^{498}$. Dat wordt niet regionaal, locus delicti, maar landelijk afgedaan. Ook al ontdekte het Openbaar Ministerie een overtreding van artikel 46 Wte'95 in Den Haag, toch was dan het parket in Amsterdam bevoegd om te vervolgen omdat zij de exclusieve bevoegdheid toegewezen had gekregen. In de praktijk zou het verschil tussen een regionaal of landelijke bevoegdheid niet zo zeer opvallen daar zowel de Autoriteit-FM als DNB in Amsterdam gevestigd zijn en zij de partijen zijn die in beginsel overtredingen zouden kunnen ontdekken. Een uitzondering hierop is de Pensioens- en Verzekeringskamer (PVK); die in Den Haag is gevestigd. In 2002 is het Functioneel Openbaar Ministerie (FOM) in het leven geroepen. Her FOM is een nieuw opgericht parket dat evenals de 19 arrondissementsparketten, het landelijk parket te Rotterdam en de 5 resortsparketten, onderdeel uitmaakt van het Openbaar Ministerie. Met de oprichting van een FOM heeft de wetgever een parket voor ogen gehad dat zich niet bezig zou houden met een bepaald territoir, maar zich zou richten op een bepaald belang; een functie: namelijk het bestrijden van bepaalde soorten van fraude. Hier moet gedacht worden aan het centraal stellen van de integriteit van de financiële sector; van zowel de fiscale fraude, het milieu, de sociale zekerheid en de voedselveiligheid ${ }^{499}$. Met dit speciaal hiervoor

497 Vgl. artikel 167 lid 1 en 2 Wv Sw:

1. Indien naar aanleiding van het ingestelde opsporingsonderzoek het openbaar Ministerit van oordeel is dat vervolging moet plaats hebben, gaat het daartoe zoo spoedig mogelijk over.

2. Van vervolging kan worden afgezien op gronden aan het algemeen belang ontleend...

403 Ter herinnering artikel 46 lid 1 We'95:

1. Het is eenieder verboden om, beschikkende over voorwetenschap, in of vanuit Nederland een transactie te verrichten of te bewerkstelligen in:

a. effecten die zijn genoteerd aan een opgrond van artikel 22 erkende effectenbeurs dan wel an een buiten Nederland gevestigde en van overheidswege toegelaten effectenbeurs of effecten waarvan aannemelijk is dat deze spoedig aan een zodanige beurs zullen worden genoteerd; of

b. effecten waarvan de waarde mede wordt bepaald door de waarde wan onder a bedoelde effecten.

(499) Kamerstukken II, $2001 / 2002,17050$, nt. 234 , p. 16. 
opgerichre parket zou het expertiseniveau van het Openbaar Ministerie moeten worden vergroot. Dit door de bij het Openbaar Ministerie aanwezige specialistische kennis samen te bundelen en door bepaalde bijzondere opsporingsdiensten (BOD) centraler aan te sturen. Het FOM zal niet alleen een centraal aanspreekpunt moeten zijn voor de vier grote BOD-en ${ }^{500}$ zoals de FIOD-ECD van het Ministerie van Financiën, de AID van her Ministerie van Landbouw Natuur en Visserij, de SIOD van her Ministerie van Sociale Zaken en Werkgelegenheid en de Inlichtingen en Opsporingsdienst van het Ministerie van VROM ${ }^{501}$, maar ook voor de financiële toezichthoudende Autoriteit-FM ${ }^{502}$. De afdoening van zaken en aangiften met een karakter dat past binnen de doelstellingen van het FOM, zullen onder verantwoordelijkheid van dit onderdeel van het Openbaar Ministerie worden afgedaan ${ }^{503}$. Met het FOM en haar doelstellingen hoopt het Openbaar Ministerie slagvaardiger op te kunnen treden in zaken waar zij in het verleden "publicitair gevoelige nederlagen (heeft) geleden ${ }^{504 n} 505$.

De oprichting van het FOM lijkt op het eerste gezicht veel voordelen voor het Openbaar Ministerie te hebben. Zo zou een versplintering van beleid tegen kunnen worden gegaan doordat er een vervolgingsbeleid gehanteerd zal kunnen worden waardoor er geen verschil tussen de diversen parketten ontstaat. Het wilde wel eens voorkomen dat bijvoorbeeld het parket van Amsterdam het besluit nam om een bepaald financieel economisch feit niet te vervolgen omdat zij dit niet opportuun

Stolwijk, E., "Functioneel OM zal beschikbare capaciteit beter kunnen benutten", Opportuun, $8^{\text {ste }}$ jaargang, nr. 6 , februari 2002, p. 13 en een interview van Marijke Vromans met de directeur van FIOD-ECD en met de directeur-generaal van bet Ministerie van Sociale Zaken en Werkgelegenheid ( $S Z W)$. Vgl. Vromans, $M$. "De bijzondere opsporingsdiensten en de bijbehorende vakdepartementen krijgen binnen enkele maanden een centraal aanspreekpunt: her Funcrioneel OM (FOM). Wat zijn de verwachtingen van dit nieuwe parket? "Twee reacties.", Opportunn, $8^{\text {sne }}$ jaargang, nr. 6, februari 2002 , p. $14-15$ m.n. p. 14.

Kamerstukken II, 2001/2002, 17050 , nr. 234, p. $15-16$.

502 Her NRC Handelsblad, d.d. 21 mei 2002, "OM wil 'fraude' centraliseren.". Kamerstukken II, 2001/2002, $28106, \mathrm{nt} .4$, p. 25.

Neem bijvoorbeeld de Clickfondszaak waarin het OM niet alleen enkele veroordelingen heeft kunnen verkrijgen, maar ook zware nederlagen heeft geleden zoals het vonnis van de arrondissementsrechtbank Amsterdam d.d. 22 juni 2001, inzake Leemhuis \& Van Loon Vermogensbeheer B. V.. Het NRC Handelsblad, d.d. 21 mei 2002, "OM wil "fraude" centraliseren."

Kamerstukken II, 2001/2002, 28300 , nr. 3, p. 12. 
achtte wegens overbelasting terwijl het parket in Maastricht of Leeuwarden een soortgelijk feit wel besloot te vervolgen. Het voordeel van her ontwikkelen van een centraal vervolgingsbeleid, is dat er bijvoorbeeld een centraal transactiebeleid tot stand kan komen. Vóór de totstandkoming van een functionele $O M$ kon het zo zijn dat het parket Maastricht contact op moest nemen met het parket Amsterdam hoe te handelen bij een bepaalde overtreding omdat het zelden in aanraking kwam met een dergelijke wetsovertreding en het desondanks een lijn wilde trekken. Dit kwam voor, maar een vaste regel was het nier. Om niet al te veel versplintering binnen het vervolgen van onder meer financieel economische delicten te hebben, maakte het Openbaar Ministerie reeds voor de oprichting van het FOM gebruik van "fraudeclusters". Volgens De Graff, destijds Officier van Justitie te Amsterdam ${ }^{506}$, waren deze clusters een stap in de goede richting. Over verschillende geografische gebieden onderzochten en/of vervolgden gespecialiseerde fraudeteams een bepaald type fraude. Met de oprichting van het FOM moet in de toekomst de afdoening van onder meer financieel economische delicten centraal worden aangestuurd. Dat betekent voor het Amsterdamse parket, dat voor de oprichting van het FOM de beursgerelateerde en fraudezaken afhandelde, een verschuiving van werkzaamheden naar het $\mathrm{FOM}^{507}$. Het pas opgerichte FOM zal zich nog moeten bewijzen, waarna uitgemaakt zal kunnen worden of de bundeling van expertise en het centraal aansturen van ondermeer het FIOD-ECD daadwerkelijk tot een geconcentreerd, effectiever en efficiënter beleid heeft kunnen leiden.

\section{De aangifte: van Autoriteit-FM naar bet (F)OM}

Aan het begin van dit hoofdstuk is er aangegeven welke regelgeving tot het terrein van het effectenrecht behoren. Dit recht is niet alleen erg dynamisch maar is vooral overwegend civielrechtelijk getint en genormeerd. Welke plaats heeft het strafrecht dan ten opzichte van het

\footnotetext{
506 Oranje, J., "Officier de Graaff stopt met 'fraude'", in het NRC-Handelsblad, d.d. 20 november 2001 .

507 Oranje, J. "Aanpak fraude heeft lange weg te gaan", her NRC-Handelsblad, d.d 22 mei 2002.
} 
effectenrecht $^{508}$ ? Waar en wanneer komt het strafrecht aan bod? Dat kan op verschillende manieren geschiedlen zoals via de WED of via het Wetboek van Strafrecht. In beginsel doet de toezichthouder, de AutoriteitFM of zelfs DNB, aangifte van het overtreden van wet- of regelgeving waarvan het primaat van de handhaving bij hen ligt. Indien het (F)OM besluit om een aangifte nader te onderzoeken kan dit uitmonden in een verdere vervolging en kan men stellen dat het strafrechtelijk traject wordt doorlopen. Vanwege procedureafspraken tussen het Openbaar Ministerie en de toezichthouders ${ }^{509}$, gaan in beginsel vele aangiften door naar het FIOD in samenwerking met de Economische Controle Dienst (FIODECD). Alleen aangiften van het overtredingen van artikel 46 W'te'95, misbruik van voorwetenschap, gingen in beginsel via het parket Amsterdam. De instelling van het FOM zal dit hoogstwaarschijnlijk veranderen omdat het FOM bij haar oprichting te kennen heeft gegeven als landelijke organisatie de financiële en economische criminaliteit aan te willen pakken. Wat er over blijft voor het parket Amsterdam en hoe de onderlinge verhoudingen op het gebied van de afhandeling van financieel economische zaken zullen liggen is vooralsnog onbekend.

Indien het strafrechtelijk traject via bijvoorbeeld een aangifte wordt gestart kan het Openbaar Ministerie, met betrekking tot de effectenhandel, een strafrechtelijk onderzoek instellen in geval de financiële regelgeving is overtreden. In dit geval ontstaat de strafbaarheid via de bijzondere strafwetgeving, de WED of wanneer het commune delicten betreft zoals valsheid in geschrifte ${ }^{510}$ via het commune strafrecht. Wanneer de WED er op wordt nageslagen, worden in artikel 1 van deze wet verschillende (financiële) wetten aangeduid die tot economisch

508 De tot nu toe gehanteerde term "effectenrecht", is voot de behandeling van het strafrechtelijk toezicht een te ruim begrip. Het strafrechtelijk traject kan niet via alle "effectenwetten" worden betreden. Het zou dan ook onterecht zijn om deze term aan te houden. Daarom zal in deze paragraaf, waar nodig, nader gespecificeerd worden welke wet- en/of regelgeving van toepassing is. Deze zal dan ook explicier aangehaald worden.

Zaals het eerder genoemde Convenant. Vgl. het Convenant bestuurlijke boeten en strafrechtelijke sancties, Stcrt., nr. 4, jrg. 2000.

$\mathrm{Vgl}$. de artikelen $225 \mathrm{~W} \mathrm{WS}$ r en verder. 
delict ${ }^{511}$ worden verheven. Volgens artikel 2 van de WED zijn de delicten genoemd in artikel 1 onder sub 2 misdrijven wanneer ze opzettelijk zijn gepleegd. Wanneer opzet ontbreekt worden deze strafbare feiten tot de overtredingen gerekend. De delicten genoemd onder sub 3 zijn alleen misdrijven dan wel overtredingen wanneer dat in de desbetreffende voorschriften ook als zodanig wordt aangegeven. Artikel 2 besluit met het gegeven dat de economische delicten zoals genoemd onder sub 5 van artikel 1 tot de misdrijven dienen worden gerekend.

Wanneer een of meerdere bovengenoemde artikelen wordt overtreden is er sprake van een economisch delict en kan via de gespecialiseerde opsporingsdienst van de WED, de ECD (nu samen met de FIOD), de opsporing al dan niet plaatsvinden. Op het terrein van de financiële regelgeving bestaan er (nog) geen aanwijzingen omtrent opsporing en vervolging van strafbare feiten. Daarnaast heeft het Openbaar Ministerie op dit gebied ook (nog) geen beleidslijnen dan wel beleidsafspraken gemaakt ${ }^{512}$ en is er dus geen regelgeving die kan worden uitgelegd als recht in de zin van 99 Wet op de rechterlijke organisatie (RO). Dit maakt het moeilijker om het beleid inzake opsporing en vervolging van financieel economische feiten te controleren. Bij de belastingwetgeving worden wel beleidsregels of - richtlijnen aangetroffen; de Algemene Wet inzake Rijksbelastingen (AWR). De reden hiervoor kan gelegen zijn in het gegeven dat het financieel economisch strafrecht relatief jong is wanneer deze wordt vergeleken met zowel her financieel economisch recht alls met de belastingwetgeving. De AWR blijkt dan een voorsprong van zo'n twee eeuwen op de financiële wetgeving te hebben. Het is dan ook niet verwonderlijk dat er binnen de AWR reeds richtlijnen omtrent vervolging bestaan ${ }^{513}$. Het belang van het al dan niet bestaan van

sut Zoals cerder is angegeven wordt in deze studie worden de definitie van economische delicten angehouden zoals De Roos deze in het kader van zijn proefschrift beschriff. Kortom: hij omschrijft een economisch delict als "delicten began door ondernemingen en personen in de conomische sfeer; dat wil zeggen: door ondernemingen, in bet kader wan buw deelneming aan het economische verkeer alsmede door personen in bet kader van de economische activiteit van ondernemingen.". Vgl. Roos, Th.A. de, "Straffaarstelling van economische delicten; een crimineel-politieke studie", anw., p. 1 . Uitgaande van december 2000.

513 Vglide ATV-richtlijnen waarin een lijn word gehanteerd aangaande het opsporen, vervolgen of transigeren inzake fiscale delicten. ATV staat voor: Aanmeldingstransacrie- en vervolgingsrichtlijnen voor fiscale delicten en douanedelicten. Vastgesteld op 13 april 1993. Stcrt. 1993/75. 
richtijnen is dat de desbetreffende instanties daar niet zomaar van mogen afwijken. Indien het Openbaar Ministerie wel zou afwijken van bestaande richtlijnen kan de gelaedeerde een beroep op de rechter doen en stellen dat her gelijkheidsbeginsel is geschonden. De Hoge Raad der Nederlanden (Hoge Raad) kan vervolgens toetsen of er inderdaad sprake is van recht in de zin van artikel 99 RO en/of het gelijkheidsbeginsel daadwerkelijk is geschonden door in te gaan tegen een bestaande richtlijn, aanwijzing of beleidsregel. Op grond van het vertrouwensbeginsel mag het Openbaar Ministerie niet zomaar afwijken van dergelijke regels. Kortom, het gegeven dat het financieel economische (straf)recht een relatief jong rechtsgebied is dat zich feitelijk nog steeds ontwikkelt, draagt eraan bij dat het Openbaar Ministerie nog geen richtlijnen of beleidsregels heeft ontworpen. Zowel hieruit als uit de bestudering van de financiële regelgeving kan worden afgeleid dat de positie van strafrecht binnen de financiële wetgeving tot nu toe marginaal is. Zo kan namelijk uit de wettelijk toebedeelde rol van strafrecht binnen het gehele financiële handhavingtraject worden geconcludeerd dat dit recht overwegend bestuursrechtelijk wordt gehandhaafd en dat er zeer weinig directe verwijzingen naar het strafrecht zijn. Een voorbeeld van een directe verwijzing naar het strafrecht zijn de artikelen $46 j^{\circ} 48$ Wte' 95 waarin expliciet wordt vermeld dat het misbruiken van voorwetenschap een misdrijf is.

\section{Het (F)OM en het verloop van het strafrechtelijk traject}

Indien er een strafklacht is ingediend tegen een overtreder van de financieel economische wet- en/of regelgeving en het Openbaar Ministerie meent tot verdere opsporing en vervolging over te moeten gaan, kan het volgende geschieden. Het verloop van het strafrechtelijk traject voor overtredingen van de financiële regelgeving is niet anders dan wanneer het commune delicten betreft. Een verschil is dat de FIODECD in sommige gevallen opsporingsonderzoeken kan verrichten. De vervolging kan ook in deze gevallen alleen maar plaatsvinden door de Officier van Justitie. Tot de oprichting van het FOM was dat de Officier van Justitie van het arrondissementsparket te Amsterdam ${ }^{514}$. Een overzicht van het strafproces toont het volgende aan. Net als elk ander 
opsporings- en vervolgingsonderzoek, begint dit met een onderzoek bij voldoende verdenking van het begaan van een strafbaar feit. Of er sprake is van "voldoende" verdenking, moet blijken uit onderliggend feitencomplex. In het geval er onvoldoende verdenking is, kan de Officier van Justitie in bepaalde gevallen besluiten om een verkennend onderzoek ${ }^{515}$ in te stellen. Dit is alleen mogelijk bij bepaalde zware delicten waaronder het handelen mer voorwetenschap ${ }^{516}$. Wanneer er wel voldoende bewijs is, kan de Officier van Justitie gebruik maken van de mogelijkheden die

Vgl. arrikel 126gg W/wS: "Indien uit feiten of omstandigheden aanwijzingen voorwloeien dat binnen verzamelingen van personen misdrijwen worden beraamd of gepleegd als omschreven in arrikel 67 , eerste lid, die gezien hun aard of de samenhang met andere misdrijwen die binnen die werzamelingen van personen worden beraamd of gepleegd een ernstige inbreuk op de rechtsorde opleveren, kan de officier van justicic bevelen dat opsporingsambtenaren daarmaar een onderzoek instellen met als doel de voorbereiding wan opsporing". Voorafgaand aan de opsporing van strafbare feiten, te weren alle onderzoek die niet door een rechter wordt verricht en die dient ter opheldering van strafbare feiten die al dan niet reeds gepleegd zijn (vgl, artikel 1260 Sv waarin reeds het beramen wan bepaalde misdrijven de mogelijkheid tot het uitoefenen wan bepaalde opsporingsbevoegdheden doet ontstaan.) en die tot doel heeft het voorbereiden van een strafrechtelijke sanctie, kan een verkennend anderzoek plaatsvinden. In tegenstelling tor een opsporingsonderzok is niet een redelijk vermoeden van schuld aan een strafbaar feit de aanleiding, maar zijn aanwijzingen de basis voor her entameren wan een verkennend onderzoek. Vgl. Corstens, G.J.M., "Het Nederlandse Strafprocesrecht", ta. p. noot 455 , p. 242.

51. Een werkennend onderzoek is mogelijk in geval het delicten betreft die worden genoemd in artikel 67 lid 1 WwSv. Het eerste lid van voomoemd artikel luidt als volgt:

Een bevel tot voorlopige hechtenis kan worden gegeven in geval van verdenking van:

a. een misdrijf warop natr de wettelijke omschrijving een gewangenisstraf van vier jaren of meer is gesteld;

b. een der misdrijven omschreven in de artikelen 132, 250bis, 285, eerste lid, $318,321,326,326 \mathrm{a}, 326 \mathrm{c}, 395$ en 417 bis van het Wetboek van Strafrecht:

c. de overtreding omschreven in arrikel 432 , onder $3^{\circ}$, van het Wetboek van Strafrecht;

d. cen der misdrijven omschreven in:

artikel 175 , tweede lid, onderdeel b, wan de Wegenverkeerswet 1994 ;

artikel 30 , tweede lid, van de Wet buitengewone bevoegdheden burgerlijk gezag; de arrikelen 52,53 , eerste lid en 54 van de Wet gewetensbezwaren militaire dienst;

arcikel 31 van de Wet op de kansspelen;

artikel 11 , tweede lid, van de Opiumwet;

arrikel 55 , tweede lid, van de Wet wapens en munitie;

artikel 46 van de Wet toezicht effectenverkeer 1995. 
de (bijzondere) strafwet hem biedt. Hij kan zo besluiten om te transigeren waardoor er vervolging wordt voorkomen of de verdachte aan te brengen bij de rechtbank; tot een zitting overgaan. In dit laatste geval is het laatste woord aan de rechter. Deze beslist of er sprake is van wettig en overtuigend bewijs om tot een veroordeling te kunnen komen. De Officier van Justitie kan in beginsel waar de overtreding een economisch delict betreft gebruik maken van extra bevoegdheden zoals aangegeven in titel III van de WED. Zo kan hij beslissen tot het in beslag nemen van bepaalde voorwerpen, daarnaast mogen de in het kader van de WED bevoegde opsporingsambtenaren, de $\mathrm{ECD}$, gegevens en bescheiden inzien en/of kopieën hiervan maken. Ook het binnentreden van een woning behoort tot de extra bevoegdheden van de FIOD-ECD 517 .

Bij het nemen van zijn besluit om het niet tot een rechtszaak te laten komen en de verdachte niet aan te brengen bij de rechrbank, kunnen er voor de Officier van Justitie verschillende indicatoren een rol meespelen. Deze "negatieve" indicatoren kunnen zuiver economisch of financieel economische dan wel sociaal economische overwegingen zijn. Een voorbeeld van een zuiver economische overweging om het niet tot een zitting te laten komen, maar het via een transactie af te doen is in geval het vervolgen en de publiciteit daar om heen zouden kunnen leiden tot de ondergang van een organisatie omdat het vertrouwen van aandeelhouders in de organisatie verdwijnt. Een financieel economische reden zou kunnen zijn dat de gevolgen van het vervolgen de desbetreffende organisatie op financieel gebied mogelijkerwijs zou belemmeren hetgeen voor de economische positie zeer ongewenst zou zijn ondat dit bedrijf een zo belangrijke plaats in onze economie inneemt ${ }^{518}$. Een voorbeeld hiervan is het vervolgen van Euronext Amsterdam. Indien het beleggers ter ore komt dat deze beurs wordt vervolgd wegens overtreding van de financiële wetgeving, kan dit het vertrouwen van (potentiële) beleggers schaden. De immer zo belangrijke integriteit van de Nederlandse

51\% De bevoegdheden van de FIOD-ECD worden als "extra" aangeduid omdat allereerst natuurlijk de opsporings-bevoegdheden zoals genoemd in het Werboek van Strafvordering gelden. Vgl. artikel 25 WED:Voor zover daarvan niet in deze wer of de in artikel 1 en artikel 1 g genoemde werten en besluiten is afgeweken gelden ten aanzien van de opsporing van economische delicten de bepalingen van het Werboek van Strafvordering.

518 Vgl. de toenmalige Officier van \ustitie De Graaff in een vraaggesprek d.d. 20 november 2000 op het Parket te Amsterdam. 
financiële wereld staat hiermee op het spel. De gevolgen zouden kunnen zijn dat beleggers wegblijven en de beurs uiteindelijk zou moeten sluiten. Dit kan er zelfs toe leiden dat de Nederlandse economie ervan te lijden zou kunnen hebben wanneer er vele miljarden (al dan niet met potentiële beleggers) naar het buitenland zouden vertrekken. Een ander negatieve indicator is sociaal economische getint. Indien het Openbaar Ministerie meent dat de vervolging van een instelling, deze onderneming in een zodanige positie kan brengen dat de solvabiliteit en/of de liquiditeit ervan in gevaar komt waardoor het voortbestaan van de organisatie wordt bedreigd en een grote groep buitenstaanders er nadeel van zou kunnen ondervinden, kan het besluiten om te transigeren. Een voorbeeld hiervan is een grote nationale bank. Vervolging en een mogelijke faillissement kunnen ertoe leiden dat cliënten van deze bank hun spaartegoeden kwijtraken. Dit maatschappelijk belang kan het Openbaar Ministerie ervan weerhouden om tot vervolging over te gaan. Voorts kan een uitleveringsverzoek het Openbaar Ministerie redenen geven om niet tot (verdere) vervolging over te gaan. Zo kan het voorkomen dat een rechtspersoon reeds in het buitenland, bijvoorbeeld de USA, in een strafrechtelijke onderzoek verwikkeld is. Voorts kunnen behalve de economische redenen en eventuele uitleveringsverzoeken, ook de werkdruk een beslissende rol spelen ${ }^{519}$. Naast de hiervoor niet-limitatief opgesomde negatieve indicatoren, zijn er in beginsel geen andere redenen om van vervolging af te zien. In de praktijk kunnen zich natuurlijk alrijd situaties voortdoen op grond waarvan het Openbaar Ministerie besluit om een vervolging achterwege te laten. Wanneer er sprake is van een verdachte, er voldoende bewijs is, er geen negatieve indicatoren zijn, het transigeren niet de oplossing biedt en er geen andere redenen zijn om van vervolging af te zien, kan de Officier van Justitie besluiten om over te gaan tot vervolging van deze verdachte. Hierbij kan het ontbreken van een eenduidig beleid betreffende de opsporing en vervolging van financiële wetsovertreders, nog voor enige moeilijkheden zorgen. Bij de vervolgingsbeslissing moet het Openbaar Ministerie namelijk aangeven

519 Volgens De Graff speelt "prioritering in de opsporingscapaciteit" een tol en moet het OM volgens hem "vrij terughoudend zijn met het micksichlos inzetten van opsporingscapaciteit". Alleen in gewal het OM genoeg bewijs heeft dat zij tot een duidelijke zaak kan komen, maakr zij reeds in een vroeg stadium gebruik van een transactic. Er vindt dan geen opsporing plaats. Mocht de verdachte ontkennen dan kan het OM alsnog overgaan tot het instellen van cen verwolgingsonderzoek. Vgl. de roenmalige Officier van Justitie Henk de Graaff in een vraaggesprek d.d. 20 november 2000 op het Parket te Amsterdam. 
waarom het de voor op te leggen sanctie heeft gekozen en hoe zij tot de hoogte van de aangegeven boete is gekomen. Het financieel economisch (straf) recht is een rechtsgebied in ontwikkeling. Het gegeven dat er (nog) niet veel verschillende strafrechterlijke uitspraken op dit gebied zijn, maakt het enerzijds moeilijker. Ook het "tekort" aan kennis bij de (straf)kamers van de arrondissementsrechtbanken draagt bij aan het minder soepel verlopen van de rechtspraak. De vrij specialistische effectenwereld heeft namelijk zijn eigen terminologie en handelswijze. Niet alle rechters zijn (al) thuis op dit (jonge) rechtsgebied.

\section{Van aangifte tot kwalificatie}

Zoals vermeld aan het begin van paragraaf 2.5.3, kan het strafrecht zowel via de WED als via het wetboek van Strafrecht de effectenwereld binnentreden. Wil een strafrechtelijke procedure via de WED worden geëntameerd, dient er in de desbetreffende financiële regelgeving aangegeven te zijn dat overtredingen daarvan economische delicten zijn. In dat geval is de brug met de WED geslagen en kan een dergelijke overtreding strafrechtelijk worden afgedaan. Welk deviant gedrag wordt door het Openbaar Ministerie strafbaar geacht? W/anneer de financiële regelgeving er op wordt naslagen, worden verschillende wetten aangetroffen die binnen het kader van dit onderzoek kunnen worden gehanteerd. In paragraaf 2.3 zijn de volgende wetten aan bod gekomen, te weten de Wre' 95 , de Wmz en deels de Wtb. Hieronder zullen wetsovertredingen uit de Wte"95 en de W/mz, die via de WED zijn gecriminaliseerd, worden besproken. Gezien de gewijzigde toezichtsrol van DNB waarin deze zich nu richt op het prudentieel toezicht, zal de aandacht worden gericht op het gedragstoezicht door de Autoriteit-FM. In deze context komen de Wte' 95 en de Wmz aan bod ${ }^{520}$. Wanneer deze twee wetten in samenhang met de WED worden bekeken, kan de conclusie worden getrokken dat de genoemde wetsartikelen voornamelijk die strafbare feiten opleveren die indruisen tegen hun doelstellingen.

520 In casu dus nitet de Wtb. Dit om reden dat het gewijzigde toezichtsmodel in samenhang met de toename van toezichtsbevoegdheden en de overheveling van gedragstypische toezichtsbewoegdheden van DNB naar de Autoriteit-FM, tot gevolg heeft dat de redactie van de Wtb op korte termijn zal moeten worden gewijzigd. Een behandeling van de bevoegdheden waar de Autoriteit-FM reeds over beschikt is bevordelijker voor de consistentie van dit geheel. Zie onder meer Kamerstukken II, 2001/02, 28 737, nt. 3 en Kamerstukken 2001/02, 28 122, nrs. 1 - 3 . 
Niet alleen overtredingen van de kaderwetten - de Wte'95 521 en de $W m z^{522}$ - leiden tot strafbaarheid, ook schending van lagere voorschriften heeft hetzelfde gevolg ${ }^{523}$.

Op grond van artikel. $1^{524}$ onder sub 2 en sub 3 van de WED blijken de aangehaalde wetsovertredingen tot de economische delicten te worden gerekend. Dit artikel en het hierop volgende artikel 1a criminaliseren

521 Een voorbeeld van een artikel uit de Wre'95 is artikel 3 lid 1. Dit artikel stelt onder meer strafbaar: het buiten een besloten kring bij uitgifte aanbieden varn effecten dan well het aankondigen van een dergelijke effectenuirgifte. Een ander woorbeeld is te vinden in artikel 4 lid 2. Daarin wordt bepaald dat de Minister van Financiën, dan wel de door delegatie bevoegde Autoriteir-FM, vrijstelling of ontheffing kan verlenen van her verbod zoals neergelegd in artikell 3 lid 1 Wte'95. Wanneer artikel 1 van de WED nader wordt bestudeerd blijkt dat er naast sub 2, ook onder sub 3 naar de Wte' 95 wordt verwezen. Sub 3 geeft aan dat overtredingen van de artikelen 46 en 47 Wte 95 aok economische delicten zijn. In artikel 46 Wte' 95 is het verbod neergelegd om met voorwetenschap effectentransacties in of wanuit Nederland te verrichten of te bewerkstelligen. Tot slot artikel 47 van de W'te'95. In dit artikel wordt het misleiden van her publiek bij de uitgifte en/of plaatsing wan effecten strafbaar gesteld. De misleiding is alleen strafbaar indien het tot doel had het publiek tot de aanschaf van effecten over te halen. Volgens artikel 48 Wre'95 zijn de overtredingen van de artikelen 46 en 47 wan deze wet misdrijven ongeacht of dat wat er in artikel 2 lid 1 van de WED staat vermeld en als aanvulling op her dercle lid van artikel 2 WED.

5.22 In artikel 2 Wmz word eenieder die de beschikking krijgt of verliest over aandelen dan wel over stemmen in het kapitaal van een vennootschap en deze (rechts) persoon weet of behoort te weten dat het percentage wan de aandelen en/of stemmen waarover hij beschikt in een andere bandbreedte valt dan voordien her geval was, verplicht hier onmiddellijk melding van te doen aan de vennootschap en aan de Autoriteit-FM. Het overtreden van bovenstaande verplichting leidt tot her begaan van een economisch delict. Hetzelfde geldr voor lid 1 van het derde artikel van de Wmz. Dit artikel beschrijt de iniriële meldingsplichr. Wanneer men een belang van aandelen en/of stemmen van minimaal $5 \%$ niet (op tijd) meldt aan de vennootschap en aan de Autorikeit-FM, begat men een economisch delict.

$523 \mathrm{Vgl}$. bijwoorbeeld artikel 1 onder sub $2^{\circ}$ WED alwar word gesteld dat overtredingen van voorschriften, gesteld bij of krachtens de in dat artikel genoende werten, economische delicten zijn. Dit houdt in dat zowel de kaderwetten als de uirvoeringsregels tot de werkingsfeer van de WED behoren.

524 Arrikel 1 WED:

Economische delicten äjn:

2 overtredingen wan voorschriften, gesteld bij of krachtens:

(...) de Wer toezicht effectenverkeer 1995, de artikelen 3, eerste lid, 4, tweede lid, 5 , eerste en derde lid, 6, tweede lid, 7, eerste, derde en zevende lid, 10, tweede lid, II eerste en vijfle lid, 11 a, derde, wierde en zesde lid. 12, tweede en vierde lid. 13, zesde en achste lid, 16, eerte achtste, negende, elfal, twatfde en dentiende lid, 17 , eerste en tweede lid, 18 , tweede lid. 19 , tweede lid, 22, eerste, derde en viffte lid, 24 , erste 
bepaalde gedragingen. Verder zijn in artikel $2^{525}$ WED de maatstaven te vinden waarmee kan worden vastgesteld of er van een misdrijf of een overtreding dient te worden gesproken. Voor de strafmaxima wordt verwezen naar artikel 6 WED. Tot slot wordt er onder sub $5^{\circ}$ van artikel 1 WED verwezen naar drie artikelen uit de WED. Overtredingen van deze artikelen, te weten de artikelen 26, 33 en 34 WED, zijn ook economische delicten ${ }^{526}$. Via laatstgenoemde artikelen heeft de wetgever getracht om te voorkomen dat er problemen met de uitvoering van de WED zouden ontstaan doordat er bijvoorbeeld geen gehoor zou worden gegeven aan de vorderingen gebaseerd op deze wet.

Zoals hiervoor is aangetoond, kan het strafrecht op grond van de W'te'95 en de Wmz via de WED in werking worden gesteld. Het is niet altijd het geval dat alle feiten onder zijn te brengen onder de hierboven genoemde wetten. Hier doet zich het kwalificatieprobleem voor. Dat houdt in de praktijk in dat Officieren van Justitie moeite kunnen hebben om een bepaalde gedraging onder een passende delictsomschrijving te plaatsen.

en derde lid, 25, tweede lid, 27, derde lid, 28, derde lid, 29, wijfle lid, 31, errte en tweede lid, 36, tweede en derde lid, 37 , tweede lid, 45, vierde lid, 46a, erste lid, 466, ecrste, derde en vijfle lid, eerste volzin en $46 d,(.$.

$3^{\circ}$ owertredingen van woorschriften, gesteld bij of krachtens:

525 Artikel 2

(...) de Wet toezicht effectenverker 1995, de artikelen 46 en 47 ; (..)

1. De economische delicten, bedoeld in artikel 1 , onder $1^{\circ}$ en $2^{\circ}$, en arrikel 1 a onder $1^{\circ}$ en $2^{\circ}$, zijn misdrijwen, voot zover zij opzettelijk zijn begaan; woor zover deze economische delicten geen misdrijven zijn, zijn zij overtredingen. (...)

3. De economische delicten, bedoeld in artikel 1 , onder $3^{\circ}$, zijn misdrijven of overtredingen, al naar gelang zij in de desberreffende voorschriften alls misdrijf dan wel als overtreding zijn gekenmerkt.

526 Artikel 1 sub $5^{\circ}$ gatat als volgt: "Economische delicten zijn: (...) de delicten genoemd in de artikelen 26, 33 en 34." Vervolgens staat er in arcikel 26 WED: "Het opzertelijk niet voldoen aan een vordering, krachtens enig voorschrift van deze wet gedaan door een opsporingsambtenaar, is een economisch delict." . Arrikel 33 stelt het volgende: "Her opzettelijk handelen of nalaten in strijd mer een bijkomende straf, als bedoeld in artikel 7, onder $a, c$ of $f$, een maarregel, als vermeld in artikel 8 , een regeling als bedoeld in artikel 10 , of een woorlopige maatregel, of het ontuiken van zodanige bijkomende straf, maatregel, regeling of voorlopige maatregel is een economischdelict." Tor slor is het volgende in artikel 34 WED bepaald "Het opzetrelijk, al dan niet door middel van een ander, ontrrekken van vermogensbestanddelen aan werhaal of tenuitvoerlegging van een krachtens deze wet opgelegde straf, maatregel of voorlopige maatregel is een economisch delict. 
Het gevolg is dan ook dat het Openbaar Ministerie de gedraging in de formulering van de tenlastelegging tracht "om te buigen", naar een passende en bestaande delictsomschrijving ${ }^{527}$. Enkele voorbeelden van het kwalificeren van gedragingen de niet letterlijk in de strafwetgeving is terug te vinden zijn:

- de prink sheets froud:

- cbuming/ provisiejagen.

- de frontrunining;

- opereren wanuit boilerrooms.

- speculeren met daily baircut.

In geval het Openbaar Ministerie de pink sheet fraud ten laste legt is er volgens het Openbaar Ministerie sprake van een vorm van fraude, "waarbij men probeert om de waarde van de effecten op te krikken, terwijl die waarde niet bestaat, om op het juiste moment de markt te laten klappen (ineenstorten: $M J B)^{528 ~ " D i t ~ w e r t o o n t ~ s t e r k e ~ g e l i j k e n i s ~ m e t ~ d e ~ i n ~ h e t ~ e e r s t e ~}$ hoofdstuk genoemde windhandel welke reeds ten tijde van de VOC hevig woedde. Een andere gedraging die niet letterlijk in de strafwetgeving terug te vinden is, is churning; het provisie jagen of "het (onder de werking van een algemene volmacht) voor rekening van cliënten uitvoeren van snelopeenvolgende en/of grote effectentransacties, louter om commissieopbrengsten te genereren zonder dat er sprake is van een witdrukkelijke op eigen initiatief van de cliënt gegeven opdracht" ${ }^{1529}$. In een dergelijk geval heeft de tussenpersoon er belang bij dat er hij zoveel mogelijk transacties voor zijn cliènt uitvoert, of dit nu in het voordeel van de cliënt is of niet.

Een andere vorm van laakbaar gedrag welke ook niet direct in de strafwetgeving terug te vinden is, is frontrunning. Dat houdt in het "meelopen" met grote effectentransacties. Een voorbeeld hiervan is een tussenpersoon die voor zijn diënt een (grote) effectenorder moet plaatsen. Alvorens hij daartoe over gaat besluit hij snel aandelen te kopen of verkopen, afhankelijk van de soort order teneinde mee te profiteren van

Volgens de Officieren van Justitie kan dit afdoen aan het oorspronkelijke feit. $\mathrm{V}$ gl. het eerder genoemd vraaggesprek met de toenmalige Officier van Justitie Henk de Graaff, d.d. 20 november 2000.

Aldus Henk de Graaff, destijds Officier van Justitie te Amsterdam, vraaggesprek d.d. 20 november 2000 .

529 Aldus Grundmann-Van de Krol in: Grundmann-Van de Krol, C.M., Recente wetgewing effectentransacties, Gouda Quint B. V., Arnhem, 1995, p. 77. 
de koersstijgingen of koersdalingen. In de praktijk wil men frontrunning onder handel met voorwetenschap scharen. Verder zijn er ook de "boilerrooms", die aan het begin van dit hoofdstuk ook ter sprake zijn gekomen ${ }^{530}$. Tot slot de gedraging die men binnen de professionele wereld kan aantreffen; het ruimer uitkomen in de "daily haircut". Dit houdt in dat de professionele handelaar, kort voor sluiting, koersen uitbrengt die hoger liggen dan het normale daggemiddelde bedraagt. Het gevolg hiervan is dar de handelaar hoger afsluit dan hij in werkelijkheid heeft. Hierdoor lijkt zijn winstvermogen groter. Het gevaar bestaat dat indien de handelaar wordt aangesproken, hij dat bedrag niet daadwerkelijk in kas heeft waardoor kan worden gesteld dat er sprake is van een vorm van misleiding. Voornoemde afkeurenswaardige gedragingen worden door een gebrek aan wetgeving vaak gekwalificeerd als publiekmisleiding of het verspreiden van vervalste berichten ${ }^{531}$ dan wel als valsheid in geschrifte ${ }^{532}$, maar ook als oneigenlijke concurrentie ${ }^{533}$. Het gemis aan passende wetgeving kan er toe leiden dat het kwalificeren onder de huidige wetgeving tot gevolg heeft dat er, volgens het Openbaar Ministerie, afbreuk aan de oorspronkelijke gedraging wordt gedaan ${ }^{534}$. Met behulp van wat "creativeit" kwalificeert het Openbaar Ministerie de laakbare gedragingen als strafbare feiten. Deze creativiteit van het OM draagt bij aan het ontstaan van het gevaar voor dark numbers. Dat wil zeggen dat er in de statistieken een vertekend beeld kan ontstaan over de gepleegde feiten. Op deze wijze zal men na een statistisch onderzoek niet snel tot de conclusie kunnen komen dat er veel strafbare feiten binnen de effectensfeer worden gepleegd zoals bijvoorbeeld churning- of boilerroom feiten. Een dergelijk onderzoek zal eerder de conclusies bevatten dat er een toename is van artikel 47 Wte' 95 overtredingen, publieksmisleiding, hetgeen een verkeerd beeld naar de wetgever toe creëert omdar deze in de veronderstelling is dat feiten zoals de boilerrooms of churning niet vaak voorkomen. Dit vertekenend signaal kan, zoals hierboven aangegeven, leiden tot een vicieuze cirkel met als gevolg dat er geen veranderingen optreden. Het Openbaar Ministerie blijft dan aangewezen op creatief kwalificeren met alle gevolgen van dien. Zo blijft de kans groot dat de door de Officieren van Justitie

Een "boilerroom" is cen ruimte waarin via een agressieve telefonische verkoopmethode, in effecten wordt gehandeld.

531 Vgl. artikel 47 Wte' $95 j^{\circ}$ artikel 1 sub $3^{\circ} j^{\circ} 2$ lid $3^{\circ} j^{\circ} 6$ lid 1 onder sub $2^{\circ}$ WED.

532. Vgl. de artikelen 225 en 226 WvSr e.v.

53. Zie artikel 328 bis W $\mathrm{WSr}$. 
gekozen kwalificering volgens de rechter niet past bij de bewezen feiten, waardoor dit niet tor de door het OM gewenste veroordelingen kan leiden maar wel weer tot een debacle voor het OM.

\section{De straffen en maatregelen}

Op grond van het voorafgaande kan worden gesteld dat het strafrechtelijk traject in beginsel via het commune strafrecht, het WvSr in samenhang met het WVSv, wordt afgelegd. In bepaalde gevallen komt het commune strafrecht op een indirecte manier aan bod, namelijk via de bijzondere wetgeving zoals de desbetreffende wet- en of regelgeving die naar de WED verwijst. In dat geval begint men bijvoorbeeld met een artikel uit de W'te'95 of de Wmz die de gewraakte handeling verbiedt. Vervolgens kan via artikel 1 van de WED worden vastgesteld of de handelling daadwerkelijk wordt gecriminaliseerd en dus binnen de sfeer van het financieel(economisch)strafrecht wordt getrokken. Zo ja, dan geeft de WED op grond van artikel $6^{53}$ zelf aan wat de strafmaxima zijn. Wanneer dit artikel nader wordt bestudeerd, kan het volgende worden opgemerkt:

534 Zie het eerder genoemde vraaggesprek met $\mathrm{H}$. de Graaff, Officier van Justitie te Amsterdam, d.d. 20 november 2000.

$5: 35$

Artikel 6:

1. Hij, die cen economisch delicr begaat, wordt gestraft:

$1^{\circ}$ in geval van misdrijf, voor zover het betreft een economisch delict, bedoeld in artikel 1 , onder $1^{\circ}$, of in artikel $1 \mathrm{a}$, onder $1^{\circ}$, met gevangenisstraf van ten hoogste zes jaren of geldboete van de vijfde categorie;

$2^{\circ}$ in geval van een ander misdrijf met gevangenisstraf van ten hoogste twee jaren of geldboete van de vierde categorie;

$3^{\circ}$ in geval van owertreding, voor zover het betreft een economisch delict, bedoeld in artikel 1 , onder $1^{\circ}$, of in artikel $1 a$, onder $1^{\circ}$, met hechtenis van ten hoogste een jaar of geldboete van de vierde categorie;

$4^{\circ}$ in geval wan een andere overtreding, met hechtenis van ten hoogste zes maanden of geldboete van de vierde categorie.

Indien de waarde der goederen, waarmede of met betrekking tot welke het economisch delict is begaan, of die geheel of gedeeltelijk door middel van het economisch delict zijn verkregen, hoger is dan het vierde gedeelte van het maximum der geldboete welke in de gevallen onder $1^{\circ}$ tot en met $4^{\circ} \mathrm{kan}$ worden opgelegd, kan, onverminderd het bepaalde in artikel 23 , zevende lid, van het Wetboek van Strafrecht, een geldboete worden opgelegd van de naast hogere categorie.

2. Bovendien kunnen de bijkomende straffen, vermeld in artikel 7 , en de matregelen, vermeld in artikel 8 , worden opgelegd, onverminderd de oplegging, in de daarvoor in aanmerking komende gevallen, van de maatregelen, elders in de wettelijke bepalingen voorzien.

3. $(n)$ 
- de strafmaxima zijn, zes/ wwee of een jaar gevangenwistraf dan wel bechtemis woor maximaal zes maanderi;

- geldboetes tan (woorbeen f 25.000,-) € 11.250,-; (f 100.000,-) € 45.000,dan wel wan $(f 1.000 .000,-) € 450.000,-$

Op grond van het vermelde in artikel 6 lid 2 WED en artikel 9 van dezelfde wet kan het Openbaar Ministerie een cumulatie van straffen en maatregelen vorderen. Laatstgenoemd artikel luidt als volgt:

\section{Artikel 9}

De matregelen termeld in artikel 8 , onder b en c, kumen te zamen met straffem en met andere matregelen worden opgelegd.

De te stellen vraag is op welke straffen en maatregelen de wetgever heeft gedoeld? Gedacht moet worden aan zowel de hoofdstraffen als de bijkomende straffen. Via de schakelbepaling van artikel $91 \mathrm{WvSr}$ zijn de straffen en maatregelen zoals vermeld in het Wetboek van Strafrecht ook van toepassing op de economische delicten zoals vermeld in de WED. Daarmee belanden wij via de effectenregelgeving, via het bijzondere strafrecht te weten de WED, op het terrein van het commune strafrecht

\section{Artikel $91 \mathrm{WvSr}$}

De bepalingen van de Titels I-VIII A wan dit Boek ${ }^{536}$ zijn ook toepasselijk op faiten waarop bij andere wetten of verordeningen straf is gesteld, tenzif de wet anders bepadit.

Aldus meermalen gesteld kan een overtreding van de effectenregelgeving worden gesanctioneerd via twee wegen, te weten direct op grond van het commune strafrecht of via de WED. De eerste weg wordt in beginsel gekozen in geval de Officier van Justitie een commun delict als valsheid in geschrifte, artikel 225 of bijvoorbeeld artikel $226 \mathrm{WvSr}$ ten laste legt. Bij de vervolging van een commuun delict kan de Officier van Justitie de straffen en maatregelen ${ }^{537}$ vorderen zoals zij zijn aangegeven in het Wetboek van Strafrecht. In titel II van het eerste boek van het Wetboek van Strafrecht zijn de straffen te vinden in artikel 9. De straffen die

536 Met "de Titels 1 - VIII A van dit Boek" wordt werwezen naar het eerste boek van het WvSr waarin de algemene bepaling zijn te vinden.

537 Puur theoretisch is het verschil russen straffen en maatregelen dat er bij de maatregelen geen verband bestaat tussen de ernst wan het strafbare feit en het leed dat de maarregel aan de veroordeelde zal toebrengen. Het gegeven dat het strafbare feit is gepleegd, is reden genoeg on de maatregel op te leggen. Bij de straffen bestaat er wel een relatie tussen her gepleegde feit en het leed wan de op te leggen straf. 
opgelegd kunnen worden variëren van hoofdstraffen tot bijkomende straffen te weten de gevangenisstraf; hechtenis, dienstverlening ${ }^{538}$; de geldboete, ontzetting uit bepaalde rechten; verbeurdverklaring en openbaarmaking van het vonnis. Verder kan de Officier van Justitie, indien toepasselijk, maatregelen vorderen. Deze maatregelen zijn te vinden in titel II A van het eerste boek van het Wetboek van Strafrecht. Tot voornoemde maatregelen behoren: de onttrekking aan het verkeer van in beslag genomen voorwerpen ${ }^{539}$, betaling van een geldbedrag aan de staat ter ontneming van wederrechtelijk verkregen voordee ${ }^{540}$. Het is in bijzondere gevallen zelfs mogelijk om de maatregel van plaatsing in een psychiatrisch ziekenhuis of om terbeschikkingstelling te vorderen ${ }^{541}$. Voorwaarde is wel dat in geval van plaatsing in voormeld ziekenhuis, de verdachte gevaarlijk is voor zichzelf, voor anderen of voor de algemene veiligheid van personen of goederen. In geval het de terbeschikkingstelling betreft, dient vast te staan dat er niet alleen een misdrijf is gepleegd waar een gevangenisstraf van vier jaren of meer op staat, maar ook dat er bij de verdachte tijdens het begaan van het strafbare feit een gebrekkige ontwikkeling of een ziekelijke stoornis van de geestvermogens bestond. De tweede weg wordt gekozen in geval de Officier van Justitie een economisch delict ten laste legt. Een voorbeeld hiervan is het in de W'te'95 neergelegd verbod om als effectenbemiddelaar of als vermogensbeheerder in of vanuit Nederland zonder vergunning, diensten aan te bieden of te verrichten. Op grond van artikel 7 lid 1 Wte'94 jo 1 onder sub $2^{\circ}$ jo artikel 2 lid 1 WED, is er dan sprake van een economisch delict. Zo arriveert men via de effectenregelgeving, de Wte'95, bij de WED. In titel II van de WED, de artikelen 5 - 16, zijn de straffen en maatregelen aangegeven: de hoofdstraffen zoals genoemd in artikel 6 lid 1 WED, de bijkomende straffen te vinden in artikel 7 WED en de maatregelen in het daaropvolgend artikel 8 . Tot de hoofdstraffen behoren de gevangenisstraf, de hechtenis en de geldboete. Afhankelijk van de aanwezigheid van opzet en dus van het feit of er sprake is van een misdrijf of overtreding, kan er een gevangenisstraf of hechtenis worden gevorderd. De duur van de gevangenisstraf, dan wel van de hechtenis of de hoogte van de geldboete is afhankelijk van het economisch delict. Op grond van artikel

538. Of het verlenen wan onbetaalde arbeid ten algemenen nutte; vgl. artikel 9 lid 1 onder a sub $3^{\circ} \mathrm{W} v \mathrm{~S}$.

539 Vgl. artikel $36 b$ en werder WWSr.

540 Vgl. artikel 36 e WW $\mathrm{Wr}$.

541 Vgl. artikel 37 e.v. WvSt: 
9 lid 2 WvSr j artikel 91 WvSr kan er een cumulatie van hoofdstraffen plaatsvinden. Dat wil zeggen dat er zowel een gevangenisstraf als een geldboete kan worden opgelegd welke kan oplopen tot $€ 450.000$,- per strafbare feit ${ }^{542}$. Daarnaast kunnen op grond van artikel 6 lid 2 WED ook bijkomende straffen worden opgelegd. Natuurlijk kan er ook alleen een bijkomende straf worden gevorderd en opgelegd. De bijkomende straf kan zelfs gepaard gaan met de oplegging van een maatregel. Zie hiervoor artikel 9 lid $3 \mathrm{WvSr} j^{\circ} 91 \mathrm{WvSr}$. Tot deze bijkomende straffen behoren de ontzetting van rechten; de gehele of gedeeltelijke stillegging van de onderneming van de veroordeelde; de verbeurdverklaring van bepaalde voorwerpen; de gehele of gedeeltelijke ontzetting van bepaalde rechren en/of voordelen die de veroordeelde in verband met zijn onderneming van overheidswege had of zou krijgen ${ }^{543}$ en de openbaarmaking van de rechterlijke uitspraak. Tot slot de maatregelen. Zoals reeds vermeld zijn de maatregelen te vinden in artikel 8 WED. Onder a van voornoemd artikel is een schakel te vinden met het commune strafrecht aangezien hier is aangegeven dat de maatregelen zoals vermeld in titel II A, boek 1 van het WvSr, ook in geval van economische delicten kunnen worden opgelegd. Daarnaast kent de WED als maatregel ook de onder bewindstelling van de onderneming van de veroordeelde en de reparatoire maatregel om dat wat is nagelaten alsnog te verrichten of om dat wat wederrechtelijk is verricht, ongedaan te maken. Verder kan als reparatoire maatregel gevorderd worden dat er prestaties worden verricht die het een en ander goedmaken. Dit alles op kosten van de veroordeelde. Artikel 9 WED vermeld, naast artikel 6 lid 2 WED, dat de maatregelen zoals genoemd in artikel 8 onder b en $c$ WED, kunnen cumuleren met andere maatregelen. Verder kunnen de maatregelen ook cumuleren met hoofdstraffen en/of bijkomende straffen. Simpel gezegd bestaat de mogelijkheid dat een veroordeelde (rechts) persoon op grond van de WED en het WvSr een geldboete opgelegd kan krijgen van vele miljoenen. Daarnaast kan de onderneming worden stilgelegd. Dit kan leiden tot vele miljoenen of afhankelijk van de soort onderneming, tot vele miljarden aan schade. Verder kan als bijkomende straf de vergunning ingetrokken worden waardoor de onderneming niet meer actief kan zijn

Vgl. artikel 23 lid $7 \mathrm{~W}$ wSr in geval her een rechtspersoon betreft. Natuurlijk is cen vrijheidsstraf niet toepasselijk op een rechtspersoon, wel op de feitelijk leidinggevende of de opdrachtgever dan wel cen andere daadwerkelijke pleger van het strafbare feit.

Denk aan de reeds verkregen vergunning of ontheffing. 
binnen de effectenwereld. Tevens kan de onderneming als maatregel "kaalgeplukt" worden. Op grond van artikel 8 onder a WED jo $91 \mathrm{WvSr}$ $j^{\circ} 36 \mathrm{e}$ WwSr kan de Officier van Justitie het wederrechtelijk verkregen voordeel van de veroordeelde (onderneming) ontnemen. De impact van een veroordeling voor een economisch delict kan aldus verstrekkend zijn. In schema ziet het er als volgt uit:

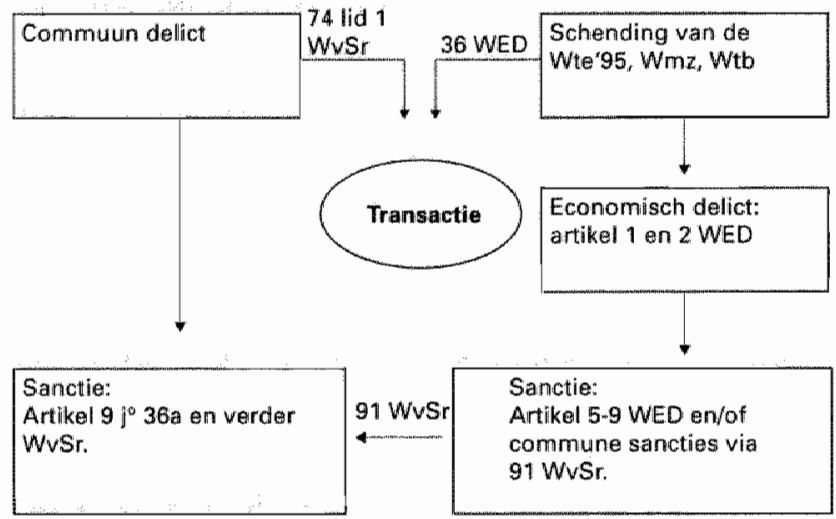

FIGUUR 2.7 Saxactionering van overtredingen van de effecternegelgeving

Een strafrechtelijke procedure sluit een andere procedure niet uit. Het is namelijk niet ondenkbaar dat zich de situatie voordoet dat er ten tijde van een strafrechtelijke procedure, een civielrechtelijke procedure aanhangig wordt gemaakt. Een voorbeeld is het geval dat een vennootschap extra aandelen aanschaft, waardoor de 5\% grens wordt overschreden. Indien de desbetreffende onderneming dit niet meldt aan de Autoriteit-FM, begaat zij een economisch delict. Dit kan uiteindelijk ertoe leiden dat het Openbaar Ministerie wordt ingeschakeld. Wanneer deze het opportuun acht, kan de Officier van Justitie besluiten om tot vervolging van de desbetreffende onderneming over te gaan. Zeer waarschijnlijk kan, indien zij het van belang acht, de Autoriteit-FM als belanghebbende civielrechtelijke maatregelen bij de rechtbank vorderen teneinde te voorkomen dat de vennootschap bij voorbeeld voor de duur van maximaal 5 jaren beschikking over de aandelen in het kapitaal van de vennootschap kan verkrijgen ${ }^{544}$. Indien er daadwerkelijk een civielrechtelijke procedure naast een strafrechtelijke procedure wordt gevoerd, 
zou dit bewijsrechtelijke gevolgen kunnen hebben. Het is van belang te weten welke procedure reeds in gang is gezet. Ingeval het de civielrechtelijke procedure betreft, kan op grond van artikel $14 \mathrm{~W} v \mathrm{v}$ v worden besloten om de strafrechtelijke vervolging te schorsen totdat de burgerlijke rechter uitspraak heeft gedaan om vervolgens deze uitspraak - indien mogelijk - mee te nemen in het strafrechtelijk proces ${ }^{545}$. De vermelding "indien mogelijk" heeft betrekking op de wijze waarop het bewijs is vergaard. Daar artikel $14 \mathrm{Wv}$ vv expliciet vermeldt dat het de burgerlijke rechter betreft, kan er van uit worden gegaan dat in geval het om een bestuursrechtelijke procedure gaat, de strafrechtelijke vervolging op grond van dit wetsartikel niet kan worden geschorst ${ }^{546}$. Het strafprocessuele recht heeft regels en normen gesteld aangaande het bewijs. De aard van het strafrecht en de bijbehorende strafprocedure vereisen een bescherming van de positie van de verdachte. De acceptatie van bewijs in een civielrechtelijk proces houdt nog geen acceptatie in een strafrechtelijk proces in. Aan het bewijs in een strafrechtelijke procedure worden zwaardere eisen gesteld. Her bewijs moet onder meer rechtmatig zijn verkregen. Daarom zal eerst moeten worden vastgesteld hoe het bewijs is vergaard in geval er civielrechrelijk of bestuursrechtelijk bewijsmateriaal tijdens de strafrechtelijke procedure wordt aangeboden. De aard van zowel de bestuursrechtelijke als de civielrechtelijke procedure vereist een zorgvuldige omgang met het bewijs dat is verkregen op grond van specifieke bevoegdheden van de toezichthouder, zoals bijvoorbeeld de Autoriteit-FM. Het kan namelijk zijn dat de Autoriteit-FM een leidinggevende, een directeur of een werknemer van een onderneming op grond van bijvoorbeeld artikel 36 lid 2 en 3 Wte' $95 j^{\circ} 1$ sub $2^{\circ}$ WED om inlichtingen verzoekt. Indien de desbetreffende (rechts)persoon dit zou weigeren zou er sprake zijn van een economisch delict ${ }^{547}$. De persoon is aldus gedwongen om te spreken. Deze afgelegde verklaringen kunnen

545 Artikel 14 WWSv luidt als volgt:

1. Indien de waardering van het te laste gelegde feit afhangt van de beoordeling van een geschilpunt van burgeriijk recht kan de rechter, in welken stand der vervolging ook, de vervolging voor een bepaalden tijd schorsen, ten einde de uitspraak wan den burgerlijken rechter over her geschilpunt af te wachten.

2. De schorsing kan telkens voor een bepaalden tijd worden verlengd en te allen tijde worden opgeheven.

546 Volgens Corstens kan de strafrechter wel het onderzoek ter terechrzitting schorsen in geval dit in het belang van het onderzoek noodzakelijk is. Vgl. Corstens, G.J.M., "Het Nederlands Strafprocesrecht", t.a.p. noot 455, p. 209.

Vgl. artikel. 26 WED. 
niet zonder meer in een strafrechtelijke procedure worden gebruikt. De jurisprudentie heeft ons geleerd dat dergelijk bewijs "geschoond" moet worden van alle toezichtinformatie wil het in een strafrechtelijke procedure worden gebruikt ${ }^{548}$. Het is wel mogelijk om de uitspraak van de strafrechter in een civiele proces of een bestuursrechtelijke procedure te gebruiken $^{549}$. Aldus kunnen we stellen dat ook de gevolgen van een strafrechtelijke procedure verstrekkend kunnen zijn. Betekent dit dan ook dat het strafrecht in Nederland als ultimum remedium de (potentiële) overtreders van de effectenregelgeving het meest afschrikt of is deze rol toch beter weggelegd voor het bestuursrecht? Deze vraag kan niet met

548 In het arrest Saunders, EHRM 17 december 1996, NJ 1997, 699. Dit arrest gaat over twee Engelse drank- en voedingsmiddelenconcerns die beide in 1986 probeerden om een derde bedrijf "Distillers" , over te nemen. Zowel het bedrijf Guiness als Argyll proberen in het kader van de overname aandelen Distillers te bemachtigen. Dit doen zij door een aandelenruil aan te bieden. Hiervoor was de beursnotering van Guiness als wan Argyll van doorslaggevende betekenis. Uiteindelijk bleek cle koers wan Guiness her meest aantrekkelijk voor de aandeelhouders van Distillers en kon eerstgenoemde Distillers overnemen. Al ontstond het vermoeden dat de koersstijging van Guiness-aandelen het gevolg waren van een onrechtmatige manipulatie. Dit heeft ertoe geleid dar er vanuit de Engelse overheid een onderzoek werd ingesteld naar de overname wan Distillers door Guiness. In het kader van dit anderzoek werd ook de directeur van Guiness, Saunders, gehoord. In dit arrest stond onder meer de vraag centraal of de tijdens het onderzoek door Saunders afgelegde verklaringen in de latere strafzaak gebruikt mochten worden. Hoe ver reilat het Nemo Tenetur beginsel; het recht on niet mee te hoeven werken atan de eigen veroordeling? Immers, in de strafzak had Saunders als verdachte het recht om te zwijgen rewijl hij tijdens het onderzoek door de Engelse toezichthouder een inlichtingenplicht had. Mogen verklaringen die de burger gedwongen was af te leggen (clenk aan de inlichtingenplicht), in een strafrechtelijke procedure - met name een strafproces - tegen hem worden gebruikt? Het antwoord is negatief. Her EHRM heeft in dit arrest beslist dat artikel 6 lid 1 EVRM, niet toestat dat afgelegde verklaringen die door middel van dwang, dus tegen de wil van de verdachte zijn verkregen, als bewijs in een strafzaak toe worden gelaten. Materiaal dat anafhankeliyk won de wil van de werdachte bestaat, bijwoorbeeld bloedmonsters of documenten, mag ook wanneer het onder dwang is verkregen, in een strafrechtelijke procedure tegen de verdachte worden gebruikt. Met andere woorden: het Nemo Tenetur beginsel strekr zich niet uit over her gebruik van afgenomen bewijsmaterialen die onafhankelijk van de wil van de verdachte bestaan. Wanneer er in de fase woor de criminal charge, zoals vervat in artikel 6 EVRM, verklaringen door de verdachre zijn afgelegd (bijvoorbeeld in een administratieve onderzoelksfase), mogen deze worden gebruikt tenzij deze verklaringen alls bewijsmateriaal zullen worden gebruikt bij de vaststelling van een eventuele strafvervolging. Vgl ook het eender genoemde Funke arrest. 
een simpel ja of nee worden beantwoord. Enerzijds kan worden gesteld dat de openbaarheid van het strafrechtelijk proces, de (negatieve) aandacht van de media niet aanlokkelijk zijn woor een onderneming. Men wil de "goede naam" van het bedrijf niet op een negatieve manier onder de aandacht van het grote publiek brengen. Dit kan leiden tot onder meer koersdalingen, winstwaarschuwingen en zelfs een ondergang van het bedrijf. Indien mogelijk vermijdt een bedrijf negatieve publiciteit. Dat wil niet zeggen dat het strafrecht dus als ultimum remedium binnen de wereld van het effectenrecht geldt. Waar vennootschappen, bestuurders van deze ondernemingen beducht voor zijn, is allereerst een reële bedreiging van de onderneming; dat wil zeggen een zeer grote kans dat de onderneming ten onder gaat. Verder vermijden de (leidinggevende) personen uit een onderneming de situatie dat zij niet meer op het terrein van het effectenwezen werkzaam kunnen zijn. Beide situaties kunnen zowel via het strafrecht als via het bestuursrecht worden bewerkstelligd. Het is namelijk mogelijk dat het Openbaar Ministerie maatregelen op grond van de WED toepast en realiseert dat de onderneming van de veroordeelde directeur onder bewind wordt gesteld ${ }^{550}$. Verder kan het Openbaar Ministerie besluiten om als bijkomende straf, naast bij voorbeeld de hoofdstraf van een geldboete van $€ 450.000$,- voor de periode van maximaal een jaar tevens de gehele of gedeeltelijke stillegging van de onderneming te vorderen ${ }^{551}$. Dit alles, te samen met de in artikel 8 onder $\mathrm{c}$ genoemde verplichting om dat wat wederrechtelijk is verricht of nagelaten, op kosten wan de veroordeelde weer ongedaan te maken, is afschrikwekkender voor de verdachte daar het een grote impact kan hebben op zowel zijn bedrijf als op zijn persoonlijke situatie. Hij kan immers niet vrijelijk over zijn onderneming beschikken. Daarnaast kan het strafrechtelijk vonnis ertoe leiden dat de veroordeelde directeur, werknemer moeilijker binnen de effectenwereld aan de slag kan komen. Dit, omdat een strafrechtelijke veroordeling de toekomstige afgifte van een vergunning via bij voorbeeld de Autoriteit-FM bemoeilijkt. De Autoriteit-FM ziet een straftechtelijke veroordeling, zeker wanneer deze veroordeling gerelateerd kan worden aan eerdere werkzaamheden binnen de sfeer van de effectenwereld, als een belemmering voor de afgifte van een dergelijke vergunning. Immers, de veroordeelde kan dan niet als betrouwbaar worden geacht. Het bedreigende van bovenstaande maatregelen ligt niet in de veroordeling, maar reeds in de fase ervoor. Al 
wanneer tegen de verdachte ernstige bezwaren zijn gerezen en in geval de belangen die door het vermoedelijk overtreden wetsartikel of wettelijk voorschrift worden beschermd een spoedig ingrijpen vereisen, kunnen voorlopige maatregelen worden opgelegd ${ }^{552}$. Dat kan betekenen dat de (rechts) persoon zich dient te onthouden van bepaalde handelingen dan wel dat hij ervoor dient te zorgen dat de door het Openbaar Ministerie aangeduide voorwerpen die in beslag genomen zouden kunnen worden, opgeslagen en bewaard worden. Verder kan bij wijze van voorlopige maatregel de onderneming op grond van artikel 29 WED geheel of gedeeltelijk stil worden gelegd; onder bewind worden gesteld, de verdachte kan geheel of gedeeltelijk worden ontzet van bepaalde rechten of voordelen die in verband met zijn onderneming van overheidswege zijn of zouden kunnen worden toegekend. Wanneer verdachte de (rechts)persoon in strijd met de bovengenoemde straffen of (voorlopige) maatregelen handelt, begaat hij volgens artikel 33 WED e.v. opnieuw een economisch delict, met alle gevolgen van dien.

\section{Het strafrecht: een ultimum remedium?}

Op grond van het voorafgaande zou verondersteld kunnen worden dat het strafrecht een afschrikwekkende werking heeft. Toch wil dit niet zeggen dat het dan maar als ultimum remedium moet worden beschouwd. Hiervoor moeten eerst de andere procedures naast worden gelegd, te beginnen met de civiele procedure. Wanneer de civiele procedure nader wordt bekeken, kan tot de conclusie worden gekomen dat de dreiging van een mogelijke civiele procedure minder afschrikwekkend is dan in geval het een strafrechtelijke procedure betreft. Dit, daar onder meer de uitkomsten van een civielrechtelijke procedure niet "hoeven ${ }^{1553}$ door te werken in de strafrechtelijke procedure. Andersom is dat wel het geval. Wanneer de bestuursrechtelijke procedure nader wordt bestudeerd, valt op te merken dat een strafvonnis wél zou kunnen leiden tot bijvoorbeeld de weigering van de Autoriteit-FM om een vergunning op grond van artikel 7 Wte'95 af te geven. De Autoriteit-FM kan namelijk bepalen dat de vergunningaanvrager niet voldoet aan dat wat er in artikel 7 lid 4 onder a wordt vereist.

552 Vgl. de artikelen 28 WED e.v.

553 Zo zou cen uitspraak wan een burgerlijke rechter op grond van artikel $1.4 \mathrm{~W}$ v $5 \mathrm{v}$ door kunnen werken in het wonnis van de strafrechter. Vgl. hiervoor arrikel 14 WWSv. 


\section{Artikel 7 Wte'95}

1. Het is werboden zonder wergwning als effectew bemiddehat of wennogenbeheerder in of vanut Nederland diensten aan te bieden of te verrichten. (...)

2. 'Onze Minister verleent, op werzoek, een wergwrwing als bedoeld in bet terste lid indien de anumager antoont dat wordt voldaan atan bij of krachtens algemene maatregel wan bestum te stellen regels ten atwaten van:

a. deskundigheid en betrowwbatrbet.

b. financiele watrborgen, al dan niet tevens op geconsolideerde basis;

c. bedrijfiwoering en vestiging wan het hoofdkantoor;

d. aan het publiek te verstrekken informatie; en

e. waarborgen woor een adequat toewicht op de ralewing wan de bij of krachtens deze wet grestelale regels. (...)

De regels die bij of krachtens AMvB waar naar hierboven wordt verwezen zijn te vinden in het eerder genoemde Besluit toezicht effectenverkeer $1995^{554}$ (Bte'95). In artikel 10 lid 2 Bte'95 wordt nader omschreven wat er onder betrouwbaarheid dient te worden verstaan.

\section{Artikel 10 Bte'95}

1. Een ieder die een effecteninstelling krachiens wet, statuten of reglementen vertegenwoordigt dan wel bet dagelijks beleid van een effecteninstelling bepalt, dient naar het oorded wan de toezichthoudende autoriteit voldoende deskundig te zijn in verband met de bedrijswoering wan de effecteninstelling.

2. De betrowubataheid wan de in bet eerse lid bedolate personen, de personen die bet dagelijks beleid tan de effecteninstelling mede bepalen en de personen die rechtstreeks of middellijk bevogd zijn de in het eerste lid bedoelde personen te benoemen of te ontslatn dienst naar het oordeel van de toezichthoudende autoriteit buiten twijfel te stadan.

Alvorens de toezichthouder overgaat tot het verlenen van een vergunning, zal zij eerst oordelen of de vertegenwoordigende personen zoals genoemd in artikel 10 lid 1 Bte'95 wel betrouwbaar zijn. Mede aan de hand van een soort "verklaring omtrent het gedrag" bepaalt de Autoriteit-FM of zij de vergunning zal verlenen. In artikel 20 onder a Bte'95 staat aangegeven dat de voornoemde personen gegevens moeten overleggen op grond waarvan de STE kan oordelen of zij bijvoorbeeld wel aan her betrouwbaarheidsvereiste voldoen. 1999 , Stb. 530 en 590. In de artikelen 10 tot en met 20, hoofdstuk IV van dit beshuic, wordt uitwoering gegeven aan artikel 7, lid 4 Wte 95 . 


\section{Artikel 20 Bte'95}

Een effecteninstelling legt, woor zover op baar wan toepassing, de wolgende gegevens aan de toczichthoudende autoriteit over:

a een verklaring omtrent de identiteit en de antecedenten van de personen, bedoeld in artikel 10, alsmede gegevens en bescheiden op basis watrvan de soevichthouder kan beoordelen of deze persones voldoen aan de in dat artikel bedoelde vereisten; (...)

Een strafrechtelijke veroordeling zal voor de toezichthouder een reden kunnen zijn om te twijfelen aan de betrouwbaarheid van de vergunningaanvragers. Het gevolg van het feit dat deze personen geen vergunning wordt verleend, is dat zij niet kunnen opereren op de effectenmarkt. Wanneer hier de vraag wordt opgeworpen welke procedure afschrikwekkender is, de strafrechtelijke of de bestuurstechtelijke procedure, dan kan dat niet direct worden beantwoord. Zoals hiervoor is aangetoond, kan een strafrechtelijke veroordeling verstrekkende gevolgen hebben. Dat zijn niet alleen alle sancties die op grond van het WvSr en op grond van de WED kunnen worden toegepast, waaronder de voorlopige maatregelen, maar ook de directe gevolgen voor het bestuursrecht te weten de weigering van de afgifte van een vergunning. Wanneer het daadwerkelijk tot een veroordeling komt heeft het strafrecht, als handhavingsinstrument, naar mijn mening een terechte afschrikwekkende functie en fungeert het als ultimum remedium.

In het volgende hoofdstuk zal de Amerikaanse toezichthouder, de Securities and Exchange Commission (SEC), centraal staan. Rekening houdend met een verschil van staatsbestel, rechtssysteem en rechtscultuur, zal worden getracht een beeld te schetsen van het Amerikaans toezicht op het effectenverkeer aldaar, mede omdat de USA vaak als voorbeeld dient en diende voor rechtsontwikkelingen in Europa c.q. in Nederland. In hoofdstuk 3 zal worden getracht om de bevoegdheden van de SEC te spiegelen aan die van de Autoriteit-FM zodat de verschillen en overeenkomsten tussen beide toezichthouders in hoofdstuk vier duidelijk kunnen worden weergegeven. Voor zover mogelijk zal dat hoofdstuk daarom een zelfde opbouw hebben als hoofdstuk twee. De verschillende rechtssystemen brengen beperkingen met zich mee. Zo zal in het volgende hoofdstuk de nadruk liggen op het vergelijken van bevoegdheden van de toezichthouders, binnen het Amerikaans federale (effecten)recht en zullen niet alle lagen van het Amerikaans recht, met hun interstatelijke verschillen met name op straf(proces) rechtelijke gebied, doorgrond kunnen worden zoals is vereist bij een zuiver rechtsvergelijkend onderzoek. 


\section{Toezicht en regulering van de Amerikaanse effectenwetgeving}

\section{Inleiding}

In de jaren twintig en dertig van de vorige eeuw waren de Amerikaanse effectenmarkten, ondanks de op dat moment bestaande wettelijk verankerde sturings- en controlemechanismen, instabiel. De reden hiervoor was terug te vinden in de vele malafide praktijken ${ }^{1}$. Naar aanleiding hiervan besloot de Amerikaanse overheid om niet alleen federale wetgeving in te voeren, maar om ook een semi-overheidslichaam in het leven te roepen dat toezicht op de effectenhandel moest houden. Dir lichaam, de Securities and Exchange Commission (SEC) moest het beleggen voor de (particuliere) belegger toegankelijk en veiliger maken. Dit trachtte de SEC te bereiken door onder meer ervoor te zorgen dat (potentiële) beleggers toegang kregen tot alle benodigde informatie betreffende de aankoop van effecten.

Tot op heden geniet de SEC een buitengewoon hoog aanzien. Zowel handelaren als beleggers die te maken hebben met Amerikaanse aandelen gaan omzichtig met haar om. Daarnaast maken haar buitenlandse collegatoezichthouders, zoals in Nederland de Autoriteit-FM; de ECD en het Openbaar Ministerie, graag gebruilk van de kennis en ervaring van de SEC. Dit is dan ook de reden dat de SEC in dit hoofdstuk nader wordt bekeken. In het volgend hoofdstuk zullen de bevoegdheden van de Nederlandse toezichthouder vergeleken worden met de SEC en zullen verschillen en overeenkomsten worden behandeld.

Hieronder zal het historisch kader worden geschetst door de situatie vóór de instelling van de SEC te beschrijven. Vervolgens zal de SEC worden besproken waarbij niet alleen naar de oorspronkelijke doelstellingen zal publishing Co., p. 4 . 
worden gekeken, maar ook naar de huidige doelstellingen en bevoegdheden. Hier zal worden aangegeven welke rol de SEC thans speelt en over welke machtsmiddelen zij beschikt. Om een duidelijk beeld van de reikwijdte van de taken en bevoegdheden van de SEC te krijgen, mag een kleine introductie in het Amerikaans recht(systeem) niet ontbreken.

\subsection{Een introductie in het Amerikaans recht}

Het Amerikaans rechtsysteem wordt beheerst door het beginsel van scheiding der machten en de leer van Checks and Balances. Dit houdt in dat een strikte scheiding wordt aangelegd tussen: de Wetgevende macht, de Uitwoerende macht en de Rechtsprekende macht. Hiermee wordt getracht om het volk te beschermen tegen enige vorm van tirannie door te voorkomen dat een bepaalde macht de controle over de gehele overheid, het gehele land, uitoefent. Deze scheiding van machten brengt met zich mee dat elke macht bevoegd en in staat is om de gedragingen van de andere twee machten te controleren. Alvorens specifieker op de $S E C$ in te gaan, die overigens onder de uitvoerende macht ondergebracht kan worden, volgt een korte inventarisatie van de machtsblokken.

\subsubsection{De verdeling van machten}

\section{De wetgevende macht}

Op grond van de constitutie is alle wetgevende macht aan het Amerikaans Congres gedelegeerd. Het Congres wordt gevormd door de Senaat en het Huis van Afgevaardigden ${ }^{2}$. Alvorens een wetsvoorstel naar de President van de Verenigde Staten gaat voor goedkeuring (of voor een veto), moet het door zowel de Senaat, als het Huis van Afgevaardigden zijn goedgekeurd. In de Senaat zijn er, per staat, 2 senatoren aanwezig ${ }^{3}$. In het Huis van Afgevaardigden wordt een andere verdeelsleutel gehanteerd. Dat wil nier zeggen dat er een ongelimiteerd aantal afgevaardigden is. Vastgesteld is dat het Huis van afgevaardigden niet meer dan 435 leden zal. toelaten. In artikel I, section 8 van de U.S. Constitution worden de bevoegdheden van het Congres beschreven.

* U.S.Constitution, article I, section 1:

All legiskative powers berein granted shall be wested in a Congress of the United States, which shall consist of a Sevate and Howse of Representatives.

3 U.S. Constitution, article I, section 3:

The Senate of the United States shall be composed of two Senators from each state, chosen by the legislature there of, for six years; and each Senator shall have one vote... 
Voorts zijn in de volgende sections, 9 en 10, de grenzen van de bevoegdheden van het Congres vastgesteld.

\section{De uitvoerende macht}

De constitutie heeft de uitvoerende macht op nationaal niveau aan de president van de Verenigde Staten van Amerika toegekend.

\section{U.S. Constitution, article $I$, section I}

The executive power shall be vested in a President of the United States of America. He shall bold bis office during the term of four years, and, together with the Vice President, chasen for the same term, be elected, as follows:....

Artikel II, section 1 van de U.S. Constitution bepaalt dat de president voor de tijd van vier jaren wordt gekozen. Een Amerikaanse president is op grond section 2 voornoemde artikel van de U.S.C. bevoegd om gezag over het leger te voeren; verdragen te sluiten; personen aan te stellen in topfuncties van overheidsdiensten; ambassadeurs aan te wijzen en rechters te benoemen.

\section{U.S. Constitution, article II, section 2}

The President shall be commander in chief of the Amy and Naty of the United States, and of the militia of the several states, when called into the actual service of the United States; he may require the opinion, in writing, of the principal officer in each of the executive departments, upon any subject relating to the duties of their respective offices, and be shall have power to grant reprieves and pardons for offenses against the United States, except in cases of impeachment. He shall have power, by and with the adrice and consent of the Senate, to make treaties, provided two thirds of the Senators present concur; and he shall nominate, and by and with the advice and consent of the Senate, shall appoint ambassadors, other pwblic ministers and consuls, judges of the Supreme Court, and all other officers of the United States, whose appointments are not berein otherwise provided for, and which shall be established by law: but whe Congress may by Law west the appintment of such inferior officers, as they think proper, in the President alowe, in the courts of law; or in the heads of departments. The President shall bave power to fill up all vacancies that may bappend during the recess of the Senate, by granting commissions which shall expire at the end of their next session.

\section{De rechterlijke macht}

Tot slot de rechterlijke macht. Volgens de Amerikaanse constitutie zijn er twee soorten rechtbanken. De eerste is de onafhankelijke Supreme Court, te vergelijken met onze Hoge Raad der Nederlanden die op grond van de constitutie tot stand is gekomen. Ten tweede zijn er de lagere 
rechtbanken die door het Congres worden ingesteld ${ }^{4}$. De Supreme Court is volgens artikel III sections 1 en 2 van de U.S.C. bevoegd om hoger beroep en in enkele gevallen zaken in eerste aanleg te behandelen.

\section{U.S. Constitution, article $U_{\text {, section } 2}$}

The judicial power shall exrend to all cases, in Law and equity, arising under this Constitution, the laws of the United States, and treaties made, or which shall be made, under their authority:-to all cases affecting ambassadors, other public ministers and consuls;--to all cases of admiralty and maritime jurisdiction; --to controversies to which the United States shall be a party;-- to controversies between two or more states;--between a state and cirizens of another statt; --between citizens of different states; --between citizens of the same state claiming lands under grants of different states, and between a state, or the citizens thereof, and foreign states, citizens or subjects. In all cases affecting. ambassadors, other public ministers and consuls, and those in which a state shall be party, the Supreme Court shall have original jurisdiction. In all the other cases before mentioned, the Supreme Court shall have appellate jurisaiction, both as to law and fact, with such exceptions, and under such regulations as the Congress shall make. The trial of all crimes, except in cases of impeachment, shall be by jury; and such trial shall be beld in the stave where the said crimes shall have been committed; but when not committed within any state, the trial shall be at such place or places as the Congress may by law bave directed.

Zoals reeds vermeld heeft de machtenscheiding tot gevolg dat de drie machten elkaar moeten kunnen controleren. Zo kan de wetgevende macht, het Congres, het gedrag van de uitvoerende macht, de President van de Verenigde Staten van Amerika, controleren door hem of haar of ieder andere uitvoerende ambtenar te ontheffen uit haar functie, via een impeachement procedure, indien bewezen kan worden dat deze rijdens de uitvoering van zijn functie een misdaad heeft begaan ${ }^{5}$.

\section{U.S. Constitution, article II, section 4}

The President, Vice President and all civil officers of the United States, shall be removed from office on impeachment for and conviction of, treason, bribery, or otber bigh crimes and misdemeanors.

4 U.S. Constitution, article III, section 1:

The judicial power of the United States, shall be vested in one Supreme Court, and in such inferior courts as the Congress may from time to time ordatin and establish. The judges, both of the supreme and inferior courts, shall bold their offices during good behaviou, and sball, at stated times, receive for their services, a compensation, which shall not be diminished during their continuance in office.

5 U.S. Constiturion, article II, section 4. Diverse Amerikaanse Presidenten, te weten Johnson, Nixon en Clinton hebben op directe of indirecte wijze te maken gehad met een (mogelijke) impeachement. Geen van deze presidenten is ooit afgezer in een dergelijke procedure. Vgl. Simon, W., International Securities Regulation: United States booklet 1, Oceana Publications inc., April 1994, p. 4. 
De President kan op zijn beurt het gedrag van de wetgevende macht controleren door zijn veto uit te spreken over wetsvoorstellen van het Congres. Het effect van zo'n presidentiële veto is relatief omdat het Congres bevoegd is om een veto van de President met tweederde meerderheid van zowell de Senaat als van het Huis van Afgevaardigden te overrulen.

\section{U.S. Constitution, article 1 , section 7}

All bills for raising revenue shall originate in the House of Representatives; but the Senate may propose or concur with amendments as on other Bills. Every bill which shall have passed the House of Representatives and the Senate, shall, before it become a Law. be presented to the President of the United States; if he approves he shall sign it, but if not he shall return it, with his objections to that House in which it shall have originaved, who shall enter the objections at large on their journal, and proceed to reconsider it. If after sach reconsideration two thirds of that House shall agree to pass the bill, it shall be sent, together with the objections, to the other House, by which it shall likewrise be reconsidered, and if approved by two thirds of that House, it shall become a law. (...) Every order, resolution, or vote to which the concurrence of the Senate and House of Representatives may be necessary (except on a question of adjourriment) shall be presented to the President of the United States; and before the same shall take effect, shall be approved by him, or being disapproved by bim, shall be repassed by wwo thirds of the Senate and House of Representatives, according to the rules and limitations prescribed in the case of a bill.

De rechterlijke macht kan wetten die inhoudelijk indruisen tegen de principes zoals vastgelegd in de Amerikaanse Constitutie, ongrondwettelijk verklaren. Tot slot kan ook de rechterlijke macht, zij het indirect, door het Congres en/of de President worden gecontroleerd. Het Congres kan in theorie die rechtbanken instellen die zij nodig acht ter aanvulling op de United States Supreme Court ${ }^{6}$. Daarnaast kan het Congres ook besluiten om her aantal rechters bij de Supreme Court te verhogen. Ondanks deze bevoegdheid heeft het Congres daar sinds 1869 geen gebruik van gemaakt ${ }^{7}$. De President kan de rechters benoemen van zijn woorkeur. Vaak zijn het rechters met dezelfde politieke kleur. Een der-

Zie U.S. Constitution, article I, section 8:

The Congress shall have power to lay and collect taxes, duties, imposts and excises, to pay the debt and provide for the rommon defense and general welfare of the Unived States; but all duties, imposts and excises shall be uriform throughout the United State;... To constitute tribunals inferior to the Supreme Coum; " en zie ook article III onder section 1: "... The judicial power of the United States, shall be vested in one Supreme Court, and in such inferior courts as the Congress whay from time to ordain and establish.

7 Simon, W., International Securities Regulation: United States booklet 1, Oceana Publications inc., April 1994, p. 4. 
gelijke benoeming door de President kan tot slot weer door de Senaat worden tegengehouden. Immers, de Senaat dient de keuze van de President te bevestigen. Dat de drie machten van elkaar gescheiden zijn, houdt in de praktijk niet in dat zij elkaar niet kunnen beïnvloeden. De SEC bijvoorbeeld, een zelfstandig bestuursorgaan ${ }^{8}$, zou in beginsel zelfstandig en dus onafhankelijk van wetgevende en uitvoerende macht moeten beslissen. Toch wil het voorkomen dat zij zich door deze machten laat beinvloeden en dat kan worden gesproken van "politieke controle". Zoals later uit paragraaf 3.5.1 zal blijken, kan de wetgevende macht de SEC "stimuleren" om bepaalde onderzoeken te verrichten. De SEC zal in haar beslissing om een zaak wel of niet nader te onderzoeken, op haar beurt gevoelig zijn voor een dergelijke "stimulans" omdat zij enerzijds voor haar budget en anderzijds voor het delegeren en toekennen van bepaalde bevoegdheden afhankelijk is van de wetgevende macht, het Congres. Daarnaast kan de uitvoerende macht, de President, uit onvrede met het door de SEC gevoerd beleid, besluiten om een andere voorzitter te benoemen.

Uit het voorafgaande is gebleken dat het ideaal van de scheiding der machten, niet in alle "lagen van de overheid" zijn uitwerking vindt. Bij de handhaving van de effectenregelgeving kan de SEC door de twee hierboven genoemde machten beïnvloed worden. De taak van de rechterlijke macht is om de beslissingen genomen door het administratieve bestuursorgaan, de SEC, te beoordelen. In de volgende paragraaf zal de rechterlijke macht nader worden bekeken en zal worden getracht het systeem van Amerikaanse rechtbanken in kaart te brengen.

\subsubsection{De verschillende rechtsprekende instanties}

De in paragraaf 3.1.1 genoemde rechtbanken zijn, in grote lijnen, onder te verdelen in rechtspraak door federale rechtbanken, statelijke rechtbanken en administratieve (hoor)zittingen. De administratieve (hoor)zittingen, of administrative tribunals, worden gehouden door de

De SEC wordt beschreven als "the agency charged with principal responsibility for the enforcement and administration of the federal securities laws." Ratner, D.L., Securities Regulation in a nutshell, St. Paul Minnesora: West Publishing Co., 1982 , p. 13. Verder wordt het volgende over de SEC vermeld: "The SEC is an independent agency; it is not attached to the Congress nor is it a part of any executive department". Vgl. Gellhorn, E. en Levin, R.M., Administrative Law and Process in a nutshell, West Group, St. Paul: Minnesota, 1997, p. 11. 
administratieve agencies waar de SEC toe behoort. Deze agentschappen behoren tot de uitvoerende macht en zijn in het leven geroepen om bepaalde functies uit te voeren. In de wetgeving waarin is bepaald dat een specifieke administratieve agentschap/organisatie in het leven dient te worden geroepen, zijn de bevoegdheden van een dergelijk agentschap te vinden. Een administratieve agentschap of organisatie heeft over het algemeen de bevoegdheid om hoorzittingen te houden. Dat houdt in dat de desbetreffende partijen de zaak voorleggen aan een Administrative Law Judge (ALJ); een hearing officer ofwel een overheidsdienaar in dienst gesteld om hoorzittingen voor te zitten. Met de uitspraak van een administrative law judge, "rullings", kunnen de desbetreffende partijen in hoger beroep gaan bij de hoogste instantie van de administratieve organisatie. In geval van de SEC zou het beroep plaatsvinden voor het voltallige bestuur van de Securities and Exchange Commission. Voorts kumnen partijen met een ruling ook in beroep gaan bij de rechtbank? De federale rechtbank mag volgens section 2 van artikel 3 van de U.S. Constitution, alleen die zaken behandelen die terug te leiden zijn tot de federale wetgeving of tot de verdragen van Amerika en de Amerikaanse grondwet; de Constitutie. De federale rechtbanken worden ook wel. Federal trial- of district courts genoemd. In elke Amerikaanse staat is er ten minste één federale district court te vinden. In 1999 waren er in de United States of America 94 district courts waar federale zaken werden behandeld. Deze district courts zijn bevoegd om in eerste aanleg zowel civiele als federale strafzaken te behandelen. In geval een zaak alleen statelijke wetgeving betreft, maar deze wetgeving te maken heeft met federale wetten, dan is de federale rechtbank bevoegd. Ook zaken tussen burgers van verschillende staten; burgers van een staat en een ander land, een buitenlandse burger of een buitenlandse ondernemer, worden voor de federale rechtbank behandeld. Boven deze federale district courts, zijn de United States Courts of Appeals, de circuit courts, te vinden. Hier komt het hoger beroep van zaken die door de federale district court en/of door andere speciale rechtbanken zijn behandeld, aan bod. Er zijn 13 circuits, dat wil zeggen: twaalf circuits die de diverse staten geografisch 
vertegenwoordigen ${ }^{10}$ en een circuit te weten de Federal Circuit. Laatstgenoemde behandelt beroepszaken afkomstig van speciale rechtbanken waarvan de U.S.A. kamer van internationale handel er een is. Boven de United States Courts of Appeals - de circuit courts - is de United States Supreme Court te vinden. In geval een partij de zaak in hoger beroep, bij een van de Courts of Appeals - de circuit courts verliest, heeft deze niet het recht om dezelfde zaak nog eens te laten behandelen door de United States Supreme Court, Amerika's hoogste rechtsprekende instantie. Het kan wel voorkomen dat de Supreme Court zelf geïnformeerd wil zijn en besluit om de zaak te bekijken, maar dan geschiedt dat vanuit de Supreme Court zelf. In een dergelijk geval laat het U.S.A. Supreme Court de lagere rechtbank weten dat het de zaak nader wil bekijken. Dit wordt ook wel de "certiorari jurisdiction" genoemd. Daarnaast heeft het U.S.A. Supreme Court ook de "obligatory appellate jurisdiction ${ }^{11 "}$. Dit laatste houdt in dat alle zaken die te maken hebben met de vraag of statelijke wet- of regelgeving niet indruisen tegen de federale Constitutie, automatisch bij het U.S.A. Supreme Court terechtkomen. Voorts heeft het Supreme Court ook een "original jurisdiction". Dat wil zeggen dat bepaalde zaken direct voor het Supreme Court komen zonder dat er een andere rechtsinstantie naar kan kijken. Een voorbeeld hiervan is een geschil tussen twee Amerikaanse staten. Tot slot heeft het U.S. Supreme Court de "exclusive jurisdiction" over procedures tegen buitenlandse ambassadeurs.

Voorbeelden van een paar circuits zijn: het eerste circuic bestaat uit Maine, Massachusetts, New Hampshire, Rhode Island en Puerto Rico. Het tweede circuit bestaat uit Connecricur, New York en Vermont. Zo worden alle staten wan de U.S.A. verdeeld in 11 circuits. Het twaalfide circuit bestaat geheel uir de District of Colombia. Het laatste en dertiende circuit is het Federal Circuit. Everetr, P.I., Legal Secretary Federal Litigation, 4th edition, 1997, James Publishing Inc., p. 1-2 tot $1-3$.

11 U.S. Constitution, article III, section 2. 


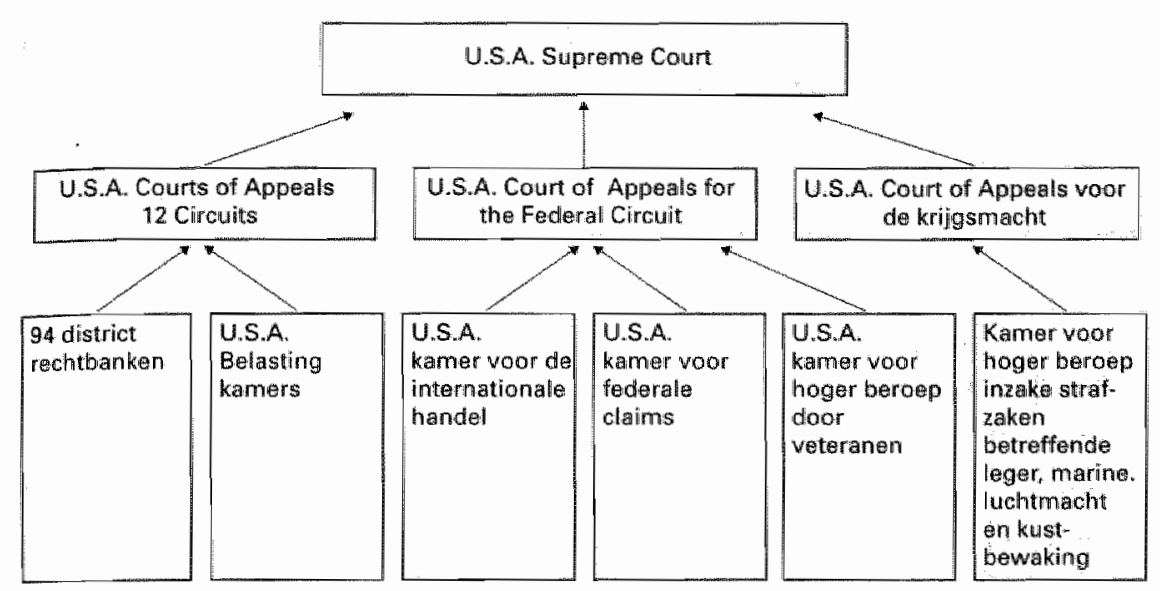

FIGUUR 3.1 Het systeem wan Amerikasinse rechtbanken

Bron: Bureau of National Affairs' divectory of State and Federal Courts, Judges and Clerks, 1999 edition p. 1

\subsection{De ontstaansgeschiedenis van de SEC}

De in de inleiding genoemde malafide praktijken, waar de manipulatie van effectenkoersen een voorbeeld van is, zorgden voor instabiele effectenmarkten. Bij prijs- of koersmanipulatie creëerden effectenhandelaren op een kunstmatige wijze hoge prijzen of koersen door grote hoeveelheden effecten op de markt te brengen of uit de markt te halen. Hierdoor kreeg de belegger de illusie dat de vraag naar bepaalde aandelen gedaald, of juist gestegen was. De kans was dan zeer groot dat de belegger daar naar ging handelen. De handelaar kon nu de aandelen tegen een lagere koers kopen of juist tegen een te hoge koers verkopen. Door zo spoedig mogelijk te handelen kon de malafide handelaar zijn voordeel halen alvorens de koersen weer stegen of daalden naar hun werkelijke (markt)waarde. Naast prijs- of koersmanipulatie werd in voornoemde periode ook grif gebruik gemaakt van "kopen op krediet". Dat wil zeggen dat ook de minder kapitaal krachtige beleggers de mogelijkheid hadden om te kunnen beleggen. Hiertoe werd door de effectenhandelaren ongelimiteerd krediet aan de beleggers verleend. Dit ging goed totdat de koersen instortten. Vanaf dat moment waren de effecten minder waard dan dat wat de beleggers hadden geleend. Deze beleggers moesten er voor zorgen dat zij hun crediteuren voldoende aanvullende zekerheid konden bieden c.q. konden terugbetalen. Tot slot maakten ingewijde personen binnen een bedrijf misbruik van bepaalde bedrijfskennis. Hierdoor konden zij voortijdig maatregelen treffen om zo te profiteren 
van de koersfluctuaties wanneer de betreffende informatie publiekelijk bekend werd ${ }^{12}$.

De effectenwetgeving, welke niet in staat was om deze ongeregeldheden tegen te gaan, bestond uit federale en statelijke regelingen. Een van de eerste federale effectenwerten was de Sherman $\mathrm{Act}^{13}$. Deze wet werd aan het eind van de $19^{\text {de }}$ eeuw ingevoerd. In 1898 werd door het Amerikaans Congres een commissie geïnstalleerd die de positie van de (potentiële) beleggers onder de loep nam. Deze commissie, The Industrial Commission, rapporteerde in 1902 aan het Congres dat het voor (potentiële) beleggers mogelijk moest zijn om toegang te kunnen krijgen tot bepaalde bedrijfsinformatie, waaronder de jaarverslagen. Op deze wijze zou de belegger meer vertrouwen in de markt kunnen krijgen. Er werden diverse pogingen gedaan om wetten in te voeren die bedrijfsinformatie toegankelijker voor beleggers moesten maken, maar veel verder dan deze pogingen kwam de federale wetgever niet. De statelijke wetgever bereikte op dat gebied veel meer. In 1913 werd de verkoop van effecten reeds in 23 staten gereguleerd ${ }^{14}$. Deze regelgeving bestond enerzijds uit regels die op het plegen van fraudeleuze handelingen met betrekking tot de verkoop van effecten diverse sancties stelden. Anderzijds gaven deze regels de voorwaarden aan waaraan voldaan moest worden bij de verkoop van effecten. De statelijke wetgeving uit de beginperiode kreeg al gauw de bijnaam: "blue sky laws". Uit diverse rechterlijke uitspraken en vonnissen was immers gebleken dat deze statelijke wetgeving voorkwam dat beleggers aandelen van malafide handelaren kochten die achteraf evenveel waard bleken te zijn als een hoopje blauwe lucht ${ }^{15}$. Weliswaar waren er meer statelijke dan federale regels, maar toch bleken eerstgenoemde regels niet altijd in de praktijk te volstaan. De verschillencle statelijke regels maakten het de fraudeurs niet onmogelijk om hun prakrijken voort te zetten. Immers, dac wat in staat $\mathrm{A}$ was verboden,

Skousen, K.F, a.w. p. 4.

13 Deze wet behoort tot de categorie: "anti-trust acts". Dat zijn wetten tegen prijsen monopolievorming die de vrije handel in het algemeen beperken. De belangrijkste Amerikaanse anti-trust wetten zijn: de Sherman Act uit 1890 , de Clayton Act uit 1914, de Federal Trade Commission Act uit 1914 en de Robinson Patman Act uit 1936.

14 Pointer, L.G. en Schroeder, R.G., An introduction to the Securities ana Exchange Commission, Plano, Texas, 1986, Business publications inc., p. 9.

15 Pointer, L.G. en Schroeder, R.G., An introduction to the Securities and Exchange Commission, a.w. p. 9. 
werd niet altijd in staat $\mathrm{B}$ of $\mathrm{C}$ strafbaar gesteld. Daarnaast schortte het ook vaak aan de uitvoering van de statelijke regels. Hierdoor bleken de statelijke regels lang niet altijd effectief te zijn. Staten die wel de moeite namen om de regelgeving na te doen leven en toezicht op een goede uitvoering te houden, werden vaak weer in de wielen gereden door het slachtoffer, de belegger. Zodra de staat poogde een bedrijf of handelaar te vervolgen, bood deze het slachtoffer een (ruime) schadevergoeding aan. Vaak nam het slachtoffer dit aanbod aan en kon de staat niet meer verder vervolgen aangezien er geen slachtoffer en/of getuige meer was. Kortom, statelijke regelgeving bleek niet voldoende te zijn wanneer niet alle staten dezelfde handelingen strafbaar stelden en reguleerden ${ }^{16}$. Dit kwam nog sterker tot uiting toen vanaf eind augustus tot en met oktober 1929 de aandelenkoersen enorm daalden. Velen raakten een groot deel van hun vermogen kwijt. De dalende koersen leken zich daarna te stabiliseren, maar aan het begin van 1930 zakten zij nog verder. Beseffende dat meer statelijke wetgeving niet de oplossing bood, ontstond er meer vraag naar en ruimte voor federale wetgeving. In 1932 gaf de Amerikaanse Senaat toestemming aan het Congres om de mogelijkheden van federale wetgeving op dit terrein te onderzoeken. Dit onderzoek, dat door een industriële commissie was uitgevoerd, gaf uiteindelijk aanleiding tot de totstandkoming van de Securities Act van $1933^{17}$ en de Securities Exchange Act van $1934^{18}$. Naar aanleiding van laatstgenoemde wet werd in 1934 de Securities and Exchange Commission (SEC) opgericht ${ }^{19}$. Na haar oprichting werd het de taak van de SEC om de uitvoering van voornoemde wetten te verzorgen ${ }^{20}$. $\mathrm{Zij}$ moest ervoor te zorgen dat de (particuliere) belegger over alle benodigde materiële informatie over effecten kon beschikken. Deze informatie moest niet alleen volledig zijn, maar ook betrouwbaar. Het was in beginsel niet de bedoeling van de SEC on te voorkomen dat er speculatieve aandelen werden verhandeld. De SEC moest er voor zorgen dat de effectenhandel zo betrouwbaar mogelijk werd en dat de beleggers weer vertrouwen in

16 Skousen, K.F., An introduction to the SEC, a.w., p. 2 - 4.

17. Deze wet zou vertaald kunnen worden als de Effectenwet 1933.

18 Deze wet zou ook wel de Effectenlandelswet 1934 genoemd kunnen worden.

19 Pointer, L.G. en Schroeder, R.G., An introduction to the Securities and Exchange Commission, a.w, p. v.

20. Voor de oprichting van de SEC was de Federal Trade Commission verantwoordelijk voor de uitwoering van de Securities Act uit 1933. Pointer, L.G. en Schroeder, R.G., An introduction to the Securities and Exchange Commission, a.w., p. 11 . 
de Amerikaanse effectenmarkten zouden krijgen. Dit zou de Amerikaanse economie ook ten goede komen. Immers, een eerlijke en doorzichtige effectenmarkt zou meer beleggers en dus meer kapitaal trekken dan een fraudegevoelige markt. Om dit te bereiken kreeg de SEC niet alleen de bevoegdheid om regels te stellen, maar ook de bevoegdheid om overtredingen van de effectenwetgeving te sanctioneren ${ }^{21}$. Uit deze wetgeving bleek dat de SEC niet alleen in het leven was geroepen om de (institutionele) beleggers te reguleren, maar dat zij ook de tussenpersonen die de (potentiële) beleggers adviezen verstrekken diende te reguleren. Voor de uitvoering van deze taken en bevoegdheden was het van belang dat de SEC met een goede interne structuur te werk ging. In paragraaf 3.3 volgt een bespreking hiervan. Vervolgens zal in paragraaf 3.4 nadruk worden gelegd op de wijze van handhaving van de (federale) effectenwetgeving. Alvorens de interne structuur te bespreken, volgt een kennismaking met de relevante Amerikaanse effectenwetgeving. Deze wetgeving bepaalt namelijk in hoeverre de bevoegdheden van de SEC reiken. Dit maakt het makkelijker om inzicht in haar interne structuur te krijgen.

\subsection{De relevante Amerikaanse effectenwetgeving}

De Amerikaanse overheid is bevoegd om zowel op federaal als op statelijk gebied het effectenverkeer te reguleren ${ }^{22}$. Federale wetgeving, of "interstatelijke wetgeving", is afkomstig van het Amerikaans Congres. De verschillende Amerikaanse staten zijn bevoegd om alleen op statelijk gebied effectenregels uit te vaardigen. Hier is dan ook het verschil tussen de beide soorten effectenwetgeving terug te vinden. Reikt statelijke wetgeving tot aan de grenzen van de desbetreffende staat; federale wetgeving is overkoepelend van aard en heeft daardoor ook een groter bereik. Wetgeving gericht op effectentransacties die de grenzen van een staat overschrijden, zal door het Amerikaans Congres zijn uitgevaardigd. De verschillende. Amerikaanse staten zijn namelijk maar tot op zekere hoogte vrij in het afkondigen van hun effectenwetgeving. Zij hebben als beperking dat de wetgeving niet in strijd mag zijn met de federale wetgeving 23 .

2 Skousen, K.E, An introduction to the SEC, a.w. p. 6-16.

2. Ratner, D.L., Securities Regulation in a mutshell, St. Paul Minnesota: West Publishing Co., 1982, p. 8 .

23. Ramer, D.L., Secturities Regulation in a nutshell, St. Paul Minnesota: West Publishing Co., 1982 , p. 9 . 
Dat de Amerikaanse overheid door middel van zowel federale- als statelijke regulering de (potentiële) belegger tracht te beschermen, blijkt onder andere door haar streven om de belegger bekend te maken met alle relevante informatie over het aan te kopen aandeel. Zo is het bijwoorbeeld van belang om te weten hoeveel het aandeel nu daadwerkelijk waard zal zijn. Daarnaast meent de Amerikaanse overheid dat de belegger voortdurend op de hoogte moet worden gehouden van het wel en wee van de onderneming wiens aandelen hij in zijn bezit heeft. Men spreekt van "disclosure" of "openbaarmaking" of "onthulling". Disclosure wordt in de Verenigde Staten van Amerika (U.S.A.) in een adem genoemd met bescherming van de belegger en met de SEC. De SEC ziet er op toe dat de belegger voldoende bescherming geniet op de effectenmarkten. Om de belegger te beschermen heeft de Amerikaanse overheid naast de disclosure-regel, ook maatregelen tegen fraude, "antifraud measurements", in de effectenwetgeving opgenomen. Een voorbeeld hiervan is de registratieplicht voor onder andere tussenpersonen die handelen in effecten. Gezien de vertrouwensrelatie met de belegger en de geringe kennis van de effectenhandel bij laatstgenoemde, vond de overheid het belangrijk om deze groep te reguleren. Naast registratieplichtigen heeft de Amerikaanse overheid in de effectenwetgeving verschillende sancties opgenomen. Het kan zijn dat een gedupeerde belegger merkt dat malafide handelaar ner onder de wettelijke sancties uit kan komen omdat de desbetreffende handeling niet in strijd met de regels is. In dat geval kan deze belegger, ook wanneer een bepaalde situatie niet wettelijk is geregeld, toch een civiele actie instellen en een beroep doen op de civiele aansprakelijkheid ${ }^{24}$. De Amerikaanse rechtspraak heeft deze vorm van sanctionering geaccepteerd. In paragraaf $3.5 \mathrm{zal}$ een bespreking plaatsvinden van de verschillende procedures.

De Amerikaanse effectenwetgeving kan worden onderverdeeld in federale kaderwetten en materiële (federale) regelgeving, te weten de uitvoeringsregels. Allereerst volgt een beschrijving van de federale wetten, waarna de uitvoeringsregelgeving zal worden besproken.

24 17 C.F.R. 5200.1 (j) General statement and statutory authority: (...)"Administrative sanctions, injunctive remedies, civil money penalties and criminal prosecution. There are also private rights of action for investors injured by violations of the Acts." Zie ook Ratner, D.L., Securities Regulation in a nutshell, St. Paul Minnesota: West Publishing Co., 1982, p. 3. 


\subsubsection{Externe regelgeving; de kaderwetgeving}

De Amerikaanse kaderwetten op het gebied van het effectenverkeer hebben de vorm van "federal statutes" of federale effectenwetgeving. De federal statutes zijn wetten, "acts", die door het Amerikaanse Congres zijn uitgevaardigd. Deze wetten zijn gelijk aan de Amerikaanse treaties (verdragen), maar evenals de verdragen ondergeschilkt aan de Amerikaanse grondwet (constitution). De federale (semi-)overheidsorganen, zoals de SEC, zijn ook bevoegd om regelgeving uit te vaardigen. Deze uitvoeringsregelgeving, de administrative rules en regulations, moet wel in overeenstemming zijn met de federale wetgeving, de federal statutes. Naast de federale (semi-)overheidsorganen, is ook de Amerikaanse president bevoegd om federale besluiten uit te vaardigen, zij her in beperkte mate ${ }^{25}$. Deze presidentiële besluiten op federaal niveau staan bekend als de executive orders ${ }^{26}$. De federale regelgeving is superieur aan de statelijke wetgeving. Tot de statelijke wetgeving behoren de state constitution, state statutes en de regelgeving van de statelijke (semi-) overheidsorganen te weten de state administratieve rules en regulations ${ }^{27}$. Onder de regelgeving van de 50 Amerikaanse staten, komt de gemeentelijke- of regionale regelgeving. Dit is de regelgeving van de verschillende counties, ook wel te beschouwen als districten. Deze counties zijn weer onderverdeeld in verschillende gemeentes. Tot de regelgeving van de verschillende counties behoren: de municipal (gemeentelijke) charters, municipal ordinances en municipal rules en regulations. In schema ziet de legislatieve hiërarchie er als volgt uit:

25. De president kan nier ongelimiteerd executive orders uitvaardigen. Deze orders dienen namelijk eerst door het Amerikaans Congres te worden goedgekeurd alworens zij van kracht kunnen worden.

26 Clark, D.S. en Ansay, T., Introduction to the Law of the United States, Kluwer Law and Taxation Publishers, Deventer, The Netherlands, 1992, p. 44.

27 Allan Farnsworth, E., An introduction to the legal system of the United States, Oceana Publications Inc., New York, U.S.A., 1996, p. $62-63$. 


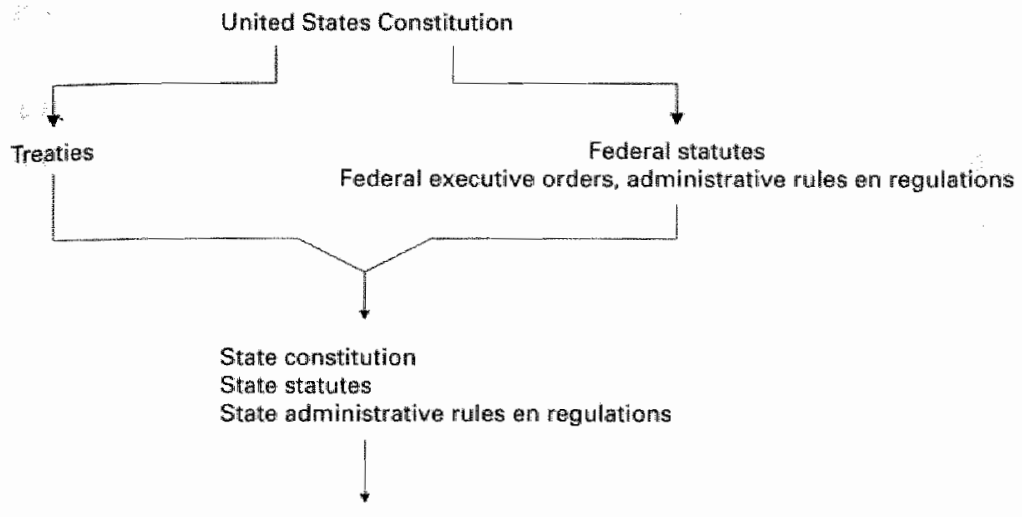

Municipa charters, mumicipal ordinances en de municipal rules and regulations

FIGUUR 3.2 De Amerikanse legislatiene biemarchie

De federale effectenwetgeving, of de federal statutes, omvat -in grote lijnen-zeven verschillende federale kaderwetten te weten:

1) de Securities act uit 1933 (SA);

2) de Securities Exchange Act uit 1934 (SEA);

3) de Public Utility Holding Company Act uat 1935 (PUHCA);

4) de Trust Indure Act wit 1939 (TLA);

5) de Investment Compary Act tit 1940 (ICA);

6) de Investment Advisers Act wit 1940 (1AA) en

7) de Securities Investor Protection Act wit 1970 (SIPA).

Van deze zeven wetten zijn er vier die een belangrijke rol vervullen: de SA'33; de SEA'34; de ICA'40 en de IAA'40. In de processen gevoerd door de SEC, particuliere beleggers of door Justitie staan dikwijls de overtredingen van deze vier wetten centraal. Deze wetten zijn ieder afzonderlijk herhaaldelijk gewijzigd ${ }^{28}$. Voor een compleet overzicht volgt hier een korte bespreking van de hierboven genoemde effectenwetten.

\section{Ad I. De Securties Act uit 1933}

Op grond van de Securities Act 1933 dienen alle effecten die aan het publiek worden aangeboden, eerst bij de Federale Handelscommissie - de FTC - te worden geregistreerd ${ }^{29}$. Later na de oprichting van de

Ratner, D.L., Securities Regulation in a nutshell, St. Paul Minnesota: West Publishing Co., 1982 , p. 10.

Bekend als "Federal Trade Commission". 
SEC, kwam de registratie onder het toezicht van de SEC. Het niet voldoen aan de registratieplicht leidt tot overtreding van deze wet. Naast de hiervoor genoemde registratieplicht, bevat deze wet ook de prospectusplicht. Dat houdt in dat alvorens effecten aan het publiek worden aangeboden, er een prospectus uitgebracht moet zijn waarin relevante informatie over de effecten en de emittent moet zijn vermeld. Voorts verbiedt deze wet elke vorm van frauduleus handellen met betrekking tot de koop of verkoop van effecten. Tot slot bevat de Securities Act uit 1933 zowel een civielrechtelijke- als een strafrechtelijke aansprakelijkheid in geval men niet overeenkomstig deze wet handelt ${ }^{30}$.

\section{Ad 2. De Securities Exchange Act uit 1934}

De basis voor effectenregulering was reeds gelegd. Deze wet ging verder dan haar voorgangster en kwam met verscheidene bepalingen die zich richtten op de verschillende actoren binnen de effectenhandel. Centraal staat de oprichting van de SEC. Vanaf dat moment, 1934, kreeg de SEC de opdracht zorg te dragen voor de Securities Act uit 1933. Naast de oprichting van de SEC leidde de Securities Exchange Act uit 1934 voor de nationale effectenbeurzen tot de verplichting om zich te laten registreren bij en te controleren door de SEC. Niet alleen de effectenbeurzen, maar ook de intermediairs, de brokers en de effectenhandelaren die een interstatelijke over-the-counter ${ }^{31}$ handel voeren kregen deze verplichting opgelegd. Inherent aan deze registratie werd de verklaring van de potentiële geregistreerden om overeenkomstig de regels van de SEC te zullen handelen. Dat hield voor de effectenbeurzen onder meer in dat de effectenbeurzen niet alleen de statutes van het Congres, maar ook de voorschriften en regellgeving van de SEC in acht moesten nemen. Daarnaast dienden de beurzen ook de aanvullende regelgeving van de SEC op de door hen zelf gevormde regels in acht te nemen. Ook de geregistreerde brokers/commissionairs en effectenhandelaren moesten vanaf dat moment voldoen aan alle wetten en voorschriften die door de SEC zijn vastgesteld ${ }^{32}$.

Pointer, L.G. en Schroeder, R.G., An introduction to the Securities and Exchange Commission, Plano, Texas: 1986, Business publication inc., p. 21.

31 Over-the-counter handel houdt in dat aandelen buiten de beurs om, onderling tussen de grote beurspartijen worden verhandeld.

32 McClure e.a., Federal Regulatory Directorys 8th edition, Washington D.C.: 1997 , p. 252. 
Naast registratie van de effectenbeurzen en bepaalde actoren binnen de effectenhandel, heeft de vaststelling van de Securities Exchange Act uit 1934 geleid tot de "disclosure". Alle voor (potentiële) beleggers belangrijk geachte informatie diende op grond van deze wet voor hen beschikbaar te worden gesteld. Als belangrijke informatie werd beschouwd: de informatie die van belang was of kon zijn voor een te nemen beslissing van een belegger betreffende de aan- of verkoop van effecten. Deze verplichting werd opgelegd aan de ondernemer wiens effecten werden verhandeld en waar het publiek eigendom van zou kunnen verkrijgen ${ }^{33}$. Voorts werd in deze wet het verbod neergelegd om de (ver)koop van effecten te manipuleren of te misleiden. Daarnaast begrensde de Amerikaanse overheid de kredietmogelijkheden voor her aankopen van effecten. Een recente financiële terugval in de jaren 1968 - 1970, leidde tot een wijziging van de Securities Exchange Act uit 1934. Deze wet werd aangevuld met een verruiming van de bevoegdheden van de SEC aangaande de nationale effectenbeurzen ${ }^{34}$.

\section{Ad 3. De Public Utility Holding Company Act uit 1935}

Een jaar na de Securities Exchange Act, kwam de Public Utility Holding Company Act tot stand. De aanleiding hiertoe was gelegen in het misbruiken van zowel elektriciteits- als gas-nutsbedrijven. Het Amerikaans Congres ontdekte dat de complexe constructie van deze nutsbedrijven bepaalde vormen van misbruik vergemalkkelijkte. Het bleek namelijk dat gas en elektra in heel Amerika in handen waren van enkele grote nutsbedrijven die zich in het oosten van het land hadden geconcentreerd. Er was onrust onder de Amerikaanse bevolking ontstaan omdat zij van mening waren dat nutsbedrijven niet landelijk maar lokaal moesten worden geleid ${ }^{35}$. Op grond van de in 1935 in werking getreden Public Utility Holding Company Act moesten openbare nutsbedrijven die buiten de staat van vestiging opereerden en die door middel van hun dochtermaatschappijen te maken kregen met elektriciteits-, nutsbedrijven of met de distributie van gas, zich bij de SEC registreren en zich houden

33. Pointer, L.G. en Schroeder, R.G., An introduction to the Securities and Exchange Commission, a.w, p. 32 .

34 Ratner, D.L., Securities Regulation in a nutshell, St. Paul Minnesota: West Publishing Co., 1982, p. 11.

35 Pointer, L.G. en Schroeder, R.G., An introduction to the Securities and Exchange Commission, a.w. p. 34. 
aan diens regulering ${ }^{36}$. Dit hield in dat de bedrijven die een belang van minimaal 10 procent van de aandelen in hun bezit hadden, verplicht werden dit te melden bij de SEC. De Public Utility Holding Company Act uit 1935 heeft er onder meer voor gezorgd dat de structuren van de nutsbedrijven doorzichtiger werden ${ }^{37}$.

\section{Ad 4. De Trust Indenture Act uit 1939}

$\mathrm{Na}$ drie wetten op het gebied van de effectenwetgeving, voerde het Congres in 1939 de Trust Indenture Act in. Deze wet richt zich op "trust indentures" of op "vermogens-beheersovereenkomsten" met een verzekerde uitkering boven de \$1 miljoen ${ }^{38}$. De aanleiding voor deze wet was dat het Amerikaans Congres ontdekte dat vele beheersovereenkomsten zelden de gewenste bescherming boden aan de aandeelhouders ${ }^{39}$. Om te voorkomen dat beleggers de dupe zouden worden van malafide vermogensbeheerders, stelde het Congres in deze wet eisen aan bepalingen die in dergelijke overeenkomsten moeten voorkomen. In beginsel vallen deze beheersovereenkomsten onder de Securities Act uit 1933 omdat alle effecten die verkocht of gekocht worden, volgens deze wet dienen te worden geregistreerd. De Trust Indenture Act uit 1939 schrijft bepaalde standaardbepalingen voor die de aansprakelijkheid en verantwoordelijkheid van partijen aangeeft. Daarnaast is in deze wet de verplichting opgenomen om beleggersbeschermende bepalingen in de overeenkomst op te nemen ${ }^{40}$.

\section{Ad 5. De Investment Company Act wit 1940}

Met de invoering van de Investment Company Act richtte de federale overheid zich op een specifieke groep: "de beleggingsmaatschappijen". Evenals bij de vorige effectenwetgeving kreeg de SEC ook hier de bevoegdheid om toezicht uit te oefenen. Het gevolg was dat deze maatschappijen verplicht werden om zich te registreren bij de SEC. Dat wil niet zeggen dat zij alleen op grond van deze wet registratieplichtig waren;

36 McCLure e.a., Federal Regulatory Directory, 8th edition, Washington D.C.: 1997 , p. 252 .

3) Ratner, D.L., Securitzes Regulation in a mutshell, Sr. Paul Minnesota: West Publishing Co., 1982, p. 11.

38. Omgerekend zou dat ongeveer 1 miljoen euro's bedragen.

39. Pointer, L.G. en Schroeder, R.G., An introduction to the Securities and Exchange Commisvion, a.us: p. 35.

40 Ratner, D.L., Sectrities Regulation in a nutshell, St. Paul Minnesota: West Publishing Co., 1982, p. 12 . 
de Securities Act uit 1933 en de Securities Exchange Act uit 1934 gaven al een registratieverplichting. De in 1940 ingevoerde Investment Company Act kwam met de verplichting, in tegenstelling tot de wetten uit 1933 en 1934, dat bedrijven wier werkzaamheden betrekking hadden op gemeenschappelijke fondsen, zich moesten laten registreren. Dat waren voornamelijk ondernemers die niet alleen bedrijfsmatig investeerden, herinvesteerden en handelden in effecten, maar die tevens voor hun investeerders effecten in eigen beheer hadden gekocht, aanboden, verkochten en vasthielden. Deze registratie had onder meer tor gevolg dat de betreffende bedrijven verplicht werden om hun financiële situatie en investeringsbeleid te openbaren en dat zij dit niet zonder toestemming van hun aandeelhouders meer mochten wijzigen ${ }^{41}$.

Een belangrijk verschil tussen de Securities Act uit 1933, de Securities Exchange Act uit 1934 en de Investment Company Act, is dat met de inwerkingtreding van laatstgenoemde wet onder meer elke vorm van arbeidsrechtelijke betrokkenheid van iemand, die reeds was veroordeeld voor fraude of iemand die ook maar enigszins daarmee kon worden geassocieerd, bij een beleggingsmaatschappij werd verboden. Daarnaast is in de Investment Company Act het verbod opgenomen om zonder voorafgaande toestemming van de SEC transacties tussen bepalde afdelingen binnen een beleggingsmaatschappij en leidinggevenden, waaronder de directie, uit te voeren. In deze wet zijn niet alleen verboden te vinden, maar ook verplichtingen voor de beleggingsmatschappijen. Zo zijn er in de wet regels te vinden die betrekking hebben op de leiding van de beleggingsmaarschappijen en op her kapitaal van een dergelijke onderneming. Daarnaast heeft de federale overheid in deze wet bepaald dat in geval een beleggingsmaatschappij haar beleid wil veranderen, zij dit eerst aan haar toezichthouder, de SEC, ter goedkeuring moet voorleggen ${ }^{42}$. In 1970 vond er een wijziging plaats van de Investment Company Act uit 1940. Toegevoegd werd de bepaling dat de "beloningen" van leidinggevenden binnen het bedrijf scherp door de SEC zouden worden gecontroleerd ${ }^{43}$.

McCLure e.a., Federal Regulatory Directory,8th edition, Washington D.C.. 1997, p. 252.

42 Pointer, L.G. en Schroeder, R.G., An introduction to the Secwrities and Exchange Conmmission, a.w. p. 35.

43 Ranner, D.L., Securities Regulation in a musshell, St. Paul Minnesota: West Publishing Co., 1982, p. 12 . 


\section{Ad 6. De Investment Advisers Act uit 1940}

De Investment Advisers Act die ook in 1940 in werking trad, is in 1960 gewijzigd. Deze wet ziet vooral toe op de (professionele) beleggingsadviseurs. Op grond van deze wet zijn alle personen die op professioneel gebied beleggingsadviezen verstrekken verplicht om alle benodigde informatie openbaar te maken. Dat wil zeggen dat zij informatie moeten verstrekken die reikt van hun specifieke achtergrond tot aan de wijze waarop hun commissie is samengesteld. In geval de SEC meent dat een beleggingsadviseur in strijd met de wet of aanwijzingen van de SEC handelt, is zij bevoegd om de registratie van deze adviseurs te schorsen of zelfs ongedaan maken.

\section{Ad 7. De Securities Investor Protection Act uit 1970}

Tot slot is er de Securities Investor Protecrion Act uit 1970. Deze wet is in het leven geroepen om ondernemingen/commissionairs die in financiële problemen zijn geraakt, te begeleiden bij een correcte afhandeling van hun schulden. Op deze wijze zullen er uiteindelijk minder gedupeerde beleggers zijn. Om de begeleiding zo goed mogelijk te laten verlopen is er naar aanleiding van deze wet een instantie in het leven geroepen. Deze instantie, genaamd: "The Securities Investor Protection Corporation (SIPC)", is onafhankelijk van de federale overheid. De SIPC, welke bevoegd is om toezicht te houden op voornoemde ondernemingen, bepaalt de wijze waarop de onderneming dan wel commissionair haar of zijn schuld dient te voldoen. Een dergelijke "betalingsregeling' moet het de desbetreffende bedrijven mogelijk maken om hun schulden te sarneren ${ }^{44}$.

In de federale effectenwetten zijn alle eisen, met betrekking tot de registratie, de periodieke rapporten en de aanvragen tor goedkeuring voor bepaalde effectentransacties te vinden ${ }^{45}$. De officiële teksten van de statutes worden door de federale overheid in de United States Statutes at Large op chronologische volgorde gepubliceerd ${ }^{46}$. Om de toegang tot deze wetten te vergemakkelijken, heeft de Amerikaanse overheid besloten om de federale kaderwetten en eventuele wijzigingen daarvan op onderwerp samen te bundelen en te publiceren in de United States Code

44 Ratner, D.L., Securities Regulation in a nutshell, St. Paul Minnesota: West Publishing $\mathrm{Co}_{0,}, 1982$, p. 13.

45 Pointel, L.G. en Schroeder, R.G., An introduction to the Securities and Exchange Commission, aw, p. 36.

th Zie titel 1, section 112 van de United State Code (1 U.S.C. \$122). 
(U.S.C.) ${ }^{47}$. Hierin zijn de belangrijkste federale effectenwetten, te beginnen met de Securities Act uit 1933, te vinden in titel 15, hoofdstukken $2 \mathrm{~A}-2 \mathrm{D}$, paragrafen 77 a tot en met $80 \mathrm{~b}-21^{48}$. De federal statutes bestaan uit verschillende "sections" die te vergelijken zijn met de Nederlandse wetsartikelen. Evenals bij de Nederlandse wetsartikellen het geval is, hebben sommige sections een subverdeling, bijvoorbeeld 1,2 , 3 of $a, b, c$, dan wel i, ii, iii. Volgens de officiële overheidspublicaties dienen de federal statutes te worden geciteerd zoals zij in de United State Code zijn aangegeven. Dat wil zeggen dat bijwoorbeeld section $77 \mathrm{~h}$ uit de Securities Act 1933 (15 U.S.C. $\$ 77$ ) geciteerd moet worden als: 15 U.S.C. $\$ 77 \mathrm{~h}$ en section $77 \mathrm{~h}$-1 als 15 U.S.C. $\$ 77 \mathrm{~h}$ (1). In de praktijk bleek dit systeem nier goed te werken. Dit leidde ertoe dat er binnen de wereld van het effectenverkeer een eigen nummering ontstond. Eenieder die werkzaam is binnen deze wereld hanteert de nummering zoals dat in de wet zelf is aangegeven. Het eerste wetsartikel van de Securities Act, $\$$ $77 \mathrm{a}$, is section 1 geworden; het tweede wetsartikel, $\$ 77 \mathrm{~b}$, section 2 enzovoort. Dat wil zeggen section $77 \mathrm{~h}$ wordt geciteerd als: $\$ 8$ en section $77 \mathrm{~h}-1$ als $\$ 8 \mathrm{~A}$ van de Securities Act. De federale effectenwetten, die niet altijd duidelijk en rechtlijnig zijn, kunnen worden beschouwd als kaderwetten die een nadere invulling behoeven. In geval van de effectenwetgeving geschiedt deze nadere invulling door de SEC, een "federal administrative agency" of een federaal administratief bestuursorgaan dat in aanvulling op de federale kaderwetgeving, de materiële regelgeving creëert. Men spreekt hier van de "federal administrative rules and regulations".

\subsubsection{Externe regelgeving; de witvoeringsregels}

De Amerikaanse effectenwetgeving kent drie soorten SEC regels c.q. SEC rules, welke te beschouwen zijn als aanvullende rechtsbronnen. De officiële teksten van deze SEC rules zijn gepubliceerd in titel 17, hoofdstuk 2, van de Code of Federal Regulations (C.F.R.). De rules zijn ieder afzonderlijk genummerd en voorzien van een titel. ledere kaderwet, zoals de Securiries Act uit 1933 en de Securities Exchange Act uit 1934 begint met een eigen nummering. In casu is dat $\$ 230$ en $\$ 240$ van de C.F.R.

4\% Campbell, D. en Hepperle, W., The U.S. Legal System: a practice handbook, The Hague, Martinus Nijhoff Publishers, 1983 , p. $33-35$. 
Deze rules worden, net als bij de federale wetgeving in de U.S.C het geval is, ook sections genoemd. In de C.F.R. hebben de rules per federale wet weer een andere nummering. De eerste rule behorende bij de Securities Act uit 1933, is genummerd: section 100; het tweede: nummer 101 en zo voort. Rules behorende bij de Securities Exchange Act uit 1934 hebben een andere nummering in de C.F.R. gekregen. Bij deze wet begint de nummering met section 0-1 en het tweede met 0-2. De eerste SEC rule behorende bij de Securities Act uit 1933, rule 100, wordt als volgt geciteerd: 17 C.F.R. $\$ 230.100$. De eerste SEC rule behorende bij de Securities Exchange Act uit 1934, rule 0-1, wordt geciteerd als 17 C.F.R. $\$ 240.0-1$. In tegenstelling tot de kaderwetgeving blijkt deze wijze van citeren well te werken. Bij toekomstig gebruik van een rule zal naast de officiële citeerwijze ook worden aangegeven wan welke wet de rule een uitwerking is. Om een compleet beeld van de Amerikaanse effectenwetgeving te krijgen dient naast de federale statutes, de regelgeving van de SEC ook rekening gehouden te worden met de zelfregulering van de verschillende actoren binnen het effectenverkeer. Alvorens in de volgende paragraaf de zelfregulering te bespreken zal worden gekeken naar de SEC regelgeving; de uitvoeringsregels.

De SEC regelgeving kan worden onderscheiden in "general rules" (de algemene regels) en "regulations" (de regulering). Tot de SEC rules behoren: 1) de procedurele of de technische regels; 2) regels die verschillende rechtsbegrippen nader uitleggen en 3) de uitvoeringsregels. Procedureleof technische regels zijn regels die een bepaalde procedure duidelijk omschrijven of die aangeven wat de minimale vereisten voor bijvoorbeeld een prospectus zijn. Zie als voorbeeld de algemene regel, general rule 135 behorende bij de Securities Act 1933 (17 C.F.R. $\$ 230.135$ (versie 1999)).

\section{General rule 135 Notice of certain proposed offerings}

a. For the purpose anly of section 5 of the Act, at notice given by an issuer that it proposes to make a public offering of securities to be registered under the Act shall not be deemed to offer any securities for sale if such notice states that the offerings will be made only by means of a prospectus and contains no more than the following additional information;

1. The name of the issuer:

2. The title, amount, and basic terms of the securities proposed to be offere, the amoun of the offering, if any, to be made by selding security bolders, the anticipated time of the offering and a brief statement of the manner and purpose of the offering withoul naming the underwiters;

(...) 
6. Notwithstanding the provisions of paragraphs (a) and (b) of this section, whe case of a rights offering of a security listed or subject to unlisted trading privileges on a national securities exchange or quoted on the NASDAQ inter-deater quotation system information with respect to the interest rate, conversion matio and subscription price may be disseminated through the facilities of the exchange, the consolidated transaction reporting system, the NASDAQ system or the Dow Jones broad tape. provided such information is already in a registration statement on file with the Commision.

In de hierboven genoemde rule wordt aangegeven dat de uitgifte van de in $\$ 5$ van de Securities Act 1933 (15 U.S.C. $\$ 77 \mathrm{e}$ ) genoemde effecten ${ }^{49}$ geregistreerd moeten worden. Voorts is in deze rule bepaald dat de geregistreerde effecten niet eerder aangeboden mogen worden dan nadat er een prospectus is uitgegeven. Vervolgens worden verdere inhoudelijke eisen aan de prospectus aangegeven. Zo is vermeld dat onder andere de naam van de emittent, de titel van de emissie en de hoeveelheid uit te geven effecten in een prospectus dienen te worden aangeduid. Een voorbeeld van een technische regel is rule 402 behorende bij regulering C van de Securities Act 1933 (17 C.F.R. $\$ 230.402$ )

\section{Regulation C rule 402 Number of copies; binding signatures}

a. Three copies of the complete registration statement, including exhibits and all other papers and documents filed as a part of the statement, shall be filed with the Commission. Each copy shall be bound, in one or more parts, without stiff covers. The binding shall be made on the side or stitching margin in such manner as to leave the reading matter legible. At least ane such copy of every registration shall be manually signed by the persons specified in section $6($ a) of the Act. Unigned copies shall be conformed.

b. Ten additional copies of the registration statement, similarly bound, shall be furmished for use in the examination of the registration statement public inspection, copying and oiher purposes. Where a registration stawement incorporates into the prospectus documents which are required to be delivered with the prospectus in liew of prospectus presentation, the ten additional copies of the registration statement shall be accompanied by ten copies of sach documents. No ather exhibits are required to accompany such additional copies.

c. Notwithstanding any other pravision of this section, if a regismation statement is filed on Form S-8, three copies of the complete registration statement, including exhibits and all other papers and documents filed as a part of the statement, shall be fled with the Commission. Each copy shall be bound, in one or more parts,

Dit zijn effecten waarmee men voornemens is om interstatelijke handel mee te woeren of via een postorderbedrijf buiten de staat te verkopen. Alvorens dat mogelijk is wereist de Securties Act 1933 dat zulke effecten eerst bij de SEC dienen te worden geregistreerd. Zie Securities Act of 1933, section 5, onder a (15 U.S.C. $77 \mathrm{e}(\mathrm{a}))$ 
without stiff covers. The binding shall be made on the side or stitching margin in such manner as to Leave the reading matter legible. At least owe such copy shall be manwally signed by the persons specified in section 6(a) of the Act. Unsigned copies shall be conformed. Three additional copies of the registration sitatement, similarly bound, also shall be fumished to the Commission for use in the examination of the registration statement, public inspection, copying and other purposes. No exhibits are required to accompany the additional copies of registration statements filed on Form S-8.

d. Notwithstanding any ather prowision of this section, if a registration statement is filed pursuant to Rule $462(b)$ and Rule $110(d)$, one copy of the complete registration statement, including exhibits and all otber papers and documents filed as a part thereof shall be filed with the Commission. Such copy should not be bound and may contain facsimile versions of manual signarures in accordance with paragraph (e) of this section.

e. Signatures. Where the Act or the rules thereunder, including paragraphs (a) and (c) of this section, requite a dacument filed with or furnished to the Commission to be signed, such document shall be manually signed, or signed using either typed signatures or duplicated ar facsimile versions of manual signatures. Where typed. duplicated or facsimile signatures are used, each signatory to the filing shall manually sign a signature page or other document authenticating, acknowledging or otherwise adopting bis or ber signdture that appears in the filing. Such document shall be executed before or at the time the filing is made and shall be retained by the registrant for a period of fue years. Upon reguest, the registrant shall furnish to the Commission or its staff a copy of any or all documents retained pursuant to this section.

Bovenstaande regel omvat alle aanwijzingen hoe de aanvraag voor registratie bij de SEC ingediend moet worden. Zo wordt onder a van deze regel aangegeven dat de registratieaanvraag in drievoud dient te worden ingeleverd voorzien van bewijs- en andere vereiste stukken. Voorts is onder a vermeld dat elk kopie ingebonden moet worden ingeleverd op een dusdanige wijze dat de inhoud te lezen blijft. Een gebonden kopie mag niet voorzien zijn van een harde kaft maar moet wel een handtekening bevatten van een persoon ${ }^{50}$ zoals genoemd in section 6 van de Securities Act 1933. Onder b tot en met e van rule 402 behorende bij regulering $C$ van de Securities Act 1933, (17 C.F.R. $\$ 230.402$ (b-e)), worden overige registratievereisten vermeld en uitgewerkt.

50) In sectie 6 van de Securities Act 1933 worden diverse personen genoemd die de in te dienen kopie moeten "meetekenen". Zo worden genoemd: de emittent, de belangrijkste uitwoerder(s)/verzorger(s) van de emissie, het voltallige bestuur, hoofdaccountant en hoofd financièn. Afhankelijk van het feit of de rechtspersoon uit het buirenland komt of nier, wordt er de handtekening van Amerikaanse vertegenwoordiger gevraagd. 
De tweede groep SEC rules verduidelijkt de kaderwetten door bepaalde in deze wetten voorkomende termen te definiëren. Een voorbeeld hiervan is de hierna te noemen algemene regel, general rule 130 behorende bij de Securities Act 1933 (17 C.F.R. $\$ 230.130$ ) waarin is uitgelegd wat er onder "regels en regulering" moet worden verstaan. Een ander voorbeeld van een definiëringregel is rule 405 behorende bij regulering $C$ van de Securities Act 1933 (17 C.F.R. $\$ 230.405$ ).

\section{Regulation Crule 405 Definition of terms}

Whless the cantext atherwise requires, all tam ased in Rule 400 to Rule 494, inclusive. or in the forms for registration bave the same meanings as in the Act and in the general ruler and regulations.

In addition, the following definitions apply, wniless the context otherwise requires:

(...)

- Commission: The term Commisston means the Securities and Exchange Commission. (...)

- Electronic filing. The term electronic filing means a document wnder the federal securities Laws that is transmitted or delivered to the Commission in electronic format. (...)

- Voting securinie: The tem voting securities means securities the bolders of which are presently entitled to vote for the election of divectors.

- Wholly owned subsidiary. The term wholly owned subsidiay means a subsidiaty substantially all of whose outstanding woting securities are owned by its parent andlor the parent's other wholly owned subsidiaries.

In deze rule treft men bepaalde begrippen aan die nader worden omschreven. Bijvoorbeeld de term "Commissie", volgens bovenstaande rule wordt de SEC met deze term bedoeld. Daarnaast is in de Securities Act 1933 ook de term "elektronisch indienen" te vinden. Deze term komt in verschillende federale effectenwetten terug. Hiermee wordt bedoeld het op elektronische wijze, bijvoorbeeld $\mathrm{E}$-mail, indienen van aanvragen bij de SEC. Voorts treft men onder de vele begrippen ook de term "effecten met stemrechten" aan. Hiermee worden effecten bedoeld waarmee de houders daarvan het recht hebben om mee te stemmen bij de verkiezing van bestuurders. De laatste definitie van bovengenoemde regel is de definitie van een "100\% dochtermaatschappij". Hiermee worden dochtermaatschappijen bedoeld waarvan alle uitstaande stemrechten in handen zijn van de oudermaatschappij of in handen van andere dochtermaatschappijen van dezelfde oudermaatschappij.

Tot slot heeft de delegatie van regelgevende bevoegdheden wan het Congres tot gevolg gehad dat de SEC in haar wetgeving uitvoeringsregels 
heeft verwerkt. Een voorbeeld hiervan is general rule 10b-1 behorende bij de Securities Exchange Act 1934 (17 C.F.R. $\$ 240.10$ b-1):

\begin{abstract}
Rule10b-1 Probibition of use of manipulative or deceptive devices or contrivances with respect to certain securities exempted from registration

The term manipulative or deceptive device or contrizance, as used in section 10(b), is hereby defined to include any act or omission to act with respect to any security exempted from the operation of section $12(a)$ pursuant to any section in this part which specifically provides that this section shall be applicable to such security if such act or omission to act would have been unlawful under section $9(a)$, or any rule or regulation beretofore or hereafter prescribed thereunder, if done or anithed to be done with respect to a security registered on a national securities exchange, and the use of any means or instrumentality of interstate commerce or of the mails or of any facility of any national securities exchange to use or employ any such device or contrituance in connection with the purchase or sale of any such security is bereby probibited.
\end{abstract}

In bovengenoemd artikel definieert de SEC de betekenis van manipulatief of misleidend handelen zoals dat in section 10 van de Securities Exchange Act 1934, (15 U.S.C. $\$ 78 \mathrm{j}$ ) wordt gehanteerd. Daarnaast is in dit artikel onder meer het verbod opgenomen om gebruik te maken van iedere vorm van manipulatief of misleidend handelen door toepassing van list en/of bedrog, dan wel van andere middelen en/of verzinselen, bij de koop of verkoop van effecten.

De hierboven genoemde drie vormen van regelgeving duiden aan dat de SEC grif gebruik heeft gemaakt van de haar op grond van de 7 effectenwetten toekomende regelgevende bevoegdheid. Naast regels heeft de SEC ook algemeen toepasbaar-verklaringen afgelegd en standaardformulieren uitgegeven. Volgens de algemene regell 130 behorende bij de Securities Act 1933 (17 C.F.R. $\$ 230.130$ ) worden deze formulieren naast de effectenwetten (de statutes) ook tot de rechtsbronnen gerekend.

\footnotetext{
Rule 130 Definition of "Rules and Regulations" as used in certain sections of the Act

The term rules and regulations as used in sections $7,10(a),(c)$ and $(d)$ and $19(a)$ of the Act, shall include the forms for registration of secwrities wnder the Act and the related instructions thereto.
}

Zoals reeds is vermeld heeft de SEC regelgeving tot doel om bij te dragen tor vereenvoudiging van de "disclosure". Als voorbeeld kunnen de hiervoor genoemde standaardformulieren aangewend worden. De rechtskracht van deze formulieren is gelijkgesteld aan de voornoemde SEC rules. Hiermee beoogt zij de verschillende beursactoren ertoe te dwingen 
om deze formulieren in te vullen en om zo de openbaarmakingverplichting na te leven. Naast deze regels en standaardformulieren doet de SEC veel aan informele regelgeving. Dat wil zeggen dat zij haar visie over actuele vraagstukken in de vorm van nieuwsbrieven openbaart en verspreidt. Voorts kan de SEC in uitzonderingsgevallen "no-action letters" ofwel een soort gedoogverklaringen afgeven. Zij geeft dergelijke verklaringen af in geval een individu er om verzoekt. Het kan namelijk zo zijin dat deze onzeker is of een bepaalde uit te voeren transactie wel volgens de regels en dus wettelijk geoorloofd is. In dat geval bekijkt een speciale afdeling van de SEC alle voorwaarden waaronder deze transactie zal worden uitgevoerd en besluit dan om deze wel of niet toe te staan. Indien zij besluit om te gedogen verklaart zij schriftelijk aan de aanvrager dat zij het bestuur van de SEC zal adviseren om geen actie te ondernemen indien deze alsnog tot actie zou willen overgaan. De voorwaarde is well dat de transactie op dezelfde wijze wordt uitgevoerd als bij de aanvraag is aangegeven ${ }^{51}$.

Uit bovenstaande kan worden geconcludeerd dat de SEC regelgeving neerkomt op:

a) de hiervoor genoemde "rules", algemeen toepasbaar verklaringen, standaardformulieren;

b) nieuwsberichten en

c) "no-action" brieven of gedoogverklaringen.

In figuur 3.3 volgt een overzicht van de rechtsbronnen van het Amerikaans effectenrecht. 


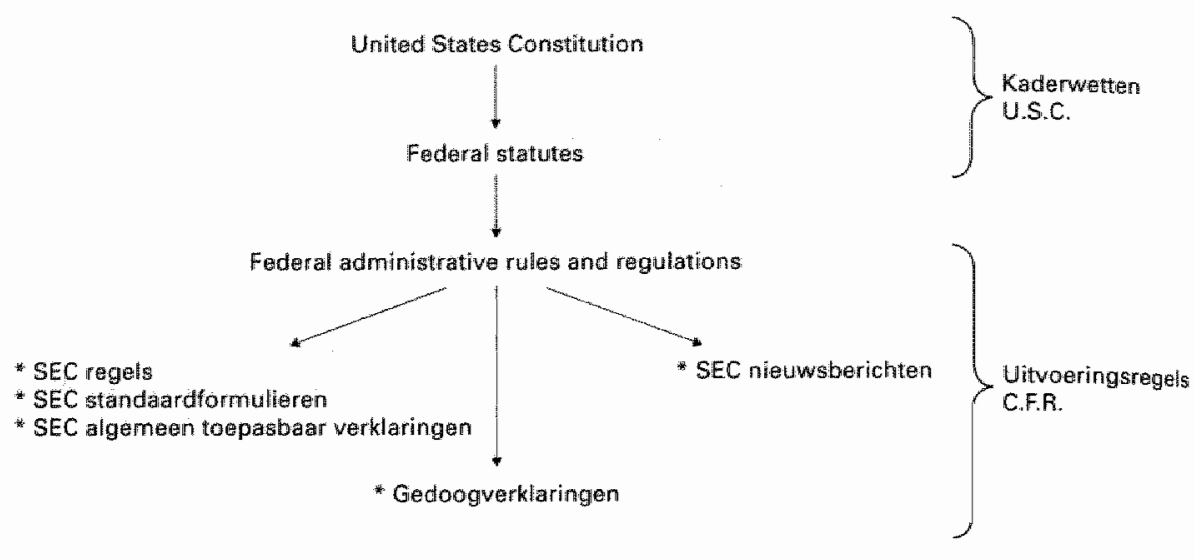

HGUUR 3.3 De rechobrontwen

\subsubsection{Interne regelgeving; zelfregulering}

Zoals reeds is aangegeven speelt de zelfregulering ook een belangrijke rol binnen de Amerikaanse regelgeving. De zelfregulering gebeurt door verschillende organisaties die door het Congres hiertoe bevoegd zijn gemaakt tot het creëren van effectentypische regelgeving.

Volgens section 3 onder punt 26 van de Securities Exchange Act 1934 (15 U.S.C. $\$ 78 \mathrm{c}(26)$ ), worden tot de zelfregulerende organisaties (Zro) gerekend:

\section{Section 3 Definitions and application}

26) The term "self-regulatory organization" means any national securities exchange, registered securities association, or registered clearing agency, or (solely for purposes of sections $78 s(b), 78 s(c)$ and $78 w(b)$ of this title) the Municipal Securities Rulemaking Board established by section $780-4$ of this title.

Hieruit kan worden afgeleid dat de voornoemde Zro's, die vervolgens zullen worden besproken, zijn:

A. de verschillende nationale effectenbeurzen ${ }^{52}$;

B. de geregistreerde nationale effectenorganisaties ${ }^{53}$;

3. Dit is een nationale zelf regulerende organisatie van effectenhandelaren. 
C. de geregistreerde clearingorganisatie ${ }^{54}$; en
D. de Municipal Securities Rulemaking Board (MSRB) ${ }^{55}$.

Deze organisaties zijn volgens section 19 sub a onder 1 van de Securties Exchange Act 1934,

(15 U.S.C. $\$ 78 \mathrm{~s}(\mathrm{a}-1)$ ), verplicht om zich bij de SEC te laten registreren en zich aan diens regels te houden.

\section{Section 19 Registration, responsibilities, and oversight of self-regulatory organizations}

(a) Registration procedures; notice of filing; other regulatory agencies

(1) The Commission shall, upon the filing of an application for registration as a national securities exchange, registered securities association, or registered clearing agenchs pursuant to section $6,15 A$ or $17 A$ of this title, respectively, publish notice of such filing and afford interested persons an opportunity to swomit written data, wiews, and arguments concerning such application. Within ninety days of the date of publication of such notice (or within such longer period as to which the applicant consents), the Commission shall-

(A) by order grant such registration, or

(B) institute proceedings to determine whether registration should be denied.

Such procedings shall include notice of the grownds for denial under considevation and opportunity for bearing and shall be concluded within one bundred eighty days of the date of a publication of notice of the filing of the application for registration. At the conclusion of such proceedings the Commission, by order, shall grant or deny such registration. The Commission may extend we time for conchusion of such proceedings for up to ninety days if it finds good cause for such extensiow and publishes its reasons for so finding or for such longer period as to which whe applicant consents. The Commission shall grant such registration if it finds that we requirevents of this chapter and the rules and regulations thereunder with respect to the applicant are sarisfied. The Comamission shall deny such registation if it does not make such finding.

Naast de plicht om zich bij de SEC te laten registreren, heeft de federale wetgever de zelfregulerende organisaties ook de bevoegdheid gegeven om leden te schorsen, lidmaatschappen te beëindigen, boetes en/of andere

Hiermee worden organisaties bedoed die berekenen welke bedragen de beursactoren, koper of verkoper, elkaar verschuldigd zijn voor de aan-of verkoop van effecten. Een clearingorganisatie houdt zich alleen bezig met de berekening van verschuldigde bedragen. Een clearing en settlement organisatie gaat verder en verzorgt ook de settlement. Dit houdt in dat een dergelijke organisatie de transacties woltooit en er voor zorgt dar de verkoper de effecten overdraagt an de koper en de koper het verschuldigde bedrag aan de verkoper overmaakt.

Dit is een zelfregulerende organisatie waarin plaatselijke effectenhandelaren zijn verenigd. 
disciplinaire straffen op te leggen. Deze bevoegdheden zijn terug te vinden in onder andere section 23 sub a onder punt 1 (15 U.S.C. $\$ 78 \mathrm{w}(\mathrm{a}-1))^{56}$.

\section{Section 23 Rules, regulations, and orders; annual reports}

(a) Pouver to make rules and regulations; considerations; public disclosure

(1) The Commission, the Board of Governors of the Federal Reserve System, and the other agencies enumerated in section 3(a) (34) of this title shall each have power to make such rules and regulations as may be necessary or appropriate to implement the provisions of this chapter for which they are responsible or for the execution of the functions vested in them by this chapter, and may for such purposes classify persons, securities, transactions, statements, applications, reports, and other matters within their respective jurisdictions, and prescribe greater, lesser, or different requirements for different classes thereof. No provision of this chapter imposing any liability shall apply to any act done or omitted in good faith in conformity with a rule, regulation, or order of the Commission, the Board of Governors of the Federal Reserve System, other agency enumerated in section 3(a)(34) of this title, or any self-ergulatory organization, notwithstanding that such rule, regulation, or order may thereafter be amended or vescinded or determined by judicial or other authority to be invalid for any reason.

Indien de Zro besluit om een van haar leden aan een disciplinaire procedure te onderwerpen, dient zij de desbetreffende persoon volgens de wet hieromtrent te informeren en aan te geven op welke gronden zij de disciplinaire sanctie wilt toepassen ${ }^{57}$. Daarnaast dient de Zro ook de toezichthouder, de SEC, hierover in te lichten. Laatst genoemde kan, indien nodig, de opgellegde sanctie bevestigen of aanpassen dan wel de zaak terugverwijzen naar de Zro voor herziening ${ }^{58}$. Indien de SEC de sanctie bevestigt, wordt dit een definitieve SEC beslissing, een final order, die vatbaar is voor beroep bij de U.S.A. Court of Appeals ${ }^{59}$.

\section{De verschillende nationale effectenbeurzen}

Voordat de SEC in het leven werd geroepen, reguleerden de Amerikaanse effectenbeurzen zichzelf door middel van regels die zij hun leden

Vgl. 15 U.S.C. $\$ 78 \mathrm{f}(\mathrm{b})(6)$ en (d)(1);780-3 (b)(7) en $78 \mathrm{~s}$ (g)(1) ook wel genoemd de sections $6(b)(6)$ en $(d)(1) ; 15 A(b)(7)$ en $(h)(2)$ en tot slot section $19(g)(1)$ van de Securities Exchange Act'34 of 15 U.S.C. $\$ 78 \mathrm{~s}$ (g)(1) (versie 1999).

Voor effectenbeurzen is dit geregeld in section 6 (d) ((2) van de Securities Exchange Act'34 of 15 U.S.C.

$\$ 78 \mathbb{E}(\mathrm{d})(2)$ en woor de NASD is dit te vinden in section $15 \mathrm{~A}(\mathrm{~h})$ Oftewel 15 U.S.C. $\$ 780-3$ (h) (versie 1999).

58 Vgl. section 19(d) e.v. Oftewel 15 U.S.C. $\$ 78 \mathrm{~s} 9$ (d) e.v. in het bijzonder onder sub (e)(1)(A) (versie 1999).

59 Zie section 25 wan de Securities Exchange Act'34 oftewel 15 U.S.C. $\$ 78$ y (versie 1999). 
oplegden. Een van de belangrijkste effectenbeurzen is de New York Stock Exchange (NYSE). Na 140 jaar van pure zelfregulering stelde het Congres de SEC in ${ }^{60}$. De pure vorm van zelfregulering verdween. Hiervoor in de plaats bleven de acht effectenbeurzen ${ }^{61}$ bevoegd om regels voor hun leden op te stellen en te handhaven, maar deze moesten dan wel in overeenstemming met de regels van de SEC zijn. In de Securities Exchange Act 1934 werd in section 5, (15 U.S.C. $\$ 78$ e), opgenomen dat beurzen pas na registratie bij de SEC als effectenbeurzen mochten fungeren. Door deze, hiervoor reeds genoemde, registratieverplichting moesten alle nationale beurzen in Amerika een registratieaanvraag bij de SEC indienen.

\section{Section 5 Transactions on unregistered exchanges.}

It shall be wnlauful for any broker, dealer, or exchange, directly or indirectly, to make use of the mails or any means or instrumentality of interstate commence for the purpose of using any facility of an exchange within or subject to the jurisdiction of the United States to effect any transaction in a security, or to report any such transaction, anless such exchange

(I) is registered as national securitios exchange under section 78 f of this title, or

(2) is exempted from such registration upan application by the exchange because, in the opinion of the Commission, by reason of the limited volume of transactions effected on such exchange, it is not practicable and not necessary or appropriate in the public interest or for the protection of investors to require such registration.

In Section 6 onder a tot en met f, (15 U.S.C. $\$ 78 f(a-f))$, van bovengenoemde wet heeft het Congres de registratie-eisen nader uitgewerkt.

\section{Section 6 National securities exchanges}

(a) Registration; application

An exchange may be registered as a national secution exchange wnder the terms and conditions bereinafter provided in wis section and in accordance with the prowisions of section 78s(a) of this title by filing with the Commission an application for registration in such form as the Conmission, by rule, way prescribe containing the rules of the exchange and such other information and dowments as the Commission, by rule, may prescribe as necessary or appropriate in the public interest or for the protection of investors.

Ratner, D.L., Securtites Regulation in a wutshell, St. Paul Minnesota: West Publishing Co., 1982, p. 195.

"1 De American Stock Exchange in New York; de New York Stock Exchange; de Boston Stock Exchange; de Chicago Board Options Exchange; de Chicago Stock Exchange; de Cincinnati Stock Exchange in Chicago; de Philadelphia Stock Exchange in Washington en de Pacific Exchange in San Francisco. Voorts is er ook een stockmarket of een effectenmarkt, namelijk de Nasdaq Stock Market. 
Onder b de punten 1 tot en met 9d, (15 U.S.C. $\$ 78 f(b)(1-9 d)$ ), van voornoemde section zijn de voorwaarden voor registratie opgenomen. Deze voorwaarden variëren van de beursorganisatie tot het in de reglementen moeten verwerken van regels die frauduleus gedrag en manipulatief handelen afkeuren. In section 6 onder b punt 1 , (15 U.S.C. $\$ 78 f$ (b)(1)), is de eis neergelegd dat een effectenbeurs op een zodanige wijze georganiseerd dient te zijn dat zij, haar leden en de personen verbonden aan deze leden, in staat moeten zijn om alle doelen, zoals zijn neergelegd in titel 15 van de United States Code, te verwezenlijken.

(b)1 Such exchange is so organized and has the capacity to be able to carry out the purposes of this chapter and to comply and (subject to any rule or order of the Conmission pursuant to section $78 q(d)$ or $78 s(g)(2)$ of this title, to enforce compliance by its members and persons assaciated with its members, with the prowisions of this chapter, the rules and regulations thereunder, and the rules of the exchange.

Naast regels die frauduleus handelen veroordelen, dienen effectenbeurzen in hun regels ook aan te geven dat zij rechtvaardigheid en billijkheid hoog in het vaandel hebben staan. Deze voorwaarden zijn te vinden in section 6 onder b punt 5,15 U.S.C. $\$ 78 f(b)(5)$.

(b) 5 The rules of the exchange are designed to prevent fraudulent and monipulative acts and practices to promote just and equitable principles of trade, to forter cooperation and coordination with persons engaged in regulating, clearing, setting, processing information with respect to ${ }_{x}$ and facilitating thansacrions in securities, to remove impediments to and perfect the mechanism of a free and open market and a national market system, and, in general, to protect investors and the public interest; and ape not designed to permit unfair discrimination between customers, issuers, brokers, or dealers, or to regulate by virtue of any authority conferred by this chapter matters not related to the purposes of this chapter or the administration of the exchange.

De registratievoorwaarden hebben tot gevolg gehad dat de nationale effectenbeurzen een scala aan regels hebben opgesteld waar hun leden zich aan moeten houden. Deze beursregels, kunnen worden onderverdeeld in twee soorten. Allereerst zijn er de regels betreffende de effectentransacties of de "beurshandel" en vervolgens zijn er regels betreffende de interne organisatie van de leden en de wijze warop zij met hun cliënten dienen om te gaan ${ }^{62}$. De regels die gericht zijn op de "beurs- 
handel" bevatten onder meer criteria voor alles aangaande de beursnoteringen. Met andere woorden: deze beursregels geven aan wanneer een.fonds aan de effectenbeurs kan worden genoreerd; wanneer een fonds uit de notering kan worden geschrapt; hoe de clearing van effectentransacties dient te geschieden en tot slot geven de beursregels aan, aan welke eisen het beursbestuur zich dient te houden. De regels die gericht zijn op de interne organisatie van de beursleden en die ook gericht zijn op de wijze waarop deze leden met hun cliënten moeten omgaan, geven duidelijk aan aan welke eisen het personeel van een beurslid moet voldoen. Daarnaast geven laatstgenoemde regels aan hoe er met de rekeningen van de cliënten moet worden omgegaan. Tot slot heeft het Congres ook regels opgesteld waar expliciet in naar voren is gekomen dat alle zelfregulerende organisaties, waaronder de acht effectenbeurzen, zich naast de eigen regels ook aan de regelgeving van de SEC zullen moeten houden. Een voorbeeld hiervan is te vinden in section 19 punt 1 onder b van de Securities Exchange Act ' $34^{63}$. In deze section, die naar aanleiding van een wetswijziging in 1975 is ingevoerd ${ }^{64}$, is onder meer te winden dat wanneer de effectenbeurzen besluiten om hun regels te wijzigen, zij eerst de SEC hiervan op de hoogte moeten stellen voordat ze daadwerkelijk tot enige vorm van wijziging over kunnen en mogen gaan.

\section{Section 19 (b) Proposed rule changes; notice; proceedings}

(1) Each self-regulatory organization shall file with the Commisston, in accordance with such rules as the Commission may prescribe, copies of any proposed rule or any proposed change in, addition to, or deletion from the rules of such self-regulatory organization (hereinafter in this subsection collectively referred to as a "proposed rule change") accompanied by a concise general statement of the basis and purpose of such proposed rule change. The Commission shall, upon the fling of any proposed rule change, publish notice thereof together with the terms of substance of the proposed rule change or a description of the subjects and issues involved. The Commission shall give interested persons an opportunity to submit written data, wews, and arguments concerning such proposed rule change. No proposed rule change shall take effect wnless approved by the Commission or otherwise permitted in accordance with the provisions of this subsection.

${ }^{64}$ Dit wetsartikel is op 4 juni 1975 ingewoerd als gewolg van de Securities Acts Amendments of 1975. Met de invoering van de Securities Acts Amendments of 1975 zijn de bevoegdheden van de SEC verruimd. Meer hierover onder: Ad B. de geregistreerde nationale effectenorganisaties. 
Dat het bovenstaande tevens voor de effectenbeurzen geldt is, zoals hieronder blijkt, nog eens expliciet opgenomen onder A van punt 1, van $g$ behorende bij section 19 van de Securities Act ' $33^{65}$.

\section{Section 19 (g) Compliance with rules and regulations}

(1) Every self-regulatory organization shall comply with the provisions of this chapter, the rules and regulations thereunder, and its own rules, and (subject to the prowisions of section $78 q(d)$ of this title, paragraph (2) of this subsection, and the rules thereunder) absent reasonable justification or excuse enforce compliance

(A) in the case of a national securities exchange, with such provistons by its members and persons associated with its members;

(B) in the case of a registered securities association, with such provisions and the prowsions of the rules of the Municipal Securities Rulemaking Board by its members and persons associated with its members; and

(C) in the case of a registered clearing agency with its own mules by its participants.

Zo zijn er in section 19 van bovengenoemde wet nog meerdere gronden voor de zelfregulerende organisaties te vinden waarvoor toestemming van de SEC is vereist. Een voorbeeld hiervan is het eerder genoemde vereiste dat de effectenbeurzen ${ }^{66}$ de SEC moeten inlichten wanneer zij aan een van haar leden een disciplinaire straf oplegt ${ }^{67}$ of wanneer zij heeft besloten om een lid voor een bepaalde periode te schorsen ${ }^{68}$. Daarnaast heeft de invoering van voornoemde section 19 ertoe geleid dat de vaste commissieprijzen die de effectenbeurzen hanteerden, werden afgeschaft om zodoende de marktwerking meer tot haar recht te laten komen $^{69}$.

\section{De geregistreerde nationale effectenorganisaties}

Aangezien er ook sprake was van een ongereguleerde effectenhandel die buiten de beurzen om geschiedde, de "over-the-counter handel" (OTC), bepaalde het Congres in 1938 met de invoering van de Maloney $\mathrm{Act}^{70}$ dat ook de georganiseerde nationale OTC-handelaren onder het toezicht

15 U.S.C. $\$ 78 \mathrm{~s}(\mathrm{~g})(1)$ versie 1999 .

En alle andere zelfregulerende organisaties.

Section 19 onder d en e van de Securities Exchange Acr 1934 (15 U.S.C. 78s (d-e).

Section 19 onder h van de Securities Exchange Acr 1934 (15 U.S.C. $\$ 78$ s (h). McClure e.a., Federal Regulatory Directory, 8th edition, Washington D.C.: 1997, p. $255-256$.

Genoemd naar senator Francis T. Maloney uit Connecticut die het wetswoorstel heeft ingediend. Op 25 juni 1938 ging deze wet in kracht van gewijsde. Uit: Homepage NASD: http:/www.nasd.com/pr_section 1.html. 
van de SEC moesten komen ${ }^{71}$. De Maloney Act werd door middel van een wetswijzing verwerkt in section 15a van de Securities Exchange Act 1934 (15 U.S.C. $\$ 780-3$ ). De georganiseerde OTC-handelaren moesten zich vanaf nu niet alleen aan hun eigen regels houden, maar ook aan de door de SEC opgestelde regelgeving. Het Congres heeft in section 15a, (15 U.S.C. $\$ 780-3$ (a)), vermeld dat deze georganiseerde handelaren zich mochten registreren als "nationale organisatie van effectenhandelaren" als een "national securities association".

\section{Section 15a Registered securities associations}

(a) Registration; application

An association of brokers and dealers may be registered as a national securities association pursuant to subsection (b) of thrs section, or as an affliated securities association pursuant to subsection (d) of this section, under the terms and conditions bereinafter provided in this section and in accordance with the provisions of section 78 (a) of this title, by filing with the Commission an application for registration in such form as the Commission, by rule, may prescribe containing the rules of the association and such other information and documents as the Commission, by rule, may prescribe as necessary or appropriate in the public interest or for the protection of investors.

Hierboven is aangegeven dat registratie van een organisatie van effectenhandelaren of -russenpersonen mogelijk is, mits aan bepaalde voorwaarden wordt voldaan. Om te weten welke voorwaarden dat zijn, wordt er onder meer verwezen naar punt $b$ en $d$ van dezelfde section. Onder punt $b$ van deze section, (15 U.S.C. $\$ 780-3$ (b)) zijn alle voorwaarden vermeld waaraan een organisatie van effectenhandelaren moet voldoen alvorens zij tot een nationale organisatie van effectenhandelaren mag worden gerekend ${ }^{72}$. Hieronder zullen enkele voorwarden worden uitgewerkt.

(b) Determinations by Cammission requisite to registration of applicant as national securities association

An association of brokers and dealers shall not be registered as a national securities association waless the Commission deternines that-

Ratnen, D.L., Securities Regulation in a nutshell, St. Paul Minnesota: West Publishing Co., 1982, p. 197.

72 In punt d wan section 15a van de Securities Exchange Act 1934, (15 U.S.C. $\$$ $780-3(d)$ ), is bepaald dat dependances van een organisatie van effectenhandelaren of effectenintermediairs pas als zodanig mogen worden geregistreerd wanneer de SEC van mening is dat zij, evenals de organisatie waar zij een dependance van zijn, ook aan alle in de wet gestelde voorwaarden voldoet. 
(2) Such assaciation is so organized and bas the capacity to be able to carry out the purposes of this chapter and to comply, and (subject to any rule or order of the Commission pursuant to section $78 \mathrm{~g}(\mathrm{~d})$ or $78 \mathrm{~s}(\mathrm{~g})(2)$ of this title) to enforce compliance by its members and persons associated with its members, with the provisions of this chapter, the rules and regulations thereunder, the rules of the Municipal Securities Rulemaking Baard, and the rules of the association.

Aldus dient de SEC duidelijkheid over een aantal zaken te hebben, voordat zij een dergelijke organisatie als nationale organisatie van effectenhandelaren zal registreren. Zo is er onder punt 2 bepaald dat desbetreffende organisatie in staat moet zijn om alle doelstellingen van de effectenwetgeving na te streven en uit te voeren. Daarnaast moet de organisatie zorg dragen woor een goede handhaving van de compliance-afdelingen van haar leden. Onder punt 6 van voornoemde section, komt een voorwaarde terug die reeds bij de effectenbeurzen is aangetroffen. Het gaat hier om de eis dat de organisatie van effectenhandelaren of -tussenpersonen regels moet hebben opgesteld die fraude en manipulatie door haar leden tracht te voorkomen en rechtvaardigheid en billijkheid voorstaan. Naast deze bekende voorwaarde is in punt 6 van section 15 a van de Securities Exchange Act 1934 de eis opgenomen dat uit de regelgeving van een organisatie van effectenhandelaren onder meer moet blijken dat zij:

- een voorstander is van een vrije en open markt;

- niet alleen het algemeen belang, maar ook de belangen van (particuliere) investeerders zall behartigen;

- geen ongelijkheid tussen de cliënten, de emittent, handelaren en/of tussenpersonen zal accepteren en

- geen toestemming geeft dat haar leden van hun cliënten vastgestelde commissiekoers, toelagen, kortingen of andere vormen van geldelijke beloningen zullen vragen.

(6) The rules of the association are destgned to prevent fraudulent and manipulative acts and pracices, to promote just and equitable principles of trade, to foster cooperation and coordination with persons engaged in wegulating, dearing, setting, processing information with respect to, and facilitating transactions in securities, to rewowe impediments to and perfect the mechanism of a free and open market and a national market system, and, in general, to protect investors and the public interest; and are not designed to permit unfair discrimination between customers, issuess, brokers, or dealers, to fix minimum profits, to impose any schedule or fix mes of commissions, allowances, discounts, or other fees to be charged by its members, or to regulate by virtuc of any authority conferred by this chapter matters not related to the purposes of this chapter or the adwinistration of the association. 
Tot op heden is er maar een instantie geweest die zich bij de SEC als nationale organisatie heeft laten registreren, de National Association of Securities Dealers (NASD). Deze organisatie die sinds 7 augustus 1939 bestaat, heeft tot 1971 alleen een regulerende functie gehad. Aan het begin van de jaren zestig, een periode van welvaart, kregen meer (institutionele) beleggers interesse in de reguliere effectenhandel en in de OTC-handel. Het Congres maakte zich zorgen voor de (potentiële) belegger, omdat niet alle OTC-handelaren en -tussenpersonen onder enige vorm van regulering vielen. Immers, niet alle OTC-handelaren hadden zich bij de NASD aangesloten. Om de beleggers te beschermen en onregelmatigheden te voorkomen, besloot het Congres dat deze groep handelaren zich of bij de NASD moest aansluiten of onder toezicht van de SEC moest komen te staan. Met de inwerkingtreding van de Securities Acts Amendments uit 1964 koos het Congres voor laatstgenoemde keuze. OTC-handelaren die zich niet bij de NASD hadden aangesloten, moesten zich aan de regelgeving van de SEC houden ${ }^{73}$. Dat hield in dat deze handelaren en intermediairs moesten voldoen aan de door de SEC gestelde voorwaarden met betrekking tot het te voeren bestuur van deze groep handelaren en de vereiste ervaring en opleiding van het personeel ${ }^{74}$. Het zou tot 1971 duren voordat de NASD voor een groter publiek bekend werd. In dat jaar introduceerde zij namelijk het elektronisch noteringssysteem voor de OTC-handel (de NASDAQ). Via dit handelssysteem mochten aangesloten OTC-handelaren en -intermediairs tegen kortingsprijzen handelen ${ }^{75}$. Sinds de invoering van het elektronisch noteringssysteem verzorgde de NASD niet alleen de regulering van OTC-handelaren en intermediairs; van de effecten die over-the-counter werden verhandeld; maar bepaalde zij ook wie toegang tot dit systeem kreeg. De OTChandelaren die niet bij de NASD waren aangesloten kregen wel toestemming om te handelen op het NASDAQ-systeem, maar mochten dit niet tegen de aangeboden kortingsprijzen doen. Deze OTC-handelaren waren verplicht om de standaardprijs te hanteren. Omdat het wettelijk

73 McClure e.a., Federal Regulatory Directory, 8th edition, Washington D.C.: 1997 , P. 255 .

7. Ratner, D.L., Secutities Regulation in a nutshell, St. Paul Minnesota: West Publishing Co., 1982, p. 199 .

75 Ratner, D.L., Securities Regulation in a nutshell, St. Paul Minnesota: West Publishing Co., 1982, p. $198-199$. 
werd vastgelegd dat leden van een geregistreerde organisatie van effectenhandelaren of -intermediairs, in dit geval de NASD-leden, niet met anderen mochten handelen die geen lid waren van dezelfde organisatie, werden de niet-leden verplicht om lid te worden wilden zij ook mee kunnen doen ${ }^{76}$. Aangezien de meeste of althans de belangrijke OTC-fondsen door de NASD-leden werden verhandeld, groeide het ledenbestand van deze organisatie dan ook danig. Desondanks bleef er een groep ongereguleerde OTC-handelaren over die besloten had zich niet bij de NASD aan te sluiten. Het Congres vond dat verdergaande regulering voor deze groep gewenst was en besloot daarnaar te handelen. Op 4 juni 1975 ondertekende de Amerikaanse president de Securities Acts Amendments van 1975. De Securities Act Amendments van 1975 waren een aanvulling op de reeds bestaande Securities Exchange Acr van $1934^{77}$. Het gevolg van deze wetswijziging was dat het Congres de bevoegdheden van de SEC verruimde door section 19 (15 U.S.C. $\$ 78$ ) in te voegen. Sindsdien oefende de SEC toezicht uit over alle zelfregulerende organisaties waar de niet-aangesloten OTC-handelaren en intermediairs ook toe behoorden ${ }^{78}$.

\section{De geregistreerde clearingorganisatie ${ }^{79}$}

Een volgende zelfregulerende organisatie is de geregistreerde clearingorganisatie. Een dergelijke organisatie zorgt niet alleen voor de berekening van het verschuldigde bedrag, maar zorgt er ook voor dat de koper de gekochte effecten in eigendom verkrijgt. Het Amerikaans Congres heefr ingezien dat het noodzakelijk was om de afhandeling van effectentransacties op een juiste en accurate manier te laten verlopen. Zij heeft erkend dat een inefficiënte wijze van clearing hoge kosten voor de beleggers tot gevolg zou hebben. Bovendien was gebleken dat de technologie telkens nieuwe mogelijkheden voor efficiënte clearingprocedures bood. De federale wetgever heeft goed functionerende clearing- en settlementorganisaties voor ogen gehad. Daarom ging hij in zijn wetgeving er toe over om alle clearing-en settlementprocedures samen

Th Dit is bepaald in section 15a, punt e onder 1 van de Securities Exchange Act 1934, (15 U.S.C. $\$ 780-3(\mathrm{e})(1))$.

7 McClure e.a., Federal Regulatory Directory, 8th edition, Washington D.C.: 1997 , p. 266.

7s Ratner, D.L., Securities Regulation in a nutshell, St. Paul Minnesota: West Publishing Co., 1982, p. 199.

79. Hier wordt de clearingorganisatie in ruime zin bedoeld; dat wil zeggen dat zij zowel clearing-als settlementactiviteiten onderneemt. 
te voegen en te onderwerpen aan standaardvoorwaarden. Immers, goede clearing- en settlementprocedures zijn van belang voor een efficiënte voltooiing van effectentransacties. Dit leidde ertoe dat onder a punt 2 van sub $A$, ( 15 U.S.C. $\$ 78 \mathrm{q}-1$ (a) (2)(A)), is vermeld dat de SEC de aangewezene is om de (potentiële) belegger te beschermen door een nationaal systeem op te zetten waardoor de clearing en settlement op een juiste en nauwkeurige wijze kan geschieden.

\section{Section 17 a National system for clearance and settlement of securities transactions}

$a(\ldots)$

(2) (A) The Commission is direcied, therefore, having due regard for the public interest, the protection of investors, the safeguarding of securities and funds, and wainumance of fair competition among brokers and dealers, clearing agencies, and towafer atgents, to use its authority under this chapter.

(i) to facilitate the establishment of a mational system for the prompt and accurate clearance and settlement of transations in securities (other than exempt securities); and

(iii) to facilitate the establishment of linked or coordinated facilities for cleatance and settlement of transactions in securities, securities options, contracts of salc for future delivery and options thereon. and commodity options; in accordance with the fondings and to carry out the objectives set forth in paragraph (I) of this subsection.

In dezelfde wet, section 17a van de Securties Exchange Act 1934, nam het Congres de eis op dat ook de clearingorganisaties bij de SEC geregistreerd dienden te $\mathrm{zijn}^{80}$.

Section 17 a National system for clearance and settlement of securities transactions

(6) Registration of clearing agencies; application; determinations by Commission requisite to registration of applicant as clearing agency; denial of participation; discipline; swmwary proceedings

(1) Except as otherwise provided in this section, it shall be unlawful for any clearing agency, unless registered in accordance with this subsection, directly or indirectly, to make use of the mails or any means or instrumentality of interstate commene to perform the functions of a clearing agency with respect to any security (other than an exempted securtity). (...)

De clearingorganisaties werden verplicht gesteld om een registratieverzoek bij de SEC in te dienen. In geval van een registratieverzoek ging laatstgenoemde niet meteen tot registratie over. Dit was pas het geval nadat 
zij aan de hand van wettelijk gestelde voorwaarden had gekeken of de clearingorganisatie kon worden geregistreerd, en zij tot een positief oordeel was gekomen. Enkele van deze registratievoorwaarden, welke te vinden zijn in section $17 \mathrm{a}$ sub $b_{*}^{81}$ zullen hieronder worden vermeld. Zo is in voornoemde section onder b sub 3 punt e vermeld dat de regels van de clearingorganisaties geen prijsschema's of andere vaste prijzen of vergoedingen voor beursdeelnemers mag opleggen. Daarnaast is in dezelfde sectie onder punt $\mathrm{g}$ vermeld dat een geregistreerde clearingorganisatie bevoegd is om passende disciplinaire straffen op te leggen ${ }^{82}$.

\section{Section 17a National system for clearance and settlement of securities transactions}

b) $3 E$ The rules of the clearing agency do not impose any schedule of prices, ar fix rates or other fees, for services rendered by its participants.

(...)

$G$ The rules of the clearing agency provide that (subject to any rule or order of the Commission pursuant to section $78 q(d)$ or $78 s(g)(2)$ of this title) its participants shall be appropriately disciplined for violation of any provision of the rules of the clearing agency by expulsion, suspension, limitation of activities, functions, and operations, fine, censure, or ary other fitting sanction.

\section{De Municipal Securities Rulemaking Board}

$\mathrm{Na}$ voorafgaande zelfregulerende organisatie te hebben behandeld, resteert nog de laatste; de Municipal Securities Rulemaking Board (MSRB). De MSRB is een raad die de handel in effecten, die door de verschillende staten en lagere overheden worden uirgegeven, reguleert ${ }^{83}$. Deze effecten hoeven niet te worden geregistreerd bij de SEC, dit in tegenstelling tot effecten die door ondernemingen worden uitgegeven. Dat wil niet zeggen dat effecten van staten en lagere overheden niet onder enige vorm van regulering staan; de aankoop en verkoop van deze effecten wordt gereguleerd door de effectenwetgeving.

In section 15b sub b onder 1 van de Securities Exchange Act 1934, (15 U.S.C. $\$ 780-4$ (b) (1)), waarin de samenstelling van de MSRB is aangegeven, is bepaald dat deze raad uit 15 personen bestaat. Van deze personen mogen er vijf niet gelieerd zijn aan een handelaar, intermediair of effectenhandelaar die in gemeentelijke effecten handelt. Hiervan moet

83 Dit is een zelfregulerende organisatie warin plaatselijke effectenhandelaren zijn verenigd. 
er minstens een persoon zijn die beschouwd kan worden als vertegenwoordiger van gemeentelijke effecten. De volgende groep van vijf personen moet verbonden zijn met en vertegenwoordiger zijn van gemeentelijke effectenhandelaren en -tussenpersonen. Niemand uit deze groep mag op enigerlei verbonden zijn met een bank of een afdeling van een bank. De personen die tot de laatste groep van vijf personen behoren, moeten verbonden zijn aan of een vertegenwoordiger zijn van gemeentelijke effectenhandelaren die tevens een bank zijn of met een afdeling van een bank.

\section{Section 156 Municipal securities}

(b) Municipal Securities Rulemaking Board; rules and regulations

(1) Nor Later than one bundred twenty days after Jume 4, 1975, the Comminsion shall establish a Municipal Securities Rulemaking Board (bereinafter in this section referred to as the "Board"), to be composed initially of fifteen members appointed by the Cowmission, which shall perform the duties set forth in this section. The initial members of the Board shall serve as members for a term of two years, and shall consist of

(A) five individuals who are not associated with any broker, dealer, or municipal securtities dealer (other than by reason of being under common control with, or indirectly controlling, any broker or dealer which is not a municipal securivies broker or municipal securities dealer), at least one of whom shall be representative of investors in municipal securities, and at least one of whom shall be representative of issuers of municipal securities (which members are bereinafter refered to as "public representatives");

(B) five individuals who are associated with and representative of municipal securities brokers and municipal securities dealers which are not banks or subsidiaries or departments or divisions of banks (wbich members are hereinafter referred to as "broker-dealer representatiwes"); and

(C) five indwiduals who are associated with and representative of muricipal securities dealers which are banks or subsidiaries or deparments or divisions of banks (which members are hereinafter referred to as "bank representatives"). Prior to the expiration of the terms of office of the initial members of the Board, an election shall be beld under nules adopted by the Board (pursuant to subsection (b) $(2)(B)$ of this section) of the members to succeed stch initial members.

De regulerende bevoegdheid van de MSRB blijkt uit sub a onder 2 van dezelfde section, (15 U.S.C. $\$ 780-4$ (b) (2)).

\section{Section 156 Municipal securities}

(2) The Boand shall propose and adopt rules to effect the purposes of this chapter with respect to transactions in municipal securities effected by brokers, dealers, and municipal securities dealers. Such rules are hereinafter collectively referred to in this chapter as "rules of the Board".) The rules of the Board, as a minimum, shatl: 
Na deze inleidende tekst volgen onder $A$ tot en met $K, 11$ punten waarin de minimumeisen van deze regelgeving zijn opgenomen ${ }^{84}$. Zo is onder $B$ bepaald dat de regelgeving van de raad voor eerlijke procedures voor de verkiezingen wan raadsleden dient te zorgen ${ }^{85}$.

B) establish fair procedures for the nomination and election of members of the Board and assure fair representation in such nominations and elections of municipal securities brokers and municipal securities dealers. (...)

Onder $\mathrm{C}$ is onder meer bepaald dat de MSRB er voor dient te zorgen dat haar regelgeving gericht is op het voorkomen van fraude en manipulatief handelen. ${ }^{86}$

C) be designed to prevent fratudulen and manipulative acts and practices, to promote just and equitable principles of trade, to foster cooperation and coordination with persons engaged in regulating, clearing, settling, processing information with respect to, and facilitating transactions in municipal securities, to remove impediments to and perfect the mechanism of a free and open market in municipal securities, and, in general, to protect investors and the public interest;

Bovenstaande bevoegdheden doen niets af aan die van de SEC. Onder punt 2 van sub b van section 15 , (15 U.S.C. $\$ 780-4$ (b)(3)), is bepaald dat geen regel van de raad de beperking van de bevoegdheden van de SEC mag beogen.

3) Nothing in this section shall be construed to impair or limit the pouser of the Commission whder this chapter.

Uit zowel het formele effectenrecht, de federale kaderwetten, de uitvoeringsregels van de SEC en de bijbehorende zelfregulering is gebleken dat de Amerikaanse effectenwetgeving is gericht op bescherming van de (particuliere) belegger door er veelal voor te zorgen dat deze de effectenmarkt goed kan doorzien en weet waar hij aan begint alvorens hij besluit om effecten aan te schaffen. Om dit te bewerkstelligen is het voor de (particuliere) belegger van belang dat hij toegang heeft of kan krijgen tot de voor hem benodigde informatie. Verder is gebleken dat de SEC niet alleen uitvoeringsregels mag creëren, maar dat zij ook zorg dient te dragen voor een goede handhaving van deze regelgeving. 


\subsection{De rol van de externe toezichthouder: de SEC}

Tijdens de bespreking van zowel de federale kaderwetten als de uitvoeringsregelgeving is de SEC meermalen aangemerkt als de instantie die toezicht houdt op de Amerikaanse effectenmarkt. Na kennis te hebben gemaakt met de relevante effectenregelgeving komt nu de wijze van handhaving van deze regelgeving an de orde. In de eerste subparagraaf, paragraaf 3.4.1, zal een algemeen beeld worden gegeven van de wijze waarop de SEC het toezicht uitoefent. Vervolgens wordt de interne structuur van de SEC in paragraaf 3.4.2 doorgenomen. Het is van belang om te weten hoe de organisatie van de SEC in elkaar steekt en welke afdeling(en) of orga(a)n(en) binnen deze organisatie voor de handhaving van effectenregelgeving verantwoordelijk is of zijn. In paragraaf $3.5 \mathrm{zal}$ specifieker te werk worden gegaan en zal de afdeling of het orgaan van de SEC centraal staan die verantwoordelijk is voor de uitoefening van het toezicht op de effectenregulering.

\subsubsection{Uitoefening van bet toezicht}

De SEC oefent het toezicht op het effectenverkeer indirect uit. Dat wil zeggen dat zij via de verschillende zelfregulerende organisaties en via de verschillende effectenbeurzen toezicht houdt ${ }^{87}$. Hierbij heeft de registratieplicht een belangrijke rol. Zoals eerder is vermeld moet een bedrijf, of een leidinggevende van zo een bedrijf, voordat hij aandelen aan het publiek aanbiedr, zich op grond van de Securities Act uit 1933 bij de SEC laten registreren. In de aanvraag tot registratie dient op een juiste en nauwkeurige wijze de inhoudelijke bedrijfsinformatie en de informatie over de te plaatsen aandelen uiteen te worden gezet. Heel vaak bevatten deze verzoeken ook een beschrijving van de eigendommen en zaken van de geregistreerde onderneming en van de aandelenvoorraden die voor de verkoop zijn bestemd. Voorts kan een dergelijk verzoek ook de verhouding aangeven van de te verkopen aandelen tot andere reeds door hetzelfde bedrijf geplaatste aandelen. Verder kan een verzoek tot registratie ook gegevens bevatten over het management van de onderneming, en een door een onaflankkelijke accountant geverifieerde financiële verklaring. Alhoewel deze informatie onmiddellijk openbaar wordt gemaakt, duurt het toch tor 35 dagen na het indienen van het 
verzoek dat de onderneming met de plaatsing van aandelen kan beginnen; vanaf dit moment is de onderneming een feit ${ }^{88}$.

Vanaf het moment dat een bedrijf een verzoek tot registratie heeft ingediend, bekijkt de afdeling Corporation Finance van de SEC of de ingeschreven verklaring juist en compleet is. Indien dit niet het geval is en het desbetreffende bedrijf weigert om dit te corrigeren, mag de SEC de registratiedatum vervroegen of schorsen. De SEC kan vervolgens een hoorzitting instellen indien is gebleken dat de vermelde feiten opzettelijke misleidend blijken te zijn. Zodra tijdens de hoorzitting bewijs naar voren komt dat het bedrijf doelbewust heeft getracht om het publiek te misleiden, kan de SEC besluiten om alle aandelen van de markt te halen door een stop order te geven. Een dergelijke stop order wordt opgeheven zodra het bedrijf juiste en complete verklaringen aflegt ${ }^{89}$.

De verplichting om geregistreerd te staan alvorens aandelen aan het publiek kunnen worden aangeboden geldt niet alleen voor Amerikaanse, maar ook voor buitenlandse (staats) aandelen die in Amerika ter verkoop zullen worden aangeboden. Op deze registratieplicht zijn enkele uitzonderingen van toepassing. Van de registratievereiste zijn namelijk uitgesloten:

a) Aandelen die binnen een besloten kring waw personen of institutionele beleggers zwllen worden awngeboden en warvan vaststatat dat deze personen toegang kunnen krijgen tot de specifieke informatic die anders door registratie openbaar gemakt. zow worder:

b) Aardelen die alleen angeboden zullen worden aan de inwoners van cen Amerikanse stant wat de witgevende onderneming zich heeft gezeteld;

c) Aandelen wan platiselijke, statelijke, federale of andere overheidsinstanties, dan wel van een liefadigheidsinstelling of wan een bank die onderworpen zijn an de Interstate Connmerce Act;

d) Aandelen die angeboden worden door kleinere bedrijuen met cen onzet tot $\$ 7.5$ milioen ${ }^{90}$.

8s McClure e.a., Federal Regulatory Directary, 8th edition, Washington D.C., 1997, p. 252 .

89 McCLure e.a., Federal Regulatory Directory, 8th edition, Washington D.C.: 1997, p. 252.

90 Dar is ongeveer $€ 7,5$ miljoen. 
e) Aandelen wan "small business invesment companies", van klewe ondernemer andat zij onder de Small Business Investonent Incentive Act van 1980 wallen. De wet tradbs bet woor de kleinere bedrijwen antrekkelijker te maken om andelen te platatsen. Door deze bedrijuen wrij te stellen wan de registratieplicht, bepalde werknemerswoordelen en pensioenafspraken, probeert de wet hata doelstelling te veruezenlijken.

Voornoemde registratieaanvragen van de brokers en effectenhandelaren worden door de Office of Aplications and Report Services in samenwerking met de Division of Market Regulation behandeld. In 1986 heeft het Amerikaans Congres bepaald dat naast bovengenoemde brokers en effectenhandelaren, alle handelaren die handelen in overheidseffecten, zich bij de SEC registreren ${ }^{91}$.

Aldus kan grofweg gesteld worden, dat tot de taken van de SEC behoren: het uitoefenen van toezicht; het behandelen van registratieverzoeken; het controleren van bedrijfsinformatie en de management van een onderneming; maar ook het sanctioneren van bedrijven, brokers en effectenhandelaren.

\subsubsection{De interne structuur van de SEC}

De Amerikaanse toezichthouder, de SEC, is een overheidslichaam dat verantwoordelijk is voor de uitvoering van het toezicht op de federale effectenwetgeving, de kaderwetten. Deze wetgeving beoogt, gelijk de Nederlandse effectenwetgeving, de (particuliere) beleggers te beschermen. Dit komt onder meer tot uiting door te streven naar een eerlijke en doorzichtige effectenmarkt. Om dit streven te verwezenlijken draagt de SEC er zorg voor dat de beleggers over benodigde informatie, betreffende de koop of verkoop van effecten, kunnen beschikken. Zij houdt niet alleen toezicht vanuit haar hoofdkantoor in Washington D.C., maar ook vanuit een van haar elf regionale en districtkantoren. De verschillende kantoren hebben elk de bevoegdheid gekregen om zelfstandig onderzoeken in te stellen naar overtredingen van de effectenwetgeving ${ }^{92}$. De wijze waarop de SEC haar taken uitoefent, is inherent aan haar interne structuur welke er als volgt uitziet. Aan het hoofd van dit overheids-

91 McCLure e.a., Federal Regulatory Directory, 8th edition, Washington D.C.: 1997 , P. 252.

92 Pointer, L.G. en Schroeder, R.G., An introduction to the Securities and Exchange Commission, a.w, p. 17. 
lichaam staan vijf commissarissen, waaruit de president Amerika een als voorzitter aanwijst. De vijf commissarissen, waar overigens niet meer dan drie tot dezelfde politieke partij mogen behoren, kunnen alleen door de Amerikaanse president worden benoemd, na advies en instemming van de Senaat. Deze commissarissen worden niet tegelijkertijd aangesteld. Jaarlijks, op 5 juni, beëindigt de benoeming van een commissaris waarna de president weer een ander voor de periode van vijf jaar kan aanstellen ${ }^{93}$.

Om haar bevoegdheden efficiënt en effectief uit te kunnen voeren heeft de SEC haar wettellijke verantwoordelijkheden en bevoegdheden verdeeld over vijf afdelingen, zie figuur 3.4. Deze afdelingen, te weten: Corporation Finance ${ }^{94}$, Enforcement ${ }^{95}$, Compliance Inspections and Examinations ${ }^{96}$, Marketregulering ${ }^{97}$ en tot slot de afdeling Investment Management ${ }^{98}$. Elke afdeling draagt zorg voor een bepaalde segment van het effectenverkeer. Het kan zijn dat sommige afdelingstaken elkaar overlappen. De afdeling Enforcement, waarvandaan de handhaving van de federale effectenregelgeving wordt geëffectueerd, zal in het kader van dit onderzoek nader worden besproken. Het is immers van belang te weten hoe de federale wetgeving door de SEC wordt nageleefd en hoe zij de handhaving hiervan tracht te bewerkstellingen.

93 Website SEC: http:/www.sec.gov/asec/asecarthtm.

9 Vrij vertaald: de afdeling "Bedrijfsfinanciën". Deze afdeling bekijkt of de bedrijven die onder toezicht van de $S E C$ staan voldoen aan de verplichting om de wettelijk bepaalde informatie openbar te maken.

95 Vanuit deze afdeling geschiedt de handhaving van alle federale effectenwetten. Deze afdeling kan vertaald worden als: "De afdeling Handhaving".

96 Dit bureatu - wij vertald: de afdeling Compliance, Inspecties en Onderzoek - is verantwoordelijk voor het in overeenstemming zijn van de verschillende compliance-afdelingen van de effectenhandelaren, de tussempersonen, de zelfregulerende organisaties, de beleggingsmaatschappijen en adviseurs, de clearingafdelingen. Ook wel "Marktregulering" re noemen. Deze afdeling assisteert de SEC bij het controleren van de nationale effectenmarkten en bepaalde acroren die op grond van de Investment Advisers Act zijn geregistreerd.

98 De afdeling Investment Management reguleert institutionele beleggers, diens adviseurs en heeft de verantwoordelijk voor de uitwoering van 3 bepaalde wetten te weten: de Investment Company Act uir 1940 de Investment advisers act eveneens uit 1940 en de Public Utility Holding Company act uit 1935. Jaarverslag SEC, 1997, p. 50 . 


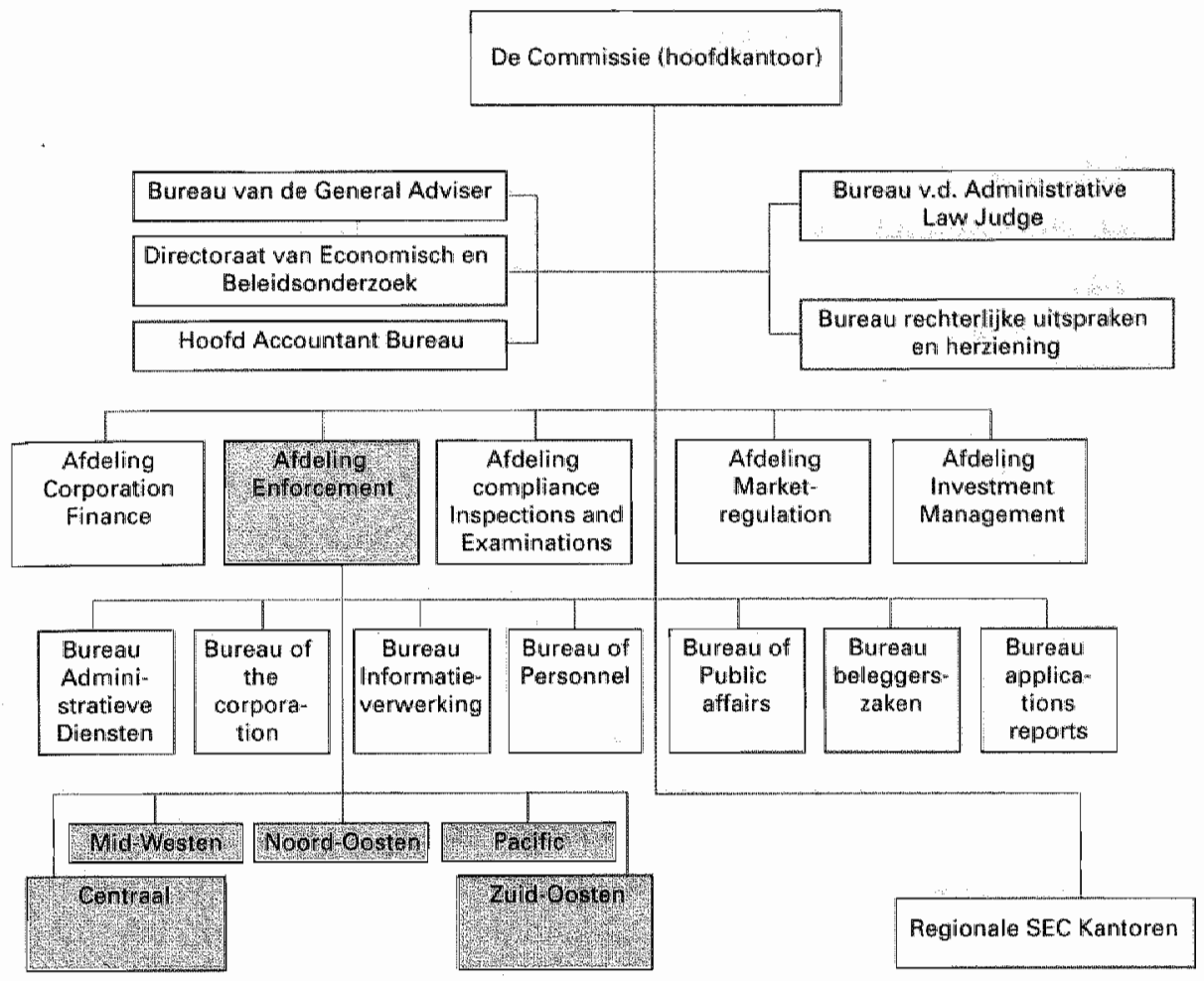

\section{FIGUUR 3.4 Organogram SEC}

Brons. An Introduction to the Securities and Exahange Commission p. 14 en Jaarverslag SEC 1997, p. 209.

\subsection{De afdeling Enforcement}

Voor 1972 werd de handhaving van de federale effectenwetgeving door meerdere afdelingen vanuit het hoofdkwartier van de SEC uitgevoerd. In 1972 is besloten om alle handhavings-werkzaamheden te bundelen en de afdeling Enforcement, vrij vertaald "de afdeling Handhaving", op te richten. Deze afdeling is verantwoordelijk voor de opsporing en het onderzoek van overtredingen van federale effectenwetgeving en -regulering. Zij onderzoekt de financiële rapportages en richt zich op mogelijke malversaties. Om de handhaving zo goed mogelijk te laten geschieden, focust de afdeling Enforcement zich op de belangrijkste actoren binnen het proces van (financiële) openbaarmaking ${ }^{99}$. Tot deze actoren behoren

9. Office of the Chief Accountant U.S. Securities and Exchange Commission, Accounting and Auditing; prepared for international institute for securities market development, Washington D.C., april, 1999, p.19. 
naast de verschillende geregistreerde ondernemingen, diens personeel en de directie, ook de accountants die de rapporten accorderen. Ondanks het feit dat een onderzoek van de afdeling Enforcement kan uitmonden in een strafrechtelijke, administratieve of civielrechtelijke zaak is deze afdeling uiteindelijk alleen bevoegd tot een civielrechtelijke en administratiefrechtelijke handhaving. De strafrechtelijke handhaving geschiedt door de fedlerale U.S. attorney's werkzaam bij het Department of Justice, het Amerikaanse Ministerie van Justitie.

Elk onderzoek dat eindigt in een rechtszaak, heeft verschillende stadia doorlopen. Deze kunnen beginnen bij een inspectie-onderzoek, overgaan in een enforcement-investigation en eindigen met óf een van de hierboven genoemde procedures of met een "settlement"; een schikking. Hieronder zullen deze verschillende stadia en de eventueel hierop volgende procedures worden besproken.

\subsubsection{De drie fases van een SEC onderzoek}

\section{Fase 1: de inspectie}

Een van manieren om een enforcement investigation, een onderzoek van de afdeling enforcement, aan te vangen is door middel van een inspectie door de SEC inspection staff. Deze afdeling kan besluiten om een inspectie te verrichten. Er zijn verschillende redenen die aanleiding kunnen geven tot een inspectie. Deze kunnen zijn: onregelmatigheden in eerder ingediende stukken, jaarverslagen en/of registratieverklaringen; eerder gevoerde procedures tegen de geregistreerde en de hieraan verbonden personen; eerdere inspectierapporten van de geregistreerde; media- of persberichten over de geregistreerde; klachten van beleggers en (anonieme) tips.

De hierboven genoemde aanleidingen kunnen tot gevolg hebben dat de inspection staff besluit om de geregistreerde firma of persoon te verrassen met cen bezoekje, een "surprise" visit. Dit zal veelal het geval zijn wanneer de SEC vreest dat desbetreffende firma of persoon bewijsmateriaal zal laten verdwijnen of zelfs zal vernietigen. Indien de inspection staff een dergelijke tegenwerking niet verwacht, zal zij haar komst aankondigen via een telefoontje naar de desbetreffende firma of via cen brief. In de praktijk blijkt het gebruik van een brief de meest gehanteerde methode, omdat de (geregistreerde) firma's of personen het met de SEC gevoerd telefoongesprek formeel bevestigd willen hebben. De inspection staff 
kan drie verschillende soorten inspecties uitvoeren. Een "routine" inspectie; een "for cause" inspectie en een "surveillance" inspectie. De routine inspectie makt een onderdeel uit van de regelmatige inspectiecylci die door de inspection staff worden uitgevoerd. In een dergelijk geval worden de boeken en stukken van geregistreerde bedrijven en personen steekproefsgewijze onderzocht op onregelmatigheden. Het door de inspection staff gevoerd onderzoek is in dit geval dan niet gericht op een speciaal doel. Bij een "for cause" inspectie is dat anders. In een for cause inspectie vermoedt de inspection staff dat er sprake kan zijn van overtredingen van de federale effectenregelgeving en is haar aandacht ook daarop gericht. Een "for cause" onderzoek zal vaak aanvangen door middel van een verrassingsbezoek. Het kan ook het geval zijn dat de inspection staff meer wil weten over bepaalde praktijken, werkzaamheden, van een specifieke bedrijfstak. Zij zal dan besluiten om een surveillance inspectie te starten. Aangezien het om het beter begrijpen van bepaalde taken en werkzaamheden gaat, heeft de inspection staff niet te vrezen dat er informatie verloren kan gaan. Immers, zij weet niet wat belangrijk is of niet. Een dergelijke inspectie zal zij dan ook door middel van een telefoongesprek dan wel een brief aankondigen.

$\mathrm{Na}$ een bezoek bij de geregistreerde firma of persoon zal de inspection staff haar onderzoek afsluiten door middel van een rapport. Dit rapport wordt opgemaakt door de junior inspection staff en gecontroleerd door de senior inspection staff, waarna het wordt verstuurd naar de afdeling Compliance Inspections and Examinations van de SEC in Washington D.C. De inspection staff noemt dit proces: het review proces. Een rapport van de inspection staff kan verschillende conclusie bevatten. Zo kan de inspection staff concluderen dat er geen wetsovertredingen zijn. Dit zal dan ook ertoe leiden dat de SEC geen verdere actie onderneemt: "no further action". Andere conclusies en gevolgen kunnen zijn: lichte wetsovertredingen, serieuze overtredingen, ernstige overtredingen zonder een verwijzing naar de afdeling Enforcement en tot slot zeer ernstige overtredingen met verwijzing van de zaak naar de afdeling Enforcement. De lichte overtredingen kunnen tot gevolg hebben dat de inspection staff dat ter plekke mondeling laat weten aan de overtreder en verzoekt om de overtreding te herstellen: "an oral notice of deficiencies". Serieuzere overtredingen worden, na afloop van de inspectie, formeel aangekondigd door middel wan een brief van de inspection staff: "a deficiency letter". Ook in dit geval zal aan de overtreder worden verzocht om de overtreding zo spoedig mogelijk te herstellen. A deficiency letter van de inspection 
staff kan ook de formalisering zijn van een eerdere oral notice of deficiencies. Het kan dan zijn dat de inspection staff besluit om tijdens de inspectie niets te zeggen, maar achteraf alsnog besluit om de overtreding door middel van een brief kenbaar te maken. De reden hiervoor kan het door de SEC gevoerd beleid zijn; de SEC heeft dan interne afspraken over de afhandeling van bepaalde overtredingen. Mocht een deficiency letter niet volstaan, kan de inspection staff de overtreder verzoeken om naar het kantoor van de SEC te komen: "an office reprimand". In geval van zeer ernstige overtredingen, die worden doorgestuurd naar de afdeling Enforcement, spreekt de inspection staff over: "a referal to the SEC enforcement staff". Zie figuur 3.5 voor een schematisch overzicht van de inspectie procedure.

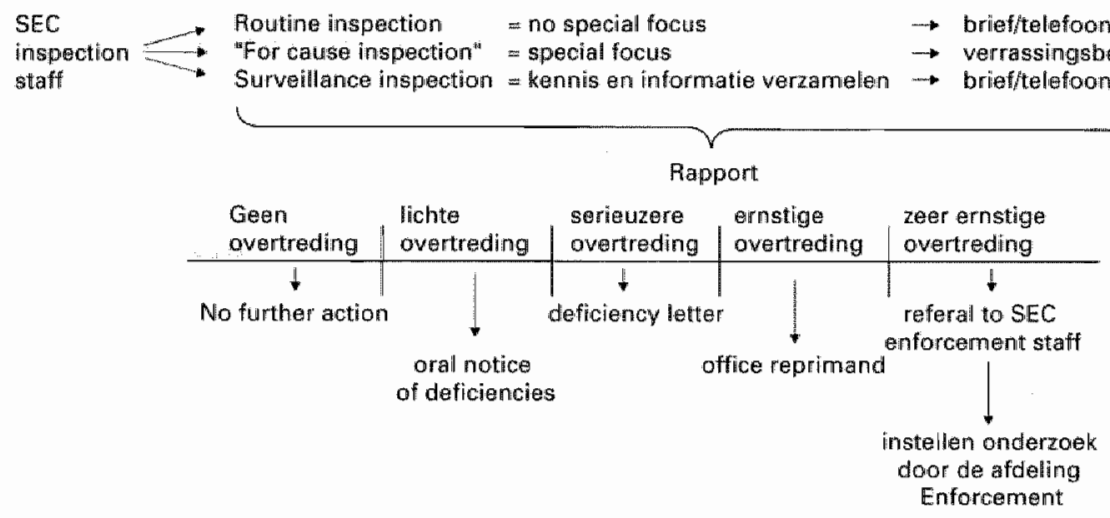

FGUUR 3.5 Fase li een SEC inspectie

Ook "preliminary inquiries", voorbereidende onderzoeken, kunnen aanleiding vormen tot het entameren van een onderzoek door de afdeling Enforcement. Mocht er specifieke informatie ter ore van de SEC staf komen dat een bedrijf of een persoon mogelijk de effectenregelgeving owertreedt, kan zij besluiten om een preliminary inquiry te starten. Dit voorbereidend onderzoek zal uit moeten maken of de berichten enige grond van waarheid bevatten en nader onderzoek door de afdeling Enforcement vereisen. Zodra de SEC staff heeft besloten om een preliminary inquiry te starten, geeft zij de desbetreffende zaak een nummer. Hierdoor is de zaak officieel tot een MUI-zaak, een "matter under inquiry". Een van de redenen om een zaak tor MUI-zaak te benoemen, is gelegen in het feit dat er vanaf dat moment bijgehouden kan worden wie, hoeveel mensen zich met de zaak bezig houden en 
hoeveel uren er totaal in worden gestoken ${ }^{100}$. Mocht blijken dat er inderdaad redenen zijn om een diepgaand onderzoek te verrichten, verwijzen de aan het onderzoek werkzame SEC ambtenaren, na intern beraad, de zaak door naar de afdeling Enforcement.

\section{Fase 2: onderzoek door de afdeling Enforcement}

De aanleiding tot het instellen van een onderzoek door de afdeling Enforcement hoeft niet alleen gelegen te zijn in de conclusies van de inspection staff of in preliminary inquiries. De afdeling Enforcement kan ook besluiten om een onderzoek te openen in geval zij een doorverwijzing krijgt van een van de andere SEC afdelingen. Daarnaast kunnen stafleden van de afdeling enforcement aanleiding vinden tot het openen van rapport in eerder ingediende rapporten en stukken van de betreffende firma en/of persoon. Ook de uitoefening van het toezicht op het effectenverkeer door de afdeling Enforcement kan deze afdeling aanleiding geven om een nader onderzoek in te stellen. Verder kan de afdeling Enforcement na een doorverwijzing van andere overheidsinstanties, zoals het Department of Justice ${ }^{101}$, besluiten om een onderzoek in te stellen. Ook het Congres kan de SEC wijzen op mogelijke overtredingen van de federale wetgeving en haar "stimuleren" om dit nader te onderzoeken ${ }^{102}$. Naast voornoemde redenen, zijn er zowel in titel 15 van de U.S. Code ${ }^{103}$ als in titel 17 van de Code of Regulation meerdere gronden te vinden die aanleiding kunnen geven tot het starten van een onderzoek. Deze reden kunnen ondermeer de klachten van beleggers zijn en/of (anonieme) tips die direct gericht zijn aan de afdeling enforcement, dan wel verhalen uit de media die de aandacht trekken van de juristen op de afdeling Enforcement.

100 Philips, R.M., Reichardt, G.R. en Missal, M.J. en Lipton, R.J., SEC investigation: The Heart of SEC Enforcenent Practice in: Kirkpatrick and Lockhart L.L.P. The Securities Enforcement Mamual: tactes and strategies, The American Bar Association, Chicago, Illinois, 1997, p. 36-37.

101 De Amerikaanse evenknie van het Nederlandse Ministerie van Justitie.

102 Vgl paragraaf 3.1.1. De verdeling van Machten.

103 15 U.S.C. $\$ 77 \mathrm{t}$ (a) of section 20 (a) van de Securities Act "33 (1999); 15 U.S.C. $\$ 77 \mathrm{~h}(\mathrm{e})$ of section 8 (e) van de Securities Act 33 (1999); 15 U.S.C. $\$ 78 \mathrm{u}$ (a) (1) en (2) Oftewel section 21 (a) (1) en (2) wan de Securities Exchange Act 34 (1999); 15 U.S.C. $\$ 80 b-9$ (a) of section 209 (a) van de Investment Advisers Act "40; 15 U.S.C. $\$ 80$ a-41 (a) of section 42 (a) van de Investment Company Act '40 (1999); 15 U.S.C. $\$ 79$ r (a) of section 18 (a) van de Public Utility Holding Company Act'35 (1999) en tot slot 15 U.S.C. $\$ 77 \mathrm{~s}$ (b) of section 321 (a) van de Trust Indenture Act 39 (1999). 


\section{C.F.R. section 202.5 Enforcement activities}

(a) Where, from complaints received from members of the public, communications from Federal or State agencies, examination of fulings made with the Commission, or otherwise, it appears that there may be wiolation of the acts administered by the Commission or the rules or ragulations therewnder, a preliminary investigation is generally made. In such preliminary investigation no process is issued or testimony compelled. The Commission may, in its discretion, make such formal investigations and authorize the use of process as it deems necessary to determine whether any person has violated, is violating, or is about to violate any provision of the Federal securities laws ar the mules of a self-regulatory organization of which the person is a member or participant. Unless otherwise ordered by the Commission, the inwestigation on examination is non-public and the reports thereon are for staff and Commission we only.

Tijdens een onderzoek door de afdeling Enforcement staat de vraag centraal of er sprake is van een belangrijke overtreding van federale effecten regelgeving. Een dergelijk onderzoek zal in beginsel beginnen als een informeel onderzoek, "a preliminary investigation" of "informal investigation" en kan vervolgens overgaan in een formeel onderzoek, "a formal investigation". Het verschil tussen beide onderzoeksvormen is gelegen in de bevoegdheden die aan de onderzoeksstaf zijn toegekend. In een informeel onderzoek hebben de stafleden van de afdeling Enforcement minder bevoegdheden dan in een formeel onderzoek. Zo zijn ze niet bevoegd om de personen die zij ondervragen te verplichten tot het afleggen van verklaringen onder ede; te verschijnen en te getuigen of om boeken en stukken in te zien. Dat wil niet zeggen dat alle verklaringen onder ede in een formeel onderzoek zijn afgelegd. Het kan namelijk ook zijn dat een persoon vrijwillig onder ede besluit te verklaren. Een verklaring onder ede wordt afgenomen door een aanwezige "court reporter ${ }^{105}$ ". In een informeel onderzoek zijn de stafleden van de afdeling Enforcement afhankelijk van de medewerking van de onderzochte subjecten. Mocht het zo zijn dat een informeel onderzoek voldoende informatie heeft opgeleverd, kunnen de stafleden besluiten om: geen enforcement procedure te starten; een administratieve- of een civielrechtelijke enforcement procedure te entameren; bij aanwezigheid van "opzet" de zaak doorverwijzen naar het Ministerie van Justitie met verzoek tot strafvervolging of bij de voltallige Commissie een verzoek indienen tot het voeren van een formele procedure. Wanneer het over-

Een court reporter is iemand die stenografische aantekeningen maakt van alle verklaringen afgelegd tijdens verhoren of processen. 
duidelijk is dat de stafleden niet op enige medewerking hoeven te rekenen en zij nog niet voldoende informatie hebben verzameld om tot een conclusie te kunnen komen, kunnen de stafleden aan het bestuur van de SEC verzoeken om een formeel onderzoek te starten. Zodra de stafleden een dergelijk onderzoek starten, verstrekken zij geen inlichtingen over het verloop van het onderzoek aan de overige partijen of aan derden omdat een formeel onderzoek volgens 17 C.F.R. $\$ 203.5$ niet openbaar is.

\section{Section 203.5 Non-public formal investigative proceedings}

Unless otherwise ordered by the Commission, all formal investigative proceedings shall be non-public.

Volgens het eerder genoemde section 202.5 uit titel 17 van de Code of Federal Regulation, is alleen de "Commission", dat wil zeggen het voltallig bestuur van de SEC, bevoegd om een formeel onderzoek in te stellen en om desgewenst een rechterlijke procedure tegen de vermeende overtreder aanhangig te maken. Pas na het verkrijgen van toestemming om een formeel onderzoek te starten, mogen de stafleden gebruik maken van de extra bevoegdheden die inherent zijn aan een formeel onderzoek.

\section{C.FR section 202.5 Enforcement activities ${ }^{106}$}

(a) The Commission may, in its discretion, make such formal intestigations and authorize the use of process as it deems necessary to determine whether any person has violated, is violating or is about to violate any prowision of the Federal securities Laws or the rules of a self-regulatory organization of which the person is a member or participarat. ...

In de praktijk proberen de advocaten van partijen die onderhevig zijn aan een informeel onderzoek van de SEC, het bij een dergelijk onderzoek te laten. Alhoewel een formeel onderzoek - in tegenstelling tor een informeel onderzoek - niet openbaar is, kan het publiek soms toch te weten komen dat een bepaald bedrijf of commissionair door de SEC wordt onderzocht. Het publiek, dat vaak uit gaat van het adagium: "Waar rook is, is vuur", kan een dergelijke onderneming c.q. commissionair dan voor lange tijd links laten liggen. Hierdoor kan het bedrijf een aanzienlijke schade oplopen, zonder dat bewezen is dat het de effectenwetgeving daadwerkelijk heeft overtreden. Daarnaast zijn bedrijven of derden die met deze bedrijven te maken hebben, er niet altijd op gesteld 
dat de SEC toegang tot belangriijke documenten zal krijgen. Een voorbeeld hiervan zijn de banken waar de subjecten van onderzoek hun rekeningen hebben lopen. Deze banken als derden zijn zonder rechterlijk bevel niet verplicht tot her geven van inzage in hun stukken. Dit kan de SEC aanleiding geven om alsnog een formeel onderzoek te starten.

De eerder genoemde extra bewoegdheden welke in een formele procedure toegepast kunnen worden zijn: verklaringen onder ede; een ruime "subpoena power" ook wel de bevoegdheid om via een rechterlijk bevel getuigen te horen en/of stukken in te zien en tot slot de bevoegdheid om bij de rechter naleving van voornoemde subpoena's af te dwingen. Section 19 van de Securities Act ' 33 geeft aan van welke bevoegdheden de SEC gebruik mag maken in haar onderzoeken.

\begin{abstract}
Securities Act section 19 (b) Special powers of Commission ${ }^{107}$
For the purpose of all inwestigations which, in the opinion of the Commission, are necessary and proper for the enforcement of this subchapter, any member of the Commission or any officer or officers designated by it are empowered to administer aaths and affirmations, subpoena wimesses, take evidence and require the production of any books, papers, or other documents which the Commission deems relevant or material to the inquiry Such atteridance of witnesses and the production of such documentary evidence. may be required from any place in the United States or any Territory at any designated place of beaning.
\end{abstract}

In bovenstaand artikel heeft de Amerikaanse wetgever onder meer bepaald dat alle verklaringen die tijdens een formeel onderzoek worden afgelegd, onder ede dienen te worden afgenomen. Hieronder vallen ook verklaringen van onderzoekssubjecten, afgelegd tijdens telefoongesprekken met juristen, analisten en/of accountants van de afdeling Enforcement. Aan de hand van deze verklaringen kunnen zij nagaan of er voldoende informatie is vergaard on te concluderen. Het kan ook zijn dat de juristen, de analisten of de accountants vinden dat zij meer gegevens nodig hebben. De stafleden van de afdeling Enforcement kunnen dan besluiten om gebruik te maken van de "subpoena power". Er bestaat voor de SEC geen verplichte volgorde om gebruik te maken van haar bevoegdheden. Indien verklaringen onder ede worden afgelegd, is de persoon verplicht om naar waarheid te antwoorden. Mocht de SEC ontdekken dat bepaalde verklaringen in strijd met de waarheid zijn afgelegd, kan zij het openbaar ministerie verzoeken om over te gaan tot vervolging 
op grond van "perjury", meineed. Perjury is strafbaar gesteld op grond van hoofdstuk 79 van het Amerikaans Wetboek van Strafrecht, The Federal Criminal Code ${ }^{108}$.

\section{U.S.C. $\$ 162$ I Perjury generally}

Whoever

(1) having taken an oath before a competent tribunal, officer, or person, in any case in which a law of the United States authorizes an oath to be administered, that be will testify, declare, depose, or certify truly, or that any written testimony declaration, deposition, or certificate by bim subscribed, is true, willfully and contrary to such oath states or subscribes any material matter which be does not believe to be true; or in any declaration, certificate, verification, or statement under penality of peryury as permitted under section 1746 of title $28^{109}$, United States Code, willfully subscribes as true any material matter which be does not believe to be true: is guilty of perjury and shall, except as otherwise expressly provided by law, be fined under this title or imprisoned not more than five years, or both. This section is applicable whether the statement or subscription is made within or without the United States.

De SEC kan in elke rechtbank van de Verenigde Staten van Amerika om de eerder genoemde "subpoena power" verzoeken. Er bestaan twee soorten "subpoena's" procedures:

a. de subpoena duces tecunn procedure, en

b. de subpoena ad testificandum procedure.

Een subpoena duces tecum houdt in dat de getuige documenten en ander materiaal mee moet nemen wanneer deze wordt opgeroepen om te getuigen. Bij een subpoena ad testificandum heeft de getuige alleen de plicht om te verschijnen. Hij of zij is in dit geval niet verplicht om extra stukken mee te nemen. Wanneer de afdeling Enforcement aan de hand van (getuigen)verklaringen, stukken en/of ander materiaal meent

In $\$ 3.4 .5$ zal perjury, bij de bespreking van de strafrechtelijke procedure, uitwoerig worden besproken. soort verklaringen kan meineed worden gepleegd. 
dat het formele onderzoek haar voldoende informatie heeft verschaft, kan zij besluiten om:

1) geen verdere actie te ondernemen en bet onderzaek af te slutten,

2) verder actie ondernemen en een enforcement procedure te starten enlof

3) evenals bij een informeel onderzoek het geval is, bij aanuezigheid van "opzet." de zaak doorverwijzen nat het Ministerie wan Justitie met verzoek tot strafvervolging.

In geval van punt 1 wordt de zaak afgesloten en kunnen de stafleden van de afdeling Enforcement volgens 17 C.F.R. $\$ 202.5$ (d) ${ }^{110}$ de partijen hiervan op de hoogte stellen. In hetzelfde artikel wordt vermeld dat een bericht dat er geen verdere actie zal worden ondernomen, niet inhoudt dat de desbetreffende partij wordt uitgesloten van een eventuele toekomstige SEC enforcement procedure of andere SEC actie.

\section{Section 202.5 Enforcement activities.}

d) In instances where the staff has concluded its investigation of a particular matter and bas determined that it will not recommend the commencement of an enforcement proceeding against a person, the staff, in its discretion, may advise the party that its formal investigation has been terminated. Such aduice if given must in no way be construed as indicating that the party has been exonerated or that no action may wlimately result from the staff's investigation of the particular matter.

Zie figuur 3.6 voor een schematisch overzicht van fase 2.

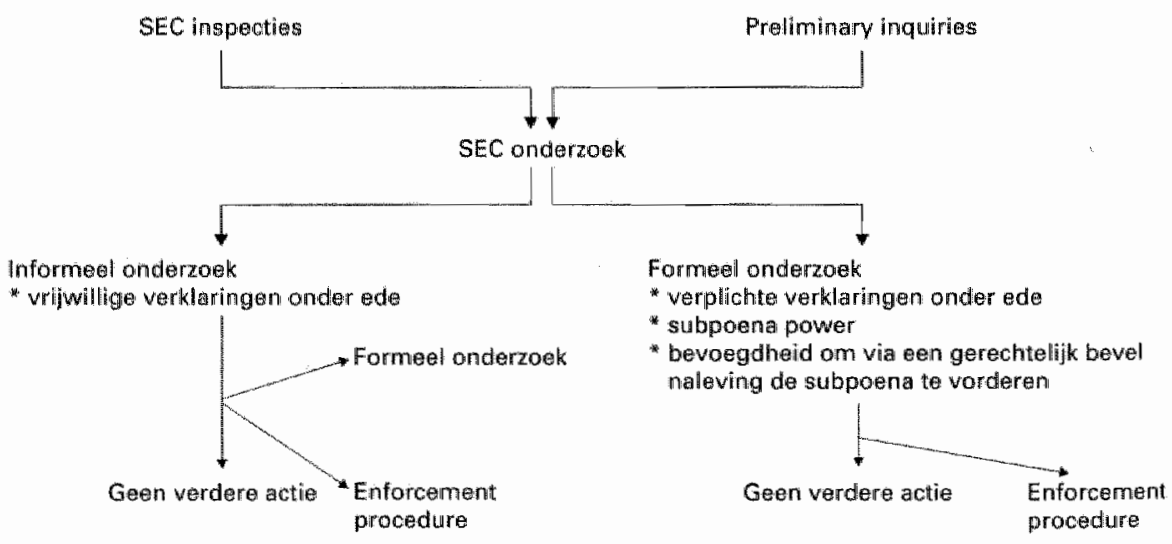

FIGUUR 3.6 Fiase 2 Ondersoet door de afdeling Enforcenent 
Wanneer de SEC staf besluit om wel verdere actie te ondernemen kan dat inhouden dat het subject van onderzoek wordt geconfronteerd met een administratiefrechtelijke procedure; een civielrechtelijke- en/of een strafrechtelijke procedure. De eerste twee procedures kunnen door de SEC zelf aanhangig worden gemaakt. Wanneer zij een strafrechtelijke procedure voor ogen heeft, dient de SEC - door gebrek aan een strafvervolgende bevoegdheid - het Department of Justice in te schakelen. Een dergelijke actie wil nog niet zeggen dat het inderdaad tot een strafrechtelijke procedure komt. Net als zijn Nederlandse collega heeft de United States Attorney het recht om zelf uit te maken wanneer zij wel of niet overgaat tot strafvervolging ${ }^{111}$. In de hier opvolgende paragrafen zullen de verschillende procedures worden besproken, maar voordat het zover is, zal de derde fase worden aangegeven waarin de SEC de overstap maakt van een Enforcement onderzoek naar een van de hiervoor genoemde procedures.

\section{Fase 3: de Wells submission en de Settlement}

In bijna alle gevallen waarin de afdeling Enforcement besluit om te willen procederen en dus een administratiefrechtelijke, civielrechtelijke of strafrechtelijke procedure aan te vangen, worden de partijen hierover ingelicht. Vervolgens kunnen de stafleden de overige partijen de gelegenheid bieden om - voor aanvang van een mogelijke procedure - te reageren op de aanvraag van een order tot procederen. De reacties van de (potentiële) gedaagde partijen op een mogelijke procedure worden een "Wells submissions" of "Wells statements" genoemd. In een Wells submission dienen de subjecten van onderzoek met duidelijk aangegeven feiten te motiveren waarom er geen enkele grond aanwezig is voor het verlenen van een order tot procederen. Omdat een Wells submission geen recht is van de partijen die verwikkeld zijn in een enforcement onderzoek, maar een mogelijkheid geboden door de SEC, mogen partijen er niet van uit gaan dat zij een dergelijk statement kunnen indienen. Regels over de wijze waarop een Wells submission dient te worden ingediend zijn niet in de Code of Federal Regulations te vinden. Om te voorkomen dat onvolledige verzoeken tot het niet instellen van een procedure bij haar worden ingediend, heeft de Commissie richtlijnen opgesteld ${ }^{112}$. Deze moeten het indienen wan een Wells submission vergemakkelijken. 
Indien de stafleden van de afdeling Enforcement na afsluiting van een enforcement onderzoek menen dat een eventueel ingediend Wells statement niet gegrond was en dat een verdere procedure op zijn plaats is, zijn zij verplicht om hiervoor toestemming aan de voltallige Commissie te vragen. Dit is onder meer op te maken uit 17 C.F.R. $\$ 201.200$ (a) onder punt 1:

\section{Section 201.200 Initiation of proceedings}

(a) Order instituting proceedings: Notice and opportunity for bearing.

(1) Generally.

Whenever an order instituting procedings is issued by the Commission, appropriate notice thereof shall be given to each party to the proceeding by the Secretary or another duly designated officer of the Commission. Each party shall be given notice of any bearing within a time reasonable in light of the circumstances, in advance of the hearing; provided, however, no prior notice need be given to a respondent if the Commission bas authorized the Division of Enforcement to seck a temporary sanction ex parte.

De toestemming voor het procederen wordt verleend in de vorm van een "order". De Commissie heeft de bevoegdheid tot het verstrekken van voornoemde orders gedelegeerd aan de secretaris van de SEC.

\section{Section 200.30-7 Delegation of authority to Secretary of the Commission ${ }^{1 / 3}$ \\ Pursuant to the provision (...) the following functions to the Secretary of the Commission to be perforned by bim or under bis direction by such person or persons as may be designated from time to tive by the Chaiman of the Commission: .... \\ (9) To designate officen of the Commission to serve notices of and orders for procedings and decisions and onders in such proceedings, the service of which is required by Rules 141 and 150 of the Commission's Rules of Practice. Secs. 201.141 and 201.150 of this chapter; ...}

In section 200 (b) rules of practice, behorende bij de SEC's Procedural Rules ${ }^{114}$, zijn de inhoudelijk eisen aangegeven waaraan een order om te mogen procederen moet voldoen. Zo dient een dergelijk order duidelijk aan te geven voor welke procedure de order is verleend. Daarnaast dient ook te worden aangegeven welk wetsartikel is overtreden en welke sanctie de SEC opgelegd zou willen zien. Dit alles heeft niet alleen de bedoeling dat degene die door de SEC voor her gerecht wordt gedaagd weet waar hij of zij aan toe is. De order wordt in de praktijk namelijk ook gebruikt

113 17 C.F.R. $\$ 200.30-7$ (section 30-7 rules of organization; conduct and exhics; and information and requests 1999 ).

11.4 17 C.F.R. $\$ 201.200(1999)$. 
om te komen tot een "settlement", een schikking; oftewel een overeenkomst tussen de SEC en de gedaagde. Immers, voornoemde order geeft bijvoorbeeld aan dat de SEC een administratieve procedure zou willen entameren en een herstellende sanctie opgelegd zou willen zien. Nu het vast staat wat de vermeende overtreding is en wat de gevolgen van een rechterlijke uitspraak zouden kunnen zijn, is het aan de partijen - SEC en gedaagde - om uit te maken of het wel zover zou moeten komen. De SEC heeft in beginsel redenen om het niet tot een proces te laten komen. Afgezien van het feit dat een procedure vele uren en mankracht kan vergen, behoeft deze niet altijd tot het voor de SEC gewenst resultaat te leiden. Ook de gedaagde is vaak geen voorstander van het voeren van een procedure. Naast de hoge kosten en de lange periode van procesvoeren, kan zijn "goede naam" of de naam van het bedrijf de nodige schade oplopen terwijl de overtreding nog niet bewezen is. De partijen zullen de eisen zoals gesteld in de order doornemen en indien deze onredelijk zijn, zal de gedaagde het alsnog tot een procedure laten komen. Uit strategische overwegingen zal de SEC geen onredelijke sancties eisen. Immers, van een kale kip kan men niet plukken waardoor te hoge geldboetes bij voorbaat niet tot een settlement, maar tot het voeren van een procedure zullen leiden; hoge kosten en een miniem resultaat. Mocht de gedaagde menen dat hij met een settlement beter af is, kan hij hiervoor kiezen dan wel zelf een settlement voorstellen ${ }^{115}$.

\section{Section 201.54 Settlement}

The applicant and counsel for the Office or Division of the Commission may agree on a proposed settlement of the award before final action on the application, either in connection with a settlement of the underlying proceeding or after the underlying proceeding hats been conduded, in accordance with the Commission's standard settlement procedure. See 17 CFR 201.240. If a pressaling party and counsel for the Office or Division of the Commission agree on a proposed settlement of an award before an application has been filed, the application shall be filed with the proposed seutlement. If a proposed settlement provides that each side shall bear its oum expenses, and the settlement is accepted, no application maty be filed.

\section{Section 201.240 Settlement}

(a) Availability

Any person who is notified that a proceeding maty or will be instituted against bim or ber, or any party to a proceeding atready instituted, maty, at any time, propose in writing an offer of settlement. (...) 
Mochten zowel de Wells submission als de settlement niet tot het door partijen gewenst resultaat leiden, gaat de SEC over tot de procedure zoals dat in de order is aangegeven. Zoals uit bovenstaand artikel kan worden opgemaakt, kan een settlement ook in een later staduim - namelijk tijdens de procedure - ingezet worden. Hieronder, in figuur 3.7, wordt de schematische uitwerking van fase 3 weergegeven waarna in de volgende paragraaf zal worden aangevangen met een bespreking van de mogelijke procedures zoals hiervoor reeds is aangestipt.

Onderzoek door de afdeling Enforcement

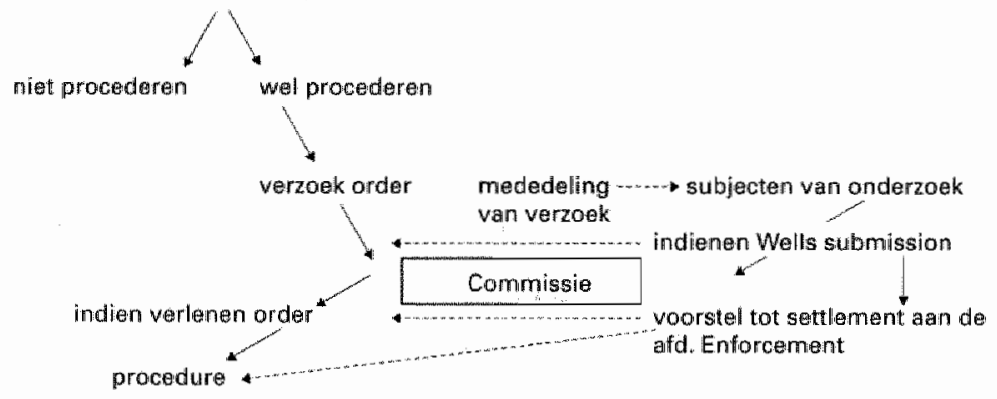

FIGUUR 3.7 Fase 3; de Wells Submission en de Setlement

\subsection{De verschillende handhavingsprocedures}

Uit de voorafgaande paragrafen is duidelijk geworden dat er drie soorten procedures mogelijk zijn; de administratiefrechtelijke, de civielrechtelijke en de strafrechtelijke procedure. Iedere procedure heeft zijn eigen kenmerken. Wat deze procedures inhouden en welke sancties er kunnen worden toegepast zal in de hierna aan de orde komen. Hierbij zal de rol van de SEC centraal staan. Getracht zal worden om haar bevoegdheden en de reikwijdte hiervan aan te geven. Voornoemde procedures zullen in de hierboven weergegeven volgorde aan bod komen.

\subsubsection{De administratieve procedure}

De enige procedure waarvan gezegd kan worden dat de SEC er het meeste invloed op heeft, is de administratieve procedure. De SEC, een administratief overheidsorgaan, dient zich bij de uitvoering van haar taken en bevoegdheden te houden aan de regels zoals de overheid die heeft opgesteld voor al haar (zelfstandige) bestuursorganen. Zij heeft niet alleen de bevoegdheid om regelgeving te formuleren en te handhaven, maar 
heeft van het Amerikaans Congres ook de bevoegdheid gekregen om te beslissen of de effectenregelgeving daadwerkelijk is geschonden. Dit geschiedt door middel van administratieve hoorzittingen geleid door een hiervoor aangewezen Administrative Law Judge (ALJ) ${ }^{116}$. Deze hoorzittingen worden "adjudicatory hearings" of "adjudicatory proceedings" genoemd $^{117}$. De administratieve hoorzittingen vertonen veel overeenkomsten met een civielrechtelijk proces, zonder jury, waarin de rechter op grond van "equity", redelijkheid en billijkheid, beslist. Dit blijkt onder andere uit 17 C.F.R. $\$ 201.32$.

\section{Rule 326 Evidence: Presentation, rebuttal and cross-examination.}

In any proceeding in which a bearing is required to be conducted on the recond affer opportunity for bearing in accord with 5 U.S.C. 556 (a), a party is entitled to present its case or defense by oral or documentary evidence, to submit rebuttal evidence, and to conduct such cross-examination as, in the discretion of the Commission or the bearing officer, may be required for a full and true disclosure of the facts. The scope and form of evidence, rebuttal evidence, if any, and cross-examination, if any in any other proceeding shall be determined by the Cominission or the hearing officer in each proceeding.

De partijen in een adjudicatory hearing zijn de desbetreffende "administrative agency" en de (rechts)personen van wie wordt vermoed dat het de wetgeving heeft overtreden. In geval van de SEC is enerzijds de SEC zelf partij en anderzijds zijn de door haar gereguleerde (rechts)personen partij in een dergelijke hearing. Zoals uit voorgaande paragrafen kan worden opgemaakt, behoren tot deze (rechts)personen:

- De commissionairs, brokers, effectenbandelaven en effectenbeurgen ${ }^{118}$ "

- De openbare nutsbedrijuent 19.

- De beleggingsmatschappijen 120 ;

- (Professionele) beleggingsadtiseurs 121 en

- Zelfregulerende organisaties te weten: de nationale effectenbeurzen, de NASD, de geregistreende clearingorganisaties en de Municipal Securities Rulemaking Boand ${ }^{122}$.

116 Een ALJ - een hearing officer - is een overheidsbeambte die speciaal in dienst is om hoorzitcingen van administratieve bestuursorganen voor te zitten.

$117 \mathrm{Vgl}$. paragraaf 3.1.2. de verschillende rechrsprekende instanties.

118 Op grond van de Securities Exchange Act '34 registratieplichtig bij de SEC.

189 Deze dienen zich op grond van de Public Utility Holding Company Act'35 bij de SEC te registreren.

120 De Investment Company Act uit 1940 heeft ervoor gezorgd dat deze maatschappijen registratieplichtig werden.

121 Zie de Investment Advisers Act " 40.

122 Vgl. 15 U.S.C. $\$ 978 \mathrm{c}$ (a) (26) en $78 \mathrm{~s}$ (a-1) of de section $3(26)$ en section 19 (a) (1)

Securities Exchange Act 34 (1999). 
Niet alleen de bovengenoemde (rechts)personen, maar ook de hieraan verbonden personen kunnen partij zijn in een door de SEC ingestelde administratieve procedure ${ }^{123}$. Een van de artikelen waar dat in naar voren komt, is section 3 onder a van punt 18 van de Securities Exchange Act ' $34^{124}$.

\section{Section 3 Definitions and application}

(a) Definitions

18) The term "person associated with a broker or dealer" or "assuciated person of a broker or dealer" "means any partner, officer, director, or branch manager of such broker ar dealer (or any person occupying a similar status or performing similar functions), any person directly or indirectly controlling, controlled by. or under common control with such broker or dealer, or any employee of such broker or dealer, except that any person assaciated with a braker or dealer whose functions are solely clerical or ministerial shall not be included in the meaning of such term for purposes of section 15(b) of this title (other than paragraph (6) thereof).

Tot de invoering van de Securities Enforcement Remedies and Penny Stock Reform Act in 1990 (de Remedies Act) was de SEC beperkt in de keuzemogelijkheid van de op te leggen sancties. Daarnaast was ook de groep beperkt tot de hierboven genoemde (rechts)personen. De Remedies Act heeft er onder meer voor gezorgd dat de SEC verschillende administratieve procedures naast een civielrechtelijke procedure mocht voeren ${ }^{125}$. De Remedies Act is niet in de vorm van één wet terug te vinden. Deze wet, die bestaat uit verschillende artikelen in de diverse effectenwetten ${ }^{126}$, is in het leven geroepen met de volgende doelstelling:

12. 15 U.S.C. $\$ 78 \mathrm{c}$ (a)(18) of section 3(a)(18) van de Securities Exchange Act "40, 15 U.S.C. $\$ 80$ b-2(a)(17) of section 202(a)(17) van de Investment Advisers Acr: 40 (versies uit 1999).

124 L U.S.C. $\$ 78 \mathrm{c}(\mathrm{a})(18)$.

125 De Remedies Acr gaf de SEC de bevoegdheid om in een administratieve procedure niet alleen een Cease and Desist order op te (laten) leggen of een civiele geldboete, maar ook ontneming van wederrechtelijk verkregen voordeel te vorderen. Voorts heeft de Remedies Act bewerkstelligd dat de Amerikaanse rechtbanken her bevel mogen geven om een civiele geldboete op te leggen en om ontneming van illegale winsten te vorderen. Tot slot heeft woornoemde wet ervoor gezorgd dat de SEC via een civiele injunctionprocedure de direcrie(leden) van een bij de SEC geregistreerd bedrijf kunnen verbannen uit de effectenbranche. Hieronder zullen voonoemde sancries uitgebreid aan bod komen.

126 De ingevoegde artikelen zijn: 15 U.S.C. $77 \mathrm{~h}-11$ of section $8 \mathrm{~A}$ van de Securities Act 33 ; 15 U.S.C. $\$ 78$ u-3 of section $21 \mathrm{C}$ van de Securities Exchange Act $34 ; 15$ U.S.C. $\$ 80 \mathrm{~b}-3(\mathrm{k})$ Oftewel section $203(\mathrm{k})$ van de Irvestment Advisers Act'40 en tot slot 15 U.S.C. $\$ 80 \mathrm{a}-9$ (f) of section 9 (f) van de Investment Company Act uit 1940 (versies uit 1999 . 
"To strengthen the enforcment powers of the (...) SEC and provide the agency with at broader wange of remedies to protect investors and watntain the integrity of the nations securrities matkets. "IIT.

Om deze doelstellingen te verwezenlijken is in deze wet bepaald dat de SEC bepaalde sancties tegen "een ieder" kan vorderen. Het is dan niet meer van belang of de desbetreffende (rechtspersoon) door de SEC wordt gereguleerd of niet. Dit zal hieronder nog aan bod komen.

De eisen waaraan de hoorzittingen van administrative agencies dienen te voldoen zijn neergelegd in de Administrative Procedure Act (APA) ${ }^{128}$. De APA is een wet uit 1946 die door middel van modellen aan de agencies voorschrijft aan welke eisen de hoorzittingen en de door de agencies gecreëerde regelgeving moeten voldoen ${ }^{129}$. In de regels die de agencies maken, zijn de eisen van de APA terug te vinden. Een voorbeeld hiervan is rule 30-9 van de SEC's organization; conduct and ethics; information and requests rules. Als gevolg van de APA heeft de SEC in deze rule haar bevoegdheden om uitspraken te doen, gedelegeerd aan de ALJ's.

\section{Rule 30-9 Delegation of autbority to bearing officers.}

Purstant to the provisions of Section $4 A$ of the Securities Exchange Act of the Securities and Exchange Commission hereby delegates, wntil the Commission orders otherwise, to each Administrative Law Judge ("Judge") the authority:

(a) To make an initial decision in any proceeding at which the Judge presides in which a bearing is requived to be conducted in conformity with the Administrative Procedure Act (5 U.S.C. 557) unless such initial decision is waived by all parties who appear at the bearing and the Conmission does not subsequently order that an initial decision nevertbeless be made by the Judge, and in any other proceeding in which the Commission directs the Judge to make such a decision; (...)

Naast het verzorgen van uitspraken, ook wel "initial decisions" genoemd, zijn ALj's ook bevoegd om te beoordelen wie zij als getuige wil horen; bevoegd om subpoena's uit vaardigen, te beslissen of aangevoerd bewijs wel geschikt is; bevoegd om een eed af te nemen en nog veel meer. In 17 C.F.R. $\$ 200.14$ (a) staan de taken en bevoegdheden van de ALJ vermeld ${ }^{130}$.

127 Philips, R.M., G.R. Missal en Lipton, R.J., SEC investigation: The Heart of SEC Enforcement Practice, a.w., noot 5, p. 134.

129 Gellhorn, E. en Levin, R.M., Administrawive Law and Process in a nutshell, West Group, St. Paul: Minnesota, 1997, p. $296-300$.

Rule 14 (a) van de SEC's organization; conduct and ethics; information and requests rules. 


\section{Rule 14 Office of Administrative Law Judges.}

(a) Under the Adxninistrative Procedure Act (5 U.S.C. 551-559) and the federal securtities laws, the Office of Administratiwe Law Judges conducts bearings in proceding instituted by the Commission. The Administrative Law Judges are responsible for the fair and orderly conduct of the proceedings and bave the authority to:

(1) Admintister oaths and affirmations; (2) Issue subpoenas; (3) Rule on offers of proof: (4) Examine witnewses:(5) Regulate the cowrse of a beaning; (6) Hold prehearing conferences; (7) Rule upon motions; and (8) Unless waived by the parties, prepare an initiol decision containing the conclusions as to the factwal and legal issues presented and issue an appropriate order.

Het begrip "Administrative Law Judge" kan voor enige verwarring zorgen wanneer men de term "Judge" letterlijk zou vertalen. Eerder is opgemerkt dat het om een hearing officer gaat; een overheidsbeambte die hoorzittingen in een administrative procedure afneemt. De ALJ mag niet vergeleken worden met een rechter zoals men die in Nederland kent of met een rechter die werkzaam is binnen het systeem van de Amerikaanse rechtbanken ${ }^{131}$. Deze ambtenaar wordt door de agency, de Commissie, geselecteerd uit een lijst die de Federal Office of Personnel Management (OPM) haar heeft aangereikt. In haar Procedural Rules heeft de SEC dit opgenomen in rule 110 rules of practice ${ }^{132}$.

\section{Rule 110 Presiding officer.}

All procedings shall be presided over by the Commission or, if the Cammission so orders, by a bearing officer. When the Commission designates that the hearing officer shall be an administrative law judge, the Cbief Administrative Law Iudge shall select, prursuant to 17 CFR 200 30-10, the administrative law judge to preside.

De personen die voorkomen op de hiervoor genoemde lijst hebben diverse examens moeten afleggen en werken over het algemeen al enige tijd voor de federale overheid. Weliswaar bij andere divisies, maar zij zijn toch bekend met de werkwijze van de federale overheid. Van de ALJ wordt verwacht dat hij of zij zoveel mogelijk feiten verzamelt. Immers, hij heeft de mogelijkheid tot het horen van partijen, ondervragen van getuigen en bekijken van aangevoerd bewijsmateriaal. Ingeval de partijen ervoor kiezen om slechts op grond van bewijsstukken een uitspraak te willen, dan is er geen taak meer voor de ALJ en wordt hij geacht uit het proces terug te treden. In dat geval spreekt men van een "summary disposition". In de praktijk zijn de ALj's geen voorstander van dergelijke 
summary dispositions. Immers, het toekennen van een zo'n verzoek zet hen buitenspel. Uit rule 250 (a) rules of practice, behorende bij de SECs Procedural Rules, kan onder meer de conclusie worden getrokken dat ALj's slechts feiten beoordelen. Indien deze niet meer ter discussie staan, maar het bijvoorbeeld om de uitleg van een rule gaat, dienen zij zich terug te trekken ${ }^{133}$. Hier ligt dan ook een groot verschil met de reguliere rechters. Immers, zij beoordelen naast de feiten ook regelgeving.

\section{Rule 250 Motion for summary disposition ${ }^{134}$}

(a) After a respondent's answer has been fled and, in an enforcenent or a disciplinary proceding, documents thave been made available to that respondent for inspection and copying pursuant to rule 230 , the respondent, or the interested division may make a motion for summary disposition of awy or all allegations of the order instituting proceedings with respect to that respondent. If the interested division bas not completed presentation of its case in chief. a motion for summary disposition shall be made only with leave of the hearing officer. The facts of the pleadings of the party against whom the mation is made shall be taken as true, except as modified. by stipulations or admissions made by that party, by uncontested affidavits, or by facts officially noted purstatnt to rule 323. (..)

De administratieve procedure begint met het verzoek van de SEC. Hierin geeft zij aan welke regel er vermoedelijk is overtreden en welke "remedial sanctions" - herstellende sancties - zij door de ALJ opgelegd zou willen zien $^{135}$. De hoorzittingen van de ALJ kunnen openbaar zijn, maar indien

17 C.FR. $\$ 201.250$ (a) (1999).

Oftewel Section 17 C.F.R. 201.250. Een "summary disposition", is een uitspraak niet gebaseerd op materiële feiten, maar op de wet. Dergelijke processen verlopen in de regel wrij snel omdat er geen nader onderzoek naar de feiren verricht hoeft te worden. Er wordt slechts naar de wet gekeken en op grond daarvan beslist. Garner, B.A., Black's Law Dictionary, West Group, $3^{\text {di }}$ druk, 1996, p. 606.

Het doel van een remedial sanction is om de belegger te beschermen. Wanneer de opgelegde remedial sanction een straf inhoudt die veel zwaarder is dan de geleden schade, is er geen sprake meer van een remedial sanction, maar van een punitieve sanctie. Vgl. noot 11 op pagina 491 in de zaak Johnson w. SEC, 87 F.3el 484 (D.C. circuit 1996). In deze zaak werd Patricia Johnson zowel door de ALJ als door de SEC voor de periode wan zes maanden geschorst als supervisor. De reden hiervoor was dat zij onvoldoende toezicht had uitgeofend op een van haar medewerkers waardoor er beleggers werden gedupeerd. Deze sanctie werd door de rechtbank onevenredig zwaar gevonden: "Here, the sanctions imposed by the SEC - censure and a six-month suspension - clearly resemble punishment in the ordinary sense of the word. The SEC not only restricted Jobnson's ability to earn a living as a supervisot during her six-month suspension, but the suspension was also likely to bave longer-lasting repercussions on ber ability to pursue her vocation. Suspended brokers must forewer after disclose the sanction, and it becomes part of their permanent public file" . 
de Commissie meent dat het in het belang van her publiek is om de zitting achter gesloten deuten te houden, is zij hiertoe bevoegd ${ }^{136}$. De ALj's bepalen de feiten aan de hand van het ingebracht en goedgekeurd bewijs en aan de hand van de door hen gehoorde getuigen(-deskundigen). Indien zij menen dat de sanctie waar de SEC om heeft verzocht terecht is, kunnen zij dat in hun initial decisions aan de desbetreffende partij opleggen.

In een administratieve procedure zijn er diverse sancties toepasbaar. De verschillende administratieve sancties zijn:

1. Het intrekken of schorsen van een SEC registratie enlof bet beperken van werkzanmbeden;

2. Een Cease and Desist order;

3. Accounting and Disgorgenent" en

4. Het opleggen uan civiele geldboeres.

Voor de Remedies Act reikte de bevoegdheid van de SEC om via de ALj sancties op te leggen slechts tot een bepaalde groep personen; de gereguleerden en andere speciaal daartoe aangewezen personen zoals accountants. De Remedies Act vergrootte deze groep en vergrootte daarbij het arsenaal aan administratieve sancties. Ondanks het feit dat de Remedies act stamt uit het begin van de jaren 90 en het al geruime tijd wordt toegepast, zijn niet alle voorwaarden voor het toepassen van deze sancties uitgekristaliseerd. Hieronder zullen bovengenoemde sancties worden besproken en zo mogelijk zal worden aangegeven wanneer de sanctie wel of niet mag worden toegepast.

\section{Intrekkingen; schorsingen en beperkingen}

De mogelijkheid voor de SEC om, weliswaar via een administratieve procedure, de registratie van onder meer een effectenhandelaar/commissionair - "broker/dealer" - , beleggingsadviseurs dan wel van beleggingsmaatschappijen in te trekken, te schorsen of om de werknemers van een bij haar geregistreerde effectenbedrijf te verbieden om werkzaam te zijn binnen de effectenwereld (te verbannen uit de effectenbranche), behoort 
tot de oorspronkelijke administratieve sancties ${ }^{137}$. Deze sancties, die alleen toepasbaar zijn in de administratieve procedure, gaan erg ver. Immers, zonder vergunning mag de desbetreffende (rechts)persoon ${ }^{138}$ niet werkzaam zijn binnen de effectenbranche. Daarom kan de SEC dergelijke acties pas instellen na een administratieve procedure te hebben ingesteld waarin zij toestemming heeft gekregen van een ALJ. De wetgever heeft dat in section 15 (b) (4) van de Securities Exchange Act ${ }^{139}$ als volgt verwoord:

\section{Section 15 Registration and regulation of brokers and dealers}

$b(4)$ The Commission, by order, shall censure, place limitations on the activities, functions, or operations of suspend for a period not exceeding twelve months, or revoke the registration of any broker or dealer if it finds, on the record after notice and opportunity for hearing, that such censure, placing of limitations, suspension, or revocation is in the public interest and that such broker or dealer, whether prior or subsequent to becoming such, or any person associated with such broker or dealer, whether prior or subsequent to becoming so associated (...)

$b(6)(A)$ With respect to any person who is associated who is seeking to become assaciated, on, at the time of the alleged misconduct, who was associated or was seeking to become associated with a broker or dealer, or any person participating, or, at the time of the alleged misconduct, who was participating, in an offering of any penny stock, the Commission, by order, shall censure, place limitations on the activities or functions of such person, or stuspend for a period not exceeding 12 months, or bar such person from being associated with a broker or deater, or from participativg in an offering of penny stock, if the Commission finds, on the record after notice and opportunity for a bearing, that such censure, placing of limitarions, suspersision, or bar is in the public interest and that such person (...)

Volgens bovenstaand artikel kan deze sanctie pas na een hoorzitting, voor de duur van maximaal twaalf maanden, worden opgelegd aan een

137 15 U.S.C. $\$ \$ 780(b)(4)$ en (6) ook wel section 15 (b) (4) en (6), 780-4 (c)(2) Oftewel section $15 \mathrm{~B}(\mathrm{c})(2), 780-5(1+2)$ Oftewel section $15 \mathrm{C}(1)$ en (2) wan de Securities Exchange Act $34 ; 15$ U.S.C. $\$ 80 b-3$ ook wel section 203 van de Investement Advisers Act '40 genoemd; 15 U.S.C. $\$ 80-8$ (e) Oftewel section 8 (e), 80a-9 (b) of section 9 (b) van de Investment Company Act '40 (versie 1999). Te weten: de intermediairs Oftewel brokers of dealers, dan wel een ieder die verbonden is met deze persoon; de municipal securities dealer Oftewel degene die handelen in effecten van lagere overheden; de government securities dealer of -broker die handelen in effecten uitgegeven voor en/of door de overheid; de transfer agent die de gegevens bij houdt van de effectenoverdrachten; de beleggingsadviseur en de beleggingsmaatschappijen. 
geregistreerde persoon of aan een hieraan gerelateerd persoon ${ }^{140}$. Bovenstaand wetsartikel duidt ook aan dat de SEC een officiële reprimande aan iemand of onderneming kan geven, die actief is binnen de effectenwereld. Daarnaast kan de SEC de werkzaamheden, functies of financiële transacties van een dergelijke persoon of onderneming beperken.

Een volgend wetsartikel, op grond waarvan de SEC iemand kan schorsen of uitsluiten uit de effectenwereld, is rule 102 (e) van de SEC's Procedural Rules $^{141}$. Een deel van deze regel luidt als volgt:

\section{Rule 102 Appearance and Practice before the Commission}

(e) Suspension and disbarment.

(1) Generally. The Commisson may censure a person or deny, temporarily or pernanevtly, the privilege of appearing or practicing before it in any way to any person who is found by the Commission after notice and opportunity for bearing in the matter:

(i) Not to possess the requisite qualifications to represent others; or

(ii) To be lacking in character in integrity or to bave engaged in unethical or improper professional conduct; or

(iii) To base willfilly violated, or willfully aided and abetted the violation of any provision of the Federal securities laws or the rules and regulations thereunder. (...)

Bovenstaande regel geeft aan het voltallig bestuur van de SEC, "the Commission", de bevoegdheid om de "beroepsgerelateerde" personen niet alleen te berispen, maar ook (tijdelijk) te schorsen of verbieden om werkzaam te zijn binnen de effecten branche. Tot de beroepsgerelateerde personen behoren alle personen die voor het uitoefenen van hun beroep afhankelijk zijn van de Commissie doordat zij bijvoorbeeld afhankelijk zijn van een vergunning afgegeven door de SEC. Deze personen kunnen onder meer accountants, advocaten of analisten zijn. Op grond van voormelde rule zal een dergelijke persoon, na een veroordeling in een strafrechtelijke of civiele injunctionprocedure, ook door de SEC administratiefrechtelijk worden gesanctioneerd. Een dergelijke veroordeling leidt

140 Maletta, J.B. en Lang, N.S., Sanctions and Collateral Consequences: The Stakes in SEC Enforement in: Kirkpartrick and Lockhart L.L.R., The Securities Enforcenent Manual: tactics and strategies, a.w., p. 134. 
immers automatisch tot een schorsing. Dit is bepaald in rule 102 (e) $(2)^{142}$.

(2) Certain professionals and convicted persons.

Any attorney who bas been suspended or disbarred by a court of the United States or of amy State; or any person whose licence to practice as an accountant, engineer. or other professional or expert bas been revoked or suspended in any State; or any person who bas been convicted of a felony or a misdemeanor involving moral turpitude shall be forthwith suspended from appearing or practicing before the Commission (...).

Voor de toepassing van rule 102 (e) is niet altijd een veroordeling vereist; zelfs een schikking kan voldoende zijn. Onder punt (e)(3)(iv) van deze regel is het volgende vermeld:

(3)(iv)... A person who has consented ${ }^{13}$ to the entry of a permanemt injunction as described in paragraph (e) (3)(A) of this rule without admitting the facts set forth in the complaint shall be presumed for all purposes under this paragraph (e)(3) to bave been enjoined by reason of the misconduct alleged in the complatnt.

Indien men accoord is gegaan met een schikking, "a consent order", dan is het van belang voor de gedaagde dat er in de schikking een regel is opgenomen die de sancties van rule 102 (e) niet meer toepasselijk verklaart. Is dat niet het geval, dan kan een schilkking alsnog dezelfde gevolgen als een veroordeling hebben ${ }^{144}$.

De SEC heeft niet de vrije hand in het schorsen dan wel permanent uitsluiten van professionelen. Dit is onder meer gebleken in de zaak Johnsen v. SEC ${ }^{145}$ waar de SEC door het Court of Appeals op de vingers werd getikt. In deze zaak had de SEC Johnson voor een bepaalde tijd geschorst en haar daarmee in feite dubbel gestraft. Het Court of Appeals heeft vervolgens beslist dat een tijdelijke schorsing van Patricia Johnson, die onvoldoende toezicht had uitgeoefend op een van haar medewerkers en daardoor beleggers had gedupeerd, onevenredig zwaar en dus ongeoorloofd was. De rechtbank nam dit standpunt in omdat een

142 17 C.F.R. $\$ 201.102$ (e)(2) versie 1999.

143 "Consented": dit verwijst naar een consent order. Anders gezegd: "een soort schilkking".

144 Lang, N.S. en Lipton, R.J., Litigating Administrative Proceedings: the SEC's incrasingly important enforcement alternative in: Kirkparrick and Lockhart L. L.P., The Securities Enforcment Manual: tactics and strategies, a.w.; p. 273.

145 Johnsen w. SEC 87 F.3d 484 (D.C. Circuir 1996). 
schorsing altijd geregistreerd blijft waardoor het Johnson's toekomstige carrière op een negatieve wijze zal blijven achtervolgen; hetgeen op zichzelf al een zware straf is. Om Johnson daarnaast de mogelijkheid ontnemen om zes maanden haar brood te verdienen was, volgens het Court of Appeals, onevenredig zwaar voor een administratieve straf. Een dergelijk straf was volgens de rechtbank niet van "herstellende" aard, maar meer van punitieve aard.

Een volgende zaak waarin de SEC door het Court of Appeals werd teruggeroepen, is de voor Amerikaanse begrippen bekende Checkosky zaak $^{146}$. Hierin heeft de SEC rwee accountants, de heren Checkosky en Aldrich, voor een periode van twee jaar geschorst omdat zij zich onder meer niet hebben gedragen volgens de algemene accountancy regels. Volgens de SEC was hiermee sprake van "improper professional conduct" en dus overtreding van de bovengenoemde rule 102 (e). De heren gingen in hoger beroep omdat zij vonden dat de SEC niet duidelijk aan had gegeven wanneer er sprake was van "improper professional conduct". Het Court of Appeals was het daarmee eens en verwees de zaak terug naar de SEC. Deze beslissing is bekend geworden onder de naam "Checkosky I". De SEC moest in een initial decision aangeven welke criteria zij had toegepast om tot de conclusie te kunnen komen dat er sprake was van "improper conduct". De Commission heeft de zaak weer behandeld, maar naar ontevredenheid van Checkosky en zijn partner waarna de zaak wederom voor hetzelfde Court of Appeals belandde. In Checkosky II leed de SEC gezichtsverlies want het Court of Appeals gaf aan dat de SEC opnieuw niet aan haar plicht had voldaan en verwees de zaak weer terug naar de SEC.

Uit het voorafgaande kan worden gecondudeerd dat de SEC wel bevoegd is tot het schorsen of het geven van een reprimande dan wel tot het uitbannen van onder meer niet geregistreerde personen uit de effectenbranche, maar niet ongelimiteerd. De SEC kan worden gecorrigeerd door de Courts of Appeals. Een volgende sanctie die in de administratieve procedure kan worden opgelegd en ook een brede doelgroep heeft, is de hierna te behandelen Cease and Desist order.

146 De initial decision inzake re David J. Checkosky en Norman A. Aldrich d.d. 26 augustus 1992; Checkosky v. SEC, 23 F.3d 452 (D.C. circuit 1994) "Checkosky I"; Herziende beslissing door de SEC in re David J. Checkosky \& Norman A. Aldrich d.d. 21 januari 1997 en tot slot Checkosky w. SEC 139 F.3d 221 (D.C. circuir 1998) "Checkosky" II". 


\section{De Cease and Desist order}

Een Cease and Desist order is de benaming van een bevel om iets te doen; iets niet te doen of om iets na te laten. Deze administratieve sanctie behoort tot een van de weinige sancties die de SEC na een initial decision kan opleggen aan zowel een gereguleerde als een niet-gereguleerde (rechts)persoon ${ }^{147}$. De Cease and Desist order en het intrekken dan wel schorsen van een SEC registratie waren de twee oorspronkelijke administratieve sancties. Voornoemde Remedies Act gaf de SEC onder meer de mogelijkheid om Cease and Desist orders ook tegen niet-gereguleerden op te leggen. Er zijn twee soorten Cease en Desist orders: de permanente en de tijdelijke order. In section $8 \mathrm{~A}$ van de Securities Act heeft de wetgever het als volgt vermeld:

\section{Section 8A Cease-and-Desist Proceedings}

(a) Authority of the Commission.

If the Commission finds, after notice and opportumity for hearing, that any person is violating, has violated, or is about to violate any provision of this title, or awy rule or regulation thereunder, the Commission may publish its findings and enter an order requiring such person, and any other person that is, was, or would be a cause of the violation, due to an act or omission the person knew or should have known would contribute to such violation, to cease and desist from committing or causing such violation and any future violation of the same provision, rule, or regulation. Such order may in addition to requiring a person to cease and desist from committing or causing a vialation, require such person to comply, or to take steps to effect compliance, with such provision, rule, or regulation, upon such terms and conditions and within such time as the Cowmission may specify in such order. Any such order may as the Commission deems appropriate, requive future compliance ar steps to effect future compliance, either permanently or for such period of time as the Commission may specify, with such provision, rule, or regulation with respect to any securitin, any issuer, ar any other person.

Alvorens de (tijdelijke) Cease and Desist order toe te kunnen passen moet de SEC in een hoorzitting aantonen dat

"any persox is violating. has violated, or is about to violate any rule or regulation ${ }^{48}$ ".

15U.S.C. $\$ 77 \mathrm{~h}-1$ of section 8 A van de Securities Act $33 ; 15$ U.S.C. $\$ 78 \mathrm{u}-3$ ook wel secrion $21 \mathrm{C}$ van de Securities Exchange Act'34 genoemd; 15 U.S.C. 80a-9 (f) (1) Oftewel secrion 9 (f) (1) wan de Investment Company Act'40 en tot slot 15 U.S.C. $\$ 80 \mathrm{~b}-3(\mathrm{k})(\mathrm{l})$ Oftewel section $203(\mathrm{k})(1)$ van de Investment Advisers Act 40 .

148 Vlg. punt XI Sanctions and remedies, onder C van de initial decision inzake Sky Scientific d.d. 5 maart 1999: 1999 WL 114405 (S.E.C.). 
Aldus moet bewezen worden dat de (rechts)persoon de desbetreffende federale effectenwet- of regelgeving overtreedr, medeplichtig is bij thet overtreden van voornoemde wetten; de federale regels heeft overtreden of op het punt staat om voornoemde regels te gaan overtreden. Over een dergelijke toekomstige overtreding heeft de ALJ in de zaak Sky Scientific besloten dat Cease and Desist order onder bepaalde omstandigheden mag worden verleend, ook wanneer het niet zeker is dat de (rechts)persoon in de toekomst over zal gaan tot het overtreden van de effectenregels. In deze zaak hebben de directie en anderen die werkzaam waren bij Sky Scientifc beweerd, dat het bedrijf mijnen bezat met enorme reserves aan kostbare (edel)metalen. Dit bleek na onderzoek niet met de waarheid overeen te komen.

De SEC heeft vervolgens zowel de directie en de supervisors, als de handelaren die handelden in ongeregistreerde aandelen Sky Scientific voor de administratieve rechter gedaagd wegens overtreding van de effectenwetten. De SEC had de ALJ om een Cease and Desist order verzocht.

"An order may issue absent a finding that a Respondent is apt to commit violations in the future, though evidence suggesting the probability of prospective violations in the future, though evidence suggesting the probability of prospective violations may be relevant in deciding whether to issue an order "14".

De SEC is er - begin 2002 - nog niet over uit of de afgifte van een Cease and Desist order zou moeten geschieden onder de voorwaarde dat er in de toekomst waarschijnlijk overtredingen zullen plaatsvinden. Er zijn initial decisions waarin is bepaald dat "future violations die zouden kunnen plaatsvinden" geen aanleiding hoeven te vormen voor het verlenen van een Cease and Desist order. Dit heeft de ALJ beslist in de zaak Joel Zbar. In de administratieve procedure voerde Zbar aan dat de SEC eerst bewijzen zou moeten aanvoeren dat hij in de toekomst weer zou overgaan tot het overtreden van de effectenwetgeving, alvorens zij over een dergelijke order zou mogen beschikken. De ALJ was een andere mening toegedaan. Volgens haar mag er reeds een Cease en Desist order worden verleend wanneer de desbetreffende persoon een overtreding begaat of heeft begaan. Eventuele toekomstige overtredingen zijn dan

Vgl. de inirial decision inzake Sky Scientific nr. XI Sanctions and remedies, onder C. 
niet meer relevant ${ }^{150}$. Er zijn ook initial decisions waarin is bepaald dat future violations die zouden kunnen plaatsvinden, bepalend zijn voor de afgifte van een Cease and Desist order. Dit was het geval in de zaak Trepp. Warren Trepp fungeerde als tussenpersoon in de obligatiehandel voor zijn cliënt, Drexel Burnham Lambert Incorporated. Omdat Trepp hierbij de wettelijke regels niet in acht had genomen, werd hij voor de administratieve rechter gedaagd. De SEC vorderde de afgifte van een Cease and Desist order. In deze zaak heeft de ALJ bepaald dat de SEC moet aantonen dat Trepp in de toekomst weer een wetsovertreding zou kunnen begaan.

"Neither the Commission nor any court of appeals bas ruled on whether the Commission must find a likelibood of future violation to issue a cease and desist order. The courts have, however, ruled that a likelihood of future violation is required when considering the cease and desist authority of other administrative agencies.".

Volgens de ALJ kan de SEC de dreiging van mogelijke toekomstige wetsovertredingen afleiden uit eerdere gedragingen. Daaruit moet blijken dat er sprake is van:

some cognizable danger of recurrent violation, something more than the mere possibility which serves to keep the case alive.

Oftewel, de SEC moet over zodanige aanwijzingen beschikken, die tot de aannemelijke conclusie zouden leiden dat er een kans op recidive is. Deze aanwijzingen kunnen zijn dat de overtredingen van gedaagde niet slechts eenmalig, maar gedurende een lange tijd plaats hebben gevonden. Daarnaast kan het relevant zijn of de gedaagde nog steeds werkzaam is in de effectenbranche of deze al geruime tijd heeft verlaten zoals bij Trepp het geval was ${ }^{151}$. Dit laatste argument treft men ook aan in de zaak Borg-Warner Corporation versus de FTC, de Federal Trade Commission. Borg-Warner Corporation, een bedrijf dat auto-onderdelen fabriceerde en verkocht, werd door de FTC beschuldigd van monopolievorming hetgeen in strijd was met de Clayton Act en de Federal Trade Commission $\mathrm{Act}^{152}$. In deze zaak heeft de Unired States Court of Appeals

150 Vgl. Joel Zbar, prehearing ruling d.d. 18 maart 1994, release no. 425,28 april 1994, 56 SEC Docker, 1784.

151 Initial decision no. 115 inzake Warren G. Trepp d.d. 18 augustus 1997.

152 Clayton Act, 15 U.S.C. 19 en 15 U.S.C. $\$ 45$ (Federal Trade Commission Act; beide in het arrest versie 1982). 
uitgemaakt dat de FTC niet tot een Cease and Desist order bevoegd was omdat de vermeende overtreding reeds was beëindigd en er geen sprake meer kon zijn van een "toekomstige overtreding"; immers er waren geen aanwijzingen hieromtrent omdat gedaagde al niet meer werkzaam was in de auto-onderdelenhandel. ${ }^{153}$.

De Cease en Desist orders kunnen in ieder geval voor actuele overtredingen worden opgelegd. Vaak gaan deze orders vergezeld van andere administratieve sancties, bijvoorbeeld van een "civiele" geldboete. Dit om te verkomen dat alleen het bevel om een bepaalde handeling wel of niet te verrichten onvoldoende zal zijn. Wanneer een Cease and Desist order niet wordt nageleefd, kan de SEC op grond wan section 21 (d)(3) van de Securities Exchange Act'34 een procedure bij de U.S. district court aanspannen en onder meer verzoeken om de oplegging van een geldboete ${ }^{154}$. In dat geval mag de desbetreffende civiele rechter de overtreder naast de boete ook bevelen om de administratieve order na te leven ${ }^{155}$. Mocht het toch zo zijn dat zelfs de civiele order niet wordt nageleefd dan pleegr de overtreder een civielrechtelijke overtreding namelijk: "minachting van de rechtbank" ofwel "civil contempt of court $^{156 " .}$.

153 Borg-Warner v. F.T.C., 746 F.2d 108 (1984).

is4 15 U.S.C. $\$ 78 \mathrm{u}(\mathrm{d})(3)$.

15515 U.S.C. $\$ 78$ u (e) Ofwel section 21 (e) van de Securities Exchange Act 34 (versie 1999).

156 In de U.S.A. kent men verschillende soorten contempt of court: de civil contempt; de constructive contempt, de criminal contempt en de direct contempt. Van een civil contempt is sprake wanneer er geweigerd wordt een gerechtelijk bevel na te leven dat ten gunste van de tegenpartij was uitgegeven. Een civil contempt procedure is dan ook herstellend van aard. De constructive of indirecr contempr en de direct contempt hebben beide betrekking op het beledigen van de rechrer dan wel van de rechtbank op een indirecte wijze (buiten de rechtbank) of op een directe wijze (ter zitting). Tot slot de criminal contempt. Deze is punitief van aard waardoor de criminal contempt procedure een strafrechtelijke is. Vgl. Garner, B.A., Blacks Law Dictionary, West Group, $3^{\text {rd }}$ druk, 1996, p. 131-132. 


\section{Section 21 Investigations, Injunctions and Prosecntion of Offenses}

A. Authority of Commission.

Whenewer it shall appear to the Commission that any person has violated any provision of this title, the nules or regulations thereunder, or at cease-and-desist arder entered by the Commission pursuant to Section $21 \mathrm{C}$ of this title, other than by committing a violation subject to a penaly pursuant to Section $21 \mathrm{~A}$, the Commission maty bring an action in the United States district court to seek, and the court shall bave jurisdiction to impose, wpon a proper showing, a civil penally to be patd by the person who committed such violation.

\section{Accounting and Disgorgement}

Een andere sanctie die alleen aan gereguleerde partijen kan worden opgelegd is de Accounting and Disgorgement ${ }^{157}$. Dit houdt in dat de boeken van voornoemde partijen worden nagekeken en indien nodig kan de SEC overgaan tot het ontnemen van wederrechtelijk verkregen voordeel. Hierbij dient de overtreder ook rente te betalen over het bedrag dat zij verzuimd heeft om aan te geven.

\section{Section $21 B$ Civil remedies in administrative proceedings}

(e) Awthority to enter an onder reguiting an accownting and disgorgement In any proceeding in which the Commission or the appropriate regulatory agency may impose a penalty under this section, the Commission or the appropriate regulatory agency may enter an onder requiring accounting and disgorgement, including reasonable interest. The Commission is authorized to adopt rules, regulations, and orders concerning payments to investors, mates of interest, periods of accrual, and such other matters as it deems appropriate to implement this subsection.

Volgens de ALj in Sky Scientific is het hoofddoel van deze sanctie:

"...not to compensate investors, wather, to purpose is to deprive a usrongdoer of bis wnjust enrichtme and to deter others from violating the securities law". ".".

In deze zaak heeft de ALJ tevens een voorwaarde voor het toepassen van deze sanctie aangegeven.

"Disgorgement may not be ussed punitively"

Met andere woorden: de aard van deze sanctie is niet leedtoevoegend, maar herstellen in de rechtmatige toestand. Omdat het niet altijd mee 
zal vallen om het exacte bedrag vast te stellen, gaat de ALJ accoord met een redelijke schatting van het bedrag ${ }^{158}$. In de SEC v. Lorin heeft de rechter bepaald dat wanneer de overtreder het niet eens is met het geschatte bedrag, hij of zij maar moet aangeven wat het exacte bedrag is. De bewijsplicht verschuift aldus ${ }^{159}$.

\section{Civiele geldboetes}

Tot slot het opleggen van "civiele" geldboetes in een administratieve procedure; de "civil monetary penalties" of "administrative fines". De eerder genoemde Remedies Act heeft ervoor gezorgd dat in de volgende wetten een grond voor het opleggen van een civiele geldboete te vinden is. Deze wetten zijn: de Securities Exchange Act '34, de Investment Advisers Act en de Investment Company Act beiden uit 1940. Deze sanctie kan zowel in een civiele- als in een administratieve procedure worden opgelegd. Voor het opleggen van een civiele geldboete in een administratieve procedure is vereist dat deze sanctie alleen kan worden opgelegd aan gereguleerde partijen en/of aan personen die verbonden zijn met dan wel werkzaam zijn bij deze partijen ${ }^{160}$. Daarnaast kan een geldboete in een administratieve procedure worden opgelegd aan eenieder die medeplichtig was bij het overtreden van de federale effectenwetten en/of -regulering ${ }^{161}$. Denk bijvoorbeeld aan een onafhankelijke accountant die de overtreding heeft veroorzaakt ${ }^{162}$.

\section{Section 15 Registration and regulation of brokers and dealers}

(4) The Commission, by order, shall censwe, place limitations on the activities, functions, or operations of, swspend for a period not exceding twelve months, or revoke the regtstration of any broker or dealer if it finds, on the record after notice and opportunity for hearing, that such censule, placing of limitations, suspension. or revocation is in the public interest and that swch broker or dealler, whether prior or subseguent to becoming such, or any person associated with such broker or dealer, whether prior or subsequent to becoming so associated-

Vlg. punt XI Sanctions and remedies, onder A van de initial decision inzake Sky Scientific d.d. 5 maart 1999: 1999 WL 114405 (S.E.C.). SEC v. Lorin 76 F.3d 458 en 462 (2nd circuit 1996).

15 U.S.C. $\$ 78 \mathrm{u}-2$ (section 21 B Securities Exchange Act 34 ); 15 U.S.C. $\$ 80 \mathrm{a}-9$

(d) (section 9[d] van de Investment Company Act"40) en 15 U.S.C. $\$ 806-3$ (i) (section 203 [i] van de Investement Advisers Acr"40). De versies wan woornoemde wetten dateren uit 1999.

161 Vgl. 15 U.S.C. $\$ 780$ (D-E) of section 15 (4)(D-E) van de Securities Exchange Acr'34 (versie 1999).

162 Zie 15 U.S.C. $\$ 78$ j-1 (d) ook wel section 10 A (d) wan Securities Act'34 genoemd (versie 1999). 
(D) bas willfully violated any provision of the Sectrities Act of 1933, the Investment Adviser Act of 1940, the Invertment Company Act of 1940, the Commodity Exchange Act, this chapter, the rules or regulations under aty of such statutes, or the rules of the Municipal Securities Rulemaking Board, or is unable to comply with any such provision.

(E) bas willfully aided, abetted, connseled, commanded, indwed, or procured the violation by any other person of any provision of the Securities Act of 1933, the Investment Advisers Act of 1940, the Investment Company Act of 1940, the Commodity Exchange Act, this cbapter, the mules or regulations under any of such statutes, or the rules of the Municipal Securities Rulemaking Board, or has failed reasonably to supervise, with a witu to preventing violations of the provisions of such statutes, rules, and regulations, another person who commits such a violation, if such other person is subject to bis supervision....

Indien de ALJ op verzoek van de SEC besluit om een civielle boete op te leggen, dient hij na te gaan of er voldoende grond aanwezig is. In verschillende wetten, waaronder section $2 \mathbb{} 1 \mathrm{~B}$ van de Securities Exchange Acr' 34 , heeft de wetgever aangegeven dat een agency of een daartoe aangewezen autoriteit een boete mag opleggen wanneer dat in het algemeen belang is.

\section{Section $2 I B$ Civil remedies in administrative proceedings}

(a) Commission authority to assess money penalties

In any proceding instinuted pursuant to sections $15(6)(4), 16(b)(6), 15 B, 15 C$, or $17 A$ of this title against any person, the Commission or the appropriate regulatary agency may impose a cionl penalty if it finds, on the record after notice and opportumity for bearing, that such person -

(1) has willfully violated any provision of the Securities Act of 1933, the Investment Company Act of 1940, the Investment Advisers Act of, of this Act, or the rules or regulations therewnder, or the rules of the Municipal Securities Rulemaking Board:

(2) has willfully aided, abetted, counseled, commanded, induced, or procured such a wolation by any other person;

(2) has willfully made or caused to be made in any application for registration or report required to be filed with the Commission or with any other appropriate regulatory agency under this chapter, or in any proceeding before the Commission with respect to registration, any statement which was, at the time and in the light of the circumstances under which it was made, false or misleading with respect to any material fact, or has omitted to state in any such application or report aty material fact which is required to be stated therein; or

(4) has failed reasonably to supervise, within the meaning of section 15(b)(4)(E) of this title, with a view ro preventing violations of the provisions of such statutes, rules and regulations, another person who commits such a violation, if such other person is subject to his supervision; and that such penalty is in the public interest. 
Aldus kan worden gesteld dat voor het opleggen van een civiele geldboete wordt vereist dat een dergelijke sanctie van algemeen belang, "public interest", moer zijn en dat de overtreding opzettelijk, "willfully", begaan moet zijn. Wanneer is het opleggen van een geldboete van allgemeen belang? In section $21 \mathrm{~B}$ onder c van de Securities Exchange Act ' 34 heeft de wetgever zes factoren aangegeven op grond waarvan de ALJ dient te bepalen of het opleggen van een civiele geldboete mogelijk is of niet. Volgens voornoemd arrikel zijn de zes factoren:

1. is de gedraging gepaard gegan met frade, bedrog, manipulatie of is er sprake van ber opattelijk dan wel werwijubar negenen wan de regelgeving;

2. is er ten gevolge wan de gedraging sprake wan (in)directe letsel dan wel schade ioegebracht an cen ander (rechts)persoon;

3. in welke mate is er sprake wan onrechtwardigde temijking bij de tegenpartij. rekening boudende met de evenutuel ongedaan gemaakte schade;

4. is de (rectis) persoon al eens door de SEC, een andere agency of een zelfregulerende arganisatie weroordeeld voor bet overtreden wat de federale- of statelijke effectenwetten, dan wel regels van zelfregulerende organisaties of heeft deze (rechts)persoon in bet (nabije) verleden een gerechtelijk bevel opgelegd gekregen dan wel een veroordeling door de rechtbank natr ad leiding wan het overtreden van voornoemde wetten, regels en/of elle ander misdrijf of overtreding zoals genoemd in section $15(b)(A)(B)$ wan de Securities Exchange Act34;

5. is de behoefte anumezig om de (rechts)persoon en evenuele andere personen af te schrikken voor het verrichten wan dergelijke gedragingen in de toekomst;

6. zijn er andere rechosgronden anwezig die het opleggen wan een civiele geldboete noodsakelije maken?

Bij de vaststelling om al dan niet een civiele geldboete op te laten leggen mag de SEC volgens section $21 \mathrm{~B}$ onder (d) van de Securities Exchange Act'34 rekening houden met bewijs aangevoerd door de tegenpartij ${ }^{163}$. Dit bewijs kan inhouden een bewijs van (on)vermogen om de geldboete te voldoen; de gevolgen van een op te leggen geldboete voor de toekomst van zijn bedrijf en de mogelijkheid om te boete te kunnen betalen, rekening houdende met derden. 


\section{Section $21 B$ Ciwil remedies in administrative proceedings \\ (d) Evidence concerning ability to pay}

In any procedting in which the Commission or the appropriate regalatory agency mat impose a penaty under this section, a wespondent may present endence of whe respondent's ability to pay such peralty. The Commission or the appropriate regulatory agency may, in its discretion, consider such evidence in determining wherher such penaly is in the public interest. Sucth evidence maty relate to the extent of such person's ability to contivue in business and the collectability of a penalty, taking into accownt any other claims of the United Stater or third paties upon sucb person's assets and the amount of such person's assets.

Nadat aan de vereisten voor het kunnen opleggen van een geldboete is voldaan, dient de ALJ de hoogte van de boete te bepalen. Ook hier is de wetgever weer behulpzaam geweest. Hij heeft de geldboetes onderverdeeld in drie categorieën en de hoogte van deze boetes afhankelijk gesteld van de desbetreffende categorie, ook wel "tiers" genoemd. In section $21 \mathrm{~B}$ onder b van de Securities Exchange Act ' 34 zijn de drie tiers te vinden. Samenvattend komen

zij op het volgende neer:

\section{Categorie I:}

Voor alle gedragingen zoals genoemd onder a van section $21 \mathrm{~B}$ van de Securities Exchange Act geldt een geldboete met een maximum van $\$ 5.000^{164}$ voor een natuurlijke persoon en van $\$ 50.000^{165}$ voor een rechtspersoon. De gedragingen waarna wordt verwezen zijn:

* het opzetrelijk overtreden van regels uit de Securities Act'33, de Securities Exchange Act'34, de Investment Company Act"40, de Investment Advisers Act' 40 of van regulering gebaseerd op deze wetten dan wel de regels van de Municipal Securities Rulemaking Board ${ }^{166}$;

* het opzettelijk behulpzaam zijn bij een overtreding van de regels zoals hierboven genoemd. Dit kan bestaan uit het geven van adviezen, maar kan tevens inhouden het bevelen tot de overtreding; het aanzetten hiertoe of her werschaffen van middelen om zodoende de overtreding te begaan ${ }^{167}$;

Gezien de koers van de euro kan gesteld worden dar $\$ 5.000,-$ ongeveer overeenkomt met $€ 5.000$,-

16615 U.S.C. $\$ 78 \mathrm{u}-2$ (a) (1) of section $21 \mathrm{~B}$ (a) (1) van de Securities Exchange Act 40 versie 1999 .

16715 U.S.C. $\$ 78 \mathrm{u}-2$ (a) (2) of section $21 B$ (a) (2) van de Securities Exchange Act'40 versie 1999 . 
* het opzettelijk doen of meewerken aan onjuiste verklaringen in een bij de SEC in te leveren of ingeleverde registratie of (periodieke) rapportage. Hiertoe behoort ook het niet (juist) inlichten van de SEC wanneer deze om (specifieke) informatie heeft verzocht ${ }^{168}$;

* het niet voldoen aan het houden van toezicht zoals is vereist in section 15 (b)(4)(E) van de Securities Exchange Act'34. In dat artikel wordt onder meer gesteld dat het toezicht op een onjuiste wijze wordt uitgeoefend indien de toezichthoudende persoon iemand, die onder zijn toezicht staat, aanzet of helpt bij het overtreden van de effectenregelgeving en daarom een dergelijke overtreding niet voorkomt 169 .

\section{Categorie II}

Ongeacht de bedragen genoemd in categorie $I$ is de maximum geldboete voor gedragingen van een natuurlijk persoon een bedrag ad. $\$ 50.000^{170}$ en voor rechtspersonen bedraage dit $\$ 250.000^{171}$. Voorwaarde hiervoor is

* dat de gedragingen gelijk zijn aan die zoals genoemd in categorie I, maar daarnaast ook

* vergezeld gaan van fraude, bedrog, manipulatie, opzettelijk of roekeloos negeren van de regelgeving ${ }^{172}$.

\section{Categorie III}

Ongeacht de bedragen genoemd in de categorieën I en II is het maximumbedrag van een geldboete voor naruurlijke personen gelijk gesteld aan $\$ 100.000^{173}$ en voor rechtspersonen aan $\$ 500.000^{174}$.

\footnotetext{
168 U.S.C. $\$ 78 \mathrm{u-2}$ (a) (3) of section $21 \mathrm{~B}$ (a) (3) wan de Securities Exchange Act'40 versie 1999.

16915 U.S.C. $\$ 78$-2 (a) (4) of section 21 B (a) (4) van de Securities Exchange Act 40 en 15 U.S.C. $\$ 78$ u-2 (b) (1) ook wel secrion 21 B (b)(1) van de Securities Exchange Act'34 genoemd. (Beide versie zijn uir 1999).

170 Idem in euro's.

17 idem in euro's.

17215 U.S.C. $\$ 78 \mathrm{u}-2$ (b) (2) of section $21 \mathrm{~B}$ (b) (2) wan de Securities Exchange Act 40 versie 1999.

173 Ongeveer $€ 100.000$,-

174 Ongeveer $€ 500.000$,-.
} 
Onder deze categorie vallen alle gedragingen die:

* gelijk zijn aan die zoals genoemd in categorie I; en

- die vergezeld gaan van fraude, bedrog, manipulatie, opzetrelijk of roekeloos negeren van de regelgeving; en

- die (in) direct geresulteerd hebben in

- aanzienlijke verliezen óf

- een significant risico dan wel een aanzienlijk verlies voor andere personen òf

- een aanzienlijke financiële winst voor de overtreder ${ }^{175}$.

In geval van een Cease and Desist procedure, het bevel om te doen of om juist na te laten, mag de SEC de ALJ verzoeken om ook een civiele geldboete op te leggen. Zoals hiervoor al is aangegeven, kan de SEC de rechter in een civiele injunctionprocedure ook om naleving van een eerder verleende Cease and Desist order verzoeken, door een civiele geldboete op te laten leggen. In deze gevallen mag de ALJ ook de accounting and disgorgement sanctie toepassen ${ }^{176}$.

Wanneer een van de partijen of een derde-belanghebbende het niet eens is met de uitspraak van de $A L J^{177}$, kan deze na diens initial decision in beroep. Doet hij dat niet, dan gaat het vonnis van de ALJ in kracht van gewijsde en geldt het als het officiële standpunt van de SEC ${ }^{178}$. Deze uitspraak van de ALJ wordt volgens rule 360 (c) van de rules regarding hearings, behorende bij de SEC's Procedural Rules, gepubliceerd in een officiële SEC publicatie; de SEC Docket ${ }^{179}$.

\section{Rule 360 Initial Decision of hearing officer}

(a) When required.

Unless the Commission directs otherwise, whe hearing offices shall prepare an initial decision in any proceding in which the Commission directs a hearing officer to preside at a hearing, provided, bowever, that an initial decision may be waived by the parties with the consent of the hearing officer pursuant to Section 201.202.

15 U.S.C. $\$ 78$ u-2 (b) (3) of section $21 B$ (b) (3) van de Securities lixchange Act'40 versie 1999 .

176 De ALJ mag het bevel geven om de boeken van voonoemde partijen na te kijken en indien mogelijk kan hij besluiten over te gaan tor ontnemen wan wederrechtelijk verkregen voordeel inclusief de rente over het bedrag dat overtreder heeft verzuind om aan te geven. Vgl. 15 U.S.C. $\$ 78 \mathrm{u}-2$ (e) of section $21 \mathrm{~B}$ (e) van de Securities Exchange Act'40 versie 1999.

177 C.F.R. $\$ 201.410$ (a) Ofwel section 410 (a) van de SEC's Procedural Rulles.

17817 C.F.R. $\$ 201.360$ (a) Ofwel section 360 (a) van de SEC's Procedural Rulles.

179 17 C.F.R $\$ 201.360$ (c). 
(c) Filing, service and publicarion. The bearing officer shall file the initial decision with the Secretary. The Secretary shall promptly serve the initial decision upon the parties and shall promptly publish notice of the filing thereof in the SEC News Digest. Thereafter, the Secretary shall publish the initial decision in the SEC Docket; pronided, howewer, that in nonpublic proceedings no notice shall be published wnless the Commission otherwise directs.

Het beroep geschiedt bij het volledige bestuur van de SEC. Niet altijd wordt een dergelijk verzoek gehonoreerd. Het bestuur mag dit weigeren ${ }^{180}$. Het volledige bestuur van de SEC, de Commission, zal de beslissing genomen door de ALJ beoordelen op grond van het dossier zoals dat door de ALJ is samengesteld en aan hen is verzonden. De Commission mag de getuigen niet nog eens horen; die taak is immers aan de ALJ voorbehouden. In het dossier zijn alle bewijsstukken op grond waarvan de ALJ heeft beslist te vinden. Voorts bevat het dossier ook het beroepschrift ${ }^{181}$.

Mocht men het ook niet eens zijn met de uitspraak van de Commission, omdat deze bijwoorbeeld de uitspraak van de ALj niet verwerpt, kan men volgens section 25 van de Securities Act' 34 in hoger beroep bij een Amerikaanse Court of Appeals die zonodig de uitspraak van de Commissie kan verwerpen.

\section{Section 25 Court Review of Orders and Rules}

a.l. A person aggrieved by afinal onder of the Commission entered purisant to this title may obrain weview of the order in the United Sutes Count of Appeals for the crincut in which be resides or has bis principal place of business, or for the District of Columbia Ciwnt by filing in such court within sixg days after the entry of the order, a written perition requesting that the order be nodified or set aside in whole or in part.

De aan het begin van deze paragraaf gemaakte opmerking dat de administratieve procedure "de enige procedure is warvan gezegd kan worden dat de SEC daar de meeste invloed op heeft", zal na de volgende paragraaf nog duidelijker worden. Immers, in deze civielrechtelijke procedure kan de SEC niet meer zelf beslissen, maar is het de rechtbank die alle beslissingen neemt. De SEC is dan een van de partijen in het geding, maar dan een met een bijzondere positie.

18117 C.E.R. $\$ 201.351$ Oftewel secrion 351 van de SEC's Procedural Rules. 


\subsubsection{De civielrechtelijke procedure}

Naast de hiervoor besproken administratieve procedure, heeft de wetgever de SEC ook de mogelijkheid gegeven om bij de federale rechtbank een civiele procedure te starten. De wetten waarin men deze bevoegdheid terug kan vinden zijn: de Securities Act $33^{182}$; de Securities Exchange Act $34^{183}$; de Investment Company Act' 40 en de Investment Advisers Act $^{\prime} 40^{184}$. De tekst van de Securities Act 33 is als volgt:

\section{Section 20 Injunctions and prosecution of offenses}

(b) Whenever it shall appear to the Commission that any person is engaged or about to engage in any acts or practices wbich constitute or will constitute a violation of the provisions of this subchapter, or of any rule or regulation prescribed under authority thereaf, the Commission may, in its discretion, bring an action in any district court of the United States, or United States court of any Territory, to enjoin such acts or practices, and upon a proper showing, a permanent or temporary injunction or restraining order shall be granted without bond...

Centraal in een civiele injunctionprocedure is de term "equitable" dat in dit verband gelijk gesteld kan worden aan de "redelijkheid en billijkheid". In deze procedure, die wordt bepaald door de Federal Rules of Civil Procedure (FRCP) ${ }^{185}$, zal de SEC eerst om een tijdelijk en later om een permanent gerechtelijk bevel verzoeken. Naast de injunction kan de rechter ook andere civielrechtelijke sancties opleggen. De voorwaarde is wel dat de SEC daar om moet hebben verzocht.

De civiele injunctionprocedures beginnen met het verzoek om spoedvoorzieningen, te weten een verzoek van de SEC om een voorlopig gerechtelijk bevel en eventueel het verzoek om het vermogen van de gedaagde te bevriezen ${ }^{186}$. Tijdens het proces zal duidelijk moeten worden of de gedaagde inderdaad de federale effectenregelgeving heeft overtreden. Daarnaast zal de SEC ook moeten aantonen dat de kans op toekomstige overtredingen zeer waarschijnlijk is. De rechter zal na een onderzoek in

9 (e) genoend (versie 1999).

185 De FRCP, 28 U.S.C., geven de regels aan waaraan alle civiele rechtszaken, die bij de federale rechtbanken aanhangig worden gemaakt, aan dienen te voldoen. 
zijn vonnis aangeven of de injunction blijwend moet zijn. Daarnaast zal hiij aangeven of er ook andere bijkomende sancties moeten worden toegepast. Deze civiele sancties worden "ancillary reliefs" genoemd.

De sancties die in een civiele injunctionprocedure kunnen worden opgelegd zijn:

1. een voorlopige of permanente injunction en eventueel

2. bijkomende sancties:

a. disgorgement of profits; $b$. voorlopige of permanente schorsing dan wet ontzetting uit bepaalde functies; $c$. bet opleggen van civiele geldboetes; $d$. bet benoemen van special onderzoekscommissie, e. bet benoernen van een onafhankelijke overkoepelend of een accountantcommissie; ff het instellen van bijzondere toezicht- en afwikkelingsprocedures; $g$. het benoemen van trustees; $b$. het nietig verklaren wan transacties; $i$. het bevriezen van vermogen; $j$. bet a anstellen van curators

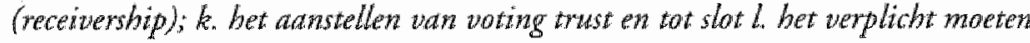
volgen van specifieke cursussen.

3. Insider Trader penalties

De injunction

Evenals in de administratieve procedure het geval is, kan er in de civielrechtelijke procedure ook een gerechtelijk bevel, een injunction, worden uitgevaardigd. In beide procedures betreft dit bevel een gebod tot het actief verrichten van bepaalde handelingen of het juist nalaten van de betwiste gedraging. De civiele injunctionprocedure kent twee soorten injunctions: de tijdelijke of "preliminary injunction" en de hierop volgende blijvende of "permanent injunction"187. In het eerste geval zal de SEC in haar verzoekschrift om een injunction aan moeten geven dat de gedragingen van gedaagde bedreigend zijn voor de belangen van het beleggend publiek. In het tweede geval zal zij moeten bewijzen dat de Amerikaanse federale effectenregelgeving is geschonden, het is dan aan de civielrechtelijke rechter om uit te maken of dat inderdaad het geval is $^{188}$. Mocht de rechter na het onderzoek ter terechrzitting menen dat de wet inderdaad is geschonden, kan hij overgaan tot het uitvaardigen

187 Gewijzigde omstandigheden zouden later aanleiding kunnen geven om een permanente injunction nier levenslang te laten bestaan. De gedaagde zal dar wel eerst aan de rechter moeten aantonen. Zie Maletta, J. B., Litigating SEC Injunctive Artions in: Kirkpartrick and Lockhart L.L.... The Securities Enforcement Mannat: tactics and strategies, a.w., p. 238.

18 Maletta, J.B., Litigating SEC Injunctive Actions in: Kirkpartrick and Lockhart L.L.P., The Securities Enforcement Manual: tactics and strategies, a.w., p. 206. 
van permanent bevel. Indien hij het tegendeel van mening is, dan wordt het tijdelijke bevel ingetrokken.

Om te voorkomen dat partijen stukken of ander materiaal ongeschikt voor bewijs maken, verzoekt de SEC voorafgaand aan het tijdelijke bevel. niet zelden om een "temporary restraining order". In rule 65 van de FRCP zijn de algemene regels voor de temporary restraining order te vinden:

\section{Rule 65 Injunctions}

(b) Tempotary Restraining Order; Notice; Hearing; Dumation.

A temporary restraining ovder may be gxanted without written or ard notice to the adverse party or that party's attorney only if

(1) it clearly appears from specific facts shown by affidavit or by the verified complat int that immediate and itmeparable injums, loss, or damage will result to the applicant before the adverse party or that party's attorney can be beard in opposition, and

(2) the applicant's attorney certifies to the court in writing the efforts, if anys which bave been made to give the notice and the reasons supporting the clatm what wotce showld not be required.(..)

In tegenstelling tot de reguliere civiele injunctionprocedure waarin beide partijen die tot gewone burgers worden gerekend dezelfde bevoegdheden hebben, gelden in een procedure van de SEC andere regels dan uit rule 65 FRCP blijkt. Een voorbeeld hiervan is het vereiste dat de SEC voor een preliminary injunction; voor een temporary restraining order of voor een permanent injunction niet hoeft aan te geven dat er sprake is van onherstelbare schade of van "immediate and irreparable injury" ${ }^{\text {" } 89}$. Zij dient slechts aan te tonen dat ${ }^{190}$ :

I. er een federale wetsovertreding is, en

II. het zeer watarschijnlijk is dat er een toekomstige overtreding zal phatsvinden.

Dit heeft de U.S. Court of Appeals in de zaak SEC v. Savoy bepaald:

"the ultimate test is whether the defendant's past conduct indicates (. .) that there is a reasonable likelihood of further violation(s) in the future(...) "wit

Maletta, J.B., Litigating SEC Injunctive Actions in: Kirkpartrick and Lockhart L.L.P., The Securities Enforcement Manual: tactics and strategies, a.w., vgl. p. 206 en p. 234 .

Maletta, J.B., Litigating SEC Injunctive Actions in: Kirkpartrick and Lockhart L.L.P., The Securities Enforcement Manual: tactics and sirategies, a.w., p. 206. 
In SEC v. Steadman ${ }^{192}$ geeft de rechter, met een verwijzing naar een eerdere zaak ${ }^{193}$, aan wanneer het zeer waarschijnlijk is dat er een toekomstige overtreding zal plaatsvinden:

"The relevant factors we consider when assessing the likelihood of recurrent violation include "whether a defendant's violation was isolated or part of a pattern, whether the violation wats flagrant and deliberate or merely technical in nature, and whether the defendant's business will present opportunities to violate the law is the futture. "SEC w. First City Fin. Corp., 890 F.2d 1215, 1228 (D.C. Cir.1989).

In de zaak van de SEC tegen First City Financial Corporation komen de criteria voor opleggen van een injunction op het volgende neer:

a. was bet een eenmalige overtreding of werd de overtreding meermalen gepleegd;

b. was het pen overduidelijke en opzettelijke overtreding of meer een van technische aard: $^{194}$

c. biedt de onderneming de gedadagde mogelijkheden om toekomstige wetsovertredingen te began?

Daarnaast heeft de rechter in SEC v. Steadman aangegeven dat een injunction bedoeld is voor personen of bedrijven die de wer opzettelijk overtreden of die een werkwijze hanteren dat bedreigend is voor her beleggend publiek.

"Injunctive relief is reserved for willful lawbreakers or those whose operations are so extremely or persistently slopty as to pose a continuing danger to the investing public..."

In de literatuur worden nog andere criteria genoemd die bepalend kunnen zijn bij het wel of niet werlenen van permanente injunctions.

192 SEC v. Steadman, 967 F. 2d p. 636 (D.C. circuit 1992). Steadman, hoofd van een beleggingsmaatschappij, werd door de SEC voor de civiele rechter gedaagd wegens overtredingen van de effectenwetgeving. De SEC verzocht de rechter tevergeefs om de afgifte van een permanente injunction.

193 SEC v. First Ciry Financial Corporation Lrd., 890 F.2d 1215, 1228 (D.C. ciruit 1989).

19 In de SEC $v$. Steadman wond de rechter dat er geen permanente injunction hoeft te worden gegeven want i.c. voldeed men niet aan de criteria hiervoor. De overtredingen waren namelijk wan technische aard en werden altijd na een warschuwing van de SEC onmiddellijk gecorrigeerd. Zie SEC v. Steadman, a.w., p. 648. 
Tot deze maatstaven, die niet cumulatief zijn, behoren:

a. De ervast wan eerder begane overtredingen;

b. De mate watrin de gedadgde volhardt in zijn onsshuld of de mate waarin de gedaagde aangeeft bewust te zijn wan zijn gedraging;

c. Is de gedaagde nog werkzaam binnern de effectemuereld of niets

d. De leeftijd gezondheid en lof persoonlijke omstandigheden van de gedaagde 195 .

Evenals in de administratieve procedure, zijn er ook in de civiele injunctionprocedure consequenties verbonden aan het niet opvolgen van een rechterlijk bevel. In dit geval kan de overtreder beschuldigd of aangeklaagd worden voor het plegen van strafrechtelijke of civielrechtelijke minachting van de rechtbank. Daarnaast kan het ook zijn dat registratie van de overtreder op wettelijke grond, bijvoorbeeld section 15(b) (4)(C) van de Securities Exchange Act'34196, wordt ingetrokken. Deze bijkomende gevolgen van een injunction, de "collateral consequences", kunnen zeer verstrekkende gevolgen hebben; men kan zelfs uit de effectenbranche worden geweerd. Hierdoor zal de overtreder genoodzaakt zijn om zijn brood op een andere wijze te verdienen, wat niet altijd even makkelijk zal zijn. Deze verstrekkende gevolgen kunnen redenen zijn voor de rechter om een permanente injunction niet op te leggen. Uit de eerder genoemde SEC v. Steadman zaak, blijkt duidelijk dat de collateral consequences meegenomen worden in de overweging om wel of geen permanent injunction op te leggen:

"(...) A permanent injunction is 'a drastic remedy" and should not be granted lightly especially when the conduct bas ceased"(..." no7

Maletta, J.B., Litigating SEC Injunctive Actions in: Kirkpatrick and Lockhart L.L. P., The Securities Enforcement Manual tactics and strategies, a.w., p. 234-235.

I5U.S.C. $\$ 780$ (b)(4)(C) (versie 1999): "The Commission, by order, shall censure, place limitations on the acrivities, functions, or operations of, suspend for a period not exceeding twelve months, or revoke the registration if any broker or dealer if it finds, on the record after notice and opportunity for hearing, that such censure, placing of limitations, suspension, or revocation is in the public interest and that such broker or dealer, whether prior or subsequent to becoming such, or any person associated with such broker or dealer, whether prior or subsequent to becoming so associated (...) is permanently or temporarily enjoined by order, judgment, or decree of any court of competent jurisdicrion from acting as an investment adviser, underwriter, broker, dealer, municipal securitiesdealer, government securities broker, government securities dealer, transfer agent, foreign person $(\ldots)^{n s}$ 
De bijkomende sancties

Naast de injunction kan de rechter besluiren om, ter ondersteuning van de injunction, een bijkomende straf op te leggen. Afhankelijk van de soort overtreding zal de SEC in haar verzoekschrift, de rechter om een of meer bijkomende straf(fen) vragen. Deze straffen, ook wel equitable remedies genoemd, vinden hun oorsprong in de rechrspraak. In 1984 heeft het Amerikaans Congres deze remedies een wettelijke grondslag gegeven. De wetten waarin men de bijkomende straffen kan vinden zijn: De Insider Trading Sanctions Act '84 (ITSA); de Insider Trading and Securities Fraud Enforcement Act' 88 en tot slot de eerder genoemde Remedies Act uit ' $90^{198}$. Ook (potentiële) overtreders maken gebruik van de nieuwste technologische ontwikkelingen. Dit heeft zijn invloed op de toepasbare sancties. Om slagvaardig op te kunnen blijven treden, maken ook de bijkomende sancties een on twikkeling door. Dit heefr tot gevolg dat de rechters steeds nieuwe bijkomende sancties kunnen toepassen. Om zich een beeld van de soort sancties te kunnen vormen, volstaan de hier behandelde bijkomende sancties. $\mathrm{Na}$ een uitvoerige bespreking van de eerste drie sancties, zullen de resterende globaal worden behandeld.

a. Disgorgement of profits ofwel ontneming van wederrechtelijk verkregen voordeel:

Deze sanctie is eerder aan de orde geweest bij de administratieve procedure. Het zal duidelijk zijn dat deze sanctie zich richt op her financieel verkregen voordeel uit wederrechtelijke gedragingen. Niet alleen de overtreder, maar ook diens relaties kunnen deze sanctie opgelegd krijgen. Het zal niet altijd even duidelijk zal zijn welk deel van de winst afkomstig is uit illegale gedragingen. Daarom heeft de rechter besloten dat:

"all profits gained while defendants were in wiolation of the law constituted ill-gotten gains" 
Dit wil zeggen dat alle winst gemaakt ten tijde wan de overtreding, beschouwd moet worden als zijnde onfechtmatig verkregen en dus vatbaar voor de sanctie van disgorgement ${ }^{199}$.

b. Temporary or permanent bar or suspension oftewel de voorlopige of permanente schorsing dan wel ontzetting uit bepaalde functies ${ }^{200}$. Deze sanctie is, evenals in een administratieve procedure, zeer zwaar. De toevoeging is dat in deze procedure de directie(leden) van een onderneming de sanctie opgelegd kunnen krijgen. Dit is in de administratieve procedure niet mogelijk. Gezien de vergaande gevolgen van een eventuele uitstoting uit de effectenbranche, heeft het Congres in de wetgeving bepaald dat deze sanctie alleen mag worden toegepast wanneer aangetoond kan worden dat de gedaagde de anti fraude bepalingen van - onder meer - de Securities Exchange Act' 34 heeft overtreden. Voorts moet, volgens section 21 van laatstgenoemde wet, uit het door gedaagde gevoerd beleid blijken dat hij niet geschikt is om een dergelijke leidinggevende positie te bekleden ${ }^{201}$.

\section{Section 21 Investigations and Actions}

d(2) In any proceeding under paragraph (I) of this subsection, the court may probibit, conditionally or unconditionally, and permanently or for such period of time as it shall determine, any person who violated section 10 (b) of this Act or the rules or regulations thereunder from action as an officer or director or any issuer that has a class of securities registered pursuant to section 12 of this Act or that is required to file reports pursudant to section 15 (d) of this Act if the person's conduct demonstrates substantial unfitness to serve as an officer or director of any such issuer....).

Wanneer de SEC van mening is dat de gedaagde niet meer binnen de effectenwereld werkzaam zou mogen zijn, wil dat niet zeggen dat de desbetreffende persoon deze sanctie daadwerkelijk krijgt opgelegd. Om te voorkomen dat een dergelijke sanctie all te lichtvaardig wordt toegepast, zijn er in de Amerikaanse rechtspraak criteria ontwikkeld aan de hand waarvan de rechters kunnen besluiten of uit het beleid, gevoerd door

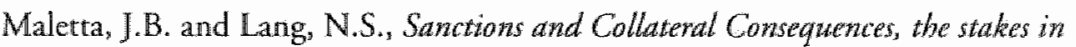
SEC Enforcement actions in: Kirkparrick and Lockhart L.L.P., The Securities Enforcement Mamual: tactics and strategies, a.w., p. $148-149$.

Deze functies kunnen zijn: "employee, officer, director, member of an advisory board, inwestment adviser or underuriter for an investment compand". Zie section 9 (b) van de Investment Company Acr "40 Oftewel 15 U.S.C. $\$ 80 \mathrm{a}-9$ (b). 
gedaagde, inderdaad de conclusie kan worden getrokken dat hij ongeschike is. Immers,

"the loss of livelihood and the stigma attached to permanent exclusion from the corporate suite ceriainly requires more ${ }^{2202}$

Deze criteria zijn:

i. Waren de overtredingen van de gedaagde ernstig genoeg?

ii. Is de gedaagde een recidivist; beeft bij de effectenregelgeving eerder overtreden?

iii. In hoeverre was de gedalgde (bewust) betrokken bif of had hij kennis van het gevoerd beleid?

iv. In hoeverre badden eventuele aandeelhouders de mogelijkbeid om zich tegen bet beleid van gedande te beschermen of was dit niet mogelijk ondat gedaagde een meerderbeidsbelang bad?

1. Staan de belanger van het beleggend publiek op het spel?

wi. Hoe watarchijniijk is het dat de gedadgde in de toekomst een dergelijke overtreding nogmaals zal begaan?

Aan de hand van bovenstaande criteria kan de rechter zich een duidelijk beeld vormen van de gedaagde en/of diens overtreding en weloverwogen besluiten om deze uit de effectenbranche te bannen of niet.

c. Het opleggen van civiele geldboetes

Ook deze sanctie is eerder aangetroffen bij de administratieve procedure. Her verschil met de civiele geldboete in een administratieve procedure is niet alleen gelegen in de hoogte van her geldbedrag. In de civiele injunctionprocedure is de rechter bevoegd hoger boetes op te leggen dan de wettelijke bedragen aangeven. Dit zal het geval zijn wanneer het bedrag van de illegale winst van de gedaagde boven de maximale geldboete ligt. In section 20 (d) van de Securties Act ' 33 is dat als volgt vermeld ${ }^{203}$ :

SEC V. SPRECHER, 1996, U.S. APP. LEXIS 10795 (DC CIRCUTT 1996).

$\mathrm{Vgl}$. The Securities Enforcement Manual tactics and strategies, a.w. p. 153, noot 126.

20. Vgl. 15 U.S.C. $\$ 77$ t (d) en 15 U.S.C. $\$ 78 \mathrm{u}$ (d) (3) ofwel section 21 (d)(3)(B) van de Securities Exchange Act "34 (versie 1999). 


\section{Section 20 Injunctions and Prosecution of Offences}

(d) Whenever it shall appear to the Commission that any person has violated awy provision of this Act, the rules or regulation thereunder, (...), the anown of penaly for each such violation shall not exced the greater of $(1) \$ 50,000$ for a natural person or $\$ 250,000$ for any other person, or (ii) the gross amownit of pecuniary gatin to such defendant as a result of the wiolation. (...).

Naast voornoemd verschil mag de rechtbank de boete niet alleen opleggen aan personen en bedrijven die bij de SEC staan geregistreerd, maar aan eenieder die de wetgeving overtreedt. Een ander verschil tussen de geldboete opgelegd in voornoemde procedure en in een civiele injunctionprocedure is dat opzet geen vereiste is voor het kunnen opleggen wan een geldboete. In de civiele injunctionprocedure kan de rechter al een geldboete opleggen wanneer aangetoond wordt dat de effectenregelgeving is overtreden of wanneer een Cease and Desist order niet wordt nageleefd ${ }^{204}$. In section 21 van de Securities Exchange Act'34 heeft de Amerikaanse wetgever het volgende aangegeven:

\section{Section 21 Investigations and Actions}

(d) (3) Whenever it shall appear to the Commission that any person has violated any provision of this Act, the rules or regulations therewder, or a cease-and-desist order entered by the Commission pursuant to section $21 \mathrm{C}$ of theis $A c t,(.$.$) , the$ Commission may bring an action in a United States district cowrt to seek, and the court shall have jurisdiction to impose upon a proper showing a civil penalty to be paid by the persan who committed such violation.

Tot slot, maar zeker niet het laatste verschil ${ }^{205}$ tussen de civiele geldboete in een administratieve- en dezelfde boete in een civiele injunctionprocedure, de boetecategorieën. Ook in de injunctionprocedure komt men de onderverdeling in categorieën tegen. Wanneer de tiers van de administratieve procedure en die van de civiele injunction procedure naast elkaar worden gelegd, valt op dat - op de kleine redactionele verschillen na - de eerste tiers inhoudelijk verschillen en de ander twee grotendeels met elkaar overeen komen. In tier 1 of categorie 1 van de (d) (3) ofwel section 21 (d) (3) van de Securicies Exchange Acr 34 (versie 1999). In de praktijk zullen er ongetwijfeld meer verschillen merkbar zijin. Zo is het niet ondenkbaar dar de SEC in haar werzoekschrift rekening zal houden met de hoogte van de op te leggen geldboete en de in soortgelijke zaken eerder doot dat betreffende district court toegekend bedrag. In een administratieve procedure zal dit minder zwaar wegen omdat de woltallige Commissie een initial decision kan overulen waardoor de SEC officieus steviger in haar schoenen staat. 
civiele injunctionprocedure mag de rechtbank voor welke overtreding van de effectenregelgeving dan ook, met inachtneming van de feiten en omstandigheden, zelf de hoogte van de geldboete vaststellen ${ }^{206}$.

\section{Section 21 Investigations and Actions}

(d) (3)(B)(i) The amount of the penalty shall be determined by the court in light of the facts and circumstances. For each violation, the amount of the penalty shall not exceed the greater of $(I) \$ 5,000$ for a natural person or \$ 50,000 for any other person, or (II) the gross amount of pecuniary gain tosuch defendant as a result of the violation.

\section{Section $21 B$ Civil Remedies in Administrative Proceedings}

(b)(1) the maximum amount of penalty for each act or omission described in subsection (a) shall be \$5,000 for a natural person or $\$ 50,000$ for any other person.

De maxima zijn in beide procedures gelijk, maar indien het financieel genoten voordeel boven deze bedragen uitstijgt, kan de rechrbank deze illegaal verkregen winst als een geldboete opleggen. In de administratieve procedure is de ALJ daar niet toe bevoegd.

\section{d-1. De resterende bijkomende sancties}

Het benoemen van een speciaal onderzoekscommissie: de "Independant special counsel" Deze sanctie spreekt voor zich. In dit geval stelt de rechtbank een onafhankelijke commissie in bestaande uit (onder meer) juristen, met de opdracht om te assisteren in de desbetreffende zaak. Het assisteren kan bestaan uit leiden van een onpartijdig onderzoek en/of het geven van een onpartijdige conclusie op grond warvan de rechter kan beslissen.

Bij het benoemen van een onafhankelijk overkoepelend- of een accountantcommissie, de independant oversight- of de audit committee, worden zelfstandige commissies door de rechtbank ingezet on onder meer een onafhankelijk accountantsonderzoek bij een daartoe aangewezen bedrijf te doen. Uit dit onderzoek kan dan blijken of de boekhouding klopt, het beleid van het bestuur naar behoren is geweest, wat het daadwerkelijk vermogen of de gemaakte winst van de onderneming is en/of andere onderwerpen, afhankelijk. 
van de rechtzaak. De conclusies van deze commissie kan de rechter meenemen bij het vormen van zijn definitieve beslissing. Indien de rechter meent dat het in de desbetreffende zaak nodig is, kan hij besluiten om een bijzondere toezichts- en afwikkelingsprocedures, de supervisory and compliance procedure en/of voting trusts, in te stellen, dan wel een door de rechtbank benoemde trustee of curator $^{207}$ benoemen en/of de directie van de desbetreffende onderneming vervangen door een ander aangestelde direcrie. In al deze gevallen dienen de aangewezen personen de belangen van derden, de gedupeerden, tijdelijk te behartigen. Tot de gedupeerden behoren niet alleen de (particuliere) beleggers, maar ook ondernemingen getroffen door het wanbeheer van hun leidinggevenden en/of directie. Voorts kan de rechter overgaan tot het nietig verklaren van illegale transacties en/of het bevriezen van het vermogen en/of fondsen van de wetsovertreder(s) ${ }^{208}$. Dit zal hij doen wanneer hij het vermoeden heeft dat de gedaagden geen compleet overzicht hebben gegeven van hun illegaal verkregen winsten. De rechter zal in de praktijk na het bevriezen van fondsen of van her bedrijfsvermogen, afhankelijk van de zaak, een ontnemingsvordering instellen dan well een curator of een onafhankelijke accountantscommissie benoemen. Tot slot kan de rechter de overtreder(s) verplichten tot het volgen van specifieke cursussen ${ }^{209}$.

\section{Insider Trader Penalties}

Een andere sanctie die niet in de administratieve procedure kan worden opgelegd, is de "insider trading penalty" oftewel de geldboete voor het misbruiken van voorwetenschap. Deze sanctie vindt zijn oorsprong in de Insider Trading Sanctions Act uit 1984 (ITSA) en de aanvulling hierop uit 1988, de Insider Trading and Securities Fraud Enforcement Act (ITSFEA). Deze wetten hebben ervoor gezorgd dat insider trading kan worden aangepakt via de sections $20 \mathrm{~A}$ en section $21 \mathrm{~A}$ van de Securities Exchange Acr' 34 en $204 \mathrm{~A}$ van de Investment Advisers Act ' $40^{210}$. Volgens voornoemd artikelen kan de SEC een procedure aanspannen bij de district

Men spreekt van "receivers" of van een "receivership".

Bevriezen van vermogen, ook well "asset freezes" genoemd. Voor het nietig verklaren van eerder gedane transacties wordt de term "rescission" gebruikt.

Maletra, J.B. en Lang, N.S., Sanctions and Collateral Consequences in: Kirkpatrick and Lockhart L.L.P. The Securities Enforcenent manual: tactics and strategies, a.w., p. $153-156$.

15 U.S.C. $\$ 98 \mathrm{t}-1 ; \$ 78 \mathrm{u}-1$ en 15 U.S.C. $\$ 80 \mathrm{~b}-4 \mathrm{a}$. 
court en kan zij de rechter verzoeken om zowel aan de insider als aan degene die supervisie op de insider moest houden ${ }^{211}$, een civiele geldboete op te leggen. In de wet wordt dit als volgt weergegeven:

\section{Section 2LA Penalties for Insider Trading}

(a) (1) Whenever it shall appear to the Commission that any person bas violated any provision of this Act or the rules ar regulations thereunder by purchasing or selling a security while in possession of material, nonpublic information in, or has violated any such provision by communicating such information in connection with, a transaction on or through the facilities of a national securities exhange or from or throwgh a broker or dealer, and which is not part of a public offering by an issuer of securities other than standardized options, the Commission may bring an action in a United States district court to seek and the court shall have jurisdiction to impose, a civil penalty to be paid by the person who commited such violation; and

(B) maty, subject to subsection (b)(I) bring an action in a United States district court to seek, and the court shall bave jurisdiction to impose, a civil penaliy to be paid by a person who, at the time of the violation directly or indirectly controlled the person who committed such violation (...).

Voornoemde geldboete mag, volgens dit artikel niet hoger zijn dan drie keer het bedrag dat door de voorkennis is "verdiend of verloren" en reeds via disgorgement van de overtreder is ontnomen.

(2) The amount of the penalty which may be imposed on the person who committed such violation shall be deternined by the court in light of the fact and circurnstances, but shall not exceed three times the profit gained or loss avoided as a result of such unlawful purchase, sale or communication.

Wat precies onder winst of verliezen moeten worden verstaan, heeft de wetgever uitgelegd onder $21 \mathrm{~A}(\mathrm{f})$. Volgens sub $(\mathrm{f})$ van voornoemde section kijkt de rechter, een redelijke rijd nadat de desbetreffende informatie publiekelijk bekend is geworden, naar het verschil tussen de aankoopof verkoopprijs en de waarde van de effecten.

(f) For purposes of this section, "profit gained" or "loss avoided" is the difference between the purchase or sale price of the security and the value of that security as measured by the wading price of the security a reasonable period after public dissemination of the nonpublic information.

211 Volgens dit artikel kan de supervisor een geldboete opgelegd krijgen wanneer hiij onder meer wist of niet wilde zien dat een ondergeschikte misbruik wan zijn voorkennis wilde maken en desondanks niets ondernam om de overtreding te voorkomen. 
Om zoveel mogelijk overtreders te kunnen veroordelen heeft de wetgever zich gericht op de potentiële tipgevers. Om hen over de streep te trekken heeft de hij onder sub e aangegeven dat de SEC bevoegd is om deze tipgevers voor hun informatie te belonen met een maximumbedrag van 10 procent van de opgelegde geldboete ${ }^{212}$.

Niet alleen de SEC, maar ieder andere effectenhandelaar die schade heeft ondervonden door het handelen van de insider, kan met behulp van de eerder genoemde section 20A van de Securities Exchange Act '34 een procedure bij de civiele rechter te starten. De wetgever heeft in dit artikel vastgesteld dat de handelaar die handelde met voorkennis in bepaalde effecten, door eenieder die tegelijkertijd handelde in dezelfde effecten, aansprakelijk gesteld kan worden.

\section{Section 20A Liability to Contemporaneous Traders for Insider Trading}

(a) Any person who violates any provision of this Act or the rules or regulations thereunder by purchasing or selling a security while in possession of material, nonpublic information shall be tiable in an action in any court of competent jurisdiction to any person who, contemporaneously with the purbhase or sale of securities that is the subject of such violation, has purchased (where such violation is based on a salle of securities) or sold (where such violation is based an a purbase of securities) securities of the same class.

Wanneer de administratieve procedure nader wordt bestudeerd, moet worden geconcludeerd dat deze geen mogelijkheden biedt om insider trading aan te pakken. Hiervoor is de SEC aangewezen op de civiele injunctionprocedure en/of de strafrechtelijke procedure. Zij kan slechts een aanklacht indienen bij het Amerikaans Openbaar Ministerie, de federale United States Atorney ${ }^{213}$ en zo pogen om een strafrechtelijke vervolging tot stand te brengen. Aangezien de beslissing om te vervolgen bij het Openbaar Ministerie ligt, kan de SEC er niet van uit gaan dat het

212 Section 21A (e) van de Securities Exchange Act 34: "Notwithstanding the provisions of subsection (d)(1), there shall be paid from amownts imposed as a penalty ander this section and recovered by the Commission or the Attorney General, such sums, not exceed 10 percent or such amownts, as the Commistion deems apropriate, to the person or persons who provide information leading to the imposition of such penalty (...)." (versie 1999).

213 De United States Atrorney is een door de president aangestelde openbare aanklager (total 93 U.S. artorney"s) die onder meer namens de federale overheid overgaan tot het aanklagen en of her vervolgen van (rechis) personen dan wel die de overheid in civiele zaken vertegenwoordigt. Een U.S. Attorney kan in een groot district, staat, assistant U.S. attorney's onder zich hebben.. Zie 28 U.S.C. $\$ 507$. 
ook daadwerkelijk tot een strafrechtelijke vervolging zal komen. Hier heeft de SEC, in tegenstelling tot de administratieve en in de civiele injunctionprocedure, geen invloed op het verloop van de zaak.

Eerder is aangegeven dat de SEC een vergaande invloed heeft op de administratieve procedure, immers de voltallige commissie kan de initial decision van de ALJ herzien. Weliswaar kan de gedaagde in beroep bij de rechtbank, maar dat doet niet af aan de wettelijk bepaalde positie van de SEC. In de civiele injunctionprocedure is opgemerkt dat de SEC niet altijd als gelijke partij wordt beschouwd, immers zij hoeft onder meer voor de afgifte van een blijvende injunction niet te bewijzen dat er sprake is van onherstelbare schade, maar volstaat reeds met de bewering dat een toekomstige overtreding niet onwaarschijnlijk is. Of de SEC nog enig invloed heeft op de strafrechtelijke procedure zal in de volgende paragraaf aan bod komen. Daarnaast zal ook worden gekeken naar de mogelijke sancties voor overtreders van het effectenrecht en zal de vraag worden beantwoord of het strafrecht slechts een van de handhavinginstrumenten is en niet meer dan dat of dat het fungeert als ultimum remedium.

\subsubsection{De strafrechtelijke procedure}

Naast de hiervoor genoemde administratieve- en civiele injunctionprocedure, behoort ook de strafrechtelijke procedure tot het arsenaal van mogelijkheden om de overtreders van het effectenrecht aan te pakken. Zoals hierboven reeds is vermeld, ligt de regie van laatstgenoemde procedure in handen van her Amerikaanse Ministerie van Justitie, bij het Department of Justice. Aan het hoofd van dit ministerie staat de "Attorney General" die samen met de in het gehele land werkzame United States attorney offices, op federaal niveau, strafrechtelijk toezicht houdt. De "fraud unit" van voornoemde ministerie behandelt de vervolging van alle strafbare feiten waarvan zij kennis heeft genomen. Deze speciale fraude sectie kan over deze informatie beschikken doordat de Ov]'s zelf op onderzoek uitgaan óf doordat er in de media veel aandacht aan een bepaalde zaak wordt geschonken. Daarnaast kan het ook voorkomen dat de fraud unit informatie van de SEC ontvangt. Zij verwijst immers ook zaken door naar het Department of Justice, die zij strafrechtelijk vervolgd zou willen zien. De aanleiding hiervoor kan gelegen zijn in de resultaten van een door haar verricht onderzoek. Het is niet ongebruikelijk dat het Department of Justice bij haar onderzoeken de hulp 
inschakelt van onder meer de afdeling enforcement van de SEC; de Federal Bureau of Investigation (de FBI) en/of de Postal Inspection Office ${ }^{214}$.

Nadat de officieren van justitie de zaken grondig hebben bestudeerd, nemen zij het besluit om eventueel te vervolgen. Bij de toepassing van hun ruime bevoegdheid om al dan niet tot vervolging over te gaan, maken de officieren van justitie onder meer gebruik van beleidsregels die door het Ministerie van Justitie zijn vastgelegd. Deze vervolgingsrichtlijnen, die te vinden zijn in de artikelen 9-27.001 tot en met 9-27.750 van de United States Attorney Manual (U.S.A.M.), staan bekend als de Principles of Federal Prosecution (principles) ${ }^{215}$. In de principles is hun doel expliciet terug te vinden in de volgende regels:

"The principles of Federal prosecution have been designed to assist in structuring the decision-making process of attorneys for the government. For the most part, they bave been cast in general terms with a view to providing guidance rather than to mandating results. The intent is to assure regularity without reginentation, to prevent wnvarranted disparity without sacrificing necessary flexibility (...)."

Samengevat komt het er op neer dat met deze beleidsregels wordt getracht om regelmaat of uniformiteit te creëren in het vervolgingsbeleid van Justitie. Immers, een besluit om wel of niet te vervolgen kan volgens de principles gevolgen hebben voor een eventuele civiele schadevergoedingsprocedure ${ }^{216}$. Ondanks voormeld doel kan het zijn dat een Amerikaanse Officier van Justitie zich niet altijd houdt aan de beleidsregels, maar besluit om in een specifiek geval van deze principles af te wijken. Dit is, na goedkeuring van de aangewezen superieur, volgens section 9-27.140 U.S.A.M. alleen toegestaan wanneer het een eerlijke en effectieve rechtshandhaving ten goede komt.

214 Grafman, S.W., Adelman, R.M. en Plaza, C.E., Criminal Enforcement of the Securities Laws: A Primer for the Securities Practitioner in: Kirkpatrick and Lockhart L.L.P., The Securities Enforcement Manual: tactics and strategies, a.w., p. 314.

215 De in dit hoofdstuk aangehaalde beleidsregels uit de USAM, die stammen uit 1993, zijn toegepast na goedkeuring van de heer Peter Clarke, District Attoney van de Fraud Unit re Washington D.C. 


\section{U.S.A.M. 9-27.140}

A. United States Attoneys (USA) may modify or depart from the principles set forth herein as necessary in the interests of fair and effective law enforcennent within the district. Any significant modification or departure contemplated as a matter of policy or regular practice must be approved by the appropriate Assistant Attorney General and the Deputy Attorney General.

Voorts zijn in de principles de mogelijkheden tot vervolging voor een Ovj vermeld, nadat deze heeft vastgesteld dat er sprake is van "probable cause"; te vergelijken met het ons bekende redelijk wermoeden van schuld aan het plegen wan een (federaal) strafbaar feit. Volgens section 9-27.200 U.S.A.M. kan de OvJ bij aanwezigheid van probable cause besluiten om:

a. te werzoeken om ecn nader onderzoek dan wel beshiten om een nader onderzock in te stellen;

b. over te gaan tot vervalging of de a anbeweling geven om tot terwolging ower to gann:

c. niet zelf te vervolgen, matr on de zaak over te dragen an een ander district;

d. miet zelf te verwolgen, maar orn over te gawn tot het entameren van een "pretrial diversion 217 "dan wel om een ander soort buitenstrafrechtelijke matregel toe te passen:

e. niet zelf te vervolgen en om ook geen werdere actie te ondernemen.

Wanneer de $\mathrm{OvJ}$ van mening is dat hij over voldoende bewijsmateriaal beschilkt om aan te kunnen tonen dat de verdachte een federale overtreding heeft begaan, wil dat niet zeggen dat hij ook daadwerkelijk tot een vervolging over zal gaan. Volgens de beleidsregels dient de OvJ zijn besluit eerst te toetsen aan de negatieve indicatoren zoals genoemd

217 Een "pre-trial diversion" kan vergeleken worden met een alternatieve afdoening. Voor de rechtzaak kunnen verdachren de gelegenheid krijgen om bijvoorbeeld een cursus te volgen, wat na een succesvolle afronding zal leiden tot her afzien wan verdere verwolging. Garner, B.A., Black's Law Dictionary: pocket edition, a.w., p. 200. 
in section 9-27.220 U.S.A.M. Hierin wordt het de OvJ afgeraden om een vervolging in te stellen wanneer:

1. de verwolging niet in het belang van de Federatie zou zijn ${ }^{218}$; dan wel

2. de verdachte voor (hetzelfde feit) reeds in eev ander district word vervolga 219 ; en tor slat of

3. er een doeltreffend buiterstrafrechtelijk alternatief voor vervolging bestat ${ }^{20}$.

In U.S.A.M. $\$ 9-27.230$ wordt dit criterium uitgewerkt. Om te bepalen of een vervolging in her belang van de Federatie is, dient na te worden gegaan: a. Wat zijn de prioriteiten van de federale toezichthouders? Valt het vergrijp onder een federaal aandachtspunt of niet?; b. Wat is de aard en de ernst wan het vergrijp? Met andere woorden: wat voor invloed heeft het vergrijp en een mogelijke vervolging op de gemeenschap en op het slachtoffer; $c$. Wat is de graad van verwijtbaarheid wan de wetsovertreder in verhouding tor de gepleegde daad? Was hij slechrs een handlanger of was hij de leider van de organisatie?; d. Heeft de werdachte reeds een strafblad? e. In welke mate is de verdachte bereid om mee te werken met het onderzoek of met de vervolging van anderen? Is medewerking wan de werdachte wan een zodanig belang dar een eventuele vervolging ondergeschikt wordt aan dit belang? Tot $s$ lot $f$. Wat zal bij een veroordeling de eventueel opgetegde straf of maatregel zijn? Weegt de waarschijnlijke straf op tegen de rijd en mocite die in de vervolging wordt gestoken? Naast de straf of maatregel dient de OvJ ook aandacht te schenken aan de persoonlijke omstandigheden van de verdachte. Is de hij erg jong of juist oud; is hij geestelijk dan well lichamelijk niet gezond of heeft hij zijn vertrouwenspositie gebruikt om zijn wersovertredingen te plegen? Bij dit criterium dient de OvJ zijn beslissing volgens U.S.A.M. $\$ 9-27.240$ te baseren op een van de hier bij behorende subcriteria. Ten cerste de vraag of andere "arrondissementen" meer belang hebben in een eventuele vervolging? Het kan namelijk zijn dat een verwolging van een federale overtreding, juist op statclijk niveau meer invloed zal hebben omdat de verdachte daar woont of omdat de desbetreffende staat de helle vervolging heeft voorbereid. Ten tweede kan de Ov] zijn beslissing om wel of nier te vervolgen baseren op het gegeven dat vervolging in zijn "arrondissement" de meeste kans op een veroordeling heeft. "Tot slot zal de Ovj niet alleen moeten kijken naar de eventuele straf of maatregel, maar ook naar bijeenkomstige gevolgen van een eventuele veroordeling. Denk bijwoorbeeld aan de uitbanning uit de effectenwereld. Aan de hand van deze criteria zal de OvJ moeten beslissen.

Indien er een mogelijkheid tor buitenstrafrechtelijke afdoening bestaat, dient de OvJ deze niet achterwege te laten. Volgens U.S.A.M. 9-27.250 dient de OvJ rekening te houden met: 1 . De mogelijke buitenstrafrechtelijke sancties. Hier moet gedacht worden aan administratieve- of civiele sancties of de eerder genoemde pretrial diversion. 2. De waarschijnlijikheid dat er een doeltreffende sanctic zal worden opgelegd in het buitenstrafrechtelijke trace. En tot slot 3: her effect van deze wijze van afdoening op de belangen van de federale toezichthouder, zoals de SEC. 
In het besluit van de OvJ om daadwerkelijk tot vervolging over te gaan, zal aangegeven moeten worden waarvan de verdachte wordt beschuldigd. Deze voorlopige beschuldiging kan voorgelegd worden aan een Grand Jury, bestaande uit ongeveer 23 juryleden. De jury beslist aan de hand van her aangevoerd bewijs of er voldoende grond is om de verdachte formeel aan te klagen. Indien de Grand Jury meent dat er meer dan voldoende bewijs voor een strafzaak is aangevoerd, zal zij een "bill of indictment", een formele beschuldiging, afgeven waarin duidelijk wordt aangegeven waarvan de desbetreffende persoon wordt verdacht. Met de afgifte van de indictment kan het strafproces voor een rechtbank beginnen $^{221}$. In de praktijk zal de OvJ bij zeer ingewikkelde en soms erg technische zaken afzien van een strafproces en het sanctioneren van de desbetreffende gedraging overlaten aan de administratieve ALJ of de civiele rechter. De reden hiervoor is het verschil in bewijslast en de kennis van de jury. De Ov]'s vinden het in zeer ingewikkelde dan wel. in technische zaken moeilijk om de jury in duidelijke bewoordingen te overtuigen van de schuld van de verdachte. De hiervoor genoemde bewijslast is afhankelijk van de soort procedure. Wanneer het strafrechtelijk bewijs wordt vergeleken met het administratieve of civiele bewijs, moet worden geconcludeerd dat aan eerstgenoemde de zwaarste eisen worden gesteld. In zowel de administratieve als de civiele injunctionprocedure bezigt de rechtbank een norm dat "preponderance of the evidence", ook wel "balance of probability" wordt genoemd. Dit houdt simpel gezegd in dat de rechter en/of jury de partij met het meest doorslaggevend bewijs, dat wil zeggen meer dan $50 \%$, in het gelijk stelt ${ }^{222}$. In de strafrechtelijke procedure daarentegen wordt de norm "beyond a reasonable doubt" gebruikt. Deze norm, die gebaseerd is op het presumptio innocentiaebeginsel, houdt in dat niemand mag worden veroordeeld wanneer er bij de juryleden ook maar een beetje twijfel over zijn schuld bestaat ${ }^{223}$. Een OvJ die besluit om tot vervolging over te gaan, zal er zeker van moeten zijn dat hij de jury ervan kan overtuigen dat de verdachte de feiten, zoals gesteld in de indictment, heeft gepleegd.

221 Garner, B.A., Black's Law Dicrionary: pocket edition, a.w., p. 280 en 310.

222 Grafman, S.W., Adelman, R.M. en Plaza, C.E., Crinninal Enforcement of the Securities Latus: A Primer for the Securities Practitioner in: Kirkpatrick and Lockhart L.L.P., The Securities Enforcemen Manualtactics and strategies, a.w, p. 313.

223 Garner, B.A., Black's Law Dictionary: pocket edition, a.w., p. 496 en 523. 
Tot de strafbare feiten behoren niet alleen de feiten zoals genoemd in de effectenregelgeving. Zoals hieronder zal worden aangetoond, kunnen in een indictment ook feiten uit de Amerikaanse federale strafwetten ${ }^{224}$ zijn vermeld. In de effectenregelgeving heeft de Amerikaanse wetgever op verschillende wijze aangegeven dat bepaalde gedragingen strafrechtelijk kunnen worden gesanctioneerd. Een voorbeeld hiervan is section 24 van de Securities Act'33. Naast de Securities Act'33 zijn er in de Securities Exchange Act'34, de Investment Company Act'40 en de Investment Advisers Act'40 soortgeliike bepalingen te vinden ${ }^{225}$.

\section{Section 24 Penalties}

Any person who willfully wialates any of the provisions of this Act, or the rules and regulations promulgated by the Commission under authority thereof, or any person who willfully, in a registration statement filed a material fact or omits to state any material fact reguired to be stated therein or necessary to make the statements therein not wisleading shall wpan conviction be fined not more than $\$ 10,000$ or imprisoned not more than five years, or both.

Deze gedragingen kunnen zowel door natuurlijke personen als door rechtspersonen worden verricht ${ }^{226}$. Dit kan worden geconcludeerd uit de tekst van de verschillende wetten, bijvoorbeeld section 2, sub a onder 2 van de Securties Act $33^{227}$ :

\section{Section 2 Definitions}

(a)(2) The term "person" means an individual, a corporation, a partnership, an association, a joint stock company, a trust, any wincorporated onganization, or a government or political subdivision theref. (...)

De Federal Criminal Code is te vinden in de United States Code, title 18 Crimes and Criminal procedure: 18 U.S.C. $\$ 1501$ e.v.

225 Securities Act 33 section 24 of 15 U.S.C. $\$ 77 \mathrm{x}$; section 32 van de Securties Exchange Act 34 of 15 U.S.C. $\$ 78 \mathrm{ff}$, section 49 van de Investement Company Act" 40 Oftewel 1.5 U.S.C. $\$ 80 a-48$ en section 217 van de Investment Advisers Act 40 Oftewel 15 U.S.C. $\$ 80 \mathrm{~b}-17$ (versie 1999 ).

226 Jörg, N., "Strafbare rechtspersonen in Amerika; corporaties en hun functionarissen in het Amerikaans strafrecht in rechtsvergelijkend perspectief", Gouda Quint B.V., Arnhem, 1990, in het bijzonder de hoofdstukken 3 en 4 . Verder zie ook Jörg, N., "Strafbare rechtspersonen in Amerika; corporaties en bwn functionarissen in bet Amerikatans strafrecht in rechtsvergelijkend perspecticf", Gouda Quint B.V., Arnhem, 1990.

227 Ook wel 15 U.S.C. $\$ 77 b(a)(2)$ en section 3 wan de Securities Exchange Act 34 of 15 U.S.C. $\$ 78 \mathrm{c}$ (versie 1999). 
In de hiervoor genoemde wetsbepalingen komt herhaaldelijk de term "willfully" rerug. Willfully geeft aan dat de bewuste gedraging vrijwillig en opzertelijk moet zijn verricht. Deze basale definitie van willfully is niet altijd toereikend. Afhankelijk van de casus kan de definitie worden uitgebreid. Een voorbeeld hiervan is de aanvulling dat de desbetreffende verdachte wist dat hij de wetsovertreding zou begaan of dat hij het risico van de wetsovertreding accepteerde. In de jury instructies van het vijfde circuit wordt "willfully" als volgt uitgelegd ${ }^{228}$;

The word "willfully", as that term has been used from time to time in these instructions, means that the act was comminted voluntarily and purposely, with the specific intert to do something the law forbids; that is to say, with bad purpose either to disobey or disregard the law. Court decisions indicate (...) that this definition is not accurate in every situation. (...) "willful is a word of many meanings, and its construction is often influenced by its context."

Hier moet de gedraging niet alleen uit vrije wil geschieden, maar de dader moet de gedraging ook beogen. Daarnaast wordt als extra vereiste gesteld dat het oogmerk van de dader gericht moet zijn op het overtreden van de wet- en/of regelgeving. Een andere definitie die in de literatuur wordt vermeld komt sterk overeen met bovenstaande. Hier wordt alleen gesteld dat de wil van de dader gericht moet zijn op datgene wat hij wil uitvoeren.

... the "willfulness" requivement means only that the defendant must have intended the act which he did, and does not required showing that be knew be was violating the secturities laws....

Pas wanneer kan worden aangetoond dat de overtredingen "willfully" zijn begaan, zijn deze gedragingen strafrechtelijk vervolgbaar. In geval van een strafrechtelijke vervolging volstaat voor het bewijs van "willful" dat de directie of een andere leidinggevende een bepaald beleid heeft gevoerd dat gericht was op het misleiden van anderen ${ }^{230}$. Om een beeld

Commitree on Pattern Jury Instructions District Judges Association fifth Circuit, 5th Circuit Pattem Jury Instructions: criminal cases, West Publishing Co., St. Paul, Minnesota, 1997, p. 13.

229 Ratner citeert hier uit de zaak United States $v$. Schwarz. Zie Ratner, D.L., Securitues Regulation in a nushell, $4^{\text {th }}$ edition, St. Paul Minnesota: West Publishing Co., 1992 , p. 253.

23* Grafman, S.W., Adelman, R.M. en Plaza, C.E., Criminal Enforcement of the Securities Laws: A Primer for the Sectrities Practitioner in: Kirkpatrick and Lockhart L.L.P., The Securities Enforcment Manual: tactics and strategies, a.w., p. 313. 
te geven van enkele federale effectenmisdrijven die leiden tot een strafrechtelijke vervolging, zullen hieronder enkele worden besproken. De meest voorkomende federale strafbare feiten, die men binnen de effectenwereld kan tegenkomen zijn onderverdeeld in feiten gebaseerd op de Federal Criminal Code, en feiten gebaseerd op de effectenregelgeving. Enkele feiten zijn:

\section{Federal Criminal Code}

* Obstruction of Justice

* Perjury

* Fraud and false statements

* Mail-en Wire froud

* Conspiracy

* Racketeering
O.g.v. de wersicbillende effectenregelgeving

* Section 17(a) van de Securties Act'33

* Section 24 van de Securities Act 33

* Section 32 van de Securities Exchange Act'34

* Rule 10b-5 behorende bij de Secwrities Exchange Act 34

Vanzelfsprekend kan en zal de aanklager in de praktijk ook feiten in de indictment opnemen die hier niet bij staan vermeld. Bovenstaande strafbare feiten, die bedoeld zijn om een globaal inzicht te verschaffen, zullen hieronder worden besproken. Allereerst komen de feiten uit de Federal Criminal Code aan bod, vervolgens zijn de wetsovertredingen van de federale effectenregulering aan de beurt.

\section{De Federal Criminal Code}

Obstruction of justice

De aanleiding tot een strafrechtelijk onderzoek hoeft niet alleen gelegen te zijn in de gedragingen die werden verricht voor het SEC onderzoek. Het kan ook voorkomen dat gedragingen verricht tijdens een SEC onderzoek strafrechtelijk worden gesanctioneerd. Hierbij dient men te denken aan het verhinderen van een goede rechtsgang, "obstruction of justice", door niet mee te werken aan een SEC onderzoek. De obstruction of justice kan tot stand komen door:

1. de informatie watar om de SEC beeft verzocht te vervalsen;

2. de desbetreffende informatie, dat als bewijs kan dienen, te vernietigen;

3. de informatie opzettelije te verbergen eniof

4. de getuige te intimideren.

Op grond van de onder 1 cot en met 4 genoemde gedragingen kunnen de verdachten strafrechtelijk worden vervolgd. Er zijn meerdere manieren om de rechtsgang te belemmeren en dus meerder soorten obstruction of justice. Hoofdstuk 73 van de Federal Criminal Code is geheel hieraan 
gewijd. De gedragingen zoals genoemd onder punt 1 tot en met 4 zijn onder te brengen onder de "obstruction of proceedings before departments, agencies, and committees", dat strafbaar gesteld is in section 1505 van de Federal Criminal Code of 18 U.S.C. $\$ 1505$. In section 1505 is bepaald:

\section{Section 1505 Obstruction of proceedings before departments, agencies, and committees}

Whoever, with intent to avoid, evade, prevent, or obstruct compliance, in whole or in part, with any civil investigative demand duly and properly made under the Antitrust Civil Proces Act, willfully withholds, misrepresents, removes from any place, conceals, covers up, destroys, mutilates, alters, or by other means falsifies any documentary material, answers to written interrogatories, or oral testimony, which is the subject or such demand; or attempts to do so or solicits another to do so; or

Whoever corruptby, or by threats or force, or by any threatening letter or communication influences, obstructs, or impedes or endeavors to influence, obstruct, or impede the due and proper administration of the law under which any pending proceeding is being had before any department or agency ot the United States, or the due and proper exercise of the power of inquiry under which any inquiry or investigation is being had by either House, or any committee of either House or any joint committee of the Congress shall be fined under this title or imprisoned not more than five years, or both.

Aldus bovenstaand wetsartikel kan obstruction of justice bestraft worden met een geldboete en/of met een vrijheidsstraf van maximaal 5 jaren. In section 3571 e.v. van de Federal Criminal Code, 18 U.S.C. $\$ 3571$ e.v., zijn de bepalingen ondergebracht die hoogtes van de geldboetes aangeven. Volgens section $3571 \mathrm{kan}$ eenieder die schuldig wordt bevonden aan een wetsovertreding een geldboete opgelegd krijgen.

Section 3571 Sentence of fine ${ }^{231}$

(a) In general

A defendant who has been found guilty of an offerse may be sentenced to pay a fine.

231. Volgens 18 U.S.C. $\$ 1$ behoren tot de misdemeanors alle wetsovertredingen waarvoor men niet de doodstraf kan krijgen en/of waarvoor het maximum van een vrijheidsstraf een jar is. In 18 U.S.C. $\$ 3559$ vindt men de classificaties voor de verschillende strafbare feiten. Voor een "Class $A$ " misdemeanor kan een vrijheidstraf $(x)$ worden opgelegd van: 1 jaar $\leq x>6$ maanden. Bij een "Class B" misdemeanor geldt een periode van 6 maanden $\leq x>30$ dagen. Tor slot geldt 
(b) Fines for individuals

Except as provided in subsection (e) of this section, an individual who bas been found guilty of an offense may be fined not more than the greatest of

(1) the amount specified in the Law setting for th the offense:

(2) the applicable amount under subsection (d) of this section:

(3) for a felony not more than $\$ 250,000$;

(4) for a misdemeatror resulting in death, not move that $\$ 250,000$;

(5) for a Class $A$ midemeanor that does not result in death, not more than $\$ 100,000$

(6) for $a$ Class $B$ or $C$ misdemeanar that does not rowlt in death, not moxe whon

$\$ 5,000 ;$ or

(7) for an infraction, not more than $\$ 5,000$.

(c) Fines for organizations ${ }^{232}$...

Op grond van 18 U.S.C. $\$ \$ 1$ jo 3571 (b) en (c) jo 1505 bedraagt de geldboete bij bovengenoemde variant van de obstruction of justice, maximaal \$250,000 voor individuele personen en $\$ 500,000$ voor organisaties. Een dergelijke geldboete kan vergezeld gaan van andere straffen zoals een vrijheidstraf, een proeftijd of een voorwaardelijke veroordeling ${ }^{233}$.

\section{Perjury}

Naast obstruction of justice kan men ook voor "perjury" oftewel meineed worden vervolgd. Dit zal doorgaans het geval zijn wanneer men tijdens een SEC onderzoek valse verklaringen onder ede af heeft gelegd. Perjury is strafbaar gesteld in 18 U.S.C. $\$ \$ 1621-1623$.

voor cen "Class C" misdemeanor: 30 dagen $\leq x>5$ dagen. Een felony is een wetsovertreding die wel kan worden gesanctioneerd net de doodstraf. Daarnaast behoort een owertreding war men een vrijheidsstraf van minimal cen jaar of meer opgelegd kan krijgen ook tot een felony. Een infraction is cen wetsovertreding waar men een wrijheidsstraf van maximaal vijf dagen kan worden opgelegd of een waar helemaal geen vrijheidsstrafkan worden opgelegd. Vgl. Garner, B.A., Bhack's Law Dictionary: pocket edition, a.w. p. 314 en 18 U.S.C. $\$ 3559$ (a)(9).

Volgens 18 U.S.C. $\$ 18$ behoren tot de organisaties: "a person other than an individuat". Bij feiten begaan door organisaties zijn de onder punt c. wastgestelde boetes verdubbeld. Voor een felony kan een organisatie een boete van $\$ 500,000$ ongeveer $€ 500.000$,- opgelegd krijgen en voor een infraction $\$ 10,000$ ofwel hetzelfole bedrag in euro's.

18 U.S.C. $\$ 3551$ (b) en (c):

(b) Indiviauals: $A$ sentence to pay a fine may be imposed in addition to any other sentence. (...).

(c) Organizations: A sentence to pay af fine may be imposed in addition to a sentence to probation. (...). 


\section{Section 1621 Perjury generally}

Whoever

(1) baving taken an oatb before a competent tribunal, officer, or person, in any case in which a law of the United States authorizes an oath to be administered that he will testiff declare, depose, or certify waly, or that any writuen testimony, declamation, depostion, or certificate by bim subscribed, is true, willfully and contrary to such oath states or subscribes any material matter which be does not believe to be true; or

(2) in any declaration, certifucte, werification, or statement under penalty of perjury as permitted under section 1746 of title 28, United States Code, willfully subscribes as ime ary material matter which be does not believe to be trus;

is guily of peryury and shall, except as otherwise expressly provided by law, be fined under this title or imprisoned not maxe than five years, or both. This section is applicable whether the statement or subscription is made within or wirhowt the United States.

Volgens 18 U.S.C. $\$ \$ 1$ jo 3571 (b) en (c) jo 1621 bedraagt de geldboete ook hier maximaal $\$ 250,000$ voor individuele personen en $\$ 500,000$ voor organisaties. Daarnaast kan tevens een vrijheidstraf worden opgelegd.

\section{Fraud and false statements}

In 18 U.S.C. $\$ \$ 1001-1035$ is het frauderen en afleggen van leugenachtige verklaringen strafbaar gesteld. Indien men tijdens een door de SEC verricht onderzoek een valse verklaring heeft afgelegd terwijl men nier onder ede stond, kan dit toch op grond van section 1001 van de Federal Criminal Code worden vervolgd. Her kan zijn dat gedurende het informele SEC onderzoek, een onderzoekssubject tijdens een telefoongesprek met een jurist een onjuiste verklaring heeft afgelegd, zonder dat hem de eed werd afgenomen. In dat geval stelt voornoemde section:

\section{Section 1001 Statement or entries generally}

(a) Except as otherwise provided in this section, whoever; in any matter within the jurisdiction of the exccutive, legislative, or judicial branch of the Government of the United States, knowingly ${ }^{239}$ and willfullyy

(1) falsifies, conceals, or covers up by any trick, scheme, or device a material fact;

(2) makes any materially false, ficticious, or fradudulent statement or representation;

"Knowingly" ligkt heel erg op her hierwoor genoemde "willfully". Voor beide is vereist dat de gedraging bewust en vrijwillig werd gepleegd. Daarnaast omvat deze term volgens de jury instructies van het 5 th circuit ook: "dat wat de verdachte had moeten en kunnen weten"; "... a defendant bad knowlegde of a fact if (...). the defendant deliberately closed bis ayes to what would otherwise have been obvious to bim...". Committee on Pattern Jury Instructions District Judges Association fifth. Circuir, 5th Cimut Pattern Jury Instructions: criminal cases, West Publishing Co., St. Paul, Minnesota, 1997 , p. 57. 
or

(3) makes or uses any false writing or document knowing the same to contatin any materially false, fictitious, or froululent staternent or entry.

Shall be fined under this title or imposed not more than 5 years, or both.

(b) Subsection (a) does not apply to a party to a judicial proceedings, or that party's counsel, for statements, representations, writings or documents submitied by such party or coundel to a judge or magistrate in that proceding.

(c) With respect to any matter within the jurisdiction of the legislatitu branch, subsection (a) shall apply only to

(1) administrative matters, including a claim for payment, a matter related to the procurement of property or services, personnel or employment practices, or support services, or a document requited by law, rule, or regulation to be submitted to the Congress or any office or officer within the egislative brach: or

(2) any investigation or revieu, conducted pursuant to the authority of any commitue, subcommitze, commission or affice of the Congress, consistevt with applicable rules of the House or Senate.

Bovenstaand artikel bepaalt dat het afleggen van onjuiste verklaringen "knowingly" en "willfully", dat wil zeggen zeer bewust moeten zijn afgelegd. Daarnaast moest de vrije wil van het de (rechts)persoon gericht zijn op het afleggen van de valse verklaring. Uit 18 U.S.C. $\$ \$ 1$ jo 3571 (b) en (c) jo 1001 sub a kan worden afgeleid dat de overtreder bestraft wordt met een geldboete met een maximum van $\$ 250,000$ of in geval van een organisatie, een maximum van $\$ 500,000$.

\section{Mail and wire fraud}

Beide vormen van fraude, worden vaak in een adem genoemd. Bij mail en wire fraud wordt er bij de uitvoering van de strafbare gedragingen gebruik gemaakt van de post en/of van telecommunicatiemiddelen. Zodra tijdens het SEC onderzoek of tijdens het door de OvJ verricht onderzoek naar voren is gekomen dat de verdachte interstatelijk handelde en hij hierbij gebruik heeft gemaakt van de telefoon en/of van de post, kan de Ovj de feiten kwalificeren als mail en/of wire fraud. Aangezien het gebruik van diverse telecommunicatiemiddelen, zoals de (mobiele) telefoon, telefax en het internet vandaag de dag niet ongebruikelijk is, kunnen en worden deze wetsartikelen veelvuldig door justitie toegepast. De delictsomschrijving voor mail fraud ofwel het frauderen per of via de post, kan men vinden onder hoofdstuk 63 van de Federal Criminal Code; 18 U.S.C. $\$ \$ 1341$ tot en met 1347. In 18 U.S.C. $\$ 1343$ is wire 
fraud oftewel het frauderen met behulp van telecommunicatiemiddelen strafbaar gesteld. Section 1341 en section 1343 zijn als volgt omschreven:

\begin{abstract}
Section 1341 Frands and swindles
Whoever, having devised or intended to devise any scheme or arrifice to defiaud, or for obsaining money or property by means of false or frawdulent pretenses, representations, or promises, or to sell, dispose of, loan, exchange, alter, give away, distribute, supply, or furvish or procutre for unltuful use any counterfeit or spurious coin, obligation, security. or other article, or anything represerted to be intimated or beld out to be such conterfeit or spurious article, for the purpose of executing such scheme or artifice or authorized depository for mall matter, any matter or thing whatever to be sent or delivered by any prizate or commercial incerstate carriex, or takes or receives therefrom, any delivered by mail or such carries according to the divection thereon, or at the place at which it is divected to be delivered by the person to whom it is addressed, any such matter or thing. shall be fined under this title or imprisoned not make than five years, or both. If the vishation affects a financial institution, such person shall be fined not more than $\$$ $1,000,000$ or imprisoned not more than 30 years, or both.
\end{abstract}

\title{
Section 1343 Fraud by wire, radio, or television
}

Whoever, having devised or intending to devise any scheme or artifice to defraud, or for abtaining money or property by means of false or fraudulent preterses, representations, or promises, transmits or causes to be transmitted by means of wine, radio, or television communication in interstate or foreign commerce, any writings, signs, signals, pictures, or sound for the purpose of executing such scheme or artifice, shall be fined wnder this title or inprisoned not more than frue years, or both. If the violation affects a financial institution, such person shall be fined not more than $\$ 1,000,000$ or imprisoned not more than 30 years, or both.

De maximumstraffen voor zowel mail- als voor wire fraud zijn een vrijheidstraf van 5 jaar en/of een geldboete van $\$ 1,000,000^{235}$. Opgemerkt kan worden dat de delictsomschrijvingen van mail-en wire fraud erg ruim zijn. Zij zijn dan ook vaak makkelijker te bewijzen dan de onderliggende overtredingen van de effectenwetten. Immers, laatstgenoemd bewijs zal vaak technischer van aard zijn dan bij mail- of wire fraud. In plaats van verklaringen en bewijsmateriaal aangevoerd door onder meer accountants, juristen en/of analisten, kan reeds volstaan worden met het bewijs dat er bijvoorbeeld bij het misleiden van (potentiële) beleggers interstatelijk telefonisch contact is geweest. Hierdoor kunnen en worden de bepalingen van mail- en wire fraud

335 Ofwel 1.000 .000 ,-. Vgl. noot 113 in Grafan, S.W., Adelman, RM. en Plaza, C.E., Criminal Enforcement of the Securities Laws: A Primer for the Securities Practitioner in: Kirkpatrick and Lockhart L.L.P., The Securities Enforcement Manual:tactics and strategies, a.w., p. 332. 
veelvuldig door de Amerikaanse Officieren van Justitie toegepast en opgenomen in een indictment.

\section{Conspiracy}

Wanneer er een afspraak tussen twee of meer personen bestaat om een federale wetsovertreding te begaan en minstens een persoon gaat over tot het uitvoeren van de wetsovertreding, kan dat op grond van 18 U.S.C. $\$ 371-373$ worden bestraft. Dit strafbaar feit, conspiracy, staat bij ons bekend als samenzwering tegen de staat. Section 371 luidt als volgt:

\section{Section 371 Conspiracy ta commit offense or to defraud United States}

If two or more persons conspire either to commit any offense againut the Uwited States, or to defraud the United States, or any agency thereof in any manner or for any purpose, and one or more of such persons do any act to effect the object of the conspinaty each shall be fined under this title or imprisoned not more than five yeats, or both. If bowever, the offense, the commission of which is the abject of the conspinacys is a misdemeanom only the maximum punishment for such conspiracy shall not exteed the maximum punishment provided for such misdemeanor.

Mocht een $\mathrm{OvJ}$ besluiten om wetsovertreders te vervolgen voor bijvoorbeeld obstruction of justice of mail fraud dan wel voor een overtreding van de effectenwetgeving en hij kan aantonen dat deze daad door minimaal twee personen is overeengekomen, dan kan hij hen ook conspiracy ten laste leggen. Het ten laste leggen van conspiracy is zelfs erg aantrekkelijk omdat de OvJ de verklaring van een van de samenzweerders tegen de andere samenzweerder(s) kan gebruiken. Rule 801 (2)(E) van de Federal Rules of Evidence (FRE) biedt hier de mogelijkheid to ${ }^{236}$. De maximale vrijheidstraf voor conspiracy is bepaald op vijf jaren en/of een geldboete van $\$ 10,000^{237}$.

236 FRE rule 801 Definitions: The following definitions apply under this article: (a) Statement. A "starement" is (1) an oral or written assertion or (2) nonverbal conduct of a person, if it is intended by the person as an assertion. (b) Declarant. A "declarant" is a person who makes a statement. (c) Hearsay. "Hearsay" is a statement, other than one made by the declarant while testifying at the trial or hearing, offered in evidence to prove the truth of the matter asserted. (d) Statement which are nor hearsay. A statement is nor hearsay if: (1) Prior statement by witness. (...) (2) Admission by party-opponent. The statement is offered against a party and is $(A)(\ldots)(E)$ a statement by a coconspirator of a party during the course and in furtherance of the conspiracy. Vgl. ook Patton, T.E en T.R. Saunders, Securities Fraud: litigating under rule 106-5, LEXIS law publishing, a.w., $\$ 15.203$. (versie 1999).

237 Ofwel $€ 10.000$,- . Zie Patton, T.E. en T.R. Saunders, Securities Fratud livigating under rule $106-5$, LEXIS $^{\circledR}$ law publishing, a.w., $\$ 15.203$. 


\section{Racketeering}

Tot slot het strafbare feit "racketeering". Letterlijk vertaald betekent dit: zwendel of afpersing en word vooral bij overtredingen van de efffectenwetgeving, in verband gebracht met de georganiseerde misdaad. Dat blijkt te meer uit de wet die racketeering strafbaar stelt: de algemene strafbaarstelling van racketeering in de sections 1951 - 1960 en de bijzondere strafbaarstelling op grond van de Racketeer Influenced and Corrupt Organizations Act (RICO). Laatstgenoemde strafbaarstelling richt zich specifiek op het zwendelen of afpersen in organisatorisch verband. De RICO, die in de sections 1961 tot en met 1968; hoofdstuk 96 van de Federal Criminal Code is verwerkt, zal hieronder worden besproken. Section 1961 , 18 U.S.C. $\$ 1961$, definieert deze vorm van racketeering als volgt:

\section{Section 1961 Definitions}

As used in this chapter

(1) "racketering activity" means

(A) any act or threat involving murder, kidnapping, gambling, arson, robbery, bribery, extortion, dealing in obscene matter; or dealing in a controlled substance or listed chemical (...), which is chargeable under State law and punishable by imprisonment for more than one year:

(B) any act which is indictable under any of the following providions of title 18 , United States Code: ..., section 1029 (relating to fraud an related activity in connection access devices),... section 1341 (relating to mail fratud), section 1343 (relating to wire fraud), section 1344 (relating to financial institution fratd). ..section 1503 (relating to obstruction of justice), ...section 1512 (relating to tampering with a witness, victim, or an informant), ... section 1952 (relating to racketering), ... section 1956 (relating to the laundering of monetary instruments), section 1957 (relating to engaging in monetary transactions in property derived from specified unlawful activity)....

(D) any offense involving frawd connected with (...), frawd in the sale of securities $(\ldots)$

Uit voormeld artikel blijkt dat deze zeer ruim is geredigeerd. Naast onder meer mail- en wire fraud, obstruction of justice en laundering of monetary instruments ${ }^{238}$, wordt nog expliciet aangegeven dat elke wetsovertreding verbonden met fraude bij de verkoop van effecten, ook onder racketeering mag worden geplaatst. De daadwerkelijk strafbaarstelling, waarin wordt vermeld dat racketeering is verboden, is te vinden in section 
$1962^{239}$. Deze section verbiedt samen met section 1961 lid 5 , elke onderneming die interstatelijke handel voert dan wel verbonden is aan een dergelijke vorm van handel, minimaal tweemaal binnen de periode van tien jaren, zwendel en/of afpersingsactiviteiten te verrichten.

Indien mogelijk verwerkt justitie deze vorm van racketeering dan ook graag in een indictment. De reden hiervoor is het ruime arsenaal aan toepasbare sancties. Immers, naast de in section 1963 opgesomde strafrechtelijke sancties, heeft de wetgever in section 1964 de civielrechtelijke sancries aangegeven. Zo heeft de wetgever in 18 U.S.C. $\$ 1963$ bepaald dat er reeds voordat de indictment is afgegeven er een restraining order, te vergelijken met een straatverbod, mag worden verleend. Daarnaast mogen bij dit strafbaar feit ook goederen verbeurd verklaard worden. Dit om te voorkomen dat de verdachte bewijsmateriaal vernietigt of wegneemt. In section 1963 (d)(1)(B)(i) is dit als volgt verwoord:

\section{Section 1963 Criminal penalties}

... (d) (1) Upon application of the United States, the contrt may enter a restraining order or injunction, require the execution of a satisfactory performatice ability of property described in subsection (at) for forfeiture under this section

(A) upon the filing of an indectment or information charging a violation of section 1962 of this chapter and alleging that property with respect to which the order is sought would, in the event of conviction, be subject to forfeiture under this section; or

(B) prior to she filing of such an indictment or information, if, after notice to persons appearing to have an interest in the property and opportunity for a bearing, the court determines that

(i) there is a substantial probability that the United States will prevail on the issue of forfeiture and that fatlute to enter the order will result in the property being destroyed, remoeved from the jutisdiction of the count, or otherwise made unavailable for forfertur" (...)

Section 1962 Prohibited activities: (a) it shall be unlawful for any person who has received any income derived, directly or indirectly, from a partern of racketeering activity or through collection of an unlawful debt in which such person has participated as a principal within the meaning of seciton 2 , title 18 , United States Code, to use or invest, directly or indirectly, any part of such income, or the proceeds of such income, in acquisition of any interest in, or the establishment or operation of, any enterprise which is engaged in, or the acriviries of which affect, interstate or foreign commerce (...). (d) it shall be unlawfull for any person to conspire to violate any of the provisions of subsection (a), (b), or (c) of this section. 
De maximumstraffen voor racketeering in organisatorisch verband zijn: een geldboete van $\$ 25,000^{240} \mathrm{en} /$ of een vrijheidstraf van $20 \mathrm{jaar}^{241}$.

Bovenstaande globale omschrijving van strafbare feiten gebaseerd op de Federal Criminal Code is niet limitatief, maar dient ter illustratie van de inhoud van een eventuele indictment. In een dergelijke indictment kunnen meerdere van voormelde strafbare feiten voorkomen. Hieruit kan worden geconcludeerd dat deze feiten cumulatief door justitie zijn toe te passen.

De verschillende effectenregelgeving

Section 17 (a) van de Securities Act'33 komt samen met 17 C.F.R. rule 240.10b-5, beter bekend als rule 10b-5 behorende bij de Securities Exchange Act 34 (rule 10b-5), vaak terug in (straf)-rechtszaken. Section 17 (a) oftewel 15 U.S.C. $\$ 77 \mathrm{q}$, luidt als volgt:

\section{Section 17 Fraudulent Interstate Transactions}

(a) It shall be wnlawful for any person in the offer or sale of any securities by the use of any means or instruments of transportation or communication in interstate commerce or by the use of the mails, directly or indirectly

(1) to employ any device, scheme, or artifice to defraud, or

(2) to obtain money or property by means of any untrie statement of a material fact or any omission to state a material fact necessary in order to make the statements made, in the light of the circumstances under which they were made, not misleading. or

(3) to engage in any transaction, practice, or course of business which operates or wonld operate as a fraud or deceit upon the purchaser.

Volgens bovenstaand artikel is een ieder die via interstatelijke handel effecten aanbiedt of verkoopt, in overtreding met deze wet. Rule 10b-5 lijkt in eerste instantie op voornoemde section 17 (a), maar blijkt een ruimere strekking te hebben.

24. Zie Patton, T.E. en T.R. Saunders, Securities Fraud: litigating under rule 106-5, LEXIS $^{\circledR}$ law publishing, a.w., $\$ 15.204$. 


\section{Rule 106-5 Employment of Manipulative and Deceptive Devices}

It shall be wnlawful for any person, directly or indirectly by the we of axy means or instrumentalizy of interstate commerc, or of the mails or any facility of any wational securities exchanges.

(a) To employ any device, scheme, or artifice to defrawd.

(b) To make any antrue statement of a material fact to omit to state a materal fact necessary in onder to make the statements made, in the light of the cincumstances wnder which they were made, not misleading, or

(c) To engage in any act, practice, or course of business which operates or would openate as a fraud or deceit upon any person,

in connection with the purchase or sale of any security.

Wanneer rule 10b-5 wordt vergeleken met bovengenoemde section 17 , valt op dat de uitbreiding gelegen is in het woord "purchase" de aankoop van effecten. Alhoewel beide artikelen fraude en het gebruik van kunstgrepen bij de verkoop van effecten strafbaar stellen, kan gesteld worden dat rulle $10 \mathrm{~b}-5$ als vangnet dient doordat nu alle misstanden mer betrekking tot de aankoop van effecten kunnen worden tegengegaan. Hierbij dient men onder meer aan insider trading en/of frontrunning te denken, waarbij men voor de aankoop van effecten over dusdanige informatie beschikt, die een eerlijke en doorzichtige markt-openbaarmaking vereist. Door dit na te laten, duperen de aankopers de (potentiële) beleggers die dezelfde aandelen later tegen een hogere koers zullen moeten kopen. Naast het feit dat rule 10b-5 een strafrechtelijke aansprakelijkheid biedt, hebben de vele mogelijkheden van deze rule ervoor gezorgd dat dit artikel het meest wordt toegepast in strafrechtelijke vervolgingen ${ }^{242}$. De overtreders van bovengenoemde artikelen kunnen op grond van section 24 van de Securities Act'33 of section 32 van de Securities Exchange Act'34 strafrechtelijk worden vervolgd ${ }^{243}$. Op grond van section 24 kunnen zij een geldboete van maximaal $\$ 10,000^{244}$ opgelegd

\footnotetext{
242 Patton, T.E. en T.R. Saunders, Securities Fraud: litigating under rule $106-5$, LEXIS ${ }^{\text {tan }}$ law publishing, a.w. $\$ 1.5 \mathrm{en} \$ 15.1$.

$243 \quad 15$ U.S.C. $\$ 77 x$ en 15 U.S.C. $\$ 78 \mathrm{ff}$.

24i $€ 10.000$,
} 
krijgen met of zonder een vrijheidsstraf van maximaal vijf jaren. De tekst van de section 24 ziet er als volgt uit:

\section{Section 24 Penalties}

Any person who willfully violates any of the provisions of this Act, or the rule and regulations promulgated by the Commission under authority thereof, or any persan who willfully, in a registration statement filed under this Act, makes any untrue statement of a material fact or omits to state any material fact required to be stated therein or necessary to make the statements therein not misleading, shall upon conviction be fined not more than $\$ 10,000$ or imprisoned not more than five years, or both.

In de Securities Exchange Act'34 is section 32 ruimer samengesteld. Hier kunnen "willful violations" van de wetten zoals genoemd in deze section, naast een maximale vrijheidstraf van 10 jaar, leiden tot een geldboete van maximaal $\$ 1,000,000$ voor natuurlijke personen en $\$ 2,500,000$ voor rechtspersonen ${ }^{245}$.

Wanneer naar de voorafgaande artikelen wordt gekeken, moet worden geconcludeerd dat er binnen de strafrechtelijke procedure twee soorten sancties zijn. Deze zijn de strafrechtelijke geldboete en/of de vrijheidsbeneming. Aangezien de mogelijkheid bestaat om meerdere procedures tegelijkertijd tegen zich te hebben lopen, kan men zowel onderzoeksubject zijn in een (formele) enforcement procedure dan wel een administratieve procedure; gedaagde zijn in een civiele procedure aangespannen door een gedupeerde belegger, als verdachte in een strafzaak. Voor een verdachte kan een dergelijke gang van zaken nadelig uitwerken. Immers, de informatie van de SEC mag door Justitie tegen hem worden gebruikt wanneer dat van algemeen belang is ${ }^{246}$. Een beperking is het misbruik van bevoegdheid. Dat wil zeggen dat de SEC geen civiele procedure mag starten om zo informatie naar Justitie door te sluizen ${ }^{247}$. In een strafrechtelijke procedure mag men zich namelijk op zijn zwijgrecht

245 Deze bedragen kunnen gemakshalve aangehouden worden voor de berekening in euro's. De koers van de euro en de Amerikaanse dollar lopen momenteel niet ver uiteen.

246 17 C.FR. $\$ 230.122$; in beginsel mag alle informatie of documenten vergard tijdens een onderzoek door de SEC niet openbaar worden gemaakt, tenzij dat van algemeen belang is, "a matter of public record".

247 Grafan, S.W., Adelman, R.M. en Plaza, C.E., Criminal Enforcement of the Securities Laws: A Primer for the Securities Practitioner in: Kirkpatrick and Lockhart L.L.P., The Securities Enforcement Manual:tactics and strategies, a.w., p. 344. 
beroepen $^{248}$. Dit zwijgen mag later ook niet tegen de verdachte worden gebruikt terwijl het zwijgen in een civiele procedure wel tegen de gedaagde kan worden aangewend". Immers de gedaagde wordt dan beschouwd als oncoöperatief, hetgeen niet in zijn voordeel werkt ${ }^{249}$. Om zijn rechtzaak niet nadelig te beïnvloeden, zal een gedaagde meewerken ondanks het gevaar dat zijn verklaringen in de (aanhangige) strafzaak tegen hem gebruikt zullen worden. Om dit soort situaties te voorkomen kan de verdachte en gedaagde aan de rechter verzoeken om de civiele rechtzaak op te schorten dan wel uit te stellen totdat de strafrechter zijn vonnis heeft uitgesproken; "staying the civil proceeding". Ondanks het feit dat de verdachte door het toekennen van een stay zich alleen op de strafzaak hoeft te richten, kan de uitkomst van deze zaak van invloed zijn op zijn civiele zaak. Het is algemeen geaccepteerd dat een strafrechtelijke veroordeling de basis mag zijn van een civielrechtelijke aansprakelijkheid. Dit, omdat er aan het bewijs in een strafzaak zwaardere eisen worden gesteld, en met meer waarborgen is omkleed dan een civieleof een administratieve rechtzaak. Gezien het voorafgaande is een strafrechtelijke veroordeling voor de civiele rechter voldoende om een civielrechtelijke aansprakelijkheid vast te stellen ${ }^{250}$.

Het antwoord op de eerder gestelde vraag of het strafrecht slechts een van de handhavinginstrumenten is en niet meer dan dat, of dat het fungeert als ultimum remedium kan alleen worden beantwoord wanneer bekend is welke procedure de wetsovertreders het meest afschrikt. Wanneer de strafrechtelijke procedure wordt geplaatst naast de administratieve en de civiele injunctionprocedure, kan de conclusie worden getrokken dat eerstgenoemde de meest vergaande gevolgen heeft. Niet alleen kan een veroordeelde een strafrechtelijke geldboete en/of een vrijheidstraf opgelegd krijgen, zijn veroordeling kan ook van invloed zijn op een administratieve en op een civiele injunctionprocedure.

Vgl. het met the Fifth Amendment van de Anerikaanse grondwet waarin onder meer is vastgelegd dat niemand twee keer voor hetzelfde feit mag worden veroordeeld "ne bis in idem" dan wel tegen zichzelf hoeft te getuigen "nemo tenetur".

249 Grafan, S.W., Adelman, R.M. en Plaza, C.E, Criminal Enfoncement of the Securities Laws: A Primer for the Securities Practitioner in: Kirkpatrick and Lockhart L.L.P., The Securities Enforcement Manual, tactics and straragies, a.w., p. 347.

250 Patton, T.E. en T.R. Saunders, Securities Fraud: litigating under mule 106-5, LEXIS law publishing, a.w., $\$ 15.3$. 
Andersom kan dit niet het geval zijn. Op grond wan het voorafgaande zal een onderzoekssubject meer te vrezen hebben van een strafprocedure, dan van de twee andere procedures. Kortom, het strafrecht kan binnen de Amerikaanse effecten regelgeving gezien worden als het meest afschrikwekkend rechtsmiddel, een ultimum remedium.

In het volgende hoofdstuk zullen de bevoegdheden van de AutoriteitFM tegen het licht van haar Amerikaanse evenknie, de SEC, worden gehouden. 


\section{Het Nederlands toezicht; een knipoog naar Amerika?}

\subsection{Inleiding}

In de hoofdstukken een en twee is getracht om tan te geven welke juridische acties de Nederlandse toezichthouders van de effecrentypische wet- en regelgeving, tegen overtreders van voornoemde regelgeving kunnen ondernemen. De bevoegdheden van deze belangrijkste toezichthouders, te weten de Autoriteit Financiële Markten ${ }^{1}$ (Autoriteit-FM) en DNB, zijn dan ook uitvoerig aan bod gekomen. De handhavingsinstrumenten van de Autoriteit-FM vertonen meer overeenkomsten met die van haar Amerikaanse evenknie, de SEC, dan bij DNB het geval is. Dit laatste is uit het vorige hoofdstuk gebleken. Met andere woorden: de Autoriteit-FM blijkt meer "waakhondallures" te hebben dan DNB. Daarom zullen de toezichtsinstrumenten van de SEC vaker worden vergeleken met die van de Autoriteit-FM.

In dit hoofdstuk zullen de juridische handhavingsinstrumenten waarover de eerder aangehaalde toezichthouders beschikken, slechts tegen de Amerikaanse toezichthouder, de SEC, worden afgezet om de eventuele verschillen en overeenkomsten uitvoerig te bespreken. Vervolgens zal in dit hoofdstuk bekeken worden of de Nederlandse wetgever voor de taakvervulling van onze effectentypische toezichthouders, de Amerikaanse SEC als voorbeeld neemt.

\subsection{De Nederlandse en Amerikaanse handhavings- instrumenten}

Zoals uit de hoofdstukken twee en drie af is te leiden, zijn zowel de Autoriteit-FM als de SEC gezaghebbende toezichthouders van her effectenverkeer. Evenals de Autoriteit-FM richt de SEC haar inspanningen

Vanaf 1 maart 2002 is de naam van de STE gewijzigd in: "Autoriteit Financiële Markten". De hier gehanteerde afkorting zal zijn "Autoriteit-FM". Met de naamswijziging heeft er ook een wijziging in bevoegdheden plaatsgevonden. Meer hierover in hoofdstuk 2. 
op het waarborgen van de betrouwbaarheid en doorzichrigheid van de nationale effectenmarkt. $Z_{0}$ is in hoofdstuk drie aangegeven dat de Amerikaanse effectentypische regelgeving is gericht op de bescherming van de (particuliere) belegger. Dit wordt bereikt door er voor te zorgen dat de (porentiële) belegger de effectenmarkt goed kan doorzien zodat hij weloverwogen in effecten kan handelen. Het toezicht op voornoemde regelgeving geschiedt op directe wijze. Dat de Nederlandse toezichthouder van effectentypische regelgeving gelijksoortige doelstellingen heeft, is uit het rweede hoofdstuk af te leiden. Om deze na te kunnen streven hebben zowel de Autoriteit-FM als de SEC als rechtgeaarde zelfstandige bestuursorganen de wettelijke bevoegdheid gekregen om niet alleen regels te stellen, maar om deze ook te sanctioneren. Alvorens tot sanctioneren over te gaan zullen de toezichthouders onderzoeken of er al dan niet sprake is van een wettelijke overtreding. Deze onderzoeken kunnen, zoals in de hoofdstukken twee en drie is aangegeven, uitmonden in een bestuursrechtelijke, civielrechtelijke of zelfs een strafrechtelijke procedure. De procedure warop zij de minste invloed hebben is de strafrechtelijke. Het opportuniteitsbeginsel, dat men ook in de vS kent, geeft de Amerikaans openbare aanklager, de United States Attorney, het alleenrecht te bepalen wanneer wel of niet tot vervolging over te gaan. Anderzijds geldt voor beide overheidsorganen (zbo's) weer dat zij het meeste in te brengen hebben in het verloop van een administratieve of een bestuursrechtelijke procedure. Hieronder zullen de verschillen en overeenkomsten in zowel de bestuursrechtelijke, civielrechtelijke en uiteindelijk strafrechtelijke procedure worden besproken. Te beginnen met de bestuurstechtelijke procedure.

\section{De Nederlandse bestuursrechtelijke- en de Amerikaanse administratieve procedure}

Tijdens deze procedure moeten beide waakhonden, de Autoriteit-FM en de SEC, zich aan de door de overheid opgestelde en voor hen geldende regels houden. Daarnaast mogen bestuursrechtelijke sancties, zowel in de Verenigde Staten van Amerika als in Nederland, niet punitief van aard zijn, maar dienen ze juist herstellend van aard te zijn ${ }^{2}$. Wanneer zowel de Nederlandse bestuursrechtelijke als de Amerikaanse administratieve procedures onder de loep worden genomen en daarbij rekening

2 Vgl. woor de VS de zaak Johnson v. SEC 87 F.3d 484 (D.C. Circuit 1996) en voor Nederland de Duitse zaak Ozturk, EHRM 21 februari 1984, NJ $1988,937$. 
wordt gehouden met de verschillende rechtssystemen, valt vast te stellen dat de toezichthouders vrijwel over dezelfde bevoegdheden beschikken. Zie figuur 4.1 .

\begin{tabular}{|c|c|c|c|}
\hline \multirow[t]{2}{*}{ SU } & \multicolumn{2}{|c|}{ Nedordand } & \multirow{2}{*}{ 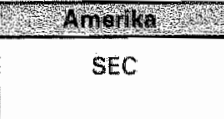 } \\
\hline & $\begin{array}{l}\text { Autoriteit- } \\
\text { FM }\end{array}$ & DNB: & \\
\hline Handhaving effectentypische wetgeving & $*$ & + & + \\
\hline Erkenning van effectenbeurzen & $-m^{*}$ & $-{ }^{*}$ & + \\
\hline Registratie pilichigen registreren & + & + & + \\
\hline Verklaring varn geen bezwaar verlenen & + & + & 7 \\
\hline Verlenen vam een Europees paspoort & + & + & $n_{i} w_{i}$ \\
\hline Woorschrifter geven & + & + & + \\
\hline Bewoeg dheid tot het creeren van regents & + & + & + \\
\hline Onderzaek doem en unlichtingen inwinnen & + & + & + \\
\hline Informeren van (buitenlandse) toezichthouders & + & + & + \\
\hline $\begin{array}{l}\text { Onderzook doen t.b.v. (buitenlandse) } \\
\text { toezth hthouders }\end{array}$ & + & + & * \\
\hline \multicolumn{4}{|l|}{$\begin{array}{l}\text { Administiratieve/bestutursrechtelijke } \\
\text { sancties (reparattoir): }\end{array}$} \\
\hline - ontheffingen/vergunningen intrekken & + & + & + \\
\hline - verklaringen van geen bezway $r$ intrekken & + & $\div$ & $?$ \\
\hline $\begin{array}{l}\text { - opleggen van een bestulurlijke boete } \\
\text { (= strafkarakter) }\end{array}$ & 4 & $?$ & (SEC vs, Johnson?) \\
\hline $\begin{array}{l}\text { - opleggen van een administratieve } \\
\text { gelldboete (VS } \neq \text { punitief) }\end{array}$ & $?$ & + & + \\
\hline - opleggen van een last onder dwangsom & If & + & $?$ \\
\hline - geven van aanwijzingen & + & + & * \\
\hline - openbaarmaking van onrechtmatig gedrag & + & + & * \\
\hline - accountant (ver)bannen & + & + & + \\
\hline - onder curatele stellen & + & + & 4 \\
\hline - gebod tot doen of nalaten & + & + & + \\
\hline $\begin{array}{l}\text { - ontneming wan wederrechtelijk verkregen } \\
\text { woordeel }\end{array}$ & - & $=$ & 4 \\
\hline
\end{tabular}

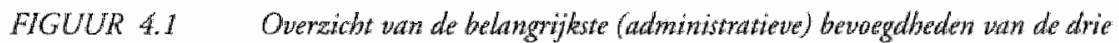
toezichthouders

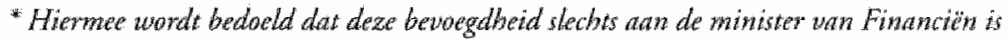
woorbehouden

Naast voornoemde overeenkomsten vallen ook meteen significante verschillen op. Een opvallend verschil is de figuur van de "Administrative Law Judge (ALJ)", die de administratieve hoorzittingen of de "adjudicatory hearings ${ }^{3 "}$ van administratieve overheidsorganen zoals de SEC, kan

3. Oftewel de adjudicatory proceedings; ook wel de administrative tribunals genoemd.

Vgl. paragraaf 3.1.2. 
voorzitten ${ }^{4}$. De ALJ wordt op werzoek van de SEC ingezet en spreekt zich - in de worm van een "ruling" SEC en anderzijds de door de SEC gereguleerde (rechts)persoon partij zijn. In deze administratieve procedure daagt de SEC niet alleen de door haar onderzochte partij voor de ALJ, maar verzoekt laatstgenoemde ook om een uitspraak te doen en een door haar bepaalde sanctie op te leggen. Indien een der partijen het niet eens is met de ruling, kan zij in beroep gaan bij de hoogste instantie van deze zbo en dat is "de $S E C$ ", het voltallig bestuur wel te verstaan.

In Nederland is het de Autoriteit-FM die, in beginsel, binnen een bestuursrechtelijke procedure zelf over een bepaalde zaak oordeelt en besluit om al dan niet een sanctie op te leggen. De beslissing van de Autoriteit-FM om al dan niet een vergunning te verlenen dan wel om deze in te trekken, of elke andere beslissing die gericht is op een bepaalde (rechts)persoon zoals het opleggen van een bestuurlijke boete, is een beschikking ${ }^{6}$. Indien de (rechts)persoon wiens belang rechtstreeks bij het besluit is betrokken, daartoe aanleiding zier, kan deze binnen een bij wet bepaalde termijn ${ }^{7}$ bezwaar indienen bij de sector Juridische Zaken $^{8}$ van de Autoriteit-FM tegen het door haar genomen besluit. Het is op grond van de effectentypische wetgeving zelfs mogelijk om een ander overheidsorgaan over de beschikking van de Autoriteit-FM te laten oordelen. Artikel 43 Wte'95 stelt namelijk dat er in beginsel administratief beroep mogelijk is bij de Minister van Financiën ${ }^{9}$. Op grond van artikel

4 Alleen in geval partijen beshuiten om slechts op grond van bewijsstukken uitspraak te doen en het horen van partijen dan wel het onderviagen van getuigen achterwege te laten of indien her slechts om de uitleg van bepaalde regelgeving gaat, wordt een ALJ nier ingezet. Zie meer hierover in paragraf 3.6.1.

5 Ook wel een "inirial decision" genoemd.

6 Vgl. artikel 1:3 Awb. Hetzelfde geldr voor bepaalde beslissingen genomen door DNB zoals het verlenen wan een vergunning aan een beleggingsinstelling.

7. Volgens artikel 6:7 Awb bedraagt deze termijn een periode van zes weken.

8 De sector Juridische Zaken van de Autoriteit-FM is niet alleen een adviesorgaan van de Autoriteit-FM, maar draagt tevens de zorg woor de afhandeling van bezwaarschriten en eventuele beroepszaken. Zie de website van de Autoriteit-FM d.d. 21 januari 2002: hrtp:/www.ste.nl/dynamic/frame.asp?main=/static/algemeen/ \& rop $=/$ static/navigation/topalgemeen.html\&left $=/$ static/navigation/ lefrmenu2.html

9 Een uitzondering is gemaakt voor een aanwijzing gebaseerd op artikel 6 Wte'95, gegewen door de Autoriteit-FM die daartoe gemachtigd is op grond van artilkel 6 Wte'95 $\mathrm{j}^{\circ}$ artikel 2 Overdrachtsbeshuit Wte'95. 
8:1 lid 1 en 8:7 Awb $j^{\circ} 44$ Wte'95 fungeert de rechtbank Rotterdam als administratieve rechter voor het instellen van beroep tegen besluiten genomen op grond van voornoemde wet ${ }^{10}$. De administratieve rechter kan door iedere belanghebbende worden ingeschakeld wanneer deze het niet eens is met het op het bezwaar genomen besluit ${ }^{11}$. Tegen de uitspraak van de rechtbank is zowel voor een belanghebbende alls voor de Autoriteit-FM hoger beroep mogelijk bij het College van Beroep voor het bedrijfsleven in Den $\mathrm{Haag}^{12}$.

Niettegenstaande het verschil in rechtssysteem ${ }^{13}$ lijken de Amerikaanse administratieve en Nederlandse bestuursrechtelijke procedure toch overeenkomsten te vertonen, bijwoorbeeld de ALj. Ondanks het gegeven dat de SEC in een Amerikaanse administratieve procedure een figuur inzet die men in Nederland niet kent, kan gesteld worden dat dit niet veel verschilt van de wijze waarop de Autoriteit-FM handelt. Immers, bezwaar- en beroepschriften worden door de sector Juridische Zaken behandeld, welke - evenals de ALJ - geen rechterlijke instantie is. Het verschil is dat de SEC de ALJ moet verzoeken om een bepaalde sanctie op te leggen. Hier lijkt de SEC voor de oplegging van een sanctie afhankelijk van het oordeel van de "onafhankelijke" ALJ. De sector Juridische Zaken van de Autoriteit-FM voert, al dan niet via een boetefunctionaris, niet alleen het onderzoek uit, maar oordeelt ook over de feiten en bepaalt of er een vergunning wordt verleend. Voor de sanctieoplegging is eerst toestemming van het bestuur van de Autoriteit-FM vereist. Op dit punt lijkt het Amerikaans systeem "onpartijdiger". Immers, in geval de afdeling Enforcement van de SEC meent dat de Amerikaanse effectenwetgeving is overtreden en er daarom gesanctioneerd dient te worden, is er altijd

10 Idem artikel 13 Wmz. Voor beschikkingen op het bezwaar van DNB vgl. artikel 33 Wrb.

11 Vgl. artikel 7:1 Awb.

12 Vgl. artikel 20 lid $11^{\circ}$ de bijlage behorende bij de Wer bestuurstechtspraak bedrijfsorganisatie. Ook voor beschikkingen die afkomstig zijn van DNB fungeert het College van Beroep voor her bedrijfsleven als een hoger beroep instantie.

13 De verschillende rechtssystemen waar hier naar wordt verwezen zijn: het Angelsalksische systeem warrop het Amerikaans toezicht is gebaseerd en het continentaal systeem dat in Nederland wordt gehanteerd. Dat een "strikte vergelijking tussen de bevoegdheden van de SEC en de STE in bepalde opzichten niet gaed mogelijk is (...) bangt samen met het feit dat bet Angelsaksische rechtssysteem, in tegenstelling tot bet continentale, een minder scherpe scheiding kent wussen administratief, civiel en strafrecht." Aldus de wetgever in het wetsyoorstel angaande de WTE'95 in Kamerstukken II, 1994/1995, 23874 , nr. 7. p. 28. 
nog een aparte instantie die, in tegenstelling tot de sector Juridische Zaken van de Autoriteit-FM, naar het schijnt onafhankelijk is van de SEC en die zich over een eventueel op te leggen sanctie kan uitspreken. Het gegeven dat de uitspraak van de AIE - nadat het in kracht van gewijsde is gegaan - als een uitspraak van de SEC moet worden gezien, zou voor enige verwarring kunnen zorgen. De ALJ en de SEC zouden zo gemakkelijk als een twee-eenheid kunnen worden gezien. Dit zou inderdaad het geval kunnen zijn als het niet tot het alleenrecht van de ALJ zou behoren om tijdens (openbare) hoorzittingen feitenonderzoek te verrichten en op grond daarvan te oordelen en sanctioneren. De SEC, de afdeling Enforcement van de SEC of ieder andere afdeling is daartoe niet bevoegd. Wat de afstand tussen de ALJ en (afdelingen van) de SEC nog meer vergroot is de aparte stap die SEC moet nemen alvorens het tot een administratieve procedure kan komen; het indienen van een verzoekschrift door de SEC bij het bureau van de AL.J.

De werkwijze van de Autoriteit-FM, waarin haar sector Juridische Zaken zelf onderzoekt, oordeelt en sancties oplegt, is - vergeleken met die van haar Amerikaanse evenknie - niet aanbevelenswaardig. De schijn kan namelijk gemakkelijk ontstaan dat de sanctieoplegger dan wel degene die de oplegging van een sanctie beoogt, de sector Juridische Zaken, geen onpartijdige kijk meer heeft op de gang van zaken gezien het eerder door dezelfde afdeling uitgevoerd onderzoek ${ }^{14}$. Sterker nog, het is het bestuur van de Autoriteit-FM die toestemming geeft om een bepaald

14 Dat dit geen irreèle gedachte is blijkt wel uir de nota naar aanleiding van her verslag met betrekking tot het wetsvoorstel 25821 dat de invoering van bestuurlijke boetes en dwangsommen (WBS) voorstond. Zie Kamerstukken II, 1998/1999, 25821 , nr. 5, paragraaf 3 in het bijzonder pagina 3 en 4 waaruit blijke dat de wetgever een verplichte functiescheiding heeft beoogd om zo te voorkomen dat er een verstrengeling van belangen en dus een schijn van partijdigheid optreedt doordat de Autoriteit-FM of DNB ter uitvoering van hun toezichtstaken naast controlebevoegdheden, ook sancties mogen opleggen. Voor de wetgewer was het - volgens voornoemd kamerstuk - reeds voldoende om gescheiden afdelingen binnen de organisatie van de toezichthouder te creëren. Dat wil zeggen, enerzijds de organisatie van de toezichthouder en anderzijds de afdeling die de sancties oplegt. De wetgever heeft dit als volgt verwoord: "In dit kader zullen de toezichthouders er derhalue voor moeten zorgen dat niet dezelfle personen bij de witoefening van toezichtwaken een overtreding constateren en vervolgens zijn belats wet bet opleggen van dwangsommen en bestuwrijke boeten". Zie Kamerstukken II, $1998 / 1999,25821$, nr. 5, p. 3 . 
onderzoek voort te zetten en om - in een later stadium - een sanctie op te leggen. Hetzelfde bestuur oordeelt dus twee keer in dezelfde zaak en de sector Juridische Zaken, die de zaak beide keren aan het bestuur heeft voorgelegd, voert de beslissing van her bestuur uit. Of dit betekent dat de Autoriteit-FM voldoet aan de wettelijk verplichte functiescheiding is nog maar de vraag. Het gegeven dat deze besluiten van zowel de SEC als de Autoriteit-FM uiteindelijk in hoger beroep door een rechterlijk college kunnen worden getoetst behoeft het dan reeds aangedane leed niet altijd te verzachten of de aanwezige schijn van partijdigheid weg te nemen. Immers, mocht een rechter in (hoger) beroep tot het oordeel komen dat de toezichthouder ten onrechte een bepaald besluit heeft genomen of dat de door de toezichthouder ingevoerde functiescheiding niet voldoet aan de wettelijk gestelde eisen, behoeft dat niet te betekenen dat de onder toezicht staande instelling daar content over zal zijn. Het procederen op zich brengt al heel wat kosten met zich mee en kan de desbetreffende (rechts)persoon, geheel tegen diens zin, "in de schijnwerpers" plaatsen.

\section{De civielrechtelijke procedure}

Het verschil in rechtssysteem tussen Nederland en Amerika kan men terugvinden in de verschillen in bevoegdheden tussen de SEC en de Autoriteit-FM. Een goed voorbeeld hiervan is de civielrechtelijke procedure. Zoals reeds in hoofdstuk twee is vermeld, heeft de Nederlandse wetgever de Autoriteit-FM geen specifieke rol in een mogelijke civielrechtelijke procedure toegekend. Immers, het civiele recht behandelt in beginsel de onderwerpen aangaande gelijke (burger)partijen. Te veel overheidsoptreden is dan niet passend. Bij deze vorm van techtshandhaving verzorgt de overheid slechts de voorwaarden waaraan een burgerlijk proces moet voldoen. De burgers beslissen of zij al dan niet hun rechten willen handhaven. Een opsomming van civielrechtelijke bevoegdheden van zowel de Nederlandse als de Amerikaanse toezichthouder(s) leidt tot het volgende schema. 


\begin{tabular}{|c|c|c|c|}
\hline 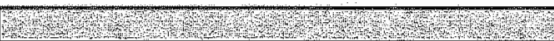 & 1) Med & & Amonk - \\
\hline & $\begin{array}{l}\text { Autoriteit- } \\
\text { FN }\end{array}$ & DNB & SEC \\
\hline $\begin{array}{l}\text { Civielrechtelike bevoegdheden: } \\
\text { - Werzoeken to ontbinding beleggings- }\end{array}$ & - & + & (via aen injunction?) \\
\hline - Verzoek tot vereffening beleggingsfonds & - & * & (via een injunction?) \\
\hline - Werzoek tot gebod doen of nalaten & - & - & + \\
\hline $\begin{array}{l}\text { - Ontrneming van wederrechtelijk werkregen } \\
\text { woordeal }\end{array}$ & - & - & $*$ \\
\hline - Schorsing of ontzetting uit functie & - & + & + \\
\hline $\begin{array}{l}\text { - Oplegging geld boete ti.t.t. Vs is dit in } \\
\text { Nederland besturersechtelijk) }\end{array}$ & + & 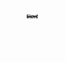 & * \\
\hline $\begin{array}{l}\text { - Benoemen wan een speciale onderzoeks- } \\
\text { commissie }\end{array}$ & + & + & + \\
\hline $\begin{array}{l}\text { - Benoemen van een onafhanikelike over- } \\
\text { koepelende commissie }\end{array}$ & - & - & 4 \\
\hline $\begin{array}{l}\text { - Benoemen van een onafhankelijke } \\
\text { accountantscommissie }\end{array}$ & - & - & + \\
\hline - Instellen wan een bijzondere clearingprocedure & - & - & * \\
\hline $\begin{array}{l}\text { - Nietig verklaren vam een wrederrechtelijke } \\
\text { transactie }\end{array}$ & - & - & 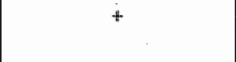 \\
\hline $\begin{array}{l}\text { - Het doem bevriezen van vermogen of fondsen } \\
\text { wan wetsovertreders (beslaglegging op } \\
\text { weimogen) }\end{array}$ & - & * & * \\
\hline $\begin{array}{l}\text { - Werplichten tot het wolgen van specifieke } \\
\text { cursussen }\end{array}$ & - & - & * \\
\hline
\end{tabular}

FIGUUR 4.2 Overzicht wan de behwgrijkste civielrechtelijke bewaegdheden wan de 3 toezichihowders

Uit dit schema valt af te leiden dat de Amerikaanse toezichthouder buitengewoon veel civielrechtelijke bevoegdheden heeft. Let well, deze bevoegdheden kan de SEC pas uitoefenen na een verzoekschrift te hebben ingediend bij een Amerikaanse federale rechtbank. Deze rechtbank kan ${ }^{15}$ het verzoek van de SEC honoreren en naast een gerechtelijk bevel verscheidene door de SEC verzochte civielrechtelijke sancties opleggen. Opvallend is dat de SEC, binnen een civielrechtelijke procedure, niet gelijk wordt gesteld aan de tegenpartij. Immers, zoals reeds uit het derde hoofdstuk naar voren is gekomen is de wettelijk bepaalde positie van de SEC er een van ongelijkheid. Zo worden aan de bewijsstukken van de SEC in een civiele injunctionprocedure minder zware eisen gesteld dan aan het bewijs van de tegenpartij.

Verder valt uit figuur 4.2 af te leiden dat de Nederlandse toezichthouders vrijwel geen civielrechtelijke bevoegdheden hebben. Een verklaring hiervoor is het gegeven dat de overheid geen noodzaak ziet om daar 
ordenend op te treden waar gelijke partijen twisten. Het gevolg is dan ook dat het zeer onwaarschijnlijk is dat men de Autoriteit-FM in een civielrechtelijk proces aangaande een onrechtmatige daad actie, als partij aan zal treffen ${ }^{16}$. De Autoriteit-FM kan via het uitgebreide sanctiearsenaal dat haar binnen een bestuursrechtelijke procedure is toegekend meer bereiken op een eenvoudigere manier. Waarom via een verzoekschrift en een onzekere (kostbare) civielrechtelijke procedure de burgerlijke rechter om schadevergoeding vragen terwijl dat in een bestuursrechtelijke procedure sneller kan via de bestuurlijke boete? Daarnaast is het natuurlijk niet onbelangrijk dat zij zelf veel (meer) invloed heeft in een bestuursrechtelijke procedure dan in het verloop van een mogelijke civielrechtelijke procedure, waar zij in eerste instantie al afhankelijk is van een onpartijdige rechter. Kortom, een civielrechtelijke procedure zal van de Autoriteit-FM naar mijn mening niet zo snel de voorkeur krijgen boven een bestuursrechtelijke procedure. De vergelijking met de positie van haar Amerikaanse collega daarentegen zal de Autoriteit-FM wellicht naar meer doen snakken. Immers, het biedt haar meer mogelijkheden naast haar huidige bestuurstechtelijke bevoegdheden. Zo zou dat én een gemakkelijkere bewijsrechtelijke positie én een uitbreiding van bevoegdheden voor de Autoriteit-FM kunnen betekenen. Of dit daadwerkelijk verwezenlijkt kan worden valt te betwijfelen. Het klinkt misschien wel als muziek in de oren van de toezichthouders, maar naast een verschil in rechtssysteem telt (onder meer) in Nederland de rechtsbescherming zwaar. Een procedure waar de overheid of een overheidsinstantie niet gelijk wordt gesteld aan een burger, kan in ons land materieel geen civielrechtelijke procedure genoemd worden. De bestuursrechtelijke procedure springt er voor de Nederlandse toezichthouders uit. Of dat na bespreking van de strafrechrelijke procedure nog steeds zo is, zal hieronder blijken.

\section{De strafrechtelijke procedure}

Tot slot de strafrechtelijke procedure. De vraag of de strafrechtelijke procedure de toezichthouders meer mogelijkheden biedt dan de hiervoor besproken bestuursrechtelijke en civielrechtelijke procedure kan kort

Vergelijk het in paragraaf 2.5 .2 geopperde idee dat an de onrechtmatige daad verbonden relativiteitswereiste, eerst opgerekt zou moeten worden alvorens de Autoriteit-FM een onrechtmatige daad actie via 6:162 BW kan instellen. Immers voornoemde "oprekking" zou tor gevolg hebben dat de belangen van de beleggers, direct kunnen worden ondergebracht onder de belangen van de Autoriteit-FM waardoor een overtreding wan de effectentypische regelgeving kan leiden tot een beroep door de Autoriteit-FM op 6:162 BW. 
worden beantwoord: integendeel. Zowel in Amerika als in Nederland hebben de hier behandelde toezichthouders de minste invloed op het verloop van een strafrechtelijke procedure. $\mathrm{Zij}$ hebben namelijk niet meer bevoegdheden dan de gewone burger. De toezichthouders kunnen slechts aangifte doen bij het Openbaar Ministerie respectievelijk bij de (assistant) U.S. attorney's werkzaam bij het Amerikaans Department of Justice. Deze beschikken namelijk over de exclusieve bevoegdheid om a] dan niet tot vervolging over te gaan. Aldus kan worden gesteld dat de strafrechtelijke bevoegdheden van de toezichthouders minimaal zijn. Vergelijk figuur 4.3.

\begin{tabular}{|c|c|c|c|}
\hline 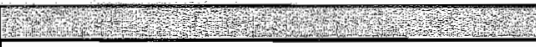 & (2) & d & Amerika \\
\hline & $\begin{array}{c}\text { Autoriteit- } \\
\text { FM }\end{array}$ & DNB & SEC \\
\hline $\begin{array}{l}\text { Strafrechitelijke sancties: } \\
\text { - Slechts de mogelijkeid om, net als iedere } \\
\text { burger, aangifte te doen met het oog op een } \\
\text { mogelijke strafrechtelijke procedure. }\end{array}$ & + & + & + \\
\hline
\end{tabular}

FIGUUR 4.3 Overaichi wan de belangrijkste strafrechtelijke bevoegdheden

Wanneer de drie gerechtelijke procedures naast elkaar worden gezet, lijkt de bestuursrechtelijke procedure de meest gunstige voor de Nederlandse toezichthouder(s) te zijn. De volgende paragraaf zal zich geheel op de bestuursrechtelijke handhavingsinstrumenten richten. Onderzocht zal worden of de Nederlandse wetgever zich laat beinvloeden door haar Amerikaanse gelijke.

\subsection{Een knipoog naar Amerika?}

Nu de positie van de Nederlandse toezichthouder(s) in de drie procedures is vergeleken met die van de Amerikaanse toezichthouder, kom ik tot de beantwoording van de eerder gestelde vraag: Maakt het Nederlands toezicht een knipoog naar Amerika? Anders gesteld: Is er een trend te signaleren dat de Nederlandse wetgever voor de taakomschrijving van onze effectentypische toezichthouders, de Amerikaanse SEC als voorbeeld neemt? Geconcludeerd kan worden dat voor de Nederlandse toezichthouder de bestuursrechtelijke procedure het middel is waarmee zij het meeste invloedrijk is. Inhoudelijk verschillen de bestuursrechtelijke bevoegdheden niet veel van die van haar Amerikaanse collega. Vanzelfsprekend brengt het verschil in rechtssysteem een organisatorisch 
onderscheid mer zich mee zoals de figuur van de Administrative Law Judge. Deze creëert door zijn ogenschijnlijk onathankelijke positie een schijn van onpartijdigheid binnen het Amerikaans administratieve proces. Dit beeld treft men niet aan in het bestuursrechtelijk proces van de Autoriteit-FM. De beslissingsbevoegdheid van het bestuur omtrent het al dan niet voortzetten van een onderzoek en na dit onderzoek het al dan niet opleggen van een sanctie, oogt niet bepaald als een "waterdichte (functie)scheiding". Dit neemt de schijn van partijdigheid niet weg. Hierover zal de rechter zich in de toekomst nog uitlaten. Tot op heden ${ }^{17}$ is het nog niet zover gekomen dat een (rechts) persoon die onder het toezicht van de Autoriteit-FM staat, in hoger beroep is gegaan in een zaak betreffende de oplegging van bijvoorbeeld een bestuurlijke boete. Dit is niet vreemd omdat de Autoriteit-FM pas sinds januari 2000 de bevoegdheid heeft om een bestuurlijke boete op te leggen. Voordat een zaak voor de hoogst mogelijke rechtelijke instantie komt, is er al weer een aantal jaren verstreken.

Terug naar de hierboven gestelde vraag. Kan ondanks het verschil in vormgeving van de bestuursrechtelijke procedure, worden gesteld dat de Nederlandse wetgever de bevoegdheden die de SEC heeft wel aantrekkelijk vindt en deze overneemt of over tracht te nemen voor de Autoriteit-FM en of DNB? Uit verschillende kamerstukken blijkt wel degelijk dat onze wetgever - ondanks de verschillende rechtssystemen lonkt naar de toezichtsinstrumenten waarover de Amerikaanse SEC kan beschikken ${ }^{18}$. Niet zelden wordt, om wetswijzigingen of wetsvoorstellen door te voeren in het (effectentypische) toezicht - al dan niet gepaard

\footnotetext{
17 Voorjaar 2002.

18 Zie bijwoobeeld de brief van de Minister van Financiën Zallm, naar de vaste Commissie voor Financiën wan de Tweede Kamer. In deze brief, te weten de "Nota naar aanleiding van het verslag en nota van wijziging betreffende het wetsvoorstel tot invoering van de dwangsom en de bestuurlijke boete in de financiele wetgeving". In deze brief verwoordr de Minister dit als wolgt: "(..) Tenslotte wordt gewezen op de situatie in bet butenland. In weel andere landen hebben financiele toezichthouders ook de bevogdheid zelf een bestur whike sanctie op te leggen (verwezen zij natar de ats bijlage bij deze nota gevoegde sectorale overzichten). In enkele landen is de toezichtbouder biemaast belast met de opsporing en vervolging van overtredingen van de toezichnetgeving, wathij men - anders daw in Nederland - over (vergande) duangmiddelen beschikt. Dit geldt bijwoorbeld voor de SEC in de" Verenigde Staten." Vgl. brief MvF d.d. 18 februari 1999 aangaande wetswoorstel 25821 dat de inwoering van bestuurlijke boetes en dwangsommen behandelt. Zie Kamerstukken II $1998 / 99,25821$, nr. 5 , p. 4 .
} 
gaande met een toename van toezichtbevoegdheden-, de (positie van. de) Amerikaanse SEC ter illustratie aangewend. Zo zijn er in de kamerstukken ter voorbereiding van de Wte'95 verschillende passages te vinden waarin de positie van de Autoriteit-FM wordt gespiegeld aan die van de $\mathrm{SEC}^{19}$. Ook bij de behandeling van de invoering van de Wet bestuurlijke sancties financiële sector (WBS), komt men de verwijzing naar de SEC weer tegen. Zo wordt er in de kamerstukken aangegeven dat de SEC

"-anders dan in Nederland- over (vergatande) dwangmiddelen beschikt. 20 "

Hierbij wordt duidelijk vermeld dat het verschil in bevoegdheden tussen de Autoriteit-FM en SEC hoofdzakelijk is gebaseerd op het verschil in rechtssysteem; her bovengenoemde Angelsaksisch rechtssysteem versus ons continentale rechtssysteem. Dat dit onze wetgever niet heeft weerhouden om de systematiek van de Amerikaanse toezichthouder te kopiëren blijkt uit het antwoord van de minister van Justitie, die mede namens de minister van Financiën reageert op kamervragen, gesteld door Tweede Kamerleden van de Socialistische Partij (SP).

"(..) Het instellen van een civiele vordering ter verkrijging van een bepaalde sanctie is een bijzonderheid uit het Angelsaksische, en in het bijzonder het Amerikaanse rechtssysteem, die zich als zodanig nier leent voor inpassing in het Nederlandse rechtsstelsel. Met het wetswoorstel tot invoering var de dwangsom en bestuurlijke boete in de financiële toezichtwetgeving (kamerstukken 25821) wordt echter in de financiële toezichtwetgeving een systematiek geintroduceerd die materieel vergelijkbatr is met de bovengeschetste anpate in de Verenigde Staten, (... $)^{2 t}$

Uit het hiervoor gestelde kan worden geconcludeerd dat er wel degelijk een ontwikkeling waar te nemen is waarin de Nederlandse wetgever, waar het uitkomt, de bevoegdheden van de Amerikaanse toezichthouder voor zover mogelijk overneemt of tracht in te passen in ons continentaal rechtssysteem. Dit wekt de suggestie dat men "Amerikaanse toestanden $^{22 "}$ in Nederland kan verwachten, maar is dat wel waar? Vermoedelijk niet, want niet alle bevoegdheden van de SEC kunnen klakkeloos in

19 Vergelijkingen tussen de STE en de SEC bij de behandeling van cle wet toezicht effectenverkeer 1995 zie de Kamerstukken II, 1994/1995, 23 874, nr. 7 met name p. $27-28$.

Vgl. kamerstukken II, 1998/1999, 25 821, nr. 5, p. 4.

$24 \quad$ Vgl. Aanhangsel Handelingen, nr. 28, vergaderjaar 1999-2000, p. 55 - 56 .

22 Amerikaanse toestanden in de zin van zeer ruime bevoegdheden voor de toezichhoudende Auroriteit $-F M$ en of DNB 
Nederland worden geïntroduceerd. Vergelijk de bevoegdheid tot beslaglegging of de ontneming van wederrechtelijk verkregen voordeel die door de SEC als dwangmiddel in respectievelijk de civielrechtelijke en/of de adminstratieve procedure kunnen worden toegepast. Dergelijke bevoegdheden komen in ons stelsel niet aan de Autoriteit-FM of DNB toe, maar aan het Openbaar Ministerie, en horen thuis op het gebied van het strafrecht. In eerste instantie zou kunnen worden gesteld dat een bespreking van het strafrecht hier niet gepast is, immers dat behoort tot het terrein van het Openbaar Ministerie. De toezichthouders - waar deze studie zich op heeft gericht - hebben op dat terrein geen (handhavings) bevoegdheden. Toch meen ik, zoals ik dat reeds in de algemene inleiding heb aangegeven, dat een bespreking van het strafrecht gepast is. Immers, alleen al uit de Clickfondszaak kan afgeleid worden dat ook via het strafrecht kan worden bereikt dat de effectentypische regelgeving wordt gehandhaafd. Dit zal niet op de directe wijze geschieden - zoals terug te zien is bij de Autoriteit-FM en DNB -, maar op een indirecte wijze. Ik noem het: "de preventieve werking van het strafrecht".

In het volgende hoofdstuk zal terugverwijzend naar de algemene inleiding, worden aangegeven waarom de gevolgen van de indirecte werking van het strafrecht in deze studie important zijn. Hierdoor zal antwoord gegeven kunnen worden op de vraag of de effectentypische regelgeving mede via her strafrecht dient te worden gehandhaafd waardoor kan worden aangegeven wat ons strafrecht toevoegt aan de handhaving van Nederlandse effectentypische regelgeving. 

Hoofdstuk 5

\section{De relatie tussen de effectentypische wetgeving en het strafrecht}

\subsection{Inleiding}

Eerder is in de algemene inleiding getracht om in grote lijnen weer te geven wat de essentie van het strafrecht is. Ook in dit hoofdstuk zal het strafrecht centraal staan. Hier zullen de eerder genoemde effecten van het strafrecht op overtreders van de effectentypische regelgeving nader worden bekeken. Het doel hiervan is antwoord te geven op de vraag of her strafrecht wel een geschikt middel is om overtredingen van de effectentypische regelgeving aan te pakken.

Uit de voorafgaande hoofdstukken is duidelijk geworden dat de effectentypische toezichthouders weliswaar geen strafrechtelijke handhavingsbevoegdheden hebben, maar dat het strafrecht wel degelijk een belangrijke rol kan spelen in het effectentypische handhavingsproces. De vraag waar wij nog voor staan luidt: wat voegt het strafrecht toe aan het effectentypische toezicht? Deze vraag zou vanuit een puur theoretische invalshoek beantwoord kunnen worden door de verschillende rechtsgebieden met elkaar te vergelijken en vervolgens aan de hand van het meest slagvaardige, dan wel het meest efficiënte rechtsgebied tot een conclusie te komen. In dat geval zou - wanneer we uitgaan van de handhaving van de Amerikaanse effectenwetgeving zoals genoemd in hoofdstuk drie en uitgaande van de Nederlandse situatie in de hoofdstukken twee en vier - het strafrecht als geschikt handhavingsmiddel naat voren komen. Het strafrecht blijkt zowel in de USA als in Nederland voldoende afschrikwekkend te zijn om als ultimum remedium te dienen wanneer andere rechtsgebieden te kort schieten. Daarnaast moet niet uit het oog worden verloren dat het strafrecht meer en eerder de mogelijkheid biedt om dwangmiddelen in te zetten. Wanneer er met deze conclusie genoegen zou worden genomen, zou men gemakshalve voorbij gaan aan een zeer belangrijk en veelal onderschat effect van het strafrecht dat vooral binnen de effectenwereld grote gevolgen kan hebben. Het strafrecht kent namelijk niet alleen grondslagen en doelen zoals vergelding en preventie, maar ook bijkomende- of neveneffecten. Eerder is de stigmatiserende 
werking van het strafrecht als bijkomend effect naar voren gekomen. Voomoemd effect komt niet alleen voor bij de handhaving van effectentypische wetgeving - binnen de effectensfeer -, maar ook de gewone man van de straat kan er mee te maken krijgen wanneer hij bijvoorbeeld een inbraak pleegt. Dat neemt niet weg dat de stigmatisering binnen de effectenwereld voor de verdachte een dusdanig effect heeft, dat overwogen moet worden of dit nog wel als een bijkomend effect beschouwd mag worden. Daarom zal in het bijzonder gekeken worden naar de daadwerkelijke uitwerking van dit neveneffect wan het strafrecht. Besproken zal worden of niet reeds via voornoemd effect het strafrechtelijk doel wan vergelding wordt uitgeoefend. Tot slot zal. antwoord worden gegeven op de vraag of de effectentypische regelgeving - zelfs in het geval dat er een laatste redmiddel is vereist - al dan niet via het strafrecht dient te worden gehandhaafd.

\subsection{Het stigmatiserend effect als (bijkomend) neveneffect of als vergelding?}

Hoe moet de uitwerking die de strafrechtelijke handhaving heeft op het gebied van de effectentypische regelgeving, worden beoordeeld tegen de achtergrond van de verenigingstheorie en de hier verdedigde opvatting van een gematigd instrumentalisme waarin aan de rechtsbescherming een belangrijke rol is toebedeeld? Kan worden gesteld dat het bijkomend stigmatiserend effect van een strafrechtelijke procedure voor effectentypische wetsovertreders gelijk kan worden gesteld aan het strafrechtelijke doel van vergelding? Ervoor kan worden gepleit dar in effectentypische zaken die in de media breed zijn uitgemeten, de "straf" door het stigmatiserend effect van een strafrechtelijke procedure al lijkt te zijn opgelegd en de schade die de verdachte individu of organisatie lijdt evenredig lijkt aan het toegebrachte leed of mag hier niet worden gesproken van vergelding zoals gebruikt in de algemene inleiding?

't Hart' noemt de toenemende invloed van de media op het strafproces "mediatisering" van het strafproces ${ }^{2}$. Hij stelt dat bij mediatisering, met

Vergelijk Hart, A.C. " $t$, "Hier gelden wetten!- over strafrecht, Openbaar Ministerie en multiculturalisme", in: Mejjers-reeks, dl. 35, uitgawe in samenwerking met het E.M. Meijers Instituut, Insrituut voor Rechtswetenschappelijk Onderzoek, Gouda Quinr, Deventer, 2001, p. $131-166$.

2 De zogenaamde "Haklkelaar-zaak" is een goed voorbeeld van een rechtszak die constant de aandacht wan de media had. Zie HR 6 april 1999, N] $1999 / 566$. 
name wanneer het de televisie betreft, er feitelijk geen sprake is van "equality of arms'3 en dat het "kwatad al is geschied" onder meer omdat de media andere invalshoeken gebruiken dan het recht $t^{4}$. De visie van het recht is volgens ' $\mathrm{Hart}$ abstract, afstandelijk en kunstmatig. De visie van de media is tegengesteld. Wanneer de media zich dusdanig in een zaak gaan mengen dat zij als medespeler kunnen worden gezien ${ }^{5}$, kan dit zeer nadelig zijn voor de verdachte als speler in een strafrechtelijke procedure, maar nog meer voor het strafprocesrecht dat op grondslagenniveau uit haar kunstmatig gecreëerde balans raakt.

Baauw $^{6}$ is in zijn oratie uitwoerig ingegaan op vraag wat een eerlijke berechting inhoudt. Het antwoord op deze vraag bevat verschillende aspecten. Een eerlijke berechting omvat volgens Baauw mede een openbare behandeling van de zaak die door een onafhankelijke en onpartijdige rechter moet worden voorgezeten en binnen een redelijke termijn afgedaan dient te worden. Daarnaast dient het vonnis openbaar uitgesproken te worden ${ }^{7}$. Verwijzend naar zijn ervaringen als advocaat in fraudezaken ${ }^{8}$ stelt hij dat de verdachte (rechts)personen "steevast" een openbare behandeling van hun zaak willen voorkomen en voorstellen

3 Doordat de discussie in de media niet gelijk kan worden gesteld aan het onderzoek ter terechtzitting, kan de verdachte niet onmiddellijk reageren. Hierdoor kan al stigmatisering plaatsvinden Vgl. Zie Harc, A.C. "r, "Hier gelden wetten!", ta.p. noot 1, p. $131-166$.

* Daarnaast kunnen de "aantijgingen" in de media ook na beèindiging van het strafproces doorgaan. Vgl. Zie Hart, A.C. "t, "Hier gelden wetten!", t.a.p. noot 1. p. $131-166$.

5 De strafrechtelijke procedure tegen de Hakkelaar was doordrenkt van publiciteit. De media werden gezien als "medespeler" doordat zij zelf onderzoek verrichtten watarvan de resultaten al dan niet via actualiteitenprogramma"s ter zitring werden besproken. Daarnaast maakten zowel de advocaten als de officieren van justitie gebruik van de media, Op deze manier werd de strijd niet alleen "in de rechtzaal", maar ook buiten de rechtzaal gevoerd. Zie Hart, A.C. 't, "Hier gelden wetten"", t.a.p. noor 1, p. $131-166$.

* Baauw, P.J., "Eerlijke berechring en bijzonder straf(proces)recht", oratie RUU, Gouda Quint, Deventer, 1999.

7 Baauw, $\mathbb{P}$ J., "Eerlijke berechring en bijzonder straf(proces) recht", t.a.p. noot 6 , p. 21 .

8 Baauw wult het begrip fraudepraktijk in door de volgende termen: "witteboordencriminaliteit, business crime, corporate crime, organisatiecriminaliteit of dirty business". Zie Baauw, P.j., "Eerlijke berechting en bijzonder straf(proces) rechr", t.a.p. noot 6, p. 18. 
om eventueel een - in wezen heel Amerikaanse - "deal9" te sluiten ${ }^{10}$. Baauw ziet hierin: "een resolute afwijzing van de belangrijkste processuele verwarvenbeid uit het EVRM"11. Deze afwijzing door dergelijke verdachten moet volgens Baauw dan ook als een "afstand van recht" worden beschouwd die zelfs "beloond" zou moeten worden ${ }^{12}$, al dan niet via een zogenaamde "deal". De bezwaren die in de literatuur te vinden zijn tegen het sluiten van een deal zijn volgens Baauw "nogal betrekkelijk". Zo meent hij dat het bezwaar van de oncontroleerbaarheid door afwezigheid van de externe openbaarheid te ondervangen is door de interne openbaarheid die volgens Baauw een veel grondiger controlemogelijkheid biedt. De verdediging dient adequate toegang te krijgen tot het gehele procesdossier. Met andere woorden, externe openbaarheid wordt hier gelijk gesteld aan de interne openbaarheid, die er moet zijn ten behoeve van de verdediging en van de raadsman als (proces) bewaker ${ }^{13}$. De externe openbaarheid omvat echter meer dan de openbaarheid met het doel "het recht van de verdachte op publieke controle van hetgeen met hem of haar (wordt) gedaan ${ }^{14 " .}$. De externe openbaarheid dient ruimer gezien te worden, namelijk als een algemene maatschappelijke eis om de machtsverhoudingen en de besluitvormingsprocessen controleerbaar te maken ${ }^{15}$. Niet alleen de belangen van de verdachte maar ook die van de overige burgers tellen hier mee.

Een ander bezwaar tegen het aangaan van een transactie is dat door het ontbreken van een openbare terechtzitting de generale preventie als

"Lees: "gebruik te maken van een transactiemogelijkheid".

10 Zie een boekbespreking wan Baauw's oratie door Van der Heuvel in RMThemis, waarin hij bezwaar uit tegen de naar zijn mening lichtvaardige wijze waarmee Baaw omgaat met de rechtsbescherming. Van den Heuvel meent dat Baauw, als adwocaat, meer engagement heeft met zijn cliëntèle, hetgeen in strijd lijkt te mijn met de Utrechtse traditie. Heuwel, G. van den, "boekbeschouwingen van: C.H. Brants, Over levende gedachten. De menselijkheid van een functioneel strafrecht en wan P.J. Baauw, Eerlijke berechting en bijzonder straf(proces)recht", RMThemis 2000 , nr. 5, p. 189.

1t Baauw, P.J., "Eerlijke berechting en bijzonder straf(proces) recht", t.a.p. noot 6, p. $18-19$.

12 Baauw, P.J., "Eerlijke berechting en bijzonder straf(proces) rechr", t.a.p. noor 6, p. $18-19$.

13 Vgl. het proefschrift van Taru Spronken: Spronken, "T., "Verdediging: een onderzoek naar de normering van het optreden van advocaten in strafzaken", dissertarie UM, Gouda Quint, Maastricht 2001.

14 Zie Hart, A.C. "t, "Hier gelden wetten!", t.a.p. noot 1, p. 149.

15 Zie Hart, A.C. "t, "Hier gelden wetten!", t.a.p. noot 1, p. $149-150$. 
beoogd strafdoel minder goed kan werken. Baauw is van mening dat de generale preventie ook zou kunnen werken door in het algemeen, per bedrijfstak aan te geven wat er door het $\mathrm{OM}$ of door de belastingdienst is geïncasseerd en dat niet altijd individualisering nodig is. In tegenstelling tot Baauw meen ik dat juist binnen de financiële wereld, de openbaarheid - het onder de aandacht van het publiek brengen van een gepleegde wetsovertreding - inherent is aan de afschrikwekkende voorbeeldfunctie van het straffen. Hier kom ik later nog op terug. Volgens Baauw leiden er meerdere wegen naar Rome. Hij meent dat het goed mogelijk is om het (voor hem) meest primaire strafdoel, te weten de proportionele vergelding, door een "deal" een "substantiële financiële aderlating" van verdachten in dergelijke fraudezaken te bewerkstelligen. Hierdoor "ontspringt" de verdachte volgens hem de dans toch niet. Baauw duidt aan dat juist in fraudezaken de door de openbaarheid veroorzaakte publiciteit een eerlijke berechting in de weg kan staan. Hij stelt dat het niet alleen gaat over "trial by the media" maar dat er zelfs kan worden gesproken van "execution by media", ondat de vermeende dader reeds door de media wordt berecht alvorens de rechter daadwerkelijk tot zijn vonnis kom. ${ }^{16}$. Daarmee wordt echter miskend dat een "deal", een "financiële aderlating", niet altijd het door het strafrecht beoogd effect tor gevolg zal hebben ${ }^{17}$. Natuurlijk kan dit wel opgaan voor de bonafide effectenhandelaar of een andere bonafide actor binnen de effectenwereld die daadwerkelijk "bloedt" door een financièle aderlating en dit als een straf ervaart, maar de situatie kan anders zijn. Het is namelijk niet ondenkbaar dat er zeer berekenende actoren met malicieuze plannen binnen de effectenwereld actief zijn. Voor dergelijke lieden is een financiële boete niet voldoende, maar zal de openbaarmaking van een rechterlijke uitspraak en de openbaarheid van het strafrechtelijke proces binnen de financiele wereld pas voldoende afschrikwekkend zijn en als een straf worden ervaren omdat zij dan niet meer onder de eigen (besmette) naam actief kunnen zijn binnen de effectenwereld. Deze (rechts)personen zullen een andere manier moeten zoeken om aan de kost te kunnen komen.

16 Baauw, P... "Eerlijke berechting en bijzonder straf(proces) reche", Ea.p. noot 6, p. 23.

17 Zo ook Van den Heuvel. Hij stelt terecht: "War geld in overvloed is beoft transactie" weinig generad of speciad effect (...). "Vgl, Van den Heuvel, G.A.A.J. "Een criminologische agenda voor strafrechthervorming in de bundel Legitieme strafvordering; rechten van de mens als inspiratie in de $21^{\text {ste }}$ eeuw", Intersentia Rechtswetenschappen, Antwerpen-Groningen, 2001, p. 182. 
Ook al zou het mogelijk zijn om onder een andere naam of onder de naam van een ander als actor binnen de effectenwereld te opereren, toch is dat allerminst aantrekkelijk.

Baauw duidt aan dat het grondrecht van een eerlijke berechting in dergelijke gevallen inhoudsloos is geworden omdat:

"bet ènkel nowmen van de naam van een persoon en of onderneming in de financiele wereld direct leidt tot schade wan een ongekende orde: miljoenen werlies door weglopen wan opdrachtgevers of afgedwangen overnames, ontslag, defunitieve uitstoting uit de branche, gebroken relaties en reputaties ${ }^{\text {th }}$.

Al ben ik van mening dat Baauw de betekenis van de generale preventie onderschat, ik erken dat hij hier een punt heeft. Immers, hoe de berekenende malafide effectenwetsovertreder te onderscheiden van degene die per abuis de wet hebben overtreden? Door - met het oog op voornoemd onderscheid - vooraf al een traject te bepalen, namelijk wel of niet "openbaar gaan", wordt reeds een oordeel over de verdachte uitgesproken voordat hij zich voor de rechter moet verantwoorden en dat past niet binnen ons strafrechtssysteem. Het zou immers betekenen dat de strafprocessuele beginselen met voeten worden getreden, omdat er een accentverschuiving plaatsvindt. De verdachte die zich tijdens het openbaar onderzoek ter terechtzitting zou moeten verdedigen, kan zich door de berichtgeving in de media "gedwongen" zien om al eerder zijn kant van het verhaal kenbaar te maken, met alle voor hem onaangename gevolgen van dien. De kans bestaat dat de verdachte die wil redden wat er te redden valt en de schade aan zijn goede naam, klandizie dan wel zijn bedrijf zoveel mogelijk tracht te beperken, juist het tegengestelde effect bereikt. In dit verband wijs ik op het gevaar dat de verdachte ter terechtzitting door het Openbaar Ministerie wordt geconfronteerd met opmerkingen van de verdachte die al dan niet waarheidsgetrouw via de media toegang tot het grote publiek hebben gekregen. De schade is dan al aangericht. Voorbeelden hiervan spelen zich af in de USA. Allereerst was er de Enron-affaire. In deze zaak, waarin sprake bleek te zijn van boekhoudkundige fraude, stortte de Amerikaanse energiegigant Enron ineen en ging failliet. Een golf van massaontslagen volgde en niet alleen in de USA, maar ook in Europa volgden geïnteresseerden met argusogen deze zaak. Er werd gezocht naar schuldigen. De aandacht richtte zich

Vgl. Baauw, P.J., "Eerlijke berechting en bijzonder straf(proces)recht", r.a.p. noot 6. p. 24. 
niet alleen op het accountantskantoor Arthur Andersen, maar ook op het leidinggevend niveau van Enron én op de politieke arena van Washington D.C. De kranten waren van mening dat de SEC veel te laat was optreden; pas nadat de misstanden breed in de pers waren uitgemeten ${ }^{19}$. Enron was - zo bleek later-de aanzet naar meerdere misstanden in de financiële wereld. Een duidelijk voorbeeld van een (passieve) veroordeling in de media zijn de beelden van de arrestatie van Scott Sullivan van het telecombedrijf Worldcom. Over de hele wereld zijn de televisiebeelden gegaan van Sullivan die geboeid door een FBIrechercheur werd afgevoerd ${ }^{20}$. Sullivan moest nog verhoord worden. Maar het beeld stond al vast: hij werd als verdachte afgevoerd. Menigeen zal bij het zien van deze beelden, zeker zo vlak na het Enron-debacle, van mening zijn dat ook Sullivan schuldig is aan het (doen) plegen van valsheid in geschriften door met de financiële boeken te "sjoemelen" en door te weinig belasting te betalen ${ }^{21}$. Dat Sullivan na het storten een borgsom weer naar huis is gegaan heeft geen televisiezender getoond. Of Sullivan nu daadwerkelijk schuldig is aan het plegen van valsheid in geschrifte is nog niet bekend, maar voor het (Amerikaanse) publiek staat dat - zeker na de televisiebeelden - al vast. Daar waar de rechter naar aanleiding van het onderzoek ter terechtzitting - áls het tot een rechtzaak komt - zijn oordeel zou moeten uitspreken over de vermeende feiten gepleegd door Sullivan, heeft het publiek zijn oordeel al geveld. De naam Sullivan is besmet geraakt en het is maar de vraag of een toekomstige werkgever, die actief is binnen de effectenwereld, hem nog zal aannemen.

Ook uit het gegeven dat het niet altijd tot een onderzoek ter terechtzitting komt omdat sommige overtredingen uit de sfeer van het strafrecht zijn gehaald blijkt dat er sprake is van de eerder genoemde accentyerschuiving binnen het straf(proces) recht. Reeds met de invoering van de Wet administratiefrechtelijke handhaving verkeersvoorschriften ${ }^{22}$ (Wahv) is er een tendens waar te nemen waarbij overtredingen van de (bijzondere) strafwetgeving uit de sfeer van het strafrecht worden gehaald en buiten

19 Redactie FET, "Revïsor kan zichzelf niet controleren", de Financieel-Economische Tijd, 19 jantuari 2002.

20 Houben, M. en Van der Walle, E., "Enron-virus komt de oceaan over", NRC Handelsblad, 30 oktober 2002.

21 Meer over de gevolgen van (strafrechtelijk getinte) publiciteit voor rechtspersonen in: Fisse, B en Braithwaire J., The impact of publicity on corporate offenders, State University Press, Albany, 1983. 
de strafrechter om worden afgedaan. Dit kan plaatsvinden doordat er een transactie met de politie of het Openbaar Ministerie wordt overeengekomen of doordat de wetsovertreder een bestuurlijke boete voldoet. In dergelijke gevallen, door deze buitengerechtelijke wijze van afdoen, is de belangrijkste drijfveer van het straf(proces) recht, te weten de waarheidsvinding, op de achtergrond geraakt. Één van de nadelen van een dergelijke vorm van afdoening is dat er door de "verdachte" aan rechtsbescherming wordt ingeboet ${ }^{23}$.

Dit brengt ons terug tot de vraag naar de verhouding tussen het stigmatiserend effect van het strafrecht en de vergelding als doel van dat strafrecht. Ik meen dat - in zaken die de publiciteit halen - de ongewenste naamsbekendheid in de pers, het verlies van klandizie, de derving van winst en de afgenomen kans om in de toekomst werkzaam te zijn binnen de effectenbranche, door de verdachte wel degelijk als een vorm van vergelding kan worden gezien. Opgemerkt dient wel te worden dat de "vergelding" in beginsel pas plaats dient te hebben, nadat de rechter zich over de zaak heeft gebogen en aan de hand van het bewijsmateriaal tot de conclusie is kunnen komen dat de verdachte daadwerkelijk schuldig is. Zowrel uit de Clickfonds-zaak als uit de HCS-zaak kan worden opgemaakt dat - indien het tot een strafzaak komt - voor onder meer de verdachten van financiële delicten de "vergelding", al dan niet mede door de stigmatiserende werking via de media, vaak al plaats heeft gevonden voordat de rechter zich over de zaak heeft gebogen. Dat die laatste zich daar vaak bewust van is, blijkt uit recente vonnissen waar er bij de oplegging van de straf - de schuldigverklaring - met die "mediasanctionering" rekening is gehouden door lagere straffen op te leggen. Een voorbeeld hiervan is de uitspraak van de arrondissementsrechtbank Amsterdam d.d. 22 juni 2001 inzake Leemhuis \& Van Loon Vermogensbeheer B.V.

Nu duidelijk is dat - in effectentypische strafzaken die de publiciteit halen - voor de desbetreffende verdachte de stigmatisering als één van de effecten van de strafrechtelijke handhaving, als een doel van het strafrecht gezien kan worden, is het niet ongepast de vraag te stellen wat de toegevoegde waarde van het strafrecht in dit soort zaken is. Zouden overtredingen van de effectenwetgeving wel strafrechtelijk moeten

23 Vgl. Corstens, G.J.M.: "Een stille revolurie in het strafrecht; afscheidsrede Katholieke Universiteit Nijmegen", Gouda Quint B.V., Arnhem, 1995. 
worden afgedaan, of is de een andere vorm van afdoening toch geschikter? Indien dat laatste her geval is, hoe zit het dan met de rechtsbescherming buiten het strafrecht? Deze vragen zullen hieronder worden beantwoord.

\subsection{Strafrechtelijke handhaving van effectentypische wetgeving?}

In de voorgaande hoofdstukken is naar voren gekomen dat het strafrecht bij de handhaving wan effectentypische regelgeving een afschrikwekkend effect en een stigmatiserende werking kan hebben op het verdachte individu of de verdachte organisatie. Verder is duidelijk dat, indien het bij effectentypische wetsovertredingen alsnog tot een strafproces mocht komen, éen van de strafrechrelijke doelen te weten "een vergelding", al voor aanvang van het onderzoek ter terechtzitting kan plaatsvinden. Daarom zou een rechterlijke veroordeling waar de gevolgen van voornoemd bijkomend effect van het strafrecht niet in zijn verdisconteerd, een dubbele vergelding of een onnodig zware leedtoevoeging tot gevolg hebben. Dit, en het gegeven dat een strafrechtelijke procedure binnen de Nederlandse en Amerikaanse financieel economische wereld als laatste redmiddel moet worden beschouwd, brengt mij tot het volgende. Bij de handhaving van effectentypische regelgeving kan de toegevoegde waarde, de functie, van het strafrecht gezien worden als een vangnet. Het strafrecht kan zeer wel als ultimum remedium dienen, als laatste redmiddel; een vangnet voor specifieke gevallen. De handhaving van de effectentypische regelgeving zal hoofdzakelijk door middel van het recht waarbinnen de desbetreffende toezichthouder opereert (het bestuursrecht), dan wel door middel van het civiele recht moeten geschieden. Pas wanneer mocht blijken dat handhaving tekort schiet dient het strafrecht ingezet te worden.

Ook De Roos en Doorenbos zijn van mening dat het strafrecht als vangnet kan dienen bij de handhaving van (financieel) economische delicten $^{24}$. In zijn dissertatie heeft De Roos aangevoerd dat hij handhaving door middel van het strafrecht ${ }^{25}$ passend vindt voor de "ernstiger" delicten die niet door het bestuursrecht kunnen worden afgedaan ${ }^{26}$.

24. Hiertoe behoren ook overtredingen van de effectentypische regelgeving.

25 Zeker in geval van een overtreding van economische delicten.

26 Vgl. het proefschrift van Th. de Roos. Roos, Th. de, "Strafbaarstelling yan economische delicten: een crimineel-politieke studie", dissertatie RUU, Gouda Quint B.V., 1987 , p. $70-79$. 
Doorenbos concludeert naar aanleiding van zijn (de)criminaliseringstoets dat het strafrecht daar een taak heeft waar de alternatieven zoals civielrechtelijke, bestuursrechtelijke handhaving of zelfregulering geen vat hebben op wetsovertreders ${ }^{27}$. Beiden zijn het er over eens dat het strafrecht niet geheel uit het handhavingsarsenaal van de financiële wetgeving dient te worden geschrapt; het kan inderdaad dienst doen als vangnet wanneer bijvoorbeeld het bestuursrecht tekort schiet.

\subsection{Conclusie}

De hiervoor genoemde vangnetfunctie van het strafrecht impliceert dat er een ander rechtsgebied is waarop in eerste instantie een beroep zou kunnen worden gedaan: het bestuursrecht. Uit het onderzoek naar de Nederlandse en de Amerikaanse effectentypische rechtshandhaving is af te leiden dat de desbetreffende toezichthouder voor de uitoefening van de toezichtstaken over een uitgebreid bestuursrechtelijk sanctiearsenaal beschikt. Verder is uit deze studie naar voren gekomen dat de Nederlandse toezichthouder, anders dan haar Amerikaanse collega, over minder civielrechtelijke sanctiemiddelen beschikt. Dit verschil is terug te voeren op het verschil in rechtsstelsel en rechtscultuur.

$\mathrm{Nu}$ in beginsel voor de handhaving van effectentypische wetgeving niet gekozen dient te worden voor het strafrecht, maar voor het bestuursrecht, moet er nog een laatste kwestie worden besproken alvorens deze studie kan worden afgesloten; de rechtsbescherming. Ondanks het gegeven dat het strafrecht - ook voor effectentypische wetsovertredingen - als ultimum remedium moet dienen, heeft dit recht als pluspunt de hieraan inherente rechtsbescherming voor de verdachte. De ongelijke positie van de verdachte ten opzichte van de met opsporing en vervolging belaste autoriteiten in de huidige gangbare opvattingen over het strafrecht, heeft bevorderd dat binnen het strafrecht rekening wordt gehouden met de rechtsbescherming van de verdachte. Deze heeft gestalte gekregen in

27 Als voorbeeld bezigt Doorenbos de vergunningsplichtigen waar administratiefrechtelijke handhavers geen vat op hebben. Het strafrecht kan dan een geschikt (hulp)middel zijn om de vergunningsplichtige aan te pakken en zo de andere actoren te beschermen. Vlg. Doorenbos, Financied strafrecht: een studie inzake strafrechtelijk gesanctioneerde voorscbriften wit de bank-ex effectemuetgeving, dissertative KUN, Kluwer, Deventer 1992, p. 508. Zie ook Corstens, G.J.M., "Een stille revolute in bet strafrecht" afscheidsrede Katholieke Universiteit Nijmegen", t.a.p. noor 23 . 
verschillende verdragen en wetsartikelen. Desalniettemin dient er constant voor te worden gewaakt dat er niet "beknibbeld" wordt op de rechten van de verdachte. In de literatuur is dit een punt van voortdurende aandacht. Hoe is het in het bestuursrecht met de rechtsbescherming gesteld? Bevindt de (rechts)persoon zich in een dusdanige positie dat deze tegen een overheidsorgaan, het zelfstandig bestuursorgaan, beschermd dient te worden? Uit hoofdstuk twee is af te leiden dat ook een (rechts) persoon binnen her bestuursrecht rechtsbescherming behoeft. Zo zal dat veelal het geval zijn bij de oplegging van een bestuurlijke boete. In paragraaf 2.5 .1 is naar voren gekomen dat bij een bestuurlijke boete het accent op genoegdoening ligt en de boete vanwege haar leedtoevoegende aard een strafrechtelijk karakter krijgt. Het gevolg hiervan is dat deze bestuurlijke sanctie in zoverre gelijk kan worden gesteld aan een strafsanctie. Daarom dient, zoals in paragraaf 2.5.1 is opgemerkt, een aantal rechtswaarborgen in acht te worden genomen. Deze vloeien onder meer voort uit het IVBPR en het EVRM. Het belang van deze rechtswaarborgen komt vooral tot uitdrukking in het recht op berechting door een rechter in een "fair trial", een eerlijk proces. Op grond van verschillende internationale verdragen zoals het hiervoor genoemde IVBPR maar vooral via de artikelen 6 en 7 van het EVRM dienc het opleggen van boetes omgeven te zijn met strafvorderlijke rechtswaarborgen. Niet bij alle bestuursrechtelijke sancties zal de mate van rechtsbescherming gelijk zijn omdat zij niet alle een strafrechtelijk karakter hebben. Het bestuursrechtelijke sanctierecht kent namelijk zowel reparatoire als leedtoevoegende of punitieve sancties. Wanneer het reparatoire sancties betreft, zoals bijvoorbeeld het verwijderen van een illegaal bouwwerk, is het optreden van de toezichthoudende instantie gericht op het herstellen van de normschending. Bij (feitelijk) punitieve sancties staat de bestraffing van de wetsovertreder centraal. In dat geval zou het uitlokken van een dergelijke sanctie - volgens de criteria zoals vastgesteld in de jurisprudentie van het EVRM - beschouwd kunnen worden als een "criminal charge". Zo kan van het geven van een aanwijzing of wan het opleggen van een bestuurlijke geldboete, dan wel het onder curatele stellen van een (rechts)persoon ook niet worden gesteld dat het accent op leedtoevoeging ligt waardoor de desbetreffende (rechts)persoon extra rechtsbescherming tegen het zelfstandig bestuursorgaan behoeft. Slechts bij de bestuurlijke boete ${ }^{28}$ kan over criminal 
charge en dus over (verdragsrechtelijke) rechtsbescherming worden gesproken ${ }^{29}$. Dit betekent niet dat het overheidsorgaan bij de toepassing van de overige bestuursrechtelijke sancties vrij is in de behandeling van de (rechts)persoon en dat deze zich maar heeft te conformeren aan de wensen van de toezichthouder. De toezichthouder blifft, vooral waar het beschikkingen betreft, gebonden aan rechtsnormen die gelden voor bestuurlijk handelen zoals de algemene beginselen van behoorlijk bestuur.

Aldus kan worden gesteld dat de positie van de (rechts)persoon zowel in een bestuursrechtelijke procedure - bij de oplegging van een punitieve of een reparatoire sanctie - als in een straf(proces)rechtelijke procedure kan worden verstevigd door (verdragsrechtelijke) rechrsbeschermende normen en beginselen. Hiermee kom ik tot de conclusie en aanbeveling dat de overtredingen van effectentypische regelgeving in beginsel bestuursrechtelijk zouden moeten worden afgedaan. Daar waar het bestuursrecht tekort schiet, kan het strafrecht alsnog een uitweg bieden. Terughoudendheid met de toepassing van het strafrecht verdient de voorkeur. Het strafrecht dient aldus werkelijk als ultimum remedium. 


\section{Samenvatting}

Dat er binnen de dynamische wereld van het Nederlandse effectenverkeer ook wel eens onoirbare praktijken kumnen plaatsvinden is ons na de Clickfondszaak niet onbekend. De inval door het Openbaar Ministerie op de Amsterdamse effectenbeurs op 25 oktober 1997 heeft destijds veel stof doen opwaaien. Plotseling heeft heel Nederland via de media het beeld voorgeschoteld gekregen dat de Nederlandse beurzen een bolwerk zijn van handelaren die er niet voor schromen om dubieuze praktijken toe te passen. We kenden dat beeld reeds uit de Verenigde Staten van Amerika (Amerika), waar de Amerikaanse toezichthouder op het gebied van het effectenverkeer (de effectentypische toezichthouder), de Securities and Exchange Commission (SEC), het Amerikaans effectenverkeer nauwlettend in de gaten houdt.

Bovenstaande inval op de toenmalige Amsterdamse effectenbeurs is de aanleiding tot dit onderzoek geweest. De inval maakt duidelijk dat de beurswereld niet alleen te maken heeft met effectentypische toezichthouders die voornamelijk op het gebied van het bestuursrecht opereren, maar ook met het Openbaar Ministerie waar het strafrecht centraal staat. Daarnaast zal het niet ontgaan zijn dat er nog een derde partij is, de gedupeerde belegger die eventueel via het civiel recht zijn gelijk kan proberen te halen. Aldus kan worden gesteld dat deze studie raakvlakken heeft met het bestuursrecht, het strafrecht en het civiel recht. Dit blijkt temeer uit de centrale onderzoekvraag. Deze luidt als volgt:

Wat is de positie van de Nederlandse voezichthouder(s) in de bandhawing wan de effectenwetgeving en boe verhoudt deze zich tot die van de Amerikadnse toezich thouder? Welke betekenis wordt daarbij in beide landen aan bet strafrecht toegekend?

De onderzoeksvraag bestaat uit vier onderdelen te weten:

1. Wat is de ral tan de Nederlandse effectentypische toezichthouder(s) in bandbaving wan de betreffende uretgeving?

2. Wat de rol van de Amerikatanse toezichthouder in de handhaving van de effectentypische wetgieving?

3. Wat is de verbouding tussen de positie van de Nederlandse en de Amerikaamse toezich thouder? 
En tot slot

4. Wat is de rol wan het strafrecht, bij de handhaving van de effectentypische wetgening, in Nederland en in Amerika?

Ter inleiding in de wereld van het effectenverkeer omvat hoofdstuk één een historische schets van het Nederlandse effectenverkeer. Dit begint bij het uirgeven van aandelen door de Verenigde Oost-Indische Compagnie (VOC) in 1606 en wordt afgesloten met het einde van de Vereniging voor de Effectenhandel (VvdE) eind 1996.

Vervolgens komt in het tweede hoofdstuk de positie van de Nederlandse effectentypische toezichthouder(s) aan de orde. Uit de vraagstelling blijkt dat er sprake is van meerdere Nederlandse effectentypische toezichthouders, te weten de Autoriteit Financiële Markten (Autoriteit-FM) en de Nederlandsche Bank (DNB). Beiden opereren op bestuursrechtelijk terrein. Zeer uitvoerig worden de toezichts- en handhavingsbevoegdheden van deze effectentypische toezichthouders geïnventariseerd. Een weergave van de ontwikkelingen in de effectentypische wetgeving vanaf de Beurswet 1914 tot aan de Wet toezicht effectenverkeer 1995 (Wre'95), de Wet toezicht beleggingsinstellingen (Wtb) en de Wet melding zeggenschap in ter beurze genoteerde vennootschappen (Wmz) - de kaderwetgeving -, geven een beeld van de reikwijdte van de huidige effectenwetgeving. Dit beeld wordt verscherpt door ook aan te geven hoe de kaderwetgeving nader is ingevuld (de uitvoeringsregels). Dat de invloed van de kaderwetgeving in samenhang met de uitvoeringsregels doorwerkt binnen de regelgeving van de beurs (de interne regelgeving) blijkt uit een uiteenzetting hiervan. Na vaststelling van de reikwijdte van de effectentypische wetgeving en de reikwijdte van het toezicht, komen - nu de handhaving besproken wordt - de toezichthouders aan bod. Gekeken is naar de bevoegdheden die de wetgever aan de Autoriteit-FM en DNB heeft toegekend om de naleving van voomoemde wetten te handhaven. Zoals eerder is besproken kunnen effectentypische wetsschendingen via het bestuursrecht, het civiel recht en het strafrecht worden tegengegaan. Met een beschrijving van de handhavingsmogelijkheden via deze rechtsgebieden wordt het tweede hoofdstuk afgesloten. Uit dit hoofdstuk kan worden geconcludeerd dat de effectentypische toezichthouders, in het bijzonder de Autoriteit-FM, over voldoende juridische handhavingsmogelijkheden beschikken, maar dat het strafrecht toch een belangrijke rol speelt bij de handhaving van de effectentypische 
regelgeving. Om zo dicht mogelijk bij een eerlijke en doorzichtige effectenmarkt te komen en de belangen van de (particuliere) belegger te kunnen beschermen, beschikt de Autoriteit-FM over verschillende bestuursrechtelijke bevoegdheden. Enkele hiervan zijn het geven van voorschriften aan de vergunningsplichtige (rechts)persoon, het opleggen van een bestuurlijke boete of het intrekken van een verleende vergunning. Daar waar bestuursrechtelijk optreden niet het gewenste resultaat heeft of daar waar dat van rechtswege is afgesproken, kan het strafrecht het van de Autoriteit-FM overnemen.

In het derde, eveneens inventariserende hoofdstuk, wordt het tweede deel van de onderzoeksvraag beantwoord, te weten de rol van de Amerikaanse toezichthoudende SEC in de handhaving van de effectentypische wetgeving. Na een introductie in het Amerikaans recht, volgt een schets van de ontstaansgeschiedenis van de SEC. Vervolgens wordt de Amerikaanse effectentypische wetgeving, gelijk de structuur van het tweede hoofdstuk, geïnventariseerd. Ook hier wordt gestart met de (federale) kaderwetgeving te weten de Securities Act, de Securities Exchange Act, de Public Utility Holding Company Act, de Trust Indenture Act, de Investment Company Act, de Investment Advisers Act en de Securities Investor Protection Act. Vervolgens worden de Amerikaanse effectentypische uitvoeringsregels geschetst. Volledigheidshalve volgt er, evenals in het tweede hoofdstuk het geval was, een inventarisatie van de effectentypische regels afkomstig van zelfregulering. Nadat de bereik van het Amerikaans effectentypische toezicht is weergegeven, volgt een beschrijving van de reikwijdte van handhavingsbevoegdheden van de SEC. Ook in dit hoofdstuk worden drie handhavingsprocedures besproken, te weten de Amerikaanse administratieve procedure, de civielrechtelijke procedure en ter afsluiting van het derde hoofdstuk de strafrechtelijke procedure.

Ook uit het onderzoek naar het Amerikaans effectentypische toezicht kan worden geconcludeerd dat de effectentypische toezichthoudende SEC over voldoende juridische handhavingsmogelijkheden beschikt. Net als in Nederland speelt in Amerika het strafrecht een belangrijke rol bij de handhaving van de effectentypische regelgeving. Om de (particuliere) belegger zo goed mogelijk te kunnen beschermen, beschikt de SEC niet alleen over verschillende administrarieve bevoegdheden, maar kan zij in een Amerikaanse civielrechtelijke procedure waar zij niet gelijk is aan de tegenpartij, de rechter zelfs om civielrechtelijke maatregelen verzoeken. 
De SEC kan overtreders van de Amerikaanse effectenwetgeving, geldboetes opleggen, verleende vergunningen intrekken en via een civiele procedure zelfs wederrechtelijk verkregen voordeel ontnemen, daarnaast kan zij onder meer voorschriften geven aan vergunningsplichtigen. Waar de administratieve bevoegdheden tekortschieten, omdat de SEC bijvoorbeeld geen vervolgingsbevoegdheid heeft, kan het strafrecht dit van de SEC overnemen.

In het vierde hoofdstuk staan het derde en vierde onderdeel van de onderzoeksvraag centraal. Allereerst wordt gekeken naar de verhouding tussen de positie van de Nederlandse en de Amerikaanse toezichthouder door de resultaten van hoofdstuk twee en drie naast elkaar te leggen. Vervolgens wordt de rol van het strafrecht vastgesteld bij de handhaving van effectentypische wetgeving in Nederland en in Amerika. Er volgt een opsomming van de verschillen en overeenkomsten van de Nederlandse en Amerikaanse effectentypische handhaving. Wanneer de drie gerechtelijke procedures naast elkaar worden gezet, kan geconcludeerd worden dat de Nederlandse effectentypische toezichthouder via het bestuursrecht het meest invloedrijk is. De rechtsculturele verschillen in ogenschouw nemend verschillen de bestuursrechtelijke bevoegdheden van de Autoriteit-FM niet veel van die van de SEC. Ondanks het verschil in vormgeving van de bestuursrechtelijke procedure lijkt het erop dat de Nederlandse wetgever de bevoegdheden van de SEC in haar eigen wetgeving overneemt of over tracht te nemen. Geconcludeerd wordt dat er een ontwikkeling zichtbaar is waarin de Nederlandse wetgever, waar het uitkomt, bevoegdheden van de Amerikaanse toezichthouder overneemt of tracht in te passen in ons continentaal rechtssysteem. Deze ontwikkeling zal hoogstwaarschijnlijk niet tot "Amerikaanse toestanden" - zoals een onevenredig sterke rechtspositie van toezichthouder ten opzichte van de vergunningsplichtige - in de Nederlandse effectenwereld leiden omdat niet alle bevoegdheden van de SEC overgenomen kunnen worden. Denk aan het ontnemen van wederrechtelijk verkregen voordeel. In Nederland is dit een strafrechtelijke sanctie en komt de toepassing hiervan niet de Autoriteit-FM, maar het Openbaar Ministerie toe. Een ander voorbeeld is de eerder genoemde ongelijke positie van de SEC in civielrechtelijke zaken.

Tot slot volgt het vijfde hoofdstuk waarin de rol van het strafrecht, bij de handhaving van effectentypische wetgeving, vanuit een ander invalshoek wordt bekeken. Uit de voorafgaande hoofdstukken is duidelijk 
geworden dat het bestuursrecht de Nederlandse effectentypische toezichthouders de meeste mogelijkheden biedt om op te treden tegen wetsovertreders. Dit lijkt erg op de Amerikaanse situatie. Verder is in deze studie duidelijk geworden dat het strafrecht toch een belangrijke rol speelt in de handhaving van effectentypische wetgeving; het heeft een vangnetfuncrie. Hoewel in deze studie is aangetoond dat het strafrecht zowel in Nederland als in Amerika voldoende afschrikwekkend is om als laatste redmiddlel, als ultimum remedium, te dienen wanneer andere rechtsgebieden tekortschieten, wordt er in het vijfde hoofdstuk toch voor het daadwerkelijk minimaliseren van de inzet van het strafrecht - waar het effectentypische wetwetgeving betreft - gepleit. De inzet van het strafrecht kan vooral binnen de effectenwereld grote gevolgen hebben. De stigmatiserende werking van een strafrechtelijke procedure komt niet alleen voor bij de handhaving van effectentypische wetgeving, maar ook de gewone man van de straat kan er mee te maken krijgen. Dat neemt niet weg dat de stigmatisering binnen de effectenwereld voor de verdachte een dusdlanig effect heeft dat overwogen moet worden of dit nog wel een als een bijkomend effect beschouwd mag worden en niet als vorm van vergelding. Op grond van een gematigd instrumentalistische opvatting waarin aan de rechtsbescherming een belangrijke rol is toebedeeld wordt het volgende afgevraagd: "Kan ervoor gepleit worden dat in effectentypische zaken die in de media breed zijn uitgemeten, de "straf" die door het stigmatiserend effect van een strafrechtelijke procedure al is opgelegd en de schade die het verdachte individu of de organisatie lijdt, evenredig lijkt te zijn aan het toegebrachte leed?" Uit dit onderzoek wordt de conclusie getrokken dat het strafrecht bij de handhaving van effectentypische regelgeving een afschrikwekkend effect kan hebben en een stigmatiserende werking op het verdachte individu of de verdachte organisatie. Verder is uit het onderzoek naar voren gekomen dat indien het bij effectentypische wetsovertredingen alsnog tot een strafproces mocht komen, één van de strafrechtelijke doelen te weten de vergelding, al voor aanvang van het onderzoek ter terechtzitting kan plaatsvinden. Daarom zou een rechterlijke veroordeling waar de gevolgen van voornoemd bijkomend effect van het strafrecht niet in zijn verdisconteerd, een dubbele vergelding of een onnodig zware leedtoevoeging tot gevolg hebben. Dit, en het gegeven dat een strafrechtelijke procedure binnen de Nederlandse en Amerikaanse financieel economische wereld als laatste redmiddel moet worden beschouwd, vormen de slotconclusie dat bij de handhaving van effectentypische regelgeving de toegevoegde waarde van het strafrecht gezien moet worden 
als een vangnet. De handhaving van de effectentypische regelgeving zal hoofdzakelijk door middel van het recht waarbinnen de desbetreffende toezichthouder opereert - het bestuursrecht - moeten geschieden. Pas wanneer mocht blijken dat handhaving tekortschiet, dient - gezien de geopperde bezwaren -, wanneer er geen andere effectieve mogelijkheden zijn, het strafrecht ingezet te worden. 


\section{Summary}

The Clickfonds affair has made it clear that inside the dynamic world of Dutch securities trading inadmissible practices occur from time to time. The Public Prosecutor's raid on the Amsterdam Securities Exchange (Amsterdamse Effectenbeurs) on 25 October 1997 raised quite a stir. Suddenly, the whole of the Netherlands was presented with an image by the media that Dutch bourses were a bastion of traders who did not shun dubious practices. We were familiar with this image in relation to the United States, where the US securities-related regulator, the Securities and Exchange Commission (SEC), keeps a close eye on the US trade in securities.

The raid on the (then) Amsterdam Securities Exchange prompted this research. The event has made it clear that the exchange world not only has to deal with security-related regulators mainly operating under administrative law, but also with the Public Prosecutor's Office with criminal law as its main focus. It will not have escaped attention that there is a third party, the injured investor, who may try to obtain justice through civil proceedings. It can be said, therefore, that this study touches on administrative, criminal and private law. This is especially evidenced by the principal thesis question, which reads as follows:

What is the position of the Dutch regulator(s) in enforcing securities legislation athd bow does it relate to that of the US regulator?

What importance is attached in the two countries to criminal hat?

The thesis question comprises the following four sub-questions:

l. What is the role of the Dutch securivies-related regulators in enforcing the relevant Legislation?;

2. What is the role of the US regulator in enforcing securities-related legislation?;

3. What is the relation between the positions of the Dutch and US regulators? and, finally,

4. What is the role of the criminal law in enforcing securities-related legislation in the Netberlands and the United States? 
Chapter I consists of an historical outline of Dutch securities trading as an introduction to the world of securities trading begins with the issue of shares in 1606 by the Verenigde Oost-Indische Compagnie, VOC, (Dutch East India Company) and ends with the dissolution of the Dutch Stock Exchange Association (Vereniging voor de Effectenhandel).

The position of the Dutch securities-related regulator(s) is subsequently discussed in the second chapter. It can be inferred from the principal thesis question that there are several securities-related regulators, namely the Autoriteit Financielle Markten (Financial Markets Authority) and the Nederlandsche Bank (Netherlands Central Bank). Both operate in the area of administrative law. A comprehensive inventory is made of the supervisory and enforcement powers of these securities-related regulators. A description of developments in relation to securities-related regulators from the 1914 Beurswet (Stock Exchange Act) until the 1995 Wet toezicht effectenverkeer (Securities Transactions (Supervision) Act), the Wet toezicht beleggingsinstellingen (Investment Institutions (Supervision) Act) and the Wet melding zeggenschap in ter beurze genoteerde vennootschappen (Disclosure of Major Holdings in Listed Companies Act), the skeleton legislation, depicts the scope of current securities legislation. The picture becomes more focused when the author shows in what way the skeleton legislation has been transposed into implementation rules. An expose on the matter shows the influence of the skeleton legislation, in conjunction with the implementation rules, on the internal bourse rules. After the scope of the securities-related legislation, the scope of supervision, has been determined, the regulators themselves are discussed in the part dealing with enforcement. The author examines the powers conferred by the legislator on the Dutch Financial Markets Authority and the Netherlands Central Bank to enforce observance of the above legislation. As discussed earlier, securities-related violations may be combated with the aid of administrative, private or criminal law. A description of the means of enforcement in these areas concludes the second chapter. Although it can be inferred from this chapter that Dutch securities-related regulators, especially the Financial Markets Authority, have sufficient powers of enforcement, criminal law plays an important role in the enforcement of securities-related legislation. In order to arrive at an optimally honest and transparent securities market and protect the interests of (private) investors, the Financial Markets Authority has various administrative powers at its disposal. Among these are setting conditions for (juristic) persons that require a license, imposing 
administrative fines, or revoking a license granted. In cases in which administrative action does not produce the desired result or where it has been so agreed under the law, the criminal law may step in and take over from the Financial Markets Authority.

In the third chapter, the author answers the second sub-question of the thesis pertaining to the role of the US regulator, the SEC, in enforcing securities-related legislation. An introduction to US law is followed by an outline of the SEC's history of origin. Subsequently, an inventory is made of US securities-related legislation, whereby the organisation of the second chapter is followed. The author first discusses US skeleton legislation, consisting of the Securities Act, the Securities Exchange Act, the Public Utility Holding Company Act, the Trust Indenture Act, the Investment Company Act, the Investment Advisers Act and the Securities Investor Protection Act. Subsequently, the American securities-related implementation rules are outlined. For the completeness sake, an inventory is made, as in the second chapter, of the securities-related rules derived from self-regulation. A description of the scope of US securities-related supervision is followed by a discussion of the scope of the enforcement powers of the SEC. In this chapter as well, three enforcement procedures are discussed, namely US administrative, civil and criminal procedure.

It may be equally concluded from US securities-related supervision that the securities-related regulator, the SEC, possesses sufficient enforcement powers under the law. As in the Netherlands, the criminal law plays an important role in enforcing securities-related rules and regulations in the United States. To optimally protect (private) investors, the SEC not only possesses a variety of administrative powers, but can even request the courts to apply private-law measures in federal civil proceedings, in which no equality of arms exists. In case of violation of US securities law, the SEC may set, for instance, condirions for licensees, impose fines, revoke licences granted and even deprive the party in question of unlawfully gained proceeds. Where administrative powers fail, because the SEC does not have the power of prosecution, the criminal law can step in and take over from the SEC.

The fourth chapter focuses on the third and fourth sub-question of the thesis. First, the relation between the position of the Dutch and the American regulator is examined by comparing the results of chapters 
two and three. Subsequently, the author determines the role of the criminal law in enforcing securities-related legislation in the Netherlands and the United States. This is followed by a listing of the differences and similarities between Dutch and US securities-related enforcement. By setting off the three legal procedures, it is concluded that the Dutch securities-related regulator can exert more influence through administrative law. When the legal-cultural differences are observed, the administrative powers of the Financial Markets Authority are not much different from those of the SEC. In spite of the difference in form of administrative procedure, it seems that the Dutch legislator introduces into its legislation powers held by the SEC or attempts to introduce them. The author concludes that there is a development in which the Dutch legislator, where convenient, adopts the powers of the SEC or attempts to fit them into our continental legal system. This development will most probably not lead to "American scenes" in Dutch securities trading-such as a disproportionately powerful legal position of the regulator as opposed to the licensee-, since not all the powers held by the SEC may be adopted. One example is the deprivation of unlawfully gained proceeds. In the Netherlands, this is a punishment under the criminal law and its application is reserved for the Public Prosecuror's Office, not the Financial Markets Authority. A second example is the unequal position of the SEC in private-law cases.

Chapter five concludes the dissertation. It examines the role of the criminal law in enforcing securities-related legislation from a different perspective. From the preceding chapters it has become clear that administrative law offers the Dutch securities-related regulators the most possibilities to act against offenders. This resembles the American situation very closely. Furthermore, it has become clear in this study that the criminal law nonetheless plays an important role in enforcing securities-related legislation; it serves as a safety net. Although the study has demonstrated that criminal law in both the Netherlands and the US is a sufficient deterrent, serving as the ultimum remedium, a last resort, where other legal areas fail, in the fifth chapter, the author advocates minimum use of the criminal law in cases of securities-related violations. Application of the criminal law may have grave consequences for securities trading. The stigmatising effect of criminal proceedings does not only occur in enforcement of securities-related legislation; the very man in the street may be affected by it. It does not alter that the effect that such stigmatisation within the securities trade has on the alleged 
offender may be such that it ought to be established whether this is in indeed an additional consequence and not a form of retribution. Departing from a moderate instrumentalist view, which assigns an important role to legal protection, the author poses the following question: 'Can it be argued that, in well-published securities-related cases, the "punishment" that is anyhow imposed as a result of the stigmatising effect of criminal proceedings -the damage suffered by the suspected individual or organisation-is proportionate to the injury inflicted?' On the basis of this study, the author concludes that, in enforcing securitiesrelated legislation, the criminal law may serve as a deterrent and have a stigmatising effect on the suspected individual or organisation. The investigation also shows that one of the objectives of the criminal law, retribution, may already materialise before the case is investigated by the court, should criminal proceedings be instituted after all. For this reason, a conviction that fails to factor in the consequences of the above additional effect of the criminal law, would constitute double retribution or inflict unnecessarily harsh injury. This, and the fact that criminal proceedings in the Dutch and US financial-economic world must be seen as a last resort, lead to the author's final conclusion that, in enforcing security-related legislation, the criminal law must be seen as a safety net having added value. Security-related regulations will mainly have to be enforced through the law under which the regulator operates, administrative law. In view of the objections discussed by the author, the criminal law should only be applied where administrative enforcement has failed. 



\section{Aangehaalde literatuur}

Albers, C.L.G.F.H., Rechtsbescherming bij bestuurlijke boeten; balanceren op een magische lijn?, dissertatie UM, Sdu Uitgevers B.V., Den Haag, 2002.

Allan Farnsworth, E., An introduction to the legal system of the United States, Oceana Publications Inc., New York, U.S.A., 1996.

Amsterdamse Effectenbeurs, Beurs en effecten: de beurshandel en de vormen van beleggen, uitgeverij Contact, Amsterdam/Antwerpen, 1993.

Baauw, P.J., Eerlijke berechting en bijzonder straf(proces)recht, oratie RUU, Gouda Quint, Deventer, 1999.

Bianchi, H., Stigmatisering, Kluwer, Deventer, 1971.

Bianchi, H. en Swaaningen R. van, Abolitionism: towards a nonrepressive approach to crime: proceedings of the second international conference on prison abolition Amsterdam 1985 uit de serie: Juridische reeks Vrije Universiteit; nr. 3. Amsterdam, 1986, Free University Press.

Boxum, J.L., J. de Ridder en Scheltema, M., Zelfstandige bestuursorganen in soorten; verslag van een onderzoek naar de praktijk van zelfstandige bestuursorganen, in opdracht van het Ministerie van Binnenlandse Zaken, Kluwer, Deventer, 1989.

Braithwaite, J. en Drahos, P, Global Business Regulation, Cambridge University Press, 2000.

Brants, C.H., Mevis, P.A.M. en Prakken, E. (red.), Legitieme strafvordering; rechten van de mens als inspiratie in de $21^{\text {ste }}$ eeuw, Intersentia Rechtswetenschappen, Antwerpen-Groningen, 2001.

Campbell, D. en Hepperle, W., The U.S. Legal System: a practice handbook, The Hague, Martinus Nijhoff Publishers, 1983. 
Clark, D.S. en Ansay, T., Introduction to the Law of the United States, Kluwer Law and Taxation Publishers, Deventer, The Netherlands, 1992.

Committee on Pattern Jury Instructions District Judges Association fifth Circuit, 5 th Circuit Pattern Jury Instructions: criminal cases, West Publishing Co., St. Paul, Minnesota, 1997.

Corstens, G.J.M., Een stille revolutie in het strafrecht; afscheidsrede Katholieke Universiteit Nijmegen, Gouda Quint B.V., Arnhem, 1995.

Corstens, G.J.M., Het Nederlandse Strafprocesrecht, 2002, vierde druk, Kluwer, Deventer, 2002.

Cross, D.H. en Diephuis, J.H., De Amsterdamse effectenbeurs uit: de serie Bank-en Effectenrecht dI. 15, Kluwer B.V., Deventer, 1988.

Cross, D.H., De regulering van de effectenhandel; recente ontwikkelingen, TVVS, 1992, nr. 92/3.

Cross, D.H., De opkomst van een rechtsgebied, Lustrumbundel 1997 Vereniging voor Effectenrecht, Vennootschaps- en Rechtspersonenrecht, deel 58 uit de Serie monografieën vanwege het Van der Heijden-instituut te Nijmegen, Kluwer, Deventer, 1997

Davis, J.P, Corporations: A Study of the Origin and Development of Great Business Combinations and their Relations to the Authority of the State, Capricorn books, New York, 1961.

Dijk, J.M. van, Wet toezicht effectenverkeer 1995; artikelgewijze commentaar in de serie Tekst \& Commentaar, deel Ondernemingsrecht, Kluwer, Deventer, 2000.

Doelder, H. de, Meijer, M.E. de en Otto, D., De bestuurlijke boete in perspectief, in: SI-EUR-reeks, dl. 20, Gouda Quint, 1999.

Doorenbos, D.R., Misbruik van voorwetenschap als economisch delict, TVVS, 1989 , nr. 89/12. 
Doorenbos, D.R., Financieel Strafrecht; een studie inzake strafrechtelijk gesanctioneerde voorschriften uit de bank-en effectenwetgeving, dissertatie KUN, Kluwer B.V., Deventer, 1992.

Driel, M. van, Zelfregulering, hoog opspelen of thuisblijven, dissertatie RUU, Kluwer, Deventer, 1989.

Eisma, S.E. en Schlingmann, F.M., Kroniek van het effectenrecht, NJB, 8 maart 2002, jrg. 77.

Eisma, S.E., De verbouwing van het Nederlandse effectenrecht, NJB, 15 november 2002 , jrg. 77 .

Enschedé, Ch.J., Beginselen van het strafrecht; bewerkt door Rüter C.F. en Stolwijk S.A.M., $8^{\text {ste }}$ druk, Kluwer, Deventer, 1995.

Everett, P.I., Legal Secretary Federal Litigation, 4th edition, 1997, James Publishing Inc.

Fisse, B. en Braithwaite J., The impact of publicity on corporate offenders, State University Press, Albany, 1983.

Franken, A., Civielrechtelijke gevolgen van handelen in strijd met effectenregelgeving -recente ontwikkelingen in: Vennootschap \& Onderneming, afl. 5, mei, 1999.

Garner, B.A., Black's Law Dictionary, West Group, $3^{\text {de }}$ druk, 1996.

Gellhorn, E. en Levin, R.M., Administrative Law and Process in a nutshell, West Group, St. Paul: Minnesora, 1997.

Goffman, E, Stigma, notes on the management of spoiled identity, Penguin Books Ltd., Harmondsworth, Middlesex, England, 1981.

Goffman, E., Totale Instituties, $3^{\mathrm{e}}$ druk, Universitaire Pers, Rotterdam, 1994. 
Grafman, S.W., Adelman, R.M. en Plaza, C.E., Criminal Enforcement of the Securities Laws: A Primer for the Securities Practitioner in: Kirkpatrick and Lockhart L.L.P., The Securities Enforcement Manual: tactics and strategies, The American Bar Association, Chicago, llinois, 1997.

Grinten, W.C.L. van der en Asser, Vertegenwoordiging en rechtspersoon, de rechtspersoon, Zwolle, 1991.

Grinten, W.C.L. van der, Kortman S.C.J.J. en Perrick, S., Civielrechtelijke gevolgen van handelen in strijd met effectenregelgeving: preadvies voor de Vereniging voor Effectenrecht 1994, Kluwer B.V., Deventer, 1996.

Grundmann, C.M., Wet toezicht effectenverkeer 15 juni 1992 in werking, Nieuwsbrief bedrijfsjuridische berichten, 29 mei 1992, nr. 11 .

Grundmann-Van de Krol, C.M., Recente wetgeving effectentransacties, Gouda Quint B.V., Arnhem, 1995.

Grundmann-Van de Krol, C.M. en Van den Ingh, F.J.P, Parlementaire geschiedenis van de Wet toezicht effectenverkeer 1995, Kluwer B.V., Deventer, 1996.

Günst, H.W., 115 jaar Vereniging voor de Effectenhandel uit: Trommelpapier, Beursdata B.V., 1991.

Hart, A.C. 't en Foqué, R., Instrumentaliteit en rechtsbescherming; grondslagen van een strafrechtelijke waardendiscussie, Gouda Quint bv, Arhnem en Kluwer Rechtswetenschappen, Antwerpen, 1990.

Hart, A.C. 't, Totale instituties en het totalitaire; beschouwing bij de aanbieding van een bundel over 'Rechtsbescherming en totale instituties aan Prof. Mr. C. Kelk bij zijn vijftigste verjaardag, uitgesproken te Utrecht op 22 oktober 1993 door A.C. 't Hart, Gouda Quint B.V., Arnhem, 1993. 
Hart, A.C. 't, Hier gelden wetten!- over strafrecht, Openbaar Ministerie en multiculturalisme, in: Meijers-reeks, dl. 35, uitgave in samenwerking met het E.M. Meijers Instituut, Instituut voor Rechtswetenschappelijk Onderzoek, Gouda Quint, Deventer, 2001.

Harmann, A.R., De wettelijke regeling van de bestuurlijke boete naar vorm en inhoud, in: Doelder, H. de, Meijer, M.E. de en Otto, D., De bestuurlijke boete in perspectief, in: SI-EUR-reeks, dI. 20, Gouda Quint, 1999.

Heuvel, G.A.A.J. van den, Een criminologische agenda voor strafrechthervorming in de bundel Legitieme strafvordering; rechten van de mens als inspiratie in de $21^{\text {ste }}$ eeuw, Intersentia Rechtswetenschappen, Antwerpen-Groningen, 2001.

Heuvel, G. van den, boekbeschouwing van C.H. Brants, Over levende gedachten. De menselijkheid van een functioneel sirafrecht en van P.J. Baauw, Eerlijke berechting en bijzonder straf(proces) recht, RM Themis, nr. 5, 2000.

Heijden, van der E.J.J., De ontwikkeling van de naamloze vennootschap in Nederland vóór de codificatie, dissertatie Universiteit Utrecht, uitgeverij Van der Vecht, Amsterdam, 1908.

Hillen, J.L.S.M., Effectenwetgeving: dl. 143-II Schuurman \& Jordens Nederlandse wetgeving, Tjeenk Willink, Deventer, 1997.

Hulsman, L.H.C. met medewerking van Bernat de Celis, J. en Smits, $H$., Afscheid van het strafrecht: een pleidooi voor zelfregulering, Het Wereldvenster, Houten, 1986.

Jörg, N., Strafbare rechtspersonen in Amerika; corporaties en hun functionarissen in het Amerikaans strafrecht in rechtsvergelijkend perspectief, Gouda Quint B.V., Arnhem, 1990.

Jörg, N. en Kelk C., Strafrecht met mate, Samsom H.D. Tjeenk Willink, Alphen aan de Rijn, $11^{\text {de }}$ druk, 2001. 
Kirkpatrick and Lockhart L.L.P., The Securities Enforcement Manual: tactics and strategies, The American Bar Association, Chicago, Illinois, 1997.

Korthals-Altes, J.Ph., De Amsterdamse effectenbeurs op een nieuwe koers; voorstellen van de Commissie Herziening Beursstructuur, mede houdende een voorstel tot wijziging van de Statuten van de Vereeniging voor den Effectenhandel, Beleidsnota, 1972.

Kraaiveld, C.J. en Nieuwenhuyzen, W.J.M. van den, Wet Effectenhandel, WPNR, nr. 5786, 24 mei 1986.

Lang, N.S. en Lipton, R.J., Litigating Administrative Proceedings: the SEC's increasingly important enforcement alternative in: Kirkpartrick and Lockhart L.L...., The Securities Enforcement Manual: tactics and strategies, The American Bar Association, Chicago, Illinois, 1997.

Levi, M., Regulating Fraud; white-collar crime and the criminal process, Tavistock publications, London and New York, 1987.

Lissenberg, E., Ruller, S. van en Swaaningen R. van, Tegen de regels IV; een inleiding in de criminologie, Ars Aequi Libri, Nijmegen, 2001.

Luyn, M. van, Wet toezicht effectenverkeer 1995, Vennootschap en Organisatie, afl. 2, februari 1996.

Maletta, J.B., Litigating SEC Injunctive Actions in: Kirkpartrick and Lockhart L.L.P., The Securities Enforcement Manual: tactics and strategies, The American Bar Association, Chicago, Illinois, 1997.

Maletta, J.B. en Lang, N.S., Sanctions and Collateral Consequences: The Stakes in SEC Enforcement in: Kirkpartrick and Lockhart L.L.P., The Securities Enforcement Manual: tactics and strategies, The American Bar Association, Chicago, Illinois, 1997.

McCLure e.a., Federal Regulatory Directory, 8th edition, Washington D.C., 1997. 
Meijer-Wichmann, C., Tegen de heerschende opvattingen omtrent misdaad en straf, uit: uitgave van het Comité van Actie tegen de bestaande opvattingen omtrent Misdaad en Straf, $3^{\text {de }}$ druk, Rotterdarn, 1924.

Mok. M.R., Regulering effectenhandel, TVVS, nr. 85/1, 1985.

Mok, M.R., Toezicht effectenverkeer (I), TVVS, nr.3, 1989.

Mok, M.R., Toezicht effectenverkeer (II), TVVS, nr. 89/4, 1989.

Mok, M.R., Toezicht effectenverkeer, TVVS, nr. 92/7, 1992.

Mulder, P.A.W. mr drs, Het internationale toezicht: IOSCO, in de bundel Financiële integriteit, normafwijkend gedrag en (zelf) regulering binnen het financiële stelsel, Gouda Quint bv, Arnhem, 1995.

Nieuwsbrief Autoriteit-FM, InZicht, jrg. 1, nr. 2, 2002, p. 4.

Nus, J.G.L. van, Overheidstoezicht op afstand; verzelfstandiging van toezichthoudende taken naar zelfstandige bestuursorganen verkend; dissertatie RUL, MAKLU: Ius Commune reeks, 1995.

Peters, A.A.G., Het rechtskarakter van het strafrecht, oratie RUU, Kluwer, Deventer, 1972.

Philips, R.M., Reichardt, G.R. en Missal, M.J. en Lipton, R.J., SEC investigation: The Heart of SEC Enforcement Practice in: Kirkpatrick and Lockhart L.L.P., The Securities Enforcement Manual: tactics and strategies, The American Bar Association, Chicago, Illinois, 1997.

Pointer, L.G. en Schroeder, R.G., An introduction to the Securities and Exchange Commission, Plano, Texas, 1986, Business publications inc..

Polak, L., Hegel's leer der straf, oratie Rijksuniversiteit Leiden, J. Emmering, Amsterdam, 1925. 
Rank, W.A.K, Stichting Toezicht Effectenverkeer (STE), Nieuwsbrief bedrijfsjuridische berichten, 7 maart 1989.

Rank, W.A.K., Wet Toezicht effectenverkeer: een nieuwe lente, een nieuw geluid?, Nieuwsbrief bedrijfsjuridische berichten, 13 juni 1989.

Ratner, D.L., Securities Regulation in a nutshell, St. Paul Minnesota: West Publishing Co., 1982.

Reijntjes, J.M., Mr A. Minkenhof, de Nederlandse Strafvordering, $9^{\text {de }}$ druk, Kluwer, Deventer, 2002.

Remmelink, J., Mr. D. Hazewinkel-Suringa's Inleiding tot de studie van het Nederlandse strafrecht, $15^{\text {de }}$ druk, Deventer, Gouda Quint, 1996.

Rogier, L.J.J., Straffend Bestuur, oratie EUR, Gouda Quint, 2001.

Roos, Th. de, Economische mededinging en witteboordencriminaliteit; enkele opmerkingen over de criminalisering van anti-trust en kartelwetgeving in de serie strafrecht en criminologie, deel 3, Ars Aequi Libri, Nijmegen, 1984.

Roos, Th.A. de, Strafbaarstelling wan economische delicten; een crimineel-politieke studie, dissertatie RUU, Gouda Quint B.V., 1987.

Russen Groen, P.M. van, Rechtsbescherming in het bestuursstrafrecht, dissertatie EUR, Gouda Quint, 1998.

Salet, R., persbericht Ministerie van Financiën nr. 96/208, d.d. 20 december 1996.

Schlingmann, F.M., Tien jaar effectenrecht II, De Naamloze Vennootschap, april 1996, nr. 73/4.

Schreuder, C.A., Publiekrechtelijke taken, private personen, dissertatie RUG, Deventer 1994. 
Simon, W., International Securities Regulation: United States booklet 1, Oceana Publications inc., april 1994.

Skousen, K.F, An introduction to the SEC, Cincinnati, South-Western publishing Co., 1987.

Slagter, W.J., Het fonds CSM uit de beursnotering?, TVVS, 1994, nr. $94 / 12$.

Spronken, T., Verdediging, een onderzoek naar de normering van het optreden van advocaten in het strafrecht, dissertatie UM, Gouda Quint B.V., 2001.

Stolwijk, E., Functioneel OM zal beschikbare capaciteit beter kunnen benutten, Opportuun, $8^{\text {ste }}$ jaargang, nr. 6, februari 2002.

Stroink, F.A.M., Het leerstuk der deconcentratie; uit de serie bestuurlijke verkenningen nr. 27, dissertatie RUU, Vuga boekerij, 's-Gravenhage, 1978.

Stroink, F.A.M. en Steenbeek, J.G., Inleiding in het staats- en administratiefrecht, Samsom, $3^{\text {de }}$ druk, H.D. Tjeenk Willink, Alphen aan den Rijn, 1989.

Stroink, F.A.M. en Nus, J.G.L. van, Bestuursrechtelijke consequenties van privatisering, in: Privatisering; themanummer Stichting $\&$ Vereniging, mei/juni, nr. 3, 1994.

Vega, D.J. de la, Verwarring der verwarringen (1688): vertaling van Confusion de Confusiones, vertaald door G.J. Geers, Martinus Nijhoff, 's-Gravenhage, 1939.

Viering, M.L.W.M., Het toepassingsgebied van artikel 6 EVRM, dissertatie KUN, W.E.J. Tjeenk Willink i.s.m. NISER, Zwolle, 1994.

Vries, J. de, Een eeuw vol effecten: Historische schets van de Vereniging voor de Effectenhandel en de Amsterdamse Effectenbeurs 1876 - 1976, $1^{\mathrm{e}}$ druk, B.V. Kunstdrukkerij Mercurius, Wormerveer, 1976. 
Vries, J. de en Damen, E., Een eeuw vol effecten, $2^{\mathrm{e}}$ druk, Amsterdam, 1986.

Vries, J. de, Damen E., Kamp, K. en Berger, J., 120 jaar beurshandel in vogelvlucht: Vereniging voor de Effectenhandel 1876-1996, Joh. Enschedé, Amsterdam, 1998.

Vromans, M., De bijzondere opsporingsdiensten en de bijbehorende vakdepartementen krijgen binnen enkele maanden een centraal aanspreekpunt: het Functioneel OM (FOM). Wat zijn de verwachtingen van dit nieuwe parket? Twee reacties, Opportuun, $8^{\text {ste }}$ jaargang, nr. 6, februari 2000.

Wijk, H.D. van en Konijnenbelt, W., Hoofdstukken van administratief recht, $7^{\text {de }}$ druk, $2^{\text {de }}$ oplage, Lemma B.V., Utrecht, 1991.

Wijk, H.D. van, Konijnenbelt, W. en Van Male, Hoofdstukken van bestuursrecht, $11^{\text {de }}$ druk, Den Haag, 1999.

Wind, E. de, De Wet effectenhandel in de prakrijk, De Naamloze Vennootschap, nr. 69/4, april 1991.

Windcott, H., The Stock Exchange, Sampson low, London, 1946, p. 2 .

Zijlstra, S.E., Zelfstandige bestuursorganen in een democratische rechtsstaat, dissertatie EUR, Den Haag, 1997.

\section{EHRM jurisprudentie:}

Engel and others, EHRM 8 juni 1976, NJ 1978, 705.

Minelli vs. Zwitserland, EHRM 25 maart 1983, NJ 1986, 698 m.n.

E.A. Alkena

Öztürk, EHRM 21 februari 1984, NJ 1988, 937.

Lutz, EHRM 25 augustus 1987, NJ 1988, 938.

Barbera, Messegue en Jabardo vs. Spanje, EHRM 6 december 1988, Series A, nr. 146.

Funke, EHRM d.d. 25 februari 1993, NJ 1993, 485.

Saunders, EHRM 17 december 1996, NJ 1997, 699. 


\section{$H R$}

HR 27 juni 1995, NJ 1995, 662.

HR 19 december 1995, NJ 1996, 249 (Zwolsman)

RB Amsterdam

President Rechtbank Amsterdam, 2 maart 1995, KG 1995, nr. 204. Rb Amsterdam, 22 juni 2001, parket/zaaknr. 13/129200-97

(Leemhuis \& Van Loon Vermogensbeheer B.V.; nier gepubliceerd)

\section{USA jurisprudentie}

SEC v. Savoy Industries Inc., 587 F.2d p. 1168 (2nd circuit 1978)

Borg-Warner v. F.T.C., 746 F.2d 108 (1984)

SEC v. First City Financial Corporation Ltd., 890 F.2d 1215, 1228

(D.C. ciruit 1989)

SEC v. Steadman, 967 F. 2 d p. 636 (D.C. circuit 1992)

Checkosky v. SEC, 23 F.3d 452 (D.C. circuit 1994) Checkosky I;

Johnson v. SEC, 87 F.3d 484 (D.C. circuit 1996)

SEC v. Lorin 76 F.3d 458 en 462 (2nd circuit 1996)

SEC v. Sprecher, 1996, u.s. app. lexis 10795 (dc circuit 1996).

Checkosky v. SEC 139 F.3d 221 (D.C. circuit 1998) Checkosky II.

initial decision David J. Checkosky \& Norman A. Aldrich d.d. 26 augustus 1992.

initial decision re Sky Scientific d.d. 5 maart 1999, 1999 W/L 114405 (S.E.C.)

Initial decision re Warren G. Trepp d.d. 18 augustus 1997.

prehearing ruling Joel Zbar d.d. 18 maart 1994, release no 425,28 april 1994, 56 SEC Docket, 1784. 


\section{Trefwoordenregister}

Aangifte 182

aanvullende rechtsbronnen 225

accounting and disgorgement 270 ,

$$
279
$$

actièn 2

$$
\text { - handel } 2
$$

actionisiten 2,3

actoren 84

adjudicarory

- hearings 265

- proceedings 265

administratief beroep 324

administratieve

- (hoor)zittingen 210

- agencies 211

- agentschap 211

- hoorzittingen 265

- organisatie 94, 141

- procedure 264-286, 322-327

- rechter 325

- sancties 275

ad.ministrative

- agency 265

- fines 280

- rules 218

- tribunals 210

Administrative Law Judge (ALJ) 211, 265

Administrative Procedure Act (APA)

267

adviescommissies 104

AEB 86

AEX N.V. 102,103

AEX

we effectenbeurs 103

- effectenbeursreglementen 112

- optiebeurs 103

afdeling

- Corporation Finance 248

- Enforcement 251-264

- Investment Management 250

AIDA 115 algehele herziening effectenwetgeving $52,65,69$

Algemeen Beurscomité 6

algemeen geldende reglementen 105 Algemeen-Beurscomité voor Publieke

Fondsen 5

algemene beginselen van behoorlijk

bestuur 346

algemene vergunningenstellsel 73

Algemene Wet inzake Rijksbelastingen (AWR) 184

Amerikaans recht 204, 206

recht(systeem) 206

Amerikaanse

- effactenverkeer $205 \mathrm{evv}$.

- effectenwetgeving 216-246

- legisllatieve hiẻrarchie 219

Amsterdanse Effectenbeurs 30

Amsterdam Exchanges N.V. 86, 102

Amsterdam Securities Trading-system (ASSET) 115

Amsterdamse effectenbeurs (AEB) 25 , $54,86,99$

ancillary reliefs 288

animateur 122

anti-fraud measurements 217

anti-trust acts 214

aspirant-lid 100

ASSET 115

Attorney General 300

Automatic Interprofessional

Dealingsystem Amsterda 115

Autoriteit Financiële Markten 39

Auroriteit-FM $43,74,75,77,78,80$, $124,125,138-144,182,205$

AWR 184

Baauw 339,340

ballance of probability 304

bandbreedte $68,69,178$

banken 87

banken en effectenkredietinstellingen

(EKI) 94 
bedrijfs

- groep 14, 15

- leden $50,89,91,93,100$

- lid 93, 101

belangrijkste

- civielrechtelijke bevoegdheden

328

- strafrechtelijke bevoegdheden 330

beleggingsinstelling $44,69,73,81$, 82,148

beleggingsmaatschappij $69,222,223$, 148

beleggingsportefeuille 67

bescherming van de beleggers 70

besloten kring 56,71

Besluit Politieregisters 124

Besluit toezicht beleggingsinstellingen $80-83$

Besluit toezicht effectenverkeer 1995 (Bte" 95) 75-78

bestuurlijlke

- boete 165

- informatieverzorging 94

bestuursleden 87

bestuursrechtelijk

- handhavingsinstrument 170

- procedure 153-171,200,

322-327

-sanctierecht 345

- sancties 345

betrouwbaarheid 81,82

betrouwbaarlheidsvereiste 203

beunhazen 4

beurs van Berlage 8

beurs wan Hendrick de Keyser 4 beurs

- actoren 37

- bestuur 237

- eigen regels 86,136

- employes 89

- erkenning 96

- gemachtigde 89,109

- handel $1,37,46$

- houder 102

- krach 30

- leden 15,35,50,89

$-\operatorname{lid} 96$
- noteringen 237

- structuur 29

- voorschrifuen 12

- voorschriften 194051

Beurswet 45

Beurswet 1914 12, 46, 129

Beurszigt 5

bevoegdheden STE 143

beyond a reasonable doubt 304

bezwaarschriftprocedure 168

bijkomende

- effect $X I V X X X I$

- sancties 288,292

- straffen 196

bijzondere

- controlles 121

- strafwergeving 183

bill of indictment 304

binnentreden woning 187

blue sky laws 214

boete

- categorieën 295

- functionaris 325

boilerrooms 192,193

bookbuildingssyteem 33

Brb 81

Bre"95 77

buitenbeurshandel $13,18,19,41$

buitengewone bedrijfsleden 50,89, 92,101

Capital Adequacy Directive (CAD)

58,95

catutie 167

CB 129

Cease and Desist order 270, 274

Centrum voor Fondsenadministratie 18

certiorari jurisdiction 212

Checks and Balances 206

churning 192

circuit courts 211

civiele

- aansprakelijkheid 217

- geldboete 280-282

- injunctionprocedure 272,287

- procedure 202 
civielrechtelink(e)

- proces 265

- maatregelen 198

- procedure $171-178,202$,

$287-300,327-329$

civil monetary penalties 280

Clayton Acr 214

clearing-en settlementprocedures 242

Clickfonds 121

- zaak 342

Code of Federal Regulations (C.F.R.) 225

collateral consequences 291

collectief beleggen 70

Collegie tot Nut des Obligatiehandels 4

commissaris voor de notering 96

commissie

- aandelenhandel 104

- agrarische producten 104

- options \& futures 104

- primaire markt 104

commissionair $9,45,87$

- sbedrijf 9

- sdwang 14

commune strafrecht 183,197

compliance 120

Compliance Inspections and

Examinations 250

consent order 273

conspinacy 313

constitutie 207,211

consument 42

consumenten

- advisering 44

- informatie 44

- kredier 44

- kredieten 141

Controle

- en naleving 119

- en naleving interne regels 99

- afdeling 134

- bevoegdheden 109

- bureau (CB) 22, 23, 86, 99,

101,129

- reglement 99

Corporation Finance 250

court reporter 256 criminal charge $166-167,345$

Daghandelaar/floorbroker 95

daily haircut 192-193

De la Vega 2

De Nederlandsche Bank N.V* 44,73, 144-149, zie DNB

Delegatiebesluic 77

- Wet toeziche effectenwerkeer 199577

Department of Justice 255,300

deskundigheid 81,82

dienstverlening 196

directoraat toezicht van DNB 146

disciplinaire straf 234,238

disclosure 217,230

district courts 211

Division of Market Regulation 249

DNB $38,43,74,77,124-125,128$, 144-149,321" zie De Nederlandse Bank N.V.

dochtermaatschappijen 229

doelen 335

dwingend overheidsoptreden 12

ECD 205

economisch delict 66,74,176

Economische Controle Dienst (ECD)

51,132

economische delicten 50

eerlijk proces 166,345

eerlijke berechting 340

Effectenclearing N.V. 17

effecten

- bedrijf 101

- beurzen 102

- fraude 47

- instellingen 77

- regelgeving 84,316

- transacties 49,108

effectentypische

- handhavingsproces 335 e.v.

- regelgeving 232,235 e. $v$.

- toezichthouders 335 e.v.

EG-richtlijnen 59

EKI 94

Enforcement 250

enforcement onderzock 252, 255-264 
Enron 340,341

equality of arms 337

equitable 287

- remedies 292

equity 265

erkenning beursbedrijf 85

ernstige bezwaren 202

Euronext 121

- Amsterdam N.V. 86, 123

- Brussel 123

- Paris 123

Europese éénwording 32

Europese Unie 58

EVRM $165-169,200,338,345$

exclusive jurisdiction 212

execution by media 339

executive orders 218

externe

- openbaarheid 338

- regelgeving $37,45,74-83$,

225-232

- regels 96

- toezichthouder 124,247

Fair hearing 166

fair trial 345

false statements 310

federal

- administrative agency 225

- administrative rules and.

regulations 225

- statutes 218

Federal Criminal Code 307

Federal Rules of Civil Procedure (FRCP) 287

Federal Trade Commission Act 214

federale

- effectenwetgeving 218

- kaderwerten 219,246

- rechtbank 210-211

- United States Atorney 299

- wetgever 214

- wetgeving 205

- wetten 211

Financial Services Act 40

financiele

- bijsluiter 44,141

- delicten 342
- instellingen 77

- sector 42,70

- toezichthouder 42

- waarborgen $49,70,81,91,149$

- wereld 339

FIOD-ECD 153

Floorbrokers 91, 95

FOM 179-185, zie Functioneel

Openbatar Minsterie

formal investigation 256

formeel onderzoek 256

formele

- effectenrecht 246

- procedure 256

Frand 310

- and false statements 310

fraudezaken 339

frontrunning 192

FT 102

FTA 102-103

FTC 219

functiescheiding 20,170,327

Functioneel Openbaar Ministerie 179, zie FOM

functioneel toezichtsmodel 42,76

fusile 32

Gebrekkige ontwikkeling 196

gedrags

- regels 108

- toezicht 42

- toezichthouder 64

geheimhoudingsplicht 101

gekwalificeerde deelneming 64

geldboete 196

gematigd instrumentalisme 336

general rules 226

georganiseerde

- handel in effecten 4

- handelaren 6

geregistreerde

- clearingorganisatie 242-244

- nationale effectenorganisaties

$238-242$

gevangenisstraf 196

Grand Jury 304

grondslagen 335 
Handel in effecten in Nederland I handels

- portefeuille 67

- regels 37

- voorschriften en 89

handhavingsprocedures 153-204. $264-320$

harmonisatie 58

- en unificatie 122

- richtlijnen 59

HCS-zak 342

hearing officer 211

hechtenis 196

herstellende sancties 269

herstruccurering 31

- van de beurzen 35

herziening effectenwetgeving 45

hoek

- lieden 87

- mannen 9,9I

- mansbedrijven 94

hoofdstraffen 196

hoorzitting 248

Huis van Afgevaardigden 206

IAA 219

ICA 219

ICBE-

- instellingen 70

- richtilin 70

impeachement procedure 208

indicatoren 187

indictment 304

informal investigation 256

informatie

- verplichting 75

- verschaffing 81

informeel onderzoek 256

infraction 309

initial decision 268,275

initiële meldingsplicht 66

injunction 288

Insider Trader Penalties 297

inspectie 252

- onderzoek 252

inspection staff 252

instellen van onderzoeken 100
Instituut voor de Effectenhandel (IIE) 22

Interdealer-broker 91,95

International Organisation of

Securities Commissio 149

internationalisering $17,27,29,53$,

54

interne

- controle 93,94

- openbaarheid 338

- organisatie 237

- regelgeving $37,84-123,232$

- structuur van de SEC 249

interstatelijke wetgeving 216

intrekken van een wergunning 153 , 160

introductie Amerikaans recht 206

Investment Advisers Act 219, 224

Investment Company Act 219 , 222-223

Investment Services Directive (ISD)

58

inwinnen van inlichtingen 100

IOSCO 117, 149-153

- werkgroepen 151

ISD 58

ITSA 292

IVBPR 345

Kader

- wetgeving 45,218

- wetten 45-52,74, 83, 229

Kas-Associatie 27

kassiersmaatschappijen 9

knowingly 310

koersmanipulatie 116,213

Koopmansbeurs 4, 8

krach 30, zie beurskrach

kredietinstellingen 77

kwalificatie 189,191

Latste redmiddel 336

last onder dwangsom 153

laundering of monetary instruments 314

ledenreglement 91,93,96

liquiditeit 82,100

liquiidity provider 122 
Maatregelen 196

- bij de rechrbank $173-176$

machtenscheiding 208

mail and wire fraud 311

Maloney Act 238

Marketregulering 250

marktwerking 238

media 336

$$
\text { - sanctionering } 342
$$

mediatisering 336

meineed 309

meldingsplicht 69,178

misbruik wan voorwetenschap 30,52 , 92, 129

modelcode 30

modernisering effectenverwerking 17

MUI-zaak 254

Municipal Securities Rulemaking

Board (MSRB) 233, 244-246

Nadere regeling toezicht

effectenverkeer $199975,77-80$

NASD 24I

NASDAQ 241

National Association of Securities

Dealers (NASD) 241

national securities association 239

nationale

- effectenbeurzen 234

- landsgrenzen 85

- organisatie van

effectenhandelaren 240

ne bis in idem 161,319

NECIGEF 28

Nederlandse

-- effectenverkeer 37

- effectenwetgeving 44

- ICBE's 73

- Organisatie van het

Effectenbedrijf 15

negarieve indicatoren 302

NEKI 94

nemo tenetur 319

neveneffect $336-343$

New York Stock Exchange (NYSE)

15,235

niet-beursleden 87 niet-effecten kredierinstellingen

(NEKI) 94

niet-georganuseerde handelaren 7

niet-georganiseerden 6

Nieuwe Handel-Socièteit 5

no-acrion letters 231

NOE 16

noteringssysteem 241

Nrte'92 127

Nrte'95 77

Nrte'99 75,77,78,80

Obligaries 3

obligatory appellate jurisdiction 212

obstruction of justice 307,313

Office of Aplications 249

onafhankelijkheids

- richtlijn 95

- vereiste 92

Onderzoek afdeling Enforcement 260 ongereguleerde effectenhandel 238 onrechtmatige

- daad 176-178,329

- daadacrie $173,176-178$

ontneming van wederrechtelijk

verkregen voordeel 292

ontrrekking aan het verkeer 196

ontzerting rechten 196

Openbaar Ministerie 132,179

openbaarmaking(s) 197

- wan het vonnis 196

- plicht 65, 68,137

opportunireitsbeginsel 180,322

ordenend overheidsoptreden 12

organisatiestructuur Amsterdam

Exchanges N.V. 34, 103

organisatiestructuur Amsterdamse

effectenbeurs 34

organogram Autoriteit-FM 142

organogram SEC 25I

original jurisdiction 212

over-the-counter handel (OTC) 220 ,

238

overheids

- inmenging 11

- interventic 45

- regulering 85 
Overzicht (administratieve)

bevoegdheden 323

Pan-Europese effectenbeurs Euronext

N.V. 12I. 123

particuliere belegger 58

partije 2

pensiounfondsen 141

perjury 259,309

permanent injunction 288

pink sheet fraud 192

plaatsing psychiatrisch ziekenhuis 196

politieke controle 210

portic 2

(potentiele) beleggers 85

pre-trial diversion 302

preliminary

- injunction 288

- inquiry 254

- investigation 256

preponderance of the evidence 304

presidentielle veto 209

presumptio innocentiae-beginsel

$X X V I I, 304$

prijscourant 5

primaire markt $1 / 2$

Principles of Federal Prosecution 301 probable cause 302

prospectus $48,53,227$

provisie

- jagen 192

- tarieven 19

prudentieel toezicht 42,82

prudentiële vereisten 104

Public Utility Holding Company Act

$219,221-222$

publieksmisleiding 52,64

PUHCA 219

punitieve sancries 345

PVK 43

Raad van Financiäle Toezichthouders

(RFT) 41

Rackereering 314

recht van enquête 101

rechrerlijke macht $207-210$

rechrs

- bescherming NXVI, 336
- bronnen 232

- sprekende instanties 210

- waarborgen 345

recidive 277

redelijke rermijn 337

redelijkheid en billijkheid 265

regelgevende bevoegdheid 230

regelgeving 218

registeraccountant 99

registratie

- pliche 217

- plichtigen 217

- verplichting 235

- voorwaarden 236

regulations 226

reguliere controles 120

relativiteirsbeginsel 172

remedial sanctions 269

Remedies Act 266

reparatoire sancties 345

Report Services 249

RFT 41

richtiijn beleggingsdiensten 58

richtlijnen 93

RICO 314

Robinson Patman Act 214

rulings 211

\section{SA 219}

samenzwering tegen de staat 313 sanctionering van overtredingen 1,98 scheiding der machten 206 schermenhandel 31 schijn van partijdigheid 331 schikking 252,273

SEA 219

SEC 247

- Docket 285

- inspectie 254

- onderzoek 252

- Procedural Rules 285

sector Juridische Zaken 325

sectoraal toezichrsmode 41

secundaire markt 112

Securties Act 1933 215, 219-220

Securities and Exchange Commission

(SEC) $128,205,215,247-264$ 
Securixies and Investment Board (SIB) 40

Securities Commissions (IOSCO) 149

Securities Enforcement Remedies and Penny Stock Re 266

Securities Exchange Act 1934215 . 220-221

Securities Investor Protection Act 219,224

senaat 206

sertlement 252

Sherman Act 214

SIB 40

solvabiliteit(s) 76,82

- en liquiditeit 741

- eis 70

- richtlijn CAD 95

statelijke

- rechtbanken 210

- wetgever 214

statutaire

- eisen 91

- zetel 92

STE 30, 40-44, 77, 78, 124,125, $126-138$

Stichting Toezicht Effectenverkeer 39, zie STE

stigmatiserend

- effect 336

- werking 335

stille curatele 99

stop order 248

straffen 194

strafprocessuele beginselen 340

strafrecht 189

strafreclatelijk

- traject 185

- handhaving 252,343

- procedure 179-204, 300-320.

$329-330,336$

- vervolging 161

straf

- sanctie 345

- vervolging 162

structuur

- IOSCO $15 \pi$

- vennootschap 102 subpoena

- ad testificandum 259

- ad testificandum procedure 259

- duces tecum 259

- duces tecum procedure 259

- power 258

summary disposition 268

systeem Amerikaanse rechtbanken

213

systeemtoezicht 42

Temporary restraining order 289

TLA 219

tijdelijke Wet effectenhandel 47

toegelaten instellingen 35,103

toelatingseisen 90

toetsingsvermogen 79

toezicht(s)

- houder 38

- normen 45

$-\operatorname{model} 43,74$

- regels effecteninstellingen 79

transactie 342

rransigeren 187

transparantice beleggingsmarkt 70

trial by the media 339

Trust Indenture Act 1939 219, 222

tuchtrechtelijk college 97

Uitgevende instelling 76

uitoefening toezicht 125

uitshiting accountant 148

uitwoetende macht 207

uitwoeringsregels $45,74,77,80$, $225-246$

ultimum remedium XIII, 160,202 , $320,343-346$

United States Attorney 261

United States Attorney Manual

(U.S.A.M.) 301

United States Code (U.S.C.) 224

United States Courts of Appeals 211

Vangnet $343-346$

VEOE 102

verbeurdverklaring 196

verdeling van machten $206-212$ 
Vereeniging woor den Effectenhandel 6

Verenigde Oost-Indische Compagnie (VOC) $I$

Vereniging woor de Effectenhandel 17 verenigingstheorie 336

vergelding $336-343$

vergunningenstelsels 71

vergunning(s)

- houders 77

- anvrager 81

- eisen 82

- plichtige 76

- vereisten 149

verklaring van geen bezwaar 64,158 verzekeraars 141

voordeurcontroles 130

voorwetensichap 64

vrijstelling 57

VwdE 6,97,99,102

Waakhond 99

WBS 159

Wok 44,141

WED 51,183

Weh 39, zie Wet effectenhandel

Wells

- starement 261,262

- submission 264

- Submission en de Settlement

264

- submission en de Setdement

261

- submissions 261

werkmatschappijen $33,102,105$

West-Indische Compagnie (WIC) 3

Wet bestuurlijke sancries financiële sector (WBS) 159

Wet Economische Delicten (WED) 50

Wet effectenhandel (Weh) $20,39,45$, $47-52$

Wet identificatie bij dienswerlening 141

Wet inzake de Wisselkantoren (Wwk) 144

Wet melding ongebruikelijke transacties 141
Wer Melding Zeggenschap in te: beurze genoreerd 65-69

Wer mat 141

Wet op het consumentenkrediet (Wok) 44.141

Wet persoonsregistratie (Wpr) 130

Wet toezicht beleggingsinstellingen (Wtb) 69-74

Wet toezicht effectenverkeer $52-65$

Wet Toezicht Effectenverkeer 1995 $32,58-65$

Wet Toezicht Kredierwezen 21

Wer Toezicht Kredietwezen 1992

(Wtk92) 144

wetgevende macht 206

willfully 306

windhandel 3

Winz 83

Wmz'92 66, 67

Wmz'96 66

Worldcom 341

Wpr 130

Wtb $69,70,71,80,83$

Wte'95 $62,74,75,78,80$

Wtk' 144

Wwk 144

Zelfregulerende organisaties 232,233

zelfregulering $35,37,84-123,232$, 246

zelfstandig bestuursorgaan 80,136 , 322

zetelvertegenwoordiger 109

zickelijke stoornis van de geestvermogens 196

Zro 234

zwarte beurs 14

zwijgrecht 168 


\section{Curriculum Vitae}

Marjorie Blagrove werd geboren op 7 oktober 1968 te Paramaribo (Suriname) en bracht het grootste deel van haar jeugd door te "s-Gravenhage. In 1989 verhuisde zij naar Utrecht en behaalde in 1990 haar VWOdiploma aan de Utrechtse Dag/Avondschool voor VWO en HAVO. Van 1.990 tot medio 1.996 studeerde zij Nederlands recht aan de Rijksuniversiteit Utrecht. Vanaf 1997 tot aan de afronding van haar manuscript in 2002 was zij verbonden aan de capaciteitsgroep Strafrecht en Criminologie van de Universiteit Maastricht, aanvankelijk als assistentin-opleiding en naderhand als junior-onderzoeker.

In het kader van haar onderzoek bezocht zij in 1999 de Verenigde Staten van Amerika, waar zij in New York te gast was bij de in het effectenrecht gespecialiseerde advocatenkantoren O'Sullivan, Graev \& Karabell en Gilbert, Segall and Young, de New York Law School en de New York Stock Exchange. In Washington D.C. bezocht zij de Securities Exchange Commission en de fraude-unit van het Amerikaans Openbaar Ministerie.

Sinds augustus 2002 is zij werkzaam als universitair docent aan de Open Universiteit te Heerlen bij de sectie Strafrecht en Criminologie. Zij is getrouwd met H.K. Jap-A-Joe jr. en is de trotse moeder van dochter Jillean. 